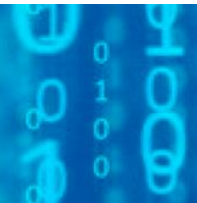 \\ UNIVERSIDADE DE SÃO PAULO \\ MUSEU DE ARQUEOLOGIA E ETNOLOGIA \\ PROGRAMA DE PÓS-GRADUAÇÃO EM ARQUEOLLOGIA
}

\section{CIBERARQUEOLOGIA EM VIPASCA:}

O USO DE TECNOLOGIAS PARA A

RECONSTRUÇÃO-SIMULAÇÃO INTERATIVA ARQUEOLÓGICA

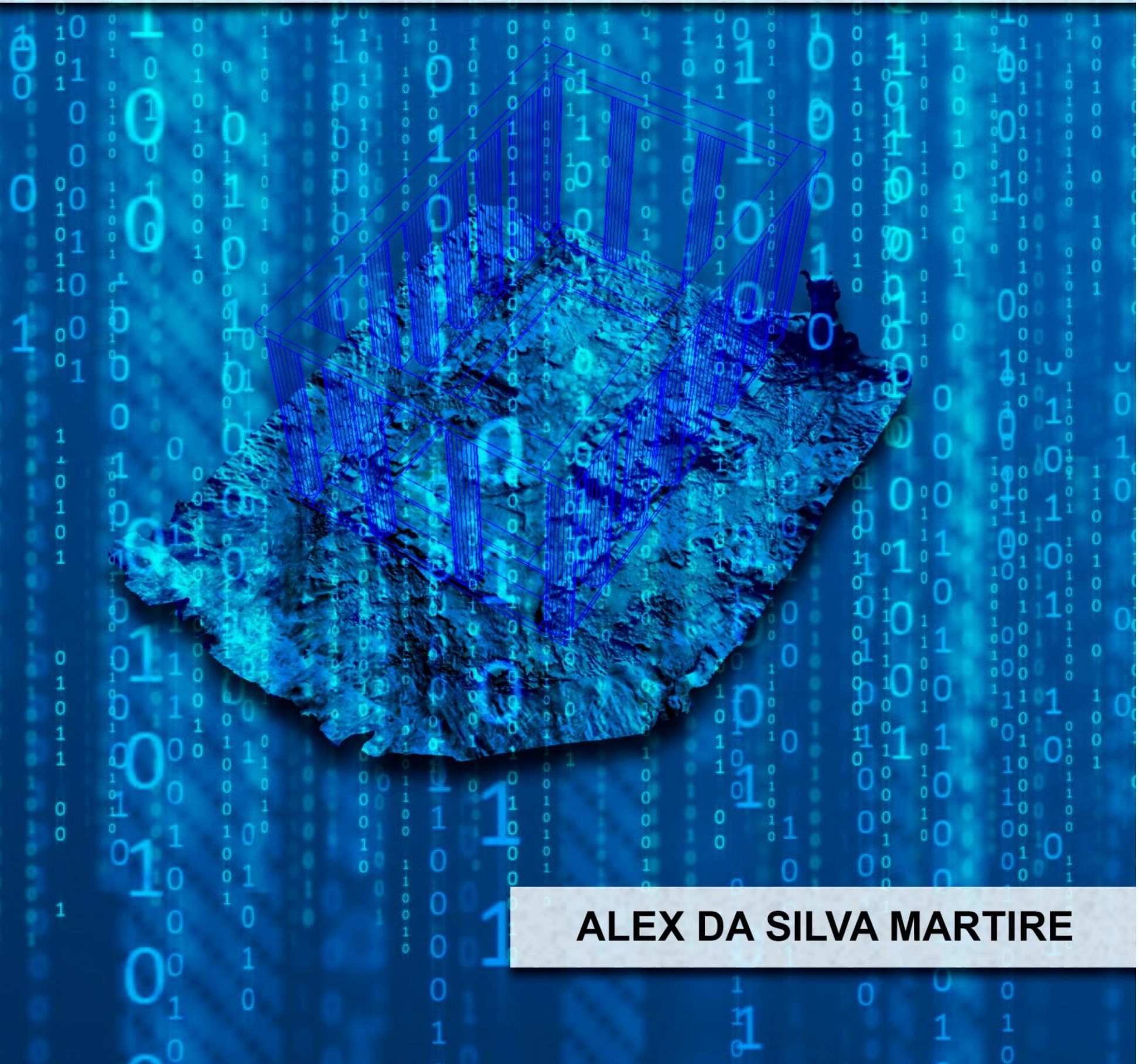


UNIVERSIDADE DE SÃO PAULO

MUSEU DE ARQUEOLOGIA E ETNOLOGIA

PROGRAMA DE PÓS-GRADUAÇÃO EM ARQUEOLOGIA

\title{
CIBERARQUEOLOGIA EM VIPASCA: O USO DE TECNOLOGIAS PARA A RECONSTRUÇÃO-SIMULAÇÃO INTERATIVA ARQUEOLÓGICA
}

\begin{abstract}
Alex da Silva Martire
Tese de Doutorado apresentada ao Programa de Pós-Graduação em Arqueologia do Museu de Arqueologia e Etnologia da Universidade de São Paulo.
\end{abstract}

Área de concentração:

Arqueologia

Orientador: Profa. Dra. Maria Isabel D’Agostino Fleming

Linha de Pesquisa: Espaço, Sociedade e Processos de Formação do Registro Arqueológico 


\section{SUMÁRIO}

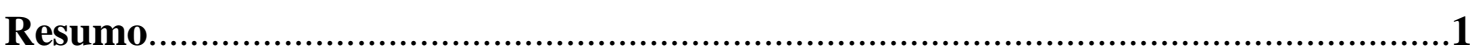

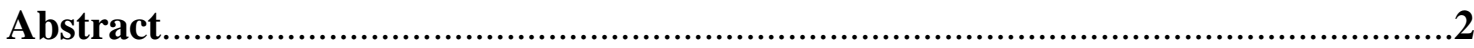

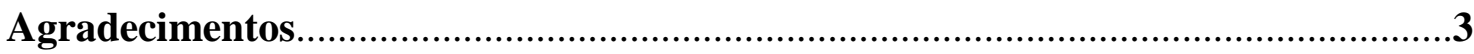

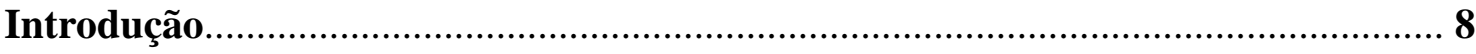

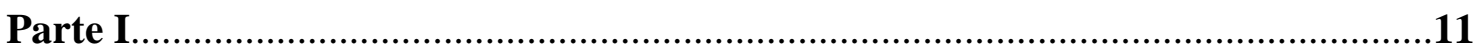

Capítulo I. Experimentando novos mundos e novos passados..........................12

Esqueça o coelho, siga o Doutor. Não haverá holodeck (por enquanto). O quê, de fato, haverá. Algumas palavras sobre mídia antes de prosseguirmos. Resumo.

Capítulo II. Informar não é algo simples.

A informação da percussão. A primeira onda cibernética. Um rato e um homeostato. A segunda onda cibernética. A (difícil) autopoiese de Maturana e Varela. Humanismo liberal: corpos em mudança. A terceira onda cibernética. Resumo.

Capítulo III. Pós-humanismo e a virtualidade. .56

Virtualizar é preciso (?), simular não é preciso (?). Experimentando além do "real": a Realidade Virtual e a Realidade Aumentada. Enxergando além do "real": visão e percepção. Resumo.

Capítulo IV. O que é ciberarqueologia?

Ciberarqueologia $=$ Arqueologia + Realidade Virtual. Enfim, a minha definição de Ciberarqueologia. Resumo.

Parte II .112

Capítulo V. A Vipasca arqueológica. 113

Os trabalhos já realizados. A Casa do Procurador. Lavaria Piloto. Morro de Algares. Morro de Mangancha. Necrópoles de Valdoca e de Farrobo. Oficina metalúrgica de Azinhal e escoriais. Resumo. 
Modelagem e Texturização (terreno; Casa do Procurador; insulae; oficina metalúrgica e fornos de redução; banho/balneário; pisão; roda hidráulica e sarilhos nos poços; tavernas, oficinas, padarias e açougue; galerias de mineração; pessoas). Interatividade/Programação (player; waypoints; quests e diálogos; GUI; fotogrametrias; galeria de imagens). Performance (lightmaps; occlusion culling; vegetação; qualidade; efeitos; performance em números). Resumo.

Capítulo VII. "O complexo de Frankenstein" ou "Costurando as ideias para mostrar a você que este trabalho teve relevância" 226

Humanidades Digitais: histórias interativas, arqueologia interativa. Entre viagens no tempo e quanta. Arqueólogos pós-humanos.

Bibliografia 



\section{RESUMO}

Este projeto constitui desdobramento e aprofundamento da temática apresentada na pesquisa de Mestrado: a paisagem romana mineradora, inserida nos projetos do Laboratório de Arqueologia Romana Provincial LARP-MAE/USP. O objetivo central é o de produzir a reconstrução-simulação tridimensional interativa da paisagem de Vipasca (Aljustrel, Portugal) a partir de seus vestígios arqueológicos. Com base nas fontes de época, bibliografia interpretativa, cartografia e trabalho de campo serão buscados recursos que possibilitem a reconstrução digital em potencial da paisagem antiga de Vipasca. Para tanto, far-se-á uso da teoria e metodologia pertencentes à Ciberarqueologia a fim de se reconstruir e simular interativamente a paisagem mineradora da região.

Palavras-Chave: Ciberarqueologia - Realidade Virtual - Mineração - Simulação Arqueologia Romana 


\begin{abstract}
This project constitutes a development and deepening of the theme presented in the Master's research: the Roman mining landscape (inserted in the projects of the Laboratory for Roman Provincial Archaeology LARP-MAE/USP). The main objective is to produce the reconstruction/interactive three-dimensional simulation of Vipasca's landscape (Aljustrel, Portugal) from its archaeological remains. Based on the sources of the period, interpretive bibliography, cartography and fieldwork, resources will be sought to enable potential digital reconstruction of the ancient Vipasca landscape. In order to do so, we will use the theory and methodology pertaining to Cyber-Archaeology in order to reconstruct and interactively simulate the mining landscape of the region.
\end{abstract}

Keywords: Cyber-Archaeology - Virtual Reality - Mining - Simulation - Roman Archaeology 


\section{AGRADECIMENTOS}

Acredito ser necessário inverter um pouco o costume da ordem dessa seção e começar por agradecer à Fundação de Amparo à Pesquisa do Estado de São Paulo (FAPESP). Sem o financiamento de minha pesquisa (em forma de bolsa de Doutorado; Processo $n^{\text {o }}$ 2012/09004-6), meu trabalho jamais teria acontecido como o planejado. Graças à bolsa e à reserva técnica eu pude fazer todas as viagens necessárias a Portugal a fim de colher material para o desenvolvimento deste trabalho. Desde a Iniciação Científica a FAPESP foi responsável pelo financiamento de meus projetos e, atualmente, também financia o Laboratório de Arqueologia Romana Provincial (LARP-MAE-USP), do qual faço parte. Sem a verba eu não conseguiria me dedicar à pesquisa. Meus sinceros agradecimentos, FAPESP.

O que vem a seguir é uma lista de nomes, mas quero deixar claro que não há hierarquização entre eles, pois todos foram importantes no decorrer do desenvolvimento do trabalho. Para ficar esteticamente bonito, irei começar os agradecimentos com preposições.

À Maria Isabel D’Agostino Fleming eu devo minha carreira acadêmica. Ela foi minha orientadora durante treze anos. Esteve presente nos momentos bons e, também, nos difíceis: profissionais e pessoais. Sem medo algum de errar, digo: só cheguei até aqui academicamente graças à Mabel. Talvez eu tivesse desistido no meio do caminho se minha orientadora fosse alguém que eu não considerasse uma amiga. Durante esses treze anos eu produzi muita coisa pensando em mim (obviamente), mas sempre tive a preocupação em fazer com que a Mabel se orgulhasse de mim: isso é o que mais me importa ainda hoje. Reconheço que não sou a pessoa mais fácil do mundo e que a Mabel teve de ter muita paciência comigo: isso só mostra que existe lealdade no meio acadêmico, e que podemos ter amigos que se preocupam conosco em todos os níveis da vida.

Ao Artur Martins eu devo este trabalho: se ele não tivesse me apoiado e me dado a abertura para estudar, livremente, tudo o que eu precisei, jamais essa tese teria existido. Conheci o Artur em 2010 na minha primeira viagem para fora do Brasil, quando fui escavar Vipasca na atual Aljustrel. Desde então, toda vez que volto a Portugal sou recebido de braços abertos por ele e sua família (que considero adotiva): sua esposa Elsa, suas filhas Raquel e Sara, e seu filho Diogo. Amo Portugal e esse amor também se deve ao fato de saber que, a cada viagem, poderei reencontrar a família Martins. Jamais 
esquecerei o fato de, em abril de 2016, a família inteira do Artur ter se reunido em sua casa em Lisboa para me oferecer um jantar de aniversário. Aprendi (e aprendo) demais com você, Artur. Obrigado, meu amigão!

À Câmara Municipal de Aljustrel agradeço pelo incentivo e apoio dados a minha pesquisa. Agradeço particularmente ao Presidente da Câmera, o Sr. Nelson Brito, à vereadora Sra. Conceição Parreira e ao assessor do Presidente Marcos Aguiar: o entusiasmo de vocês foi inspirador para o desenvolvimento de um bom trabalho.

Ao Marcelo Zuffo e à Roseli Lopes eu devo a paixão pela Realidade Virtual. Em 2012 ingressei no Doutorado e, com muita coragem, matriculei-me numa disciplina na Escola Politécnica (um arqueólogo na Poli, vejam só!). Meus temores sumiram nos primeiros momentos da aula dos professores Marcelo e Roseli: foram extremamente acolhedores e gostaram de ter um arqueólogo na turma. Desde então, estou envolvido com a Poli em algum projeto do Marcelo. Confesso que isso alimenta uma antiga vaidade minha: quando adolescente eu queria ser engenheiro. Tudo bem, sei que frequentar a Poli não faz de mim um engenheiro, mas poder trabalhar com os profissionais de lá me satisfaz em nível pessoal.

Aos meus colegas do LARP eu devo muitas discussões (acadêmicas ou não) que, de um modo ou de outro, ajudaram a modelar meu perfil profissional. Agradeço de coração. E faço um agradecimento especial à Tatiana, ao Marcio e ao Alessandro, com quem tive o prazer de trabalhar mais proximamente. Obrigado pelos incentivos desde sempre, e por não acharem que as minhas ideias são estranhas!

Aos meus colegas do LABECA eu devo o agradecimento pelos trabalhos em conjunto (e pelos copos descartáveis que "roubei" de vocês para beber café): Rodrigo, Carol, Bruna, Paula - obrigado! Agradeço também às professoras Maria Beatriz Florenzano e Elaine Hirata pelo apoio durante todo esse tempo, e por acreditarem em meu trabalho.

Ao professor Eduardo Neves eu devo o agradecimento pela participação em minha banca durante a Qualificação, em 2014. Nunca escondi de ninguém a admiração que tenho pelo trabalho do professor Edu e tê-lo fazendo apontamentos relevantes sobre meu trabalho foi uma honra enorme. 
Aos meus amigos mais próximos eu devo desculpas por quatro anos de sumiços intermitentes por causa da tese. Ivan, Leonardo, Moisés e Danilo: obrigado por serem o alívio cômico-facebookiano-cervejeiro que precisei durante esse tempo. Du, obrigado pelos quase trinta anos de amizade e por sempre estar animado para discutir os mais diversos temas. Carol, obrigado pelo convite para me apresentar na UFPel (foi importantíssimo para mim!). Daniela, obrigado pela garrafinha de Inca Kola e a ocarina, e também as conversas acadêmicas que tivemos. Gláucia, obrigado por esses anos de amizade e apoio (e saiba que tenho muito orgulho de ter acompanhado sua trajetória acadêmica). Também agradeço a você que ler esse trabalho e for meu amigo: não posso citar todos os nomes aqui por questão de espaço, mas sinta-se agradecido (a)!

Aos meus pais e irmão, agradeço por existirem e por moldarem quem sou.

Por fim, devo dizer que, durante o Doutorado, pude realizar o grande sonho pessoal da minha vida (quem me conhece sabe qual é). Apesar de ter consciência de que estudar no Brasil ainda é um privilégio, não posso deixar de me orgulhar do caminho que trilhei e de onde cheguei até aqui. Talvez eu possa inspirar aqueles que, como eu, moram na periferia de uma cidade violenta, estudaram em escolas públicas, mas, mesmo assim, desejam realizar seus sonhos.

Durante minha trajetória eu conheci muita gente fantástica. Eu fui mais bem tratado do que mereci. E cheguei mais longe do que jamais imaginei.

Encerro essa etapa de minha vida com a sensação de dever cumprido.

Obrigado a todos. De verdade. 
Danilo Tabone - colega de Doutorado no MAE que, infelizmente, jamais terá seu trabalho concretizado.

Augusto Lacerda (vulgo Pezão) - amigo de infância e adolescência que, mesmo não me reconhecendo mais em seus últimos anos de vida por causa da doença que o levou, jamais será esquecido. 
Não deixe a Universidade atrapalhar seus estudos

- frase que vi pichada no muro da FAU

Pesquisar deve ser sempre divertido

- Mabel Fleming para mim, em uma reunião 


\section{INTRODUÇÃO}

Acredito que, se está com esse trabalho em mãos, algo deve ter chamado a sua atenção.

Eu apostaria que a razão disso é a palavra "Ciberarqueologia" no título. Ela é um termo bastante recente (ainda mais em português), tendo surgido há mais de uma década na Arqueologia. E, tratando-se de algo novo, acho que merece ser bem explicado.

$\mathrm{Na}$ verdade, precisei de mais de duas centenas de páginas para tentar explicá-la a você. E, mesmo assim, tenho certeza de que haverá mais questionamentos do que soluções. Mas isso não é ruim: toda pesquisa deve fomentar a dúvida e a vontade de aprofundar o tema. Se, ao final da leitura, você se sentir inclinado a pesquisar mais sobre o assunto então meu objetivo terá sido cumprido.

Como verá, essa pesquisa não é muito "convencional". Aqui eu discorro sobre Filosofia, Engenharia e Arqueologia. Mais: eu ofereço a você um aplicativo de computador que permitirá participar de uma simulação em uma antiga área de mineração romana, Vipasca (atual Aljustrel, em Portugal). Mas o mais importante de tudo é: desejo estabelecer um contato com você. Quero que conversemos depois da leitura. A Ciberarqueologia é um campo novo no Brasil e precisamos de pesquisadores. Se essa pesquisa servir para inspirá-lo, terei alcançado o meu objetivo mor.

Ciberarqueologia é a união da Arqueologia com a Realidade Virtual, é o uso de dispositivos eletrônicos para a análise e a extroversão de resultados em ambientes tridimensionais interativos. Porém, dizer que Ciberarqueologia é apenas isso seria simplificá-la demais, correndo o risco de cair no senso comum de "uso de computadores na Arqueologia". Ela é muito mais do que isso, como poderá notar. O trabalho ciberarqueológico está baseado na teoria da Cibernética - que existe há mais de setenta anos - e em metodologia própria, ainda em desenvolvimento. Nesse trabalho encontrará a pormenorização dos conceitos fundamentais da Ciberarqueologia e um longo relato da produção do aplicativo Vipasca Antiga.

Dividi esse trabalho em duas partes, sendo a primeira conceitual, e a segunda prática. Embora eu sugira a leitura completa em ordem, você pode ficar livre para escolher a parte que mais lhe interessar. 
No Capítulo I discorro sobre aquilo que você lerá no decorrer da pesquisa. Apresento a interessante conceituação de holodeck e pontuo o debate sobre o uso de mídias diversas no aprendizado das pessoas.

O Capítulo II é a síntese da história da Cibernética. São apresentadas as "três ondas" de desenvolvimento cibernéticas. Sinceramente, não espero que seja uma leitura fácil, pois o tema é bastante complexo. No entanto, tentei ao máximo exemplificar as partes que considerei mais complicadas e espero que ajude você um pouco a passar por esse capítulo sem traumas maiores.

Questões centrais sobre Realidade e Virtualidade são pormenorizadas no Capítulo III. De longe, esse é o capítulo mais “incomum” da pesquisa. Talvez eu consiga convencer você de que a realidade é mais subjetiva do que parece e que você não é mais humano.

No Capítulo IV eu finalmente apresento a Ciberarqueologia (viu como ela é complexa e precisou de três capítulos preparatórios?). Faço um panorama de seu desenvolvimento e uma comparação com a Arqueologia Virtual (na qual não interagimos em tempo real). Também dou a minha definição de Ciberarqueologia (e, novamente, é algo polêmico - por enquanto).

A parte prática inicia-se no Capítulo $\mathbf{V}$, onde faço um apanhado das escavações prévias ocorridas na região de Vipasca, pormenorizando cada localidade relevante na paisagem na qual me baseei para desenvolver meu aplicativo ciberarqueológico. Esse é o capítulo mais arqueológico desse trabalho e serve como um respiro para o capítulo seguinte.

O Capítulo VI é a prática ciberarqueológica da pesquisa. Escrevo sobre cada item que modelei, texturizei e programei em 3D. Apresento minha metodologia e as dificuldades surgidas no processo de desenvolvimento. Obviamente, esse capítulo só será plenamente absorvido se você utilizar o aplicativo Vipasca Antiga para ver, "ao vivo", tudo o que relato. É interessante, confie em mim!

Finalizo essa pesquisa no Capítulo VII falando sobre Humanidades Digitais, Doctor Who, simbiose entre homens e máquinas e como tudo isso está ligado à Ciberarqueologia (sim, está). Por ser um capítulo conclusivo, ele tem um quê de melancolia, afinal, é aqui que me despeço de você. Muito obrigado. De nada. 
O aplicativo ciberarqueológico (produto final dessa pesquisa) Vipasca Antiga pode ser baixado no endereço:

\section{www.vipasca.com}


PARTE I 


\section{CAPÍTULO I}

\section{EXPERIMENTANDO NOVOS MUNDOS E NOVOS PASSADOS}

Somos todos histórias no final. Apenas faça alguma boa, sim?

- O Doutor, Temporada 5, Episódio 13

"Eu poderia lhes contar minhas aventuras... começando por esta manhã", disse Alice um pouco tímida; "mas não adianta voltar a ontem, porque eu era uma pessoa diferente."

- Lewis Carroll, Alice no País das Maravilhas

Combinar Arqueologia com Computação não é tarefa fácil. É bem verdade que usamos computadores para redigirmos nossos relatórios, artigos, dissertações e teses. Também não foge à regra o uso de computadores para prepararmos nossas apresentações em PowerPoint (que se tornam um "sucesso" quando utilizamos fundos coloridos e setas animadas ao invés de fundo branco e letras pretas - resquício dos retroprojetores de transparências). Sejamos honestos: arqueólogos temem computadores. Somos capazes de destrinchar cadeias operatórias, entendermos a Arqueologia Cognitiva do Renfrew, escrevermos sobre a complexidade social presente nos rótulos de nossa bebida favorita (SHANKS \& TILLEY 1992), debatermos horas e horas se o Pós-Processualismo é melhor do que o Processualismo (embora todos sejamos fãs de Gordon Childe), mas simplesmente não gostamos de computadores. Hoje em dia temos notebooks e tablets, mas continuamos usando papel e lápis em campo: seria a simples manutenção de uma tradição? O gosto pelas manchas de terra na folha branca? Obviamente, existem arqueólogos que se tornaram adeptos da tecnologia portátil em campo, mas ainda são em pequeno número, principalmente no Brasil. Isso leva a crer que não continuamos a usar papel e lápis por simples tradição: usamos por falta de costume e, provavelmente, por receio de novas tecnologias. Não deixa de ser irônico que nós, pesquisadores de artefatos tão relacionados à tecnologia, sejamos reticentes com relação à introdução de novidades em nosso meio de pesquisa.

Porém, não se deve culpar essencialmente o indivíduo arqueólogo. Muitas vezes, ele apenas não tem acesso à informação e, na maioria dos casos, não possui verba para 
adquirir os equipamentos. Há, é claro, os "luditas" da arqueologia que simplesmente renegam tudo o que é novo, mas a cada ano que passa esses estão minguando. Felizmente. Podemos, sim, constatar que, apesar do temor que nós arqueólogos sentimos pelos computadores, essas máquinas estão nos auxiliando enormemente. Desde os anos 1980 estamos usando Sistema de Informações Geográficas (SIG) em nossa área de pesquisa com resultados bastante positivos: o que antes eram emaranhados de folhas de papel vegetal representando camadas de um mapa, com o SIG passaram a habitar todos um mesmo arquivo digital de computador. Ganhamos espaço. Ganhamos tempo. O SIG nos permite analisar terrenos de paisagens antigas e até mesmo fazer predições, e tudo isso ao alcance de nossos computadores portáteis. Quando não estamos utilizando programas tão complexos quanto um SIG, estamos fazendo planilhas eletrônicas e estabelecendo gráficos em colunas ou pizza para mostrar os resultados de nossos estudos.

Então talvez eu tenha exagerado ao dizer que nós arqueólogos temos pavor de computadores? A resposta é sim, e não. Nós usamos essas sofisticadas máquinas com dois, quatro, oito processadores, repletas de GigaByte de Memória RAM, com placas de vídeo possuidores de milhares de núcleos CUDA e telas em Full HD simplesmente para redigirmos textos, montarmos gráficos, produzirmos mapas (em sua maioria bidimensionais) e criticarmos uns aos outros no Facebook. O que nós arqueólogos fazemos com os computadores é digno de causar transtornos em qualquer cientista da computação ou engenheiro. Sim, nós subutilizamos nossas máquinas. Não é bem verdade, então, que temos ojeriza a computadores: nós gostamos e os usamos. Mas estamos sempre na zona de conforto de nossos conhecimentos prévios e, a qualquer tentativa de introdução de algo novo, logo dizemos: “Ah, isso é muito avançado para mim. Não entendo - nem quero entender - nada de computadores". Não tenho a menor dúvida de que essa afirmação simplesmente não existirá nas próximas duas ou três gerações de arqueólogos. A tecnologia está muito próxima de atingir a sua Singularidade (KURZWEIL 2006) e o uso aprofundado dos computadores será assunto corriqueiro a todos no futuro.

Até lá, contudo, será necessário que experimentemos novos mundos (ou seja, diálogos interdisciplinares) e também novos passados (simulações computacionais arqueológicas). 


\section{ESQUEÇA O COELHO, SIGA O DOUTOR}

Digamos que você esteja caminhando tranquilamente por uma rua próxima à sua casa em uma entediante manhã de domingo e, de repente, depara com uma grande caixa azul em formato de uma antiga cabine telefônica policial inglesa. Surpreendente, não? Mas torna-se ainda mais estranho quando um homem sai da caixa autodenominando-se “O Doutor" e lhe pergunta ao estender a mão: “Tudo do tempo e do espaço, em toda parte e em qualquer lugar, cada estrela que sempre foi ... onde você quer começar?"

O que você faria? Estenderia a mão ao misterioso Doutor?

Se sua resposta foi "não", creio que este trabalho não lhe interessa mais e pode parar de lê-lo por aqui. Agradeço a atenção.

Se sua resposta foi "sim", então fique mais um pouco e permita-se navegar pelo tempo e espaço, para qualquer lugar que desejar. Isto é o que proponho com meu trabalho: a possibilidade de conhecer um local no passado, um lugar que será modelado em computadores e, se bem produzido, deixará você imerso nessa nova realidade. Iremos para Vipasca, antiga zona mineradora do Império Romano, que hoje está situada sob a atual vila de Aljustrel, em Portugal. Mas não iremos agora. Antes, é necessário que se discorra sobre o que foi feito e como foi feito. Haverá teoria, claro. E metodologia também. Enfim, entenderemos o que proponho com Ciberarqueologia, termo que vem sendo utilizado no âmbito arqueológico desde o início dos anos 2000. O caminho é longo, mas não deixa de ser prazeroso. Se, assim como eu, você gostar de computadores, prepare-se: em breve estaremos aterrissando em Vipasca com a nossa TARDIS ${ }^{1}$.

\section{NÃO HAVERÁ HOLODECK (POR ENQUANTO)}

Obviamente, não seremos apresentados a uma Vipasca que pode ser tocada de forma concreta. Ainda não temos tecnologia para isso, infelizmente. Isso é algo que existe em séries de TV como Doctor Who e Star Trek. Esta, a propósito, há muitos anos vem

\footnotetext{
1 Acrônimo de Time and Relative Dimension in Space (Tempo e Dimensão Relativos no Espaço). Espaçonave utilizada para viagens no tempo no seriado televisivo britânico Doctor Who.
} 
nos fazendo sonhar com a possibilidade de materialização computacional. Estou falando do holodeck da Enterprise. Relembremos um dos episódios de A Nova Geração.

Data Estelar 41997.7

$\mathrm{Na}$ mesa de reuniões da tripulação, ao invés de discutirem os cumprimentos que o capitão deve fazer aos Jarada (civilização que facilmente se ofende com uma única sílaba pronunciada de modo incorreto), Jean-Luc Picard está animadíssimo com a experiência realizada no holodeck da nave há pouco tempo:

"E quando olhei para a rua, realmente vi automóveis" - sorri o capitão da Enterprise ao contar sua experiência de viver como Dixon Hill aos presentes na sala. "Daquela janela, eu pude ver um quarteirão. Tudo estava correto: sons, cheiros...". Picard então conclui: "O senso de realidade era absolutamente incrível. Quando aquela mulher me beijou, foi tão... real".

"Bem, estou voltando para lá".

A personagem fictícia de Dixon Hill, um detetive particular da década de 1940 na Califórnia, ganha vida nas ruas de San Francisco por meio do capitão Jean-Luc Picard, que incorpora o papel de investigador ao mesmo tempo em que Dixon Hill é incorporado pela figura do capitão. Dixon Hill é o avatar de Picard. Certamente, este termo não é estranho às pessoas, uma vez que todos poderão se lembrar do filme homônimo lançado em 2009 e de como as personagens adentravam corpos dos nativos $\mathrm{Na}$ 'vi a fim de interagir em seu mundo e conquistar sua confiança. $\mathrm{O}$ conceito de avatares, embora surgido no contexto religioso hindu significando manifestação corporal de um ser divino sobre um terrestre, pouco mudou: seu uso, contudo, deixou de ser literalmente físico para se readaptar em um ambiente digital - hoje podemos fazer o papel de deuses e incorporar personagens de computador que, na realidade, não passam de zeros e uns. Dixon Hill interage com as pessoas a seu redor e sofre as consequências de seus atos porque Picard assim o quis: é Picard quem fala e gesticula, mas é Dixon Hill quem transmite as informações no mundo noir em que existe. O capitão Jean-Luc Picard, assim, está experimentando uma realidade virtual extremamente imersiva, que só é possível porque a mídia utilizada para a simulação é um holodeck, ou seja, uma sala que consegue projetar tridimensionalmente no espaço qualquer objeto (holograma), e mais: esses objetos 
possuem massa e, no caso de personagens humanos, interagem com uma naturalidade que parece ter posto um ponto final ao teste de Turing.

O holodeck pode ser usado como analogia para o derradeiro display (ultimate display) mencionado pelo cientista da computação Ivan Sutherland em 1965:

O derradeiro display seria, obviamente, uma sala dentro da qual o computador pode controlar a existência da matéria. Uma cadeira mostrada em tal sala deveria ser boa o bastante para sentarmos. Algemas mostradas em tal sala deveriam prender, e uma bala mostrada em tal sala deveria ser fatal. Com a programação apropriada, tal sala poderia ser, literalmente, o País das Maravilhas no qual Alice caminhou.

Nele, é possível atingir um estágio quase semelhante ao nirvana propalado pelos budistas: anulando a consciência da realidade física (ao invés da ganância, dor e ilusão do termo em seu contexto original). A simulação torna-se tão próxima do que entendemos por realidade que, em determinado momento, ela se confunde com a realidade projetada pelo display: é como o filósofo chinês do século III a.C. Chuang Chou se indagando sobre sua real forma: ele é o homem que sonhou ser borboleta, ou é a borboleta que sonhou ser um homem? A realidade é um conceito que pode ter várias definições, dependendo de quem a analisa. Do mesmo modo, a realidade, quando se torna virtual, adentra outro campo próprio, com definições próprias, que serão exploradas mais adiante.

\section{O QUÊ, DE FATO, HAVERÁ}

Por uma questão tecnológica, não temos um holodeck onde possamos (re)encenar peças de Shakespeare (MURRAY 2003) ou observarmos Aníbal cruzando os Alpes com sua manada de elefantes. Sendo o holodeck uma mídia, ou seja, um meio de se projetar uma simulação, podemos afirmar que outras mídias também são válidas, mesmo que não sejam baseadas em holografia. Desse modo, um computador, teclado, mouse e monitor já são suficientes para gerar no usuário/espectador um grau de imersão que o fará se sentir transportado para o ambiente que lhe é mostrado. Poderíamos ampliar esse grau de imersão com a utilização de óculos de realidade virtual ou uma Caverna (não se preocupe com termos, por enquanto): tudo dependeria de uma questão de - novamente - tempo e 
espaço: tempo para se desenvolver a simulação, e espaço físico para montar os equipamentos. A questão da verba é mais delicada e, talvez, até mesmo a mais crucial. No entanto, proponho neste trabalho soluções de baixo custo que poderão levar o usuário a um grau de imersão satisfatório.

(Já adianto, porém, que nenhuma delas será um holodeck).

\section{ALGUMAS PALAVRAS SOBRE MÍDIA ANTES DE PROSSEGUIRMOS}

Antes de, enfim, adentrarmos a TARDIS e partirmos, é importante que se faça uma ressalva logo aqui no início. E a faço em forma de pergunta: Esteja a simulação correndo em um holodeck ou em um computador pessoal simples, ela, por si só, substituiria a construção do conhecimento à qual estamos acostumados? (Entenda-se por isso a tradicional tríade escola, livro e caderno).

Acredito que esse questionamento seja fundamental, pois não devemos, jamais, dizer que uma simulação computacional é aquilo que realmente aconteceu no passado. Não o é. A simulação é uma interpretação e uma representação. Então se entrássemos no holodeck da Enterprise e pedíssemos para o computador gerar o dia em que Júlio César foi assassinado no Senado não veríamos o fatídico dia, de fato, mas, sim, uma construção digital do evento, algo formado por zeros e uns e projetado por meio de luzes. O simples fato de ser uma simulação valeria menos para a gente em fatores cognitivos? Aprenderíamos menos por causa de termos observado uma construção digital e não o dia, digamos, real? Afinal, não é isso o que aprendemos nas escolas? Nós estudamos História por meio de livros e das explicações dos professores. Sim, aprendemos desse modo. Caso, hipoteticamente, tivéssemos já nos dias de hoje um holodeck ele substituiria as salas de aula e os professores? De modo algum! O meio digital e o meio pessoal (ou seja, escolas) são ambos válidos e nos ensinam o mesmo assunto, porém, de modos diferentes e, principalmente, não excludentes.

O debate sobre a influência da mídia na aprendizagem não é algo novo. Essa questão tem estado à tona há anos, sendo bastante conhecido o embate entre os pesquisadores Robert Kozma e Richard Clark na década de 1990. Em seu artigo de 1991, Kozma explana que a definição de mídia se dá por meio da tecnologia empregada (a característica mais óbvia), seus símbolos e suas potencialidades processadas. O efeito 
principal do meio tecnológico empregado na mídia é o de habilitar duas outras capacidades: os sistemas de símbolos que podem ser utilizados, e os processos que podem ser realizados com eles. Embora um sistema de símbolos seja um conjunto de elementos que estão inter-relacionados por sintaxe e são usados para relacionar campos de referência, eles sozinhos não são suficientes para descrever um meio e seus efeitos cognitivos: é necessário que haja um processamento dessa informação simbólica, e isso se dá por meio da mídia escolhida. Para exemplificar suas ideias, Kozma escolheu quatro tipos de mídias: livros, televisão, computadores e multimídia. Os livros talvez sejam um dos tipos de mídia mais antigos e tradicionais que temos: seus sistemas de símbolos (os textos) fornecem ao leitor a capacidade de criar uma representação mental baseada naquilo que decodifica; ao mesmo tempo, o leitor tem uma estrutura que é apresentada completa a ele, podendo pular trechos ou voltar às partes mais complexas (as figuras também auxiliam no processo cognitivo, muitas vezes deixando claro aquilo que se mostra difícil quando aprendido apenas por caracteres escritos). A televisão possui um processo de informação diferente, uma vez que os sistemas de símbolos linguísticos e picturais são apresentados ao mesmo tempo e, como mostra o autor, dão mais resultados positivos do que o aprendizado apenas por meio de textos ou áudio (não há uma competição por recursos cognitivos, ao contrário do que muitos possam pensar). Os computadores, por sua vez, diferem das mídias anteriores, pois são capazes de trabalhar e processar os símbolos, são mais interativos: a todo o momento, os computadores conseguem transformar informações textuais em visualização gráfica e/ou auditiva e viceversa, criando novos modelos de representação dentro de micromundos feitos pelos usuários. Por fim, a multimídia oferece aos usuários sempre a opção de mudança nos meios, indo do nível macro ao micro, mas colocando em risco o aprendizado se não for bem orientado (pode ocorrer dispersão de objetivos devido à grandeza da multimídia).

O artigo de Kozma traz uma abordagem que se faz cada vez mais necessária, ainda mais hoje em dia, em que a internet é algo corriqueiro e praticamente todas as pessoas residentes em centros urbanos (a maioria no mundo, de acordo com o censo demográfico) têm acesso ao conteúdo disponível na rede. O fato é: hoje temos uma quase infinidade de recursos, dos mais diferentes tipos e das mais diversas qualidades. O que precisamos saber, contudo, é como filtrar todas as informações para apre(e)nder algo delas. É inquestionável o que Kozma defende em seu texto: a mídia influencia, sim, o aprendizado. Como ele mostrou, livros, televisão e computadores (e seus conteúdos) fazem parte de 
nossa vida atualmente, e são recursos imprescindíveis em sala de aula. No entanto, talvez o mais importante seja o professor saber dosar o uso de cada meio, não hierarquizando em demasia um em detrimento do outro. Desse modo, não dá para negar que textos são essenciais para o processo cognitivo de alfabetização e construção de representações mentais, porém, o livro tradicional em si, aquele feito em papel e lido a partir de páginas colocadas uma ao lado da outra, está mudando: hoje em dia as publicações digitais estão se tornando corriqueiras e as crianças que nascem agora estão se acostumando mais a "tocar em telas" do que virar páginas: o que torna esse processo tão interessante, a meu ver, é que voltamos às origens dos primeiros textos, que eram todos lidos de cima para baixo sempre, não da esquerda para direita (como no caso das folhas dos livros). Os vídeos também auxiliam no aprendizado, já que trazem um processo diferente, mostrando com mais clareza aquilo que criamos mentalmente ao lermos. Porém, no caso dos computadores, infelizmente Kozma não aborda em seu artigo - mesmo que escrito na década de 1990 - a realidade virtual.

Esse artigo de Robert Kozma é uma resposta às ideias publicadas por Richard Clark em 1983. Quando, em 1991, o artigo foi publicado, Kozma fez questão de deixar bem claro que não concordava com Clark sobre sua afirmação de que as mídias são meros veículos que fornecem instrução, mas que não influenciam no aprendizado do aluno. Porém, lendo o texto com mais atenção, podemos notar que Richard Clark deixa explícito aquilo que Kozma deixa implícito: o que realmente influencia no aprendizado não é a mídia em si, mas o conteúdo elaborado para ela. Richard Clark é enfático no título de seu artigo de 1994 (“Media will never influence learning”): o que influencia não é a ferramenta, é o que está por trás dela, o seu conteúdo. O autor afirma, por exemplo, que a motivação para o aprendizado não é responsabilidade direta da mídia - ela, por si só, não consegue fazer isso - mas, sim, que depende dos educadores motivarem seus alunos a buscarem essas mídias. Pessoalmente, creio que para Kozma isso está claro nos exemplos apresentados acima, mas ele simplesmente não tocou no assunto: tanto é assim, que o título de seu trabalho é "Learning with media", não "Learning from media", ou seja, a ferramenta auxilia a educação, mas não é capaz de, por si mesma, ensinar algo a alguém.

Richard Clark e Robert Kozma, no fim, abordam o mesmo tema: o uso da mídia para o aprendizado e, mais importante, o seu conteúdo. A discussão teórico-metodológica de ambos é benéfica aos educadores, pois tocam em pontos chave do aprendizado por 
meios eletrônicos, principalmente. Cada mídia tem sua característica e precisa ser abordada de um modo singular, tomando-se cuidado com o método empregado. Se levarmos em consideração apenas o conteúdo a ser explanado, Clark está com a razão ao afirmar que a mídia nunca vai influenciar o aprendizado. Mas devemos também atentar para o fato de que os meios influenciam, sim, a educação quando bem aplicados, e é isso o que Kozma defende. Analisando-se ambos os textos, a discussão torna-se mais rica e conseguimos entender que os dois autores estão falando sobre o mesmo objeto, mas sob perspectivas diferentes.

Feita essa longa ressalva e agora sabendo que a mídia influencia o aprendizado, podemos continuar nossa jornada ao longo do tempo e espaço para obtermos mais algumas informações. No final, tudo se resume a isso: informação. Todos nós somos pacotes de células ambulantes recheados de informação. Mas, ânimo, isso não é ruim!

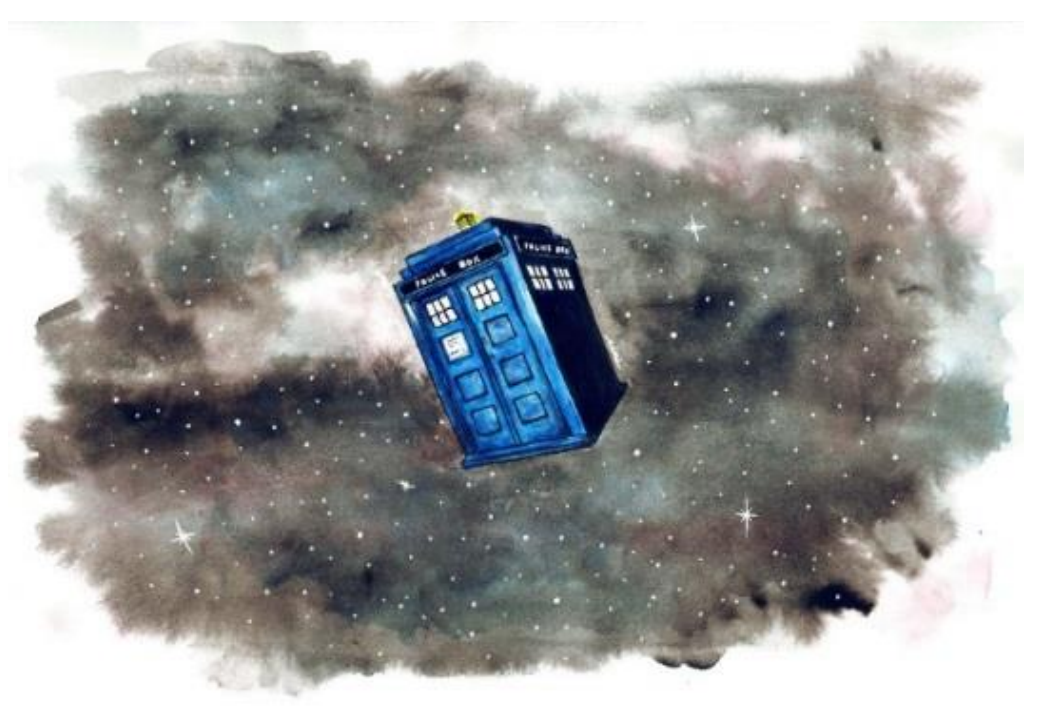

Fig. 1 - TARDIS (por thegreatperhapss in: deviantART). 


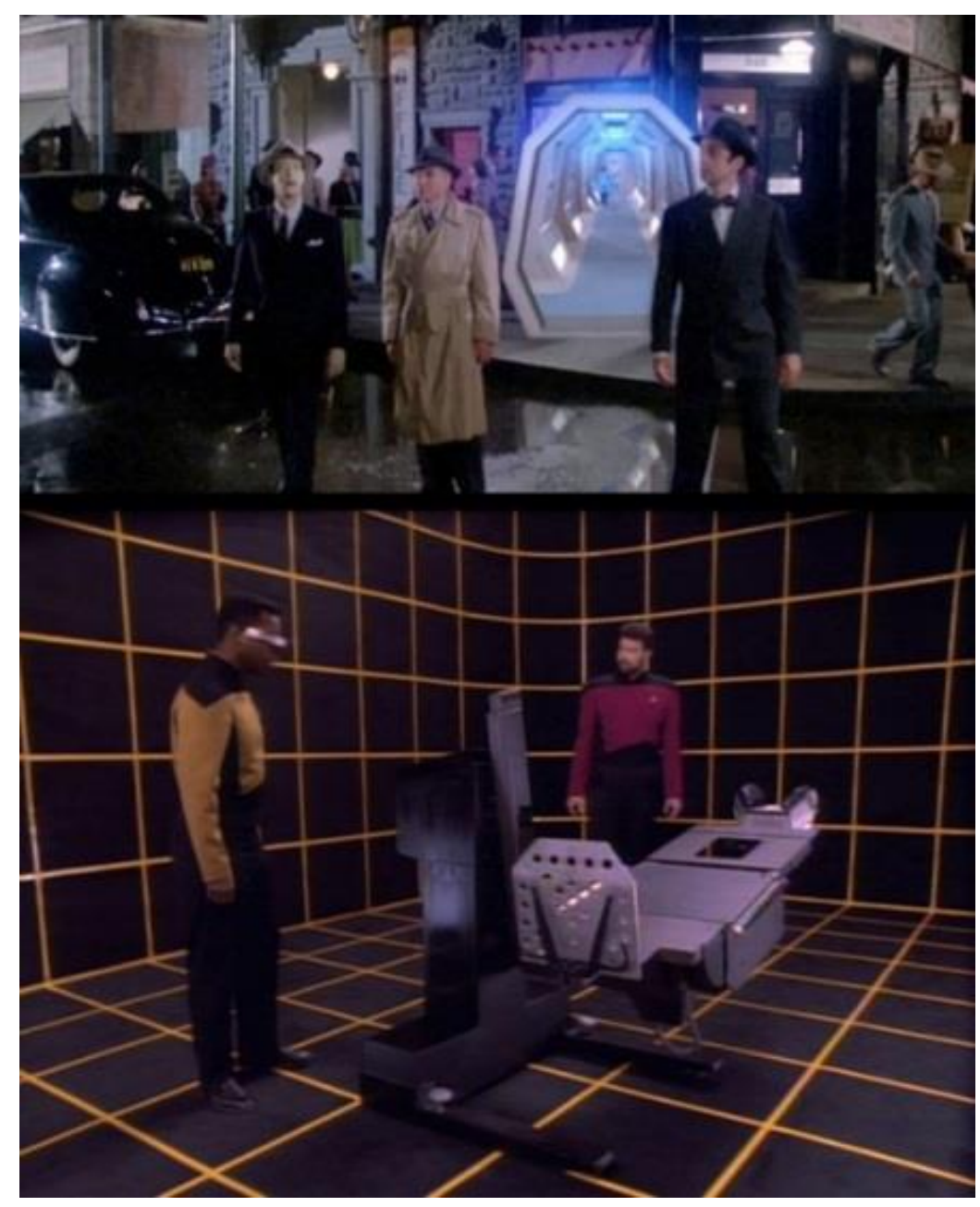

Fig. 2 - Acima: Dixon Hill (ao centro) no holodeck (atrás, a porta de acesso à Enterprise); Abaixo: Tripulantes da Enterprise no holodeck desativado (curiosamente, jamais foi explicado como as paredes do ambiente não faziam com que os usuários fossem de encontro a elas durante as simulações). 


\section{RESUMO - EXPERIMENTANDO NOVOS MUNDOS E NOVOS PASSADOS}

Comecei este capítulo polemizando a relação dos arqueólogos com os computadores (afinal, polêmicas prendem a atenção dos leitores). Fiz um pequeno ataque (educado, claro) aos arqueólogos que subutilizam ou até mesmo que têm calafrios quando precisam sentar em frente a um computador e utilizar algum outro programa que não seja um editor de textos ou planilhas. Não sejam assim! - digo eu. Computadores são amigos e não necessariamente teremos um futuro tenebroso como apregoa aquela série britânica de TV Black Mirror $^{2}$.

O capítulo continuou apresentando um dispositivo interessantíssimo que existe na série Star Trek, o holodeck: um simulador de passados em escala real. Infelizmente, logo após a apresentação eu joguei um balde de água fria em você dizendo que isso não existe (ainda). Contudo, o holodeck pode servir como uma metáfora para as simulações computacionais que fazemos atualmente.

Terminei este capítulo sumarizando a discussão entre Robert Kozma e Richard Clark na década de 1990 sobre a influência da mídia no aprendizado. Fico ao lado de Kozma nessa questão: o tipo de mídia pode ajudar ou atrapalhar o aprendizado; por isso, é necessário que todo o conteúdo da mídia seja muito bem elaborado, explorando ao máximo os seus pontos positivos.

(Por fim, acho que ficou claro neste capítulo que você está diante de uma pesquisa realizada por alguém bastante nerd, que adora ficção científica e computadores. E, sim, sou fã incondicional de Doctor Who!)

\footnotetext{
${ }^{2}$ Assista. É ótima.
} 


\section{CAPÍTULO II}

\section{INFORMAR NÃO É ALGO SIMPLES}

O DNA humano é como um programa de computador, mas muito, muito mais avançado do que qualquer software jamais criado.

- Bill Gates, A Estrada do Futuro

E uma nova filosofia surgiu chamada física quântica, sugerindo que a função do indivíduo é informar e ser informado. Você realmente só existe quando está em um campo compartilhando e trocando informações. Você cria as realidades que habita.

\section{- Timothy Leary, Caos e Cibercultura}

Todos nós somos pacotes de células ambulantes recheados de informação.

Não fui eu quem disse isso pela primeira vez. Na verdade, não sei quem o disse primeiramente, mas, com certeza, a pessoa responsável por popularizar essa ideia foi o biólogo queniano Richard Dawkins em seu livro O gene egoísta, de 1976. Muito antes de ser conhecido como um defensor assíduo do ateísmo, Dawkins já havia dado contribuição enorme ao meio acadêmico com a sua obra que inverte a perspectiva da evolução proposta por Darwin no século XIX. Esqueça o organismo ou a espécie: Dawkins afirma que nossos corpos são meros receptáculos dos genes, que nossos organismos são "máquinas de sobrevivência” desses genes. Em suas próprias palavras (2007: 66):

Eles [os genes] não se extinguiram, pois são mestres antigos na arte de sobreviver. Mas não espere encontrá-los no mar, flutuando à deriva; há muito que desistiram dessa liberdade altiva. Hoje em dia, eles se agrupam em colônias imensas, seguros no interior de gigantescos e desajeitados robôs [nossos organismos], guardados do mundo exterior, e com ele se comunicam por caminhos indiretos e tortuosos, manipulando-o por controle remoto. Eles estão dentro do leitor e de mim. Eles nos criaram, o nosso corpo e a nossa mente, e a preservação deles é a razão última da nossa existência. Percorreram um longo caminho, esses replicadores. Agora, respondem pelo nome de genes, e nós somos suas máquinas de sobrevivência".

Assustador, não? No fim, somos apenas isso: robôs controlados por genes que, graças ao seu egoísmo, conseguem sobreviver há milhões e milhões de anos. As ideias de 
Dawkins levam um certo tempo para serem digeridas e, passada a depressão inicial, se mostram realmente interessantes do ponto de vista informacional: se tudo no mundo é um emaranhado de informações, por que não nos enxergarmos assim também? Os genes são ácidos nucleicos. Podem ser ácidos ribonucleicos (RNA) ou ácidos desoxirribonucleicos (DNA); os primeiros fazem a síntese de proteínas da célula enquanto os segundos são responsáveis por armazenar as características hereditárias de cada ser vivo. Aproximando-se mais o microscópio, percebemos que toda molécula de DNA é formada por unidades menores, os nucleotídeos. E neles é que está contida toda a informação de nossas vidas: as bases denominadas A, C, G e T formam um código, uma transmissão de mensagens que, ao se juntarem às outras bases, produzem a famosa dupla hélice de DNA descoberta por James Watson e Francis Crick em 1953. Contudo, quatro anos antes do trabalho de James Watson, o cientista da computação Claude Shannon rabiscou em uma folha de papel uma ordem de potências de dez referentes à quantidade de bits que poderiam armazenar uma informação. Um cartão perfurado de computadores poderia armazenar $10^{3}$ bits de informação; uma página digitada com espaçamento simples, $10^{4}$ bits; e a constituição genética do homem, $10^{5}$ bits. O palpite de Shannon ocorreu anos antes da descoberta de Watson e Crick mas já indicava um caminho: na realidade, precisava ser ainda acrescido de quatro ordens de magnitude para estar correto, chegando a $10^{9}$. Foi a primeira vez que alguém sugeriu que o genoma era formado por um armazenamento de informações calculável em bits.

A informação é o cerne do mundo que habitamos e, assim sendo, também é o cerne da Ciberarqueologia. Mas, afinal, o que é uma informação?

\section{A INFORMAÇÃO DA PERCUSSÃO}

De acordo com a raiz latina, informação vem do nominativo informatio que, por sua vez, deriva do verbo informare, significando "dar forma à mente".

Pessoalmente, gosto bastante dessa definição etimológica, pois ela nos permite uma grande abertura do leque de possibilidades de uso. Sendo a informação algo que dá forma ao que temos em mente, todas as nossas vidas estão baseadas nela: nós enxergamos com os olhos, mas as imagens são formadas no cérebro para que possamos interpretá-las; uma poesia é a concretização de nossos sentimentos mais profundos; um desenho feito no papel ou em uma parede de caverna é um modo de dar forma às imagens que temos 
em mente; um algoritmo desenvolvido num computador é a sequência de processos que previamente pensamos; e por aí vai.

Contudo, quando pensamos em informação, quase sempre nos vem à mente códigos escritos, sejam em forma de letras, sejam como números. Nem sempre damos valor à informação oral, pois ela tende a se dissipar mais rapidamente com o passar do tempo (embora seja incontestável a importância da figura do aedo grego - pessoa responsável por narrar oralmente as histórias de seu povo - por exemplo). E também não devemos nos esquecer que somos bombardeados diariamente com dezenas de milhares de informações invisíveis, tais como ondas de rádio e TV, além de internet Wi-Fi e sistemas de telefonia móvel. Se tivéssemos uma visão capaz de enxergar todas informações que nos perpassam a cada instante, certamente veríamos um mundo admiravelmente novo!

Mas nem sempre as informações são como as conhecemos. Por exemplo, James Gleick nos conta as aventuras do capitão inglês William Allen na África por volta de 1840. Certo dia, enquanto navegava o rio Níger com o objetivo de interferir na atividade dos traficantes de escravos, Allen observou o comportamento de seu piloto camaronês, a quem chamava Glasgow, e fez a seguinte anotação em seu diário:

De repente, ele se mostrou completamente alheio, e assim permaneceu, concentrado no que estava ouvindo. Quando foi chamada sua atenção, ele disse: "Você não ouve meu filho falar?". Como não estávamos escutando nenhuma voz, perguntamos a Glasgow como ele sabia daquilo. Ele respondeu: "Tambor me falou, me diz subir no convés". Isso pareceu ser bastante singular. (GLEICK 2013: 22)

William Allen testemunhou aquilo que o escriturário da Companhia Real Africana Francis Moore já havia visto em 1730, enquanto navegava o rio Gâmbia: a África subsaariana possuía um intricado sistema de informação, de transmissão de mensagens, por meio do batuque de tambores. Cada vilarejo possuía seus tambores e os sons podiam percorrer mais de 150 quilômetros em questão de uma hora devido a um sistema simples: as mensagens dos tambores eram replicadas de vilarejo a vilarejo até chegar ao destinatário. Esse tipo de transmissão de informação era totalmente desconhecido pelos europeus: impossível não lembrar a anedota que Suetônio nos conta ao mencionar o fato de que, muitas vezes, Júlio César chegava antes de seu mensageiro enviado para anunciar a sua vinda. No entanto, curiosamente, o primeiro grande sistema de transmissão de 
informações no Ocidente foi baseado em percussões também, utilizando o batuque eletromagnético pulsante percorrendo o fio do telégrafo: o código inventado por Samuel F. B. Morse em 1841 (GLEICK 2013: 27).

Tudo bem. Olhando por essa perspectiva, a informação parece toda hora migrar de mídia. Tambores, eletricidade, ondas de rádio, internet sem fio... Ela se origina em um corpo, mas não necessariamente fica atrelada a ele. Isso, em minha opinião, é fundamental saber quando lidamos com transmissão de informações: cada vez mais estamos ficando libertos de receptáculos de informação. Ainda somos as máquinas de sobrevivência regidas por genes, tal como Richard Dawkins propõe, mas até mesmo isso estamos sendo capazes de modificar. Muito em breve deixaremos de ser humanos e passaremos a ser "algo além de humano", seremos pós-humanos. Estamos perdendo nossos corpos como os conhecemos. E, consequentemente, nossas informações estão sendo remodeladas.

Pensando bem, o Doutor sempre se regenera em outro corpo quando está morrendo e, assim, continua a viajar com sua TARDIS pelo tempo e espaço. Mas como essa modificação tão importante das informações começou? Houve algum período em que os homens perceberam que a informação está perdendo seu corpo (seja ele qual for, orgânico ou sintético)? Certamente houve. Estamos falando da cibernética. Graças a essa área de pesquisa iniciada em meados do século XX, hoje podemos estudar - e adentrarmundos virtuais. Não pretendo neste trabalho pormenorizar profundamente a história da cibernética - que, por sinal, é fascinante! - mas, sim, apresentar as ideias básicas que nos

ajudarão a relacionar a Arqueologia com a Realidade Virtual (ou Computação; ou Engenharia). O caminho não é curto, então, sem mais demora, comecemos.

\section{A PRIMEIRA ONDA CIBERNÉTICA}

A primeira onda (ou fase) cibernética, segundo a crítica literária pós-moderna $\mathrm{N}$. Katherine Hayles (1999), durou de 1945 até 1960, e foi marcada pelo conceito central de homeostase.

Ao tratarmos sobre o início dos estudos cibernéticos, somos obrigados a recorrer às Macy Conferences on Cybernetics, ocorridas entre 1946 e 1953 em Nova York, Estados Unidos. Essas conferências reuniam especialistas de diferentes áreas do mundo 
todo em discussões bastante acaloradas e que representavam o sonho de qualquer acadêmico: não era necessário submeter artigos completos para participar das conferências, tudo ocorria em um tom mais informal.

A primeira Macy Conference versou sobre o triunfo da informação sobre a materialidade. O matemático húngaro John von Neumann e o matemático estadunidense Norbert Wiener apresentaram suas ideias sobre o fato de que, na equação homemmáquina, a entidade mais importante era a informação, não a energia. Mostraram como era central em um sistema a quantidade de informação que o percorria e quão rápido o percorria. Ao enfatizar esse aspecto informativo no lugar do energético, Wiener deixou claro que o elemento fundamental é a mensagem, e que o elemento fundamental da mensagem, por sua vez, é a decisão. Controle a informação e o poder irá surgir.

Mas o que seria a informação para Wiener, nesse caso? Ele tomou como referência (ou melhor, digamos que ele pensou ao mesmo tempo, já que era reconhecidamente uma pessoa bastante orgulhosa) o conceito de informação proposto por Claude Shannon: $a$ informação é uma função de probabilidade que não tem dimensões, não tem materialidade, e não necessariamente tem conexão com significado. Para simplificar, a informação, entendida por Wiener, representava uma escolha, uma decisão. Vou tentar simplificar usando o exemplo citado por Katherine Hayles (1999: 52): você faz uma ligação telefônica e a voz programada pergunta se o número que deseja está entre 1 e 16 . Caso positivo, tecle 1; caso negativo, tecle 0 . Usando esse mesmo esquema binário, respondemos às perguntas se o número está entre 1 e 8 , e depois entre 1 e 4, e, por fim, entre 1 e 2. Desse modo, o programa sabe que o número tem de ser 3 ou 4 e pergunta: "Se for 3 , tecle 1 ; se for 4, tecle 0" - falando o número final em seguida. Usando essas divisões binárias, precisamos de cinco respostas para comunicar nossa escolha. E nossa decisão pode ser traduzida em informação quando aplicamos a teoria da probabilidade a ela; assim:

$$
E=\log _{2} n
$$

Sendo $E$ o número binário de escolhas necessárias para identificar um elemento entre um conjunto temos, em nosso caso, o seguinte:

$$
E=\log _{2} 32=5
$$


São cinco as escolhas que tivemos de fazer, como dito acima. E Norbert Wiener definiu informação $I$ como o logaritmo do número $n$ de elementos no conjunto da mensagem:

$$
I=\log n
$$

Mas não se assuste, leitor! Se, assim como eu, você for da área de Humanidades e seus conhecimentos de matemática forem tão profundos quanto uma colher de café, o mais importante não é compreender as fórmulas acima, mas o significado: decisões formam informações. Recorda-se o que eu disse sobre o conceito de informação que emprego neste trabalho? Assim sendo, a informação continua a ser algo que se forma na mente, mas que nós escolhemos o quê será formado.

Acredito, porém, que nesse momento você já esteja se perguntando há muito tempo o que é cibernética, afinal. Guarde bem o que foi dito até aqui, pois iremos retomar logo a seguir. Por ora, cabem parênteses para explicar a cibernética na ótica de seu fundador, Norbert Wiener.

(Em 1950, Wiener publicou aquela que se tornaria obra de referência quando falamos sobre o assunto, Cibernética e Sociedade. O uso humano de seres humanos. Nela, o matemático discorre sobre como a linguagem dos homens pode ser aplicada às máquinas. Wiener começa dizendo que cunhou o termo cibernética para abarcar suas ideias e que a palavra deriva do termo grego kubernetes, ou seja, piloto, timoneiro dos navios; aquele que regula a todo instante o percurso no mar porém, o autor afirma que só depois veio a saber que "cibernética" já havia sido usada por Ampère com referência à ciência política, no século XIX.

Segundo Wiener, a tese de seu livro "é a de que a sociedade só pode ser compreendida através de um estudo das mensagens e das facilidades de comunicação de que disponha; e de que, no futuro desenvolvimento dessas mensagens e facilidades de comunicação, as mensagens entre o homem e as máquinas, entre as máquinas e o homem, e entre a máquina e a máquina, estão destinadas a desempenhar papel cada vez mais importante" (1968: 16). Desse modo, o propósito da cibernética é desenvolver linguagem e técnicas que nos auxiliem com o problema de 
comunicação e controle em geral. A informação gerada nessa comunicação é uma medida de organização, assim como a entropia que veremos mais adiante - é uma medida de desorganização. Wiener diz (1968: 21): "na verdade, é possível interpretar a informação conduzida por uma mensagem como sendo, essencialmente, o negativo de sua entropia e o logaritmo negativo de sua probabilidade". Por fim, ainda podemos encontrar na obra do autor mais quatro conceitos importantes: 1) o feedback ${ }^{3}$, ou seja, retroalimentação de um sistema baseada nos sinais de entrada e saída; 2) o sistema nervoso e as máquinas automáticas são semelhantes pois são aparelhos que tomam decisões baseadas em decisões ocorridas no passado ${ }^{4}$; 3) nenhuma teoria da comunicação pode evitar a discussão da linguagem e, finalmente, 4) a linguagem não é atributo exclusivo dos homens: também pertence às máquinas.)

Fechados os parênteses e deixando claro, de vez, que cibernética para Wiener é um conjunto de decisões em forma de linguagem que geram informações, podemos retomar.

\footnotetext{
3 “Nessa conversação entre as várias partes de uma máquina, é amiúde necessário tomar conhecimento do que a máquina já disse. Aqui entra o princípio de realimentação (feedback), que já discutimos e que é mais antigo que sua exemplificação no mecanismo do governo do navio; em verdade, tão antigo pelo menos quanto o regulador de velocidade da máquina a vapor de Watt. Este regulador impede a máquina de desgovernar-se quando a resistência ao seu trabalho é removida. Quando ela começa a desgovernarse, as bolas do regulador se alçam por ação centrífuga e, ao alçar-se, movem uma alavanca que interrompe parcialmente a entrada de vapor. Destarte, a tendência ao aumento da velocidade produz uma tendência, parcialmente compensatória, à sua diminuição. Tal método de regulagem recebeu uma completa análise matemática às mãos de Clerk Maxwell, em 1868.

"Neste caso, a realimentação é usada para regular a velocidade de uma máquina. No mecanismo de governo do navio, ela regula a posição do leme. $O$ homem à roda do leme põe em movimento um sistema de transmissão leve, que emprega cadeias ou transmissão hidráulica, a qual aciona um componente na sala que contém o mecanismo de governo. Há algum tipo de aparelho que registra a distância entre esse componente e a cana do leme; e tal distância controla a admissão de vapor aos orifícios de entrada de uma máquina de governo a vapor, ou alguma admissão elétrica similar, no caso de uma máquina de governo elétrico. Quaisquer que possam ser as conexões específicas, essa alteração na admissão ocorre sempre numa direção que faz coincidir a cana do leme e o componente acionado pela roda do leme. Destarte, um só homem executa com dificuldade a velha roda do leme movida pela força humana" (WIENER 1968: 149-150).

4 "Os mais simples dispositivos mecânicos têm de decidir entre duas alternativas, como ligar ou desligar uma chave. No sistema nervoso, a fibra nervosa individual também decide entre conduzir ou não um impulso. Tanto na máquina quanto no nervo, há um dispositivo específico para fazer com que as decisões futuras dependam das passadas, e, no sistema nervoso, boa parte da tarefa é realizada naqueles pontos extremamente complicados, denominados 'sinapses', nos quais numerosas fibras nervosas aferentes se ligam a uma única fibra nervosa eferente. Em muitos casos, é possível definir a base dessas decisões como o limiar de ação da sinapse, ou, em outras palavras, dizer quantas fibras aferentes devem deflagrar para que as fibras eferentes possam deflagrar" (WIENER 1968: 34).
} 
Pode-se reparar que a teoria proposta por Wiener (e Shannon) é formulada inteiramente sem nenhuma referência a o quê a informação significa. Por que essa separação? Para que a informação tivesse um valor que permanecesse estável conforme se movia de um contexto para outro (se fosse o contrário, o valor da informação mudaria constantemente, uma vez que significado está sempre atrelado ao contexto). Para simplificar, tomemos, novamente, um exemplo proposto por Hayles (1999: 53): se você estivesse em um escritório sem janelas e me perguntasse como está o tempo lá fora, eu responderia: "Está chovendo"; por outro lado, se estivéssemos ambos na rua sendo banhados por uma chuva torrencial, minha resposta teria outro significado. No primeiro caso, estou dizendo algo que você não sabe; no segundo, estou sendo irônico. Ou seja, uma conceituação de informação que amarre informação ao significado teria dois diferentes valores para duas diferentes circunstâncias, ainda que a mensagem ("Está chovendo") fosse a mesma. Essa definição de informação como uma função de probabilidade tornou-se o cerne da primeira onda de estudos cibernéticos. A teoria da informação proposta dessa maneira simplesmente elimina um problema central: o observador é ignorado dentro de um sistema de comunicação baseado em probabilidades.

No entanto, mesmo tendo sido utilizada pela maioria dos ciberneticistas da época, nem todos concordavam com essa teoria que descontextualizava a informação. $O$ maior exemplo de crítica a esse tipo de ideia veio do pesquisador britânico Donald MacKay, que formulou uma teoria na qual o significado também fosse levado em consideração. $\mathrm{Na}$ sétima Macy Conference, MacKay foi duramente criticado por propor uma teoria em que a subjetividade fosse um fator relevante (até mesmo essencial): até então, somente a objetividade era considerada realmente científica. Em que consistia a teoria de Donald MacKay? Criticando o modo como Shannon calculava a informação (considerando a seleção de mensagens dentro de um conjunto), dizendo que esse tipo de informação seletiva não era o bastante, MacKay formulou o conceito de informação estrutural, que indica como a informação seletiva deve ser entendida, ou seja, é sobre como uma mensagem interpreta outra mensagem: em outra palavra, metacomunicação. Para facilitar a compreensão, digamos que eu chegue, vestindo minha camisa do Corinthians, a um grupo de amigos palmeirenses que discutem futebol e fale em alto e bom som: "O time do Palmeiras foi Campeão Mundial!’. Todos ficarão sérios. Então, para tentar salvar o momento, eu emendo: “Ah, é só uma piada!”. Considerando-se que eu saia vivo dessa 
situação, o que acabei de fazer foi uma metacomunicação: eu indiquei que a mensagem anterior tinha outro tipo de estrutura que não a inicial.

MacKay inverteu os valores ditados por Shannon e Wiener. Estabelecendo uma correlação entre natureza e efeito, o ciberneticista construiu um modelo em que reconhece a constituição mútua de forma e conteúdo, de mensagem e receptor (HAYLES 1999: 56). A contribuição de MacKay foi enorme, uma vez que triangulou reflexividade (grosso modo, o papel do observador no sistema), informação e significado, diferenciando-se bastante da teoria Shannon-Wiener. Mas - e sempre existe um "mas" para negar tudo o que foi dito anteriormente - suas ideias esbarraram em um grave problema: como quantificar a sua proposta. Donald MacKay não conseguiu produzir nenhum modelo matemático convincente para as mudanças da mensagem engatilhada na mente do receptor/observador, e isso fez com que sua teoria não fosse amplamente difundida entre os engenheiros elétricos de sua época. Não devemos nos esquecer, contudo, que o embate acadêmico não se limita apenas aos resultados das pesquisas: o que a primeira onda da cibernética assistiu foi à "divisão" entre estadunidenses (Shannon e Wiener) e britânicos (MacKay). Foi uma disputa praticamente regional/ideológica que, ainda hoje, nós todos presenciamos na Academia, seja a qual área pertençamos.

Porém, mesmo com a "derrota" de MacKay no âmbito norte-americano, suas ideias não foram totalmente descartadas. Em 1968, o governo dos EUA enviou um memorando ao neurofisiologista e ciberneticista Warren McCulloch a fim de que ele revisasse as ideias de Donald MacKay. Em seus apontamentos, McCulloch bem observou que, enquanto Shannon e Wiener definem informação nos termos do que ela é, MacKay a define nos termos do que ela faz (HAYLES 1999: 56). Essa dicotomia deixou bem claro que se começava a tomar forma uma das rivalidades mais profícuas da história da cibernética: a homeostase e a reflexividade. Tornar a informação em algo a coloca ao lado da homeostase (ou seja, a informação pode ser transportada de um meio para outro mantendo seu valor quantitativo estável); torná-la uma ação, a aproxima da reflexividade. Segundo N. Katherine Hayles (1999: 57): "Homeostase venceu com folga na primeira onda da cibernética porque ela era mais manuseável quantitativamente. Reflexividade perdeu porque a especificação e delimitação do contexto rapidamente se tornou um projeto não manuseável".

A contribuição de McCulloch à cibernética não parou na observação dessa dicotomia. Se os humanos são máquinas de informação e processamento como alegavam 
os estudiosos das Macy Conferences, então algo dentro de nossos corpos nos permitia processar o código binário responsável pelas decisões. Esse "equipamento biológico" foi encontrado no modelo de Warren McCulloch e Walter Pitts para o neurônio, sendo utilizado como metáfora para explicar as conexões entre circuitos neurais relativamente simples e as complexidades da experiência corporificada. O neurônio McCulloch-Pitts tem entradas que podem ser estimuladoras ou inibidoras. $\mathrm{O}$ neurônio só dispara se a quantidade de estimulação for maior do que a de inibição. Estando os neurônios conectados em forma de rede, eles são capazes de atuar como proposições lógicas. Vejamos alguns exemplos: se os neurônios A e B estão conectados ao neurônio C e ambos são necessários para que o $\mathrm{C}$ dispare, então podemos fazer a seguinte proposição: "Se A $e$ B são verdadeiros, então C é verdadeiro"; se o neurônio A e o B podem disparar o neurônio C, dizemos que "Se A ou B são verdadeiros, então C é verdadeiro"; por fim, se o neurônio B é inibidor e o neurônio C disparar na entrada do neurônio A somente se o B não disparar, podemos dizer que " $\mathrm{C}$ é verdadeiro somente se A é verdadeiro e $\mathrm{B}$ não for verdadeiro" (HAYLES 1999: 58). Ou seja, os neurônios agem de acordo com a lógica booleana e isso permitiu (e permite) aos estudiosos aplicarem modelos matemáticos para inferir resultados: os cérebros computam pensamentos do mesmo modo que os computadores calculam números.

Transformar o corpo em um fluxo de código binário pulsando através dos neurônios foi um passo essencial para se ver o ser humano como um padrão informacional. Em contexto, essa transformação pode ser vista como uma necessária simplificação que deu uma importante contribuição à neurofisiologia. Fora do contexto, ela é extrapolada para a conclusão de que não é diferença essencial entre pensamento e código. (HAYLES 1999: 61)

\section{UM RATO E UM HOMEOSTATO}

A cibernética não teria resistido tanto ao tempo se ficasse apenas no plano teórico. Além de dialogarem nas Macy Conferences, os participantes apresentavam trabalhos práticos, que corroboravam os estudos teóricos. Dois casos bastante famosos e elucidativos de aplicações cibernéticas pertenceram a Claude Shannon e W. Ross Ashby. 
Claude Shannon desenvolveu um rato eletrônico. O aparato consistia em um grande quadrado dividido em 25 quadrados menores: em qualquer um dos quadrados era possível fixar o sensor elétrico que reconheceria o alcance do objetivo, e a função do rato eletrônico era caminhar pelo traçado labiríntico aprendendo com seus erros e acertos até chegar ao sensor. De acordo com o experimento de Shannon, "pressuposições corporificadas no rato eletrônico incluem a ideia de que humanos e máquinas cibernéticas são mecanismos de busca que aprendem, por meio de um feedback corretivo, a alcançar um estado estável” (HAYLES 1999: 65). Sendo assim, ambos - máquinas e humanos são processadores de informação que tendem à homeostase quando funcionam corretamente.

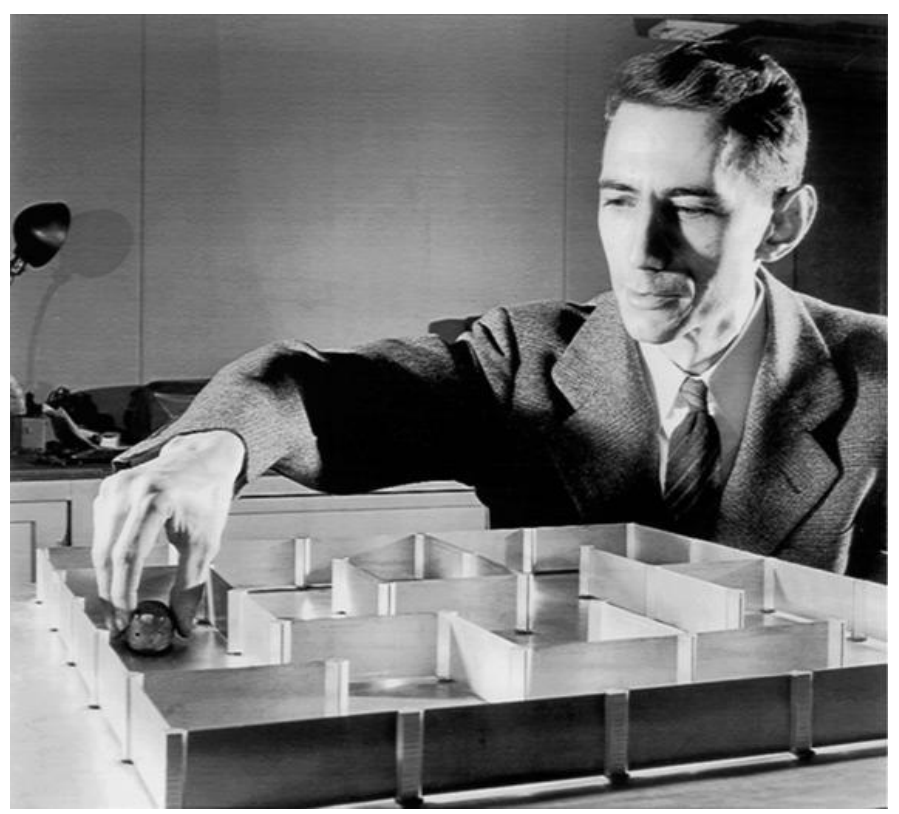

Fig. 3 - Claude Shannon e seu rato eletrônico (in: http://thecharnelhouse.org/2013/09/10/anaddendum-on-architecture-and-habituation).

A homeostase, por sua vez, foi mais bem ilustrada com o aparelho desenvolvido pelo psiquiatra inglês W. Ross Ashby, o homeostato. Ele era um dispositivo eletrônico construído com transdutores (dispositivos eletrônicos que transformam um sinal de entrada em outro; por exemplo: uma antena de televisor) e potenciômetros (resistores reguláveis). Ao receber um sinal de entrada que mudasse seu estado prévio, o aparelho buscava por uma configuração de variáveis que pudessem retorná-lo à condição inicial. Se isso tudo for muito complexo de se imaginar, lembre-se do estabilizador conectado ao seu computador. Qual a função dele? Regular a entrada de energia, controlando os picos de tensão a fim de sempre manter a saída de alimentação constante em 110 ou 220V. 
O homeostato de Ashby foi apresentado como um modelo de organismo que buscava manter as variáveis essenciais dentro de limites pré-estabelecidos a fim de se sobreviver. Interessantemente, Ashby concebeu seu homeostato como um dispositivo regulador que incluía organismo e ambiente (e esse tipo de pensamento, não surpreendentemente, vai também adentrar a corrente Processualista da arqueologia nessa mesma época). Com seu aparelho, W. Ross Ashby reforçou as ideias em voga de que: 1) os humanos são mecanismos que respondem a seus ambientes tentando manter a homeostase; 2) a restrição para se criar máquinas inteligentes reside em formular os problemas de modo correto; e 3) um conceito de informação que privilegia a exatidão sobre o significado serve melhor a um modelo de construção do que um conceito de informação impreciso (HAYLES 1999: 67).

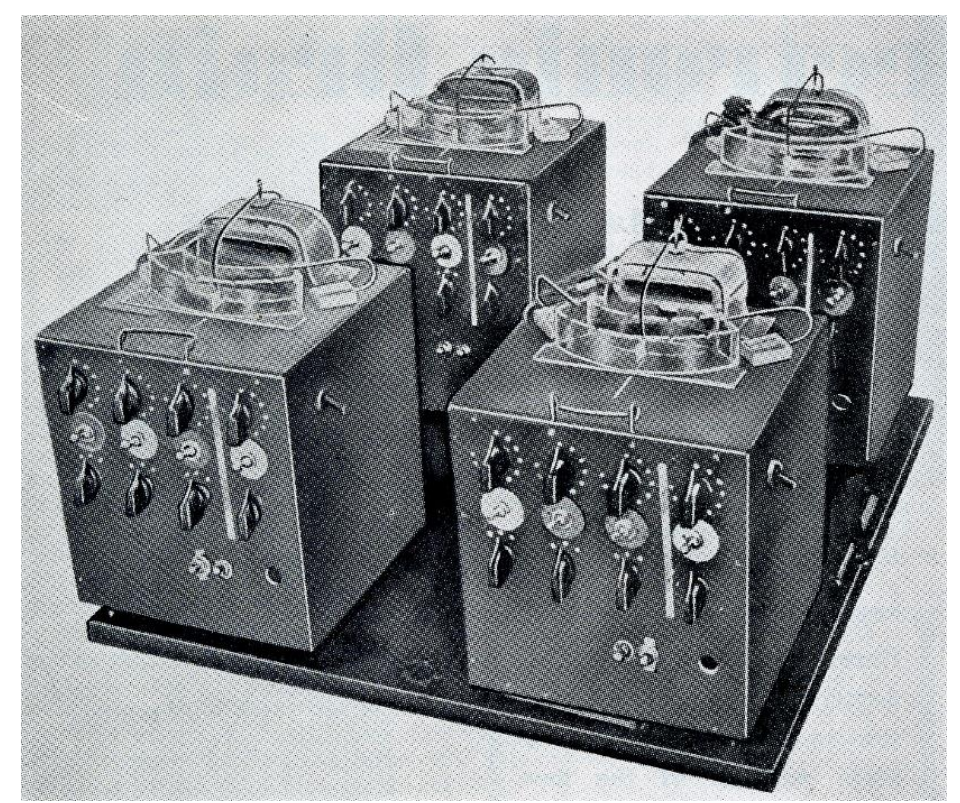

Fig. 4 - O homeostato (in: http://www.vintagecomputer.net/electronic_brain).

Entretanto, essas ideias não passaram muito tempo sem críticas, mesmo com o fim das Macy Conferences, em 1953. Os pensamentos de Donald McKay e Warren McCulloch reverberavam entre os participantes: a reflexividade ganharia novo fôlego Gregory Bateson organizou uma conferência a fim de explorar as implicações reflexivas da cibernética: para ele, não mais a homeostase se encaixava como modelo de pesquisas - essa descontextualização não trazia nenhum avanço científico; ao contrário, representava uma distorção sistemática. Abriam-se, então, os braços para o observador. 


\section{A SEGUNDA ONDA CIBERNÉTICA}

Falar sobre a segunda onda da cibernética é discutir reflexividade, é analisar o observado e o observador. Entre 1960 e 1985, esse tema foi recorrente entre os especialistas, principalmente ao se orientarem por meio dos trabalhos dos biólogos chilenos Humberto Maturana e Francisco Varela.

A ligação entre a primeira e a segunda ondas cibernéticas foi realizada pelo cientista austríaco radicado nos EUA Heinz von Foerster, colega de Warren McCulloch. Em sua obra Observing Systems, von Foerster desenvolveu com mais profundidade as implicações epistemológicas sobre a inclusão do observador como parte do sistema. Uma das questões centrais em seu trabalho era responder à pergunta: "Como sabemos que a outra pessoa existe?". Segundo ele, nós tomamos conhecimento do outrem porque o experimentamos em nossa imaginação. Essa experiência nos leva a acreditar que a outra pessoa, tal como nós, também nos experimenta em sua imaginação. As ideias de von Foerster, assim, estão conectadas ao solipsismo, ou seja, a crença de que, além de nós, só existem nossas experiências. Porém, se pensarmos sobre o que foi dito, logo chegamos à conclusão de que a proposta de Heinz von Foerster não tem um caráter muito rigoroso: quem garante que, ao ver ou interagir com outra pessoa, ela não esteja pensando sobre o episódio 10 da temporada 5 de Doctor Who ao invés de me conceber em sua imaginação? $\mathrm{Na}$ verdade, dependendo da conversa, realmente seja mais interessante pensarmos nesse episódio, que é uma linda declaração de amor à obra de Van Gogh.

Convencido sobre a importância da reflexividade na cibernética, von Foerster convidou Humberto Maturana para uma palestra na Universidade de Illinois em 1969, na qual o chileno apresentou a cognição como um fenômeno biológico. Isso foi o bastante para alavancar e aprofundar o trabalho de Heinz von Foerster e fazê-lo, em 1970, criticar abertamente o behaviorismo (estudo psicológico do comportamento humano) em seu artigo "Molecular Ethology: An Immodest Proposal for Semantic Clarification": segundo ele, o foco do behaviorismo deveria migrar do observado para o observador, pois animais não são caixas-pretas que geram saídas previsíveis para entradas dadas - ao invés de buscar por mecanismos no ambiente que transformem organismos em máquinas triviais, devemos achar mecanismos dentro dos organismos que lhes permitam transformar seu ambiente em máquina trivial (HAYLES 1999: 134). Von Foerster, desse modo, estabelece uma ferrenha crítica à epistemologia objetivista. 
Estando Maturana no centro do assunto, é hora de nos debruçarmos sobre seu trabalho e acompanhar a sua própria evolução epistemológica que moldou a reflexividade na cibernética.

Em seu artigo "What the Frog's Eye Tells the Frog's Brain" - escrito em conjunto com Jerome Lettvin, Warren McCulloch e Walter Pitts - Humberto Maturana demonstra que os receptores sensórios da rã falam com o cérebro em uma linguagem altamente processada e específica. Implantando microelétrodos no córtex visual de uma rã, os cientistas mediram a força de respostas neurais a vários estímulos: nesse ponto, o cérebro do animal se torna parte de um circuito cibernético (o cérebro da rã deixou de pertencer a ela apenas), fornecendo retroalimentação ao conjunto. Com esse experimento, os cientistas descobriram que objetos pequenos e rápidos têm máximo retorno neural, enquanto que objetos grandes e lentos evocam pouca ou nenhuma resposta - isso explica porque as rãs são tão boas em caçar moscas, por exemplo. Os resultados do artigo logo o estabeleceram como um clássico, pois deixava claro que o sistema perceptivo da rã não apenas registrava a realidade como a construía. Citando o trabalho: "isso mostra que os olhos da rã falam ao cérebro em uma linguagem já altamente organizada e interpretada ao invés de transmitir alguma cópia mais ou menos correta da distribuição de luz sobre os receptores" (LETTVIN et al. 1959: 1950). Esse artigo também foi responsável pela máxima estabelecida por Humberto Maturana algum tempo depois: "Tudo o que é dito, é dito por alguém" (MATURANA \& VARELA 2011: 32).

Humberto Maturana, então, afirma que a percepção não é fundamentalmente representacional: falar objetivamente sobre um mundo que existe é um engano, uma vez que um mundo é pré-construído pelo observador. Na tentativa desesperada de tornar esse conceito mais palatável, podemos dizer o seguinte: os sistemas vivos operam dentro dos limites de uma organização que está fechada em si mesma e deixa o mundo do lado de fora.

Ficou mais fácil? Não?! Tudo bem, não é simples explicar as ideias de Maturana e Varela, muito menos entendê-las... E para complicar ainda mais, temos de adentrar o conceito-chave de seus pensamentos, uma palavra de origem grega que é difícil até mesmo de ser pronunciada. Estou falando da autopoiese. 


\section{A (DIFÍCIL) AUTOPOIESE DE MATURANA E VARELA}

Como todo bom cientista, Maturana e Varela cunharam um termo novo que pudesse dar conta de suas ideias. Utilizando o idioma grego, ambos chegaram à palavra autopoiese (ou autopoiesis), que significa “criação própria". Esse termo apareceu em sua grande obra denominada Autopoiesis and Cognition: The Realization of the Living, publicada em 1980. Sete anos depois, visando um público mais leigo, os autores discorreram sobre suas ideias principais em A árvore do conhecimento: as bases biológicas da compreensão humana. A princípio, a iniciativa foi boa, pois tornaria a complexa autopoiese mais fácil de entender. Porém, não foi isso o que aconteceu: se o leitor quiser conhecer esse livro, desejo boa sorte, pois nem escrevendo para os leigos o assunto se tornou mais simples. De qualquer modo, vou tentar aqui esboçar os conceitos centrais relacionados ao tema.

Nas palavras dos autores (2011: 52): “Nossa proposta é que os seres vivos se caracterizam por - literalmente - produzirem de modo contínuo a si próprios, o que indicamos quando chamamos a organização que os define de organização autopoiética". Para exemplificar sua conceituação, Maturana e Varela evocam o plano celular. Primeiramente, todos os componentes moleculares de uma unidade autopoética devem estar dinamicamente inter-relacionados numa rede de interações, tal como acontece no metabolismo celular. Dentro desse metabolismo, há produção de componentes que, por sua vez, integram uma rede de transformações que geram esses componentes. Alguns desses componentes atuam como fronteiras para a rede de transformações, formando a membrana da célula, que deixa de ser parte do metabolismo celular porque, ao mesmo tempo, atua como limitadora da extensão da rede de transformações que produz seus componentes e também participa dessa rede.

O que temos então é uma situação muito especial, no que se refere às relações de transformação química: por um lado, é possível perceber uma rede de transformações dinâmicas, que produz seus próprios componentes e é a condição de possibilidade de uma fronteira; de outra parte vemos uma fronteira, que é a condição de possibilidade para a operação da rede de transformações que a produziu como uma unidade. É importante notar que não se trata de processos sequenciais, mas sim de dois aspectos de um fenômeno unitário. (MATURANA \& VARELA 2011: 53-54) 
Segundo Maturana e Varela, aquilo que caracteriza um ser vivo é a sua organização autopoiética, pois seres vivos diferentes têm estruturas distintas, mas são iguais em organização. A estrutura, para eles, são os componentes e relações que constituem concretamente uma unidade particular e sua organização. Já a organização, é formada pelas relações que ocorrem entre os componentes de algo, tornando possível o seu reconhecimento como membro de uma classe específica. Um exemplo pode ser visto em nossos computadores: sua organização demanda que na placa-mãe estejam conectados componentes corretos que farão o computador funcionar, tais como processador, memória RAM, placa de vídeo, Hard Disk, saídas USB, fonte de alimentação etc. Porém, nós podemos escolher os fabricantes desses componentes e quais as suas características: Vou querer trocar um pente de memória RAM de $8 \mathrm{~GB}$ por um de 2GB? (Se fizer isso, deveria consultar um médico); Meu HD de 1TB não é mais suficiente, então devo comprar outro de 5400 ou 7200 RPM?; Minha placa de vídeo tem cinco anos e quero trocar por outra mais atual (caso verídico: o meu). Enfim, o que importa é que a organização de seu computador tem de ser sempre a mesma para ele funcionar, não importando os tipos (ou seja, a estrutura) de componentes que você espete (mas, repito, não troque 8GB de RAM por 2GB; não faça isso). O mesmo pode ser aplicado aos seres humanos: a nossa organização não muda, independentemente de passarmos por mudanças em nossa estrutura (por exemplo, quando atingimos a puberdade, ficamos doentes ou, no caso das mulheres - até o momento - , quando ficam grávidas).

A autopoiese, então, mostra que seres vivos são sistemas autônomos, pois são capazes de especificar sua própria legalidade, aquilo que lhe é próprio. E agora vem a parte mais interessante disso tudo: por seres vivos, não queremos dizer apenas seres orgânicos! Se todos os sistemas vivos são autopoiéticos, então todos os sistemas físicos, se autopoiéticos, podem ser considerados vivos (HAYLES 1999: 138). Sendo direto ao assunto: as máquinas são seres vivos na ótica da autopoiese. Talvez isso faça com que você tome mais cuidado para não deixar seu smartphone cair no chão, ou pare de esmurrar seu computador quando perder uma partida de Call of Duty: assim como você, eles estão vivos (e conseguem pensar). E pode ficar ainda melhor: de acordo com as ideias de Maturana, o seu carro sempre funciona, independente de dar partida ou não, pois ele sempre opera de acordo com a sua estrutura no momento. Isso é um modo positivo de se ver as coisas, não? 
Pouco após a publicação de A árvore do conhecimento, Maturana e Varela se distanciaram. Francisco Varela, ao contrário de seu colega, repensou suas próprias concepções sobre autopoiese e as reescreveu: o resultado foi visto no capítulo "Describing the Logic of Living: The Adequacy and Limitations of the Idea of Autopoiesis", do livro de 1981 editado por Milan Zeleny, Autopoiesis: a Theory of Living Organization.

Varela criticou a autopoiese por ter ido, ao mesmo tempo, muito longe, mas não tão distante. Ela foi longe demais porque se tornou um paradigma não apenas para organismos biológicos como se estendeu para os sistemas sociais: para o autor, a ideia de produção de componentes não pode ser aplicada livremente a qualquer coisa sem perder o seu valor inicial - jamais poderia ser aplicada a sistemas sociais, uma vez que eles não produzem os componentes que instanciam sua organização: Varela afirma que a autopoiese deveria ficar restrita ao domínio das células e dos animais. Ao mesmo tempo, a autopoiese não foi muito distante na construção de uma ponte entre seus próprios conceitos e a primeira onda cibernética, que enfatizava o fluxo de informação, a teleologia e o comportamento. Francisco Varela escreveu que deveriam ser considerados termos explanatórios válidos a informação, a codificação e as mensagens - desde que ficassem subordinadas à autopoiese (pois ela, sozinha, não consegue explicar satisfatoriamente os fenômenos de natureza lógica $e$ cognitiva).

Em um trabalho mais recente (1991), The Embodied Mind: Cognitive Science and Human Experience, escrito com Evan Thompson e Eleanor Rosch, Varela deu um passo importante para sublinhar a descorporificação da informação. Junto com seus coautores, foi cunhado o termo enaction", que "vê o engajamento ativo de um organismo com seu ambiente como a pedra angular do desenvolvimento do organismo" (HAYLES 1999: 155). A diferença entre autopoiese e enaction pode ser apontada de acordo como ambas as teorias compreendem a percepção. A teoria autopoiética enxerga a percepção como o sistema que responde ao evento disparado no ambiente ao redor. A enaction, por sua vez, enfatiza que a percepção se dá por meio de ações guiadas perceptualmente, ou seja, que o movimento dentro de um ambiente é crucial para o desenvolvimento de um organismo.

No caso da cognição, a autopoiese estabelece que ela ocorre através de uma operação recursiva de um sistema que representa a ele mesmo as suas próprias

\footnotetext{
${ }^{5}$ Por ser um termo de difícil tradução, optei por deixá-lo em inglês. Contudo, a palavra "aplicação" poderia ser empregada, talvez, mas no sentido de "aplicação de uma lei/ordenação/estabelecimento".
} 
representações; já a enaction, ao contrário, vê as estruturas cognitivas emergindo de padrões sensório-motores recorrentes. Assim, "ao invés de enfatizar a circularidade dos processos autopoiéticos, a enaction enfatiza as ligações do sistema nervoso com as superfícies sensórias e habilidade motoras que conectam o organismo ao ambiente" (HAYLES 1999: 156).

A autopoiese de Maturana, porém, foi mais utilizada como base científica durante a segunda onda cibernética do que a enaction de Varela. Embora sendo um conceito de difícil assimilação, a autopoiese foi fundamental para colocar o observador em destaque dentro de um sistema. Ela também ajudou a reconfigurar o Humanismo Liberal em voga até então. A contraposição das leituras de Norbert Wiener e Humberto Maturana sobre o "humano" é essencial para entendermos melhor como a informação está mudando de corpo (ou perdendo-o). Assim, antes de adentrarmos a terceira onda cibernética, convém pormenorizar o assunto.

\section{HUMANISMO LIBERAL: CORPOS EM MUDANÇA}

Um grande amigo meu enfrenta problemas em seu joelho há anos. Ele tocou bateria durante muito tempo e isso gerou um desgaste em sua cartilagem. Desde então, ele se submete a cirurgias e dolorosas injeções locais a fim de fortalecer seus músculos e nervos. Enquanto as pesquisas com células-tronco não se desenvolverem - e calarem, de vez, as alas conservadoras da sociedade - meu amigo sofrerá com as injeções e procedimentos cirúrgicos. Todo processo pós-operatório envolve fisioterapia e o uso de bengala para manter o equilíbrio e sustentação de seu corpo. Isso leva semanas, meses. E durante todo esse tempo ele fica dependente de sua bengala para ter uma vida ativa (e ir aos shows de rock).

A pergunta que faço agora é a mesma que Gregory Bateson fez a seus estudantes durante um curso de graduação: podemos dizer que a bengala é parte de meu amigo?

Segundo o próprio Bateson (1999: 251), sim, ela é. A bengala e ele fazem parte de um mesmo sistema, pois a bengala fornece informações sobre o ambiente para o meu amigo. Do mesmo modo, meus óculos fazem parte de mim (até que eu vença o medo de operar minha miopia), pois graças a eles há trocas de informação entre mim e o ambiente 
que me cerca. Não estamos, então, muito distantes daquilo que foi proposto como ciborgue: a fusão de organismos biológicos e dispositivos cibernéticos. A filósofa Donna Haraway, em seu ensaio "A Manifesto for Cyborgs" (1985), escreveu sobre as potencialidades do ciborgue para romper categorias tradicionais. O ciborgue viola a distinção homem/máquina ao substituir cognição por feedback neural; do mesmo modo, ao explicar o comportamento de termostatos e pessoas por meio de teorias de retroalimentação, estrutura hierárquica e controle, a distinção animado/inanimado desaparece (HAYLES 1999: 84). Os ciborgues também podem causar pesadelos, como no caso de Darth Vader, ou despertar nossa libido, afinal, até mesmo o detetive (androide?) Rick Deckard teve uma noite de amor com a ciborgue Rachael Rosen em Blade Runner, escrito por Phillip K. Dick em 1968.

A cibernética abriu todo um campo novo de pesquisas e permitiu que nossos corpos fossem vistos como constructos passíveis de mudanças radicais e redefinições. "Ao mesmo tempo em que a cibernética estava reconfigurando o corpo como um sistema informacional, ela também esteve apresentando a si mesmo como uma ciência da informação que iria remapear terrenos intelectuais" (HAYLES 1999: 85). Contudo, Norbert Wiener, o pai da cibernética, ficou reticente com relação aos avanços da área nos campos sociais e humanísticos. Ao invés de apoiar todas as novas ideias que surgiam a todo instante, Wiener viu-se frente a frente com questões perturbadoras: Onde a dissolução cibernética das fronteiras deveria parar? Em que ponto a ansiedade provocada pela dissolução superou o êxtase? Essas indagações marcaram a obra de Norbert Wiener, que ilustra as dinâmicas complexas envolvidas na criação do ciborgue durante o período fundacional da cibernética, entre 1940 e 1950.

Em seu trabalho, ao falar sobre as relações igualitárias entre homem e máquina, Wiener reforçou os valores do humanismo liberal, a saber: um ser coerente e racional; o direito desse ser à autonomia e liberdade; senso de agência ligado à crença de um esclarecido autointeresse. Embora frisasse esses aspectos em seus escritos, isso não impediu Wiener de trabalhar com as Forças Armadas estadunidenses durante a Segunda Guerra Mundial a fim de aperfeiçoar máquinas que matassem seres humanos - ele aplicou a cibernética aos radares de autoajuste, à artilharia antiaérea automatizada e aos misseis guiados.

Mas esse sujeito humano liberal enfrentava problemas para existir dentro dos próprios conceitos elaborados por Norbert Wiener. Segundo o autor, o homem é um 
organismo feito de células que, em alguns casos, também funcionam como organismos, deixando evidente que o fluxo de informações acontece em múltiplos níveis hierárquicos. Pois bem, se assim o somos, então, novamente, podemos evocar o gene egoísta de Richard Dawkins - não passamos de máquinas de sobrevivência guiadas por DNA e RNA: somos uma realidade cibernética. Desse modo, o grande perigo da cibernética, de acordo com Wiener, é que ela pode potencialmente aniquilar o sujeito liberal como centro de controle, ele deixará de ter agência no mundo. Katherine Hayles resume bem o papel de Wiener com relação ao humanismo liberal (1999: 112):

Visto em uma perspectiva histórica, Wiener não obteve sucesso em conter a cibernética dentro do círculo de valores do humanista liberal. Somente por um breve período, no fim de 1940 e início de 1950, a dinâmica tensão entre cibernética e sujeito liberal pôde se manter (...). Pelos anos 1960, a ligação entre humanismo liberal e autorregulação uma ligação estabelecida pelo Iluminismo do século XVIII - já estava bastante fraca; pelos anos 1980, ela estava largamente rompida. É crédito de Wiener ele ter tentado criar uma versão de cibernética que pudesse aumentar a liberdade humana ao invés de subvertê-la. Mas ninguém, nem mesmo o pai da disciplina, pode ter controle total sobre o quê a cibernética significa quando ela se propaga por meio da cultura promiscuamente. Ainda que a cibernética tenha perdido a chance de ser uma ciência universal, suas premissas estiveram em mutação e reprodução em outros lugares. As vozes que falam ao ciborgue não falam como únicas, e as histórias que elas contam são bem diferentes daquelas narrativas que Wiener lutou para autorizar.

Humberto Maturana, por sua vez, ajudou a reconfigurar o sujeito humanista liberal. Criticando a primeira onda cibernética (que atribuiu propriedades biológicas às máquinas), Maturana focou o modo como a vida era definida pelos primeiros ciberneticistas, não a ideia de que as máquinas possam ter vida: seus argumentos foram contrários à concepção de John von Neumman sobre uma máquina auto reprodutora segundo o biólogo chileno, faltou a von Neumman a modelagem dos fenômenos de reprodução celular, hereditariedade e genética para se dizer, de fato, que a máquina seria um sistema vivo: ou seja, a máquina de von Neumman não possuía processos autopoiéticos. Mais uma vez, vemos aqui a diferença marcante entre a primeira e a 
segunda onda da cibernética: enquanto para Wiener e seus colegas o comportamento era o mais importante, para Maturana o que contavam eram os processos autopoiéticos geradores de comportamentos (HAYLES 1999: 140-141). Tomando-se como exemplo o homeostato de Ross Ashby, na perspectiva de Maturana, ele seria bastante falho ao apenas se comportar ciberneticamente, pois não era capaz de produzir os componentes que estruturavam sua organização.

Tal como na primeira onda cibernética, as questões de formação de limites/fronteiras também estavam sob o holofote da segunda onda. As fronteiras são cruciais para a formação da subjetividade. Contudo, ao contrário do que propalava Norbert Wiener sobre o fim da autonomia do sujeito liberal, a autopoiese de Maturana tem entre seus principais efeitos assegurar aos sistemas vivos suas qualidades autônomas e individuais. Mas quanto de autonomia os sistemas autopoiéticos retêm para si mesmos? E quanto de autonomia eles exigem dos sistemas nos quais estão estruturalmente inseridos? Em uma perspectiva teórica autopoiética, o horror de Wiener ao "ser humano ser forçado a agir como uma engrenagem em uma máquina é um sistema que é capaz de agir autopoieticamente ao invés de alopoieticamente" (HAYLES 1999: 142). Fica mais fácil entendermos o conceito de alopoiese (do grego alo, "diferente" e poiesis, "criação") proposto por Maturana e Varela por meio de um exemplo citado por N. Katherine Hayles (1999: 141): quando dirigimos um carro, seus componentes internos estão bem estabelecidos e estruturados, funcionando, o conjunto, autopoieticamente; porém, se pensarmos nos pistões dentro do carro, eles estão utilizando a energia da queima de combustível não para repararem a si próprios mas, sim, para que haja força o suficiente para nos movimentarmos e fazermos curvas a fim de chegarmos aos nossos destinos, ou seja, estão agindo de forma diferente do que o objetivo de autorreprodução proposto pela autopoiese - estão agindo alopoieticamente. Percebem-se, assim, resquícios do humanismo liberal do século XVIII nas ideais de Maturana: os homens continuam autônomos quando em relação ao ambiente que os cerca.

No entanto, há uma ruptura clara com o Iluminismo quando analisamos a visão de Maturana sobre a objetividade. De acordo com a autopoiese, não há separação entre ciência e ética, ou seja, ela rejeita a dicotomia cientista-observador/mundo observado. Para Maturana, observar não é tornar o observador distante do que está sendo observado, ao contrário: o observador somente consegue observar porque está estruturalmente ligado ao fenômeno que vê. E essa autonomia do observador, embora em um primeiro momento 
possa se assemelhar muito com aquela proposta por Wiener (liberal), teve uma mudança significativa. Segundo Hayles (1999: 143):

Autonomia como Maturana a concebeu não é coerente com o laissezfaire capitalista; não é coerente com a ideia de que cada pessoa é por si só e o Diabo contra todos; e não é coerente com a posição ética de que a ciência poderia executar um programa de pesquisa sem estar preocupada sobre como os resultados da pesquisa seriam usados. Nesses casos, o individualismo e autonomia de Maturana desafiam as premissas imbuídas na subjetividade liberal (...).

Essa contestação da subjetividade liberal fica mais clara quando levamos em conta o observador de Maturana, que o define como "um sistema vivo e que, qualquer entendimento de cognição como um fenômeno biológico, deve considerar o observador e seu papel nesse fenômeno" (2010: 48). Mas é importante deixar claro que, dentro dessa reflexividade, a figura do observador, para Maturana, não tem profundidade psicológica ou especificidade. $\mathrm{O}$ observador de Maturana é muito próximo ao proposto por Einstein em sua teoria da relatividade: o observador é aquele que vê-qualquer indivíduo de qualquer espécie que ocupe essa posição poderia ver mais ou menos a mesma coisa. Embora as percepções do observador construam a realidade mais do que passivamente a percebam, essa construção depende mais do posicionamento do que da personalidade. Assim sendo, na teoria autopoiética o oposto de objetivismo não é o subjetivismo, mas o relativismo!

O leitor que conseguiu chegar até aqui deve se perguntar agora: como o observador, então, é produzido se os processos conscientes e inconscientes não são importantes para Maturana? Deixemos que ele mesmo responda (2010: 14):

Tornamo-nos observadores por meio de representações de nossas interações geradas repetidamente, e por interagirmos com muitas representações simultaneamente nós geramos relações com as representações que podemos interagir e repetir esse processo recursivamente, assim permanecendo mais no domínio das interações do que no da representação.

Desmotivador tentar entender isso, não? Lemos três, quatro vezes e ainda assim é difícil entender... Felizmente, N. Katherine Hayles (1999: 143) apresenta uma luz ao fim do túnel: o sistema observador é um tipo particular de unidade autopoiética que é capaz 
de gerar representações de suas próprias interações; quando esse sistema interage recursivamente com essas representações, ele se torna o observador. O sistema pode, então, recursivamente gerar representações dessas representações e interagir com elas, chegando a um pensamento do observador muito próximo de: "Eu sou um sistema observador observando a ele mesmo se observando". Enfim, caso não tenha ajudado muito com a explicação de Hayles, o importante frisar é: a reflexividade de Maturana, ao ser capaz de olhar para suas próprias representações, coloca o sujeito humano como um observador. E esse observador, por sua vez, só se torna autoconsciente por meio da linguagem - ele precisa ser capaz de descrever a si mesmo descrevendo a si mesmo. Em outras palavras, para Maturana, a consciência é um epifenômeno (fenômeno causado por outro fenômeno). $\mathrm{O}$ ato de se pensar representa apenas uma fração do total dos processos autopoiéticos, e a autoconsciência representa apenas uma fração do ato de se pensar. Assim, a teoria autopoiética dá à consciência um papel muito mais periférico do que ao individualismo ou à autonomia.

A principal mudança no humanismo liberal, desse modo, se dá pela figura do observador. Enquanto a primeira onda da cibernética tendeu a obscurecer a importância da corporificação e do observador, a segunda onda justamente enfatizou esses atributos. Os filósofos seguidores de Wiener tentaram alienar a informação de seu corpo. A teoria autopoiética, por sua vez, chama a atenção para que a informação é uma abstração que não tem base nos processos físicos corporificados dos sistemas vivos: essa informação não existe sem um corpo a não ser como uma inferência feita por um observador (HAYLES 1999: 149).

Com relação aos ciborgues, a primeira onda cibernética os pintou como amálgamas entre o orgânico e o mecânico. Já a autopoiese usou sua visão estendida sobre a vida para especular se os sistemas sociais estão vivos: o ciborgue para a teoria autopoiética é um estado, não uma espécie mecânico-humana como imaginada por Phillip K. Dick em Blade Runner, por exemplo. Por fim, a autopoiese preserva a autonomia e individualidade características do humanismo liberal, mas enxerga o pensamento como um efeito secundário que surge quando uma entidade autopoiética interage com suas próprias representações (HAYLES 1999: 149).

Resumindo tudo o que foi dito neste item: o corpo da informação continua a ser contestado; o império do ciborgue continua a se expandir; o sujeito liberal, embora ainda 
mais autônomo individualmente, está literalmente perdendo sua mente como sede da identidade (HAYLES 1999: 149).

\section{A TERCEIRA ONDA CIBERNÉTICA}

Eis que, finalmente, chegamos à terceira onda da cibernética: a minha preferida. Desde os anos 1980 essa fase cibernética está trilhando seu caminho. Se os já grandes avanços no campo da cibernética das ondas anteriores eram surpreendentes, na terceira onda se tornam maravilhosos e ainda mais acelerados: a partir dos anos 80 o uso de computadores pessoais aumentou significativamente e, o mais importante, houve reduções relevantes em seus valores - esse fato permitiu que não apenas centros tecnológicos de ponta e universidades liderassem os estudos cibernéticos: usuários "comuns", trabalhando em seus quartos ou garagens em tempo livre, também contribuíram, e estão contribuindo, para os avanços desses estudos. Atualmente, é impossível ignorar os "outsiders" do meio acadêmico: graças a eles pululam diariamente invenções interessantíssimas que, devido à popularização da internet, estão sempre ganhando destaque na mídia, ou rompendo barreiras por meio de ferramentas como o Facebook, Twitter e YouTube.

A terceira onda cibernética enfatiza a evolução do sistema em novas direções, buscando ampliar a auto-organização proposta pela segunda onda para loops (laços) recursivos. E, assim como aconteceu na passagem da primeira para a segunda onda com Heinz von Foerster, o responsável por fazer a ligação entre a segunda e terceira ondas foi Francisco Varela. Como vimos, Varela e Maturana estenderam o conceito de ser vivo para sistemas artificiais. Porém, Varela continuou a trabalhar sobre esse conceito e, juntamente com Paul Bourgine, ajudaram a impulsionar o campo de estudo da Vida Artificial (Artificial Life) ao publicar os textos da First European Conference on Artificial Life em um volume denominado Toward a Practice of Autonomous Systems, em 1992. $\mathrm{Na}$ introdução do livro, Varela e Bourgine afirmaram que as raízes cibernéticas da Vida Artificial (doravante V.A.) estavam na cibernética, mais precisamente em experimentos como o homeostato de Ross Ashby. Do mesmo modo, os autores forneceram outra definição para a autonomia:

(...) refere-se à capacidade básica e fundamental [dos seres vivos] de ser, de afirmarem sua existência e gerando um mundo que é pertinente 
e significante sem ser pré-digerido antecipadamente. Assim, a autonomia de um ser vivo é entendida aqui em respeito a suas ações e o modo como modela um mundo em significâncias. Essa exploração conceituação anda de mãos dadas com o design e construção de agentes autônomos e sugere uma enorme gama de aplicações em todas as escalas, de células às sociedades. (VARELA \& BOURGINE 1992: xi)

Percebemos, então, que essa definição de autonomia difere daquela apresentada por Maturana, a quem a percepção estava ligada diretamente a processos internos do que a estímulos externos. Ao dizerem que a autonomia "modela um mundo em significâncias", Varela e Bourgine deixam claro que a organização do sistema, mais do que permanecer imutável, pode transformar a si mesma por meio de um comportamento emergente (HAYLES 1999: 223).

Contudo, nem todos os pesquisadores da terceira onda concordaram com a visão de Varela sobre a percepção, que fazia com que organismos "descorporificados" fossem o melhor meio de se construir V.A.: enquanto alguns estudiosos se concentravam em simulações, afirmando que a corporificação não era necessária, outros diziam que somente formas corporificadas podiam capturar toda a riqueza da interação dos organismos com o ambiente. Segundo N. Katherine Hayles (1999: 223), o observador, antes posto no centro das atenções pela autopoiese de Maturana, agora era relegado novamente à periferia, mas sem ser varrido de cena - o observador permanece como narrador e narrativa nas histórias sobre V. A.

Christopher G. Langton, cientista da computação estadunidense, foi um dos pais fundadores da V. A.. Durante a década de 1980, Langton se debruçou sobre a temática de como a vida orgânica poderia estar relacionada com a vida artificial e vice-versa. Christopher Langton foi o editor do volume Artificial Life de 1987, que trouxe os trabalhos apresentados em um workshop interdisciplinar sobre síntese e simulação de sistemas vivos ocorrido em Los Alamos, Novo México. Tornando-se um livro-base da área de V.A., dentre inúmeros ensaios, o escrito pelo próprio Christopher Langton é um dos mais relevantes por trazer algumas definições que norteariam o campo de V.A. pelas próximas gerações. 
A conceituação do autor sobre V.A. é clássica e merece ser reproduzida na íntegra aqui (LANGTON 1988: 1):

Vida Artificial é o estudo dos sistemas feitos pelo homem que exibem comportamentos característicos de sistemas vivos naturais. Ela complementa as tradicionais ciências biológicas preocupadas com a análise de organismos vivos ao tentar sintetizar comportamentos parecidos com a vida dentro de computadores e outras mídias artificiais. Ao estender a fundação empírica na qual a biologia está baseada indo além da cadeia de carbono que se desenvolveu na Terra, a Vida Artificial pode contribuir com a biologia teórica ao mover a vida-comoa-conhecemos para dentro de um quadro maior, o da vida-como-elapode-ser.

A V.A., de acordo com as ideias de Langton, enxerga a vida como uma característica da organização da matéria, não como uma característica da matéria que já está organizada. Enquanto a Biologia está interessada na matéria da base da vida, a V. A. está interessada com a forma da base da vida. Ao contrário da Biologia, que tradicionalmente começa do topo - enxergando o organismo como uma complexa máquina biomecânica - e segue analisando de cima para baixo (órgãos, tecidos, células, organelas, membranas e moléculas) em busca dos mecanismos da vida, a V. A. começa da base - enxergando o organismo como uma grande população de máquinas simples - e segue trabalhando sinteticamente até chegar ao topo, "construindo enormes agregados de simples e regulados objetos que interagem uns com os outros não-linearmente no apoio de dinâmicas globais" (LANGTON 1988: 2). Podendo essa técnica de modelagem basetopo ser aplicada a qualquer nível hierárquico de sistemas vivos do mundo natural - por exemplo, modelagem de dinâmicas moleculares em escalas de milissegundos à modelagem de evolução de populações em milênios -, Christopher Langton apontou que a ferramenta ideal para essa abordagem sintética do estudo da vida é o computador.

Outro ponto importantíssimo da V. A. refere-se ao termo "artificial" presente em seu nome. Christopher Langton cita a definição proposta pela monografia de Herbert A. Simon (1969), The Sciences of the Artificial: o objeto artificial imita o real ao apresentar a mesma face ao sistema externo, tornando a imitação possível por causa de distintos sistemas físicos que podem ser organizados de modo a exibir comportamentos idênticos (LANGTON 1988: 3). Assim, a V. A. estuda a vida natural ao tentar capturar a essência 
comportamental dos componentes que constituem um sistema vivo, e dotando um conjunto de componentes artificiais de repertórios comportamentais similares. "Se organizados corretamente, o agregado de partes artificiais deve exibir o mesmo comportamento dinâmico do sistema natural" (LANGTON 1988: 3).

Ao mesmo tempo em que a V.A. ia se desenvolvendo, outra área de pesquisa, fundada em 1956 por John McCarthy, Marvin Minsky, Allen Newell e Herbert Simon durante uma conferência no Dartmouth College (New Hampshire, EUA), estava ganhando novo fôlego: a Inteligência Artificial (Artificial Intelligence).

A Inteligência Artificial (doravante I.A.) sempre teve como o seu Santo Graal o teste proposto por Alan Turing: brilhante matemático e cientista da computação britânico que poderia ter dado contribuições ainda mais significativas para o seu campo de estudo se não tivesse sido levado ao suicídio em 1952 pelo governo inglês por ser homossexual. O teste projetado por Turing - e até hoje não solucionado - visava fornecer uma definição operacional satisfatória de inteligência: basicamente, trata-se de um homem separado de um computador por meio de uma parede; o computador passará no teste de inteligência humana se o interrogador humano, depois de propor algumas questões por escrito, não conseguir distinguir se as respostas escritas obtidas são de outra pessoa ou de um computador. Para conseguir tal feito, os computadores deveriam, segundo Turing, ter as seguintes características (NORVIG \& RUSSEL 2014): processamento de linguagem natural - permitindo ao computador a comunicação em um idioma natural com sucesso; representação de conhecimento - ou seja, armazenar o que se sabe ou ouve; raciocínio automatizado - uso das informações armazenadas para responder questões e obter novas conclusões; aprendizado de máquina - a fim de se adaptar a novas circunstâncias e detectar e extrapolar padrões. Segundo o cientista e futurologista Ray Kurzweil, estamos a muito pouco tempo de assistirmos aos computadores passarem no teste de Turing: mais precisamente, em 2029 as máquinas alcançarão inteligência que confundirá os seres humanos.

A ausência de contato físico entre homem e computador no teste de Turing é deliberada, pois a simulação física de uma pessoa é desnecessária para a inteligência. Mas o que vem a ser "inteligência"? Acredito que a resposta de Kurzweil (2007: 110) seja interessante: "Meu ponto de vista é que a inteligência é a capacidade de utilizar recursos 
limitados de maneira ideal - incluindo o tempo - para atingir (...) objetivos”. E, por mais incrível e estranho que possa parecer, até mesmo em nossa época de internet e Googleficação os recursos são limitados: não temos fontes infinitas de informação para serem utilizadas de modo inteligente. Assim, temos de lidar com o que está diante de nós da maneira mais prática possível a fim de solucionar problemas. A inteligência, então, a meu ver, vai se formando de acordo com os questionamentos que fazemos e com o armazenamento das respostas em nossos cérebros. E também é importante deixar claro que "ser inteligente" é algo extremamente subjetivo: quem é mais sábio, um doutorando que passa dias lendo seus livros e redigindo artigos no melhor estilo publish or perish (publique ou pereça), ou uma pessoa que viaja o mundo e está em contato direto com diferentes culturas? Quem é mais inteligente, um jogador de futebol que precisa tomar decisões em milésimos de segundos ou um xadrezista que pode demorar alguns minutos para decidir qual movimento fará no tabuleiro? Enfim, são questionamentos aos quais as respostas dependerão exclusivamente da subjetividade de cada um de nós. Subjetividade esta que também está ligada a nossa inteligência.

Mas retornando à I.A., pode-se apontar que ela e a V.A. têm um objetivo em comum, o estudo da geração de comportamentos complexos, mas que ambas diferem em relação ao modo com o qual a tecnologia da computação é empregada para se chegar aos resultados. Christopher Langton (1988: 38) escreveu sobre essa diferenciação:

I.A. tem baseado sua metodologia para gerar comportamento inteligente no paradigma computacional. Isso é: a I.A. usa a tecnologia da computação como um modelo de inteligência. A V.A., por sua vez, tenta desenvolver um novo paradigma computacional baseado nos processos naturais que suportam os organismos vivos. Isso é: a V.A. usa a tecnologia da computação como uma ferramenta que explora as dinâmicas das estruturas interativas de informação. Ela [a V.A.] não adota o paradigma computacional como metodologia de geração de comportamento, nem tenta "explicar" a vida como se fosse um programa de computador.

Apesar de abordaram a mesma problemática sob óticas diferentes, a V.A. e a I.A. conseguem trabalhar juntas em áreas como a neurociência e a robótica. Dentre os roboticistas, Hans Moravec e Rodney Brooks são dois dos pioneiros e mais conhecidos pesquisadores da área. Analisando como o ser humano será reconfigurado em face aos 
corpos artificiais de informação, Moravec privilegia a consciência como a essência do ser humano e a quer preservar intacta; Brooks, entretanto, afirma que a propriedade essencial dos seres humanos é a habilidade de se movimentar e interagir com o ambiente ao redor (HAYLES 1999: 235). Embora tendo orientações diferentes, ambos enxergam o futuro humano intrinsicamente conectado à Vida Artificial: segundo eles, a distinção entre vida natural e artificial, em breve, não mais existirá - será muito difícil ou impossível distinguir inteligência de homens e máquinas. Hans Moravec, no prólogo de seu famoso livro Mind Children: The Future of Robot and Human Intelligence, rabisca algumas palavras sobre o futuro da humanidade. Por ser uma escrita tão apaixonada - e por eu gostar tanto daquilo que está escrito - reproduzo aqui um excerto que, embora longo, é cativante (1992: 9-10):

Envolvidos, desde há milhares de milhões de anos, numa corrida inexorável aos armamentos, no calor de uma batalha fratricida infindável, os nossos genes acabaram, finalmente, por ser ultrapassados por eles próprios. Produziram uma arma tão poderosa que acabará por aniquilar, do mesmo modo, vencedores e vencidos. Este dispositivo não é a bomba de hidrogênio - o uso indiscriminado de armas nucleares apenas atrasaria a extinção que acaba de ser engendrada, que é de longe bem mais interessante.

Aquilo que se aguarda não é o esquecimento total, mas antes um futuro que, do nosso ponto de vista, pode, com mais propriedade, ser descrito pelas expressões "pós-biológico" ou mesmo "sobrenatural". Trata-se de um mundo cujas últimas consequências para a raça humana, arrasada pela vaga de mudanças culturais, destronada pela própria descendência constituída por criações artificiais, ainda não são conhecidas, mas relativamente ao qual não só são já previsíveis, como até já foram dados muitos passos intermédios. Hoje as nossas máquinas são ainda criações simples, carecem dos mesmos cuidados paternais e das mesmas atenções que qualquer recém-nascido, mal merecendo, por isso, ser qualificadas de "inteligentes". Porém, ao longo, do próximo século amadurecerão, tornar-se-ão entidades tão complexas como nós, acabando por transcender tudo aquilo que conhecemos - serão criaturas de quem nos orgulharemos quando se identificarem como nossos descendentes. 
Libertos do passo de caracol característico da evolução biológica, os rebentos da nossa mente irão ao encontro dos desafios imensos e fundamentais do universo mais vasto. Nós, humanos, nos beneficiaremos durante algum tempo do seu labor, mas, mais cedo ou mais tarde, à semelhança dos filhos naturais, eles partirão em busca do próprio destino, enquanto nós, pais idosos, nos desvaneceremos silenciosamente. Muito pouco se perderá nesta passagem de testemunho - os nossos descendentes artificiais serão capazes, e terão toda a vantagem em fazê-lo, de se lembrar de quase tudo a nosso respeito, talvez até do funcionamento pormenorizado de mentes humanas individuais.

Na visão de Moravec, a Era da vida baseada em cadeias de carbono está perto de seu fim: seremos substituídos por máquinas inteligentes como formas de vida dominante no planeta. Se essas vidas artificiais irão transcender ou não o Vale da Estranheza (Uncanny Valley) apontado por Masahiro Mori em 1970 ainda não sabemos, mas para que haja convivência minimamente pacífica entre homens e robôs estes terão de vencer a barreira da ojeriza que sentimos por seres que se assemelham demais a nós mesmos (uma ótima discussão sobre esse assunto está presente no filme A. I. Inteligência Artificial, dirigido por Steven Spielberg em 2001).

Diferentemente daqueles pesquisadores que trabalham com carne (os que estudam V.A.), os que trabalham apenas no campo da computação enxergam a complexidade do corpo de outra maneira. Para estudiosos da I.A., como o cientista cognitivo estadunidense Marvin Minsky, por exemplo, a corporificação não é relevante. Afirmando que somente com o advento das linguagens de computação é que passou a existir um modo simbólico de descrição para dar conta dos seres humanos, Minsky diz que uma pessoa não é cabeça, pernas e braços: o homem é um enorme processador com muitos milhões de partes pequenas que são arranjadas como milhares de computadores - essa ideia é central em sua obra The Society of Mind. Nela, o autor afirma que essa "sociedade” é (1988: 17)

(...) um esquema no qual cada mente é feita de muitos processos menores. Estes são denominados agentes. Cada agente mental por si mesmo pode apenas fazer coisas simples que não necessitem de mente ou pensamento de modo algum. Porém, ao juntarmos esses agentes em sociedades - de modos muito especiais - isso leva à verdadeira inteligência. 
Os agentes de Minsky são mais facilmente compreendidos por meio do exemplo que ele mesmo cita: o ato de beber chá. Embora pensemos que tudo o que fazemos é pensado e feito por nós, Marvin Minsky diz que, na realidade, são apenas os nossos agentes sem mente atuando. Os seus agentes de "segurar" querem manter a xícara em suas mãos. Os seus agentes de "equilíbrio" fazem com que você não derrame o chá. Os seus agentes de "sede" querem que você beba o chá. E, finalmente, seus agentes de "movimento" querem levar a xícara aos seus lábios. Sozinhos, esses agentes não têm muita serventia. Porém, em conjunto, atuando como uma sociedade, eles nos fazem fazer o que pretendemos (MINSKY 1988: 20).

Ora, esses agentes também podem estar presentes em máquinas artificiais, você não acha? Se assim o for, realmente a corporificação deixa de ser relevante. Essa estrutura de agentes pode estar presente em qualquer organismo vivo, natural ou artificial. O que nos impedirá, então, de em um futuro breve mapearmos totalmente o cérebro humano, identificarmos todos os agentes (ou neurônios; ou genes egoístas - fica a seu critério) e, a partir de um escaneamento, salvarmos a cópia de dados em um HD ou numa Nuvem?

O que vimos até agora sobre a terceira - e ainda em voga - onda da cibernética pode afetá-lo de duas maneiras distintas: 1) Você pode rir de tudo isso e dizer a si mesmo que os corpos, tal como os humanistas liberais pensaram, ainda existem e que o seu "eu", imodificado, é completamente livre e racional; 2) Você pode realmente estar interessado no que está por vir, com a ciência avançando a cada dia e nos permitindo modificar nossos corpos como bem pretendemos.

Veja bem, a mente humana sem um corpo humano não é uma mente humana. Do mesmo modo, uma mente artificial, sem um corpo artificial, não é uma mente artificial (HAYLES 1999: 246). O corpo é diferente da corporificação. Nossos corpos são normativos, são uma organização estruturada como disse Maturana (e como a maioria dos biólogos vai concordar): tenho rins, coração, fígado, olhos, cérebro etc. Para eu continuar a viver, terei de ter esses órgãos, mesmo que sejam artificiais. Por uma pessoa ter recebido um implante de um coração artificial você passa a enxergá-la como máquina? Acredito que não... Semelhantemente, se amanhã ou depois descobrirem que os computadores ganham um poder de processamento nunca antes imaginável caso recebam enxertos de pele humana dentro de seus circuitos integrados, eles seriam humanos perante seus olhos? Também acredito que não... A corporificação, por sua vez, é contextual. Quando o Doutor viaja com sua TARDIS para a Roma Antiga, ele não deixa de ser um 
alienígena do planeta Gallifrey, apenas corporifica a figura de um homem romano para poder interagir com o ambiente ao seu redor. Do mesmo modo, quando criamos um avatar em um mundo digital, ele é uma corporificação nossa, não o nosso corpo biológico de fato (isso fica bem claro no filme Avatar de 2009, dirigido por James Cameron).

A informação está descorporificada. Nós, humanos, continuamos a ter nossos corpos: com acréscimos de próteses artificiais ou não. Os seres humanos não perderam seu corpo. A informação, com o decorrer dos anos de estudos cibernéticos, deixou de ser corporificada, ou seja, presa a seu invólucro original, mas continua a ser informação (aquilo que dá forma ao que está na mente): o que acontece hoje em dia, simplesmente, é que essa informação - seja ela qual for - pode migrar de um lugar para outro.

E justamente nessa migração de informação é que começa a existir uma diferença entre os humanos que éramos e os humanos que somos atualmente. $\mathrm{O}$ humanismo liberal do Iluminismo, aquele em que o sujeito existe como um ser natural, dono de si mesmo e completamente livre, como nos mostrou a evolução dos estudos cibernéticos, deixou de existir. Hoje não somos mais seres naturais, humanos puros (numa concepção liberal): a nossa inteligência é coproduzida com as máquinas inteligentes - é um processo simbiótico. Nós, agora, somos vistos como máquinas de processamento de informações semelhantes a outros tipos de máquinas de processamento de informações. Máquinas se sobrevivência orgânicas (segundo Dawkins) e máquinas artificiais ficaram dependentes. Deixamos de ser humanos.

Tornamo-nos pós-humanos. 


\section{RESUMO - INFORMAR NÃO É ALGO SIMPLES}

Relendo este capítulo para montar o seu resumo ${ }^{6}$ fica bastante claro para mim: é um divisor de águas nesta pesquisa. Ou o leitor desiste aqui, ou se prepara para algo ainda mais "incomum" (que virá no capítulo a seguir). Prefiro acreditar que "estranhezas" possam gerar curiosidade...

No início eu apresentei a definição de informação com a qual trabalho (e a de que mais gosto pessoalmente): de acordo com a raiz latina, informação vem do nominativo informatio que, por sua vez, deriva do verbo informare, significando "dar forma à mente". É uma definição simples que nos permite enxergar todas as nuances da informação e como ela pode variar de mídia para mídia (para tanto, citei o exemplo da comunicação por tambores na África subsaariana do século XVIII).

A partir daí, entrei no campo científico que estuda a informação existente no diálogo entre homens e máquinas: a cibernética. Utilizando a divisão proposta pela crítica literária pós-moderna N. Katherine Hayles, apresentei as "três ondas cibernéticas" que se fazem presentes nesse campo de estudos. A Primeira Onda teve seu auge entre 1945 e 1960, tendo por base os estudos de Norbert Wiener (considerado o "pai"” da cibernética), Claude Shannon e W. Ross Ashby: em seu cerne está o conceito de homeostase, ou seja, a autorregulação dos sistemas por meio de sinais de entrada (input) e saída (output). A Segunda Onda (1960 - 1985) começou nos trabalhos dos biólogos chilenos Humberto Maturana e Francisco Varela: a autopoiese proposta pela dupla contribuiu para a difusão da ideia de reflexividade nos sistemas, ressaltando o papel do observador como sujeito atuante nas mudanças e na forma como o mundo ao redor é criado e representado. A Terceira Onda (1980 até hoje) afirma que não há muitas diferenças entre homens e máquinas se os sistemas forem construídos de modo semelhante: a Vida Artificial proposta por Christopher G. Langton lida com a estrutura física dos organismos artificiais, enquanto a Inteligência Artificial (principalmente sob o viés de Marvin Minsky) preocupa-se com a consciência computacional. Terminei o capítulo dizendo que nosso corpo não é relevante quando falamos de informação. Somos pós-humanos.

\footnotetext{
${ }^{6}$ Acredito que não seja novidade, mas vale a pena reiterar: nós acadêmicos costumamos nos esquecer daquilo que lemos. Incluindo nossos próprios textos.

${ }^{7}$ Chamo a atenção aqui para a noção machista de "pais" na Ciência. Por que não há "mães" em alguns campos de estudos? Desafio o leitor a elaborar uma lista de quantas vezes na literatura científica aparece este termo. É urgente repensarmos - e criticarmos - o sexismo acadêmico ainda muito presente no século $\mathrm{XXI}$.
} 


\section{CAPÍTULO III}

\section{PÓS-HUMANISMO E A VIRTUALIDADE}

1. A Humanidade será profundamente afetada pela ciência e tecnologia no futuro. Nós almejamos a possibilidade de alargamento do potencial humano ao superar o envelhecimento, as deficiencias cognitivas, o sofrimento involuntário, e o nosso confinamento ao planeta Terra.

2. Acreditamos que o potencial humano ainda não foi realizado em sua maior parte. Há possíveis cenários que levariam a maravilhosas e extremamente valiosas melhorias nas condições humanas.

3. Reconhecemos que a humanidade encara sérios riscos, especialmente do mau uso de novas tecnologias. Há possíveis cenários realísticos que levariam à perda da maioria, se não todas, das coisas que valorizamos. Alguns desses cenários são drásticos; outros, sutis. Embora todo progresso seja mudança, nem toda mudança é progresso.

4. É necessário investir esforços de pesquisas no entendimento desses prospectos. Precisamos cuidadosamente deliberar qual o melhor meio de reduzir riscos e agilizar aplicações benéficas. Também precisamos de fóruns nos quais as pessoas possam construtivamente discutir o que pode ser feito e uma ordem social em que as decisões responsáveis possam ser implementadas.

5. Redução dos riscos da extinção humana, desenvolvimento de meios para a preservação da vida e da saúde, o alívio de sofrimentos graves e o aperfeiçoamento da precaução e sabedoria devem ser buscados como prioridades urgentes e generosamente financiados.

6. Decisões políticas devem ser guiadas por visão moral responsável e inclusiva, pesando seriamente as oportunidades e os riscos, respeitando a autonomia e os direitos individuais, e demonstrando solidariedade e preocupação com os interesses e dignidade de todas as pessoas ao redor do globo. Também devemos considerar nossas responsabilidades morais para com as gerações que existirão no futuro.

7. Nós defendemos o bem-estar de toda senciência, incluindo humanos, animais não-humanos, qualquer intelecto artificial futuro, formas de vida modificadas, ou outras inteligências às quais o avanço tecnológico e científico possa trazer.

8. Favorecemos liberdade morfológica - o direito de modificar e aperfeiçoar o corpo, a cognição e as emoções. Essa liberdade inclui o direito de usar ou não técnicas e tecnologias para estender a vida, preservar o ser por meio de criogenia, upload, e outros meios, e a escolher futuras modificações $e$ aperfeiçoamentos.

- Transhumanist Declaration, 2012 $^{8}$

\section{Calma!}

Ser pós-humano não é motivo para que se jogue da varanda de seu prédio. Do mesmo modo, não lhe dá poderes mutantes como alguns X-Men. Você pode ficar tranquilo, as mudanças são sutis e graduais. Caso não tenha viajado com a TARDIS para outro planeta nas últimas duas décadas, tenho certeza de que já fez alguma pesquisa no Google, ou já baixou algum filme pirata, ou já recorreu à Wikipédia para sanar alguma

\footnotetext{
${ }^{8}$ A Declaração Transhumanista teve seu primeiro esboço (1998) assinado por: Alexander Sasha Chislenko, Anders Sandberg, Arjen Kamphuis, Bernie Staring, Bill Fantegrossi, Darren Reynolds, David Pearce, Den Otter, Doug Bailey, Eugene Leitl, Gustavo Alves, Holger Wagner, Kathryn Aegis, Keith Elis, Lee Daniel Crocker, Max More, Mikhail Sverdlov, Natasha Vita-More, Nick Bostrom, Ralf Fletcher, Shane Spaulding, T.O. Morrow e Thom Quinn.
} 
dúvida. Não há vergonha alguma em admitir isso (mesmo que a pirataria seja um tanto discutível): você aprendeu com o seu computador. Entre os bilhões - ou mais - de bits armazenados nas nuvens espalhadas pelo mundo, você já obteve informação de alguns deles. Sua inteligência aumentou graças ao mundo digital dos computadores. E os computadores também aprenderam com você: não é surpreendente quando entramos na loja virtual da Amazon ou na Netflix e ali haja sugestões de produtos/filmes que realmente se encaixam em nossos perfis? Pois é, isso representa um acréscimo na inteligência das máquinas artificiais. Sejamos honestos: nós nos tornamos mais inteligentes conforme interagimos, seja com outros seres humanos, seja com outros animais, seja com o meioambiente, seja com nossas ferramentas, seja com computadores e outras máquinas artificiais. O sistema ecológico que habitamos não é mais apenas "natural", é artificial também. Com o avanço da tecnologia e das próteses artificiais, provavelmente deixaremos de ser Homo Sapiens Sapiens e ganharemos outra nomenclatura, a de Homo Sapiens Silex.

Os estudos sobre pós-humanismo têm sido encabeçados por grandes autoridades nos campos da filosofia, engenharia, biotecnologia e ciência da computação. Dentre eles, o futurólogo Max More é um dos principais especialistas na área, tendo colaborado na redação da Declaração Transhumanista (Transhumanist Declaration) de 1998. Recentemente, ele e Natasha Vita-More editaram o livro The Transhumanist Reader (2013), que, trazendo uma coletânea de ensaios de diversos autores expoentes, se tornou referência absoluta para aqueles que desejam se aprofundar na temática. Rapidamente, apresentarei alguns apontamentos interessantes dessa obra. O intuito, claro, não é esgotar o tema, até mesmo porque isso é impossível em qualquer área cognitiva: vou apenas pinçar aquilo que me auxiliará a dialogar a Arqueologia com a Realidade Virtual.

Falar de Pós-Humanismo é falar de Transhumanismo, e vice-versa. Alguns pesquisadores alegam que o transhumanismo é a ponte que faz a ligação entre o humanismo e o pós-humanismo. Outros, dizem que o transhumanismo é a filosofia que está presente na figura do pós-humano. Para fins de compreensão, aqui vou abordar o transhumanismo como a discussão por trás da questão tecnológica que nos permite sermos pós-humanos. Desse modo, para mim, o transhumanismo é, ao mesmo tempo, uma filosofia $e$ um meio de se chegar ao pós-humanismo (entendendo-se por "meio" os aparatos tecnológicos que pensem, no nível mais fundamental, em um sistema binário). 
O transhumanismo pode, sim, ser descrito como uma espécie de filosofia de vida não-religiosa que rejeita a fé, a veneração e o sobrenatural, enfatizando a vida sendo formada por razão, ciência, progresso e o valor da existência (MORE \& VITA-MORE 2013: 4). Pessoalmente, tenho ressalvas com o termo "progresso", pois ele facilmente pode ser mesclado com "evolução" e, assim, erroneamente, abrir precedentes para eugenias e outras "teorias" de pureza. Porém, o transhumanismo tem o progresso como uma de suas pedras angulares e, tal como afirma Max More, suas raízes estão no Iluminismo, concebendo a ideia como uma possibilidade e desejo, não uma inevitabilidade. Assim, o progresso segundo os transhumanistas se opõe à fé, uma vez que nós devemos criar melhores futuros - com base na razão, tecnologia, método científico e criatividade humana - ao invés de esperarmos ou rezarmos para forças sobrenaturais (MORE \& VITA-MORE 2013: 4).

Uma grande diferença entre humanismo e transhumanismo está na ênfase que o último dá aos meios e fins. Enquanto o humanismo tende a depender exclusivamente do refinamento educacional e cultural para melhorar o ser humano, o transhumanismo emprega a tecnologia para superar os limites impostos por nossas heranças biológicas e genéticas. Para os transhumanistas, a natureza humana não se fecha em si mesma nem é vista como perfeita: ela apenas é um ponto na trilha evolucionária e nós podemos aprender a remodelar nossa própria natureza de modos que consideremos desejáveis e valiosos. "Ao ponderada, cuidadosa e ousadamente aplicarmos tecnologia a nós mesmos, podemos nos tornar alguma coisa não mais precisamente descrita como humano: podemos nos tornar pós-humanos" (MORE \& VITA-MORE 2013: 4). A definição de Max More sobre o ser pós-humano é emblemática e merece ser citada por inteiro (2013: 4):

Tornar-se pós-humano significa exceder as limitações que definem os aspectos menos desejáveis da "condição humana". Seres pós-humanos não deverão mais sofrer com doenças, envelhecimento e morte inevitável (...). Eles poderão ter grandes capacidades físicas e liberdade de forma - geralmente referida como "liberdade morfológica" (...). Póshumanos deverão também ter grandes capacidades cognitivas, e emoções mais refinadas (mais alegria, menos raiva, ou quaisquer mudanças que cada indivíduo desejar). Transhumanistas tipicamente tentam expandir a gama de possíveis ambientes futuros para a vida póshumana, incluindo a colonização do espaço e a criação de ricos mundos virtuais. Quando os transhumanistas se referem à "tecnologia" como o 
meio primário de mudanças efetivas na condição humana, isso deve ser entendido de modo amplo a fim de incluir a concepção de organizações, economias, políticas e o uso de métodos e ferramentas psicológicas.

Outro ponto marcante do transhumanismo é aquilo que Max More (2013: 6) denomina racionalismo crítico. Baseado na obra do filósofo da ciência austríaco naturalizado britânico Karl Popper, o racionalismo crítico difere radicalmente das ideias do Iluminismo. Muitos pensadores iluministas defendiam o fundacionalismo, dizendo que as teorias epistemológicas deveriam ser calcadas em crenças básicas ou fundamentos para a elaboração do conhecimento. O racionalismo crítico, por sua vez, rejeita essa justificativa centrada em uma autoridade (podendo ser Deus) para afirmar que não existem fundamentos para o conhecimento: adquirir ou aperfeiçoar o que sabemos é baseado essencialmente em conjunturas e críticas.

Do mesmo modo, a questão da identidade para os transhumanistas acaba sendo importantíssima. A maioria dos pesquisadores descrevem a si mesmos como materialistas, fisicalistas ou funcionalistas: acreditam que nossos pensamentos e sentimentos (ou sensações) são essencialmente processos físicos. Assim, os transhumanistas são funcionalistas, ou seja, propalam que o "eu" tem de ser instanciado em algum tipo de meio físico, mas não necessariamente humano (ou biológico). Por exemplo, se os neurônios biológicos de alguém forem sendo, gradualmente, substituídos por neurônios artificiais que funcionem cognitivamente do mesmo jeito, a mesma mente e personalidade irá persistir apesar de estar em um substrato não-biológico (MORE \& VITA-MORE 2013: 7). O funcionalismo, assim, é uma forma de fisicalismo que difere da teoria da identidade (um estado mental é idêntico a um estado específico do cérebro) e do behaviorismo (termos mentais podem ser reduzidos a descrições comportamentais): os estados mentais são relações causais com outros estados mentais, sensores de entrada e saídas comportamentais. "Por estarem os estados mentais constituídos por seu papel funcional, eles podem ser lançados em múltiplos níveis e manifestarem-se em muitos sistemas, incluindo os não-biológicos, desde que o sistema apresente as funções apropriadas" (MORE \& VITA-MORE 2013: 7).

Por fim, devo ressaltar um dos aspectos do transhumanismo (ou pós-humanismo) que mais interessa a este trabalho que está lendo: a simulação. Contudo, lidar com simulação é lidar com a virtualidade. Para facilitar o entendimento, vou juntar os dois assuntos em um tópico só. Vejamos. 
VIRTUALIZAR É PRECISO (?), SIMULAR NÃO É PRECISO (?)

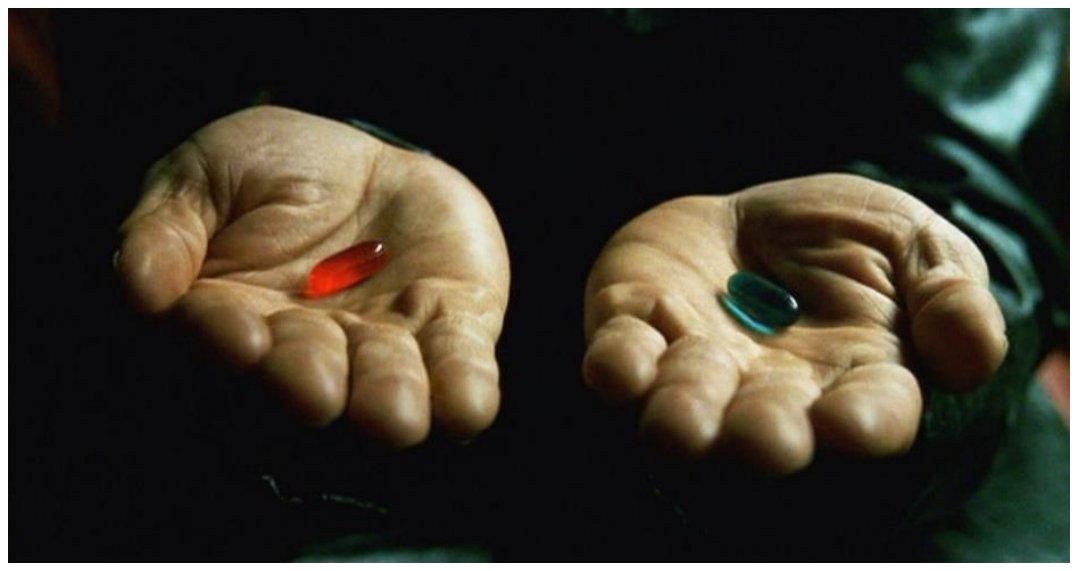

Fig. 5 - Cena do filme The Matrix (dir. Andy \& Lana Wachowski), 1999.

\section{Certamente você conhece a imagem acima.}

Qual das pílulas escolheria? A azul, que lhe faria despertar em sua confortável cama como acontece todos os dias? Ou a vermelha, que lhe mostraria o que está por detrás de tudo aquilo que você considera real?

Nós sabemos que o protagonista Neo acabou optando pela pílula vermelha oferecida por Morpheus e desconectou-se da Matrix, uma simulação computadorizada na qual os seres humanos permanecem ligados fisicamente. Essa simulação, conforme podemos ver nas duas partes da animação The Second Renaissance dirigida por Mahiro Maeda para a coletânea de filmes The Animatrix (2003), foi criada após uma guerra mundial entre humanos e robôs (que se cansaram da exploração e humilhação infligidas a eles) na qual as máquinas venceram. Os seres humanos foram subjugados e presos a casulos que os conectavam à simulação de um mundo anterior ao surgimento das máquinas superinteligentes. Então, a partir dos pulsos neurais oriundos desses "bebêshumanos", as máquinas se tornaram autossuficientes naquilo que as mantém vivas: energia elétrica.

Poderíamos nós viver, nesse momento, em uma simulação produzida por computadores?

Essa mesma questão foi proposta pelo filósofo sueco Nick Bostrom em 2003. Em seu artigo "Are you living in a computer simulation?", Bostrom diz que ao menos uma das proposições a seguir é verdadeira (2003: 243): 
1. A espécie humana muito provavelmente será extinta antes de alcançar um estágio "pós-humano";

2. É extremamente improvável que qualquer civilização pós-humana possa rodar um número significativo de simulações sobre sua história evolucionária (ou suas variações);

3. Estamos quase certamente vivendo em uma simulação de computador.

Tomando por base um conceito emprestado da filosofia da mente, o substrato independente, Nick Bostrom afirma que os estados mentais podem residir em múltiplos tipos de substratos físicos ou digitais; ou seja, uma pessoa cônscia de si mesma poderia habitar uma mente artificial se a construção física de ambos fosse semelhante. Mas esse cérebro de silício não existe ainda, pois não alcançamos esse alto estágio de poder de computação: para simular as sinapses de um cérebro e seus disparos, por exemplo, seria necessário computar entre $10^{16}$ a $10^{17}$ operações por segundo. Se não só o cérebro humano, mas também um meio-ambiente completo estivessem presentes na simulação, iriam requerer poder de processamento computacional adicional. Sendo assim, caso queiramos simular absolutamente o mundo todo que um ser humano conhece (com as construções, crenças, sentimentos, fatores biológicos etc.), precisaríamos, de acordo com Bostrom, rodar a simulação em um computador capaz de processar entre $10^{33}$ a $10^{36}$ operações por segundo. As civilizações pós-humanas, então, teriam de ter poder de computação o bastante para rodar várias simulações do passado histórico humano a fim de que nós, atualmente, vivêssemos em uma simulação como no filme The Matrix.

De acordo com de Nick Bostrom a proposição 1 é bastante simples. Se 1 for verdade, então a humanidade irá quase certamente falhar em alcançar o grau pós-humano (e isso não quer dizer que seremos extintos, apenas que não nos tornaremos pós-humanos no sentido tecnológico proposto pelo transhumanismo). A proposição 2, por sua vez, esbarra na vontade de as populações pós-humanas desejarem simular seus antecessores, seja porque somente alguns indivíduos terão riquezas suficientes para possuir computadores poderosos que rodem essas simulações, seja pela proibição ética por parte dos governos das sociedades pós-humanas de que se "estudem" os antecessores humanos. A proposição 3, finalmente, é a que mais intriga: se for verdade, então tudo o que enxergamos, tal como o cosmos, é meramente um pequeno pedaço de uma totalidade física existente; mesmo simulados, poderíamos nos tornar pós-humanos e, do mesmo modo, rodarmos simulações de nossos ancestrais. Para Nick Bostrom, se dentro de nossas 
realidades formos capazes de simular nossos ancestrais, então isso é uma forte evidência contra as proposições 1 e 2: nós poderíamos concluir que, de fato, vivemos em uma simulação computacional.

As provocações de Nick Bostrom são interessantíssimas, não? No entanto, antes que o leitor corra o risco de ficar perdido em seus pensamentos se é ou não um programa de computador, vamos ver o que, de fato, significa simulação.

A simulação é uma palavra de origem latina, a simulationem que, por sua vez, deriva do nominativo simulatio, significando "imitação, fingimento", ou seja, algo que não está mais ali. Deixando-se a raiz latina de lado, e adentrando o campo acadêmico, podemos dizer que não existe uma única definição de simulação, porém, uma das mais famosas pertence ao filósofo francês Jean Baudrillard, que escreveu em sua obra Simulacros e Simulação, publicada em 1981:

\begin{abstract}
Dissimular é fingir não ter ainda o que se tem. Simular é fingir ter o que não se tem. O primeiro refere-se a uma presença, o segundo a uma pura ausência. Mas é mais complicado, pois simular não é fingir: “Aquele que finge uma doença pode simplesmente meter-se na cama e fazer crer que está doente. Aquele que simula uma doença determina em si próprio alguns dos respectivos sintomas" (Littré). Logo, fingir ou dissimular deixam intacto o princípio da realidade: a diferença continua a ser clara, está apenas disfarçada, enquanto que a simulação põe em causa a diferença do "verdadeiro" e do "falso", do "real" e do “imaginário". O simulador está ou não doente, se produz "verdadeiros" sintomas? Objetivamente não se pode tratá-lo nem como doente nem como não doente. (BAUDRILLARD 1991: 9-10).
\end{abstract}

Segundo a visão de Baudrillard, a simulação existe quando não temos mais algo real: ela é a substituição daquilo que existiu por algo que nunca existiu. O filósofo vai além, dizendo que: "Hoje a abstração já não é a do mapa, do duplo, do espelho e do conceito. A simulação não é já a simulação de um território, de um ser referencial, de uma substância. É a geração pelos modelos de um real sem origem nem realidade: hiperreal" (1991: 8). Esse hiper-real, ou seja, algo que é "mais real do que o real" é um conceito que, assim como a definição de simulação feita por Baudrillard, esbarra em uma simples pergunta: Afinal, o que é real? 
Não é tarefa simples definir o que é real. Muitas pessoas podem dizer que real é o que existe, mas, pensando-se assim, por que muitas dessas mesmas pessoas dizem que um arquivo de editor de texto no computador (como o que estou usando nesse exato momento) é algo virtual? O arquivo, de fato, existe, não? Afinal, estou trabalhando nele agora. Se você estiver com meu trabalho em mãos, impresso em papel, ele é mais real do que se o ler na tela do seu computador (ou tablet, ou smartphone)? Se você chegou à conclusão de que tudo, papel ou meio digital, é real, parabéns: você compartilha das mesmas ideias do filósofo francês da informação que tem recebido bastante destaque acadêmico nos últimos anos, o Pierre Lévy - e em quem eu me baseio também para discutir a realidade.

Pierre Lévy tem contribuído enormemente para o campo da comunicação, estudando as relações entre a Internet e a sociedade. Entre suas obras traduzidas para o português, podemos destacar As tecnologias da inteligência: o futuro do pensamento na era da informática, Cibercultura e $O$ que é o virtual? - possuindo esse livro algumas definições importantes para nós nesse instante. Em $O$ que é o virtual?, publicado na França em 1995, Lévy lançou novos olhares sobre as conceituações de real e virtual, apontando ideias que fizeram os estudiosos repensarem suas próprias definições. Não é muito fácil aceitar e assimilar suas concepções em um primeiro momento (tendo em vista que a maioria de nós passou a vida toda opondo real ao virtual), tampouco é simples de explicar. Farei aqui uma brevíssima tentativa de explanar os conceitos de Pierre Lévy, mas seria muito importante os interessados nesse debate lerem a obra original para melhor compreensão. Para fins didáticos, vou separar as três definições principais que norteiam seu pensamento:

1) Real: é aquilo que existe no momento, é o presente. Seguindo o exemplo de Lévy, o real é como uma árvore que enxergamos.

2) Virtual (do latim virtus, "força, potência"): é o potencial de algo vir a ser real, embora o virtual em si seja real. Dentro da semente está uma árvore em potencial, a semente é o virtual da árvore e, como semente, é real também. Uma árvore pode, do mesmo modo, vir a ser uma folha de papel, logo, a árvore também contém o virtual, mesmo sendo real. A virtualização é um questionamento, é uma problemática que deve ser respondida em algum momento. 
3) Atual: é o que algo é de fato, é uma espécie de "codificação". O atual da árvore é ser madeira, seiva, galhos, raízes e folhas. A atualização, então, se opõe não ao real, mas ao virtual, uma vez que fornece respostas às problemáticas geradas pela virtualização. Assim sendo, a virtualidade e atualidade são dois tipos diferentes da realidade.

Em outras palavras: tudo é real! Mas em estágios distintos e que ocorrem ao mesmo tempo (ou não). Retomemos o exemplo do arquivo de texto que estou digitando. Estou vendo e interagindo com o teclado do meu computador para que surjam caracteres na tela: isso é o real. Contudo, esse arquivo de texto não está sendo redigido em um só dia e, por isso, ele fica armazenado em meu computador em forma de bits e bytes: ele é o virtual, pois nele está contido um arquivo de texto em potencial, que pode vir a ser real (quando eu clicar duas vezes para ele abrir) ou não (se eu o mantiver guardado em meu disco rígido, virtualmente). Todo o processo de transformação dos bits e bytes em uma janela de editor de texto que acontece quando clico duas vezes sobre o ícone com o nome do meu arquivo é o atual. E a todo instante o real se atualiza, pois digito caracteres e mais caracteres para formar palavras que surgem na tela LCD.

Assim, se tomarmos por base as ideias de Pierre Lévy - que são opostas aos conceitos de real/simulação de Jean Baudrillard - e considerarmos que não existe a dicotomia real/virtual, pois tudo é real, então nenhuma simulação pretende substituir algo que não existe, mas mostra-se como um desenvolvimento, outra maneira de se buscar informações a partir da realidade.

E o que seria, então, nesse contexto, aquilo que ocasionalmente ouvimos falar: a realidade virtual?

EXPERIMENTANDO ALÉM DO “REAL”: A REALIDADE VIRTUAL E A REALIDADE AUMENTADA

Provavelmente, os videogames são o meio de realidade virtual mais difundidos no mundo. Apenas para ilustrar, o jogo Bioshock Infinite vendeu nos EUA - somente no mês de março de 2013 - 878 mil cópias: isso já seria muito se não fosse por um fato 
interessante - o game só foi lançado no dia 26 daquele mês ${ }^{9}$. Isso corrobora aquilo que vem acontecendo há quase uma década: a indústria de videogames tem superado o mercado de filmes no quesito lucro. Por que, então, um jogo eletrônico, que muitas vezes chega a custar o triplo ou o quádruplo de um valor de ingresso de cinema, tem conseguido superar a indústria cinematográfica? Acredito que existam vários fatores a favor dos games, mas dois deles devem ser mencionados aqui:

1) o enredo/roteiro: de uns anos para cá, é inegável que as histórias presentes nos jogos eletrônicos têm sido muito mais elaboradas e inteligentes do que os filmes de Hollywood (e alguns do mundo, em geral). Na verdade, há uma tendência atual de que os jogos se espelhem nos filmes, como é o caso dos recentes Max Payne 3 e Far Cry 3 - ambos lançados em 2012 e que trazem diversas cenas e jogabilidade que emulam os filmes de ação. O que talvez cause estranhamento é que a recíproca não é verdadeira: os filmes têm optado cada vez mais por abusar dos efeitos especiais em detrimento da narrativa. Sendo assim, uma boa parte da plateia que vai aos cinemas opta por ter uma diversão mais completa em suas casas, deixando de ir aos cinemas (que só tem feito aumentar os valores dos ingressos).

2) a interatividade: esse é o fator, a meu ver, principal do sucesso dos videogames. Embora o enredo seja muito relevante hoje em dia, não foi assim nos primórdios dos jogos eletrônicos. O primeiro videogame, inventado por William Higinbotham (que trabalhava no Departamento de Energia dos EUA), foi lançado em 1958 no laboratório Brookhaven National com o intento de atrair visitantes: tratava-se de um display eletrônico interativo ligado a um osciloscópio que permitia aos usuários disputarem uma partida de tênis - de onde vem seu nome, Tenis for Two (RABIN 2011: 4). Três anos depois, no MIT, o jovem estudante Steve Russell criou em um computador DEC PDP-1 um jogo espacial em que o objetivo era uma nave destruir a outra atirando torpedos, nascendo, então, o Spacewar. Porém, apenas no final dos anos 1970 é que os videogames se tornaram realmente famosos, chegando ao mercado estadunidense (e depois ao restante do mundo) a famosa invenção da empresa de Nolan Buschnell, o Atari 2600, trazendo para os lares sucessos como Pong,

\footnotetext{
9 http://www.baixakijogos.com.br/noticias/31867-numeros-em-marco-bioshock-infinite-e-xbox-360lideram-os-rankings-de-vendas
} 
Pac-man, Pitfall! e Enduro (além de jogos horríveis, como E.T. the ExtraTerrestrial...). Na década de 1980, com os videogames alcançando 8-bit de processamento, começou, de fato, a introdução de narrativas nos jogos. Embora o primeiro game lançado pela Nintendo tenha sido Donkey Kong (1981), aquele personagem que se tornaria um sinônimo de videogames só chegou aos mercados, como protagonista principal, em 1983, o encanador bigodudo Mario, no jogo Mario Bros. O game já apresentava um grau de narrativa um pouco maior do que as tentativas realizadas na geração Atari, com Mario (e seu irmão Luigi) tendo de resgatar a Princesa Peach das garras do vilão Bowser. Contudo, o grande trunfo da narrativa interativa no mundo dos videogames veio com o jogo The Legend of Zelda em 1981, em que o herói Link passava por várias aventuras em um RPG (role-playing game, "jogo de interpretação de personagens") para resgatar a Princesa Zelda. No final da década de 1980, a Nintendo chegou a dominar $90 \%$ do mercado dos videogames: algo que jamais qualquer outra empresa conseguiu até hoje (RABIN 2011: 10). Na sétima geração - com seus 256-bit - temos um grau elevadíssimo de interatividade aliada a enredos complexos e cativantes. Tanto o Nintendo Wii, como o Xbox 360 e o PlayStation 3 já utilizam sistemas de comandos de jogos que vão além do tradicional joystick: o Wiimote e o PlayStation Move têm controles que utilizam sensores que capturam movimentos dos jogadores, enquanto o Kinect do Xbox 360 vai além, permitindo que o usuário controle o jogo usando somente o seu corpo (posicionado em frente à câmera do dispositivo). A recém-chegada oitava geração, com o Nintendo Wii U, o Playstation 4 e o Xbox One prometem ainda mais revoluções tecnológicas no modo como jogamos. Por terem chegado ao mercado somente no fim de 2013 (com exceção do Nintendo Wii $U$, de 2012), ainda é cedo para analisarmos como esses consoles se sairão; contudo, dificilmente perderão para seus antecessores no quesito diversão. Com tantas opções, não é de se estranhar que a interatividade, a capacidade do jogador em assumir o papel de um personagem na tela e modificar a história com decisões próprias (e pré-programadas), seja aquilo que nos encanta nos videogames desde os seus primórdios. Os videogames oferecem algo que o cinema, ainda, não consegue: permite-nos interagir com a história. 


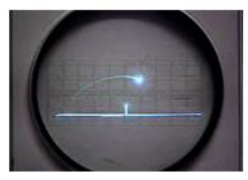

Tenis for Two, 1958.

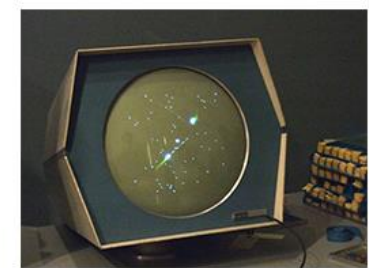

Spacewar, 1961.

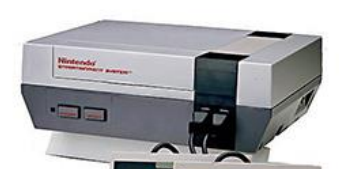

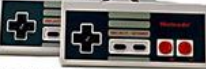

NES (8-bit), 1983

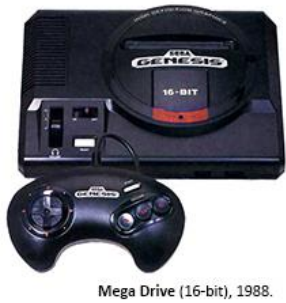

Mega Drive (16-bit), 1988.

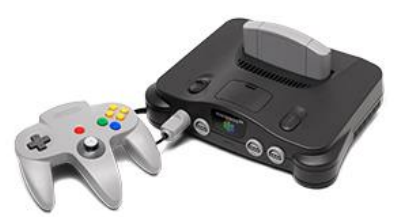

Nintendo 64 (64-bit), 1996.

Dreamcast (128-bit), 1998

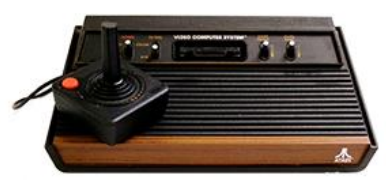

Atari 2600, 1977 .

$$
\text { Atari 2600, } 1977
$$
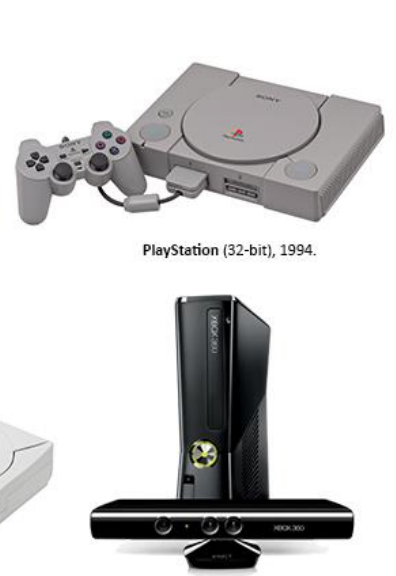

XBOX $360,2005$.
Kinect, 2010. Kinect, 2010.
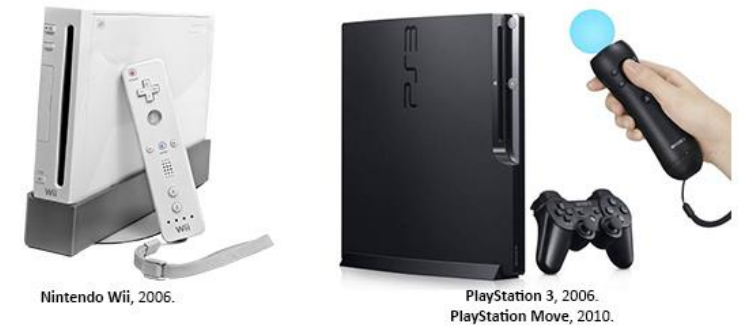

Fig. 6 - Exemplos de consoles na história dos videogames.

Desse modo, os videogames são R.V., pois geram imersão e interatividade em tempo real, que são duas características fundamentais para que uma aplicação de R.V. exista $^{10}$. Porém, mais do que o mercado doméstico, a realidade virtual vem sendo pesquisada por instituições acadêmicas (e empresas) desde a sua descoberta. Infelizmente, ainda existe uma tendência em dizer que a realidade virtual praticada nas universidades é "mais séria" e "superior" à que existe na indústria dos jogos eletrônicos. Em minha opinião, são áreas distintas que trabalham com os mesmos princípios tecnológicos, mas que não devem ser postas em nível hierárquico: o desenvolvimento de uma aplicação em realidade virtual para reabilitar pacientes que sofreram acidente vascular cerebral tem a mesma importância de um jogo eletrônico repleto de quebra-

\footnotetext{
${ }^{10}$ Embora muitos pesquisadores apontem também que, além da imersão e da interatividade em tempo real, é necessário haver um ambiente virtual tridimensional, não sou adepto desse último quesito. Tendo envelhecido junto com os videogames desde o Atari, posso afirmar que gráficos 2D ou 3D não influenciam em nossa sensação de imersão: jogar algum game da franquia Zelda em 2D no Super Nintendo sempre me deixou imerso do mesmo modo como se estivesse jogando em 3D no Nintendo 64 ou no Nintendo 3DS, por exemplo.
} 
cabeças para uma criança, um adolescente ou um adulto. Importante também deixar claro que não há idade para o uso de realidade virtual, que videogames não são "coisa de criança", enquanto exposições virtuais interativas em museus são voltadas para o "público adulto". Transcendendo essa barreira de preconceitos e pré-conceitos, podemos desenvolver a realidade virtual em um grau mais amplo e de uso mais público e corriqueiro.

E agora você me pergunta: Mas o que vem a ser o conceito de Realidade Virtual?

No senso comum, o virtual se opõe ao real, sendo este aquilo que eu percebo com todos os meus sentidos e aquele o que eu identifico por meio de algum dos meus sentidos: o real é o "palpável”, o virtual é uma "representação do real". A Realidade Virtual (doravante R.V.), considerando-se essa definição, seria uma realidade "falsa", algo fictício. Contudo, baseando-se naquilo que foi proposto por Pierre Lévy, a R.V. não é um termo em que uma palavra anula a outra: o virtual, sendo uma realidade em potencial, é ele mesmo real. Desse modo, podemos entender "realidade virtual" como uma realidade que pode vir a ser real. É uma realidade dentre as várias realidades que o virtual pode conceber.

A virtualização da realidade é algo que há séculos intriga os seres humanos e sua concepção/definição foi sendo modificada ao longo do tempo. A principal ideia por trás do conceito virtual pode ser encontrada na obra A República do filósofo grego Platão, redigida no século IV a.C.. O "Mito da Caverna" de Platão descreve uma caverna separada por um muro alto que, do lado de dentro, tem prisioneiros acorrentados de costas ao muro, enquanto o lado de fora da caverna está aberta ao mundo, com pessoas vivendo normalmente e acendendo fogueiras: uma pequena abertura no muro é o que liga os dois lados; os prisioneiros, nascidos dentro da caverna e, por consequência, sem ter noção do mundo exterior, veem sombras refletidas na parede - são imagens das pessoas do lado de fora que, graças à luz das fogueiras, adentram a caverna pela pequena abertura no topo do muro; junto com as sombras, chega o som dos homens de fora e os prisioneiros, sem terem percepção do que acontece do outro lado do muro, acreditam com convicção de que essas sombras são a realidade; se um dos prisioneiros conseguisse se libertar e escalar o muro, ele iria deparar com uma outra realidade, a do mundo dos homens que acendem as fogueiras na natureza - estaria, então, semeada nesse prisioneiro libertado a dúvida: se 
voltar para dentro da caverna e contar a seus companheiros corre o risco de, ou ser ignorado, ou até mesmo ser morto devido à acusação de mentira.

A alegoria da caverna de Platão talvez seja o que melhor exemplifica a R.V.: a capacidade de fazer com que nós acreditemos em algo que nos chega de modo indireto, criado pelas leis da física ou por programação de computadores. A R.V., então, pode ser definida como algo que possui o potencial de se tornar real (fictício ou verossímil). Vejamos agora os seus conceitos básicos e algumas de suas aplicações na área da Educação.

A R.V. teve seus primeiros experimentos na década de 1940, quando após o término da Segunda Guerra Mundial a força aérea dos EUA passou a construir simuladores de voo para treinar seus pilotos. Um pouco mais de uma década depois, em 1956, Morton Heilig desenvolveu o Sensorama. Inspirado pelo sucesso do Cinerama (cinema + panorama) nos anos 1950 nos EUA, que consistia em três telas de cinema colocadas em série formando uma concavidade de $146^{\circ}$, o Sensorama de Heilig era um simulador multissensorial apresentado em forma de cabine que misturava visão estereoscópica, áudio estéreo, vibrações mecânicas, aromas e vento - contudo, o Sensorama não era interativo (NETTO et al. 2002). Em 1961, a Philco patenteou um vídeo-capacete (HMD) com sensores de movimento que em pouco tempo foi bastante difundido entre os engenheiros. (SHERMAN \& CRAIG 2003: 25).

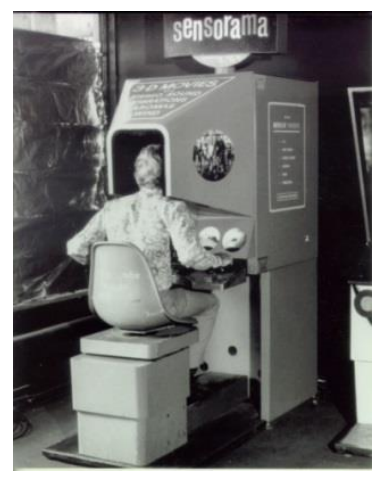

Fig. 7 - Sensorama, 1956 (in: http://www.mortonheilig.com).

Durante sua pesquisa de doutorado no Massachusetts Institute of Technology (MIT) em 1963, o cientista da computação Ivan Sutherland desenvolveu o dispositivo que é considerado por muitos como um precursor na área da Computação Gráfica, o Sketchpad. Para efeitos de comparação, o Sketchpad funcionava como os tablets de hoje: 
utilizando uma caneta óptica (light pen), o usuário conseguia desenhar diretamente na tela do computador formas geométricas simples, como linhas retas, círculos e hexágonos. A inovação trazida pelo Sketchpad, tal como descreveu em seu artigo (SUTHERLAND 1964), estava na interação homem-máquina dentro de um sistema de comunicação gráfica que deu origem ao CAD (Computer-Aided Design, "desenho auxiliado por computador"). Mas Ivan Sutherland continuou suas pesquisas e foi além, desenvolvendo em 1968 o primeiro dispositivo HMD (Head-Mounted Display, "vídeo-capacete estereoscópico") de Realidade Virtual e Realidade Aumentada. O pesquisador definiu brevemente o seu invento na introdução de seu artigo (SUTHERLAND 1968):

A ideia fundamental por trás do display tridimensional é apresentar ao usuário uma imagem em perspectiva que muda conforme ele se movimenta. A imagem retinal dos objetos reais que nós vemos é, afinal de contas, apenas bidimensional. Assim, se colocarmos imagens bidimensionais nas retinas dos observadores podemos criar a ilusão de que ele está vendo um objeto tridimensional. Embora a apresentação estéreo seja importante para a ilusão tridimensional, ela é menos importante do que a mudança que existe na imagem quando o observador movimenta sua cabeça. A imagem apresentada pelo display tridimensional deve se mover de acordo com a cabeça do usuário.

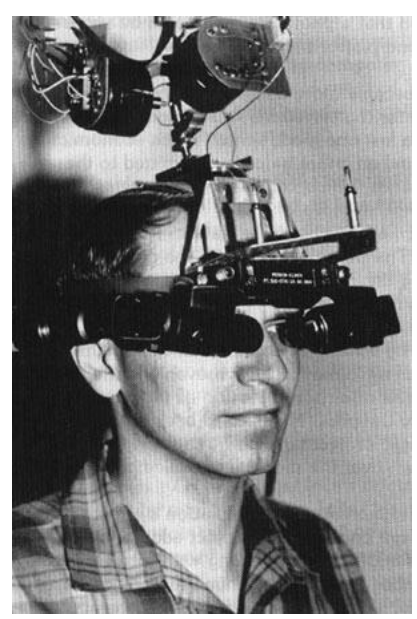

Fig. 8 - HMD de Ivan Sutherland, 1968 (in: http://zakros.com). 
O dispositivo criado por Sutherland, então, trabalhou com uma característica essencial da R.V., que é a imersão. Com o capacete colocado, o usuário tem a sensação de estar imerso em outro ambiente que se mostra verossímil. O grau de imersão varia de acordo com o dispositivo utilizado: mesmo com o uso de óculos 3D, a nossa sensação de imersão é ligeiramente inferior à proporcionada por um HMD, que preenche toda a nossa visão. É diferente estar diante de um monitor de computador 3D ou com um capacete ou óculos de RV - o nosso grau de visão é bem maior do que os monitores, permitindo-nos observar o que está ao seu redor, prejudicando o efeito tridimensional; o mesmo acontece em uma CAVE (Cave Automatic Virtual Environment, "caverna"), quando nossa sensação de imersão sofre uma quebra devido às arestas que unem as telas da caverna e atrapalham a paralaxe.

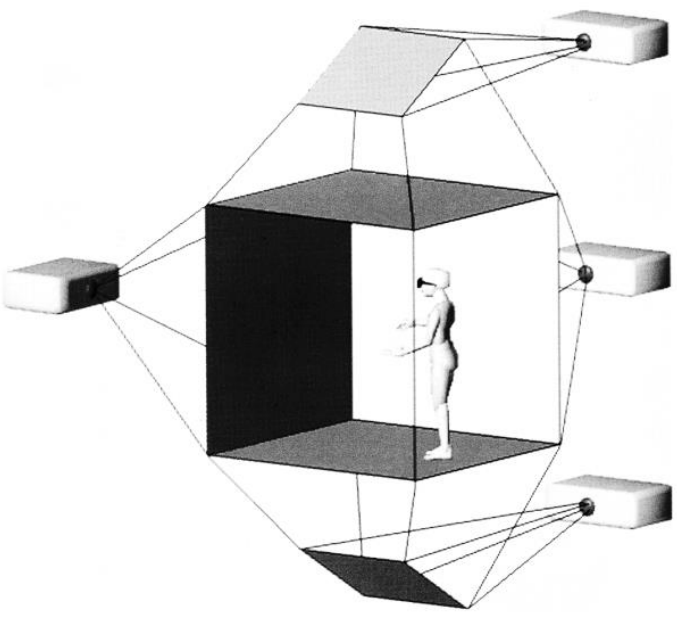

Fig. 9 - Esquema de um CAVE com o posicionamento dos projetores atrás da tela (NETTO et al. 2002).

Em 1984, William Gibson criou em sua obra literária Neuromancer o termo cyberspace (ciberespaço), que acabou sendo adotado no meio da realidade virtual. Gibson define ciberespaço como: "Uma alucinação consensual vivenciada diariamente por bilhões de operadores autorizados... uma representação gráfica de dados abstraídos dos bancos de todos os computadores do sistema humano" (2008: 75). No ano seguinte, os cientistas da computação Jaron Lanier e Thomas Zimmerman saíram da Atari e fundaram a empresa VPL Research, que se especializou no desenvolvimento e venda de óculos de R.V. e DataGlove (luva capaz de captar a movimentação e inclinação dos dedos da mão): também é creditado a Lanier a cunhagem do termo "Realidade Virtual". A CAVE (Caverna), por sua vez, foi apresentada ao público primeiramente durante a conferência 
SIGGRAPH de 1992: desenvolvido pelo Eletronic Visualization Lab da Universidade de Illinois (Chicago), o conceito de CAVE consiste em uma sala em que as quatro paredes, o teto e o chão são telas sobre as quais são projetadas imagens estereoscópicas para criar a sensação de imersão nos usuários enquanto interagem com os aplicativos (MAZURYK \& GERVAUTZ 1996: 3). Uma CAVE também foi produzida no Brasil pelo Laboratório de Sistemas Integráveis (LSI) na Escola Politécnica da Universidade de São Paulo em 2001, a CAVERNA Digital. Por fim, deve-se destacar que ainda esse ano chega ao mercado o Oculus Rift, um projeto originado no Kickstarter que pretende vender óculos HMD, a custo acessível, voltados para a indústria dos games: os primeiros testes com desenvolvedores têm sido muito positivos ${ }^{11}$.

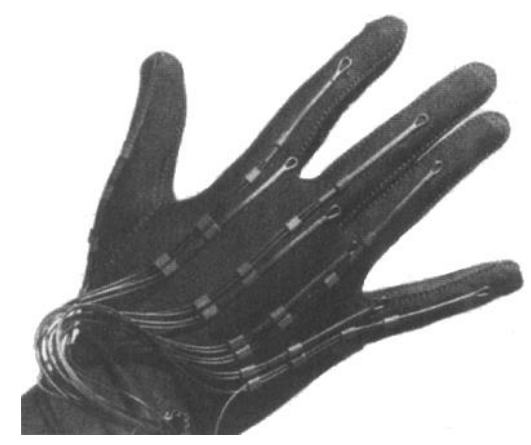

Fig. 10 - DataGlove, 1985 (in: http://www.yorku.ca/mack/Barfield.html).

Conforme já mencionado, a R.V. tem em seu cerne a imersão. O grau de imersão, porém, varia de acordo com os sistemas de R.V. empregados. Há três tipos de imersões possíveis (MAZURYK \& GERVAUTZ 1996: 5):

1) Desktop: a aplicação de RV mais simples que existe, usando um monitor para exibir a imagem (estereoscópica ou monoscópica) do mundo e sem suporte a outro sensor de saída;

2) Aquário (Fish Tank): uma versão melhorada do desktop, utilizando HMDs;

3) Sistemas imersivos: deixam o usuário completamente imerso no mundo gerado por computador com o auxílio de HMD (ou CAVE) e sensores hápticos e de áudio.

As aplicações de RV, por sua vez, podem ser classificadas da seguinte maneira (de acordo com NETTO et al. 2002):

\footnotetext{
${ }^{11}$ www.oculusvr.com
} 
1) Telecolaboração: usuários remotos compartilham um ambiente virtual para realizar uma tarefa em comum;

2) Telepresença (ou teleoperação): usuário pode operar, à distância, um robô em um ambiente remoto que emite feedback sensorial ao usuário humano;

3) Visualização Científica: usuário manipula, em ambiente virtual 3D, uma determinada quantidade de dados computacionais.

As sessões de R. V. proporcionadas por um aplicativo também podem ser triplamente categorizadas; a saber (NETTO et al., 2002):

1) R.V. passiva: o usuário explora o ambiente de forma automática e sem interferência (toda a rota e pontos de observação são definidos na programação);

2) R.V. exploratória: o usuário tem liberdade para navegar por onde quiser, mas não pode interagir de outra forma com elementos presentes na cena;

3) R.V. interativa: o usuário tem liberdade para navegar por onde quiser e pode interagir com os elementos da cena, que respondem e reagem à ação do usuário (por exemplo: uma porta que se abre para o participante entrar).

Afora a imersão, a R.V. também conta, como já apontei, com a interação em seu funcionamento. Isso é o que difere basicamente a animação da R.V.: a interatividade. Enquanto na animação o usuário é passivo, apenas observando o que é mostrado na tela, na R.V. ele é o protagonista principal, atualizando a todo momento a realidade mostrada na tela ou HMD. A interação do usuário no ambiente acontece, na maioria dos casos, em seis graus de liberdade (6DOF - six degrees of freedom), ou seja, seis tipos de movimentação: para frente/para trás, acima/abaixo, esquerda/direita, inclinação para cima/para baixo, angulação à esquerda/à direita e rotação à esquerda/à direita; porém, também existem dispositivos que permitem 3DOF e 2DOF (como o mouse comum de computador).

Os sensores na R.V. são responsáveis por permitir a imersão/interação dos usuários e consistem em dispositivos de hardware que atuam em conjunto com softwares. Esses dispositivos são separados em duas grandes categorias: os dispositivos de entrada e os de saída, responsáveis por realizar o tracking do usuário (o rastreamento de sua posição no ambiente virtual).

- Dispositivos de Entrada (input): 
1) Eletromagnéticos: nesse método, o transmissor emite um campo magnético de baixa frequência que é captado pelo receptor - desse modo, as ondas eletromagnéticas informam ao sistema de RV onde o usuário se encontra e efetua os cálculos necessários de posicionamento no ambiente virtual; embora sendo o método mais barato, os dispositivos eletromagnéticos acabam por sofrer influências negativas de objetos metálicos, não sendo sempre fácil a sua calibração (SHERMAN \& CRAIG 2003: 78-79);

2) Mecânicos: um dispositivo mecânico ligado ao computador é acoplado ao usuário, recebendo as respostas de movimentação realizadas pelo participante; um dos dispositivos mais conhecidos desse gênero é o BOOM (Binocular Omni-Oriented Monitor), que consiste em um visor montado sobre um braço mecânico com um contrapeso, permitindo 6DOF (NETTO et al. 2002);

3) Ópticos: o meio mais comum de rastreamento óptico é o uso de uma câmera de vídeo que atua como um olho eletrônico a fim de "observar" o objeto ou pessoa a ser rastreado (muito parecido com o dispositivo Kinect da Microsoft) (SHERMAN \& CRAIG 2003: 81);

4) Ultrassônicos: o transmissor (o usuário falando) emite ondas sonoras que são captadas pelo receptor e decodificadas; apesar de ser um método comum e não dispendioso, os ruídos presentes nas ondas sonoras podem interferir no resultado final (SHERMAN \& CRAIG 2003: 84);

5) Inerciais: método que usa instrumentos eletromagnéticos para detectar a movimentação relativa dos sensores enquanto mede mudanças nas forças giroscópicas, na aceleração e na inclinação (SHERMAN \& CRAIG 2003: 85);

6) Neurais (musculares): método que rastreia o movimento individual das partes do corpo, medindo as respostas elétricas da pele para determinar atividades nervosas e musculares em áreas específicas; funciona melhor em extremidades, como os dedos (SHERMAN \& CRAIG 2003: 86-87).

- Dispositivos de Saída (output):

1) Visuais: como principais dispositivos desse tipo de saída temos os já mencionados Head-Mounted Display (HMD) e Binocular Omni-Oriented Monitor (BOOM), além dos monitores de computador e sistemas de projeção comuns ou estereoscópicos (no caso da estereoscopia, utilizamse ou os óculos obturadores - shutter-glasses, que sincronizam com a taxa 
de atualização frequencial das imagens projetadas/exibidas -, ou os óculos polarizados passivos, como os de cinema e televisores 3D) (NETTO et al. 2002);

2) Auditivos: os sistemas de som requerem menos computação do que os visuais, e são mais baratos também. Para criar a sensação de imersão, é necessário que haja uma distribuição 3D do som, tornando-o o mais próximo possível do mundo físico. Os dispositivos de som podem ser caixas acústicas posicionadas estrategicamente nos ambientes de R.V. ou fones de ouvido (headphone) - que atualmente conseguem simular, além dos dois canais já tradicionais, cinco ou sete canais de som, criando o efeito surrond;

3) Hápticos: os dispositivos de reação tátil estimulam sensações como tato, tensão muscular, temperatura, pressão e/ou peso (NETTO et al. 2002). São dispositivos eletromecânicos que demandam bastante tempo para serem calibrados corretamente e trabalhados com eficácia pelos usuários. Muitos dispositivos hápticos têm sido usados na área médica para simular cirurgias ou operar pacientes à distância.

De acordo com o que foi acima apresentado, e colocando novamente em evidência a discussão entre Robert Kozma e Richard Clark, é importante deixar claro agora que a R.V. é uma mídia de aprendizagem. Ela, por si só, não é capaz de auxiliar no processo cognitivo, ela não é um "mundo à parte" que os estudantes vão experimentar e automaticamente aprender algo: cabe ao professor/pesquisador elaborar o conteúdo que será aplicado por meio de R.V., levando sempre em consideração todas as vantagens e desvantagens de cada tipo de aplicação de RV que já foram mencionadas acima.

A R.V. na Educação não deve ser utilizada como um mero passatempo, uma curiosidade computacional para os alunos. O seu uso deve sempre agregar na cognição, evitando-se apresentá-la como um lazer que difere totalmente do tradicional "giz e lousa": ambos são importantes e não devem ser hierarquizados. Somente com um trabalho sólido realizado pelos educadores é que, ao experimentar uma aplicação em R.V., os alunos alcançarão não apenas a imersão e a interação, mas também o envolvimento, que é outra característica central na R.V.. O trabalho prévio com os alunos antes de usarem qualquer 
dispositivo de R.V. fará com que se sintam, de fato, envolvidos na proposta quando ela lhes for apresentada.

Dentre as justificativas para o uso da R.V. na Educação, podemos citar (PANTELIDES 1995; WICKENS 1992):

1) Maior motivação dos usuários;

2) O poder de ilustração da R.V. para alguns processos e objetos é muito maior que o de outras mídias;

3) Permite análise de muito perto e muito longe;

4) Permite que pessoas portadoras de alguma deficiência realizem tarefas que de outra forma não seriam possíveis;

5) Dá oportunidades para experiências;

6) Permite que o aprendiz desenvolva o trabalho no seu próprio ritmo;

7) Não restringe o prosseguimento de experiências ao período da aula regular.

É importante também ressaltar que a R.V. pode trabalhar tanto na educação presencial como na Educação à Distância (EAD) - ou educação sem distância (TORI 2010; MOORE 1993), segundo a proposta do engenheiro e professor da Escola Politécnica da USP e do Centro Universitário Senac, Romero Tori (uma vez que o uso de ambientes virtuais interativos não distanciam alunos de professores). Por exemplo, um hospital equipado com dispositivos de R.V. conseguiria fornecer às crianças internadas em tratamento um cronograma de aulas para que elas não se prejudicassem ao faltar às escolas.

A R.V. pode ser inserida na proposta cada vez mais atuante de que o professor não é o detentor do conhecimento, mas, sim, um facilitador. Os ambientes virtuais contêm os mesmos elementos principais que todo processo de aprendizagem educacional deve ter: a discussão - entre o instrutor e o estudante; a interação - entre o estudante e algum aspecto do mundo definido pelo instrutor; a adaptação - do mundo pelo instrutor e ação do estudante; e a reflexão - sobre o desempenho do estudante pelo instrutor e pelo aluno (BURKLE \& KINSHUK 2009). Em outras palavras, a Educação é um processo constante de descoberta, exploração, observação e construção. E sobre o uso da R.V. na educação, escreveram os professores e engenheiros da Escola Politécnica (USP) Marcelo Zuffo, Roseli Lopes e a $\mathrm{Dr}^{\mathrm{a}}$ Irene Ficheman (ZUFFO et al. 2008: 115): 
A realidade virtual expande os processos normais de aprendizagem, onde o aprendiz é encorajado a participar de um processo criativo e divertido, explorando assuntos que nos métodos tradicionais levaria mais tempo para serem ensinados. A utilização da realidade virtual contribui para a motivação dos alunos, pois permite a ilustração de alguns processos e objetos, promove uma análise da realidade visualizada sob diferentes ângulos e permite a visualização e exploração de lugares inexistentes ou de difícil acesso.

Podemos citar aqui um exemplo de sucesso de R.V. aplicada à Educação que contou com a colaboração dos pesquisadores mencionados e uma grande equipe multidisciplinar de engenheiros, cientistas da computação, astrônomos, arquitetos, cineastas, artistas, músicos e pedagogos: a instalação denominada Nave Mário Schenberg, que ocupa lugar no Parque de Ciência e Tecnologia da Universidade de São Paulo e inclui projeções estereoscópicas de dados espaciais, animações em três dimensões, filmes, sistemas de interação e jogos interativos (ZUFFO et al. 2008: 117). Homenageando o físico brasileiro homônimo, a Nave Mário Schenberg é um ambiente de realidade virtual colaborativo apoiado por computador (Computer Supported Cooperative Work - CSCW) que simula e recria uma nave espacial dividida em seis estações, onde os alunos (divididos em grupos) são responsáveis por trabalhar em conjunto para solucionar problemas a fim de salvar a população Tectracty de um planeta fictício que está em risco por conta da proximidade com o sol que está prestes a explodir. O objetivo pedagógico da instalação é despertar nos alunos o interesse por áreas como Astronomia e Física, além de enfatizar a importância da colaboração na resolução de problemas e a importância da preservação de recursos naturais da Terra. Desse modo (ZUFFO et al. 2008: 120):

A utilização da realidade virtual num contexto educativo pressupõe uma concepção de ensino diferente da tradicional. A criação de mundos virtuais coloca, à disposição de educadores e alunos, uma nova ferramenta, auxiliando-os a delinear um novo paradigma na área da comunicação educacional. Aproveitando esse potencial que a realidade virtual pode trazer para a educação, a Nave Schenberg proporciona a expansão dos processos normais de aprendizado. Espera-se que, após a visita, os alunos tenham vontade de buscar mais informações relacionadas aos temas abordados e que a instalação da Nave 
impulsione a pesquisa e o desenvolvimento de soluções nacionais que mesclem tecnologia de última geração e paradigmas educacionais, ampliando, desta forma, a oferta de ferramentas educacionais inovadoras.

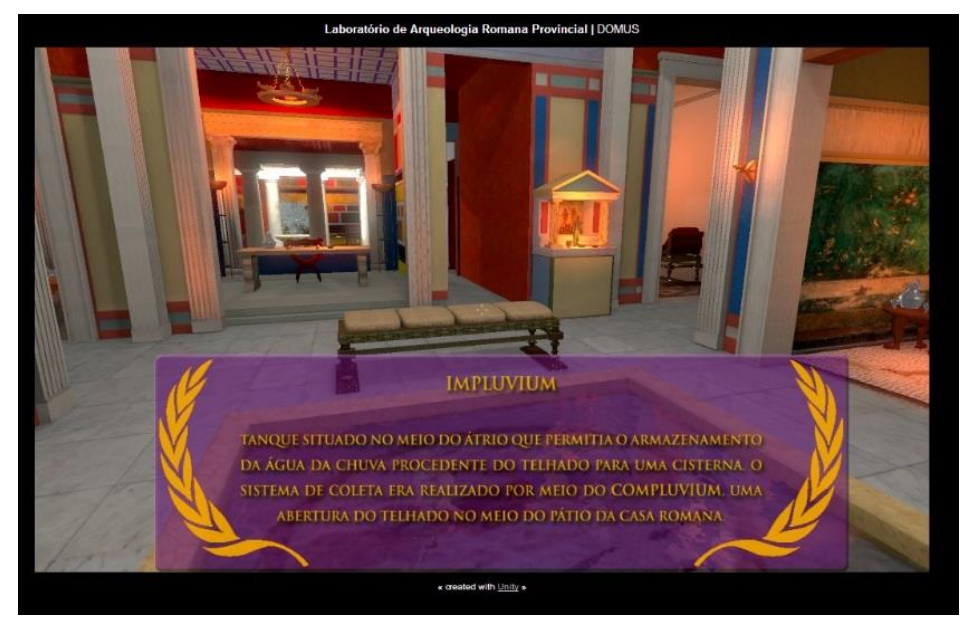

Fig. 11 - Exemplo de realidade virtual: aplicativo DOMUS desenvolvido pelo Laboratório de Arqueologia Romana Provincial (LARP) do MAE-USP. Acervo pessoal, 2013.

Além da R.V., outra área que vem se desenvolvendo com fôlego enorme é a da Realidade Aumentada (R.A.). Segundo Allan B. Craig (2013: 15), a R.A. é "um meio no qual informação é adicionada ao mundo físico sendo registrada nesse mundo". Já o cientista da computação Ronald T. Azuma, em seu artigo seminal "A Survey of Augmented Reality", de 1997, define a área como

uma variação de Ambientes Virtuais (A.V.), ou Realidade Virtual, como é mais comumente chamado. As tecnologias de A.V. imergem completamente o usuário em um ambiente sintético. Enquanto imerso, o usuário não pode ver o mundo real ao seu redor. Em contraste, a R.A. permite ao usuário ver o mundo real, com objetos virtuais sobrepostos ou compostos com o mundo real. Portanto, a R.A. suplementa a realidade ao invés de substituí-la completamente. Idealmente, pareceria ao usuário que os objetos reais e virtuais coexistem no mesmo espaço, semelhantemente aos efeitos alcançados no filme Uma Cilada para Roger Rabbit. (...) A R.A. pode ser pensada como um "meio termo" entre A.V. (completamente sintético) e telepresença (completamente real). 
Azuma aponta, ainda, três características básicas da R.A.: 1) combina real e virtual; 2) interação em tempo real; 3) registrada em 3D. Allan Craig, por sua vez, se debruça sobre essas três características e as amplia, chegando aos seguintes aspectoschave (2013: 16):

1) o mundo físico é aumentado pela informação digital sobreposta em uma visão no mundo físico;

2) a informação é mostrada juntamente com o mundo físico;

3) a informação mostrada é dependente da locação do mundo real e da perspectiva física da pessoa no mundo físico;

4) a experiência da realidade aumentada é interativa, isto é, uma pessoa pode perceber a informação e fazer mudanças nessa informação caso deseje: o grau de interatividade pode ir desde uma simples mudança de perspectiva física (por exemplo, enxergar em um diferente ponto de vista) até manipular ou até mesmo criar nova informação.

A partir do que foi dito acima, podemos dizer que a R.A. permite que uma camada de informação (digital, sempre) seja posta sobre o mundo físico que observamos. Imagine a seguinte situação: por alguma razão que só você sabe, numa certa noite decide pegar seu carro para comprar algo no mercado mais próximo. Tudo seria tranquilo se você não tivesse escolhido visitar alguma cidade que mais parece ter saído de algum livro do Stephen King - ou seja, só há gente estranha, pouca iluminação e, para variar, o mapa que você comprou no posto de gasolina mais próximo (que ficou a mais de 50 quilômetros para trás) está desatualizado há anos. Seria uma tragédia se você não tivesse trazido consigo seu smartphone. Graças a esse maravilhoso dispositivo, sua noite está salva (por enquanto, afinal, nunca se sabe...): você seleciona o aplicativo de GPS, busca por "mercado" e, num instante, surge a localização mais próxima. Porém, como dito, você está em um lugar em que as ruas são drasticamente mal iluminadas e totalmente esburacadas: é perigoso dirigir e olhar a tela do dispositivo ao mesmo tempo (já que a saída de áudio está queimada faz tempo). O que fazer? Vivendo em um futuro não muito distante do meu, você sabe que apertando um simples botão toda a informação de seu GPS é transferida para o para-brisa touchscreen de seu carro. Ao fazer isso, imediatamente surge um ponto pulsante no vidro que parece atravessar os prédios. Ao mesmo tempo, sensores implantados nos postos de iluminação defeituosos, por algum milagre, estão funcionando e captam o sinal oriundo de seu carro. Eles decodificam a 
informação e liberam pequenos feixes de luz que, sobrepostos ao asfalto, vão lhe guiando até o mercado. Parabéns, você chegou ao inóspito mercado gerenciado por algum sujeito mal-encarado graças à Realidade Aumentada (agora pague a conta e suma daí antes que seja tarde demais!).

Por ser a R.A. algo com o qual devemos interagir no mundo físico, não há muitas aplicações que estejam presas aos computadores desktops que conhecemos (ou até mesmo aos notebooks/laptops). A maioria das aplicações de R.A. são desenvolvidas para dispositivos portáteis, como o smarthphone que acabamos de ver, ou tablets: é o que convencionou-se denominar A.R. Mobile (Augmented Reality Mobile, ou Realidade Aumentada Móvel - RAM). Os principais benefícios da RAM incluem (JÚNIOR et al. 2013: 61): a portabilidade; a mobilidade; estar disponível a qualquer hora e em qualquer lugar o acesso, de forma flexível, a diversos recursos e em tempo real; economia de tempo; rapidez de comunicação; capacitação e envolvimento dos alunos. Contudo, os desenvolvedores sempre precisam ter em mente as limitações reais da RAM, uma vez que ela é um conjunto de software e hardware, dependendo muito deste último para existir. Assim sendo, é necessário considerar o hardware do público alvo: não adianta ter uma aplicação R.A. notável se quase nenhum usuário possuir dispositivos capazes de executála. Devemos, então, sempre levar esses fatores em consideração quando formos trabalhar com RAM (JÚNIOR et al. 2013: 62): tamanho da tela do dispositivo; consumo de energia; a precisão de localização; câmera de qualidade; processamento e memória; registro; segurança; tempo real; dependência; desempenho; cobertura; quantidade de dados; dinamicidade; interação; conteúdo. O conteúdo é o fator primordial em toda e qualquer aplicação, não devendo, jamais, ser relegado ao segundo plano.

Por fim, a R.A. pode ser classificada de acordo com a forma de visualização, segundo Romero Tori (2010: 159-160):

1) Optical see-through: uso de equipamentos ópticos, como óculos com visores ou projetores de vídeo semitransparentes, que mesclam imagens virtuais à cena real, que pode ser observada diretamente pelo usuário;

2) Video see-through: a cena real é captada por uma ou mais câmeras, misturada aos elementos virtuais e enviada ao usuário, que visualiza apenas o vídeo final; neste caso, se o vídeo for interrompido, o usuário fica sem nenhuma visão do ambiente real; 
3) Monitor: similar ao video see-through, com diferença de que a imagem é visualizada em um monitor;

4) Projeção na realidade virtual baseada em projetores, as imagens são geradas sobre objetos do mundo real, podendo dispensar o uso de óculos, capacetes ou monitores.

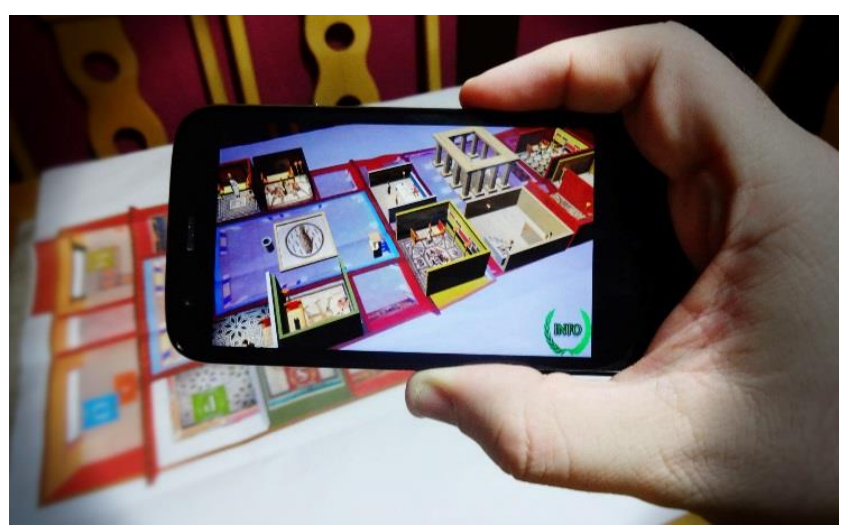

Fig. 12 - Exemplo de realidade aumentada: aplicativo DOMUS RA desenvolvido pelo Laboratório de Arqueologia Romana Provincial (LARP) do MAE-USP. Acervo pessoal, 2014.

\section{ENXERGANDO ALÉM DO “REAL": VISÃO E PERCEPÇÃO}

Antes de prosseguirmos em nossa jornada com a TARDIS e o Doutor, é importante esboçar brevemente dois conceitos muito relevantes quando lidamos com Realidade Virtual: o da estereoscopia e o da percepção.

Imagine-se uma sala de cinema, com suas poltronas que rangem, pipocas espalhadas pelo chão e os óculos 3D com manchas de dedos nas lentes. A sala escurece e a luz da cabine de projeção passa sobre sua cabeça: a imagem aparece e o som distorce os alto-falantes - a magia do cinema começa.

O filme que é exibido no cinema, tal como Avatar, é feito a partir de uma série de fotografias que passam rapidamente em sequência diante de um projetor de luz. São necessárias 24 fotografias diferentes para cada segundo de filme. Mas nada disso aconteceria se não fosse pelos experimentos realizados por Joseph Nicéphore Niépce no século XIX, culminando com a primeira fotografia conhecida que chegou até nós, de 1826, intitulada La cour du domaine du Gras. 


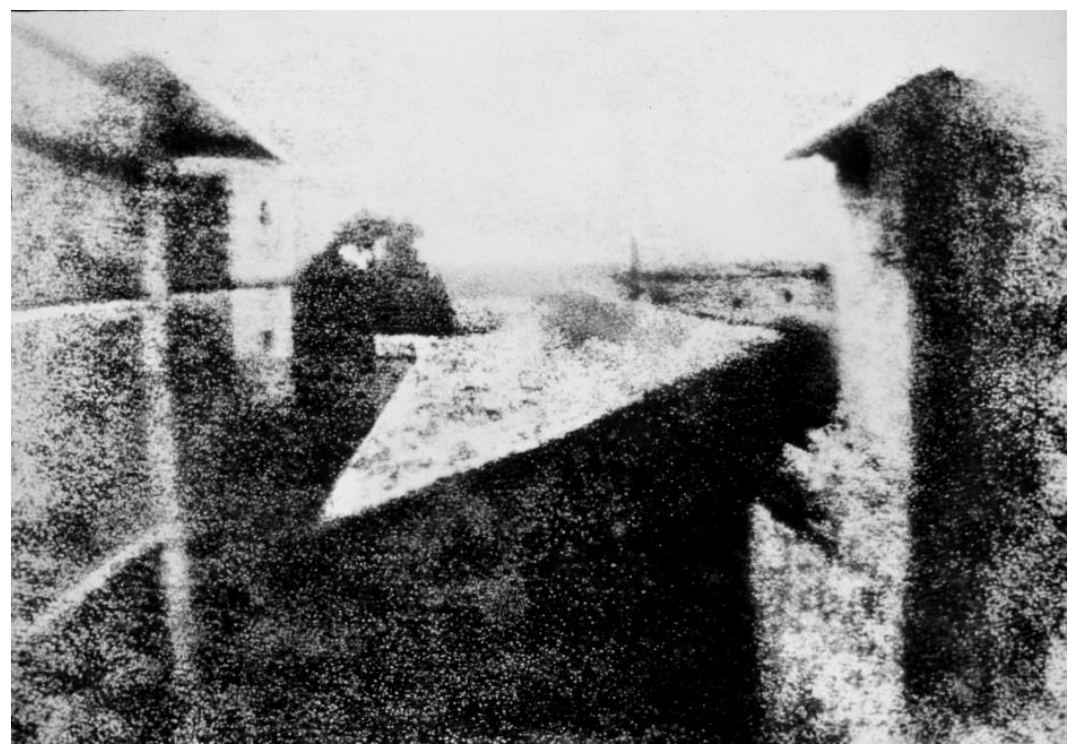

Fig. 13 - La cour du domaine du Gras, 1826 (in: Wikimedia Commons).

Niépce utilizou uma câmera escura, um dispositivo formado por uma caixa fechada que conta com um pequeno orifício para a entrada de luz, formando uma imagem invertida daquilo que é visto fora da câmera. Essa imagem invertida se deve ao princípio da física óptica de que a luz se propaga em linha reta e vem sendo estudado desde os tempos de Euclides, no século III a.C. Desse modo, a imagem é formada atrás do ponto de visão fornecido pelo orifício na caixa ou, nos dias de hoje, na câmera fotográfica.

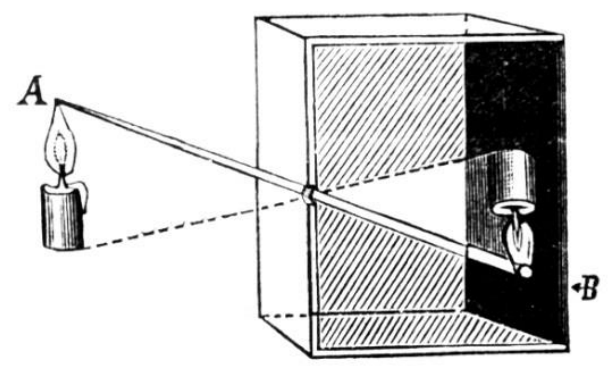

Fig. 14 - Câmera Escura (in: Wikipedia).

Os olhos dos seres humanos se comportam de modo semelhante: a luz de fora incide em nossas pupilas (o orifício da câmera escura), as imagens são projetadas invertidas em nossas retinas e depois são levadas ao nosso córtex estriado, na parte de trás do cérebro. Contudo, embora ainda possa existir uma definição simplista de que os olhos "captam fotografias" e as projetam em nossos cérebros como se fossem um filme em uma "tela interior", a realidade é diferente, uma vez que nossos olhos não enxergam um mundo estático e plano como as câmeras fotográficas: nós enxergamos profundidade, 
nós vemos três dimensões. A descrição da "tela interior" não nos ajuda a entender como sabemos quais objetos estamos observando ou como estamos aptos a descrever suas características (forma, textura, movimento, tamanho) ou suas relações espaciais uns com os outros (FRISBY \& STONE 2010: 11). De fato, é bastante tentador explicar a visão como uma representação fotográfica da realidade, porém, isso não dá conta do que realmente acontece, pois o sistema visual está imbuído de complicados processos que requerem um grande número de interpretações que vão além das impressões de pontos de luz em um filme fotográfico para formar imagens. Nem sempre o que nossos olhos enxergam é aquilo o que os nossos cérebros processam e nos entregam como visão. Isso fica claro com ilusões de óptica. Veja o exemplo abaixo.

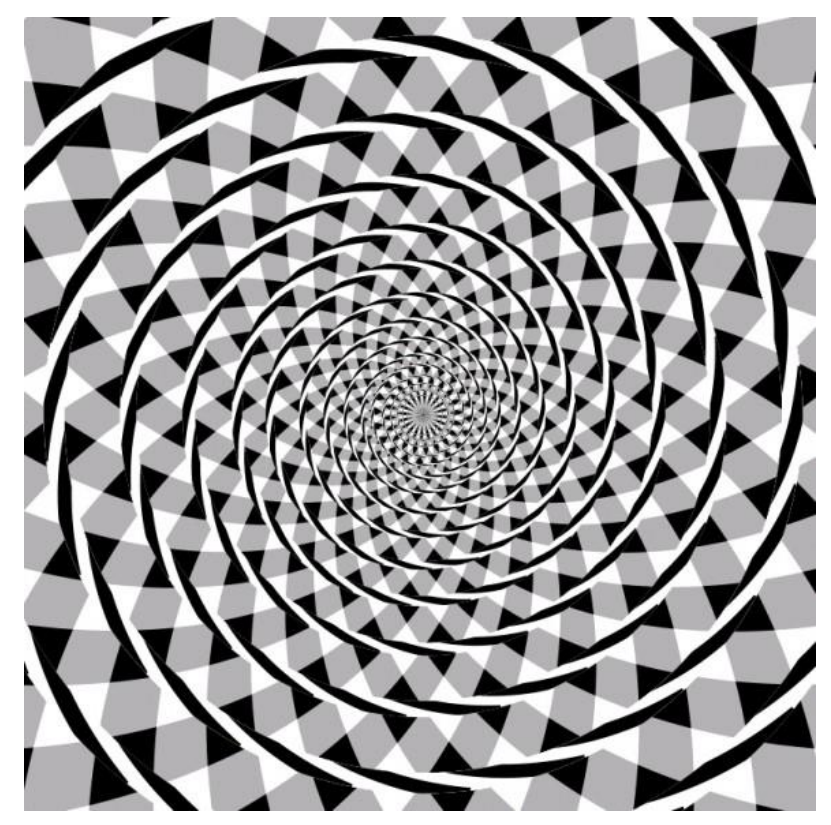

Fig. 15 - Espiral de Fraser, 1908 (in: Wikimedia Commons).

Pressupondo que tenha uma visão normal, você acabou de enxergar uma forma espiral, correto? Isso foi o que o seu cérebro interpretou. Tente novamente, mas dessa vez siga a espiral com o seu dedo!

A espiral o psicólogo britânico James Fraser nos mostra que, na verdade, não há espiral alguma. Existem apenas círculos na imagem, mas que para o nosso cérebro é difícil identificar. Assim, a teoria da "tela interior" não se mostra adequada, de modo algum, para o sistema visual. Nossos olhos são semelhantes às câmeras obscuras, porém, a nossa visão não é uma mera reprodução daquilo que chega até nossas retinas: há muito mais complexidade, o que acaba por afastar a ideia de que enxergamos "fotografias". 
Ainda na sala de cinema, os trailers acabaram e é mostrado na telona o aviso para colocar os óculos 3D. O filme começa e há um estranhamento momentâneo, uma adaptação. Logo as imagens em movimento ganham profundidade ou saltam da tela: esse é o efeito 3D pelo o qual cobram mais caro o ingresso. No entanto, o que vemos tridimensionalmente na tela grande nada mais é do que o modo natural com o que enxergamos o mundo. Sendo nossos olhos parecidos com câmeras escuras, podemos afirmar que temos duas câmeras, então; que nossa visão é estéreo porque essas duas "câmeras" estão posicionadas em dois diferentes lugares em nosso crânio, captando o mundo em dois ângulos distintos que convergem no cérebro, criando a noção de profundidade.

A visão binocular, contudo, apesar de ter sido objeto de análise por Ptolomeu no século II d.C. (que estudou a diplopia - a percepção de duas imagens a partir de um único objeto), pelo estudioso árabe Alhazen no ano 1000 e mais tarde por Kepler (1611) e Descartes (1637) - que associaram a percepção de profundidade com a sensação de convergência binocular - , só foi comprovada, de fato, pelo físico britânico Charles Wheatstone em 1838, com a invenção do dispositivo denominado estereoscópio (derivado do grego skopion,"ver", e stereo, "sólido"): consistia em dois espelhos centrados em $45^{\circ}$ para cada olho que refletiam imagens para o olho direito e o esquerdo (ZONE 2007: 5). Sir David Brewster, inimigo declarado de Wheatstone, passou longos anos aperfeiçoando o estereoscópio até chegar, em 1851, a uma versão que utilizava lentes ao invés de espelhos: seu dispositivo se tornou um verdadeiro sucesso na Europa e foi muito comum pessoas que podiam arcar com os custos do estereoscópio verem fotografias em três dimensões (cada fotografia tinha um grau de captação ligeiramente diferente da anterior): as fotografias estereoscópicas também atravessaram o Atlântico e chegaram a ser bastante difundidas aqui no Brasil, principalmente com os incentivos do Imperador D. Pedro II (que contratou o alemão Revert Henry Klumb como professor de fotografia da Princesa Isabel) e a difusão do Sistema Verascope de câmeras portáteis que facilitaram o olhar fotográfico de amadores como Carlos da Rocha Fernandes, que no início do século XX foi responsável por constituir um acervo com 540 imagens estereoscópicas (ADAMS 2004). 


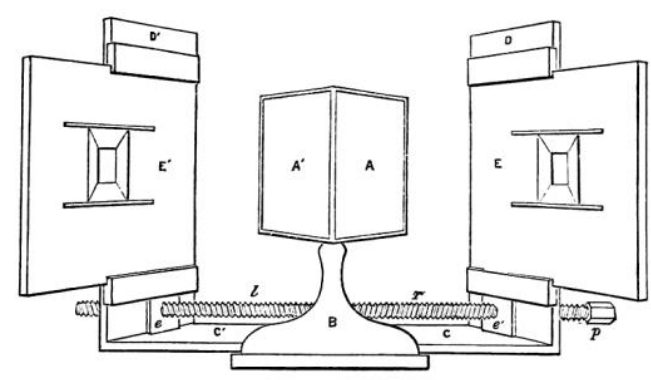

Fig. 16 - Estereoscópio de Charles Wheatstone (ZONE 2007: 6).

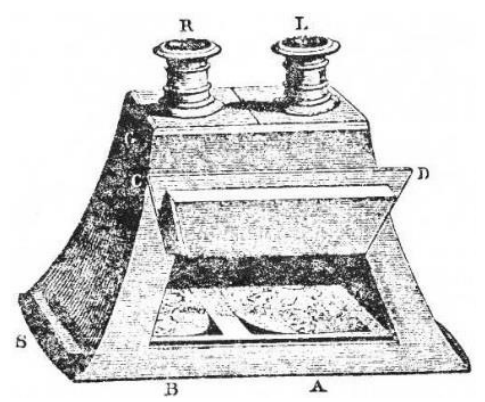

Fig. 17 - Estereoscópio de David Brewster (ZONE 2007: 11).

Porém, a visão binocular não é condição fundamental para a percepção tridimensional. Cada olho tem a sua própria noção de profundidade e isso pode ser comprovado se você fechar um dos olhos e andar pela sua casa: dificilmente caminhará esbarrando em tudo e derrubando as coisas; ou seja, o mundo observado não se torna plano quando só utilizamos um dos olhos. A resposta para a intrigante questão "Por que temos dois olhos?" é bem simples: possuir dois olhos é um bom seguro contra a perda de um deles (FRISBY \& STONE 2010: 420). A estereoscopia, no entanto, como se deduz pelo termo, precisa da visão binocular para funcionar, e é ela que está presente hoje em filmes 3D como Avatar e em alguns games. A necessidade de transformar as fotografias estereoscópicas em algo com movimento surgiu antes mesmo do advento do Cinema com os Irmãos Lumière em 1895: até 1864, as fotografias estereoscópicas eram todas visualizadas individualmente, nos estereoscópios inventados décadas antes. Com o decorrer dos anos, os inventores foram estudando e aperfeiçoando meios de fazer com que as fotografias fossem vistas por mais de uma pessoa ao mesmo tempo. A solução encontrada pelo francês Louis Ducos du Hauron, em 1864, foi a de projetar as fotos em uma área plana, tal como a tela de cinema: dessa forma, muitas pessoas podiam visualizar os mesmos conteúdos simultaneamente (ZONE 2007: 53-59). Mais do que isso, du Hauron criou um dispositivo que mostrava as fotografias sequencialmente de modo mais suavizado e, o que interessa para este trabalho, também elaborou uma técnica que fazia 
com que as pessoas na plateia conseguissem ver as fotografias tal como as viam nos estereoscópicos: essa novidade foi chamada de anáglifo (termo grego que corresponde a “cinzelado em relevo").

A estereoscopia anáglifa consiste em um método de subtração que utiliza duas lentes, uma vermelha e uma azul/ciano ou verde. Com os óculos vermelho/azul ocorre um fenômeno que faz com que a lente vermelha nos permita apenas enxergar o espectro vermelho (anulando o azul), e que a lente azul nos permita enxergar apenas o espectro azul (anulando o vermelho): por causa de o filtro colorido cancelar a cor oposta na fotografia esse método é chamado de subtração. O efeito de profundidade no anáglifo, porém, nada tem a ver com a visão colorida. Os filtros coloridos servem apenas para separar a imagem em duas metades para que somente uma seja projetada na retina de cada olho: nós enxergamos profundidade com a técnica anáglifa porque as duas imagens componentes não são idênticas, simulando aquilo que observamos no mundo natural - as imagens nunca chegam iguais aos nossos olhos porque eles estão posicionados em lugares diferentes em nossa cabeça (a isso damos o nome de disparidade binocular). A figura abaixo nos auxilia a entender a técnica anáglifa.

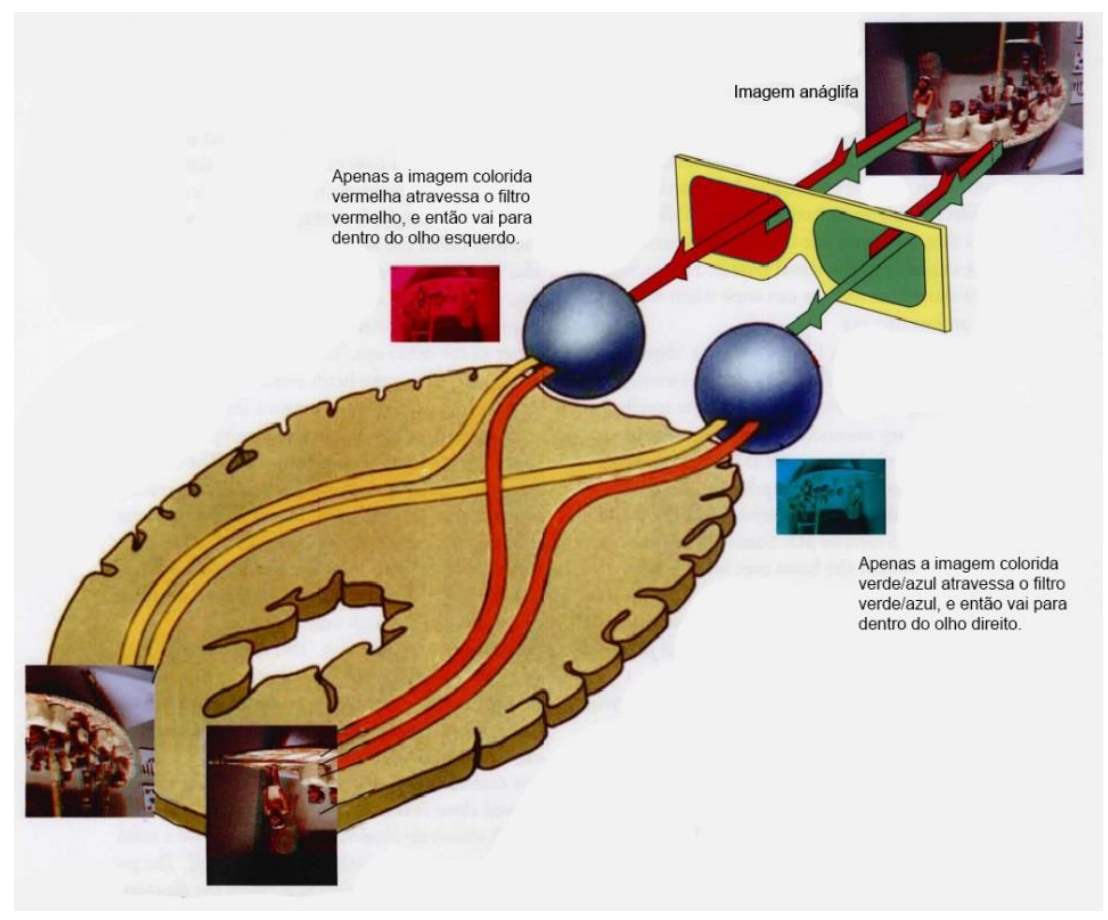

Fig. 18 - Como o anáglifo funciona (adaptado de FRISBY \& STONE 2010: 422). 


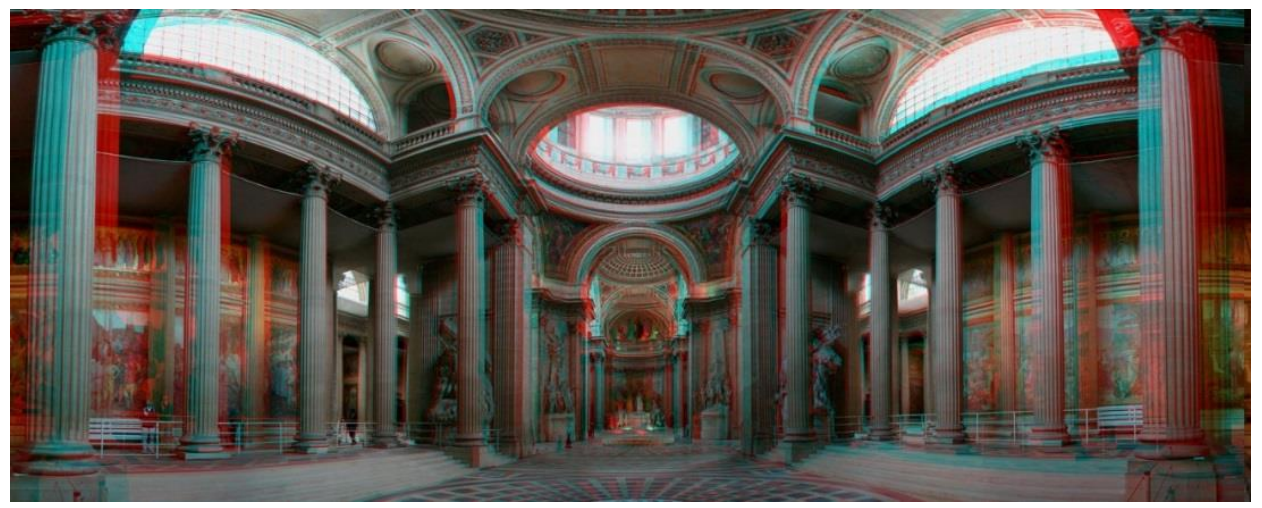

Fig. 19 - Panthéon de Paris: exemplo de imagem anáglifa (in: Wikipedia).

A técnica anáglifa pode ser estendida a qualquer tipo de estereoscopia que envolva o uso de óculos. Embora as lentes coloridas tenham sido muito usadas no Cinema até meados do século XX - e continuam sendo utilizadas ainda hoje devido ao seu baixo custo -, o que temos atualmente nas salas de cinema e em televisores 3D são os óculos com lentes polarizadas, que permitem uma maior fidelidade às cores que originalmente foram gravadas em vídeo. A técnica de polarização é muito parecida com a anáglifa, com a diferença de que as lentes filtram as luzes emitidas pelo projetor: assim, uma das lentes filtra a luz em apenas uma direção, enquanto a outra filtra na direção oposta (por exemplo: vertical e horizontal). Essa técnica foi aperfeiçoada e patenteada pelo inventor estadunidense Edwin H. Land em 1929, que acabou por fundar uma empresa especializada nessa temática em 1936, a Polaroid Corporation. Graças a Land, a história do cinema assistiu a um verdadeiro boom de filmes 3D a partir de 1951, quando a obra dirigida por Arch Oboler, Bwana Devil, estreou no Festival of Britain e causou frenesi por ser o primeiro filme estereoscópico totalmente em cores (ZONE 2007: 149-153; 185186).

James Cameron deve muito a esses inventores e cientistas do passado, que dedicaram muito tempo de suas vidas ao estudo de como nós enxergamos o mundo e como essa visão tridimensional pode ser recriada a partir de objetos bidimensionais. Mas nem só o cinema se beneficiou da estereoscopia. Como dito, a R.V., que vem sendo desenvolvida desde a década de 1960, também se apoia nas técnicas estereoscópicas a fim de criar a sensação de imersão em suas diversas aplicações. A estereoscopia, embora facultativa, tem sido muito empregada no âmbito da virtualização e trabalha em conjunto com a interatividade. 
Já com relação à presença, esse é um conceito bastante difícil de definir e mensurar. Faça esse pequeno exercício, pergunte a si mesmo: Como sei que estou presente? Como consigo afirmar que minha presença é real?

É muito complicado responder a isso!

Se eu coloco um HMD e entro em uma domus romana do século I d.C. simulada em computador eu estou presente nela? Se a resposta é não, por que mesmo sentindo-me caminhando por ela eu digo que não estou presente? Se a resposta é sim, seria um indício de que estou quase sentindo como se estivesse viajando com o Doutor e sua TARDIS? A presença na realidade virtual é diferente da presença naquilo que comumente denominamos "real"? Muitos podem oferecer uma resposta cartesiana, dizendo que "Penso, logo sou". A essa resposta, emendo outra pergunta: esse "eu" que "pensa" não passa de genes egoístas que controlam nossos corpos - eles pensam, nós não - então, quem pensa, afinal?

A presença se apresentando como um nó górdio, temos de tentar chegar a alguma solução. O que proponho é a definição mais simples possível: a presença é a sensação de "estar lá", mesmo que possa haver muitos "estarem lá", que depende exclusivamente do sujeito. Desse modo, tento resolver um problema grave e praticamente sem solução me ausentando da discussão: a presença vai ser o que você quiser que seja - será a sensação que você me descrever. Caso diga que caminhar em uma zona de mineração romana dos séculos I e II d.C. criada por computador não lhe faz sentir-se presente, eu entenderei (embora, provavelmente, todo o trabalho em criar meios de imersão se mostre em vão). Se disser que realmente sentiu-se caminhando pelo chão árido e praticamente pôde respirar as fumaças tóxicas vindas da queima de minérios, eu também entenderei (e, nesse caso, ficarei mais feliz, confesso).

Muitos pesquisadores têm se dedicado ao estudo de presença em ambientes virtuais tridimensionais interativos. Por exemplo, no artigo "The sense of embodiment in Virtual Reality", de 2012, Konstantina Kilteni, Raphaela Groten e Mel Slater, propõem um novo conceito para a mensuração de presença em ambientes virtuais, o Sense of Embodiment $(\mathrm{SoE})^{12}$, referindo-se ao conjunto de sensações que surgem em conjunção

\footnotetext{
${ }^{12}$ Senso de Corporificação.
} 
com o controle, o pertencimento e o "estar dentro" de um corpo (especialmente em relação às aplicações de R.V.).

Para estabelecer a definição de SoE, os autores o dividem em três categorias - que não necessariamente precisam ocorrer ao mesmo tempo sempre (KILTENI et al. 2012: 375-377):

1) Senso de Auto Localização: relação entre um ser e o seu próprio corpo (sensação de se estar localizado dentro de um corpo físico), e se difere de "presença" pois ela se refere à relação entre um ser e o ambiente;

2) Senso de Agência: a sensação de ter um controle motor global, incluindo a subjetiva experiência de ação, controle, intenção, seleção motora e consciência de vontade (ela está presente em movimentos ativos);

3) Senso de Pertencimento do Corpo: implica no fato de o corpo ser a fonte das sensações experimentadas, esse senso tem duas influências: bottom-up (informação sensória que chega a nossos cérebros a partir de nossos órgãos sensórios) e top-down (processos cognitivos que modulam o processamento dos estímulos sensórios).

Com essa nova abordagem proposta pelos autores do artigo, é possível mensurar a presença, uma vez que ela é analisada como o participante reage dentro do sistema de ambiente virtual interativo baseando-se em suas ações no mundo real.

Ao contrário de métodos tradicionais como questionários para se medir o grau de presença (pois questões não permitem a diferenciação entre a experiência na realidade e na realidade virtual), é proposto novo meio de mensuração a partir de dois conceitos novos: Place of Illusion (PI) ${ }^{13}$ - a ideia de sensação ao se estar em um lugar ditado pelo ambiente virtual -, e Plausibility (Psi) ${ }^{14}$ - a ilusão de que o que está aparentemente ocorrendo realmente está ocorrendo. Tendo esses dois conceitos em mente, foram selecionados 20 participantes (metade mulheres, metade homens) na faixa etária de 20 a 35 anos de idade, sendo que só dois deles já haviam tido experiências com realidade virtual. Usando HMDs e vestindo roupas para capturas de movimento (ou estando diante de um powerwall), os participantes foram postos em uma sala, sentados em uma cadeira. A aplicação, por sua vez, também simulava uma sala com uma pessoa sentada em uma

\footnotetext{
${ }^{13}$ Lugar de llusão.

14 Plausibilidade.
} 
cadeira. De acordo com as opções criadas pelos pesquisadores, os participantes podiam escolher entre ter ambientes com ou sem sombras, reflexos, movimentação do avatar em tempo real, entre outros.

Os resultados mostraram dados interessantes sobre presença em ambientes imersivos. Chegou-se à conclusão de que (SLATER et al. 2010):

a) Contingências sensor-motoras naturais são importantes para PI (88\% dos participantes escolheram HMD);

b) Correlações entre ações próprias e eventos são importantes para Psi (maioria dos participantes preferiu avatares dinâmicos e reflexo no espelho da sala virtual);

c) Iluminação realista pode ser importante para Psi (ao contrário do grupo PI, os participantes do grupo Psi preferiram aumentar o realismo das luzes);

d) O corpo virtual é importante para PI e Psi (os participantes se sentiram presentes ao terem seu corpo refletido no espelho e utilizá-lo como na realidade).

Os pesquisadores ainda apontam meios de se melhorar o SoE e, consequentemente, o grau de presença por parte dos usuários (KILTENI et al. 2012):

1) Senso de Auto Localização: trabalhar com a perspectiva em primeira pessoa em relação aos olhos do corpo artificial e respostas táteis sincronizadas com o aplicativo;

2) Senso de Agência: facilmente providenciado em RV quando o movimento do participante é mapeado ao corpo virtual em tempo real (ou próximo ao tempo real);

3) Senso de Pertencimento do Corpo: no caso da influência bottom-up, pode ser melhorado aumentando-se as correlações sensórias entre a estimulação física do corpo biológico e a estimulação vista no corpo do avatar (o corpo virtual também deve obedecer certas restrições estruturais e morfológicas a fim de ter uma aparência mais humana).

Assim sendo, fica claro como a questão da presença é delicada no âmbito de aplicações virtuais (e até mesmo no campo filosófico). Porém, ao tratarmos de R.V., é imprescindível levar esse ponto em consideração. Nem sempre é possível chegar a um grau de presença satisfatório, entretanto. Por ser algo tão subjetivo, a presença acaba sendo trabalhada mais sobre o ponto de vista do desenvolvedor do que do usuário final. 


\section{RESUMO - PÓS-HUMANISMO E A VIRTUALIDADE}

Para mim, pós-humanismo e transhumanismo são sinônimos (porém, é mais fácil encontrar o segundo termo em pesquisas na internet). Nesse capítulo eu abordei, mesmo que superficialmente por causa do objetivo central desta pesquisa, os conceitos gerais do Transhumanismo que, grosso modo, é a utilização de tecnologia (computacional) para melhorar a vida dos seres humanos. Uma das vertentes de estudo do transhumanismo é a simulação virtual, e isso me levou a discutir o que, de fato, é real.

Resumi as ideias propostas por Pierre Lévy sobre real, virtual e atual, mostrando que real não é o oposto de virtual (embora quase todos pensem isso), mas, sim, que o atual faz frente ao real (e se modifica quase sempre). Em outras palavras: real é aquilo que existe no momento (o presente); virtual é o potencial de algo vir a ser real (uma semente é uma árvore em potencial, por exemplo); atual é o que algo é de fato (por exemplo, madeira, seiva, galhos, raízes etc. que compõem uma árvore).

Acreditando que o leitor irá filosofar sobre essas conceituações de Lévy, sem mais delongas entrei no campo da Realidade Virtual, que surgiu na década de 1940 nos EUA com simuladores de voo para a Segunda Guerra Mundial. Tracei um breve histórico dos videogames e apresentei uma lista de dispositivos utilizados em realidade virtual para enfatizar dois aspectos centrais desse campo de conhecimento: a imersão do usuário e a interatividade em tempo real com o sistema (você se lembra da Cibernética e o seu sistema de feedback mencionado anteriormente? Então...). Terminei essa parte diferenciando Realidade Virtual de Realidade Aumentada e também como ambas podem ser utilizadas na Educação.

Segui com o capítulo até o fim apresentando uma sessão sobre estereoscopia e presença: duas características importantes da Realidade Virtual. Apresentei, então, as bases da visão humana, ou seja, estereoscópica, e como enxergamos o mundo em três dimensões. Discuti, também, um pouco sobre a questão da presença em ambientes virtuais 3D e como é difícil analisá-la já que depende da subjetividade do usuário (aquilo que posso considerar imersivo não necessariamente terá o mesmo efeito sobre você, por exemplo). 


\section{CAPÍTULO IV}

\section{O QUE É CIBERARQUEOLOGIA?}

Qualquer tecnologia suficientemente avançada é indistinguível da mágica

- Arthur C. Clarke

Tenhamos as cabeças abertas, mas não tão abertas ao ponto de nossos cérebros se desprenderem delas.

- Richard Dawkins

Enfim chegamos ao termo que serve de título a este trabalho: Ciberarqueologia.

Se fui bem sucedido até aqui, sei que o leitor já terá uma ideia do que esse conceito significa. Basta desmembrar a palavra para notarmos que nada mais é do que uma junção entre Cibernética + Arqueologia. "Mas, lendo tudo o que li, posso dizer que 'cibernética' é uma concepção muito ampla" - você, corretamente, irá afirmar. Concordo plenamente! É necessário que digamos o que "cibernética" significa nesse contexto. Vamos chegar lá daqui a pouco. Adianto, no entanto, que estamos falando sobre a Realidade Virtual presente no campo cibernético.

"Se a ideia gira ao redor da R.V., por que não denominarmos Arqueologia Virtual ao invés de Ciberarqueologia?" - novamente sou indagado pelo leitor. Creia-me, o termo "Arqueologia Virtual" já existiu. E não faz muito tempo.

Em 1990, o cientista da computação Paul Reilly publicou o artigo que iria despertar parte da comunidade científica arqueológica para o tema da computação gráfica. Em "Towards a Virtual Archaeology", Reilly define a arqueologia virtual da seguinte maneira (1990: 133):

O conceito-chave é virtual, uma alusão a um modelo, uma réplica, a noção de que alguma coisa pode agir como substituta para um original. Em outras palavras, ele se refere a uma descrição de uma formação arqueológica ou a uma simulação de uma formação arqueológica. (Dados simulados normalmente irão ser modelados por critérios usados para registrar uma formação atual.) O problema, portanto, é identificar os componentes quintessenciais da formação arqueológica sob 
investigação. Todos têm implicações para a representação de dados e manipulação de informação.

Pessoalmente, acho que a definição de Reilly mais confunde do que esclarece, mas é possível extrair sua ideia central: cabe ao arqueólogo identificar os pontos críticos (ou seja, principais) de uma escavação para que ela possa, depois de terminado o trabalho, ter seus dados computados e gerar uma simulação tridimensional. Todos os arqueólogos sabem que, mesmo com o desenvolvimento de técnicas não invasivas, nós ainda somos grandes destruidores: nossa função é trazer à luz significados obtidos de artefatos por meio de escavações sistemáticas. Uma vez escavado, o contexto anterior está perdido. A cada camada temos de registrar nosso trabalho para que depois possamos recuperá-lo em laboratório e darmos sentido a todo esse monstro do Dr. Frankenstein chamado Arqueologia. O que Paul Reilly propôs é irmos além do registro em papel: com os computadores, podemos recriar as etapas de escavação com seus contextos originais, facilitando o entendimento e permitindo que futuros pesquisadores possam visualizar como foi o trabalho de campo mesmo não tendo estado presentes lá.

É preciso prestar atenção ao conceito de "simulação" ao qual Reilly está se referindo. Estávamos no início dos anos 1990 quando ele cunhou a Arqueologia Virtual. Apesar de os computadores pessoais começarem a se tornar mais comuns na época, o seu poder de processamento era ainda bastante limitado. A simulação, nesse caso de Reilly, é uma simulação passiva, ou seja, o arqueólogo apenas visualizava os resultados prontos na tela do monitor. Os cálculos matemáticos transformavam os registros de campo em registros digitais e mostravam na tela os modelos finais. Diferentemente da simulação que viemos falando até agora (aquela relacionada à cibernética), a "simulação" da Arqueologia Virtual eram, na verdade, vídeos renderizados.

Quando você assiste àquelas reconstruções digitais de templos gregos ou cidades maias no Discovery Channel ou no History Channel (quando ainda tinham programas históricos em sua programação...) o que você está vendo é Arqueologia Virtual. Embora baseada em estudos arqueológicos sérios e importantes, a Arqueologia Virtual trabalha com aquilo que poderia ser real - de acordo com Pierre Lévy - de modo diferente da R.V., utilizando animações tridimensionais. Não tenho absolutamente nada contra esse método, pois acredito que, dependendo do objetivo final, tal como no caso de programas de TV, os vídeos sejam um modo interessante e bastante positivo de transmissão de 
conhecimento para muitas pessoas ao mesmo tempo. Contudo, a contribuição cognitiva acaba perdendo um pouco a sensação de presença, como já vimos.

A Arqueologia Virtual, no entanto, acabou sendo mais utilizada em programas televisivos, cinema e vídeos educativos do que pelos próprios arqueólogos. Em meados da década de 1990, o arqueólogo Maurizio Forte editou uma grande compilação de trabalhos nessa área no volume Virtual Archaeology. Re-creating Ancient Worlds (1996). Apesar de todas as críticas que a obra recebeu pelos arqueólogos (lembra-se de que eu disse que arqueólogos não gostam de computadores?), para mim, ainda é um trabalho extremamente importante não apenas para a discussão do uso de recursos gráficos na arqueologia como também por ser um dos primeiros textos a contribuir para o diálogo entre arqueologia e ciência da computação.

Felizmente, todas as críticas não foram suficientes para desanimar o teimoso grupo de arqueólogos que trabalhavam com computação gráfica. Embora derrotada no meio acadêmico, a Arqueologia Virtual ainda resiste por meio de programas educativos na internet ou TV. No entanto, ela foi posta à sombra pelos arqueólogos. No início dos anos 2000 o diálogo entre arqueologia e computadores se tornou corriqueiro, e fez surgir uma nova área de pesquisa: a Ciberarqueologia.

\section{CIBERARQUEOLOGIA $=$ ARQUEOLOGIA + REALIDADE VIRTUAL}

Em novembro de 2013 tive a grande honra de conhecer o Prof. Dr. Maurizio Forte pessoalmente. Convidado para participar de um workshop e apresentar uma palestra no âmbito do I Simpósio Internacional do Laboratório de Arqueologia Romana Provincial da USP, pude passar alguns bons momentos conversando com o professor. Dentre as várias coisas que um doutorando afoito fala para aquele que é o pioneiro da área que estuda, recordo-me de, antes de apresentar meu trabalho no Simpósio, ter virado para o Maurizio Forte ao meu lado e dito nervosamente: "Fico sem graça em falar sobre ciberarqueologia antes de você... Sabe, foi você quem desenvolveu tudo isso". O professor, então, esboçando um sorriso de canto de boca, respondeu: "Existem várias definições de ciberarqueologia. Certamente você tem a sua". Eu não tinha. Eu não havia parado para pensar sobre isso até aquele momento. 
Mais recentemente, em maio de 2014, ao assistir à palestra do cientista da computação, o Prof. Dr. David Arnold, em um evento na Escola Politécnica da USP sobre documentação digital de patrimônios, algo semelhante ocorreu. Ao término da apresentação, fui parabenizar o professor e lhe perguntar se já havia trabalhado com o escaneamento 3D em escavações. Além de dizer que conhecia o professor Maurizio Forte, David Arnold ainda me perguntou (após eu ter mencionado minha área de pesquisa): "O que é ciberarqueologia para você??". Mais uma vez, fiquei um pouco desconcertado com a questão, mas respondi brevemente.

Pretendo daqui a pouco esclarecer o que é ciberarqueologia para mim. No entanto, cabem mais algumas palavras sobre o surgimento dessa área. Surgimento este, que está ligado diretamente aos trabalhos do professor Maurizio Forte (atualmente na Duke University).

Em 2010 foi publicado o volume da coleção BAR International Series denominado Cyber-Archaeology. Editado por Maurizio Fore, a coletânea traz artigos de dois workshops ocorridos 2009 e 2010 que versaram sobre ciberarqueologia e ambientes virtuais colaborativos para o patrimônio cultural. Na introdução da obra, Maurizio Forte discorreu sobre os principais pontos da ciberarqueologia. Seu texto ainda hoje é usado como base para os estudos nessa área. Vou agora apontar alguns tópicos presentes nele.

Primeiramente, fica claro que é difícil introduzir e definir possíveis limites, fraquezas e potencialidades de um novo campo de pesquisa em relação às novas tecnologias, altos níveis de corporificação, sistemas imersivos e redes de trabalho sociais 3D: a ciberarqueologia ainda é muito recente para fazermos um balanço tão profundo (FORTE 2010: 9).

Como o próprio nome diz, a ciberarqueologia trabalha com um processo de interpretação que está calcado na perspectiva cibernética: tal como na terceira onda mencionada, há loops recursivos - o feedback criado por diferentes interatores operando o mesmo ambiente gera outros feedbacks, não interconexões pré-determinadas. O centro desse processo interpretativo - e consequentemente da geração de conhecimento - não está no modelo, dados ou ambientes, mas, sim, nas relações mútuas produzidas pela interação/corporificação/enaction (descrita por Varela, conforme vimos). Estando a cognição da enaction, desse modo, atrelada à experiência motor-perceptiva, toda a 
informação dos objetos se forma em um sistema recíproco entre observadores e observados. Em outras palavras, "a interação cibernética ou o comportamento em um ambiente virtual podem ser totalmente reconsiderados como uma troca de informação entre organismo e ambiente" (FORTE 2010: 9). Assim, o princípio básico é que percepção e ambiente são governados por propiciamentos (affordances ${ }^{15}$ ) que são desenvolvidos durante o processo de simulação, representando a ligação virtual entre objeto e ambiente, ou seja, o código para reinterpretar o passado no espaço e no tempo.

Ainda em seu texto, Maurizio Forte elenca características marcantes dentro do contexto ciberarqueológico. Cabe aqui a citação por extenso (2010: 10).

- Considerando as premissas [descritas acima], é bastante difícil aceitar o termo "reconstrução do passado", porque ele remete a uma ideia de gerar um conhecimento "pré-definido" e não, ao contrário, um conhecimento "possível". Um conhecimento possível vem de uma simulação do passado, não de sua reconstrução.

- Este ponto é muito importante na discussão sobre ciberarqueologia porque ele enfatiza a potencialidade-virtualidade da interpretação versus a atualidade do mundo físico. No processo ciberarqueológico o foco é a simulação, isto é, o comportamento dinâmico do ator virtual e o ecossistema digital. Consequentemente, o workflow (fluxo de trabalho) apto a mover e migrar dados do campo para um ambiente de simulação pode gerar diferentes propiciamentos e modelos cibernéticos: cada um pode criar um feedback e isso é um novo códigomapa para a interpretação (BATESON 1999). Assim sendo, podemos apresentar os seguintes pontos:

a) A ciberarqueologia pode representar hoje uma trilha de pesquisa de simulação e comunicação, na qual (...) o feedback representa seu núcleo. A arqueologia faz parte inteiramente da sociedade contemporânea e é porta de acesso (gateway) para o mundo antigo: ela não pode representar o mundo antigo. $\mathrm{O}$ processo cibernético cria propiciamentos e através deles nós somos capazes de gerar mundos virtuais por meio de interações e interconexões;

\footnotetext{
${ }^{15}$ Um termo de tradução difícil, mas que significa o quanto um objeto (ou um ambiente) tem de potencial para ser manipulado da maneira como foi pensado originalmente. Por exemplo: a válvula de uma torneira, que nos "convida" a girá-la.
} 
b) A ciberarqueologia não é necessariamente visual: é dinâmica, interativa, complexa, autopoiética e não necessariamente orientada ao fotorrealismo;

c) O passado não pode ser reconstruído, mas, sim, simulado. A simulação cibernética desenvolve propiciamentos e neles as relações constituem a potencialidade do processo de interpretação;

d) Passado em potencial: é mais apropriado pensar em um passado em potencial, um tema co-evolutivo na evolução humana gerado por ciberinterações entre mundos;

e) A validação desse processo ciberarqueológico depende dos relacionamentos entre as sociedades do passado e do presente;

f) A ciberarqueologia é um processo de reconstrução-simulação. A arqueologia do terceiro milênio é capaz de processar, interpretar e comunicar muito mais dados e informação do que nos últimos dois séculos;

g) Nos anos 1990 a maior parte dos projetos de pesquisa em arqueologia virtual era orientada visualmente; agora nós pensamos que, no terceiro milênio, eles devem ser ciberneticamente orientados;

h) A capacidade de transmitir conhecimento e interpretação depende da complexidade de diversos fatores: tecnologia, formato, precisão, indução-dedução, comunicação, contexto, ontologias etc. Estamos cientes de quantos dados podem ser produzidos e disseminados nesta Era? E quão rápido é esse processo?;

i) A ontologia virtual da informação arqueológica, ou da cibernética arqueológica, refere-se a todas as relações interconectadas que o datum (dado) produz, o código de transmissão, e sua transmissibilidade;

j) O datum nunca é neutro e, consequentemente, nós temos de aperfeiçoar as propriedades dos propiciamentos.

Para facilitar o entendimento do que foi dito, vou aqui discorrer brevemente sobre cada item apontado por Maurizio Forte sob a minha perspectiva:

a) Por estar em um ambiente virtual tridimensional, o feedback se torna ainda mais rápido e passível de análise. Lidando a ciberarqueologia com simulações, a retroalimentação é primordial, pois ela fará com que a comunicação entre usuário e ambiente virtual aconteça. Caso você já tenha jogado algum game de RPG (Role-Playing Game), saberá muito bem como esse feedback 
acontece: naqueles momentos em que você tem de escolher uma resposta - a uma personagem - dentre várias em uma lista, a retroalimentação fará com que a sua escolha influencie em todo o decorrer da narrativa e no próprio desenvolvimento de seu avatar. Já no caso de a arqueologia ser uma porta de acesso ao mundo antigo, Maurizio Forte está reiterando aquilo que é essencial saber quando trabalhamos com simulações: elas são interpretações, não representações de um passado, pois é impossível nós representarmos (falarmos em nome) aquilo que deixou de existir há tanto tempo. O que a ciberarqueologia faz é nos propiciar meios de entendermos o passado: ela não é o passado ressuscitado;

b) Quando diz que a ciberarqueologia “não é necessariamente visual”, Maurizio Forte está se referindo à Arqueologia Virtual que, como já vimos, é completamente passiva. Cabe ressaltar o interessante aspecto mencionado pelo autor, o do fotorrealismo: é comprovado que não precisamos estar imersos em ambientes virtuais visualmente arrebatadores no ponto de vista de "ser real" para aprendermos algo naquele ambiente. Mais uma vez, podemos recorrer aos videogames: quantos não foram os jogos em estilo cartunesco (ou até mesmo "quadrado", como no caso dos antigos games do Atari ou do Minecraft) que fizeram com que você entrasse em estado de flow, esquecendose do mundo ao seu redor? Isso prova que gráficos fotorrealistas não são prérequisitos para a $\mathrm{R} . \mathrm{V}$.;

c) Como dito no item a), não existe reconstrução do passado mas, sim, simulação. A ciberarqueologia trabalha com o virtual, ou seja, na concepção de Pierre Lévy, com aquilo que pode ou poderia ser real;

d) O passado em potencial pode ser visto, novamente, dentro da noção de Lévy para o virtual;

e) No caso da validação cibernética oriunda dos relacionamentos entre sociedades do passado e do presente, acredito que Maurizio Forte se refira aos estudos sobre o passado necessários ao bom entendimento por nós, pessoas do agora. Porém, confesso que esse ponto ainda é um pouco desconexo para mim; 
f) Apesar de concordar com o fato de nós termos mais informações hoje em dia do que nos últimos dois séculos, discordo da afirmação do autor sobre a ciberarqueologia ser um processo de reconstrução. Mais à frente explicarei o porquê;

g) Novamente, o contraponto entre Arqueologia Virtual e a Ciberarqueologia: enquanto a primeira é puramente visual e passiva, a última busca nas interações presentes na simulação a sua razão de ser;

h) A tecnologia envolvida na ciberarqueologia abarca várias áreas e sempre estará em desenvolvimento conforme a Engenharia avançar. Acredito que todo o processo de dados se tornará ainda mais rápido no futuro e, com relação ao armazenamento de dados, temos pesquisas bastante profícuas nas áreas de Cloud Computing ${ }^{16}$ (Computação em Nuvem) e Big Data ${ }^{17}$ para guardar e analisar toda essa informação. E por trabalharem sempre com o conceito de elasticidade, praticamente não há limites de armazenagem e processamento nesses campos de pesquisa;

i) A natureza da ciberarqueologia são as relações interconectadas (ou seja, desde a escavação até o processamento computacional) que um dado produz;

j) Um dado obtido e trabalhado pela ciberarqueologia nunca é neutro: passa tanto pelo crivo do passado, quanto do presente e da tecnologia empregada em sua obtenção. Assim sendo, é necessário que os pesquisadores melhorem os meios de propiciar sua divulgação.

Segundo Maurizio Forte, a ciberarqueologia é autopoiética porque

\footnotetext{
${ }^{16}$ Segundo a definição do NIST (MELL \& GRANCE 2011: 2): “A computação em nuvem é um modelo que permite um ubíquo, conveniente e sob demanda acesso a um pool compartilhado de recursos computacionais configuráveis (por exemplo: redes de trabalho, servidores, armazenagem, aplicações e serviços) que podem ser rapidamente providenciados e distribuídos com o mínimo de esforço gerencial ou interação de um provedor de serviços".

17 "Big Data são recursos de informação com grande volume, alta velocidade e/ou alta variedade que requerem novas formas de processamento a fim de permitir o aperfeiçoamento nas escolhas, descobertas e otimização de processos" (BEYER \& LANEY 2012).
} 
o processo autopoiético pode descrever com propriedade o que pode acontecer em um processo ciberarqueológico: a criação de informação e conhecimento não é pré-determinada, nem é um processo unilinear. Ao contrário: é um efeito de múltiplas interações, conexões e feedback - é a apresentação de uma multiplicidade. Na autopoiese o sistema cibernético pode gerar conhecimento independentemente dos atores envolvidos; se nós estudarmos o código, vamos achar a interpretação. (FORTE 2010: 10)

Assim, a ciberarqueologia opera como uma máquina autopoiética, gerando networks de processos em espaços de conhecimento não pré-determinados (FORTE 2010: 11). O autor ainda diferencia a figura da célula nos estudos de Maturana e Varela e na ciberarqueologia: enquanto na autopoiese de Maturana e Varela a unidade é representada pela célula biológica, no processo ciberarqueológico uma unidade pode ser uma célula digital, um organismo ou sua representação.

Maurizio Forte continua seu texto relembrando a metáfora dos bonecos e suas cordas, ou seja, os rizomas como propuseram o filósofo Gilles Deleuze e o psicanalista Félix Guattari (2000: 15):

Os fios da marionete, considerados como rizoma ou multiplicidade, não remetem à vontade suposta una de um artista ou de um operador, mas à multiplicidade das fibras nervosas que formam por sua vez outra marionete seguindo outras dimensões conectadas às primeiras. 'Os fios ou as hastes que movem as marionetes - chamemo-los a trama. Poderse-ia objetar que sua multiplicidade reside na pessoa do ator que a projeta no texto. Seja, mas suas fibras nervosas formam por sua vez uma trama. E eles mergulham através de uma massa cinza, a grade, até o indiferenciado (...).

Tomando-se o exemplo do boneco Pinóquio, podemos explicar melhor o que foi acima descrito por Deleuze e Guattari: há fatores dependentes (as mãos de Pinóquio são movidas pela ação de Gepeto) e fatores independentes (a multiplicidade dos fios, por interações mútuas, geram outros movimentos imprevisíveis) na dinâmica das marionetes (FORTE 2010: 11). Desse modo, o exemplo do boneco Pinóquio nos serve como metáfora para o que acontece no ambiente de simulação tridimensional: a interação de diferentes usuários com os modelos e dados é imprevisível, ao mesmo tempo em que a troca de 
informações ocorrida durante a simulação auxilia no processo dinâmico da interpretação. É sempre uma atividade recíproca.

Interpretando-se o passado como rizomas, Maurizio Forte (2010: 11) acrescenta três pontos aos conceitos-chave já explicitados:

- A informação 3D pode ser apontada como o núcleo do processo de conhecimento porque gera feedback entre o interator, o cientista e o ecossistema;

- A Realidade Virtual online e off-line representa um possível ecossistema passível de trabalhar com processos de conhecimento e comunicação de baixo para cima e de cima para baixo;

- O passado, assim, é gerado e codificado por um "processo de simulação".

Desse modo, o texto de Maurizio Forte reforça as ideias que o autor já vinha desenvolvendo desde o início dos anos 1990 e optei por usá-lo como base aqui na discussão sobre ciberarqueologia por apresentar todos os conceitos fundamentais dessa área. Na bibliografia, o leitor encontrará uma vasta lista de outros artigos relacionados à ciberarqueologia (e estudos de casos) caso tenha interesse em aprofundar o conhecimento.

Antes de conceituar como enxergo a ciberarqueologia (e como ela será usada na parte prática deste trabalho), vou apenas fazer dois rápidos apontamentos sobre questões que acredito serem bastante relevantes.

A primeira refere-se ao modo como a Arqueologia Virtual nos anos 1990 e a Ciberarqueologia nos anos 2000 lidam com seus dados. Até o início dos anos 2000, praticamente todos os dados obtidos em campo durante as campanhas de escavação arqueológicas eram analógicos. O registro das quadras era feito em papel e lápis. As fotografias eram analógicas, precisando de revelação e, consequentemente, muitas se perdiam por falta de qualidade (que só era vista quando impressas). O mundo dos computadores, embora mais baratos, era dominado por desktops, tornando impossível levá-los ao campo. Os mapas, embora começando a ser feitos em computadores, ainda eram, em sua maioria, produzidos manualmente. Assim, para se chegar ao digital, era preciso pegar toda essa enorme quantidade de dados e converter - da melhor maneira possível - para zeros e uns a fim de serem trabalhados em computadores. Isso tomava tempo e consumia dinheiro. 
Com o avanço tecnológico da microeletrônica, os anos 2000 assistiram a um crescimento gigantesco de dispositivos acessíveis financeiramente. Tudo aquilo que era analógico passou a ser digital. Os cadernos e registros de campo podem ser trabalhados em tablets ou laptops. As câmeras fotográficas digitais trouxeram a facilidade de se lidar com arquivos RAW e fazer edições no computador diretamente, sem necessitar de revelação (além de permitir ao arqueólogo, em campo, conferir se as fotografias estão boas ou não). O SIG se tornou comum entre os arqueólogos, permitindo a rápida confecção de mapas e sua análise digital. O GPS começou a se comunicar diretamente com os computadores (e os pontos podem até mesmo ser obtidos por meio de smartphones). Os escâneres 3D apresentaram-se como uma nova ferramenta aos arqueólogos, permitindo coletar pontos de nuvens e texturas em tempo real para a modelagem tridimensional. Por fim, a computação em nuvem permitiu que todos os mega, giga, tera ou peta bytes de informações digitais coletadas das escavações sejam armazenadas em ambientes confiáveis e analisadas em ambientes colaborativos de pesquisa. Desse modo, o campo puramente digital da Ciberarqueologia trouxe economia de tempo e dinheiro para os pesquisadores, eliminando a etapa intermediária de conversão de dados. 


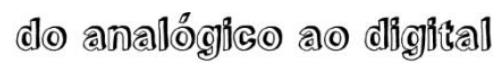
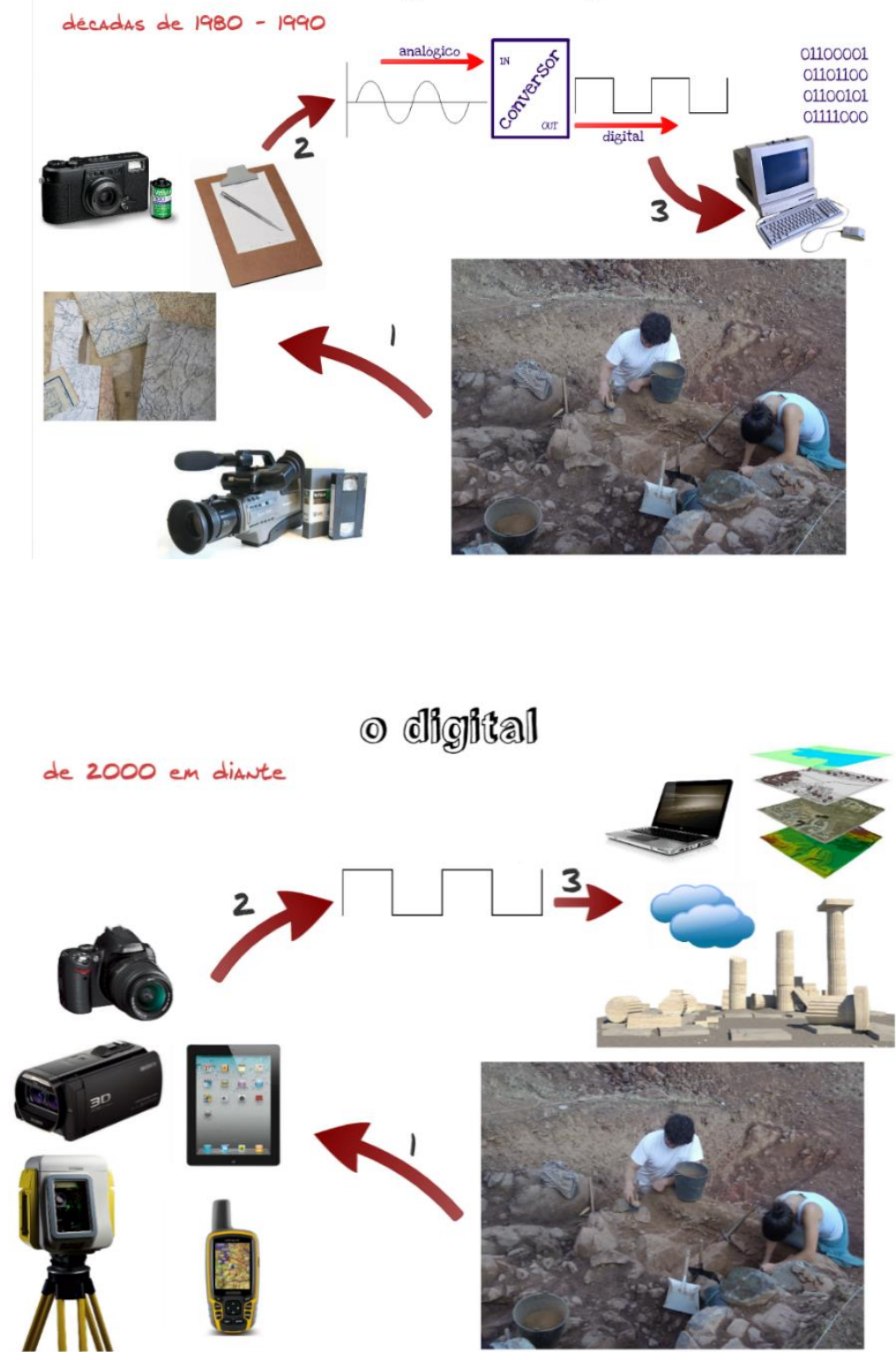

Fig. 20 - A passagem do analógico para o digital: a diferença metodológica entre Arqueologia Virtual e Ciberarqueologia.

O segundo, e último, apontamento que gostaria de fazer se refere ao termo "reconstrução", que aparece bastante no texto de Maurizio Forte, e na bibliografia ciberarqueológica em geral. Fui convencido pelas ideias apresentadas por Jeffrey T. Clark em seu artigo "The Fallacy of Reconstruction" de que, na verdade, a palavra "reconstrução" é bastante falha.

O leitor mais atento irá sabiamente deduzir: "O título de seu próprio trabalho possui "reconstrução"”. Sim, ele tem. Denominei "reconstrução-simulação" e acredito que ele deva permanecer assim. Usando "reconstrução" eu já dou uma ideia clara a quem for 
ler meu trabalho. "Reconstrução" é um termo de fácil assimilação pelo senso comum. Não tenho a menor dúvida de que você, ao ler o título, o entendeu como "algo sendo feito novamente". Contudo, agora que fiz essa ressalva com relação à permanência de "reconstrução" no título, vou explicar, de acordo com as proposições de Jeffrey Clark (2010), o porquê de ser preferível usarmos construção ao invés de "reconstrução".

Segundo Clark, se afirmarmos que algo foi "reconstruído", isso significará que esse algo foi recriado justamente como era. Isso significaria que alguém sabia absolutamente como algo costumava ser e o replicou - implicando certo grau de "verdade".

\footnotetext{
Alguém pode ser capaz de reconstruir um vaso quebrado a partir dos fragmentos, ou uma casa queimada seguindo a planta original e as fotografias, mas ninguém pode reconstruir uma casa que existiu certa vez no passado e da qual temos informação fragmentada sobre traços característicos e artefatos. O que alguém pode fazer é construir um modelo, verbal ou visual, de como a casa pode ter se parecido (dada a evidência disponível). Quanto mais complexo for o fenômeno que estamos examinando arqueologicamente, mais difícil é reconstruí-lo. (CLARK 2010: 63-64)
}

Assim, dizer que alguém criou uma reconstrução arqueológica, na maioria dos casos, é falacioso. Isso não é sinônimo de malicioso, mas, sim, é um legado da disciplina arqueológica que vem sendo perpetuado. O surgimento do termo "reconstrução" no contexto arqueológico apareceu pela primeira vez no trabalho de Alfred Kroeber discípulo de Franz Boas - em 1937, durante o Histórico-Culturalismo. Escrevendo o verbete sobre arqueologia para a Encyclopedia of the Social Sciences, Kroeber afirmou: "Arqueologia - etimologicamente o estudo dos começos - tem a reconstrução histórica como seu objetivo". Essa noção de que a reconstrução histórico-cultural era o foco principal da arqueologia se enraizou na disciplina e fez com que os arqueólogos buscassem por meio da descoberta e estudo de normas culturais a "reconstrução" da cultura no decorrer do tempo.

Nos anos 1940 e1950, a reconstrução ganhou novo ímpeto e passou a ser estudada sob o viés de reconstrução de estilos de vidas passados graças ao estreito diálogo com a etnografia. Já nas décadas de 1960 e 1970, a Nova Arqueologia (ou Processualismo), apesar de fazer duras críticas à reconstrução histórico-cultural, acabou, ironicamente, por 
reforçar essa ideia justamente no trabalho de um dos seus maiores expoentes. Lewis Binford no capítulo "Archaeological Perspectives", presente em New Perspectives of Archeology (1968), identificou três objetivos da arqueologia: 1) a reconstrução da história cultural; 2) a reconstrução dos estilos de vidas passados; 3) o estudo do processo cultural. Por fim, a partir da década de 1980, com a crítica feita ao Processualismo pelo PósProcessualismo de Ian Hodder, Michael Shanks, Christopher Tilley e outros, o papel da interpretação ganhou destaque, juntamente com o aprofundamento dos conceitos de contexto, multivocalidade e agência. Desse modo, já não é mais correto falar em $a$ reconstrução do passado: agora existem muitas, embora o termo "reconstrução" ainda seja largamente utilizado (CLARK 2010: 65-66).

Porém, Walter Taylor já havia discorrido sobre a falácia da reconstrução na década de 1940, como podemos ver no excerto a seguir (TAYLOR 1948: 35-36):

(...) será bom comentar sobre a falácia e o perigo engendrados pelo uso do termo reconstrução histórica. As palavras reconstrução e ressíntese são fundamentalmente erradas e têm sido responsáveis por muita perda de confiança, particularmente entre os antropólogos (...). Se não se pode dizer com certeza se o passado foi ou não recriado em detalhe ou em essência, não pode ser dito que esses contextos são ou não ressíntese ou reconstruções. Esses termos implicam em uma reconstrução exata das especificações anteriores as quais (...) não podem ser verificadas e, assim, conhecidas. O desconhecido não pode ser tomado como um valor padrão. Portanto, argumentos prós e contra a reconstrução histórica na antropologia ou em qualquer outra disciplina [histórica] são irrelevantes, e torna aparente que o trabalho de todas as disciplinas históricas realmente leva à construção e síntese, não à reconstrução e ressíntese. Disto, a real tarefa dos estudantes em disciplinas históricas está em enxergar quão plausíveis e aceitáveis as construções podem ser feitas. Nem os antropólogos nem os historiadores deveriam usar o termo reconstrução, pois soa inadequado: eles sabem que sua pesquisa nunca irá permiti-lo, realmente, reconstruir a vida de tempos passados com certeza e em sua completude. Ao invés disso, deveriam perceber que até mesmo os contextos escritos dos melhores e mais completos arquivos são construções e que as diferenças residem na natureza dos respectivos dados, não nos fatores teóricos básicos. 
Apesar do esforço de Taylor, a noção de "reconstrução" permaneceu - e permanece - na arqueologia. Se não podemos, então, denominar "reconstrução", como chamamos a esse processo e produto? Segundo Jeffrey Clark (2010: 67), nós construímos modelos, e se quisermos chamá-los modelos científicos ou modelos interpretativos, as características básicas são as mesmas. Os modelos são afirmações das relações entre múltiplas variáveis que oferecem uma descrição ou explicação sobre algum fenômeno. Ao contrário do que se pode pensar (ainda mais se continuarmos dentro das ideias de "reconstrução"), os modelos não representam o ponto final de uma pesquisa: eles são ferramentas construídas a fim de nos ajudar a pensar e a melhorar nossa compreensão sobre algum fenômeno complexo.

Modelos são produzidos a partir do diálogo entre observações empíricas, pressupostos, interpretação lógica e extrapolação, e imaginação criativa. (...) Por definição, modelos não são a coisa real: são simplificações. Como simplificações, alguma coisa é deixada de fora, e os modelos são, assim, sempre falsos. Informação é deixada de fora ou porque é desconhecida, ou porque poderia providenciar detalhes desnecessários ao propósito do modelo. (...) Nesse sentido, então, ao construir um modelo alguém está seletivamente adicionando informação. (...) Do ponto de vista da arqueologia interpretativa, alguém sempre está adicionando informação baseado em uma inescapável subjetividade [do observador]. A adição seletiva de informação é o caso se alguém está lidando com um modelo verbal ou modelo visual (...). A seleção de informação é baseada naquilo que alguém sabe, pensa (consciente ou inconscientemente), presume e conjectura. (CLARK 2010: 67-68)

Do excerto de Jeffrey Clark, gostaria de chamar a atenção para a oposição entre "real" e "falso". As ideias do autor dialogam, desse modo, com a noção de simulacros e simulação de Baudrillard, que já vimos e com a qual, como deixei claro, não compactuo. Não acredito que um modelo seja falso mas, sim, uma interpretação tão real - e válida quanto qualquer outra. Tomar os modelos como algo falso esvazia de sentido todo o trabalho do arqueólogo em sua construção, mesmo que Jeffrey Clark insista no contrário. Porém, sua concepção de informação seletiva é muito positiva e acredito que se encaixa perfeitamente na proposta de modelagem que tenho para este trabalho. 
Os modelos, então, são o produto da construção arqueológica. No caso da Arqueologia Virtual e da Ciberarqueologia, os modelos são tridimensionais. Deve-se, sempre, evitar chamar um modelo de "reconstrução", pois, além de ser um termo problemático, pode levar à errada ideia de que o modelo é, de algum modo, falho ou que deve ser utilizado com ressalvas. A principal diferença entre os modelos da Arqueologia Virtual e da Ciberarqueologia é que os primeiros são usados passivamente, apenas por renderização de animações, enquanto os segundos são utilizados em tempo real.

Feitos esses dois apontamentos - as diferenças metodológicas entre Arqueologia Virtual e Ciberarqueologia, e entre reconstrução e construção - posso, então, definir o que entendo por Ciberarqueologia e como ela será trabalhada aqui.

\section{ENFIM, A MINHA DEFINIÇÃO DE CIBERARQUEOLOGIA}

"Ciberarqueologia" é um termo que parece muito fácil de ser assimilado quando ouvido (ou lido) pela primeira vez: logo pensamos em computadores, afinal, "cibernético" tem algo a ver com computadores, correto? Quem pensa assim, não está inteiramente errado. Sim, a ciberarqueologia lida com computadores. Mas a problemática é mais profunda. Como apresentei até agora, a cibernética é uma área de estudos bastante rica e complexa em definições. Quando analisada com cautela, vemos o quão interessante ela é, e como ela influenciou e foi influenciada por outras áreas cognitivas, como a biologia, a sociologia e, é claro, a arqueologia.

Recordo-me que não há muito tempo, ao conversar com o Prof. Dr. Marcelo Zuffo (Poli-USP) e lhe contar que estava estudando cibernética, ele me disse em tom preocupado: "Olha, tome cuidado com isso". Eu ri, claro, mas só fui entender o que ele havia me alertado um tempo depois, quando finalmente mergulhei no mundo da cibernética para elaborar este trabalho. A cibernética é um campo maravilhoso, mas no qual podemos facilmente nos perder se não tomarmos cuidado. Isso acontece com a ciberarqueologia também: por ter a cibernética como uma de suas bases teóricas (a outra, obviamente, é a arqueologia), se não deixarmos claro a qual cibernética nos referimos e como trabalharemos com ela, corremos o risco de voltarmos à estaca zero de "uso de computadores na arqueologia". Ora, arrisco-me a dizer que todos os arqueólogos usam 
computadores hoje em dia, pois, sem eles, não escreveriam seus relatórios, artigos, dissertações, teses e projetos de pesquisa. Isso é uma coisa. Outra bem diferente é usar computadores em conjunto com os trabalhos arqueológicos - e é isso o que a ciberarqueologia faz.

Embora a cibernética não esteja, assim como qualquer outra área, tão bem delimitada em suas definições, sendo que ainda hoje podemos lidar com homeostase ou, como sugere Maurizio Forte (2010: 10), a autopoiese, defendo a terceira onda cibernética como base para estudos ciberarqueológicos.

Desse modo, como consequência dessa terceira onda, para mim, a ciberarqueologia é uma arqueologia pós-humana.

A seguir, aponto os temas centrais de porquê a ciberarqueologia ser pós-humana:

- A ciberarqueologia é pós-humana, pois trabalha com simulação (conforme proposta pelo transhumanismo) em realidade virtual. O grau de imersão nessas simulações pode variar e dependerá de fatores relacionados a softwares e hardwares, mas elas nunca deixarão de ser uma realidade virtual, um passado em potencial que, graças aos computadores, se tornam reais;

- A ciberarqueologia é pós-humana, pois apresenta-se como simbiose entre sistemas orgânicos e sistemas artificiais. O arqueólogo lida com elementos de Vida Artificial e Inteligência Artificial para elaborar a sua simulação em Realidade Virtual. Nós dependemos dos computadores e demais máquinas artificiais para avançarmos em nosso trabalho ciberarqueológico. Do mesmo modo, os computadores e demais máquinas virtuais dependem de nós, máquinas de sobrevivência orgânicas, para receberem updates e upgrades. As pesquisas nas áreas de Ciência da Computação e Engenharia podem ser impulsionadas pela pesquisa arqueológica, que estabelecerá novas barreiras tecnológicas a serem transpostas pelos profissionais da área de Exatas. Reciprocamente, o trabalho oriundo dos laboratórios de engenharia das universidades e empresas instigará os arqueólogos a utilizarem novas ferramentas tecnológicas em sua área.

- A ciberarqueologia é pós-humana, pois não se fecha em si mesma. Tal como propõe o transhumanismo, estamos em constante mudança. Essas mudanças podem ser físicas, como o acréscimo de próteses artificiais ou, futuramente, o upload ou download de dados para o cérebro, como também biológicas. Nós seremos diferentes. Nosso modo 
de fazer arqueologia será diferente: diretamente em conjunto com os sistemas artificias (sem haver hierarquização). A ciberarqueologia não fica (nem ficará) presa aos dogmas das correntes de pensamento arqueológico anteriores, pois sua própria conformação é expansível: não apenas está preocupada com a relação sistema/homem/ambiente - ela vai além, lidando com a relação homem/máquina na práxis arqueológica.

Estamos a poucos anos da Singularidade ${ }^{18}$, que chegará em 2029. Quando a alcançarmos, será muito improvável que o arqueólogo como o conhecemos hoje continue existindo: toda Arqueologia será uma Arqueologia Pós-Humana. Nossas relações com as máquinas serão tão naturais e tão simbióticas que aprenderemos, todos, a falar a linguagem dos sistemas artificiais (ou eles aprenderão a nossa). Desse modo, os arqueólogos também serão pós-humanos, pois estarão familiarizados com essa realidade artificial e com a informação migrando de corpos a todo o momento. Nós, arqueólogos, não mais apenas escavaremos e trabalharemos em nossos laboratórios como fazemos hoje: iremos, nós mesmos, ser responsáveis por elaborar nossas simulações pois elas serão algo corriqueiro. Assim, o arqueólogo pós-humano será alguém com habilidades avançadas em computação, podendo desenvolver códigos de programação, modelagens 3D e conhecendo o equipamento físico com o qual trabalhará. As hipóteses arqueológicas serão postas à prova em simulações de realidade virtual, permitindo o acesso colaborativo de todos os envolvidos nas pesquisas.

Dito o que entendo por Ciberarqueologia, e deixando claro que ela será trabalhada na Parte II sob a ótica pós-humana, creio que é necessário mencionar, por fim, os dois modos como a ciberarqueologia é estudada e aplicada na prática:

1) Coleta de dados no campo (com dispositivos que transformam as informações em meio digital), e visualização científica tridimensional em laboratório a fim de se

\footnotetext{
18 Segundo o criador do termo, Ray Kurzweil, em entrevista cedida à Revista Piauí em 2010 (edição 43): "Quando falo sobre a singularidade quero chamar a atenção para um fenômeno que é o da ascensão exponencial da interação entre a biologia humana com a tecnologia que criamos. O paradoxo está no fato de que a inteligência biológica pode ser educada e melhor organizada, não pode mais passar por evoluções significativas, ao passo que a inteligência não-biológica, a dos computadores, tem sua capacidade multiplicada por mil a cada década que passa. Esse ritmo está diminuindo para menos de uma década". In: http://revistapiaui.estadao.com.br/edicao-43/so-no-site/ray-kurzweil-e-o-mundo-que-nosespera
} 
analisar o que está sendo escavado (e, posteriormente, todo o conjunto de dados obtidos). Por exemplo, trabalhos que são desenvolvidos em Çatalhöyük (FORTE 2013), na Turquia, onde cada etapa da escavação é registrada tridimensionalmente para servir como reconstituição do sítio (que, ainda hoje, é um processo bidimensional, centrado em relatórios de campo, desenhos de estratigrafias/vestígios, e fotografias);

2) Divulgação de resultados elou como recurso didático-educativo. Desenvolvimento de aplicativos e programas que façam a interação entre usuário (seja ele arqueólogo ou público em geral) e ambientes virtuais tridimensionais. Assim, são mostrados todos os resultados oriundos das pesquisas anteriores e ocorre a multivocalidade, onde todas as pessoas podem opinar e trabalhar juntas para melhorar a experiência imersiva digital realizada por meio de computadores.

Como estudo de caso, irei trabalhar com a antiga zona de mineração romana denominada Vipasca, que hoje está na vila de Aljustrel, em Beja, Portugal. Primeiramente, vou apresentar Vipasca e os trabalhos arqueológicos que vêm sendo realizados na região. Depois irei pormenorizar todo o trabalho de construção tridimensional realizado que leva à simulação em Realidade Virtual. É hora, então, de voltarmos à TARDIS e, junto com o Doutor, irmos para o Império Romano. Segure-se: turbulências espaço-temporais podem ocorrer durante a viagem! 


\section{RESUMO - O QUE É CIBERARQUEOLOGIA?}

Este capítulo é central na pesquisa (afinal, dá o título a ela).

Comecei por estabelecer uma comparação entre a Arqueologia Virtual surgida nos anos 1990 com o trabalho de Paul Reilly - centrada em visualizações 3D não-interativas - e a arqueologia que trouxe a realidade virtual para o campo de pesquisa no início dos anos 2000, a Ciberarqueologia.

Apresentei, então, os conceitos centrais da ciberarqueologia sob a ótica de seu pioneiro, o arqueólogo Maurizio Forte. Citei por extenso as características centrais da ciberarqueologia, das quais retomo aqui só algumas: a simulação é o foco central, isto é, o comportamento dinâmico do ator virtual e o ecossistema digital; a reconstruçãosimulação é essencial na ciberarqueologia; a validação do processo ciberarqueológico depende dos relacionamentos entre as sociedades do passado e do presente. A seguir, fiz apontamentos sobre cada característica elencada por Maurizio Forte.

O capítulo seguiu com a diferenciação da coleta de dados proposta pela ciberarqueologia frente ao que vinha sendo feito até então. Em outras palavras, a ciberarqueologia trouxe o domínio do digital ao campo essencialmente analógico existente até finais dos anos 1990: agora utilizamos dispositivos eletrônicos digitais em nossa prática arqueológica (sempre que podemos arcar com os custos, claro).

Retomei, então, um dos pontos elencados por Maurizio Forte para discordar da ideia de "reconstrução". Utilizando como base o artigo de Jeffrey T. Clark sobre a falácia da reconstrução na arqueologia, explicitei a impossibilidade de reconstruirmos o passado arqueológico: para tanto, seria necessário, por exemplo, erigirmos um edifício antigo tal como ele foi construído originalmente, usando as mesmas técnicas e materiais. Desse modo, concordo com Clark ao dizer que não reconstruímos, mas, sim, construímos modelos arqueológicos (digitais ou não).

Finalizo este capítulo dando a minha definição de Ciberarqueologia (sim, pode existir mais de uma, variando de pessoa para pessoa). Para mim, a ciberarqueologia é póshumana (ou transhumana), pois ela lida com simulações computacionais de realidade virtual, apresenta-se como simbiose entre sistemas orgânicos e artificiais, e não é fechada em si mesma (está em constante mudança uma vez que a tecnologia também muda constantemente). 
PARTE II 


\section{CAPÍtUlO V}

\section{A VIPASCA ARQUEOLÓGICA}

Feche os olhos e veja.

- James Joyce, Ulisses

A mineração é a arte de explorar depósitos minerais com lucro. Uma mina inútil só serve para o sepulcro de uma mula morta.

\section{- T. A. Rickard}

Não importa quão quente esteja na vila de Aljustrel, sul de Portugal: em algum momento você irá tomar seu café em uma das várias cafeterias simpáticas espalhadas pelo traçado urbano. Se tiver ânimo - e força suficiente nas pernas - pode subir as dezenas de degraus que levam à antiga Igreja de Nossa Senhora do Castelo e lá papear com a Dona Clarisse, a senhora que zela pela igreja há uns bons anos e que sempre está acompanhada por algum cão preguiçoso que deita estirado à porta do edifício à procura de sol. Comida boa por lá não falta: seja na casa de amigos ou nos restaurantes, qualquer pessoa nunca passará fome em Aljustrel. No verão, a vila para na hora do almoço e só retoma a vida quando o sol dá trégua no fim da tarde: é encantador ver o pôr do sol roçando os moinhos na paisagem campestre, e também é um bom momento aos pouco tímidos de entabular conversa com as senhoras que sentam à entrada das casas, esperando que o ar quente seja soprado para fora dos cômodos. Aos românticos, um aviso: as moças aljustrelenses são lindas e o sol dourado faz com que fechem os olhos de modo encantador. Se for de ônibus a Aljustrel, partindo de Lisboa, conhecerá as belas planícies portuguesas e as plantações de sobreiros, de onde se extraem as cortiças, que abastecem a economia local e servem, como rolhas, para proteger o bem de consumo que é a alma portuguesa: o vinho. Ao contrário do norte do país, o sul é plano, liso, nada montanhoso, com vegetação rasteira que pode muito bem servir como cenário a algum filme de Terrence Malick. O Alentejo de Portugal é bucólico, mas, infelizmente, sofreu demais com a ditadura de Salazar e, até hoje, colhe as consequências. Os alentejanos também são vítimas de preconceitos por parte dos moradores ao norte: são chamados pela alcunha de "mouros", em tom depreciativo, pois a população ao norte do país diz que o forte sol que castiga o Alentejo 
torna as pessoas preguiçosas. Para quem mora no Brasil, sabe como é essa situação: os nordestinos recebem as mesmas ofensas das pessoas do sudeste e sul, em uma mostra gratuita de imbecilidade.

Quando conheci Aljustrel foi em 2010. "No Alentejo você saberá o que é calor!" - dizia-me a população no extremo norte. Quem me conhece pessoalmente, sabe o quanto não me adapto ao calor e, por isso, quando parti de Vila Pouca de Aguiar rumo a Aljustrel em setembro daquele ano, fui esperando encontrar uma verdadeira sucursal do Inferno na Terra. Sim, estava muito calor em Aljustrel e, para alguém que nunca havia saído do país como eu na época, pude sentir como o verão europeu é diferente do brasileiro: é extremamente seco (creio que seja assim como as comidas se sentem nos fornos). Foi difícil, sim, não minto, escavar debaixo do sol alentejano. Porém, tive uma recompensa inimaginável: a beleza da vila me conquistou. A zona arqueológica na qual trabalhei ficava dentro da atual área de mineração e, tenho de admitir, foi amor à primeira vista. Muitas pessoas podem achar que os terrenos de mineração são feios, esburacados, sem vida e que fedem a enxofre. Ao contrário, enxergo uma coloração única, que somente a mistura de minérios e solo pode oferecer, e fiquei emocionado ao chegar ao local e tomar consciência do quanto os homens modificam a paisagem na qual vivem: é um trabalho colossal o da mineração. As atividades mudam a região onde ocorrem. Muda a vida das pessoas que, geralmente, tendem a viver para a mineração. Contudo, só fui pensar mais profundamente nessas questões quando, no dia 7 de setembro de 2010 , encontrei, durante a escavação, o meu primeiro vestígio de ânfora romana. Foi uma alegria! E guardo a recordação em foto com carinho: eu agarrado à minha ânfora, sorrindo. Naquele dia, antes de dormir na excelente hospedagem oferecida pelo município aos arqueólogos, finalmente me dei conta: "Se tudo isso é assim hoje, como seria, então, durante a época romana?"

Essa é a questão que vem me assombrando desde então. E graças a ela estou, nesse momento, redigindo este texto. 


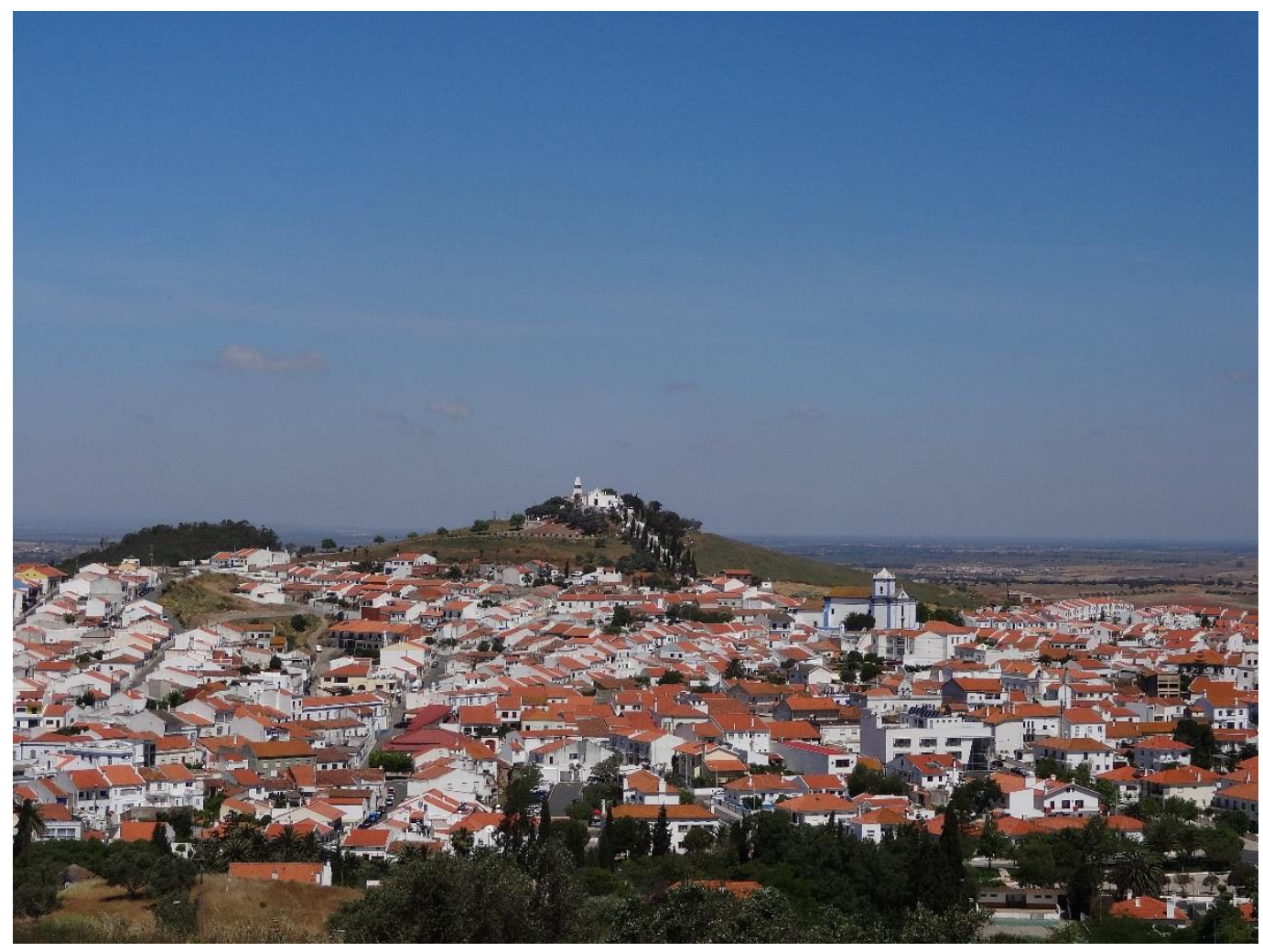

Fig. 21 - Vista de Aljustrel a partir do Moinho. Acervo pessoal, 2013.

\section{OS TRABALHOS JÁ REALIZADOS}

Geologicamente, Aljustrel está localizada sobre a Faixa Piritosa Ibérica (FPI): conjunto de grandes depósitos de sulfetos polimetálicos e maciços de manganês que se estende desde a mina de Las Cruces (Sevilha, Espanha), até a mina da Caveira (Grândola, Portugal). Entre suas maiores jazidas, podemos destacar as de Aznalcóllar, Riotinto, Tharsis, Buitrón e Sotiel Coronada, na Espanha; e São Domingos e Aljustrel em Portugal. De origem vulcano-sedimentar, a formação de sulfetos de ferro teve lugar em águas profundas sem movimento, impedindo a renovação do oxigênio. Os elementos principais dos sulfetos são o enxofre e o ferro, que atingem cerca de $91 \%$ da massa mineral da FPI. A sílica é encontrada em proporções de $4 \%$ do total, sendo os $5 \%$ restantes correspondentes a elementos minoritários tais como o cobre $(0,3$ a $1,5 \%)$, chumbo $(0,2$ a $0,7 \%)$, zinco $(0,4$ a 2,00\%), arsênico $(0,2$ a $0,7 \%)$, ouro, prata, cobalto, selênio, cádmio, tálio, índio, germânio, níquel, manganês, titânio, bismuto e antimônio (PÉREZ MACÍAS et al. 2013: 6-10). No caso de Aljustrel, em todas as massas predomina mais o zinco $(5,51 \%)$ do que o cobre $(1,67 \%)$. 
Com estas condicionantes geológicas, o mineiro antigo tinha à sua disposição, nas massas de sulfetos polimetálicos do sudoeste ibérico, ferro na zona de oxidação (chapéu de ferro), prata na base deste chapéu de ferro e sulfetos de cobre na zona de enriquecimento secundário, nas proximidades do nível freático e sobre os sulfetos primários sem alteração. O ouro aparece em quantidades tão ínfimas que só com as modernas técnicas mineralógicas de cianetação ${ }^{19}$ se conseguiu obter, já no último quartel do século XX. (PÉREZ MACÍAS et al. 2013: 6-10)

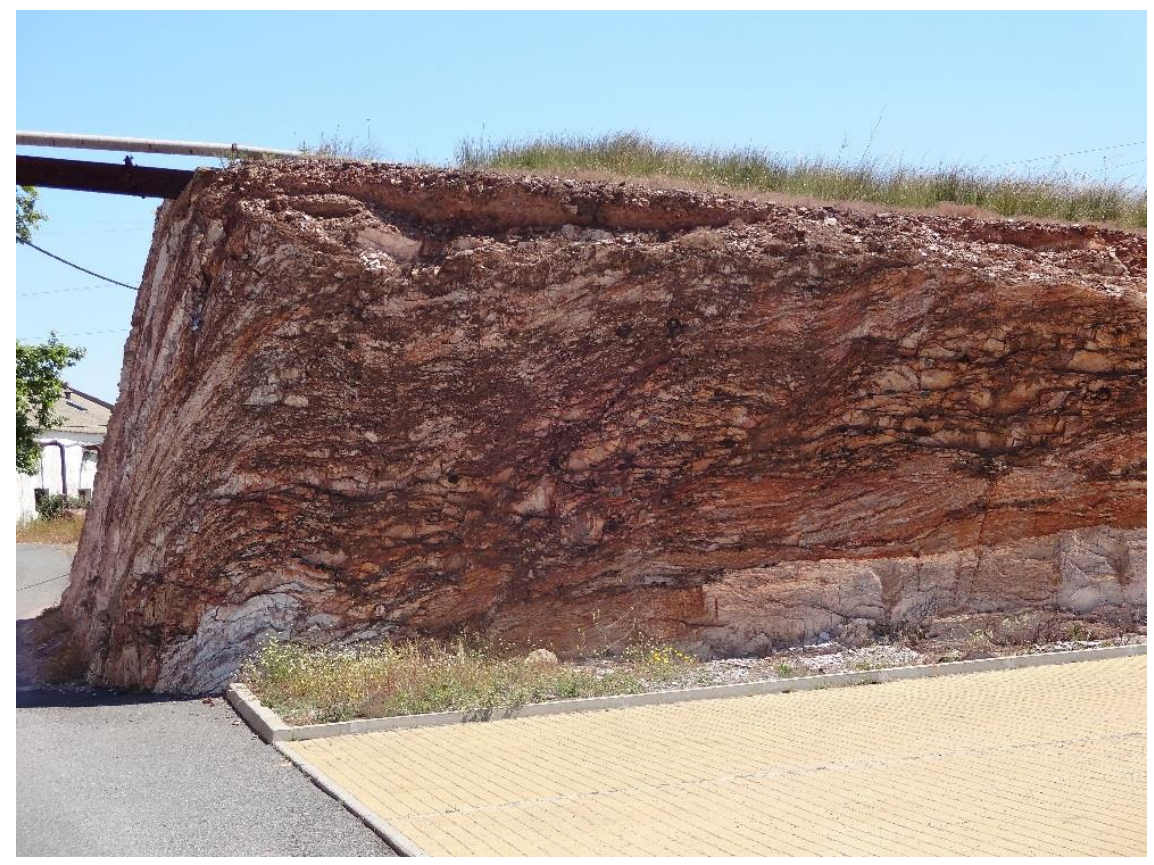

Fig. 22 - Chapéu de ferro (gossan) de Algares. Acervo pessoal, 2013.

A mineração em Aljustrel se faz presente desde o III $^{\circ}$ Milênio a.C., mas foi somente sob a dominação romana (por volta dos séculos I e IV d.C.) que a região começou a produzir em escala industrial. Conhecida pelo nome pré-romano de Vipasca, o território foi um importante vicus (aldeia, em latim) dentro da cidade de Pax Iulia. Não vou aqui entrar em detalhes sobre a discussão terminológica jurídica do metallum Vipascense, bem como a sua administração (conhecida principalmente por meio das Tábuas de Vipasca, do século II d.C. ${ }^{20}$ ), pois esses assuntos - juntamente com as técnicas e tecnologias

\footnotetext{
${ }^{19}$ Carbonitretação realizada em meio líquido.

${ }^{20}$ Para a leitura do texto completo e sua análise, conferir MARTINS 2012.
} 
empregadas na extração mineral - já foram pormenorizados em minha dissertação de Mestrado (MARTIRE 2012).

Para fins didáticos, vou dividir Vipasca de acordo com as suas áreas escavadas, desde 2006, no âmbito do Projecto Vipasca - trabalho conjunto entre o Município de Aljustrel e a Universidad de Huelva (Espanha), sendo encabeçado pelo diretor do Museu de Aljustrel, o arqueólogo Artur Martins, e o professor da universidade de Huelva, Juan Aurelio Pérez Macías. Irei, então, discorrer sobre as seguintes intervenções arqueológicas: Casa do Procurador, Lavaria Piloto, Morro de Algares, Morro de Mangancha, Necrópoles de Valdoca e de Farrobo, e Oficina Metalúrgica de Azinhal (bem como seus escoriais).

\section{CASA DO PROCURADOR}

Localizada na área de Algares, seus vestígios foram postos a céu aberto durante os trabalhos de mineração do século XIX. Escavações anteriores ao Projecto Vipasca revelaram se tratar de um edifício de peristilo central rodeado por compartimentos. $\mathrm{O}$ espólio encontrado nas escavações levou os investigadores à conclusão de que o edifício seria uma domus (casa) que serviria como residência ao administrador imperial das minas, o procurator metallorum, dando o nome, então, de Casa do Procurador ao conjunto arqueológico (embora, até o momento, não existam evidências suficientes que atestem se tratar, de fato, do ambiente em que o procurador residia quando visitava o vicus).

Devido aos trabalhos de mineração contemporâneos em Algares, houve uma alteração significativa no terreno que, analisado pelos pesquisadores do Projecto Vipasca, apontou não somente o afloramento de muros que corroboram duas fases de ocupação da Casa do Procurador, como também existem vestígios de diversas estruturas romanas que foram cortadas pelo maquinário pesado da mineração atual, evidenciando, então, que a área de povoamento no local seria muito superior à que se supunha e com um período de ocupação muito maior no tempo. Essas estruturas sugerem que não pertenciam ao Baixo Império, mas, sim, à própria organização do povoado de Vipasca, que foi crescendo de um lado ao outro do chapéu de ferro de Algares. Dentre os espólios das escavações efetuadas no setor I da Casa do Procurador (área intervencionada em meados do século XX por Abel Viana e Freire de Andrade), pode-se dizer que as cerâmicas comuns de mesa estão presentes em abundância: as tigelas de corpo globular e bordo saliente, as tigelas 
globulares de bordo reentrante e caçarolas com bordo de martelo têm pastas avermelhadas ou acinzentadas. No caso das cerâmicas de mesa, a novidade é a taça de grande diâmetro com corpo carenado e bordo espessado com lábio saliente biselado no interior, embora também existam abundantes taças de corpo hemisférico. Já as cerâmicas finas contam com a predominância de sigillatas hispânicas das oficinas de Andújar e Tricio em suas formas mais recorrentes, manifestando o esplendor de Aljustrel nos séculos I e II d.C. Por fim, as ânforas encontradas oferecem os melhores índices cronológicos: as ânforas de transporte de azeite para a Bética, do tipo Dressel 20, são do período Júlio-Cláudio, enquanto as ânforas de formas Flávias e Antoninas são datadas entre o final do século I e o século II d.C. As ânforas do Baixo Império, por sua vez, são maioritariamente lusitanas (locais), informando-nos que houve, sim, um decréscimo na produção mineradora de Vipasca entre a segunda metade do século III e século IV d.C. Todos os materiais recolhidos em campo e catalogados apontam que a área da Casa do Procurador I não pertencia a um local de povoamento tardio como se pensava. $\mathrm{O}$ balizamento oferecido pelos vestígios estende-se desde inícios do século I d.C. até o século IV d.C., coincidindo com todo o período de produção romana na região. 


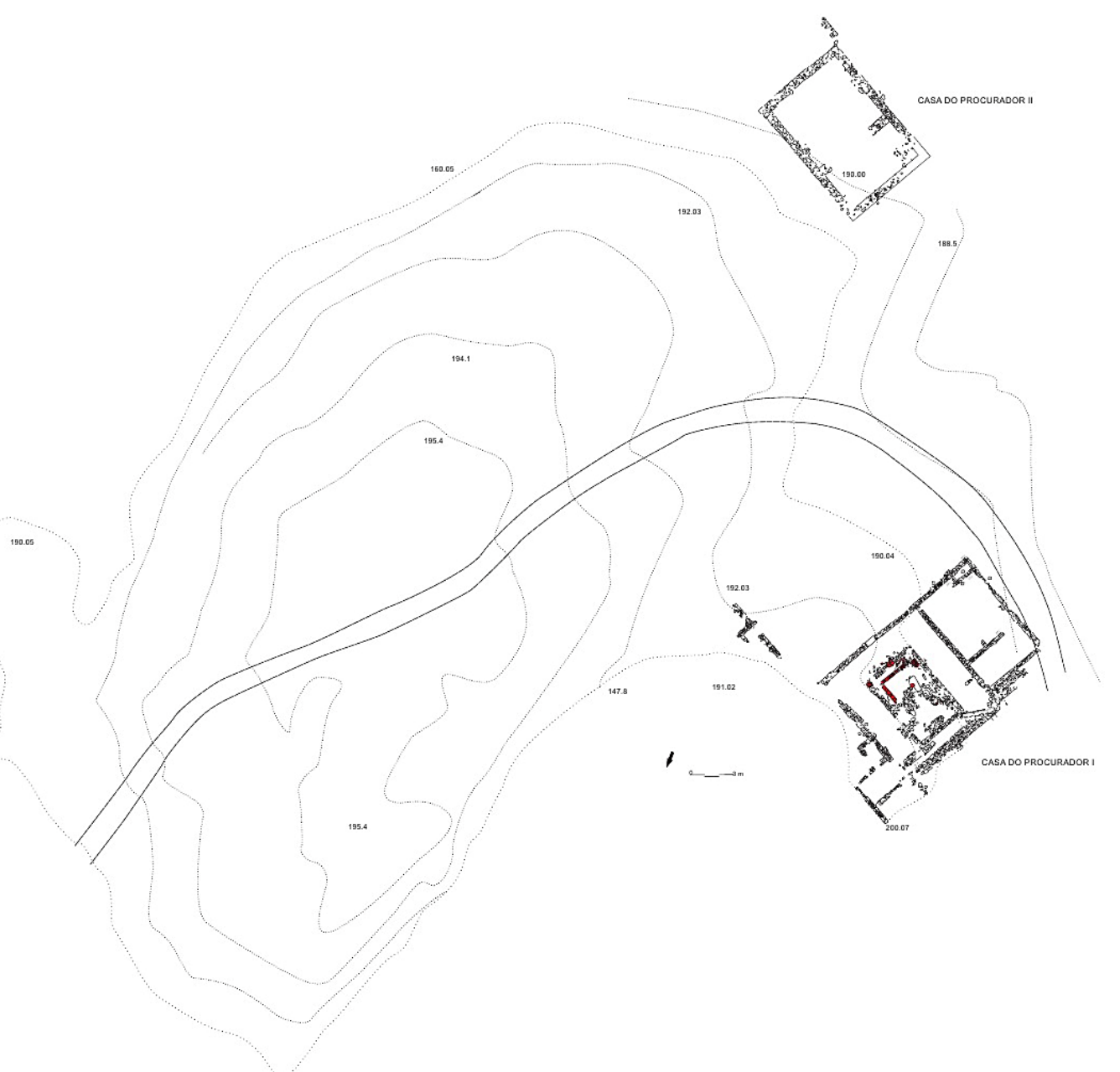

Fig. 23 - Visão geral das plantas escavadas da Casa do Procurador I e II distribuídas topograficamente. Imagem cedida por Artur Martins.

Os investigadores do Projecto Vipasca dividiram a Casa do Procurador I em 55 U.E. (Unidade Estratigráfica). Por se tratar de um edifício que será apresentado como modelo 3D no âmbito de meu trabalho, vou resumir agora as características de cada U.E., que podem ser visualizadas na Figura 24 (PÉREZ MACÍAS et al. 2013: 199-224). 


\begin{tabular}{|c|c|c|c|}
\hline U.E. & Tipo de Unidade & Descrição & Dimensões \\
\hline 1 & Construtiva & $\begin{array}{l}\text { Muro de contenção parcialmente escavado, construído em xisto com fiadas de } \\
\text { argamassa de barro (técnica construtiva comum a todo edifício). }\end{array}$ & $\begin{array}{l}11,80 m \text { - comprimento } \\
0,45 m \text { - largura } \\
0,85 m \text {-altura }\end{array}$ \\
\hline 2 & Construtiva & $\begin{array}{l}\text { Muro mais comprido do edifício, destruído em alguns pontos devido aos } \\
\text { trabalhos mineiros e à plantação de eucaliptos. Destaque para a existência de } \\
\text { um silhar de xisto na metade de seu comprimento que, pela posição axial, pode } \\
\text { se tratar de um vão de porta. Muro que serve de união a todos os muros } \\
\text { escavados. A existência do vão de porta indica que o acesso serviria para a } \\
\text { comunicação entre dois ambientes ou como entrada no edifício a partir do } \\
\text { exterior. }\end{array}$ & $\begin{array}{l}15 m \text { - comprimento } \\
0,44 m \text { - largura } \\
0,85 m \text { - altura }\end{array}$ \\
\hline 3 & Construtiva & $\begin{array}{l}\text { Muro de alvenaria de lajes de xisto com argamassa de barro com assentamento } \\
\text { cuidado de suas pedras. Bastante afetado pelo traçado do caminho feito pela } \\
\text { empresa mineira. }\end{array}$ & $\begin{array}{l}9 m \text { - comprimento } \\
0,47 m \text { - largura } \\
0,46 m \text { altura }\end{array}$ \\
\hline 4 & Construtiva & $\begin{array}{l}\text { Muro de divisão dos compartimentos I e II da planta. Provavelmente havia um } \\
\text { vão para a comunicação entre os dois compartimentos. }\end{array}$ & $\begin{array}{l}5,13 m \text { - comprimento } \\
0,47 m \text { - largura } \\
0,87 m \text { - altura }\end{array}$ \\
\hline 5 & Construtiva & Muro de alvenaria mal conservado ao nível da primeira fiada de fundação. & $\begin{array}{l}\text { 6,90m - comprimento } \\
0,60 m \text { - largura } \\
0,15 m \text { - altura }\end{array}$ \\
\hline 6 & Construtiva & $\begin{array}{l}\text { Vestígio da sapata de um muro em que se conservam apenas algumas pedras } \\
\text { sobre uma camada de seixos de quartzo, pequenos fragmentos de escórias de } \\
\text { cobre e fragmentos atípicos de cerâmica comum romana (envolvidos em } \\
\text { argamassa de má qualidade). }\end{array}$ & $\begin{array}{l}2,45 m \text { - comprimento } \\
0,50 m \text { - largura } \\
0,15 m \text { - altura }\end{array}$ \\
\hline 7 & Construtiva & Muro de alvenaria conservado em sua fundação. & $\begin{array}{l}5,60 m \text { - comprimento } \\
0,50 m \text { - largura } \\
0,15 m \text { - altura }\end{array}$ \\
\hline 8 & Construtiva & $\begin{array}{l}\text { Muro de alvenaria de lajes de xisto que delimita o espaço do pátio juntamente } \\
\text { com as U.E. } 1,2 \text { e } 24 \text {. Encontrase sobre a U.E. 52, que pertence a uma edificação } \\
\text { anterior. }\end{array}$ & $\begin{array}{l}5,30 \text { - comprimento } \\
0,50 m \text { - largura } \\
0,15 m \text { - altura }\end{array}$ \\
\hline 9 & Construtiva & $\begin{array}{l}\text { Muro de alvenaria de lajes de xisto e argamassa de cal conservado apenas na } \\
\text { fundação. Define a área central do pátio. }\end{array}$ & $\begin{array}{l}9,50 \text { - comprimento } \\
0,45 m \text { - largura } \\
0,10 m \text { - altura }\end{array}$ \\
\hline 10 & Construtiva & $\begin{array}{l}\text { Muro de alvenaria de baixa qualidade, com construção menos cuidada na } \\
\text { ordenação das fiadas. Conserva-se nesta unidade a marca do local onde } \\
\text { assentava a base de uma coluna e ladrilhos no topo do muro. A base das colunas } \\
\text { do pórtico servem para calcular a altura original dos quatro muros que dividem o } \\
\text { pórtico do pátio: cerca de } 0,17 \mathrm{~m} \text { de altura. }\end{array}$ & $\begin{array}{l}\text { 3,80m - comprimento } \\
0,40 m \text { - largura } \\
0,17 m \text { - altura }\end{array}$ \\
\hline 11 & Construtiva & $\begin{array}{l}\text { Pequeno canal formado por duas linhas d elajes de xisto colocadas } \\
\text { verticalmente, servindo para a drenagem das águas pluviais vindas do pátio (IV). }\end{array}$ & $\begin{array}{l}3,45 m \text { - comprimento } \\
0,45 m \text { - largura } \\
0,25 m \text { - profundidade }\end{array}$ \\
\hline 12 & Construtiva & $\begin{array}{l}\text { Série de ladrilhos encontrados no centro do pátio (IV) que correspondem a uma } \\
\text { estrutura pequena retangular muito destruída pelos eucaliptos. }\end{array}$ & $\begin{array}{l}\text { Não é possível } \\
\text { fornecer as dimensões } \\
\text { exatas }\end{array}$ \\
\hline 13 & Construtiva & $\begin{array}{l}\text { Fiada de ladrilhos colocados horizontalmente no interior dos muros que } \\
\text { sustentam as colunas do espaço porticado do pátio. Os ladrilhos estão colocados } \\
\text { em duas fiadas, uma inferior, mais larga, e uma superior mais estreita, formando } \\
\text { um pequeno degrau. Possivelmente a moldura de ladrilhos teria ligação com o } \\
\text { implúvio central, construída utilizando a técnica de opus testaceum. }\end{array}$ & $\begin{array}{l}\text { Dimensões dos } \\
\text { ladrilhos: } \\
\text { 41/28,5/4,5cm } \\
\text { Dimensões da moldura } \\
\text { de ladrilhos: } \\
0,49 \mathrm{~m} \text { - largura } \\
0,08 \mathrm{~m} \text { - altura }\end{array}$ \\
\hline 14 & Construtiva & $\begin{array}{l}\text { Sapata de muro de alvenaria não escavado totalmente. As argamassas utilizam } \\
\text { um aglomerante de cal. Muro que corresponde a uma edificação anterior ao } \\
\text { edifício do pátio central. }\end{array}$ & $\begin{array}{l}3 m \text { - comprimento } \\
0,40 m \text { - largura } \\
0,23 m \text { - altura }\end{array}$ \\
\hline 15 & Construtiva & $\begin{array}{l}\text { Muro de alvenaria que imbrica com a unidade anterior formando um ângulo } \\
\text { reto. }\end{array}$ & $\begin{array}{l}1 \mathrm{~m} \text { - comprimento } \\
0,40 \mathrm{~m} \text { - largura } \\
0,23 \mathrm{~m} \text { - altura }\end{array}$ \\
\hline 16 & Construtiva & $\begin{array}{l}\text { Pavimento de lajes de xisto sobre camada de argamassa de cal não conservado } \\
\text { integralmente. }\end{array}$ & $\begin{array}{l}\text { Não é possível } \\
\text { fornecer as dimensões } \\
\text { exatas }\end{array}$ \\
\hline 17 & Construtiva & $\begin{array}{l}\text { Pequeno topo de muro na área noroeste da escavação. Evidencia uma fase de } \\
\text { edificação anterior à estrutura do pátio central. }\end{array}$ & $\begin{array}{l}\text { 1,30m - comprimento } \\
0,45 m \text { - largura } \\
0,10 m \text { - altura } \\
\end{array}$ \\
\hline 18 & Construtiva & $\begin{array}{l}\text { Vestígio de muro situado no talude do caminho que leva à chaminé da empresa } \\
\text { de mineração Transtagana. }\end{array}$ & $\begin{array}{l}\text { 0,30m - comprimento } \\
0,45 m \text { - largura } \\
0,25 m \text { - altura }\end{array}$ \\
\hline 19 & Construtiva & $\begin{array}{l}\text { Pequena sapata de um muro de alvenaria no espaço porticado do pátio. } \\
\text { Provavelmente pertence a uma fase anterior à da edificação do pátio central. }\end{array}$ & $\begin{array}{l}\text { 0,90 - comprimento } \\
\text { 0,45m - largura } \\
\text { 0,10m - altura }\end{array}$ \\
\hline 20 & Construtiva & $\begin{array}{l}\text { Base de pavimento com argamassa de cal na área de pórtico da estrutura } \\
\text { central.. }\end{array}$ & $\begin{array}{l}\text { Não é possível } \\
\text { fornecer as dimensões } \\
\text { exatas }\end{array}$ \\
\hline
\end{tabular}




\begin{tabular}{|c|c|c|c|}
\hline 21 & Construtiva & $\begin{array}{l}\text { Camada de pavimento de argamassa rico em cal no compartimento l, definido } \\
\text { pelas U.E. 1, 2, } 3 \text { e } 4 \text {. Nesta unidade recuperou-se um fragmento de taça da } \\
\text { forma Drag. } 24 / 25 \text { de sigillata hispânica de Tricio, constituindo-se, até o } \\
\text { momento, o único registro post quem que permite datar a remodelação do } \\
\text { habitat de Vipasca que cedeu lugar ao edifício de pátio central. }\end{array}$ & $\begin{array}{l}\text { Não é possível } \\
\text { fornecer as dimensões } \\
\text { exatas }\end{array}$ \\
\hline 22 & Construtiva & Camada de pavimento de argamassa rica em cal no compartimento I. & $\begin{array}{l}\text { Não é possível } \\
\text { fornecer as dimensões } \\
\text { exatas }\end{array}$ \\
\hline 23 & Deposicional & $\begin{array}{l}\text { O sedimento está por todas as partes da edificação, exceto nos compartimentos } \\
\text { I e II. Constitui-se de terras em que abundam as alvenarias resultantes da } \\
\text { destruição dos muros, tégulas e ladrilhos, de materiais de cobertura e muita } \\
\text { cerâmica. Entre seus materiais destacam-se as ânforas de procedência lusitânia } \\
\text { (Dressel 14) e da Baía de Cádiz (Dressel 7-11), sigillata hispânica da oficina de } \\
\text { Andujar (Drag. 15,17 e 27), e uma caçarola com vidrado transparente de tom } \\
\text { melado de cronologia medieval). }\end{array}$ & $\begin{array}{l}\text { Não é possível } \\
\text { fornecer as dimensões } \\
\text { exatas }\end{array}$ \\
\hline 24 & Construtiva & $\begin{array}{l}\text { Muro de alvenaria na área norte do pátio, servindo de divisão entre a área do } \\
\text { pórtico e os compartimentos que formariam a ala norte, praticamente } \\
\text { destruídos pela corta da empresa mineradora Transtagana. }\end{array}$ & $\begin{array}{l}\text { 4,60m - comprimento } \\
0,54 m \text { - largura } \\
0,25 m \text { - altura }\end{array}$ \\
\hline 25 & Deposicional & $\begin{array}{l}\text { Unidade que cobre todas as estruturas e os seus derrubes (nos locais onde não } \\
\text { foi alterada pelas escavações anteriores). Contém terras de consistência muito } \\
\text { solta e de cor parda, incorporando abundante material arqueológico, elementos } \\
\text { de construção e cerâmicas de todas as fases de ocupação da Casa do Procurador } \\
\text { I. Foi a unidade que mais forneceu quantidade de aterial arqueológico, podendo- } \\
\text { se destacar: ânforas de tipo lusitano (Dressel 14), cerâmicas de cozinha } \\
\text { (caçarolas de bordo curvo e potes de bordo bífido), fragmentos de sigillata } \\
\text { itálica, sigillata hispânica das oficinas de Andujar (Drag. 35) e Tricio (Drag. 37), e } \\
\text { sigillatas africanas (Hayes 63), que selariam o nível de abandono em momentos } \\
\text { posteriores à segunda metade do século IV d.C. }\end{array}$ & $\begin{array}{l}\text { Não é possível } \\
\text { fornecer as dimensões } \\
\text { exatas }\end{array}$ \\
\hline 26 & Construtiva & $\begin{array}{l}\text { Muro de alvenaria de lajes de xisto qe não conserva todo o seu comprimento } \\
\text { original. É o muro divisório do porticado (III) e do pátio central (IV). }\end{array}$ & $\begin{array}{l}3 m \text { - comprimento } \\
0,29 m \text { - largura } \\
0,37 m \text { - altura }\end{array}$ \\
\hline 27 & Construtiva & Pequena construção de ladrilhos em forma de U diante do vão da U.E. 2. & $\begin{array}{l}\text { Não é possível } \\
\text { fornecer as dimensões } \\
\text { exatas }\end{array}$ \\
\hline 28 & Construtiva & $\begin{array}{l}\text { Camada de argamassa que se conserva junto às U.E. } 10 \text { e } 26 \text {, desaparecendo nos } \\
\text { restantes quadrantes do pátio, junto às U.E. } 46 \text { e } 9 \text {, onde se conserva a moldura } \\
\text { de ladrilhos. }\end{array}$ & $\begin{array}{l}\text { Não é possível } \\
\text { fornecer as dimensões } \\
\text { exatas }\end{array}$ \\
\hline 29 & Construtiva & $\begin{array}{l}\text { Pavimento de lajes de xisto na área do pátio e de que se conservam algumas } \\
\text { partes, epecialmente junto à moldura de ladrihos. }\end{array}$ & $\begin{array}{l}\text { Não é possível } \\
\text { fornecer as dimensões } \\
\text { exatas }\end{array}$ \\
\hline 30 & $\begin{array}{l}\text { Construtiva. Casa do } \\
\text { Procurador II }\end{array}$ & Muro de alvenaria bem aparelhado. & $\begin{array}{l}\text { 6,25m - comprimento } \\
0,50 m \text { - largura }\end{array}$ \\
\hline 31 & $\begin{array}{l}\text { Construtiva. Casa do } \\
\text { Procurador II }\end{array}$ & Muro de alvenaria de lajes de xisto. & $\begin{array}{l}\text { 9,5m - comprimento } \\
0,50 m \text { - largura }\end{array}$ \\
\hline 32 & $\begin{array}{l}\text { Construtiva. Casa do } \\
\text { Procurador II }\end{array}$ & $\begin{array}{l}\text { Resto de muro de alvenaria de lajes de xisto cujo comprimento total não ficou } \\
\text { completamente definido. }\end{array}$ & $\begin{array}{l}\text { 7,82m - comprimento } \\
0,50 m \text { - largura }\end{array}$ \\
\hline 33 & $\begin{array}{l}\text { Construtiva. Casa do } \\
\text { Procurador II }\end{array}$ & Muro de alvenaria de lajes de xisto. & $\begin{array}{l}10 m \text { - comprimento } \\
0,54 m \text { - largura }\end{array}$ \\
\hline 34 & $\begin{array}{l}\text { Construtiva. Casa do } \\
\quad \text { Procurador II }\end{array}$ & $\begin{array}{l}\text { Muro de alvenaria de lajes de xisto formada por pedaços de muros que devem } \\
\text { se unir. }\end{array}$ & $\begin{array}{l}\text { Não é possível } \\
\text { fornecer as dimensões } \\
\text { exatas }\end{array}$ \\
\hline 35 & Deposicional & $\begin{array}{l}\text { Derrube de tégulas e ímbrices na área porticada que rodeia o pátio central (III). } \\
\text { Provavelmente o único lugar em todo o edifício em que ainda se conserva o } \\
\text { nível original de destruição in situ. }\end{array}$ & $\begin{array}{l}\text { Não é possível } \\
\text { fornecer as dimensões } \\
\text { exatas }\end{array}$ \\
\hline 36 & Construtiva & $\begin{array}{l}\text { Muro de alvenaria e tijolo na área superior da Casa do Procurador I, detruído em } \\
\text { parte pela corta da Transtagana. }\end{array}$ & $\begin{array}{l}\text { 1,90m - comprimento } \\
0,49 m \text { - largura } \\
0,30 m \text { - altura }\end{array}$ \\
\hline 37 & $\begin{array}{l}\text { Construtiva. Casa do } \\
\text { Procurador II }\end{array}$ & $\begin{array}{l}\text { Pequeno afloramento de muro que pode adossar a uma das esquinas da casa do } \\
\text { Procurador II. O adossamento pode indicar que a Casa do Procurador II faça parte } \\
\text { de um edifício de maiores dimensões e a existência de grandes compartimentos } \\
\text { retangulares, como na Casa do Procurador I, aponta para que se trate de um } \\
\text { edifício com a mesma funcionalidade. }\end{array}$ & $0,49 m$ - largura \\
\hline 38 & Construtiva & $\begin{array}{l}\text { Delimita ao norte os compartimentos VIII e IX, podendo se estender ao resto das } \\
\text { unidades da área norte do edifício, mas sem estar conservada em toda a sua } \\
\text { extensão. }\end{array}$ & $\begin{array}{l}5,45 m \text { - comprimento } \\
0,55 m \text { - largura } \\
0,43 m \text { - altura }\end{array}$ \\
\hline 39 & Construtiva & Separa os compartimentos VI, VII e VII. & $\begin{array}{l}2,57 m \text { - comprimento } \\
0,55 m \text { - largura } \\
0,34 m \text { - altura }\end{array}$ \\
\hline 40 & Construtiva & Muro de separação dos compartimentos VIII e IX. & $\begin{array}{l}\text { 3,50m - comprimento } \\
0,55 m \text { - largura } \\
0,40 m \text { - altura }\end{array}$ \\
\hline
\end{tabular}




\begin{tabular}{|c|c|c|c|}
\hline 41 & Construtiva & $\begin{array}{l}\text { Restos de uma estrutura de tendência circular com pequena câmera de } \\
\text { combustão ao centro, situada na zona norte da escavação. Construída em } \\
\text { alvenaria de xisto e rochas vulcânicas, incorpora diverso material construtivo } \\
\text { romano, fragmentos de tégulas, ímbrices e ladrilhos. É claramente uma estrutura } \\
\text { posterior às fases construtivas romanas, já que está sobre a fiada de ladrilhos do } \\
\text { pátio, ou seja, foi construída quando o edifício romano já se encontrava } \\
\text { completamente abandonado. Provavelmente um forno para obtenção de cal. } \\
\text { Esse dado é relevante pois, se uma vez abandonado o edifício teve seus } \\
\text { mármores reaproveitados, isso indica que ele e suas construções ao redor } \\
\text { possuíam um conjunto decorativo escultórico ou arquitetônico - o que está de } \\
\text { acordo com o modelo do edifício e a singularidade de alguns de seus materiais } \\
\text { cerâmicos. }\end{array}$ & $\begin{array}{l}\text { 2,10m - diâmetro } \\
0,50 m \text { - interior da } \\
\text { câmara de fogo }\end{array}$ \\
\hline 42 & Construtiva & $\begin{array}{l}\text { Pequeno muro de planta circular com aparelho de alvenaria de xisto e diverso } \\
\text { material construtivo romano reaproveitado. }\end{array}$ & $\begin{array}{l}0,75 m \text { - comprimento } \\
0,55 m \text { - largura } \\
0,40 m \text { - altura }\end{array}$ \\
\hline 43 & Construtiva & $\begin{array}{l}\text { Muro situado na zona oeste da escavação com uma técnica construtiva que } \\
\text { diverge da utilizada nos demais muros do setor, utilizando alvenaria de rochas } \\
\text { vulcânicas no lugar de xisto. }\end{array}$ & $\begin{array}{l}2,40 m \text { - comprimento } \\
0,57 m \text { - largura } \\
0,53 m \text { - altura }\end{array}$ \\
\hline 44 & Construtiva & Muro paralelo à U.E. 8 na área oeste do edifício. & $\begin{array}{l}\text { 6,50m - comprimento } \\
0,55 m \text { - largura } \\
0,05 m \text { - altura }\end{array}$ \\
\hline 45 & Construtiva & $\begin{array}{l}\text { Muro cortado pela U.E. } 41 \text { e pelas raízes de um eucalipto. Um dos muros que } \\
\text { delimitam o espaço do pátio central. }\end{array}$ & $\begin{array}{l}1,60 m \text { - comprimento } \\
0,45 m \text { - largura } \\
0,10 m \text { - altura }\end{array}$ \\
\hline 46 & Construtiva & Faz parte, com a U.E. 45, do muro de separação do pátio e do pórtico. & $\begin{array}{l}\text { 3,80m - comprimento } \\
0,40 m \text { - largura } \\
0,20 m \text { - altura }\end{array}$ \\
\hline 47 & Construtiva & Muro de alvenaria na ala oeste do edifício que separa os compartimentos IX e X. & $\begin{array}{l}2,10 m \text { - comprimento } \\
0,50 m \text { - largura } \\
0,10 m \text { - altura }\end{array}$ \\
\hline 48 & Construtiva & $\begin{array}{l}\text { Muro situado fora da área de escavação, fazendo parte de um setor } \\
\text { independente das demais unidades descritas. }\end{array}$ & $\begin{array}{l}0,50 m \text { - comprimento } \\
0,45 m \text { - largura } \\
0,40 m \text { - altura }\end{array}$ \\
\hline 49 & Construtiva & Muro de alvenaria bastante afetado pela plantação de eucaliptos. & $\begin{array}{l}2 m \text { - comprimento } \\
0,45 m \text { - largura } \\
0,31 m \text { - altura }\end{array}$ \\
\hline 50 & Construtiva & $\begin{array}{l}\text { Muro de alvenaria que se une, em ângulo reto, à U.E. 49. Bastante afetado por } \\
\text { escavações clandestinas. }\end{array}$ & $\begin{array}{l}2,70 m \text { - comprimento } \\
0,45 m \text { - largura } \\
0,25 m \text { - altura }\end{array}$ \\
\hline 51 & Construtiva & Muro de alvenaria de lajes de xisto. & $\begin{array}{l}2 m \text { - comprimento } \\
0,45 m \text { - largura } \\
0,31 m \text { - altura }\end{array}$ \\
\hline 52 & Construtiva & $\begin{array}{l}\text { Pequeno arranque de muro no talude do caminho de acesso à corta da empresa } \\
\text { Transtagana. }\end{array}$ & $\begin{array}{l}\text { 2,20m - comprimento } \\
0,45 m \text { - largura } \\
0,31 m \text { - altura }\end{array}$ \\
\hline 53 & Construtiva & $\begin{array}{l}\text { Preenchimento das estruturas de uma fase anterior para assentar a fundação das } \\
\text { U.E. } 45 \text { e } 46 .\end{array}$ & $\begin{array}{l}1 \mathrm{~m} \text { - comprimento } \\
0,30 \mathrm{~m} \text { - Iargura } \\
0,10 \mathrm{~m} \text { - altura }\end{array}$ \\
\hline 54 & Construtiva & Fundação de alvenaria dentro da zona de pátio. & $\begin{array}{l}1,75 m \text { - comprimento } \\
0,90 m \text { - largura } \\
0,10 m \text { - altura }\end{array}$ \\
\hline 55 & Construtiva & Muro parcialmente derrubado que se situa nas fiadas inferiores da U.E. 24. & $\begin{array}{l}1,50 m \text { - comprimento } \\
0,30 m \text { - altura }\end{array}$ \\
\hline
\end{tabular}

Tendo apresentado as sequências estratigráficas da Casa do Procurador, é possível apontar quatro fases distintas de ocupação do edifício. Vejamos:

$1^{a}$ Fase: a diferença da técnica construtiva entre esta e as demais fases é que se nota a utilização de alvenarias de maiores dimensões que servem como base para as fundações da segunda fase. As orientações dos muros coincidem com os da segunda fase, mostrando que a reforma do edifício não alterou a ortogonalidade deste setor do povoado mineiro de Vipasca. Cronologicamente, corresponde à primeira ocupação romana do 
local, havendo menor cuidado com a escolha de matérias-primas para a edificação: foram utilizados xistos carboníferos (que formam o encaixe das mineralizações e possuem depósitos sedimentares de fácil extração a partir das pedreiras). A utilização dos xistos torna desnecessária a utilização de argamassas ricas em cal para fixar as alvenarias - basta uma simples camada de argila para unir as fiadas. Embora não haja material suficiente para se estabelecer a data de fundação do povoado de Vipasca, a sigillata hispânica de Tricio (forma Drag. 26/27) encontrada na U.E. 21 foi bastante característica de meados a finais do século I d.C., servindo de base para o balizamento temporal do povoado. Muito provavelmente, o povoamento de Vipasca se iniciou em data posterior a 25 a.C., já sob administração de Augusto (coincidindo com os primeiros vestígios de exploração industrial das massas de Aljustrel) (PÉREZ MACÍAS et al. 2013: 227-229).

$2^{a}$ Fase: a maior parte das U.E. pertence a esta fase construtiva. Todas as U.E. delimitam um edifício de planta retangular cujo elemento em destaque é o pequeno pátio central (IV) rodeado por um pórtico octostilo ${ }^{21}$ (III) nos seus quatro cantos. O pátio possui dimensões de $5,5 \mathrm{~m}$ por $3,5 \mathrm{~m}$ e encontra-se delimitado por um muro com cerca de $30 \mathrm{~cm}$ de altura - local em que as oito colunas que suportavam o pórtico se apoiavam. $\mathrm{O}$ elemento central desse pátio seria um impluvium, construído em ladrilhos. O pórtico (III), por sua vez, tem largura de $2 \mathrm{~m}$ e a partir dele é feita a comunicação entre as várias áreas do edifício; a aparição de tesselas de mosaico pode ser um indício de que este local central estaria pavimentado com opus musivum. Por meio da planta, pode-se dizer que a Casa do Procurador seja, muito provavelmente, uma domus de período imperial na qual o átrio itálico acabou por se converter em um pequeno pátio porticado interior como eixo central das habitações (semelhantemente aos modelos encontrados no norte da África): desse modo, a Casa do Procurador seria muito parecida com as moradias presentes em pequenos municípios, como o caso de Munigua (Espanha). A investigação até o presente momento, contudo, não permite afirmar se estamos diante de uma casa de peristilo axial ou de uma casa de átrio e peristilo, ainda que ambos os casos representem ambientes domésticos de certa nobreza (típico das domus). Por fim, deve-se ressaltar, mais uma vez, que não há provas concretas de que a Casa do Procurador tenha sido, de fato, utilizada como sede da administração imperial da zona de mineração da região (PÉREZ MACÍAS et al. 2013: 229-236).

\footnotetext{
${ }^{21}$ Oito colunas.
} 
$3^{a}$ Fase: algumas U.E. informam ter havido remodelações no edifício (de acordo com a sobreposição de alguns muros). As modificações se fazem presentes especialmente no espaço porticado do pátio, mostrando uma alteração na dimensão da estrutura, deixando de ser um quadripórtico e passando a ser um pórtico assimétrico de três lados. Nos demais compartimentos não foram encontrados sinais significativos de reformas. Essa remodelação do ambiente pode estar relacionada à crise ocorrida no Império durante meados dos séculos II e III d.C., que ocasionou um abandono desse setor do povoado de Vipasca, sendo retomado mais tarde, justificando, assim, as reformas estruturais. Sobre esses dois períodos de crise, escrevem os autores (PÉREZ MACÍAS et al. 2013: 238):

Para a sua cronologia [a da terceira fase de ocupação da Casa do Procurador] definiram-se duas datas, uma da segunda metade do século II d.C., e outra da segunda metade do século III. Relativamente à primeira, refere-se que a invasão dos mauri do norte da África estaria na origem da paralisação das minas. Na Casa do Procurador não há vestígios de uma destruição com estas características, não existem níveis de arrasamento, mesmo a passagem da primeira para a segunda fase é uma operação intencional que constrói um novo edifício sobre os restos do anterior, sendo a passagem da segunda para a terceira fase um processo paulatino de ruína de algumas partes do edifício, consentâneo com um abandono temporário devido a decréscimo populacional, uma vez que esta destruição não afetou o conjunto da estrutura. Mais razoável se apresenta a outra datação da segunda metade do século III d.C., uma altura em que a administração imperial consegue recuperar a produção e que se vai traduzir na recuperação do antigo edifício da $2^{\mathrm{a}}$ fase, reparando ou modificando os elementos derrubados, o que supõe a mudança formal de alguns elementos e o desaparecimento de parte do porticado, cuja área passa a fazer parte do pátio central descoberto.

$4^{a}$ Fase: a última fase de ocupação está relacionada com a possível existência de fornos de cal (como atestam as U.E. 41 e 42). As argamassas de base carbonatada (opus caementicum), bastante utilizadas pelos romanos, requeriam a calcinação de formações calcárias para a obtenção de cal. Foi comum por todo o Império a existência de fabricantes de cal que reaproveitavam mármore de estruturas existentes: assim é o caso desta fase da Casa do Procurador. Também é importante ressaltar que nesta fase foram encontrados 
vestígios de cerâmica islâmica: porém, não há como afirmar que a casa foi utilizada como habitação em período medieval (PÉREZ MACÍAS et al. 2013: 239-240).
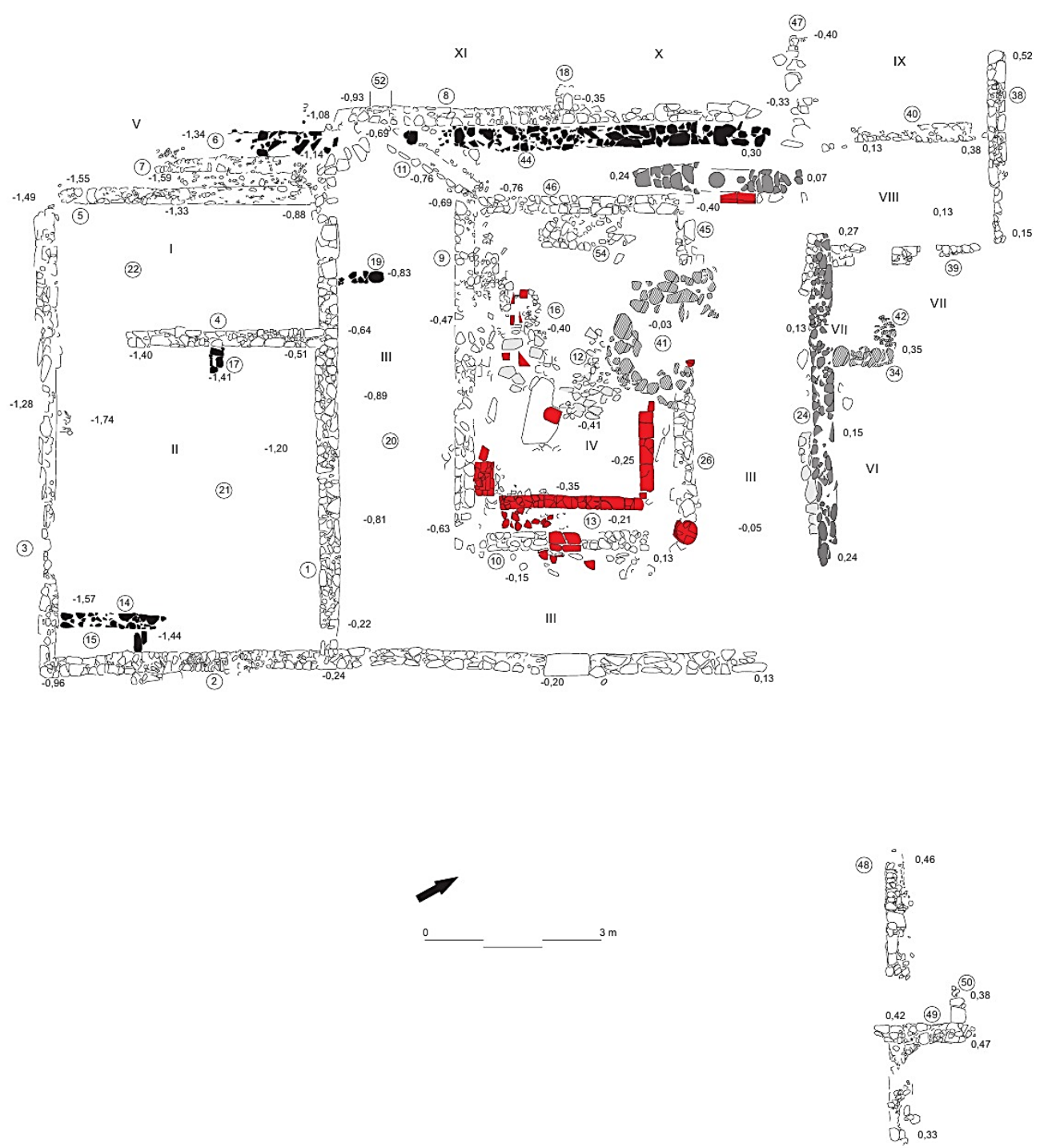

STSP

Fif

Sidis

4FASE

Fig. 24 - Planta da área escavada da Casa do Procurador I mostrando as unidades estratigráficas e as fases de ocupação. Imagem cedida por Artur Martins. 


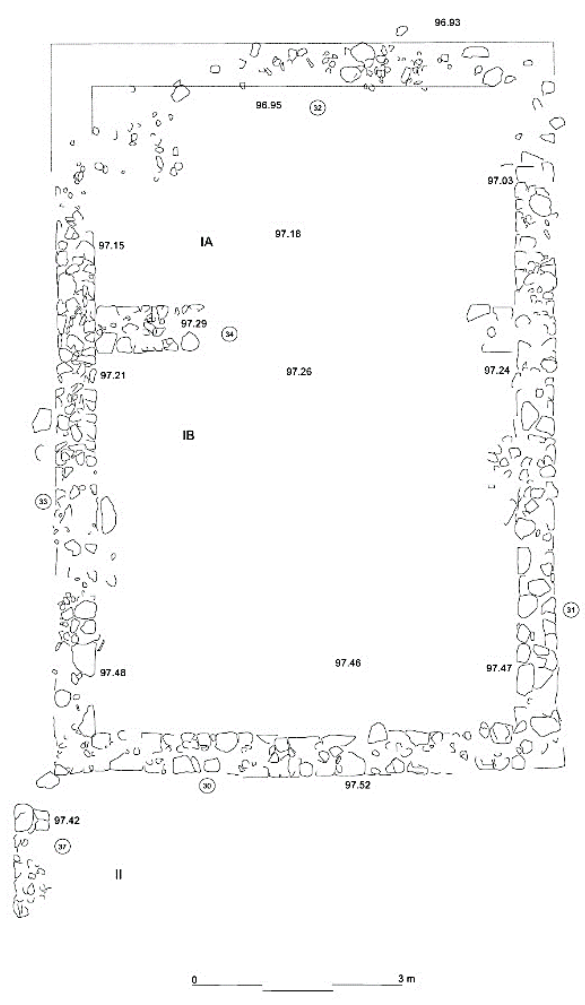

Fig. 25 - Planta da área escavada da Casa do Procurador II. Imagem cedida por Artur Martins.

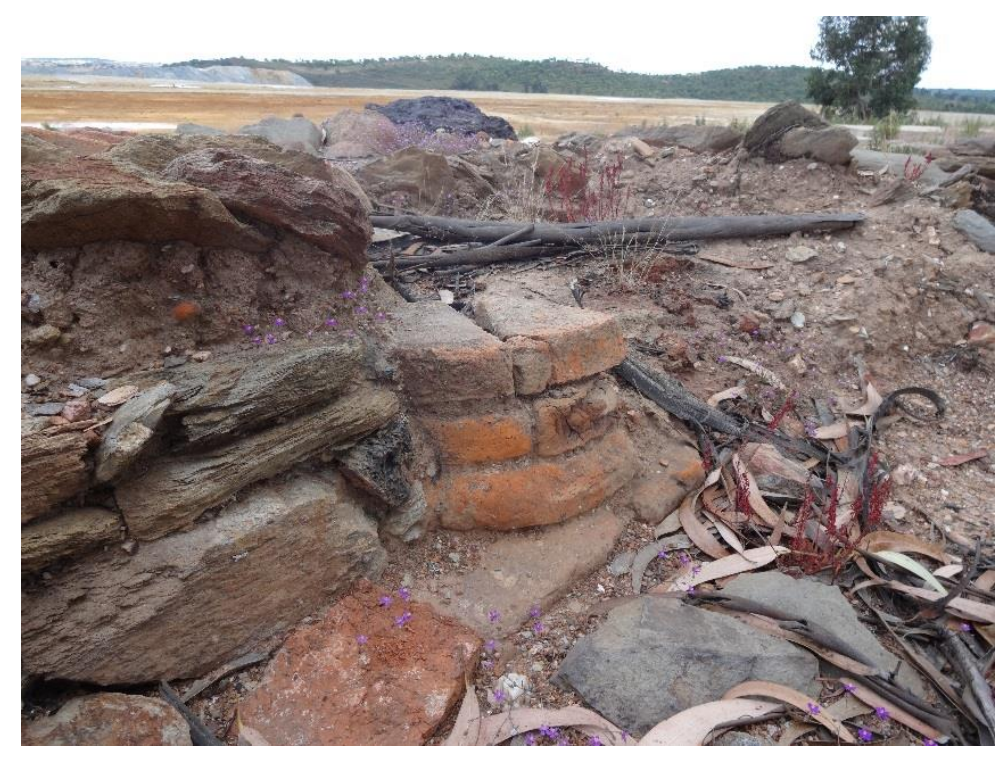

Fig. 26 - Detalhe de uma das colunas que formavam o pórtico da Casa do Procurador I. Acervo pessoal, 2013. 

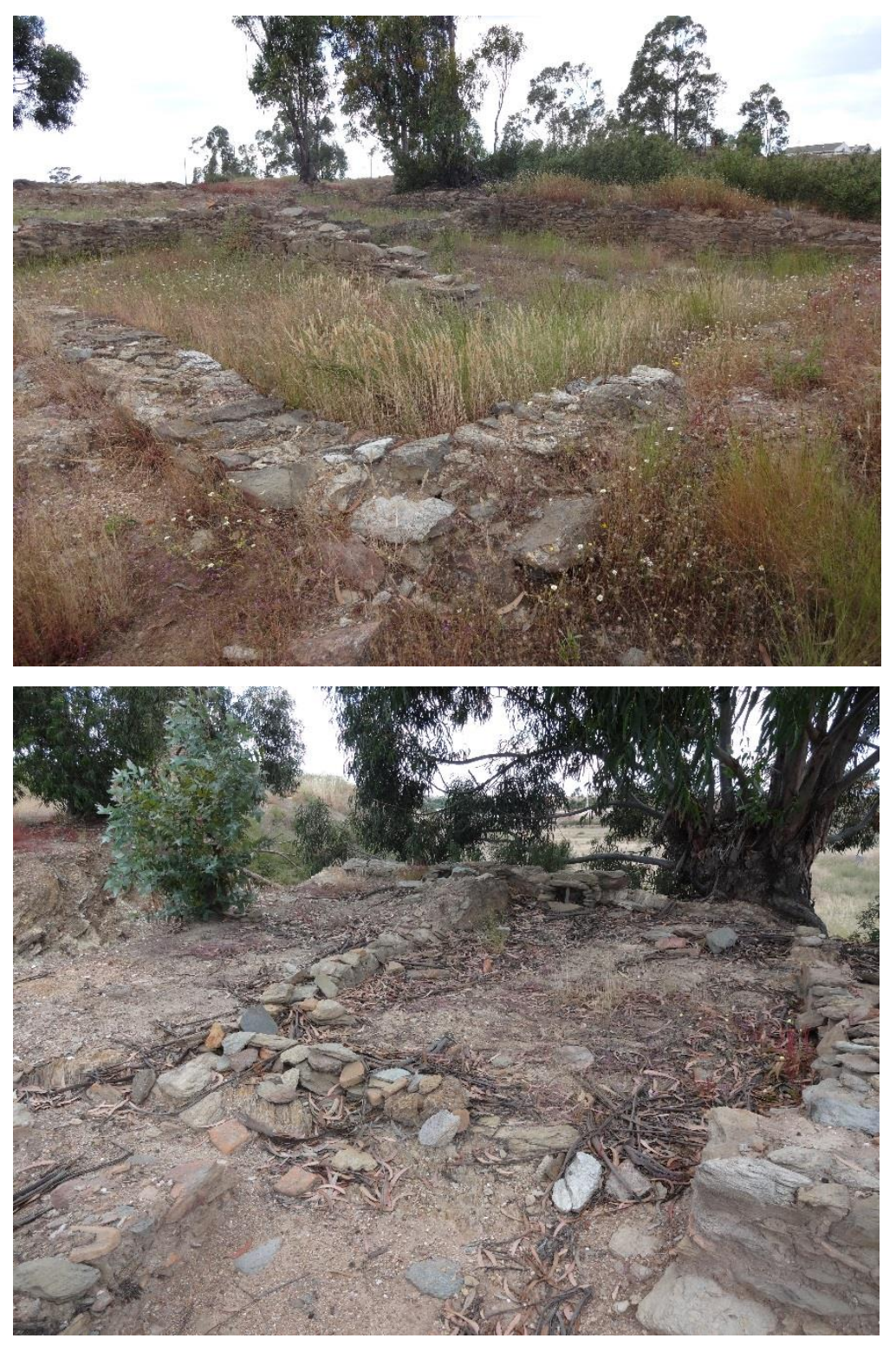

Fig. 27 - Vistas da Casa do Procurador I. Acervo pessoal, 2013.

\section{LAVARIA PILOTO}

As escavações na região da Lavaria Piloto de Aljustrel trouxeram à luz estruturas romanas aparentemente organizadas em núcleos independentes, semelhantes às insulae tipo de habitação popular bastante comum entre os romanos, consistindo em um edifício de vários andares com divisões internas nas quais moravam famílias de plebeus. As estruturas encontradas apontam para técnicas construtivas de alvenaria, com pedras mal aparelhadas, e, de acordo com o espólio achado, que teria uma cronologia entre os séculos II e III d.C., embora seja bem provável que a data chegue aos séculos I e IV d.C. 
Em uma das áreas escavadas, foi encontrada uma casa romana que difere do padrão atrium-tablinum-peristylum, possuindo apenas um pequeno átrio descentrado. Em outro local, foi escavado um conjunto de compartimentos de planta retangular ortogonalmente organizados, contudo, não é possível afirmar, com base nos vestígios, a funcionalidade desses cubículos, ou até mesmo delimitar unidades familiares. De acordo com o padrão da planta, provavelmente estamos diante de uma insula.

De acordo com a análise das cerâmicas encontradas na região de escavação, podese dizer que a cronologia da Lavaria Piloto é comparável à da Casa do Procurador. Dentre as cerâmicas comuns, destacam-se as panelas e caçarolas (que poderiam ser utilizadas tanto como utensílio de cozinha, bem como recipiente funerário); também foram recolhidos pratos, jarros, dollia, pesos de tear e taças. Também estão entre o espólio sigillatas itálicas, hispânicas, do sul da Gália e africanas, além de ânforas dos períodos alto e baixo imperiais. Diferentemente da Casa do Procurador, a área da Lavaria Piloto, de acordo com os vestígios encontrados (mais comuns), seria habitada por um operariado com escasso poder de compra (PÉREZ MACÍAS et al. 2013: 258-266).

\section{MORRO DE ALGARES}

As escavações em Algares foram primeiramente realizadas em duas etapas, ambas sob a coordenação do arqueólogo Claude Domergue. Em 1967, foi realizada uma sondagem de $3 \mathrm{~m}$ por $3 \mathrm{~m}$; já em 1969, foi aberta uma vala de $13 \mathrm{~m}$ de comprimento por $2 \mathrm{~m}$ de largura.

A partir destes dois cortes é descrita uma estratigrafia constituída por: um estrato habitacional da segunda metade do século I d.C., presente tanto na sondagem de 1967 como na trincheira de 1969, com cerâmicas sigillatas itálicas, hispânicas e do sul da Gália, fragmentos de lucernas e minério de cobre (malaquita); uma segunda ocupação da segunda metade do século III, apenas presente na trincheira de 69 com: sigillata africana D, dois Antoninianos e minério de cobre (malaquita). (PÉREZ MACÍAS et al. 2013: 278)

No entanto, faltam mais escavações no local para estabelecer completamente as plantas das estruturas e compreender algumas de suas funcionalidades. 


\section{MORRO DE MANGANCHA}

Localizado sobre um cerro de vertentes pronunciadas coroado por um afloramento de jaspes manganíferos, o sítio de Mangancha, a princípio, não teria relação alguma com a mineração das massas de Aljustrel (que pertencem ao conjunto do povoado da Casa do Procurador, Lavaria Piloto, necrópole de Valdoca, e da oficina metalúrgica e os escoriais de Azinhal). Sua localização, de difícil acesso, no território da região aponta para características de defesa de Vipasca.

Sondagens iniciais evidenciaram cerâmicas manuais e vestígios de estruturas habitacionais que foram datados entre os séculos X e VI a.C., dando a Mangancha, nessa etapa anterior, a característica de um castro, ocupado desde época proto-histórica até o período republicano romano. Esse castro foi, então, sobreposto por estrutura romana (a qual, até o momento, não é possível afirmar se estava muralhada ou não). Entretanto, com as pesquisas desenvolvidas pelo Projecto Vipasca na região a partir de 2007, fica claro que não houve, com base na análise de evidências artefatuais, continuidade de ocupação, como se pensava até então.

O período proto-histórico de Mangancha foi dedicado à mineração e metalurgia do cobre (como mostram os inúmeros fragmentos de malaquita), bem como cerâmicas manuais e potes de origem fenícia. A inexistência de escórias entre os vestígios não significa que a economia não fosse baseada na metalurgia: na proto-história, a redução do minério se dava em vasilhas-forno, deixando poucas escórias, a maioria de tamanho reduzido (difíceis de detectar). No século I d.C., a partir de Augusto, a ocupação romana na região se intensificou, como mostram as sigillatas itálicas e ânforas das formas Haltern 70 e Oberaden 83, porém, deve-se destacar o fato de ter sido encontrado um fragmento de cerâmica campaniense (possivelmente um prato de fundo plano ou uma tigela côncava) do tipo Lamboglia 5 ou 8e, fazendo com que a data inicial de ocupação possa ter ocorrido entre meados do século II a início do século I a.C. Segundo os pesquisadores do Projecto Vipasca, o Morro de Mangancha teria funcionado, em época romana, como um acampamento militar (castellum):

Os trabalhos de investigação nas regiões mineiras do sudoeste levaram a concluir que, no período de Augusto, foi levado a cabo um intenso programa de exploração mineira das massas polimetálicas da Faixa Piritosa Ibérica e nas massas filonianas da Faixa Piritosa e de Ossa Morena. Estes trabalhos pressupunham a descoberta das 
potencialidades mineiras da região e o arranque da sua exploração, após o esgotamento pelas societas republicanas, dos coutos mineiros de Múrcia, Córdoba e Jaén, transferindo para o sudoeste a exploração dos coutos mineiros, onde a produção de cobre e prata irá sendo incrementada, como podemos constatar nas estratigrafias horizontais e verticais dos escoriais, até alcançar o pico máximo nas épocas Flávia e Antonina. A política de Augusto foi o momento de partida que permitiu o arranque da economia mineira nesta região. No período tardorepublicano não foi possível uma verdadeira colonização devido à instabilidade da própria conquista, com as insurreições contínuas dos lusitanos e os problemas de conflitos civis, com relevância para o episódio Sertoriano. Por outro lado, na segunda metade do século I a.C., um dos problemas endêmicos da Serra Morena era a insegurança que se verificava nos caminhos perante os ataques de bandidos e ladrões, muito ativos em finais do século I a.C., de acordo com a correspondência entre Anisio Polião e Cícero (Cícero, Ad Fam., 10, 31, 1). No ano 45 a.C., durante a última fase da guerra civil Hispânica, é referido que, devido às frequentes incursões dos bárbaros (lusitanos), todos os povoados que se encontravam afastados dos centros urbanos estavam protegidos por torres e fortins (Bellum Hispaniense, 8, 3). Augusto irá dar início a uma nova política policial para acabar com estes problemas, já que, segundo Suetônio, reprimiu os assaltos nos caminhos, estabelecendo uma rede de postos militares em locais estratégicos (De vita Caesarum, II, 32). Estas fortificações seriam mais abundantes em regiões com recursos mineiros que começavam a ter importância econômica, como nos demonstram os vestígios arqueológicos. (PÉREZ MACÍAS et al. 2013: 285-286)

Ainda carecemos de um estudo que possa verificar a relação entre os castella e as minas da região sudoeste da Península Ibérica, mas provavelmente suas construções significativamente próximas aos locais de extração de minérios sejam indícios de que houve, de fato, a edificação dos castella como meio de proteção das minas. Contudo, essa militarização das zonas mineras do sudoeste termina com a administração de Cláudio, tornando Mangancha algo representativo do primeiro impulso de mineração no território, até meados do século I d.C. A pergunta a que ainda não conseguimos responder atualmente é: para onde se transferiu o aquartelamento militar depois do abandono de 
Mangancha? Sabemos, porém, por meio das Tábuas de Bronze de Aljustrel (ou Tábuas de Vipasca), que havia soldados no vicus.

\section{NECRÓPOLES DE VALDOCA E DE FARROBO}

A necrópole do bairro de Valdoca (ou Val D'Oca) foi descoberta quando mais casas foram construídas para abrigar os operários das minas de Aljustrel. Em meados da década de 1950 tiveram início as primeiras intervenções no local, trazendo à luz 496 sepulturas romanas de fossas retangulares, cobertas com lajes de xisto ou pedras de tamanho diverso. A necrópole contava com sepultamentos de inumação e incineração, sendo estas as que fornecem maior número de espólio, enquanto as sepulturas de inumação eram maiores e não possuíam espólios ou ossos (devido à forte acidez dos solos).

Predominam as sepulturas de incineração (65\%) sobre as de inumação (35\%). Dentre as sepulturas sem espólio, $86 \%$ são de inumação e $37 \%$ de incineração. As sepulturas com apenas uma peça representam 12\% de inumação e 19\% de incineração. Já as sepulturas com mais de uma peça, contabilizam 2\% de inumação e $44 \%$ de incineração. O estudo completo dos materiais recolhidos aponta para uma cronologia que vai desde a época de Augusto/Tibério (devido às cerâmicas sigillatas itálicas), até à segunda metade do século III d.C. (por meio das sigillatas africanas). Destaca-se, também, a presença de lamparinas (lucernas) da figlina (assinatura de pertencimento) de L.I.R. nas sepulturas 118 e 353, relacionadas ao oleiro lisboeta Lvcivs Ivlivs Rebvrrinvs (cuja sepultura foi encontrada na necrópole de La Dehesa, em Riotinto, Espanha) (PÉREZ MACÍAS et al. 2013: 43-44).

A necrópole do Monte do Farrobo, por sua vez, é formada por 36 sepulturas de incineração e 2 de inumação. Na sepultura de número 20 foi encontrada uma lamparina com disco decorado do século II d.C. (Dressel 28, margo com decoração fitomórfica, discus ornamentado com a representação mitológica de um tritão, duplo orificia de alimentação), uma taça de cerâmica vidrada tipo alcachofra (kantharoi invietrato, variante da forma López Millor IIIb, de época Flávia), sigillata africana C (Hayes 42, de meados do século III d.C.) e diversos recipientes de vidro, entre eles, uma taça com inscrição a ouro no fundo com a epígrafe DVLCIS VIVAS. Na necrópole de Farrobo foi 
recolhida também a inscrição de Valério Rufo (atualmente exposta no Museu de Aljustrel) (PÉREZ MACÍAS et al. 2013: 45-46).

\section{OFICINA METALÚRGICA DE AZINHAL E ESCORIAIS}

A officina de Azinhal foi descoberta acidentalmente, quando o maquinário da empresa mineradora local trouxe à luz vestígios de muros que estavam sob uma camada de escórias romanas. As campanhas realizadas pelo Projecto Vipasca no local da oficina centraram-se na limpeza superficial dos topos dos muros e na escavação da continuidade desses muros, sem ainda intervencionar pormenorizadamente cada parte da estrutura. Devido ao tamanho do edifício, não temos, até o momento, a sua planta geral, pois a cada campanha uma nova área é encontrada. Porém, já se pode afirmar que a oficina de Azinhal é um edifício industrial de tratamento de minério de cobre que se insere no esquema produtivo deste minério em época romana. Em Azinhal, também foram encontrados, próximos aos tanques de lixiviação, restos de outros muros sob as escórias que, provavelmente, pertencem a outras oficinas semelhantes à escavada. No entanto, é correto afirmar que a officina de Azinhal

constitui um caso único de instalação minero-metalúrgica de época romana, cujo estado de conservação e os paralelos com edifícios hispânicos de tipologia semelhante, nos abrem fundadas expectativas sobre os procedimentos efetuados em época romana no processamento dos sulfetos. (PÉREZ MACÍAS et al. 2013: 298)

As intervenções anteriores, realizadas pela Universidade de Toulouse, identificaram o carvão utilizado para a queima dos minérios de cobre como sendo do gênero Quercus, provavelmente azinheira (Quercus Ilex), árvore que está presente na região ainda hoje. Não foram encontradas amostras do minério nem indícios de sua procedência exata, porém, a análise das escórias aponta para a utilização de sulfetos de cobre-fero (calcopirita) e sulfetos de ferro com teores de cobre (pirita), supondo, então, a existência de uma officina de dessulfuração (necessária para a redução dos minérios), a qual se apresenta muito semelhante às instalações de queima desenhadas por Georgius Agricola no século XVI. De acordo com a área escavada, o combustível necessário para a calcinação ficaria em um compartimento coberto, enquanto a queima ocorreria no compartimento adjunto, aberto. O espólio recolhido no local pela equipe de Toulouse, 
estabelece uma cronologia que vai desde o início do século I d.C. (sigillata do sul da Gália Drag. 24/25, 29, 30 e 37), até o seu abandono no começo do século II, sendo coberto por escórias durante os séculos II e III (PÉREZ MACÍAS et al. 2013: 300).

O Projecto Vipasca, por sua vez, iniciou seus trabalhos no local com a limpeza dos muros expostos e a definição dos limites do edifício (que ainda está sendo delimitado). A limpeza superficial individualizou 15 unidades construtivas, formando 8 ambientes construídos. Até o momento, os limites externos do edifício possuem dimensões superiores a 25 metros no comprimento e 20 metros de largura (continuando para além da área intervencionada). Segue abaixo o resumo das unidades estratigráficas (U.E.) apresentadas pelo projeto (PÉREZ MACÍAS et al. 2013: 301-311).

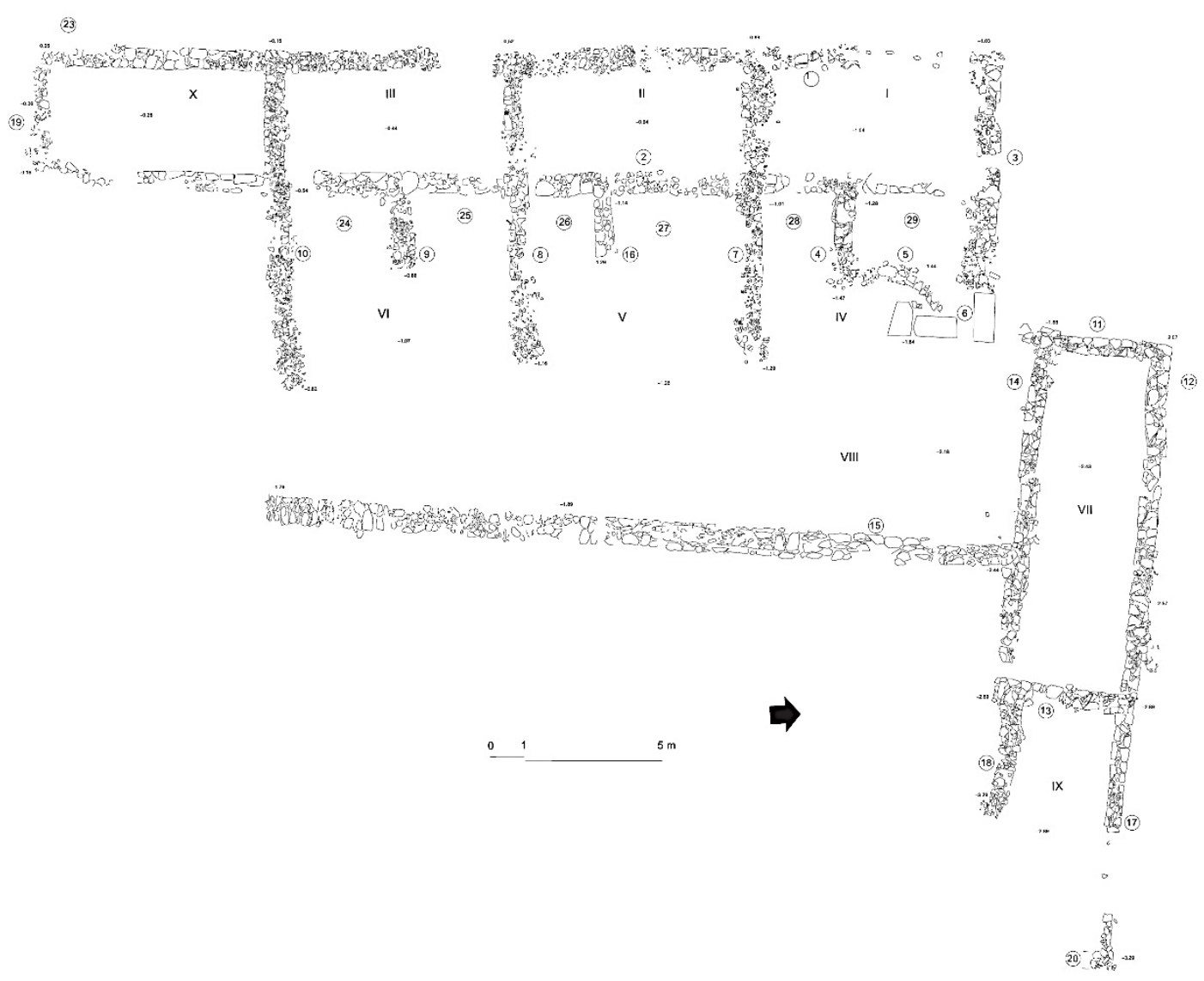

Fig. 28 - Planta da área escavada da oficina metalúrgica de Azinhal. Imagem cedida por Artur Martins. 


\begin{tabular}{|c|c|c|c|}
\hline U.E. & Tipo de Unidade & Descrição & Dimensões \\
\hline 1 & Construtiva & $\begin{array}{l}\text { Muro de alvenaria de lajes de xisto que forma um dos muros principais da } \\
\text { oficina. Percorrendo um dos lados da estrutura em sua totalidade, forma vários } \\
\text { compartimentos (I, II, III e X). Seu comprimento provavelmente se estende para } \\
\text { além da área intervencionada. }\end{array}$ & $\begin{array}{l}23 m \text { - comprimento } \\
0,45 m \text { - largura }\end{array}$ \\
\hline 2 & Construtiva & Muro de lajes de xisto paralelo à U.E. anterior. & $\begin{array}{l}23 m \text { - comprimento } \\
0,45 m \text { - largura }\end{array}$ \\
\hline 3 & Construtiva & $\begin{array}{l}\text { Pequeno muro de lajes de xisto cujo percurso não se encontra completamente } \\
\text { delimitado. }\end{array}$ & $\begin{array}{l}7 m \text { - comprimento } \\
0,45 m \text { - largura }\end{array}$ \\
\hline 4 & Construtiva & $\begin{array}{l}\text { Pequeno muro de lajes de xisto que forma uma divisão interna, perpendicular à } \\
\text { U.E. } 2 \text { e que serve de divisão do compartimento IV em dois compartimentos } \\
\text { menores. }\end{array}$ & $\begin{array}{l}3 m \text { - comprimento } \\
0,45 m \text { - largura }\end{array}$ \\
\hline 5 & Construtiva & $\begin{array}{l}\text { Pequena estrutura de lajes de xisto de forma semicircular. As pedras que a } \\
\text { compõem estão queimadas devido às altas temperaturas. A forma semicircular e } \\
\text { a ação do fogo identificam essa estrutura como sendo um forno, porém, por ser } \\
\text { cortada pelos muros da U.E. 4, também pode representar um primeiro momento } \\
\text { de uso desta zona em que o minério era calcinado em fornos de planta circular. }\end{array}$ & $\begin{array}{l}0,48 m \text { - largura } \\
4 m \text { - arco do círculo }\end{array}$ \\
\hline 6 & Construtiva & $\begin{array}{l}\text { Estrutura composta por três grandes blocos de xisto que rematam a U.E. } 3 \text { e } \\
\text { fecham o compartimento formado pelas U.E. } 2,3 \text { e } 4 \text {. }\end{array}$ & $\begin{array}{l}\text { Dimensões dos blocos: } \\
1,20 \mathrm{~m} \text { - comprimento } \\
0,45 \mathrm{~m} \text { - largura }\end{array}$ \\
\hline 7 & Construtiva & $\begin{array}{l}\text { Muro de alvenaria de xisto, perpendicular às U.E. 1 e 2, e paraela à U.E. 3, } \\
\text { formando com elas dois espaços diferenciados, o compartimento I le o } \\
\text { compartimento IV (sendo este dividido em duas áreas pela U.E. 4) }\end{array}$ & $\begin{array}{l}7 m \text { - comprimento } \\
0,45 m \text { - largura }\end{array}$ \\
\hline 8 & Construtiva & $\begin{array}{l}\text { Muro de alvenaria de lajes xisto. Tal como a U.E. 7, serve para compartimentar o } \\
\text { espaço interior da oficina. }\end{array}$ & $\begin{array}{l}7 m \text { - comprimento } \\
0,45 m \text { - largura }\end{array}$ \\
\hline 9 & Construtiva & Muro de alvenaria de lajes de xisto. & $\begin{array}{l}2,5 m \text { - comprimento } \\
0,45 m \text { - largura }\end{array}$ \\
\hline 10 & Construtiva & $\begin{array}{l}\text { Muro de alvenaria de lajes de xisto. Perpendicular às U.E. } 1 \text { e } 2 \text {, delimita com a } \\
\text { primeira o compartimento III e com a segunda o compartimento VI. }\end{array}$ & $\begin{array}{l}9 \mathrm{~m} \text { - comprimento } \\
0,45 \mathrm{~m} \text { - largura }\end{array}$ \\
\hline 11 & Construtiva & Muro de alvenaria de lajes de xisto. & $\begin{array}{l}\text { 3,5 - comprimento } \\
0,45 \mathrm{~m} \text { - largura }\end{array}$ \\
\hline 12 & Construtiva & $\begin{array}{l}\text { Muro de alvenaria de lajes de xisto que forma um dos lados maiores do } \\
\text { compartimento VII. Muro bem aparelhado que parece marcar um dos limites } \\
\text { externos do edifício. }\end{array}$ & $\begin{array}{l}10,5 m \text { - comprimento } \\
0,45 m \text { - largura }\end{array}$ \\
\hline 13 & Construtiva & $\begin{array}{l}\text { Muro de alvenaria de xisto em conexão estratigráfica com as unidades U.E. } 11,12 \\
\text { e } 14 \text {, formando o compartimento VII. }\end{array}$ & $\begin{array}{l}3,5 m \text { - comprimento } \\
0,45 m \text { - largura }\end{array}$ \\
\hline 14 & Construtiva & $\begin{array}{l}\text { Muro de alvenaria de xisto que representa um dos lados maiores que } \\
\text { constituem o compartimento VII. }\end{array}$ & $\begin{array}{l}\text { 10,5 - comprimento } \\
0,45 \mathrm{~m} \text { - largura }\end{array}$ \\
\hline 15 & Construtiva & $\begin{array}{l}\text { Embasamento de um uro de alvenaria de lajes de xisto que percorre toda a } \\
\text { estrutura em paralelo com as U.E. } 1 \text { e } 2 \text {. }\end{array}$ & $\begin{array}{l}23 m \text { - comprimento } \\
1 \mathrm{~m} \text { - largura }\end{array}$ \\
\hline 16 & Construtiva & Muro de alvenaria de xisto parcialmente limpo. & $\begin{array}{l}2,5 m \text { - comprimento } \\
0,45 m \text { - largura }\end{array}$ \\
\hline 17 & Construtiva & Muro de lajes de xisto que não se conserva em todo o seu comprimento. & $\begin{array}{l}10,5 m \text { - comprimento } \\
0,4 m \text { - largura }\end{array}$ \\
\hline 18 & Construtiva & $\begin{array}{l}\text { Fundações de um muro que teve suas alvenarias muito deslocadas por pressão } \\
\text { das terras. }\end{array}$ & $\begin{array}{l}\text { 6,10m - comprimento } \\
0,80 \mathrm{~m} \text { - largura }\end{array}$ \\
\hline 19 & Construtiva & $\begin{array}{l}\text { Muro de lajes de xisto muito destruído. Juntamente com as U.E. 1, } 2 \text { e 10, fecha o } \\
\text { compartimento X (que está na continuidade dos compartimentos I, II e III). }\end{array}$ & $0,45 m$ - largura \\
\hline 20 & Construtiva & $\begin{array}{l}\text { Arranque de muro de alvenaria com lajes de xisto que forma um dos lados } \\
\text { menores do compartimento IX. }\end{array}$ & $\begin{array}{l}0,30 m \text { - comprimento } \\
0,45 m \text { - largura }\end{array}$ \\
\hline 21 & Sedimentar & $\begin{array}{l}\text { Terras finas e compactas de tonalidade avermelhada.Pavimento do } \\
\text { compartimento X, no espaço formado pelas U.E. 1, 2, 10 e 19. Destaca-se o } \\
\text { recolhimento de tégulas e ímbrices, além de uma asa de ânfora de tipo lusitano } \\
\text { Dressel 14. Os vestígios podem indicar que o compartimento X teria cobertura } \\
\text { (do mesmo modo que os compartimentos I, II e III). A cor avermelhada é a } \\
\text { mesma encontrada no chapéu de ferro de Algares, indicando que as terras } \\
\text { possam ter sido finamente trituradas para se buscar minério de prata (contudo, a } \\
\text { ausência de concentrações rentáveis de prata na terra terá levado ao seu } \\
\text { aproveitamento como argila em construções industriais). A coloração das terras } \\
\text { de outros compartimentos varia do amarelo ao avermelhado (com brancos e } \\
\text { cinzentos), indicando a presença da queima de minérios (juntamente com os } \\
\text { vestígios de carvão). }\end{array}$ & $\begin{array}{l}\text { Ocupa toda a } \\
\text { superfície do } \\
\text { compartimento } X\end{array}$ \\
\hline 22 & Sedimentar & $\begin{array}{l}\text { Terras compactadas de tonalidades acinzentadas, com carvões abundantes no } \\
\text { compartimento } X \text {. }\end{array}$ & $\begin{array}{l}\text { Ocupa uniformemente } \\
\text { todo o compartimento } \\
\mathrm{X}\end{array}$ \\
\hline 23 & Sedimentar & Capa de escórias que cobria os muros e preenchimentos do compartimento $\mathrm{X}$. & $\begin{array}{l}\text { Estende-se por todas } \\
\text { as áreas não escavadas } \\
\text { da oficina }\end{array}$ \\
\hline 24 & Sedimentar & $\begin{array}{l}\text { Nível de escórias e alvenarias que preenchem o compartimento VI sobre o } \\
\text { pavimento de terra batida, entre as U.E. 2, 9e 10. Não há vestígios de queima. }\end{array}$ & $\begin{array}{l}\text { Não é possível } \\
\text { determinar as } \\
\text { dimensões }\end{array}$ \\
\hline 25 & Sedimentar & $\begin{array}{l}\text { Terras proveninetes da queima de sulfetos que preenchem o compartimento } \mathrm{VI} \\
\text { entre as U.E. } 2,8 \text { e } 9 \text {. }\end{array}$ & $\begin{array}{l}\text { Ocupa a superfície do } \\
\text { compartimento VI }\end{array}$ \\
\hline 26 & Sedimentar & Terras que preenchem o compartimento $\mathrm{V}$, entre as U.E. 2, 8 e 16. & $\begin{array}{l}\text { Ocupa a superfície do } \\
\text { compartimento } V\end{array}$ \\
\hline 27 & Sedimentar & $\begin{array}{l}\text { Nível de escórias e pedras que preenchem o compartimento V, entre as U.E. 2, } 7 \\
\text { e } 16 .\end{array}$ & $\begin{array}{l}\text { Ocupa a superfície do } \\
\text { compartimento } V\end{array}$ \\
\hline 28 & Sedimentar & $\begin{array}{l}\text { Nível de terra batida avermelhada que constitui o pavimento do compartimento } \\
\text { IV, entre as U.E. } 2,4 \text { e } 7 \text {. }\end{array}$ & $\begin{array}{l}\text { Ocupa a superfície do } \\
\text { compartimento IV }\end{array}$ \\
\hline 29 & Sedimentar & Resíduos provenientes da queima de sulfetos, entre as U.E. 2, 3 e 4. & $\begin{array}{l}\text { Ocupa a superfície do } \\
\text { compartimento } \\
\text { formado pelas U.E. } 2,3 \\
\text { e } 4\end{array}$ \\
\hline
\end{tabular}


Mesmo com as unidades estratigráficas estabelecidas pelos pesquisadores do Projecto Vipasca, não é possível afirmar que houve uma construção por fases. Tampouco, a cronologia proposta pelos investigadores da Universidade de Toulouse pode ser levada em consideração sem ressalvas: todo o material cerâmico recolhido por eles foi encontrado fora do contexto dos compartimentos, não evidenciando claramente uma suposta fase de abandono e ruína no fim do século I d.C. (embora possa ter ocorrido em algum momento do século II d.C.). Provavelmente, Azinhal seria uma área de queima desde os primórdios da exploração romana em Aljustrel, tendo, num primeiro momento, a queima sido efetuada em fornos circulares e, num segundo momento, tendo sido construída a oficina. A técnica construtiva empregada, por sua vez, corresponde a momentos pré-Flávios, da primeira metade do século I d.C.

De acordo com as campanhas arqueológicas já empreendidas, é possível estabelecer algumas conclusões preliminares (PÉREZ MACÍAS et al. 2013: 313):

Primeiro, sobre a acumulação estratigráfica em que se sucedem três fases: uma inicial, de queima de fornos em forma circular; outra é de estarmos perante um edifício destinado à queima, em espaços quadrangulares, com armazenamento de resíduos; finalmente, que o local foi utilizado como escombreira, depois do abandono do edifício, sepultando por completo seus vestígios. Como referimos, as tégulas e ímbrices permitem-nos concluir que se trata de uma officina aeraria romana, mas não há nada que nos permita distinguir a cronologia de cada uma das fases de ocupação.

Continuam os autores (PÉREZ MACÍAS et al. 2013: 313-314):

Essas falhas não são um obstáculo a que possamos caracterizar o edifício como um complexo para tratamento e concentração de minério de cobre, com uma extensão superior a 25 metros de comprimento e 20 metros de largura. Na planta do que conhecemos podemos distinguir três zonas, uma retangular de que ainda não conhecemos as suas dimensões exatas, tendo na sua face sul, uma das que têm maiores dimensões, duas linhas divisórias, uma formada por salas retangulares cobertas, os compartimentos I, II, III e X, onde estão adossados outros habitáculos abertos na face sul e sem cobertura, os compartimentos IV, V e VI que, por sua vez, se encontram parcialmente divididos por muros mais curtos, as U.E. 4, 16 e 9. A comunicação entre os espaços cobertos 
e descobertos faz-se por um pequeno vão com cerca de $0,60 \mathrm{~m}$ de largura. Em todos esses espaços abertos com muros curtos, um dos compartimentos assim formados possui cinzas de pirita e o outro, sem este tipo de terras, serviria como acesso aos espaços fechados. Segundo esta hipótese, um desses espaços (espaço aberto) seria utilizado para a queima enquanto o outro serviria para proceder à seleção do minério triturado que, por sua vez, transitaria para o espaço coberto e fechado impedindo assim a ação das águas da chuva que poderiam alterar sua composição. $\mathrm{O}$ centro deste setor do edifício parece ser formado por uma área aberta, o espaço VIII, onde poderão ter sido levados a cabo trabalho de queima de minério ao ar livre, embora esta hipótese careça de confirmação completa da área em causa.

A localização da oficina, por sua vez, pode dar sinais de preocupação por parte dos romanos com a saúde e segurança do povoado de Vipasca. A queima de minérios de cobre libera na atmosfera dióxido de enxofre que contém, entre seus metais pesados, o arsênico. Variando de acordo com as condições meteorológicas, as fumaças da queima de enxofre ficavam ao nível do solo, provocando sérios problemas de saúde aos que estão em contato. $\mathrm{O}$ afastamento da área da queima (oficina) da região da Casa do Procurador e do povoado da Lavaria Piloto era um modo de assegurar o bem-estar dos moradores do vicus. Porém, mesmo com esse distanciamento entre povoado e complexo minerador, muito provavelmente as condições de vida em Vipasca não seriam as melhores em questões de salubridade (PÉREZ MACÍAS et al. 2013: 329-330). 


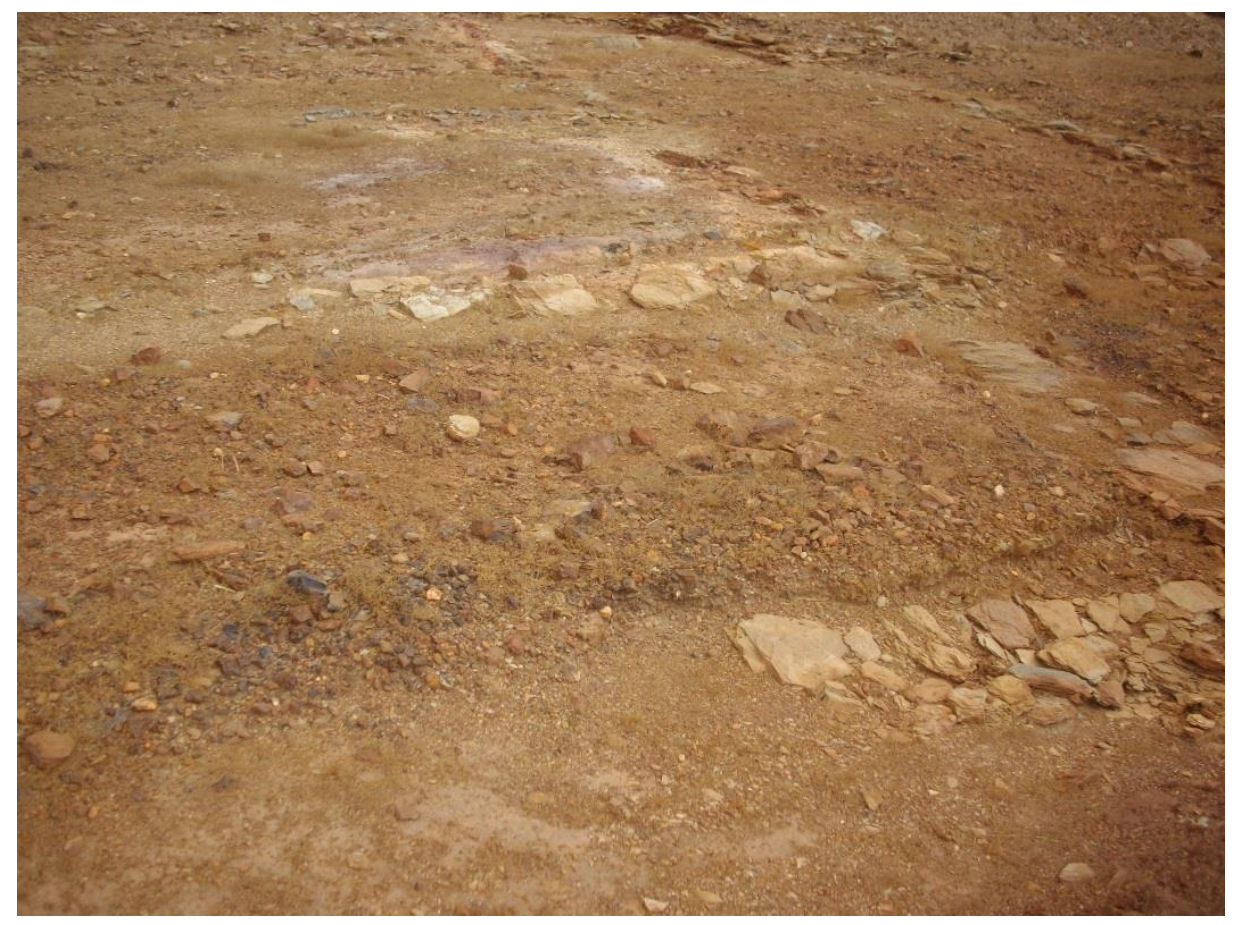

Fig. 29 - Detalhe de um dos compartimentos de queima da oficina em Azinhal. Acervo pessoal, 2010.

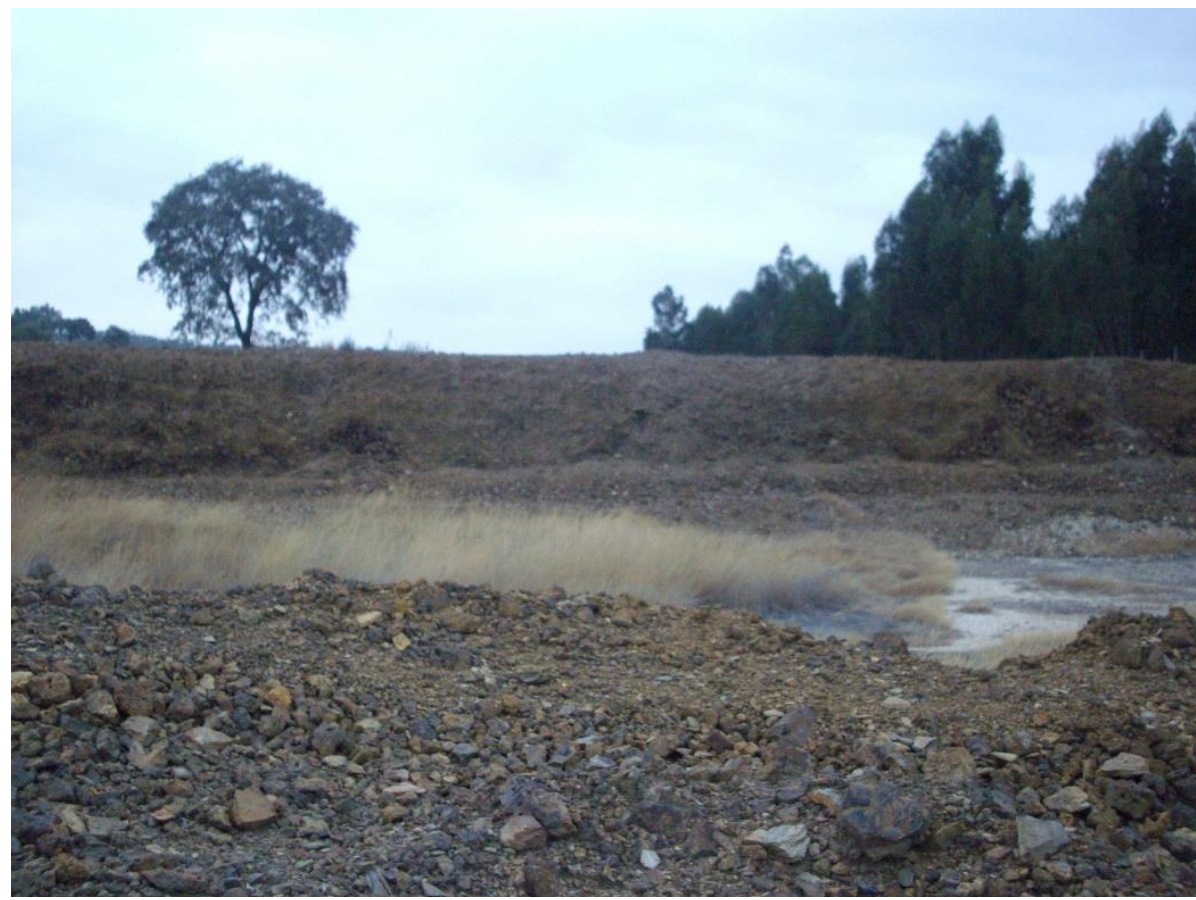

Fig. 30 - Escorial em Azinhal. Acervo pessoal, 2010. 
O escorial romano em Aljustrel foi primeiramente analisado por L. V. Salkield em seu artigo "Ancients slags in the South West of Iberian Peninsula", publicado em 1970. Segundo seu estudo, existem dois tipos de escórias romanas na região sudoeste da península: as que possuem em sua composição valores de cobre superiores a $0,50 \%$ são consideradas escórias relacionadas com a produção de cobre; as com valores de cobre abaixo de $0,50 \%$ e chumbo acima de $0,50 \%$ estão relacionadas com a produção de prata. Aljustrel, de acordo com a análise de Salkield, seria produtora de cobre apenas (até então, os estudiosos achavam que os romanos também produziam prata na região, por pertencer ao mesmo cinturão pirítico que as minas da Espanha, por exemplo, de Riotinto).

Por meio de análise por fluorescência de raios $\mathrm{x}$ e varreduras pontuais de microscopia eletrônica, as amostras de escórias recolhidas pelo Projecto Vipasca na área da oficina em Azinhal mostram o seguinte resultado de composição (em porcentagem) (PÉREZ MACÍAS et al. 2011: 4):

\begin{tabular}{|c|c|c|c|c|c|c|c|c|c|c|c|c|}
\hline $\mathbf{N a}$ & $\mathbf{M g}$ & $\mathbf{A l}$ & $\mathbf{S i O}_{2}$ & $\mathbf{S}$ & $\mathbf{K}$ & $\mathbf{C a}$ & $\mathbf{T i}$ & $\mathbf{M n}$ & $\mathbf{F e}$ & $\mathbf{C u}$ & $\mathbf{Z n}$ & $\mathbf{P b}$ \\
\hline 1,09 & 0,62 & 9,48 & 31,3 & 1,21 & 1,67 & 1,42 & 0,34 & 0,11 & 51,6 & 0,55 & 0,63 & 0,29 \\
\hline
\end{tabular}

Apesar de conter chumbo em sua composição, a quantidade encontrada nas amostras não é suficiente para classificá-las como escórias de prata: por situar-se abaixo de $0,50 \% \mathrm{~Pb}$, não há índice mínimo para o chumbo ter eficácia como coletor de minério de prata. Contudo, provavelmente também haveria produção de chumbo em Aljustrel, uma vez que foram encontrados lingotes desse metal na região relacionados com sepultamentos na necrópole do Farrobo (a cerca de $3 \mathrm{~km}$ de Aljustrel): em uma das lápides está escrito: M(arco) VALERIO/RVFO. VIRO/M(arco). VALERIO/MARCELLO. F(ilio)/M(arco). VALERIO/MARCELLO. NEP(oti)/AGRIA RVFINA/F(aciendum) C(uravit)/H(ic). S(iti). S(unt). V(obis). T(erra). L(evis) (PÉREZ MACÍAS et al. 2011: 6) - os nomes estão ligados à gens Valeria, sendo a onomástica comum na região e em outras áreas de distritos mineiros ao longo do sudoeste ibérico. Além disso, foi encontrada em uma das sepulturas de Farrobo uma taça de cerâmica vitrificada de cor verde: que era obtida pela fusão do silicato de chumbo com o cobre, os dois materiais explorados em Vipasca.

Embora autores como Claude Domergue acreditem que o termo scauriae (escórias) que aparece nas Tábuas de Bronze de Aljustrel se refira ao reaproveitamento 
de escórias de épocas anteriores à romana para a obtenção de cobre, recentemente essa ideia tem sido debatida (PÉREZ MACÍAS et al. 2011: 7). Em Aljustrel não há sinais de escoriais pré-romanos de prata e de cobre, além de o processo de redução-fundição não aparecer no tex to das Tábuas e ser ineficaz nesse caso: tentativas realizadas no século XX para o reaproveitamento de minério das escórias fracassaram. As escórias das minas do sudoeste ibérico sempre foram reaproveitadas como fundentes ao longo dos séculos, mas nunca para a recuperação de cobre a partir de fundição.

A única forma de reaproveitamento de escórias conhecida no mundo romano era a da cementação. Os escoriais de Azinhal não foram despejados de forma aleatória, eles formam uma estrutura semelhante ao xadrez, gerando tanques.

Este método consistia em regar o minério de baixo teor, previamente calcinado ao ar livre, com água ácida proveniente da mina; a água lixiviava o cobre, fazendo-o precipitar nos tanques onde se encontrava sucata de ferro, produzindo-se uma reação química que libertava o cobre (cáscara) enquanto o ferro, com algum cobre, se depositava no fundo dos tanques. Este método, conhecido como Cementação Artificial, permitia um melhor aproveitamento do minério marginal de cobre, de baixo teor, para tratá-los diretamente por redução. Anteriormente, o aproveitamento do cobre dissolvido nas águas provenientes da mina era feito por Cementação Natural, recolhendo-se o cobre que se precipitava e cementava nestes canais (PÉREZ MACÍAS et al. 2011: 8).

O cobre obtido por cementação natural tornava-se, assim, mais puro.

Terminados os apontamentos arqueológicos sobre Vipasca, é hora de nos debruçarmos sobre a produção do aplicativo ciberarqueológico interativo denominado Vipasca Antiga ${ }^{22}$.

\footnotetext{
22 Para baixar, acesse: www.vipasca.com
} 


\section{RESUMO - A VIPASCA ARQUEOLÓGICA}

Para os mais puristas, este é o capítulo que, de fato, faz jus a uma pesquisa arqueológica (ao invés de computação/engenharia/fillosofia). Como não gosto de rótulos, prefiro pensar que é um capítulo de extrema importância no conjunto geral, pois é a partir dos vestígios que elaborei o ambiente virtual tridimensional que você verá no próximo capítulo.

Começo com uma ode à Aljustrel, cidade portuguesa que mora em meu coração. Desde 2010 meus trabalhos estão ligados a ela e toda vez que a visito sinto que estou em um lugar especial, que me faz bem. Tenho grandes amigos em Aljustrel, e devo muito a eles.

Passado o momento de nostalgia, elenco as principais características geológicas de Aljustrel (a antiga cidade romana de Vipasca), atentando ao fato de que ela está localizada sobre uma faixa rica em sulfetos polimetálicos, predominando o zinco. Também menciono que a mineração na região de Aljustrel ocorre desde o III $^{\circ}$ Milênio a.C. e sob dominação se tornou a principal fonte produtora de cobre do Império.

Para fins didáticos, eu continuo o capítulo dividindo Vipasca de acordo com as áreas escavadas pelos arqueólogos. Apresento, pois, a Casa do Procurador (uma domus com espólio de luxo), a Lavaria Piloto (na qual estão vestígios de insulae romanas), o Morro de Mangancha (local de um castellum romano), as Necrópoles de Valdoca e Farrobo (com seus sepultamentos de incineração e inumação), e a Oficina de Azinhal (um conjunto de compartimentos nos quais os minérios eram triturados e queimados).

Este capítulo foi um tanto descritivo, mas é assim que a Arqueologia deve se comportar muitas vezes para que possamos, dos dados, interpretarmos o material arqueológico. Peço desculpas ao leitor por isso, mas acredito que entenda a importância de todas as tabelas que apareceram por aqui. 


\section{CAPÍtulo Vi}

\section{VIPASCA ANTIGA: RELATANDO O DESENVOLVIMENTO}

O céu sobre o porto tinha a cor de uma televisão sintonizada num canal fora do ar.

- William Gibson, Neuromancer

Então Hiro na verdade não está ali. Ele está em um universo gerado por computador que seu computador está desenhando em seus óculos e bombeando para dentro de seus fones de ouvido. Na gíria, este lugar imaginário é conhecido como o Metaverso. Hiro passa um bocado de tempo no Metaverso. Dá de mil a zero no U-Stor-It.

- Neal Stephenson, Snow Crash

\section{MODELAGEM E TEXTURIZAÇÃO}

\subsection{Terreno}

Toda a modelagem do aplicativo ciberarqueológico denominado Vipasca Antiga começou pelo item mais básico de qualquer interatividade em primeira pessoa: o chão sobre o qual pisamos, ou seja, o terreno.

Embora o terreno do Alentejo português não seja um dos mais complexos encontrados na natureza (uma vez que é formado, em sua maioria, por planícies), a geomorfologia de Aljustrel tem como característica marcante os afloramentos minerais. Isso fez com que tanto os romanos antigos como os portugueses contemporâneos se assentassem ao redor do chapéu de ferro da região, buscando nele a sua sustentação econômica. O chapéu de ferro é o principal marco na paisagem aljustrelense e, no período romano, todo o povoado conhecido como Vipasca se estabeleceu nas proximidades dele.

Quem visita Aljustrel hoje em dia irá notar que, da base do chapéu de ferro, estende-se uma colina que desce até a Ribeira (ou ribeirão) de Feitais, sendo todo esse espaço pertencente à atual empresa mineradora da região (Fig. 31). Assim sendo, temos na paisagem três importantes marcos: o chapéu de ferro no ponto mais alto, a colina e a ribeira. Essas características foram pensadas em ser destaque no aplicativo tridimensional. 


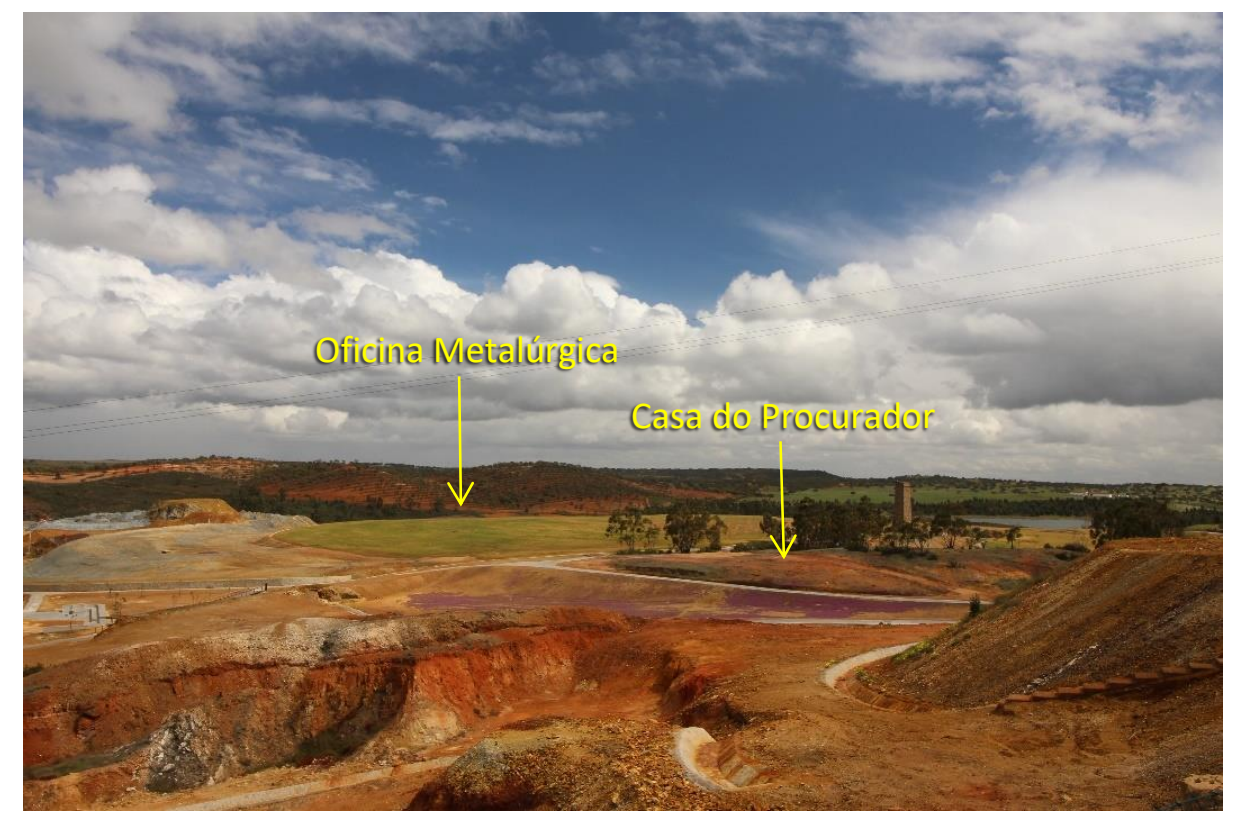

Fig. 31 - Vista da Casa do Procurador a partir da base do chapéu de ferro: notar o sentido descendente.

Desse modo, como dito, o primeiro passo de todo o processo de desenvolvimento foi a elaboração do terreno de Vipasca já dentro do motor gráfico (engine) Unity. A tentativa inicial foi a de capturar os dados geográficos a partir do mapa online Bing e gerar um arquivo 3D. Utilizou-se um asset (utilitário/ferramenta, em uma tradução livre) encontrado na loja da Unity denominado World Composer ${ }^{23}$, que permite selecionar qualquer área em um terreno do Bing e transformá-lo em objeto volumétrico. Embora a captura dos dados e sua conversão tenha sido um sucesso, o resultado final não foi satisfatório, pois a baixa resolução do modelo 3D não permitia identificar com clareza os principais marcos da paisagem mencionados (Fig. 32).

\footnotetext{
${ }^{23}$ www.assetstore.unity3d.com/en/\#!/content/13238
} 


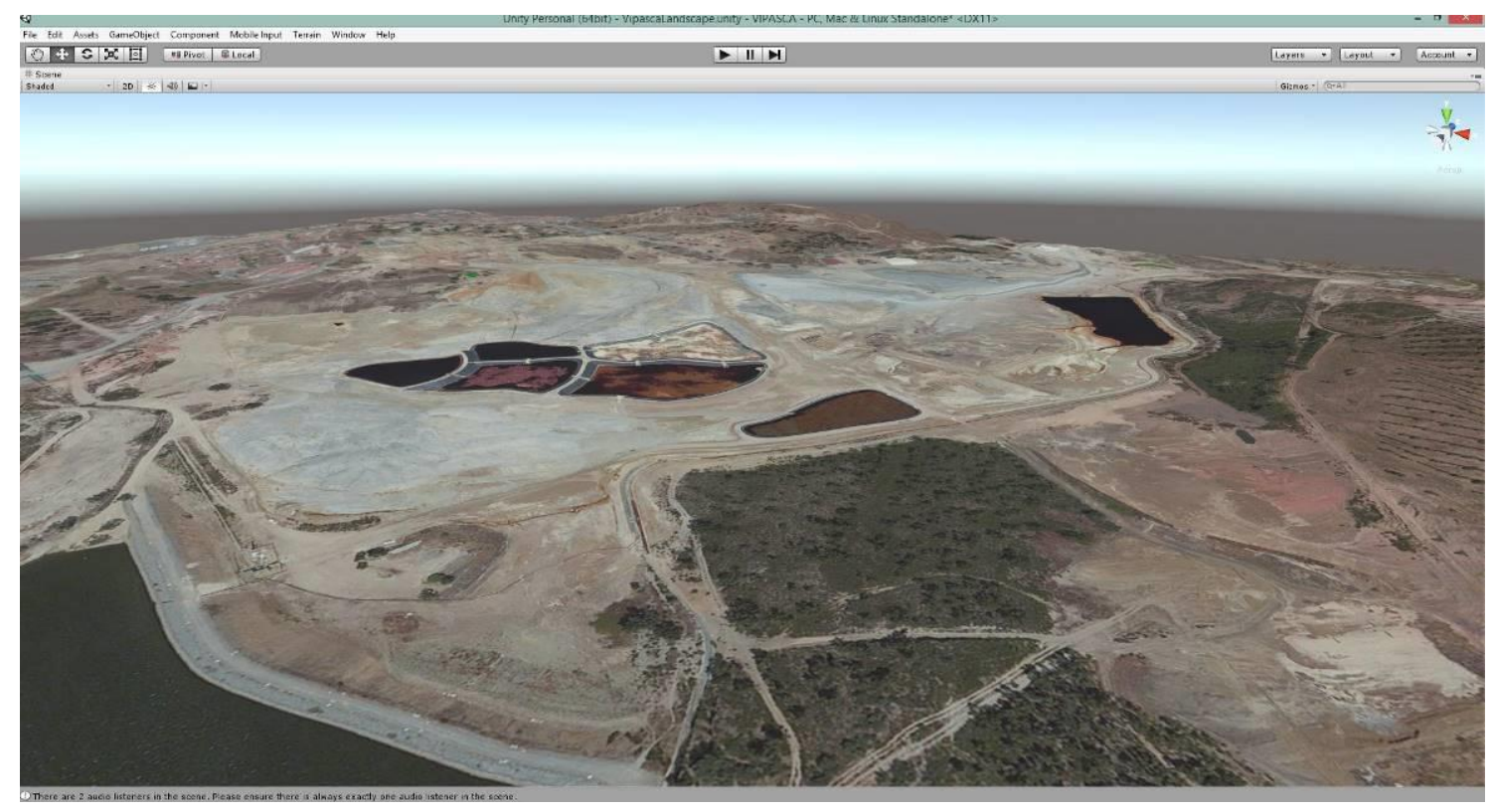

Fig. 32 - Terreno gerado com o World Composer: praticamente impossível notar a colina na paisagem devido à baixa resolução do modelo tridimensional.

A solução para esse problema, então, foi a modelagem do terreno a partir do zero. Para facilitar a composição das nuances do terreno (por exemplo: irregularidades), partiuse da base fornecida pelo criador de relevos denominado Gai $^{24}$. Com ele, foi estabelecido um terreno com resoluções de 2048 unidades de comprimento por 2048 unidades de largura e 600 unidades de altura (sendo cada unidade do Unity equivalente a 1 metro), como se pode ver na Fig. 33.

\footnotetext{
${ }^{24}$ www.assetstore.unity3d.com/en/\#!/content/42618
} 


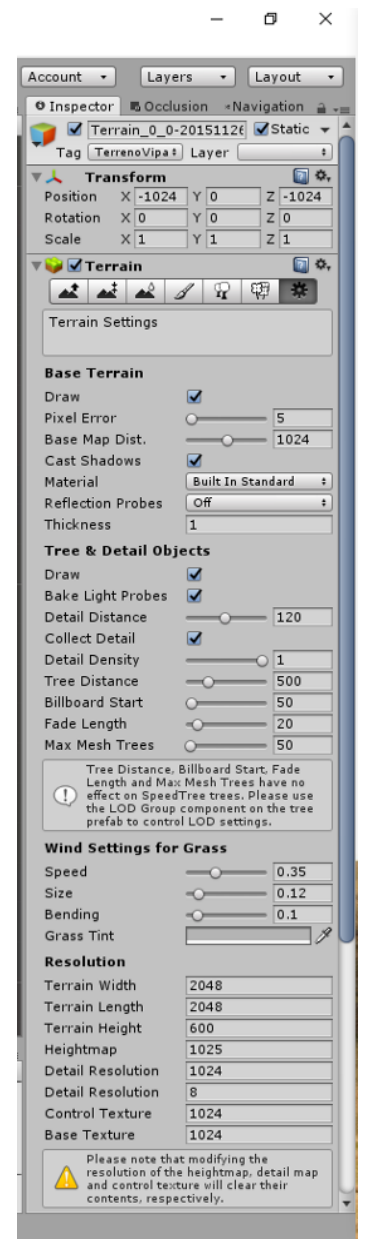

Fig. 33 - Configurações finais do terreno.

O esculpimento e a texturização do terreno foi um processo que levou quase quatro semanas para ser finalizado devido à complexidade e ao grau de detalhamento necessário para que o terreno fosse verossímil quando navegado em primeira pessoa. Destaca-se o fato de o chapéu de ferro não ter a forma que se observa hoje em dia (praticamente desmontado em sua totalidade) (Fig. 34): como o aplicativo está balizado no século II d.C., o chapéu de ferro ainda não havia sido explorado em demasia pelos romanos. Todo o processo de produção do terreno (e do aplicativo como um todo) foi realizado com a consultoria do arqueólogo e diretor do Museu de Aljustrel Artur Martins, reconhecido especialista português na área de mineração Antiga: houve trocas praticamente diárias de e-mails entre mim e o Artur durante todos os nove meses de desenvolvimento de Vipasca Antiga; assim sendo, cabe aqui o agradecimento especial à figura de Artur Martins, sem a qual Vipasca Antiga não teria alcançado o resultado final satisfatório. No final, o terreno esculpido e texturizado ficou com sua forma igual à mostrada nas Figs. 35 - 39. 


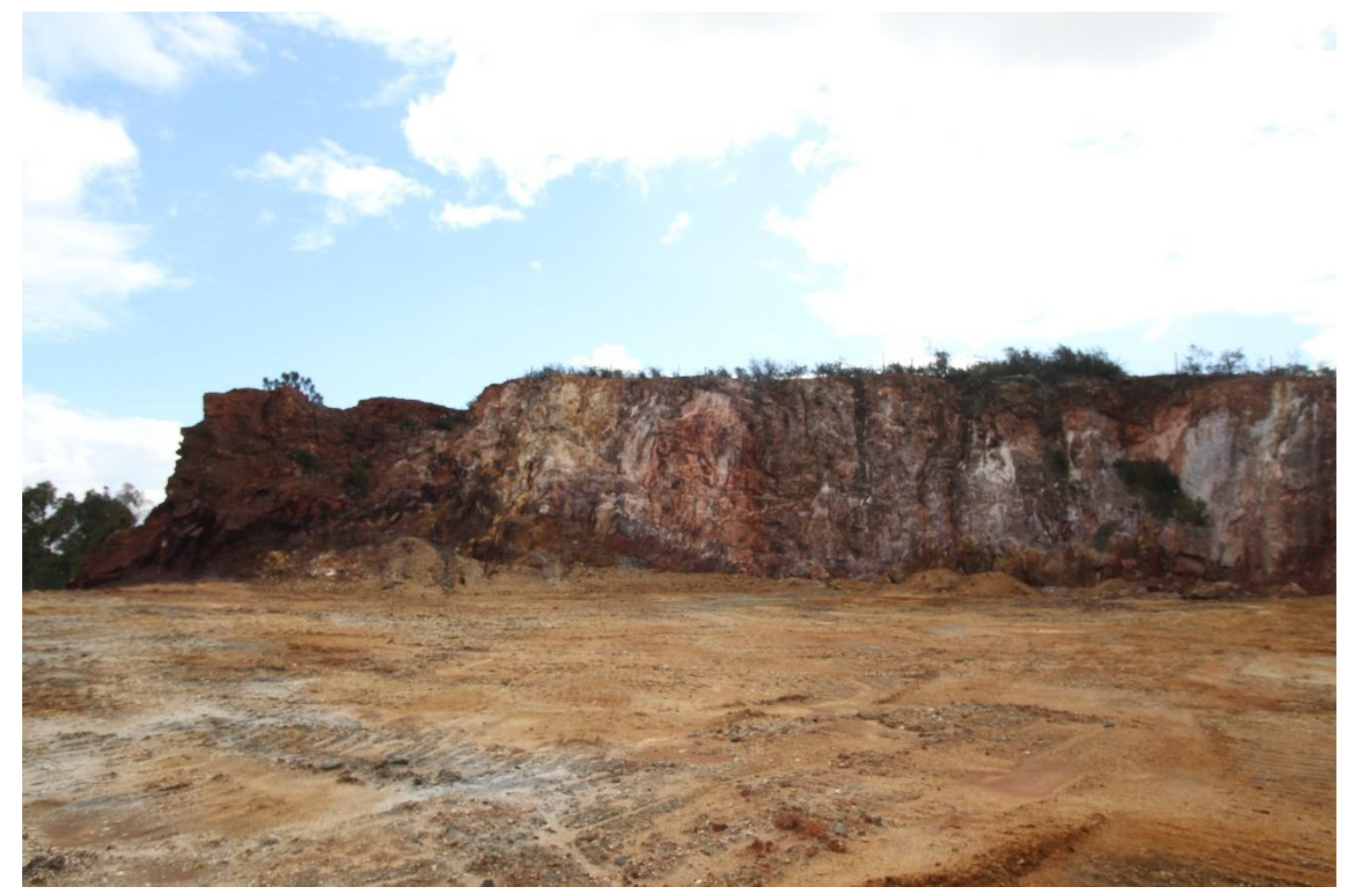

Fig. 34 - Chapéu de ferro explorado pelos romanos em Aljustrel.

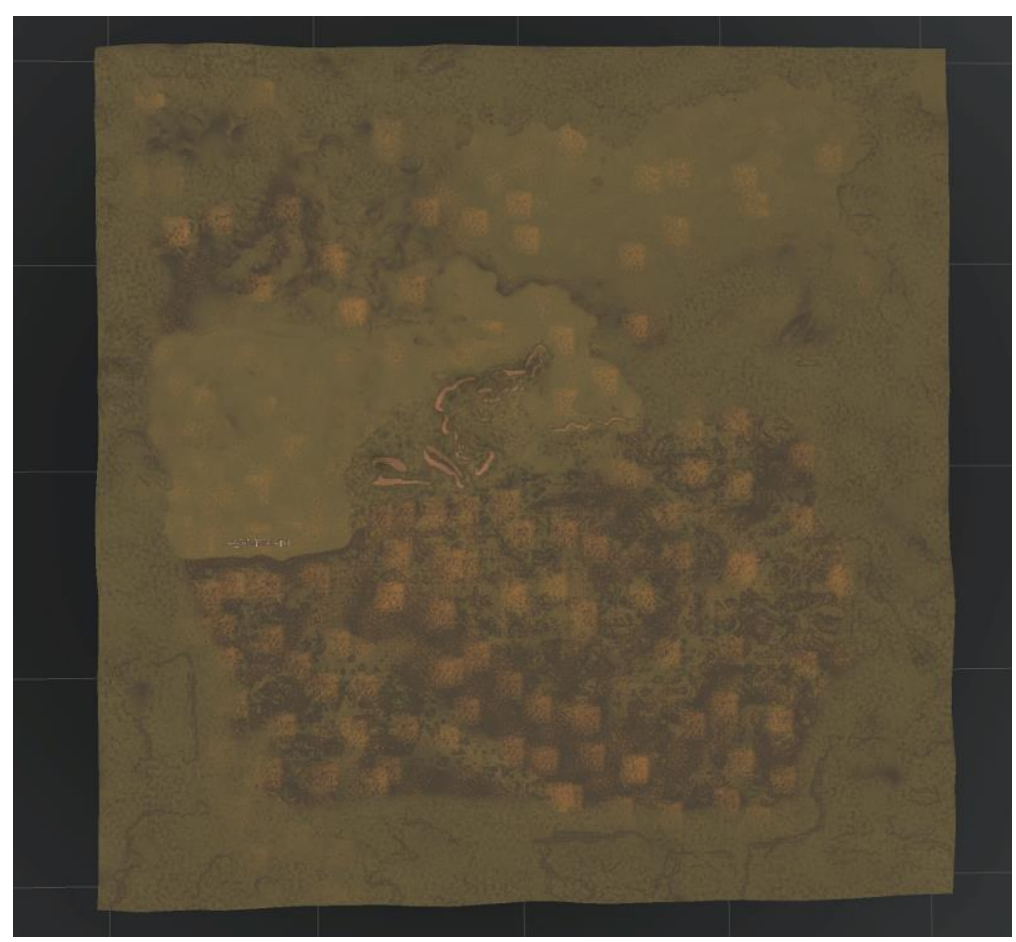

Fig. 35 - Terreno visto perpendicularmente $\left(90^{\circ}\right)$. 


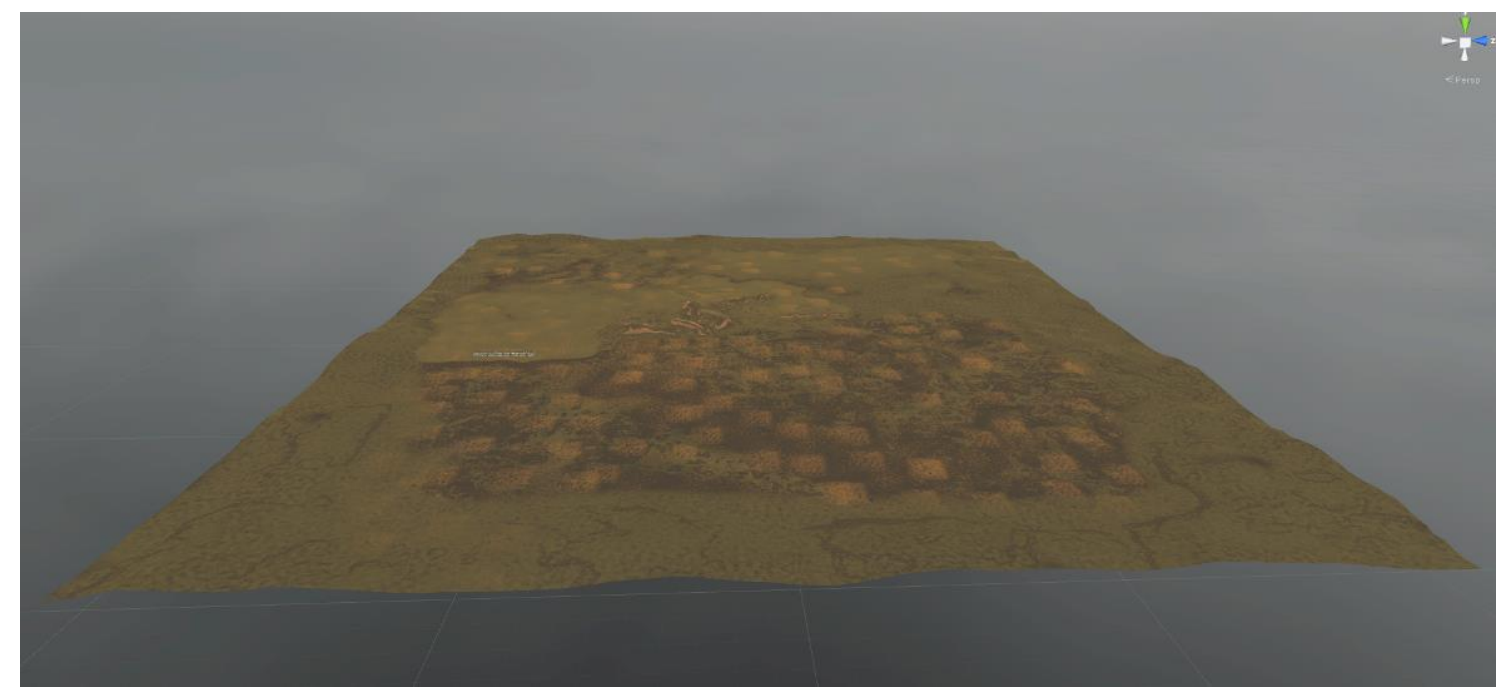

Fig. 36 - Terreno em perspectiva.

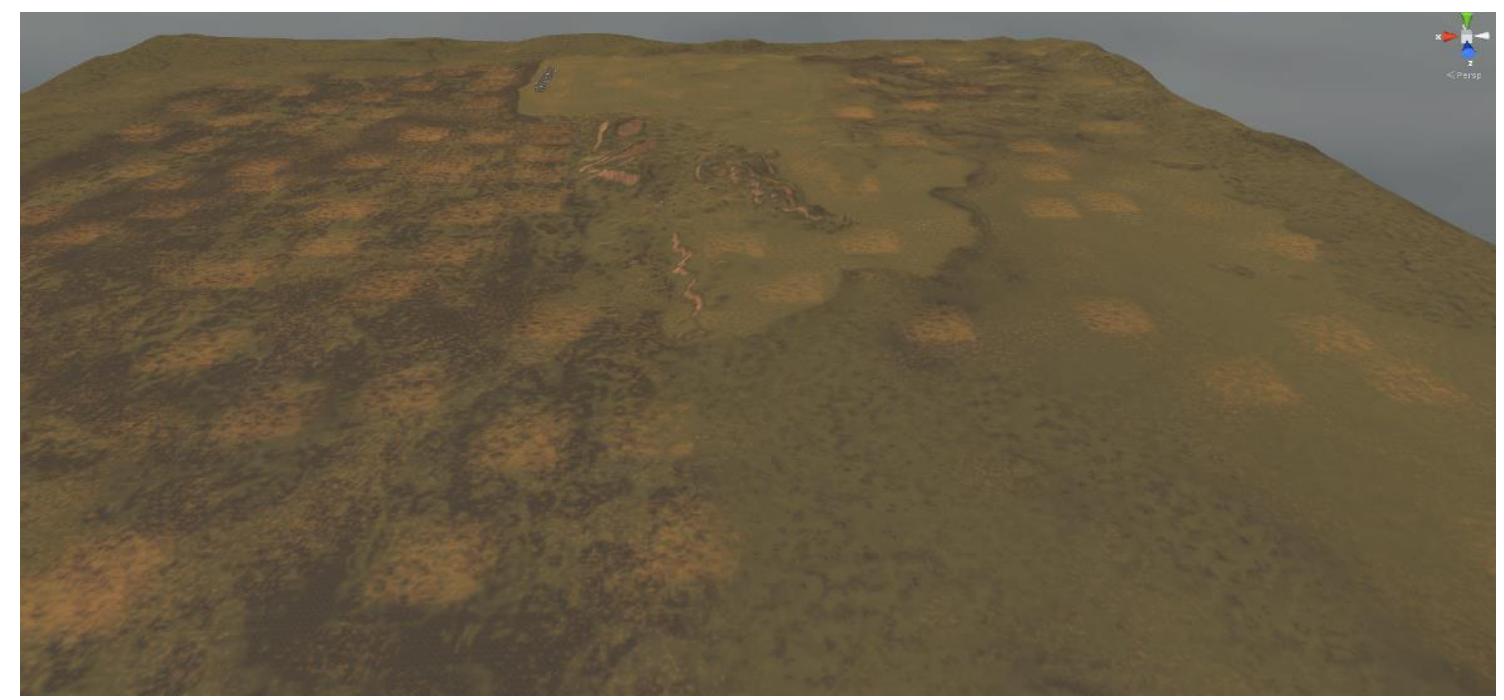

Fig. 37 - Terreno em perspectiva: todas as texturas foram pintadas no modelo à mão, sobrepondose camadas. 


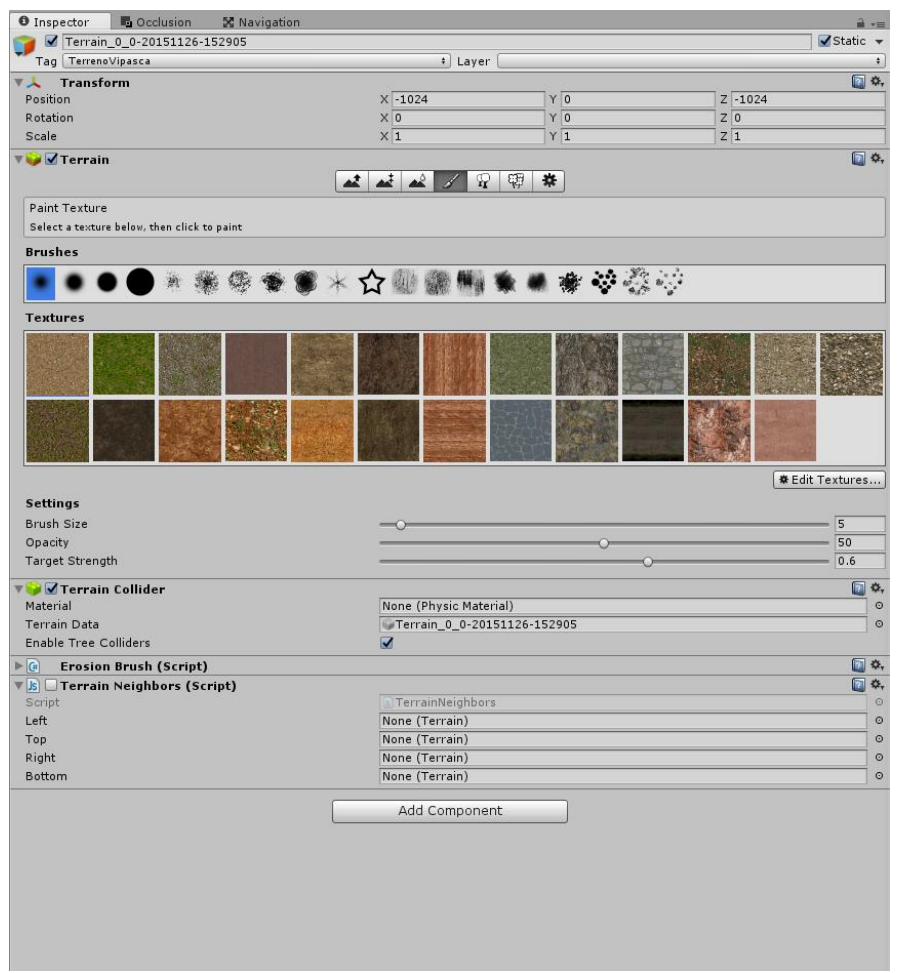

Fig. 38 - Texturas utilizadas na pintura do terreno: uma miríade de terras, gramas, rochas, pedras de calçamento e cores do chapéu de ferro (neste caso, obtidas a partir de fotos realizadas no local em 2016).

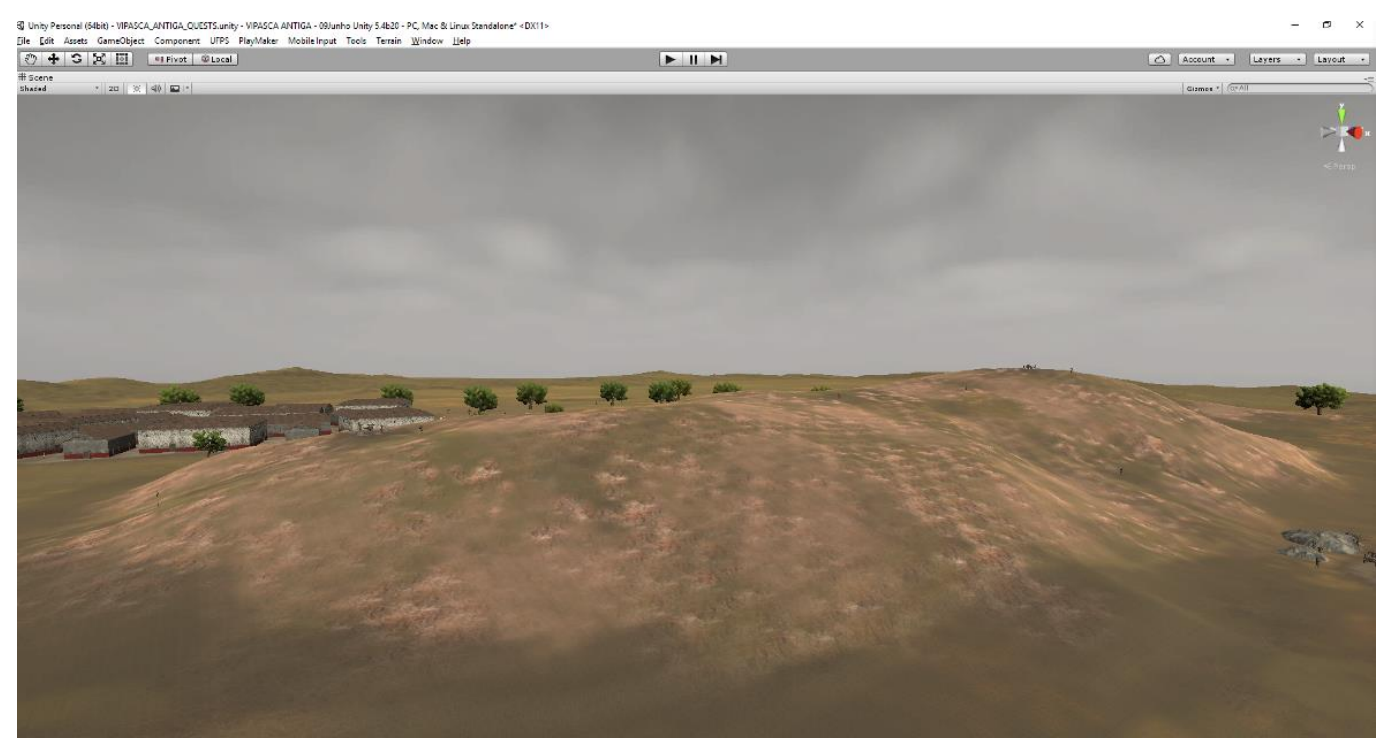

Fig. 39 - Vista da versão final do chapéu de ferro com sua coloração típica destoante na paisagem. 


\subsection{Objetos}

Terminado o terreno, começou a etapa de produção/modelagem dos objetos que estão espalhados pelo território de Vipasca. Todos os objetos aqui mencionados foram modelados utilizando-se o software Autodesk Maya, exceto quando mencionado o contrário.

Uma das principais preocupações da modelagem referia-se às moradias, uma vez que seriam parte significativa na ambientação do aplicativo, representando os locais em que o usuário caminharia e observaria o cotidiano. Tal como em todos os povoamentos romanos antigos, duas edificações destacam-se nesse quesito: as domus (casas térreas) e as insulae (apartamentos).

\subsubsection{Casa do Procurador}

Sendo a Casa do Procurador (uma domus) um dos mais importantes vestígios na paisagem arqueológica atual de Aljustrel, as campanhas de escavação avançaram muito no decorrer dos anos e hoje em dia é possível estabelecer sua planta, dando-nos ideia de sua totalidade no período romano. A modelagem da Casa do Procurador baseou-se na planta produzida pelos arqueólogos do Projecto Vipasca (parceria entre o Município de Aljustrel e a Universidade de Huelva), tendo a maior parte da domus construída digitalmente a partir do desenho (Fig. 40): os demais cômodos, que não foram atestados na escavação/planta, foram, então, hipoteticamente construídos com base nos padrões observados pessoalmente nas áreas arqueológicas de Pompeia, Herculano e Óstia Antiga (Fig. 41). 


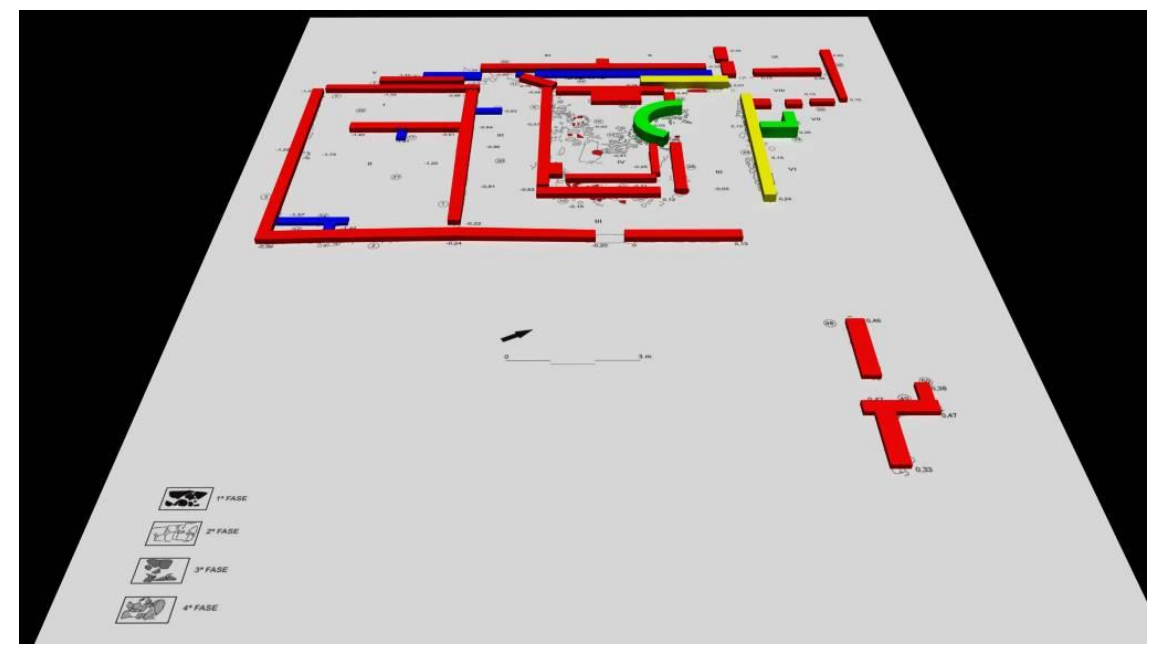

Fig. 40 - Blocagem (ou seja, posicionamento de geometrias simples) dos muros da Casa do Procurador a partir de sua planta (PÉREZ MACÍAS et al. 2013: 243)

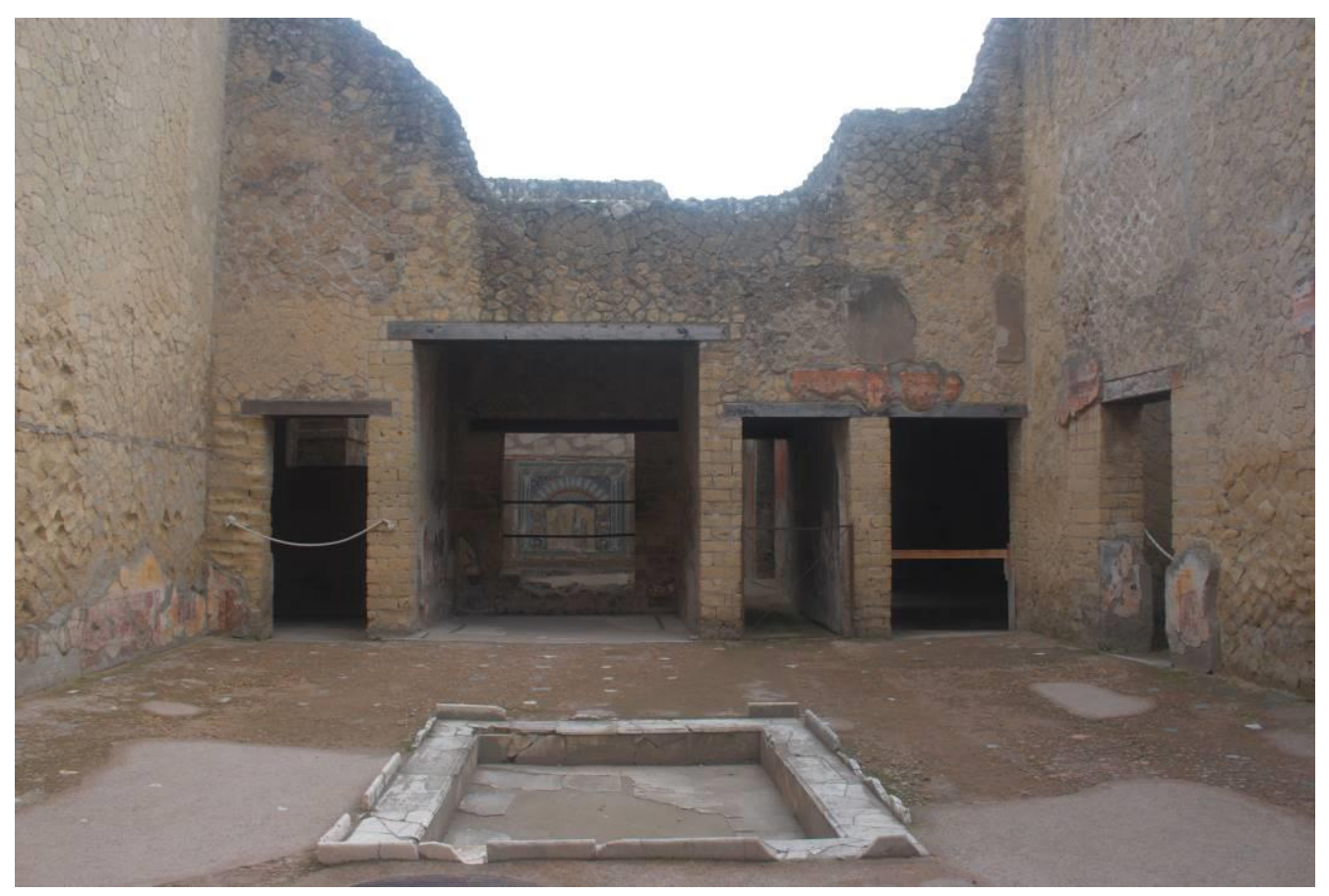

Fig. 41 - Casa di Nettuno ed Anfitrite (detalhe do impluvium no átrio), Herculano, 2014.

A principal referência da Casa do Procurador é o seu átrio colunado, ao redor do qual os cômodos do edifício estavam posicionados. Afora a blocagem na planta do edifício, foi obtido um modelo tridimensional do átrio por meio da técnica da fotogrametria - na qual uma série de fotografias é processada em um software (nesse caso, o Agisoft Photoscan) a fim de se obter um objeto 3D - que serviu como base de escala real tanto para o término da blocagem como para o modelo final (e posteriormente, como um vestígio interativo dentro do aplicativo Vipasca Antiga, que será mencionado 
mais adiante). As Figs. 42-43 mostram a construção do modelo do átrio colunado (o número final de colunas foi diminuído para 10, representando o valor correto que estaria presente em época romana) sobre a fotogrametria, enquanto as Figs. 44-45 mostram um primeiro modelo blocado da Casa do Procurador (que foi modificado em sua versão final, optando-se por eliminar a hipotética existência de loja inferior - conforme sugere Artur Martins - a fim de facilitar o posicionamento no terreno dentro do Unity, bem como a ampliação dos muros do fundo da casa - cômodo que foi estabelecido como o tablinum no Vipasca Antiga).

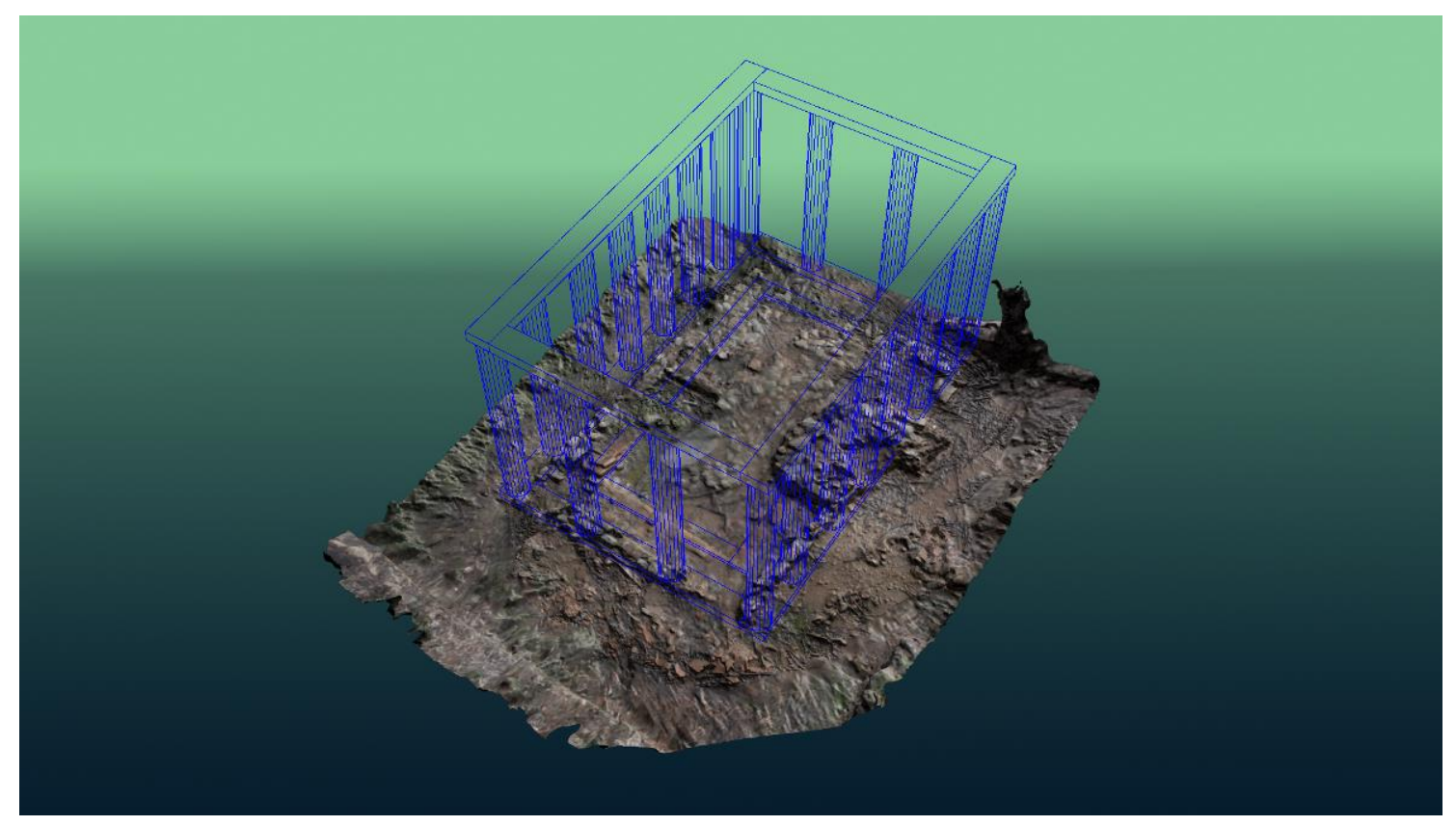

Fig. 42 - Modelo do impluvium sobre a fotogrametria. 


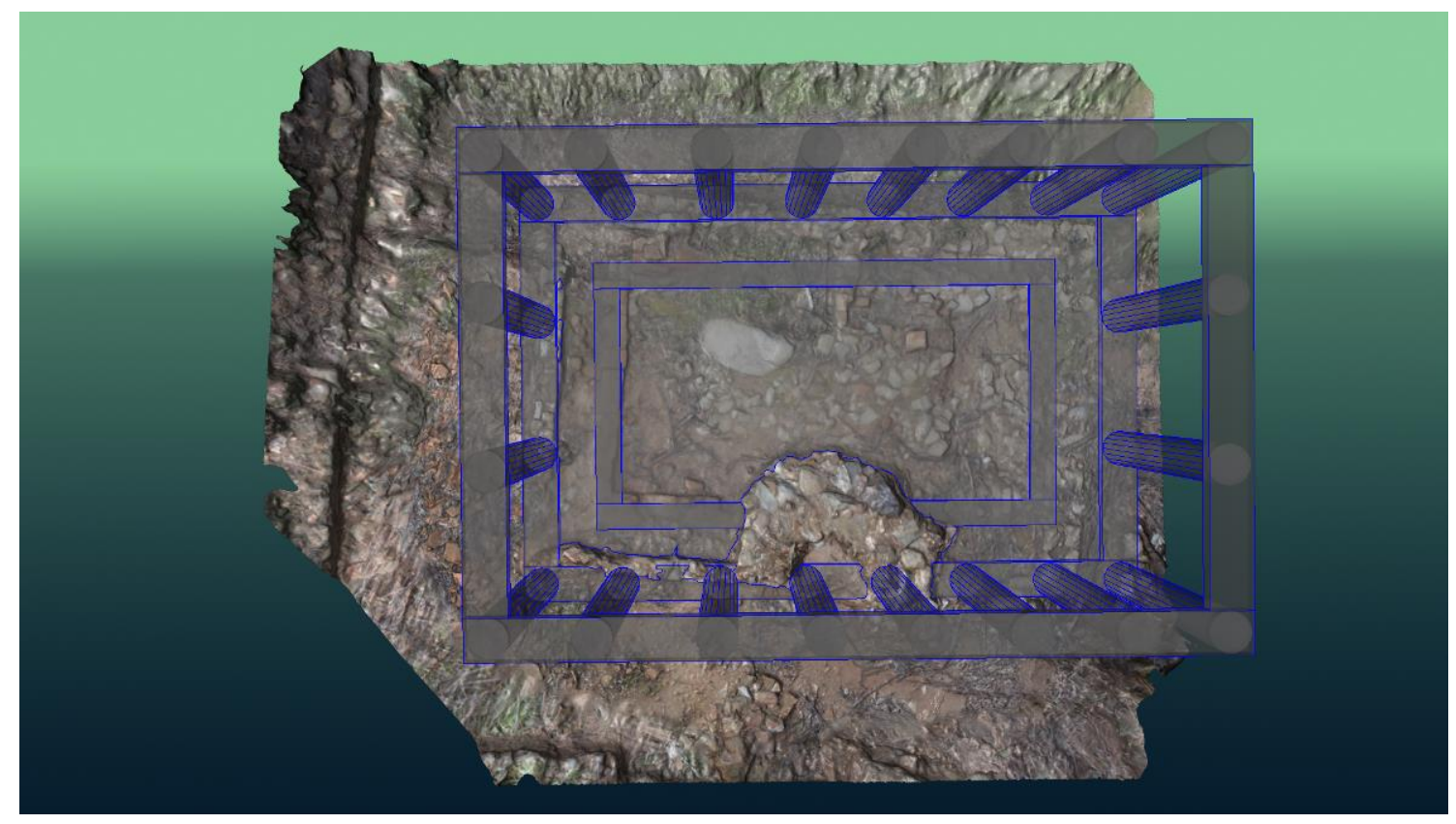

Fig. 43 - Vista perpendicular $\left(90^{\circ}\right)$ do modelo do impluvium e colunas sobre fotogrametria.

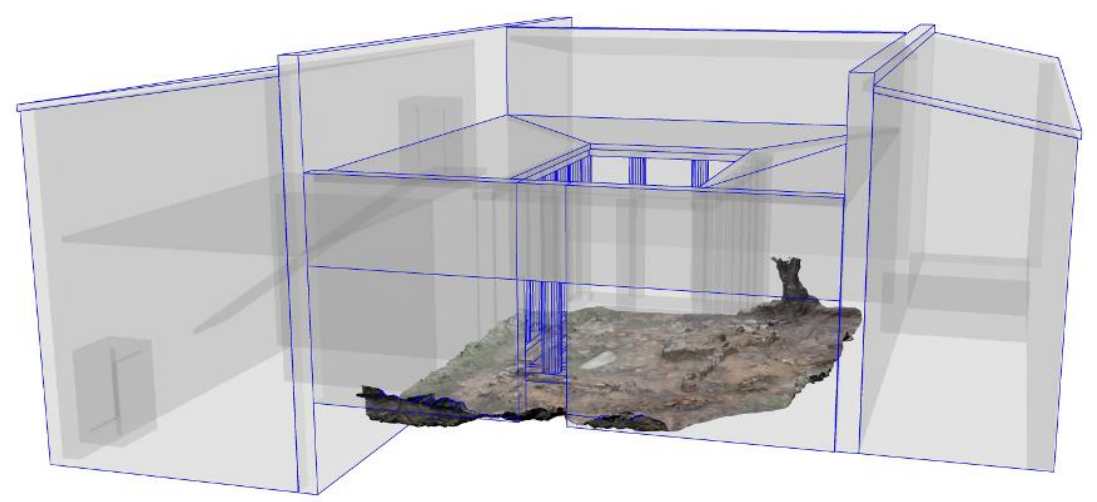

Fig. 44 - Blocagem dos muros sobre a fotogrametria. 


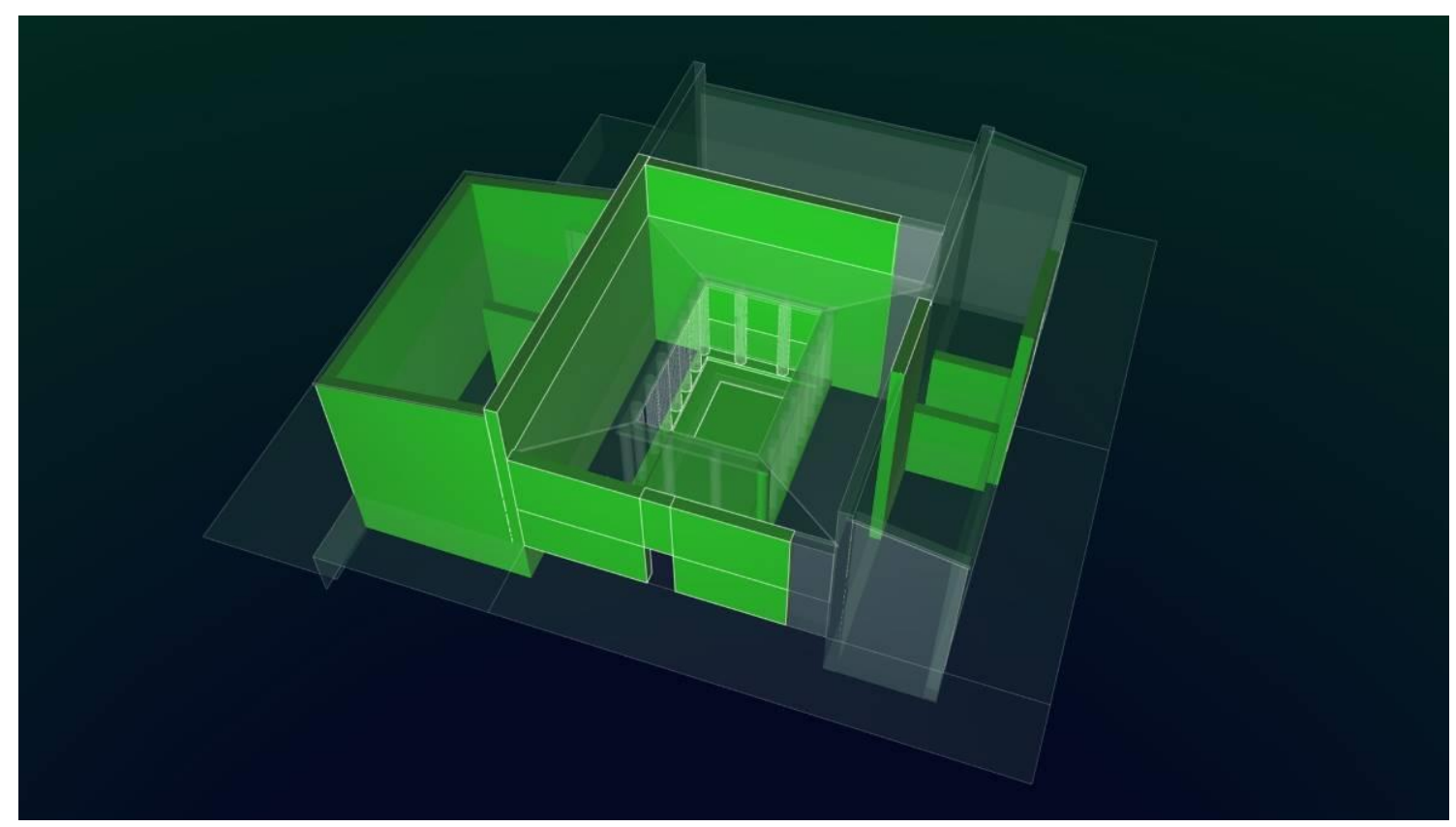

Fig. 45 -Blocagem dos muros sobre a fotogrametria: destaque para a hipótese da existência de uma loja inferior sugerida por Artur Martins (retirada na versão final para posicionamento no terreno, seguindo-se apenas a planta original). As áreas em verde claro são as blocagens realizadas a partir dos vestígios que estão no terreno atualmente; as áreas translúcidas são hipóteses de construção.

O modelo final da Casa do Procurador possui 18314 vértices e 16338 faces (totalizando 32728 triângulos): uma contagem adequada para um objeto que está disponível para a visualização em primeira pessoa em um motor gráfico de jogos. Optouse por uma modelagem o mais simples possível (visando a performance do aplicativo), em que figuras geométricas primitivas foram utilizadas (em sua maioria cubos) para dar o contorno geral da casa. Todos os detalhes foram obtidos por texturização e bump mapping ${ }^{25}$ : essa escolha foi uma consequência natural de aprendizado adquirido no desenvolvimento do aplicativo DOMUS do Laboratório de Arqueologia Romana Provincial (LARP) do Museu de Arqueologia e Etnologia da USP (www.larp.mae.usp.br/rv) quando, durante a modelagem, o detalhamento da casa foi todo modelado, gerando um altíssimo número de triângulos e vértices na tela, fazendo com

25 Wikipedia (https://pt.wikipedia.org/wiki/Bump_mapping): “Bump mapping é uma técnica de computação gráfica, cada pixel do objeto que está sendo renderizado e se aplica uma perturbação em sua superfície normal, baseada num mapa de altura previamente especificado, que como consequência varia a intensidade de luz 'refletida' por este pixel. A iluminação é aplicada após os cálculos dando a cada pixel seu respectivo brilho. O resultado é uma superfície renderizada com mais detalhes e imperfeições lembrando o mundo real. Normal map e parallax mapping são as técnicas mais comuns para a criação deste efeito, fazendo com que o algoritmo original se pareça obsoleto". (Acesso em 12/07/2016) 
que o processamento do computador se tornasse um gargalo para uma experiência satisfatória do aplicativo (MARTIRE et al. 2015: 85-103). A texturização da Casa do Procurador (e da maioria dos objetos presentes no Vipasca Antiga) foi realizada fazendose o mapeamento $\mathrm{UV}^{26}$ do modelo (Fig. 46) e aplicando-se texturas criadas no Photoshop (para os estilos de pinturas nas paredes internas, baseadas em vestígios de Pompeia e Herculano) e substâncias dinâmicas adquiridas na Asset Store do Unity desenvolvidas pela empresa Allegorithmic ${ }^{27}$ (Fig. 47): essas substâncias são materiais PBR (Physicallybased rendering ${ }^{28}$ ) com variáveis modificáveis que possuem todos os elementos com os quais o Unity trabalha, a saber: albedo ${ }^{29}$, metallic/smoothness ${ }^{30}$, normal map ${ }^{31}$, height map $^{32}$, occlusion $^{33}$, emission ${ }^{34}$, detail mask ${ }^{35}$ e tiling $^{36}$.

\footnotetext{
${ }^{26} \mathrm{O}$ processo de projetar uma imagem $2 \mathrm{D}$ em um objeto 3D. Simplificando, poderíamos entender como o papel que embrulha um presente. As letras UV correspondem aos eixos $\mathrm{X}$ e $\mathrm{Y}$ da imagem/textura 2D. Mais informações: https://en.wikipedia.org/wiki/UV_mapping (Acesso em 12/07/2016) ${ }^{27}$ www.allegorithmic.com

28 Materiais que emulam a iluminação de modo convincente. Para saber mais: www.marmoset.co/toolbag/learn/pbr-theory (Acesso em 12/07/2016)

29 Cor básica que reflete a luz difusamente. Mais informações: http://www.marmoset.co/toolbag/learn/pbr-practice (Acesso em 12/07/2016)

${ }^{30}$ Característica metálica do material: quanto maior o valor, mais reflexivo ele se torna. Mais informações: https://docs.unity3d.com/Manual/StandardShaderMaterialParameterMetallic.html (Acesso em 12/07/2016)

${ }^{31}$ Simula o relevo em uma superfície, propiciando a impressão de maior de profundidade. Fornece nível de detalhamento sem a necessidade de usar mais polígonos. Mais informações: https://pt.wikipedia.org/wiki/Normal_map (Acesso em 12/07/2016)

${ }^{32}$ Imagem bidimensional utilizada para armazenar valores relativos à elevação de uma superfície, gerando modelos tridimensionais. Em escala de cinza, a cor branca representa os pontos mais altos enquanto a cor preta representa os pontos de menor altitude. Mais informações: https://pt.wikipedia.org/wiki/Normal_map (Acesso em 12/07/2016)

${ }^{33} \mathrm{O}$ mapa de oclusão é usado para informar quais áreas do modelo serão afetadas pela luz indireta (ou seja, luz do ambiente e reflexos). Mais informações: https://docs.unity3d.com/Manual/StandardShaderMaterialParameterOcclusionMap.html (Acesso em 12/07/2016)

${ }^{34}$ Controla a cor e a intensidade de iluminação emitida por uma superfície. Mais informações: https://docs.unity3d.com/Manual/StandardShaderMaterialParameterEmission.html (Acesso em $12 / 07 / 2016)$

35 Camada de textura que se sobrepõe à camada principal. Mais informações: https://docs.unity3d.com/Manual/StandardShaderMaterialParameterDetail.html (Acesso em 12/07/2016)

36 "Telhadura", ou seja, quantas vezes a mesma imagem/textura se repete nos eixos $\mathrm{X}$ e $\mathrm{Y}$ em um material.
} 


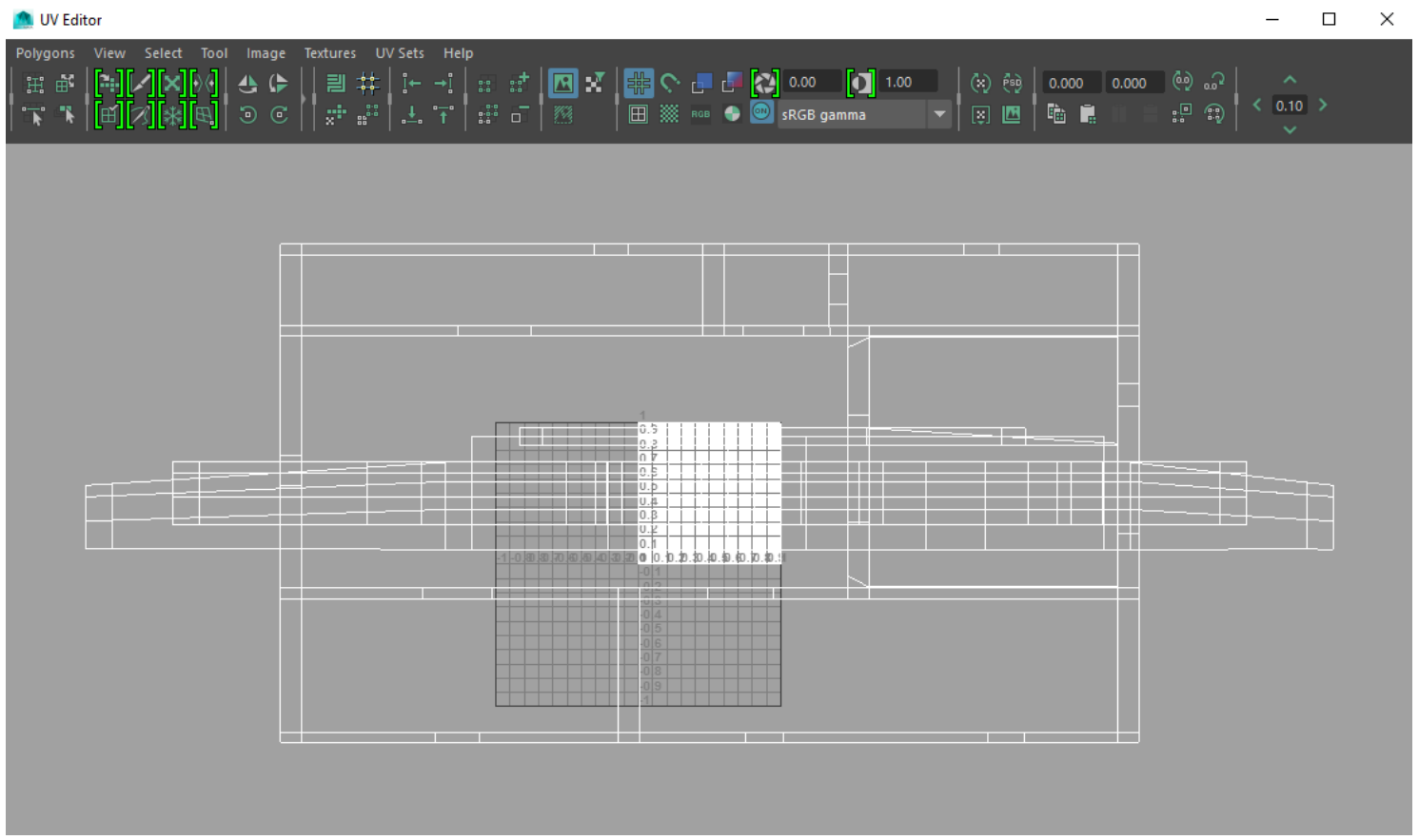

Fig. 46 - Início do mapeamento UV das paredes exteriores da Casa do Procurador.

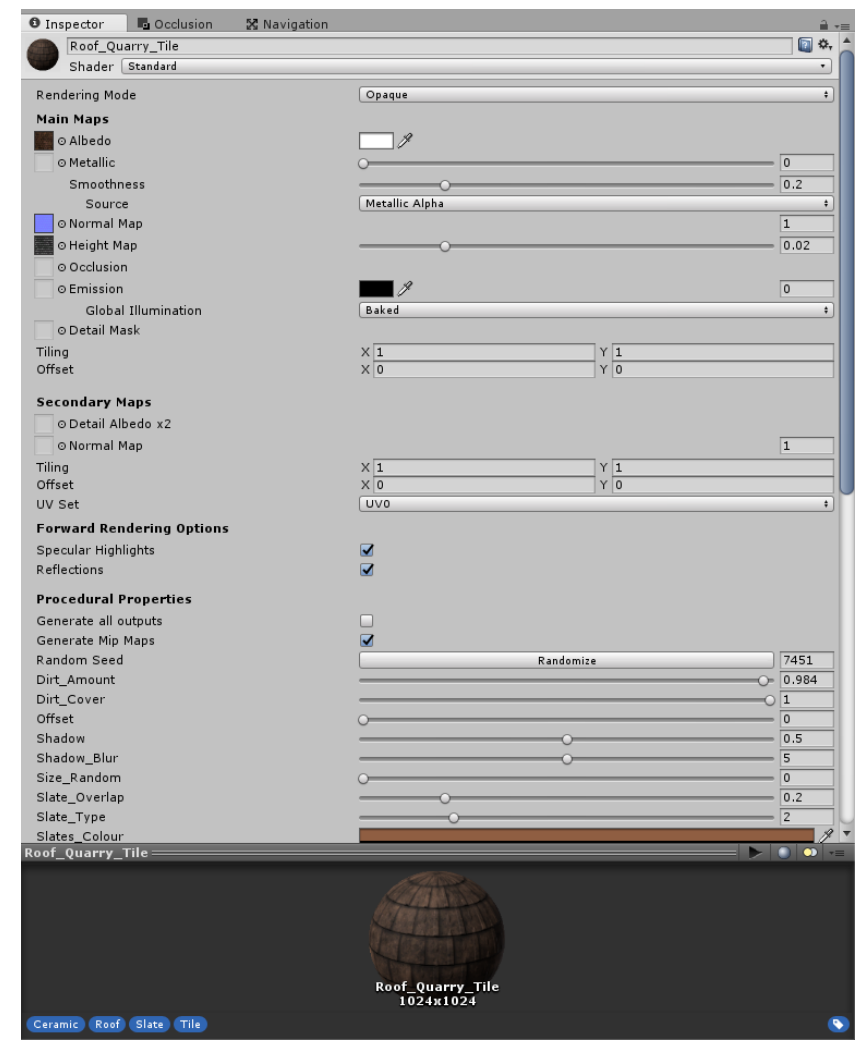

Fig. 47 - Edição de uma substância dentro do motor gráfico Unity. 
O modelo finalizado foi exportado, sem as texturas (para não haver redundâncias no motor gráfico), para o Unity no formato proprietário da Autodesk, o FBX. Nas Figs. 48-50 podemos ver mais detalhes da versão final modelada dentro do Autodesk Maya.

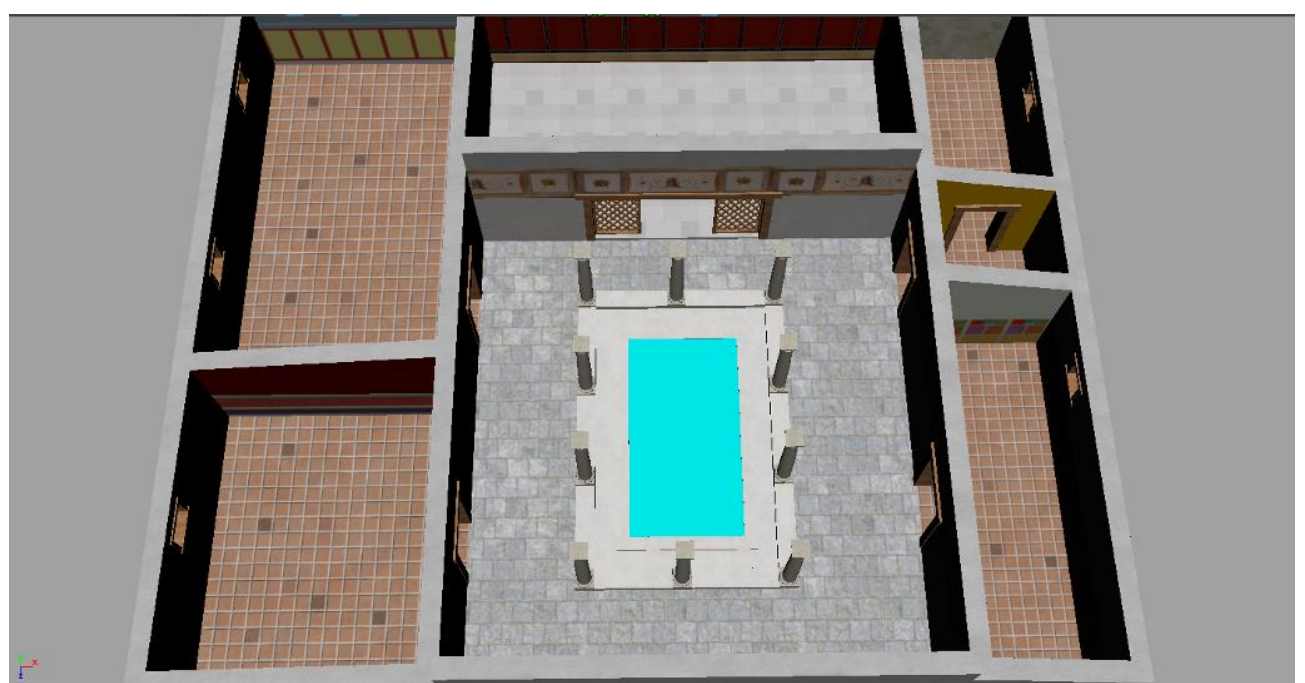

Fig. 48 - Vista geral da Casa do Procurador finalizada (o suporte do telhado e as telhas foram omitidos para a visualização).

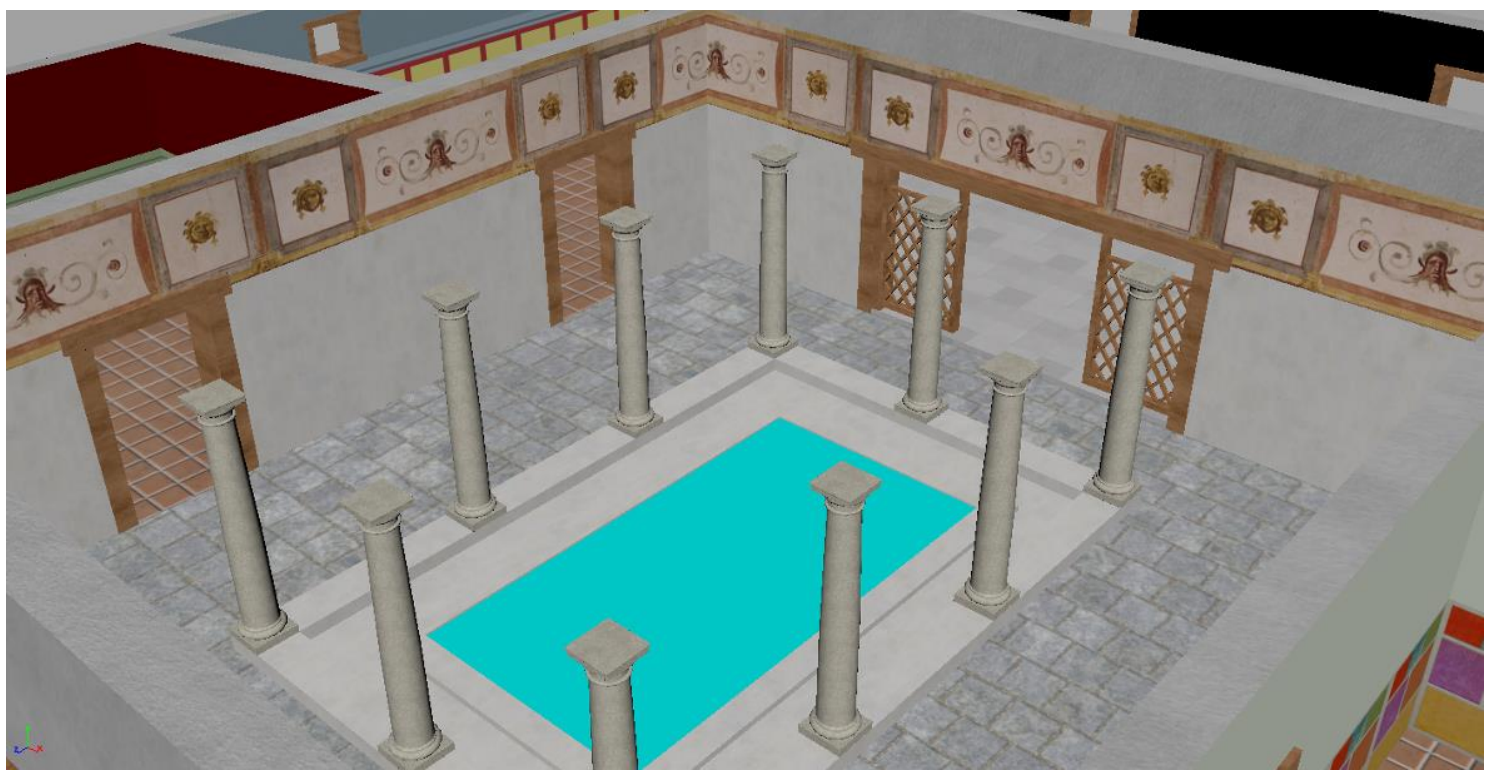

Fig. 49 - Detalhe do átrio com a decoração (afrescos) e as colunas rodeando o impluvium. 


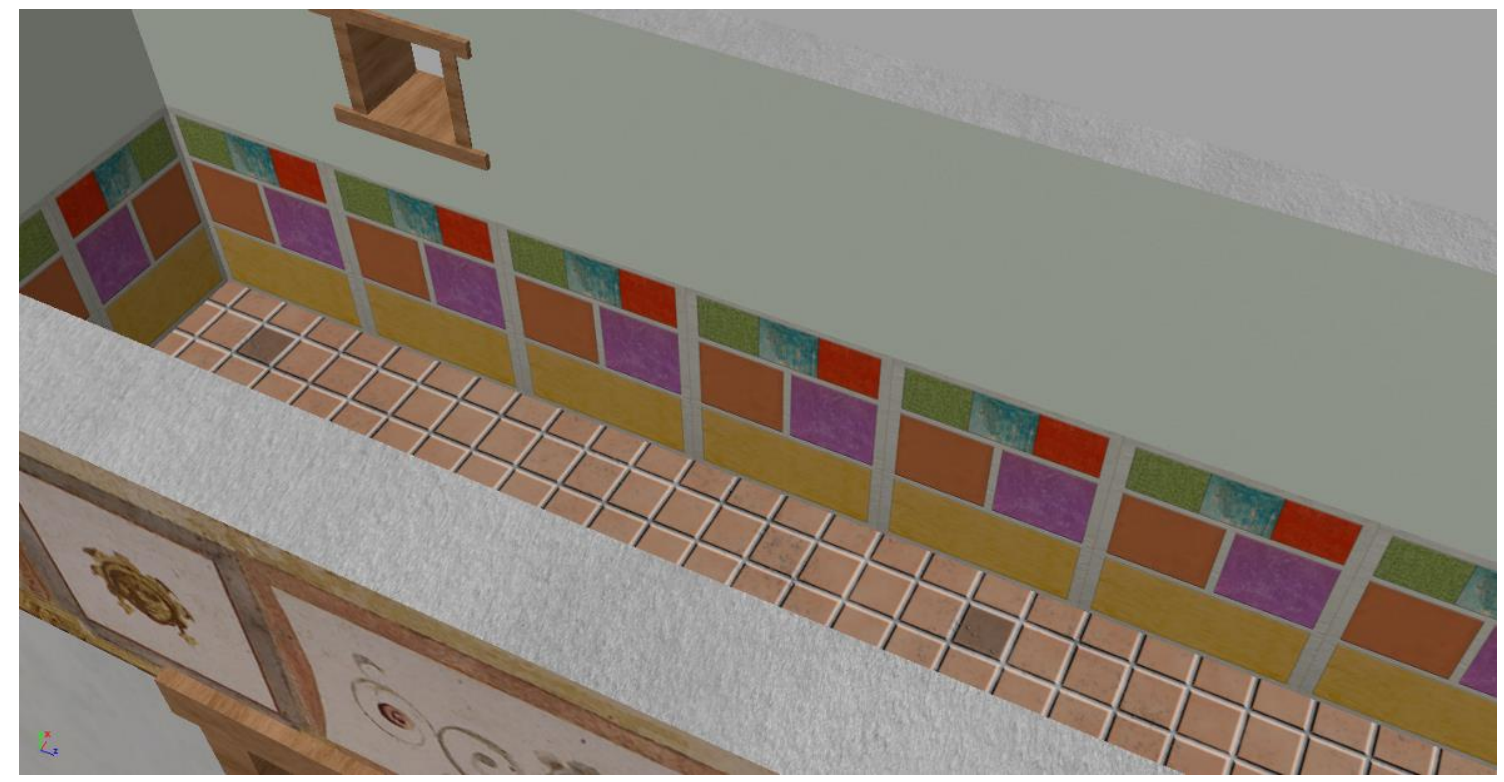

Fig. 50 - Detalhe das pinturas (afrescos) criadas no editor de imagens Adobe Photoshop.

Outros três modelos de casas foram produzidos, todos genéricos, baseando-se em plantas de domus comumente encontradas em Pompeia e Herculano. Como essas domus teriam apenas um papel figurativo na paisagem, ou seja, no aplicativo o usuário apenas veria suas fachadas, os modelos contaram com um número reduzido de polígonos, ficando o detalhamento apenas para os batentes das portas e as molduras das janelas, conforme podemos ver nas Figs. 51-53.

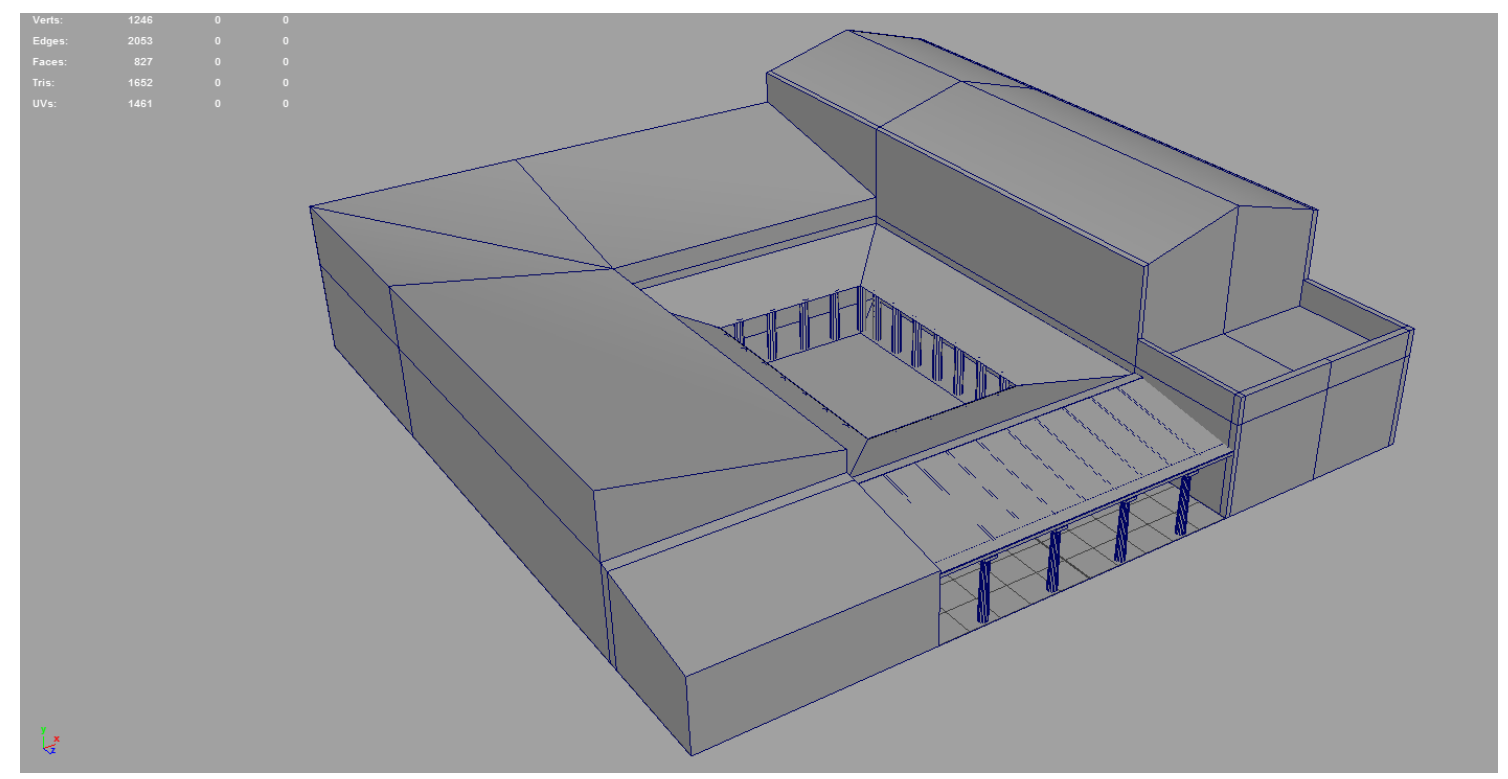

Fig. 51 - Modelo de domus com colunas na entrada e no átrio. 


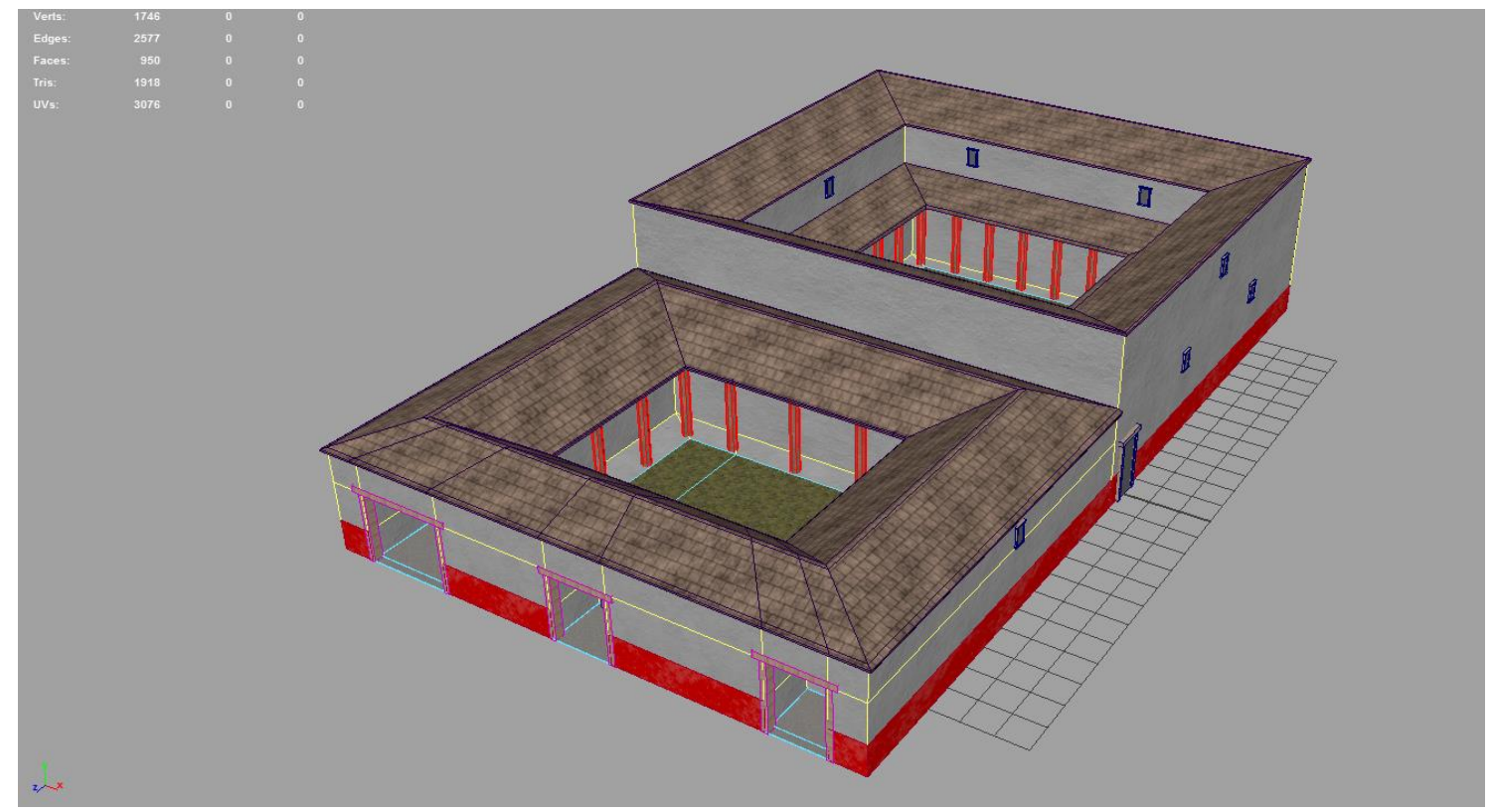

Fig. 52 - Modelo de domus com espaços para duas lojas/tabernas e peristilo.

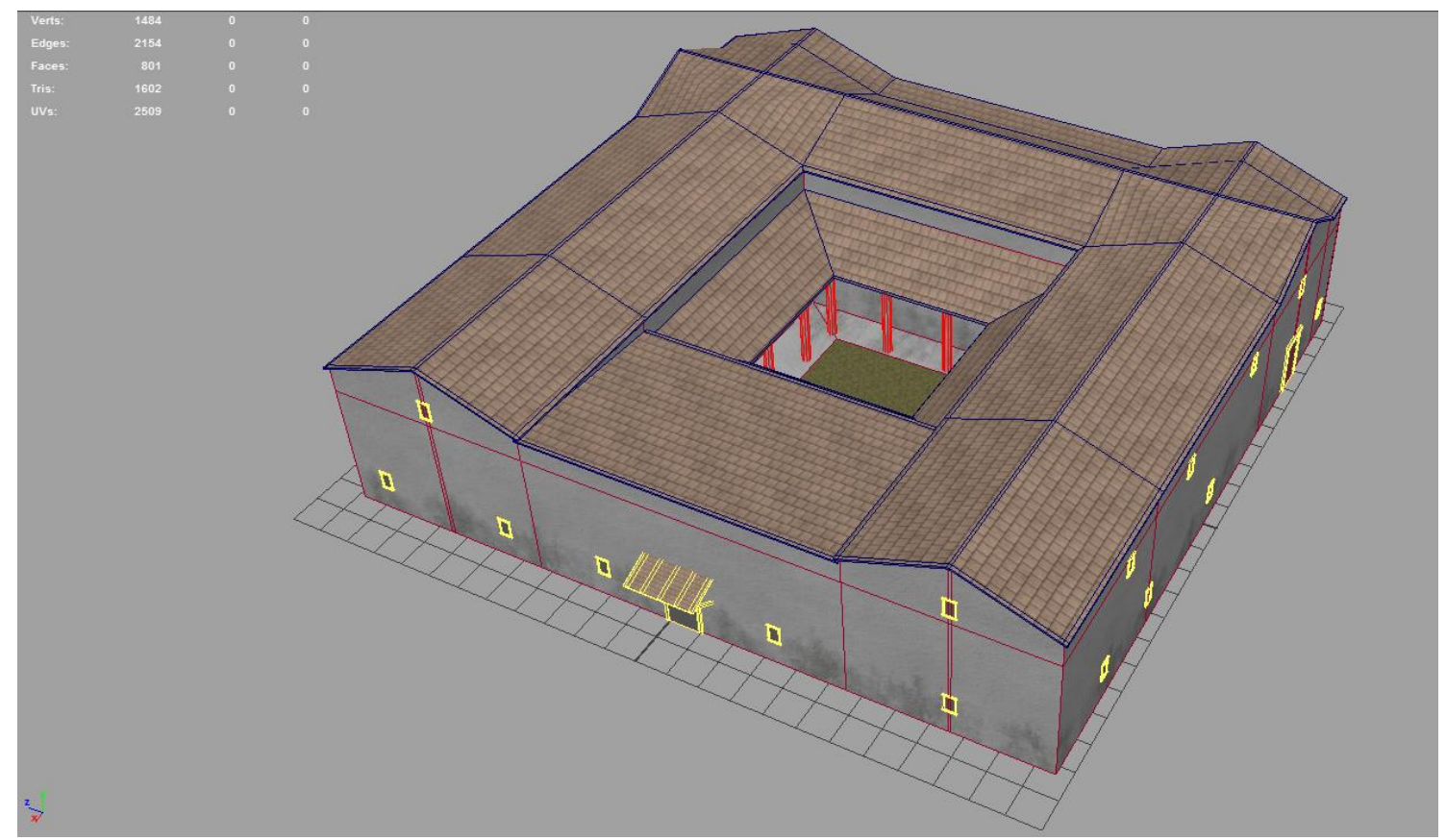

Fig. 53 - Modelo de domus: em amarelo, as molduras da janelas e batentes das portas.

Assim como a Casa do Procurador, e todos os demais objetos modelados, as domus foram exportadas em formato .FBX. 


\subsubsection{Insulae}

As insulae de Vipasca, ao contrário da Casa do Procurador, e semelhantemente à maioria do povoado romano antigo da região, não contam com muitos vestígios postos à luz do dia. Intervenções arqueológicas denotam a existência de insulae espalhadas ao redor do chapéu de ferro e próximas à oficina metalúrgica e à Ribeira de Feitais, porém não é possível atestar quais seriam suas alturas e/ou se teriam uma imponência parecida com a das insulae de Óstia, por exemplo (Fig. 54).

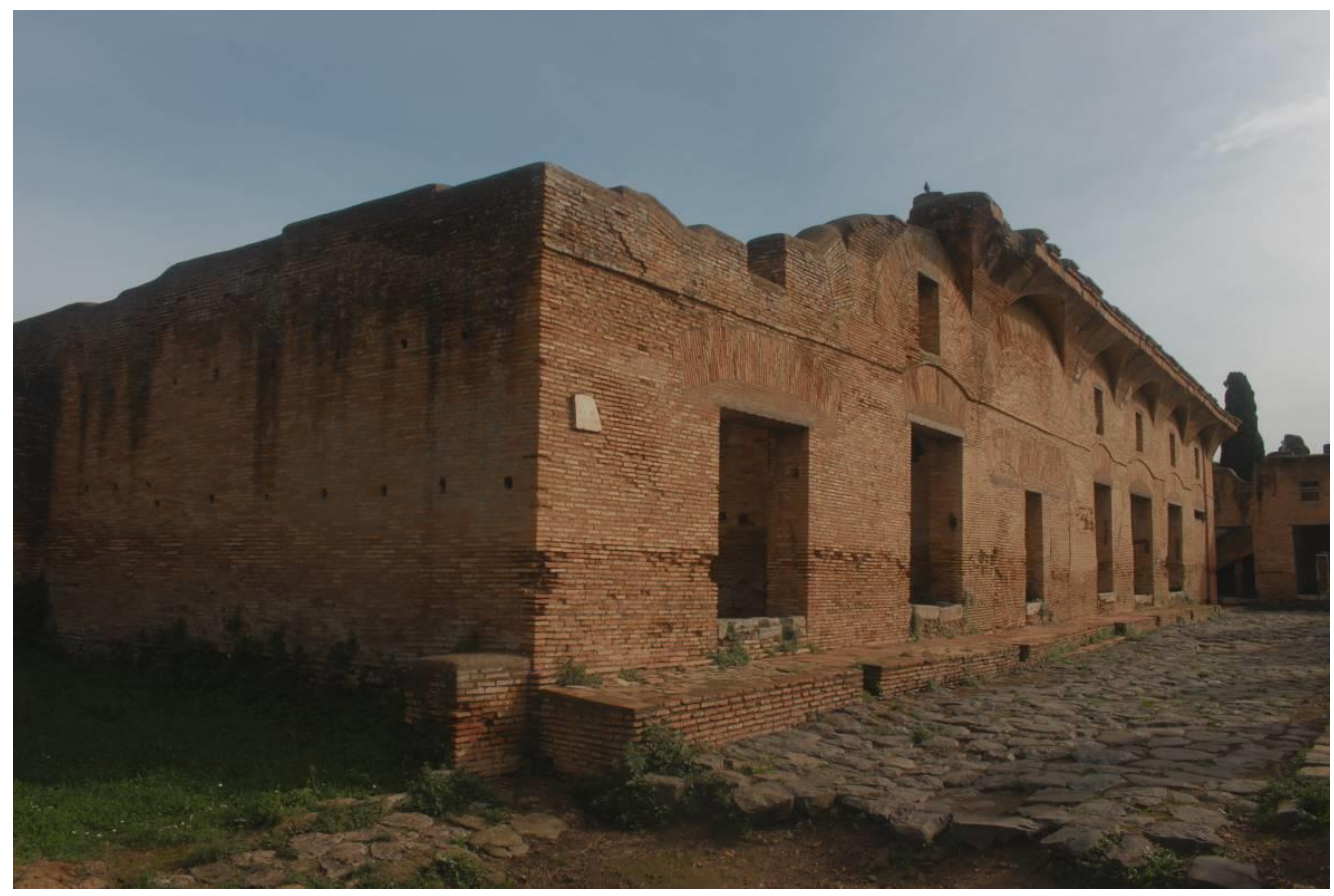

Fig. 54 - Insula Casa di Diana, Óstia Antiga, 2014.

Em um primeiro esboço, foram modelados seis quarteirões/insulae com fachadas diferenciadas, algumas contando com varandas e suportes colunados. Contudo, duas razões fizeram com que esses quarteirões fossem abandonados para o desenvolvimento do aplicativo: 1) embora pensados - e modelados - para terem o menor número possível de polígonos, o conjunto deles na paisagem de Vipasca traria um grande trabalho de processamento tanto para a CPU (Central Processing Unit) ${ }^{37}$ quanto para a GPU (Graphics Processing Unit) $^{38}$ : algo desnecessário tratando-se de modelos de fachada,

\footnotetext{
37 Processador central do computador. Mais informações: https://pt.wikipedia.org/wiki/Unidade_central_de_processamento (Acesso em 12/07/2016)

38 Processador auxiliar, encontrado em placas de vídeo. Mais informações:

https://en.wikipedia.org/wiki/Graphics_processing_unit (Acesso em 12/07/2016)
} 
apenas figurativos na paisagem; 2) Conversas com o arqueólogo Artur Martins trouxeram à tona o fato de Vipasca ter sido uma área mineradora muito insalubre, na qual as pessoas viveriam por mera necessidade econômica: desse modo, Vipasca provavelmente não contaria com a organização urbanística hipodamiana ${ }^{39}$ que os quarteirões modelados trariam - as insulae talvez fossem "semeadas" ao invés de "ladrilhadas" (tomando-se aqui a liberdade quase anacrônica de empregar os termos e ideias do historiador Sérgio Buarque de Holanda em sua obra Raízes do Brasil, de 1936), e também, provavelmente, seriam muito mais simples visualmente do que as que haviam sido modeladas (Figs. 5560).

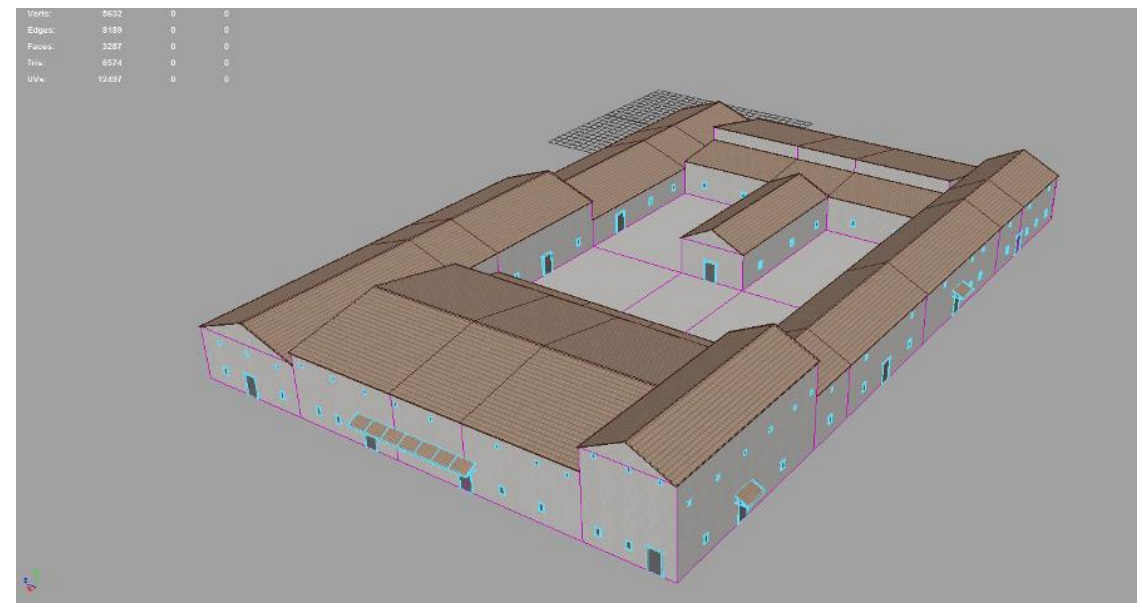

Fig. 55 - Quarteirão 01.

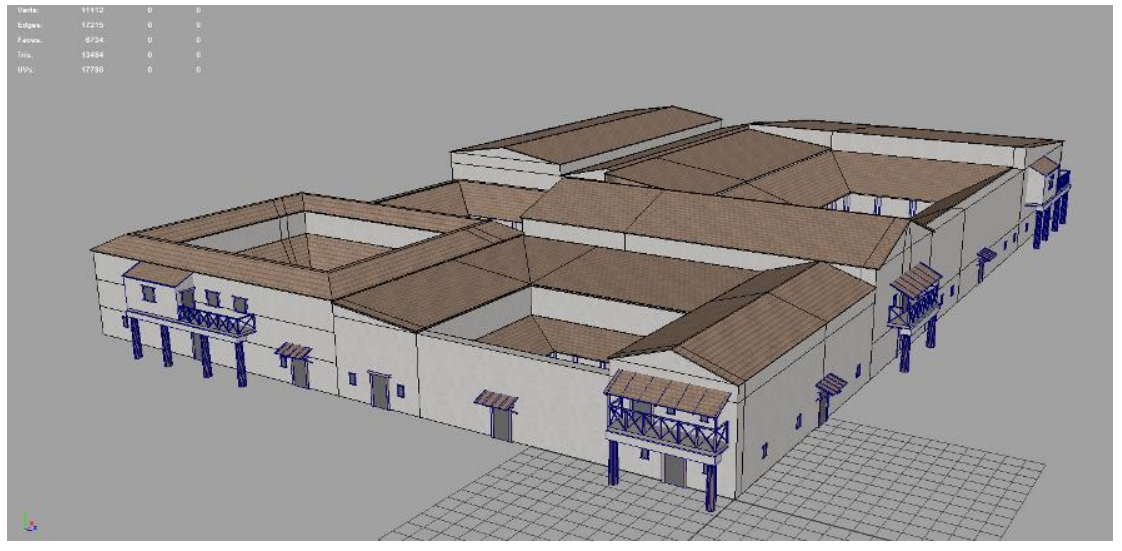

Fig.56 - Quarteirão 02.

\footnotetext{
${ }^{39}$ Em formato de "tabuleiro de xadrez", com ruas postas paralelamente umas às outras.
} 


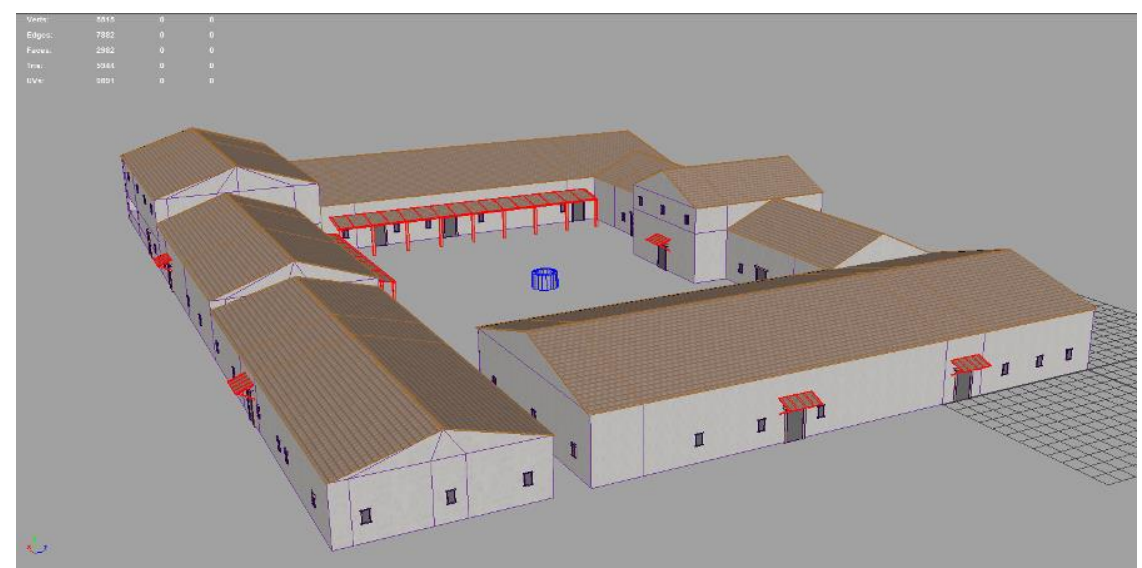

Fig. 57 - Quarteirão 03.

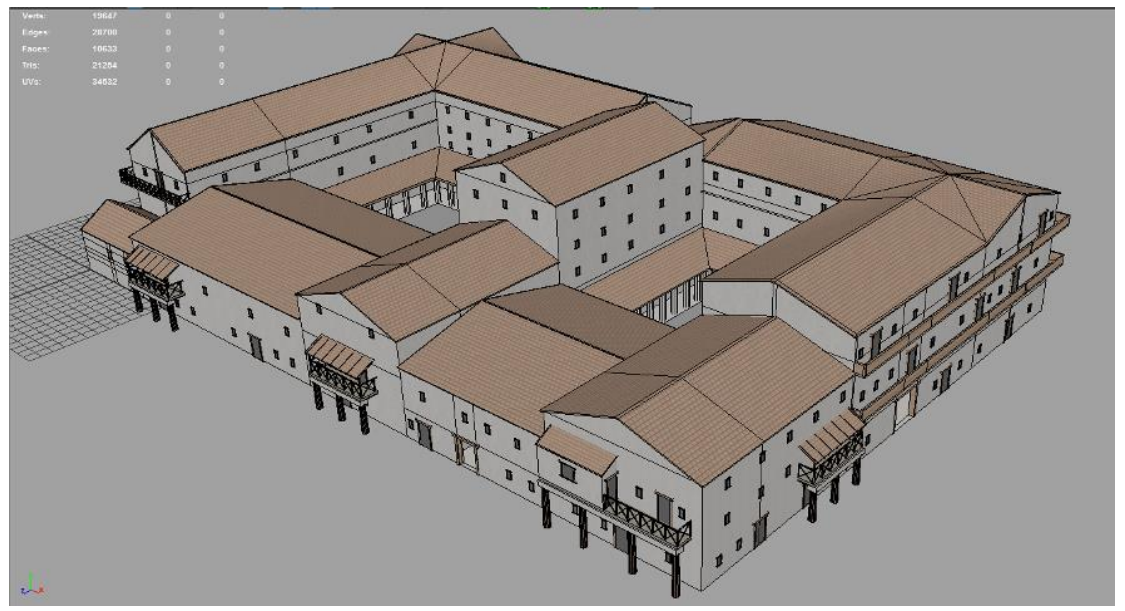

Fig. 58 - Quarteirão 04.

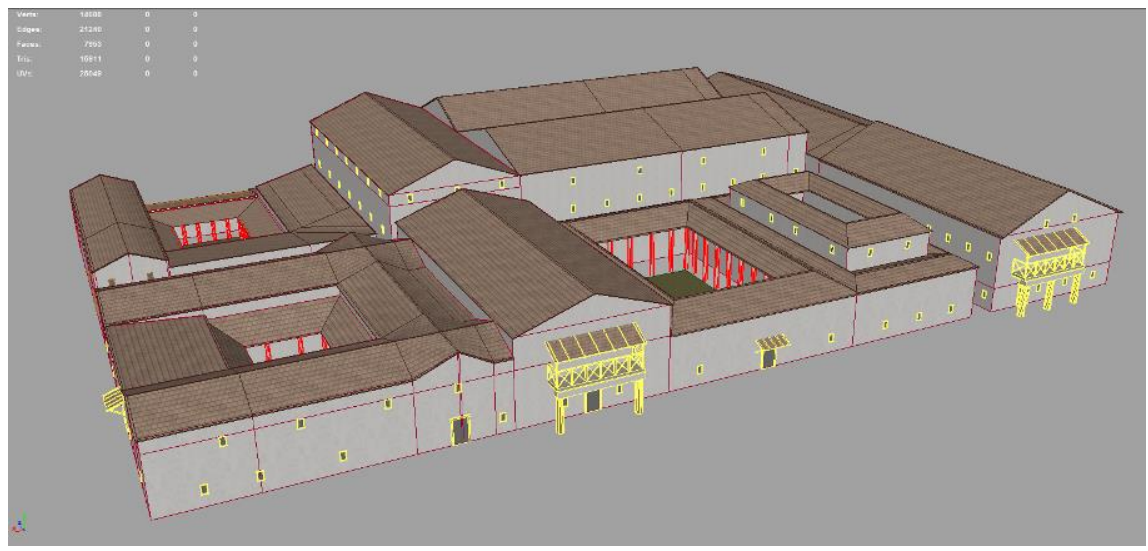

Fig. 59 - Quarteirão 05. 


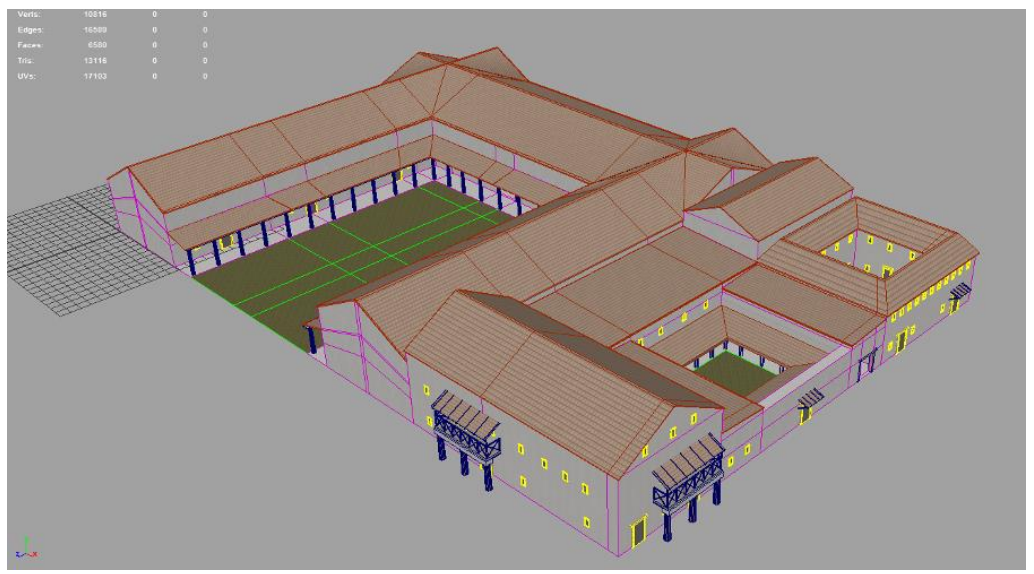

Fig. 60 - Quarteirão 06.

As insulae, então, foram remodeladas do zero. Houve uma simplificação ainda maior da malha (mesh) dos objetos tridimensionais a fim de não afetarem demais a performance do aplicativo final. Basicamente, as insulae foram divididas em dois grupos: 1) As insulae novas ficariam em uma área denominada por mim de "Aglomerado Abastado", ou seja, a parte do povoado onde estaria a Casa do Procurador, todas as domus e o fórum - essas insulae contam com texturas de paredes e madeiras mais "limpas', quase novas se comparadas às 2) insulae antigas: que compõem os demais quatro aglomerados espalhados pela paisagem, que seriam as partes "menos abastadas" de Vipasca, principalmente por uma parte deles ficar na descida da colina, em direção à oficina metalúrgica (área de grande concentração de poluentes). Assim, existem em Vipasca Antiga, quatro modelos de insulae, totalizando cindo variações (Figs. 61-64), pois um dos modelos (Insula Antiga 01) repete-se no "Aglomerado Abastado", modificando-se apenas as texturas para versões mais "limpas".

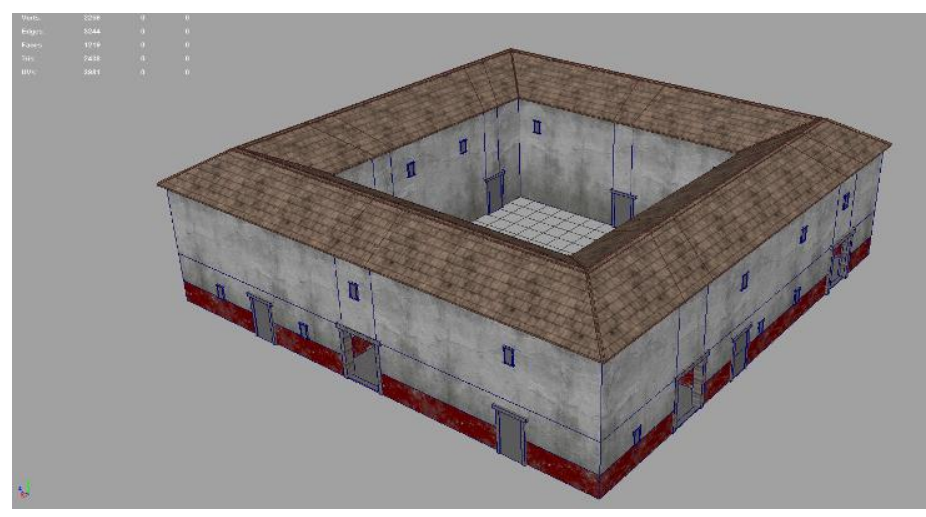

Fig. 61 - Insula Antiga 01. 


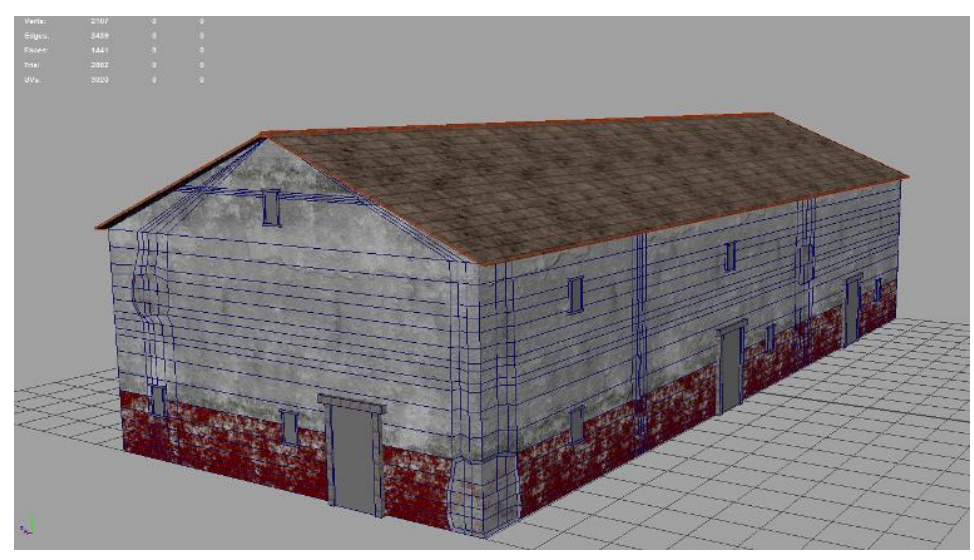

Fig. 62 - Insula Antiga 02.

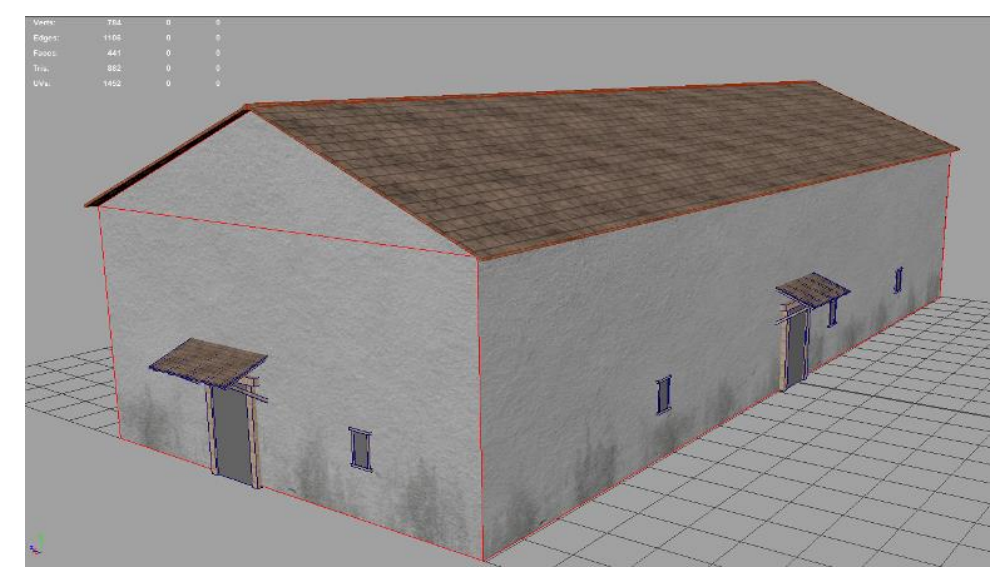

Fig. 63 - Insula Nova 01.

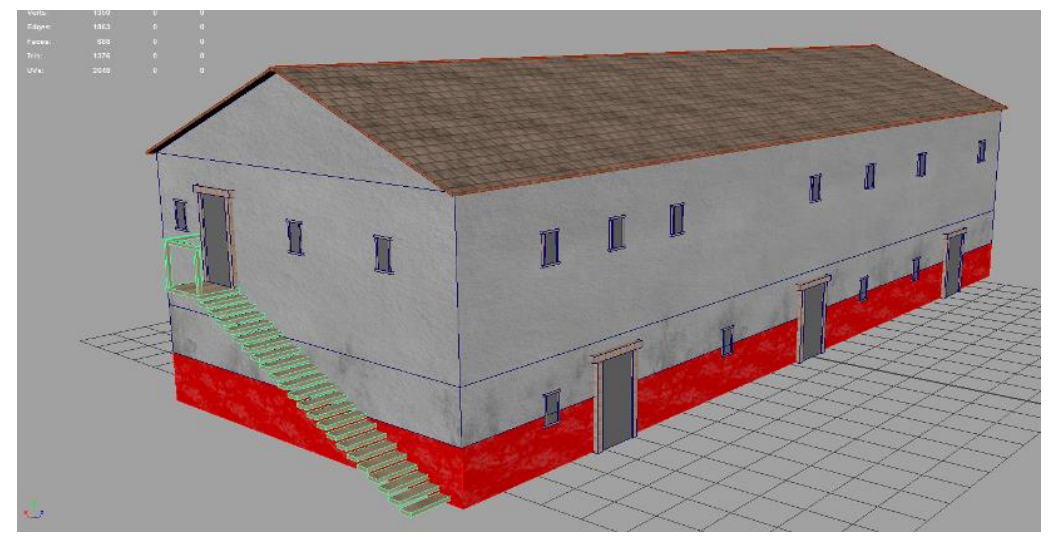

Fig. 64 - Insula Nova 02. 


\subsubsection{Oficina Metalúrgica e Fornos de Redução}

A officina aeraria (oficina metalúrgica) localizada em Azinhal, semelhantemente à Casa do Procurador, foi intervencionada pelo Projecto Vipasca e possui uma planta definida (da extensão escavada, pois se acredita que ela possa ser maior do que aquilo que está exposto). Vestígios de queimas no solo, muros de pedras e pedaços de telhas dão a entender que se trata de um edifício único conhecido até então quando se trata de mineração romana antiga. A oficina possuía uma clara separação entre a parte voltada à queima (céu aberto) e o local de armazenamento de minérios (coberto pelas telhas), conforme podemos ver em sua blocagem (Fig. 65).

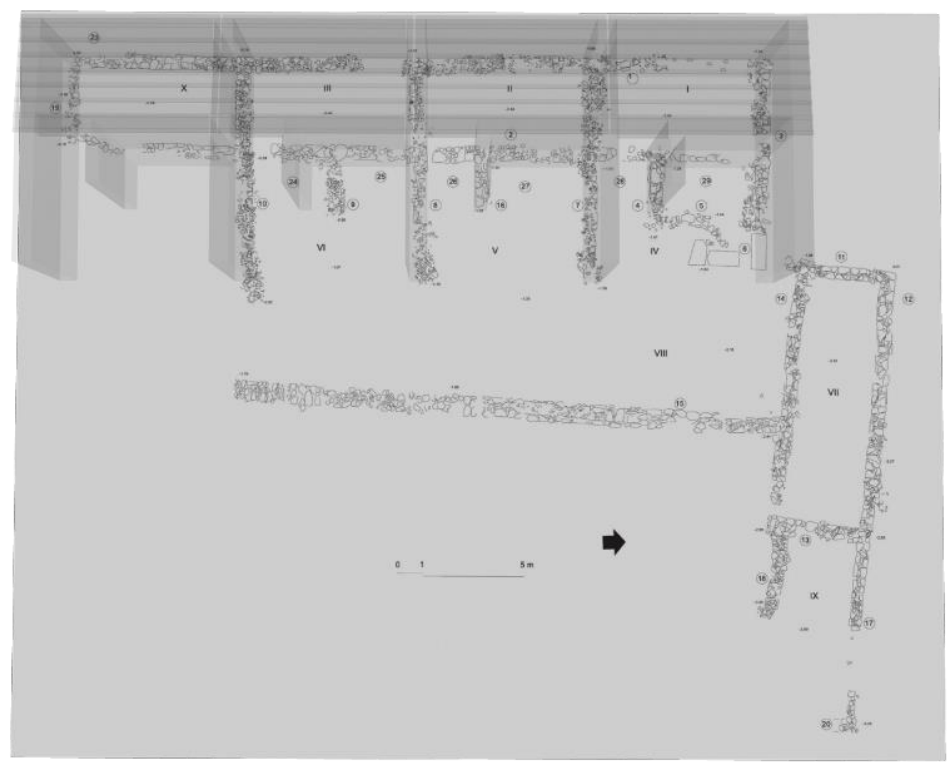

Fig. 65 - Blocagem dos compartimentos da oficina sobre sua planta (PÉREZ MACÍAS et al. 2013: 331).

A modelagem da oficina, ao contrário da maioria dos objetos do aplicativo, foi realizada diretamente no motor gráfico Unity. Para tanto, utilizaram-se muros de pedras adquiridos na Asset Store ${ }^{40}$. Os muros foram posicionados de acordo com a planta e depois cobertos com vigas de madeira e telhas (esses, modelados no Autodesk Maya).

${ }^{40}$ www.assetstore.unity3d.com/en/\#!/content/6822 
Modelos tridimensionais de escórias/minérios ${ }^{41}$, lenhas ${ }^{42}$ e fogo ${ }^{43}$ compõem o conjunto principal (Figs. 66-67).

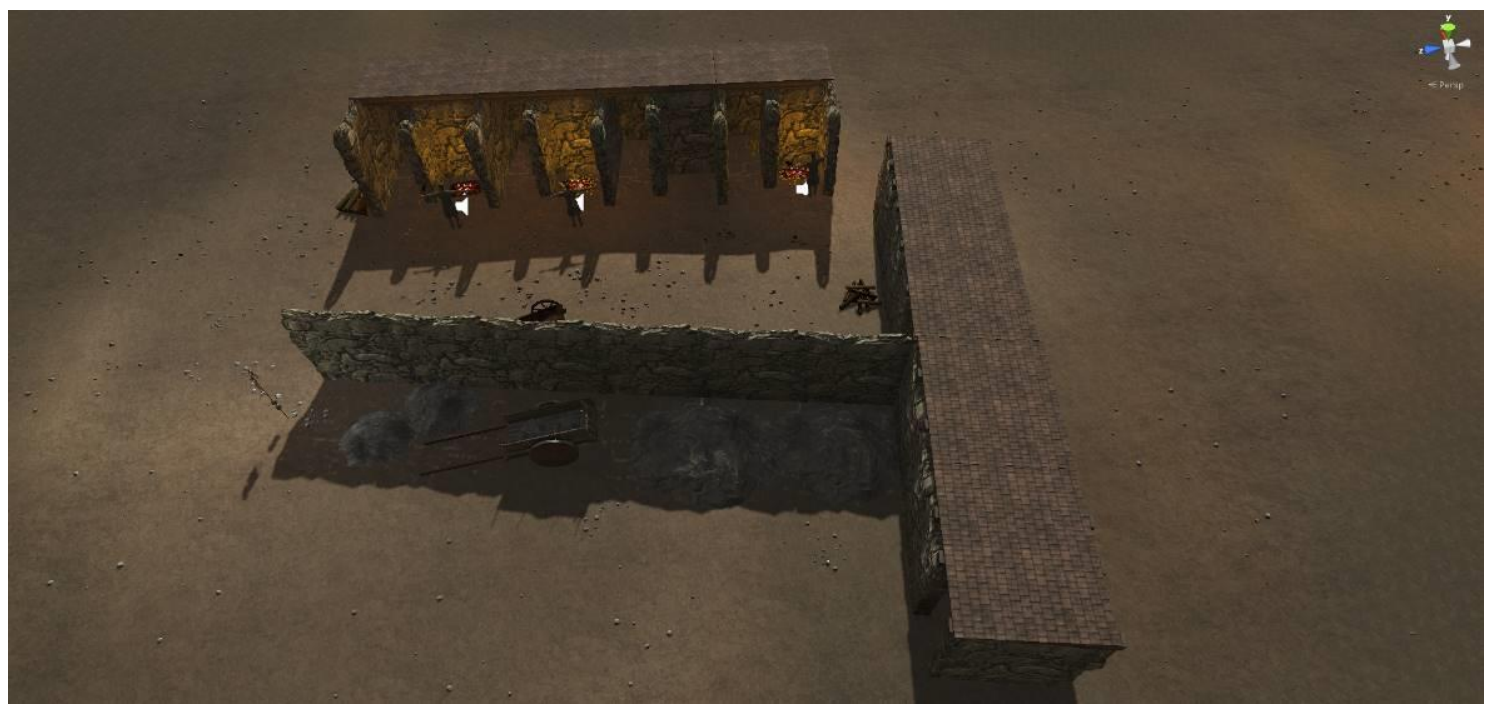

Fig. 66 - Oficina metalúrgica construída diretamente no Unity.

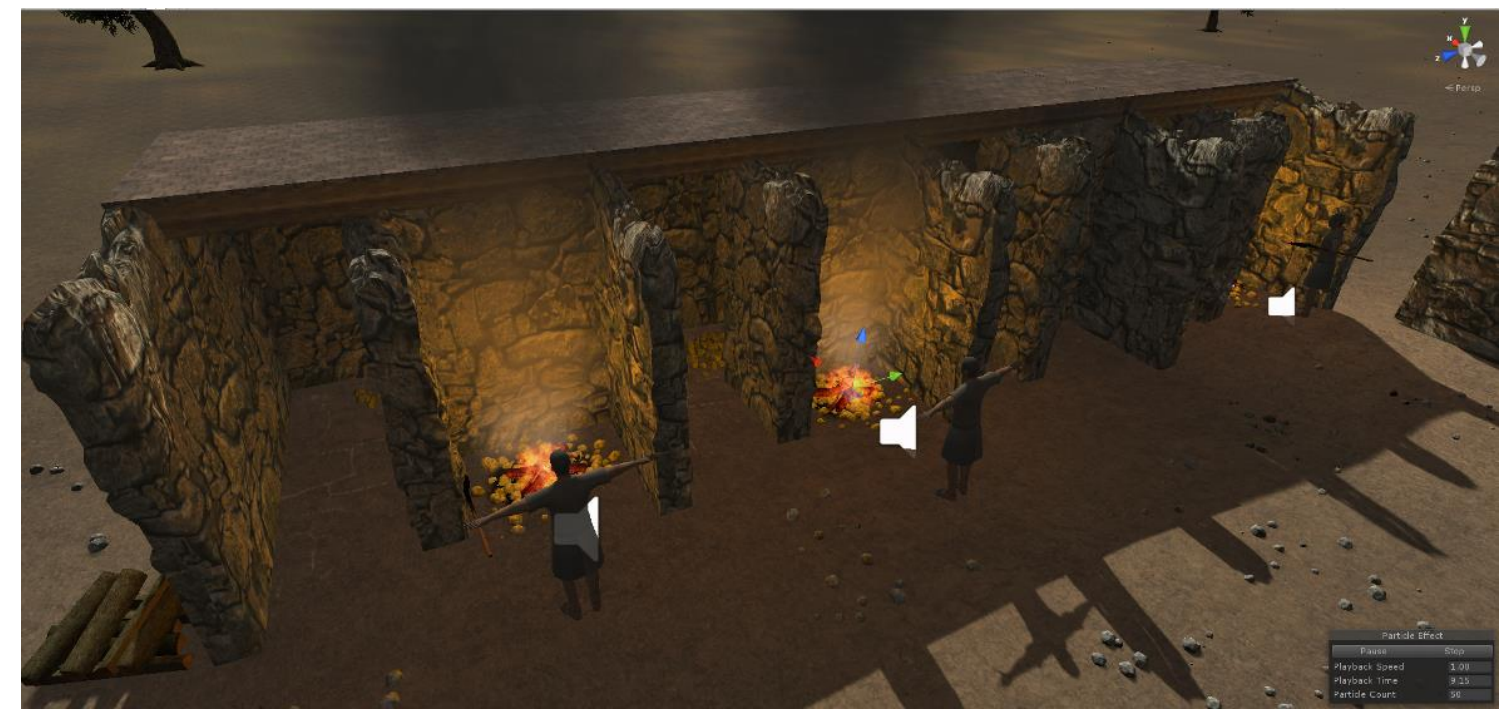

Fig. 67 - Pormenor da oficina metalúrgica construída diretamente no Unity.

\footnotetext{
${ }^{41}$ www.assetstore.unity3d.com/en/\#!/content/19856

42 www.assetstore.unity3d.com/en/?\#!/content/14281

${ }^{43}$ www.assetstore.unity3d.com/en/?\#!/content/13549
} 
Assim como a Casa do Procurador, aos vestígios da oficina metalúrgica foram fotografados em diversos ângulos para o trabalho de fotogrametria (Fig. 68). Os resultados não foram inteiramente satisfatórios devido ao fato de a área não ter sido intervencionada há alguns anos, fazendo com que houvesse dificuldade em caracterizar os aspectos mais relevantes dos vestígios por falta de limpeza. Assim, apenas um compartimento foi considerado apto para a fotogrametria, tendo seu modelo tridimensional (Fig. 69) colocado no aplicativo Vipasca Antiga posteriormente.

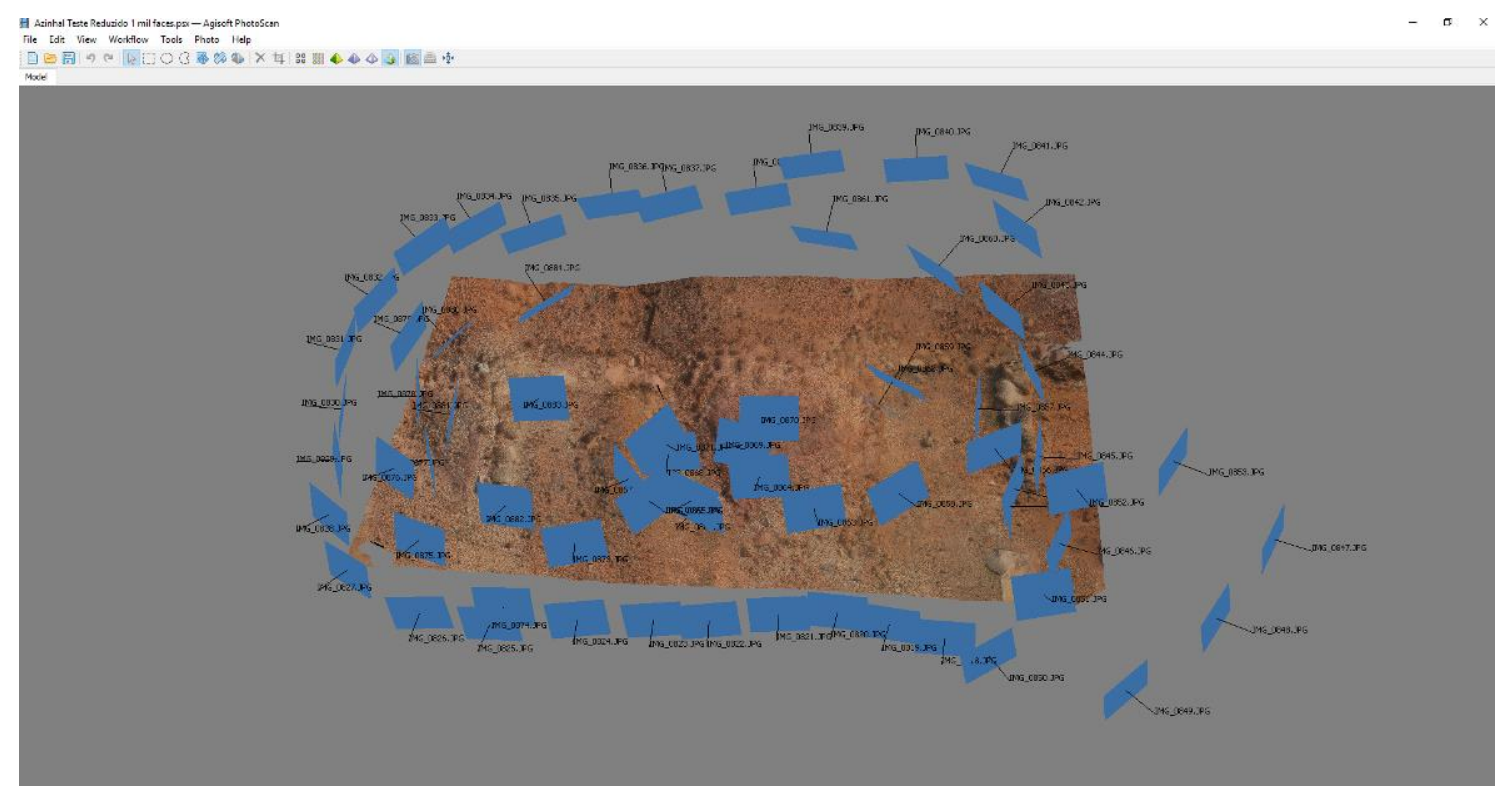

Fig. 68 - Os retângulos azuis dentro do software Agisoft Photoscan representam os posicionamentos da câmera durante as fotografias.

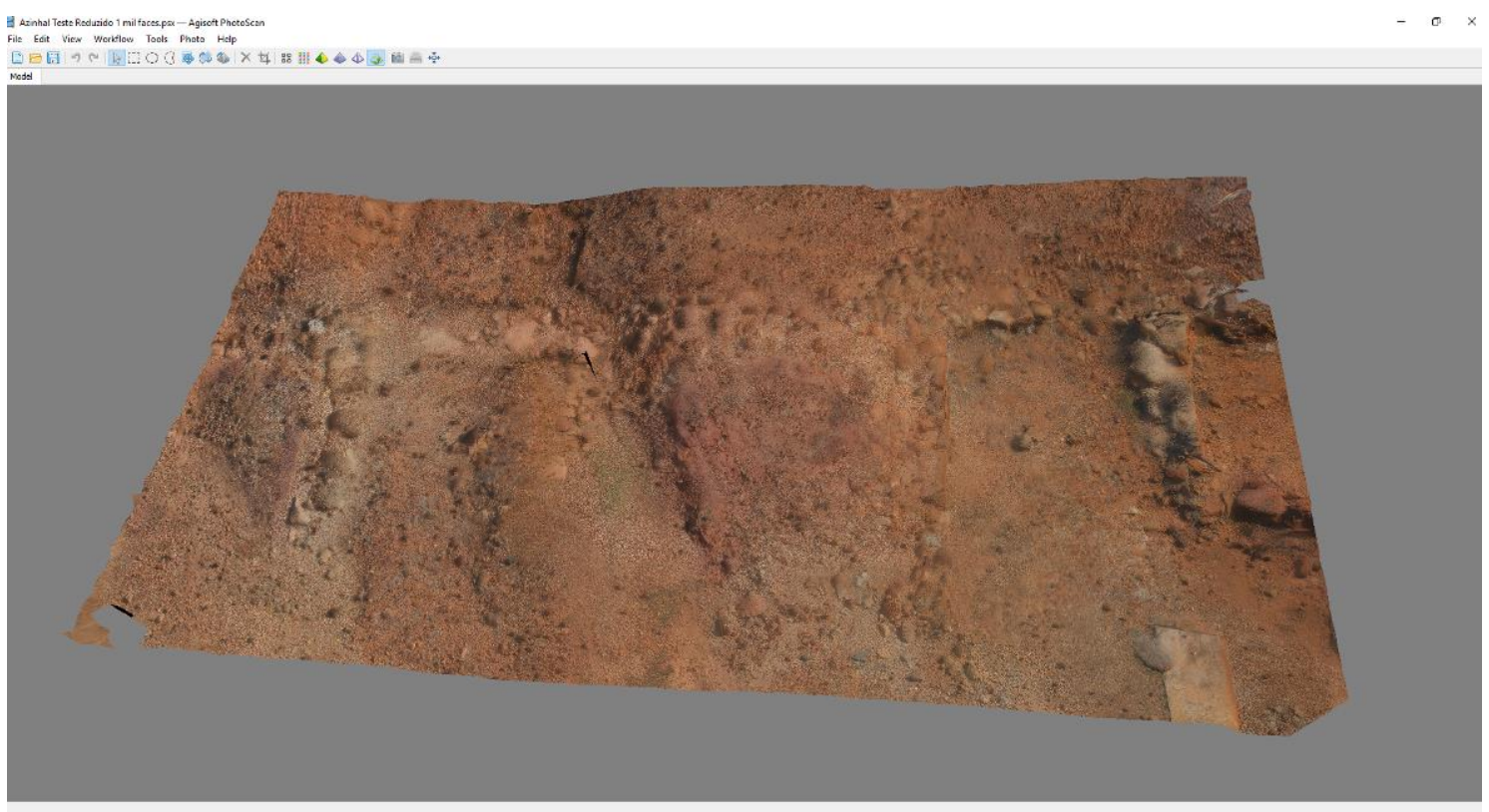

Fig. 69 - Modelo 3D final obtido a partir de fotogrametria no software Agisoft Photoscan. 
Os fornos de redução, na maioria das vezes, são uma incógnita nas paisagens mineradoras antigas. Sua própria construção não favorece a obtenção de vestígios: os fornos eram destruídos para a retirada das ligas metálicas que davam origem aos lingotes de ouro, prata ou cobre. Porém, acredita-se que os fornos tinham um formato cônico com aberturas na base e no topo, favorecendo a existência de uma corrente de ar que auxiliava na queima dos minérios e, para facilitar a quebra das estruturas, os fornos seriam produzidos em argila.

Os fornos para o aplicativo Vipasca Antiga foram modelados seguindo-se essas ideias (Fig. 70) e posicionados próximos à oficina metalúrgica, na margem oposta da Ribeira de Feitais.

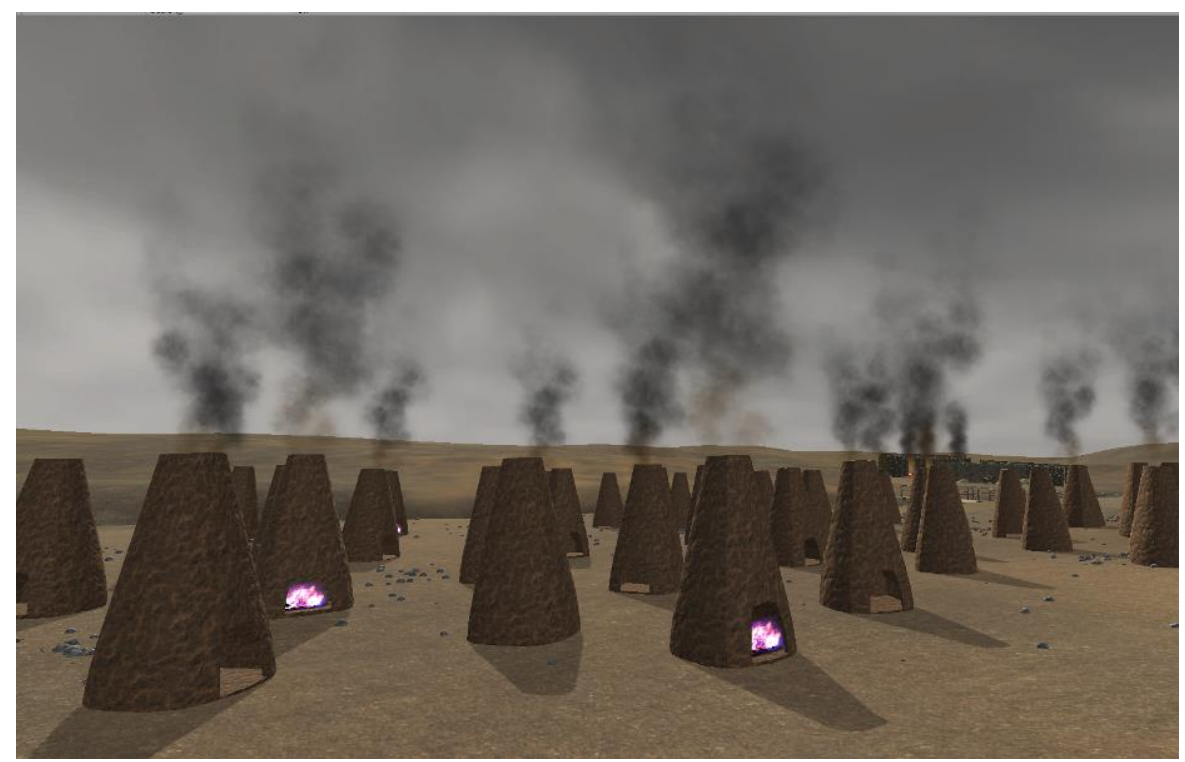

Fig. 70 - Fornos de redução no aplicativo Vipasca Antiga.

\subsubsection{Banho/Balneário}

Não há registros sobre vestígios do balneário de Vipasca, mas ele certamente foi um edifício importante no povoado, uma vez que é mencionado nas chamadas Tábuas de Bronze de Vipasca (MARTIRE 2012: 86):

A primeira placa foi encontrada em maio de 1876 durante os trabalhos efetuados pela Companhia de Mineração Transtagana em escoriais romanos abandonados. Comumente conhecida por Lex Metallis Vipascensis, ou LMV, a tábua tem $78,5 \mathrm{~cm}$ de altura por $52 \mathrm{~cm}$ de largura e possui espessura variando entre 8 e $13 \mathrm{~mm}$. Seu lado direito foi cortado no sentido da altura e possui inscrições frente e verso, 
invertidas. Apesar de primeiramente ter sido denominada "Tábula de Bronze de Aljustrel" por Álvaro d'Ors quando foi encontrada, a placa não é feita com esse material, uma vez que não há estanho em sua composição, ao contrário, foi produzida com cobre impuro proveniente da região de Aljustrel. Esse tipo de produção em cobre e chumbo fora mencionado por Plínio (XXXIII, 20). A segunda tábua, a Lex Metallis Dicta - ou LMD - foi achada entre escoriais romanos abandonados em 1906 pela empresa concessionária das minas de Aljustrel Sociétè Anonyme Belge des Mines d'Aljustrel. Ela possui $77 \mathrm{~cm}$ de altura por $55 \mathrm{~cm}$ de largura e $10 \mathrm{~mm}$ de espessura, também feita em cobre impuro, não bronze. Diferentemente da LMV, a LMD pode ser datada entre os anos 117 a 138 d.C., uma vez que existe alusão ao imperador Adriano.

A LMV estabelece a regulação dos arrendamentos de serviços dentro do território mineiro, dentre eles, o uso e manutenção do balneário. A lei faz menção ao fato de o arrendatário ter de sempre manter as caldeiras de bronze limpas e fornecer água quente para os banhos ${ }^{44}$.

Como não há vestígios locais do edifício, o balneário foi inteiramente modelado "genericamente": os principais componentes dos banhos no período entre os séculos I e II d.C. estão presentes no objeto tridimensional, a saber: o frigidarium (sala com piscina de água fria), o tepidarium (sala de vapor; sendo uma transição espacial entre o frigidário e o caldário), o caldarium (sala com piscina de água quente em tamanho menor do que o frigidário) e o peristilo (jardim colunado para simples caminhar ou praticar exercícios físicos). O modelo do balneário finalizado (Fig. 71) foi posto às margens da Ribeira de Feitais como a hipótese de facilitação de escoamento das águas das piscinas quando necessário. Contudo, deve-se ressaltar novamente: não foram encontrados ainda vestígios do balneário ou indícios de sua localização na paisagem atual de Aljustrel.

\footnotetext{
${ }^{44}$ Em minha dissertação de mestrado (MARTIRE 2012) discorri sobre os aspectos jurídicos/legislativos encontrados na LMV e na LMD. Recomendo a leitura do capítulo 3 ("A administração das minas") para aprofundamento no tema, pois foge ao escopo deste trabalho a retomada pormenorizada de toda a discussão acerca das Tábuas de Bronze de Vipasca. Do mesmo modo, para a transcrição completa das Tábuas e notas contextuais introdutórias, recomendo a leitura da obra publicada pelo Município de Aljustrel (MARTINS 2012)
} 


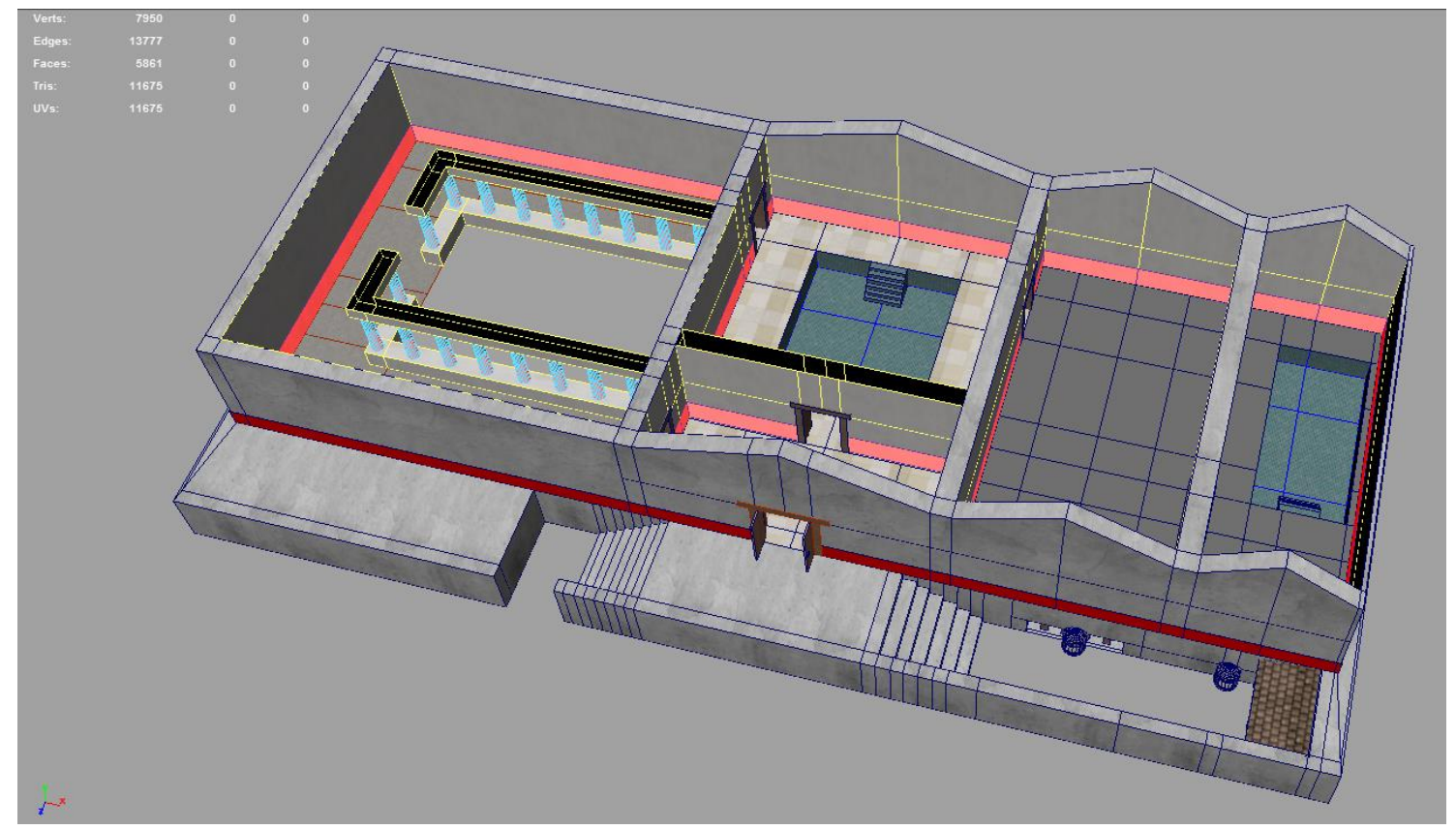

Fig. 71 - Balneário: o frigidário está logo após a porta de entrada do edifício, o tepidário é a sala intermediária entre o frigidário e o caldário (local com a menor piscina); as colunas formam o peristilo.

\subsubsection{Pisão}

O caso do pisão romano é semelhante ao do balneário. Ele é mencionado na legislação, mas não temos vestígios a céu aberto. Contudo, é provável que estivesse localizado próximo à Ribeira de Feitais devido à grande necessidade de volume de água tanto para a limpeza dos panos como para a movimentação da roda hidráulica conectada ao mecanismo dos malhos que percutiam os tecidos.

Embora muitos vestígios de lavanderias existam em sítios romanos, todas elas empregam força de trabalho humana para pisoar os tecidos (geralmente são edifícios cobertos com pequenos tanques de água nos quais os trabalhadores passavam o dia a pisar os panos): a hipótese do arqueólogo Artur Martins - e que foi modelada para o Vipasca Antiga - é a de que o pisão de Vipasca fosse tracionado pela água (muito provavelmente da ribeira). Desse modo, buscamos referências contemporâneas (que se baseiam em tradições muitas vezes seculares) para a modelagem do mecanismo. As principais fontes acabaram sendo a dos pisões existentes em Aldeia do Pontido (Fanfe, Portugal) e Tabuadela (Montalegre, Portugal) (Fig. 72). 


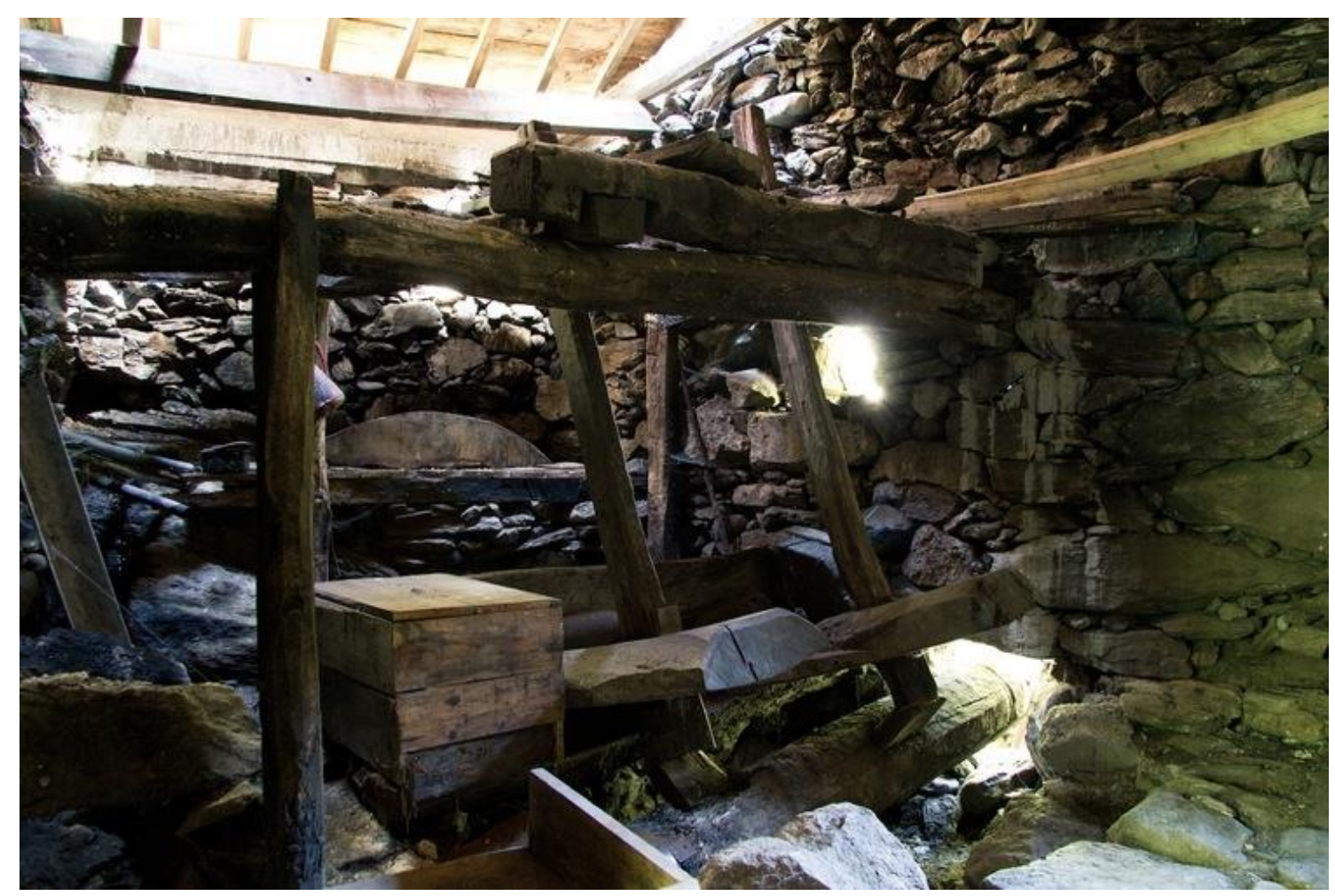

Fig. 72 - Pisão de Tabuadela. In: http://www.saberfazer.org/research/2011/9/8/o-piso-detabuadela)

A modelagem do conjunto do edifício do pisão foi realizada no Autodesk Maya, bem como o mecanismo e sua animação. $\mathrm{O}$ modelo finalizado foi exportado em formato .FBX (Fig. 73).

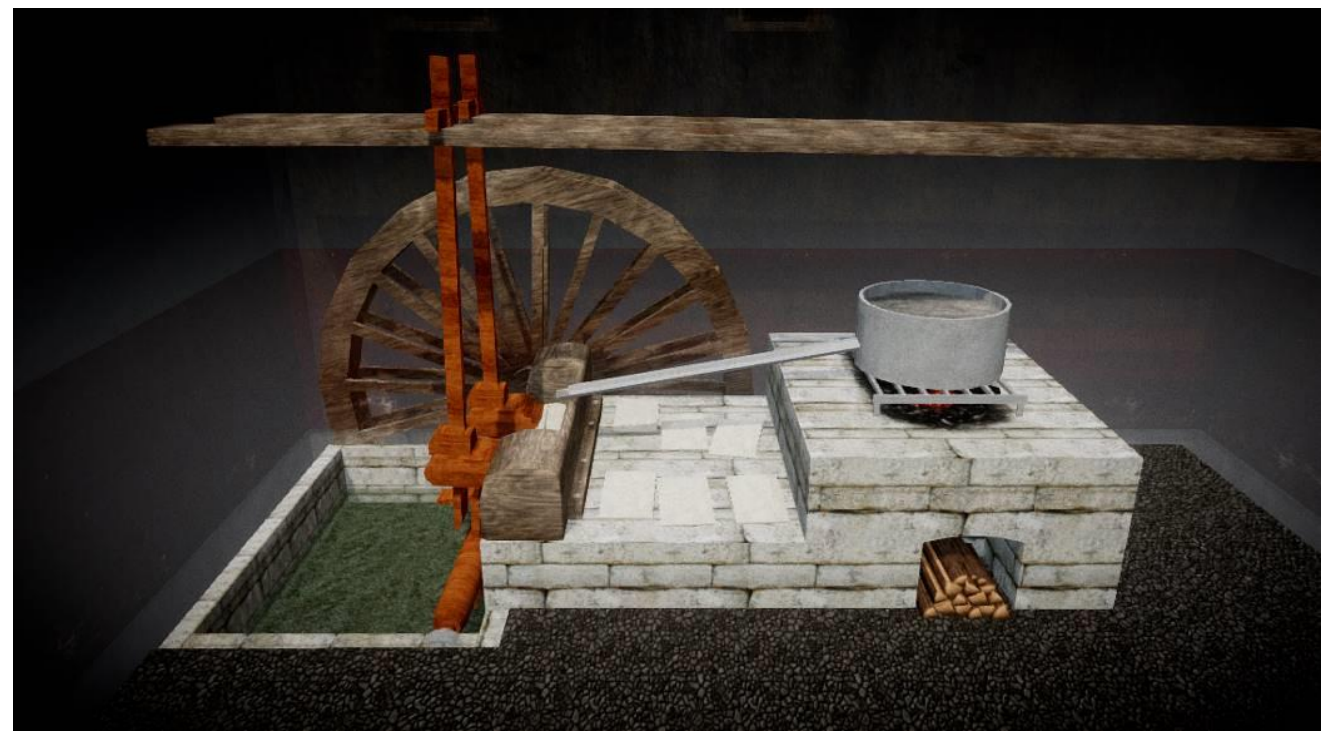

Fig. 73 - Mecanismo do pisão modelado em destaque. 


\subsubsection{Roda hidráulica e Sarilhos nos poços}

Os lençóis freáticos são uma constante preocupação nas atividades mineradoras. Em período romano não foi diferente: para soerguer grandes quantidades de água para fora das galerias de extração mineral, eram empregados parafusos de Arquimedes ou então rodas hidráulicas (mais funcionais, embora necessitassem de maior espaço). As rodas eram transportadas desmontadas e depois tinham suas peças remontadas dentro das minas, obedecendo, muitas vezes, a uma numeração constante nas madeiras.

Tratando-se de áreas de mineração, um dos exemplos mais bem conservados de rodas hidráulicas está em Riotinto, Espanha (OJEDA CALVO 2006). Para a modelagem da roda que está nas galerias do aplicativo Vipasca Antiga, foi usada como referência a construção em escala 1:1 de um exemplar presente no Museo Minero de Riotinto (Fig. 74).

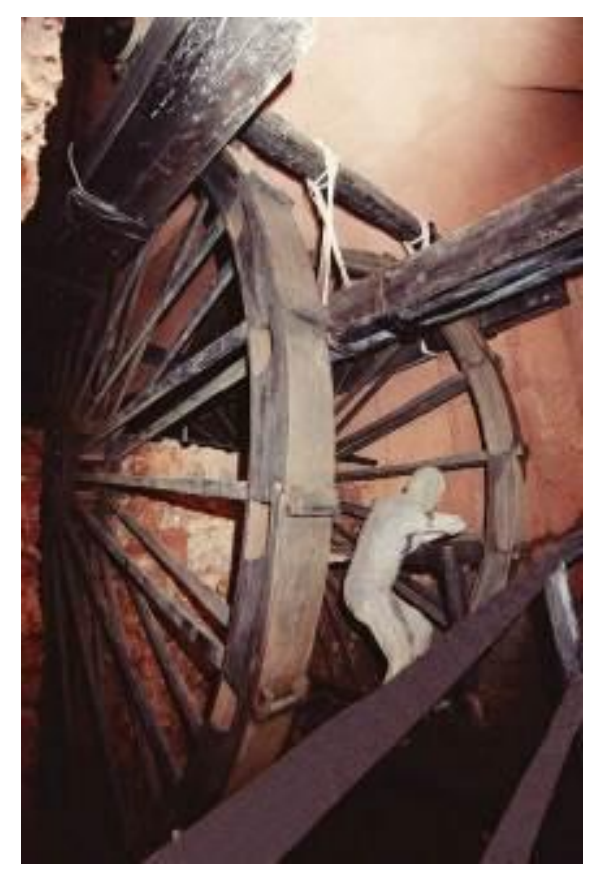

Fig. 74 - Reconstituição de roda em escala 1:1 no Museo Minero de Riotinto. Foto: Aquilino Delgado Domínguez.

O modelo tridimensional, porém, difere da roda de Riotinto por contar com tábuas que unem as duas metades do mecanismo: a sugestão de Artur Martins foi a de que a roda em Vipasca fosse tracionada com o homem dentro dela, semelhante a uma "roda de 
hamster". O modelo final foi animado - já com o homem caminhando - no próprio Autodesk Maya e depois exportado para o Unity (Figs. 75).

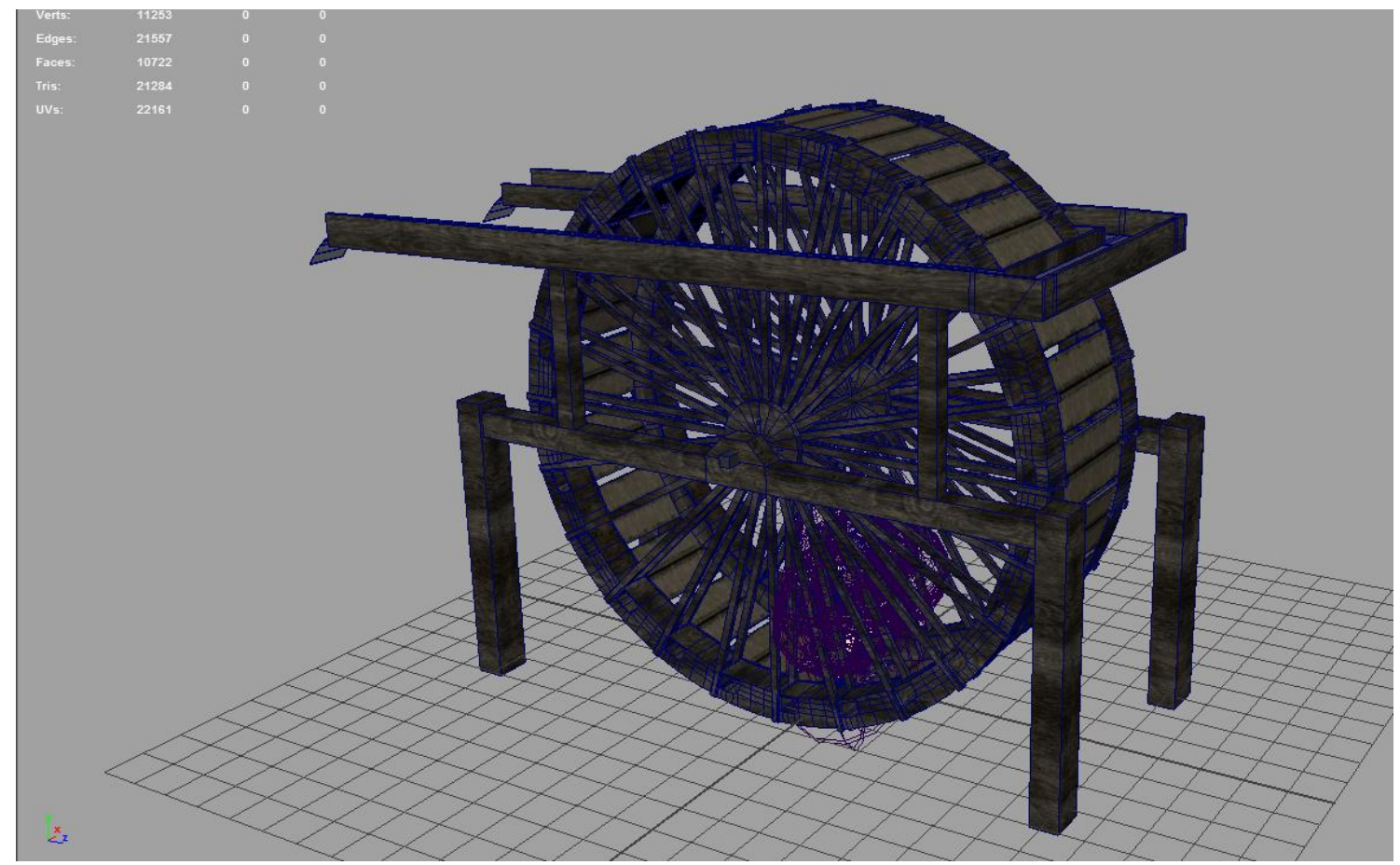

Fig. 75 - Roda hidráulica.

Os sarilhos dos poços que estão no topo do chapéu de ferro em Vipasca Antiga foram modelados a partir da maquete que está em exposição no Museu de Aljustrel. A maior dificuldade encontrada no caso dos sarilhos não foi a modelagem do objeto em si, mas, sim, o seu posicionamento no terreno. O motor gráfico Unity não conta com um sistema de criar concavidades na malha do terreno, impossibilitando fazer "furos" com precisão. Desse modo, a solução foi, literalmente, "afundar" uma parte do chapéu de ferro e cobrir as imperfeições com uma "tampa" de terra modelada, que serviu de base para o sarilho (Figs. 76-77). 


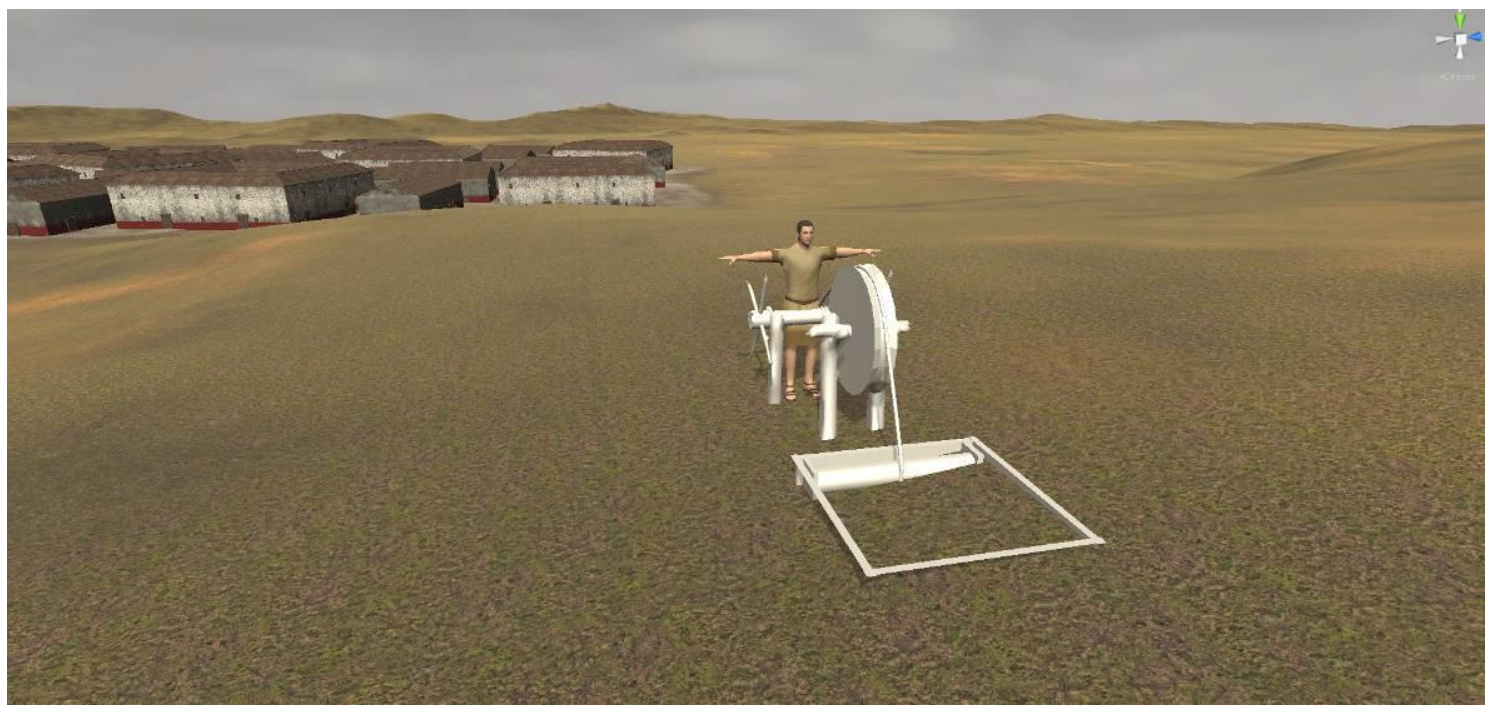

Fig. 76 - Sarilho posicionado sobre o chapéu de ferro: impossibilidade de fazer "buracos" na malha dentro do Unity.

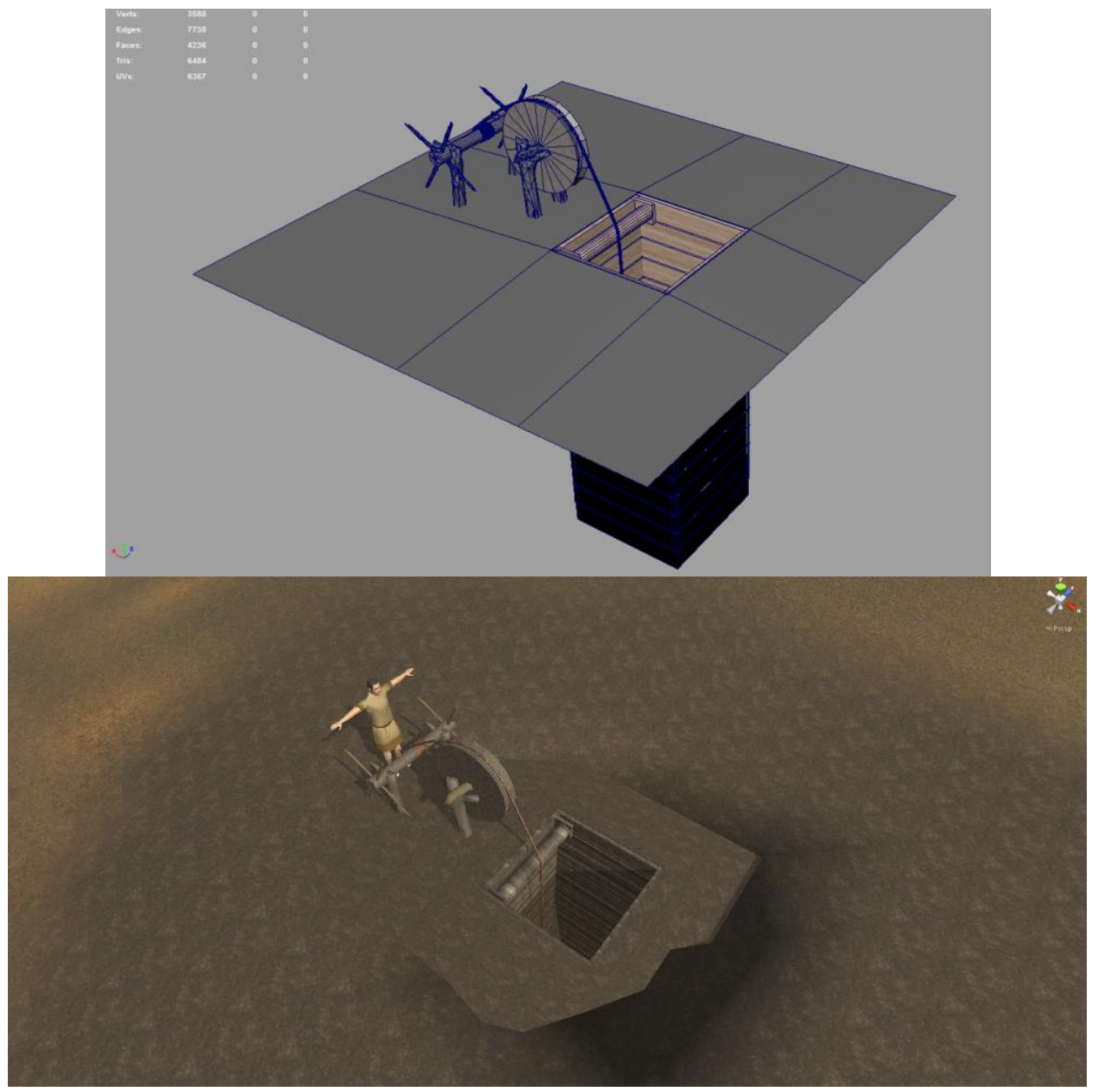

Fig. 77 - Solução para o posicionamento do sarilho: a modelagem de uma cobertura emulando terra. 


\subsubsection{Tavernas, Oficinas, Padarias e Açougue}

As modelagens dos elementos comerciais de Vipasca Antiga tiveram por base, em sua maioria, os vestígios encontrados em Pompeia, Herculano e Óstia Antiga. Não há registros de tais comércios na paisagem arqueológica da atual Aljustrel, contudo, eram elementos comuns a todo assentamento romano antigo, movimentando a vida local.

Tanto a taverna como a padaria foram inspiradas nos ambientes que existem nas três localidades acima mencionadas. Muitas vezes não havia uma separação nítida entre tavernas e padarias, podendo ambos os locais vender mesma mercadoria, porém, para facilitar a navegação do usuário no aplicativo, optei por construir dois ambientes distintos. No caso das tavernas, foi modelado o balcão com os recipientes cerâmicos que continham preparados alimentícios (Fig. 78). As padarias também tiveram seus fornos, balcões e pães modelados e posicionados antes da exportação para o Unity (Fig. 79).

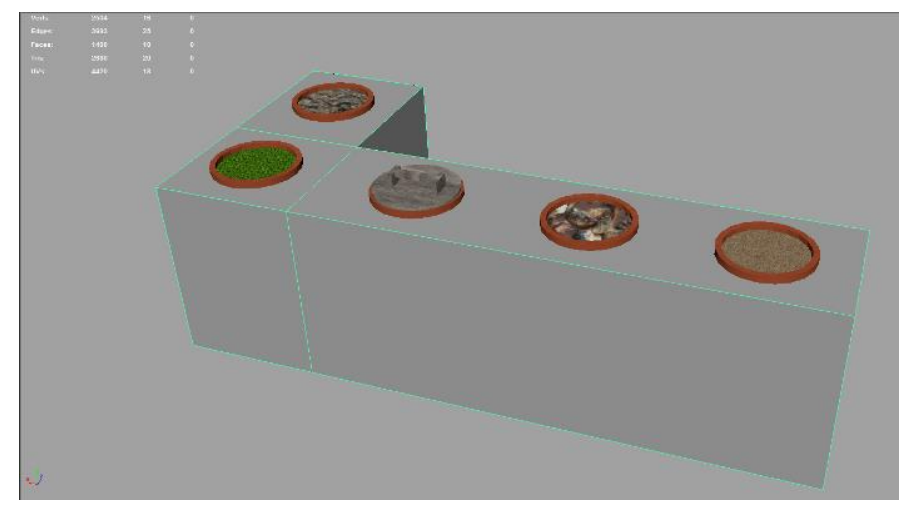

Fig. 78 - Balcão da taverna.

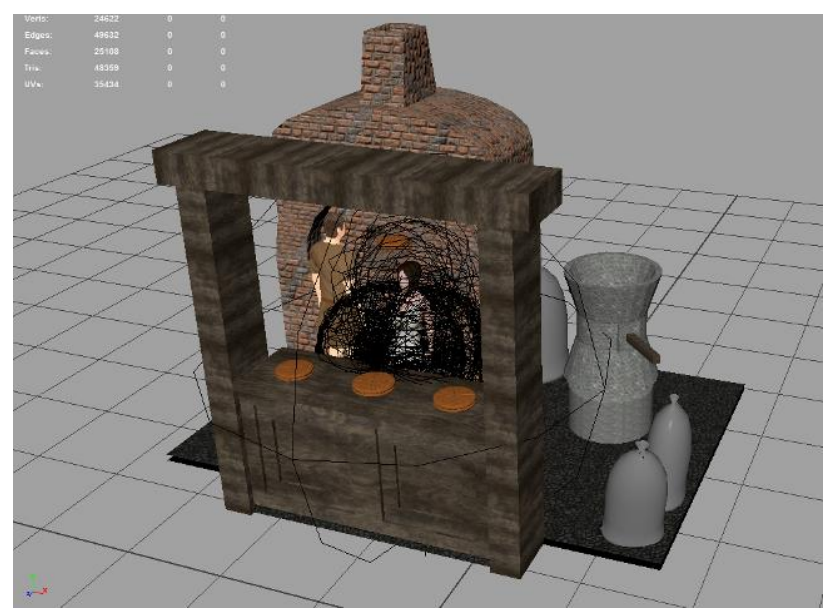

Fig. 79 - Padaria. 
As oficinas e o açougue foram modelados tendo por inspiração ilustrações encontradas em livros e na internet. Ao contrário das tavernas, onde havia um elemento básico a quase todas (o balcão com os recipientes), as oficinas de cerâmica e os açougues variavam bastante, embora, no caso das oficinas, muito provavelmente um número grande contasse com tornos de modelagem no século II d.C.. Desse modo, foram colocados apenas tornos e algumas cerâmicas no caso das oficinas (Fig. 80), e algumas peças de carne no açougue (Fig. 81): soluções simples, mas que não escapam daquilo que havia na Antiguidade.

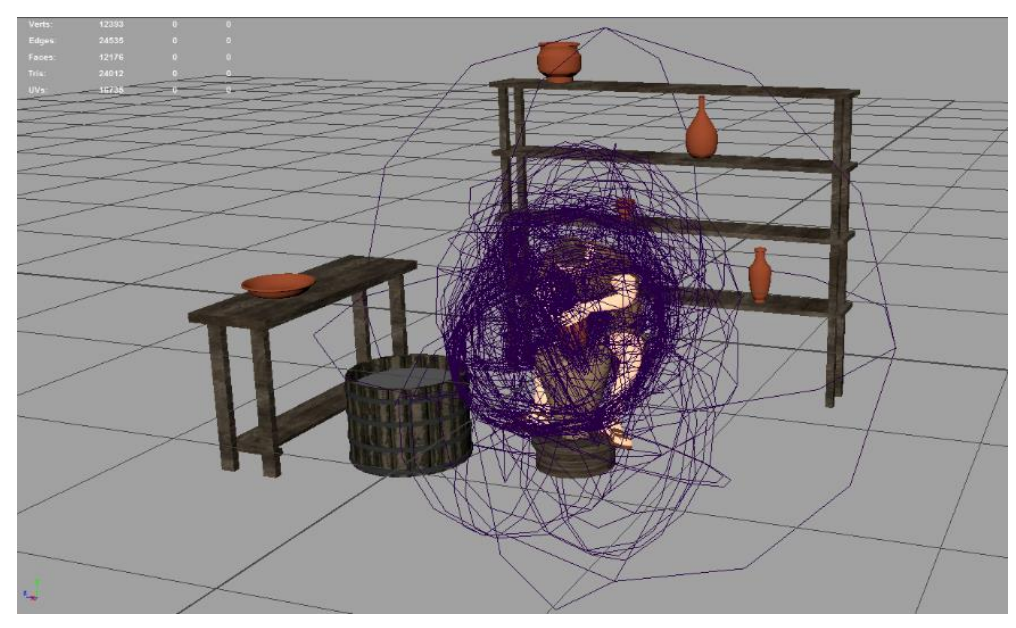

Fig. 80 - Oficina do ceramista.

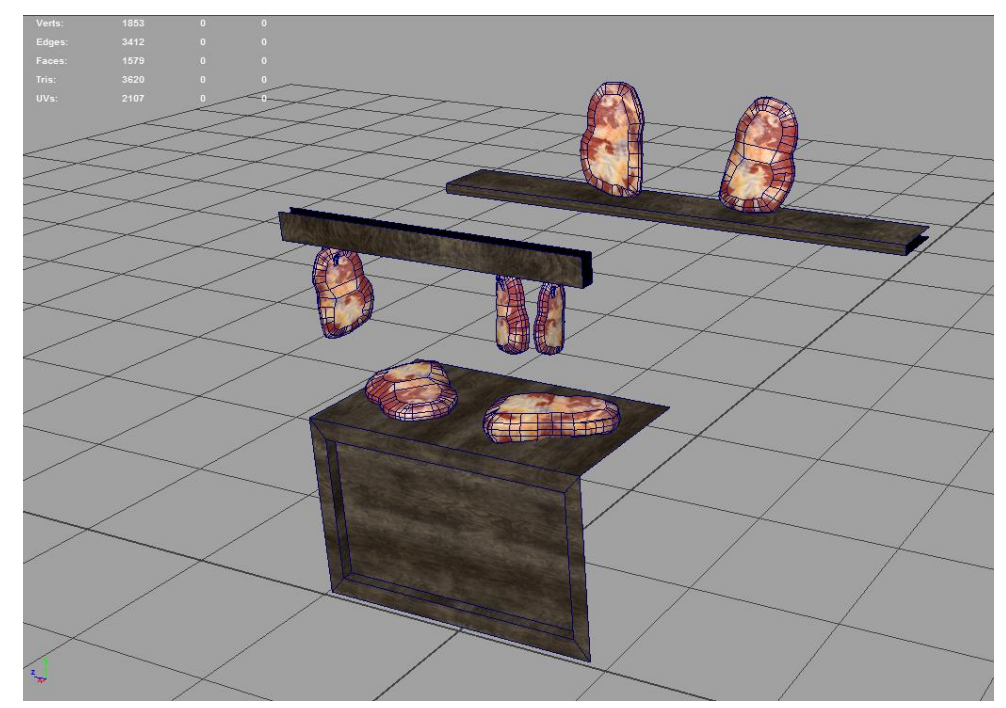

Fig. 81 - Açougue. 


\subsubsection{Galerias de mineração}

As galerias de extração mineral foram modeladas a partir do que foi observado pessoalmente em Trêsminas (Vila Pouca de Aguiar, Portugal) e Aljustrel. Em Trêsminas pude visitar, durante minha pesquisa de Mestrado (2009-2012), as galerias subterrâneas do complexo mineiro da região e realizar uma série de fotografias (por exemplo, Fig. 82): essas referências me auxiliaram a compor os modelos das galerias em que os homens trabalhavam com picaretas para retirar o minério do chapéu de ferro (Fig. 83).

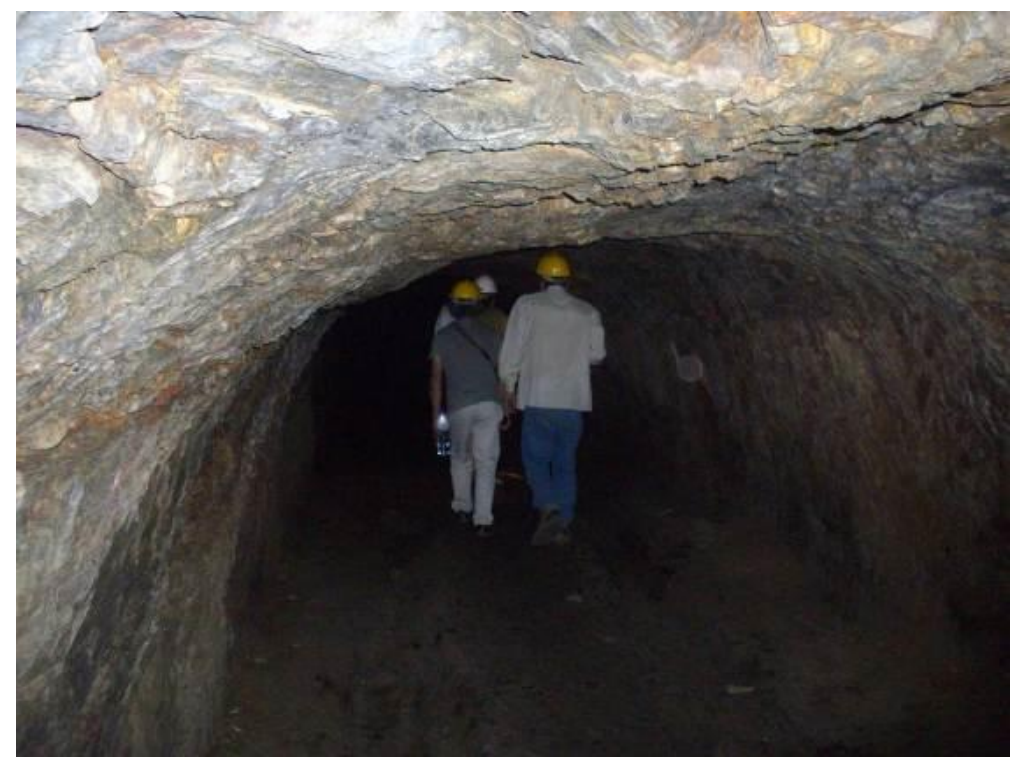

Fig. 82 - Galeria dos Alargamentos, Trêsminas. Vila Pouca de Aguiar, 2010. A galeria tem 140 $\mathrm{m}$ de comprimento por $2 \mathrm{~m}$ de largura e $1,5 \mathrm{~m}$ de altura (tendo sido aberta a $50 \mathrm{~m}$ abaixo do topo da exploração). Recebe esse nome devido a quatro alargamentos que permitiam a passagem de carros de transporte (como podemos notar pelos sulcos no chão) nos dois sentidos que alcançavam as estradas para levar o material à lavagem e trituração.

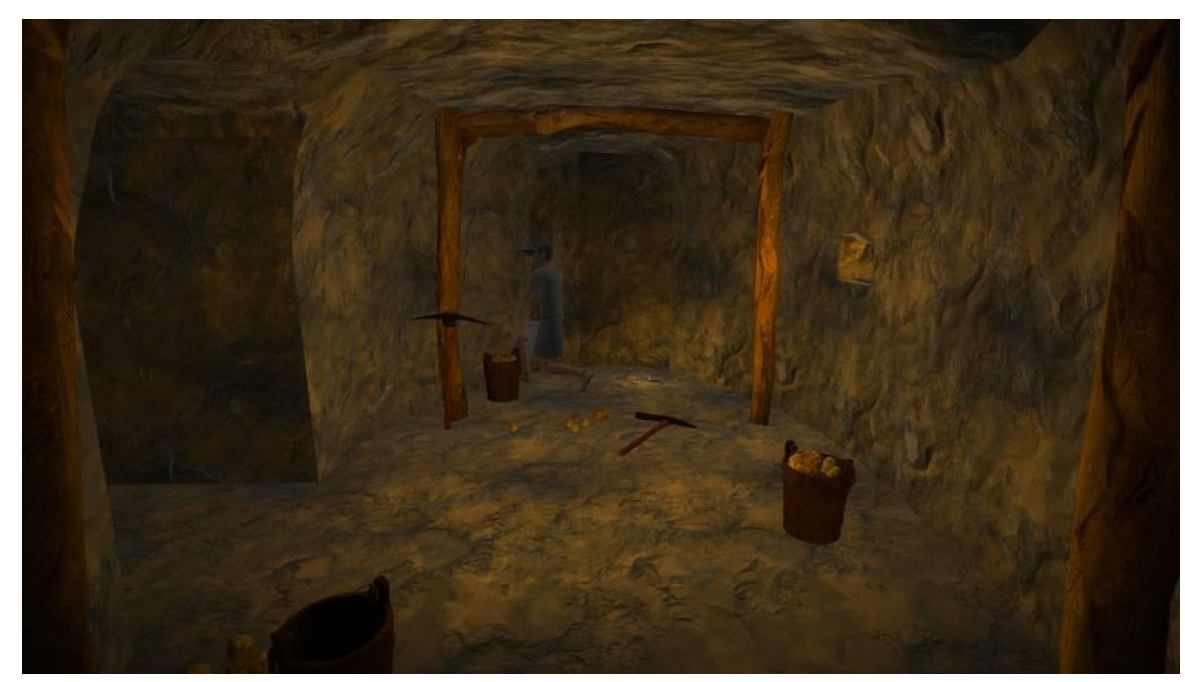

Fig. 83 - Galeria de extração mineral dentro do aplicativo Vipasca Antiga. 
A galeria/túnel na qual a câmera é animada e passa por um trabalhador caminhando agachado (Fig. 84) foi baseada nos vestígios das galerias romanas existentes no interior do chapéu de ferro em Aljustrel. Eram galerias de diâmetro diminuto, fazendo com que os homens ou as crianças conseguissem atravessá-las apenas debruçando-se sobre o chão, como podemos ver na Fig. 85. O seu modelo tridimensional foi modelado também no Autodesk Maya e exportado para o Unity, sendo acoplado ao modelo das galerias onde estão os homens com picaretas e a roda hidráulica (Fig. 86).

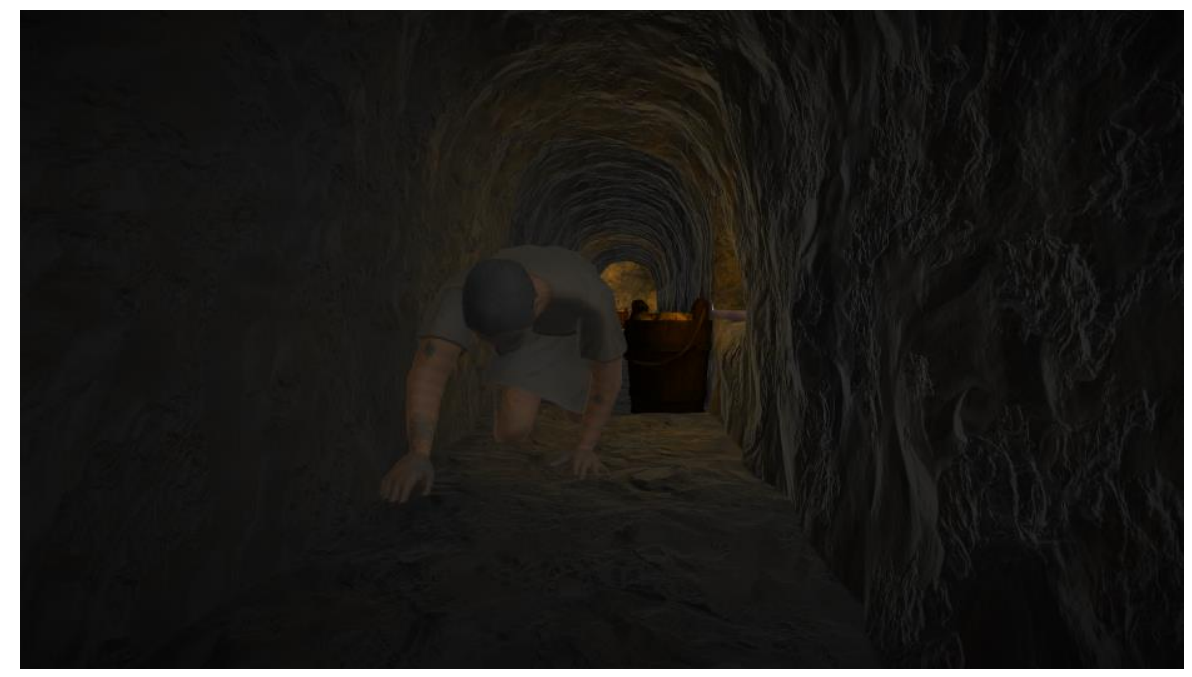

Fig. 84 - Câmera animada dentro da galeria mostrando trabalhador movimentando-se.

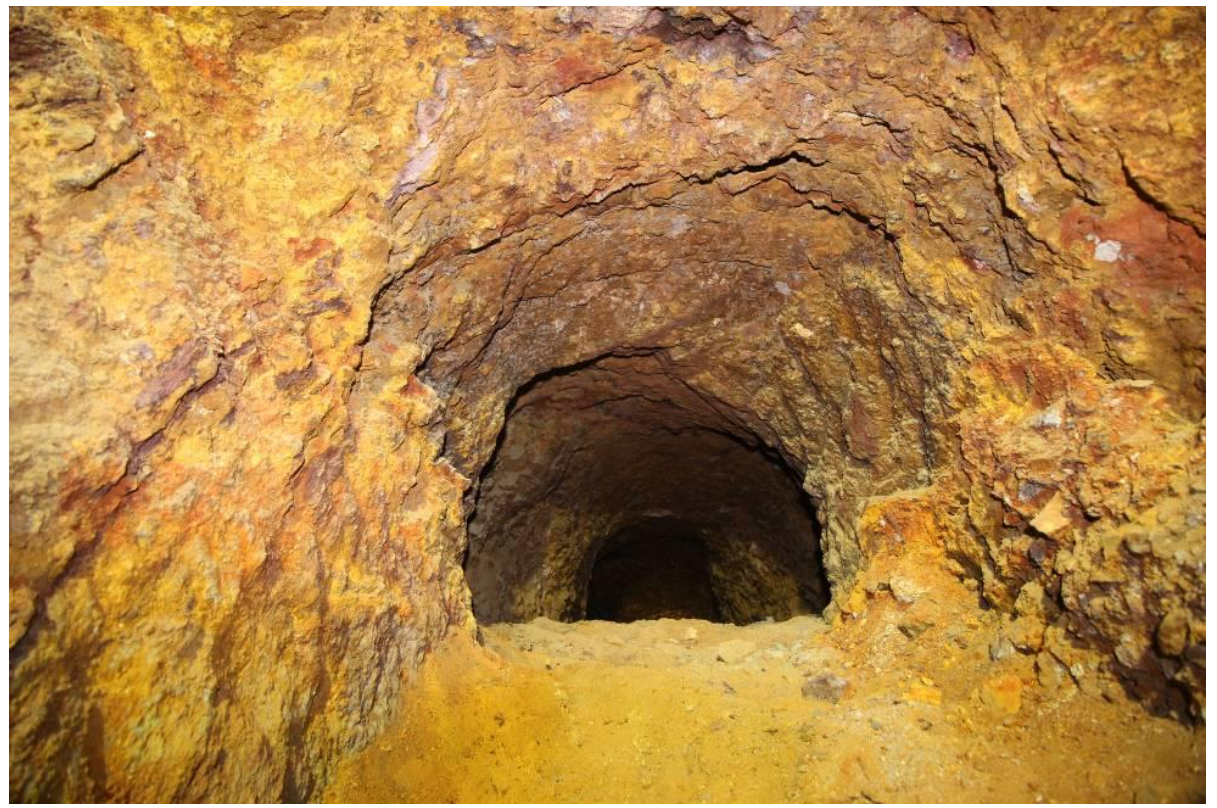

Fig. 85 - Galeria romana no chapéu de ferro em Aljustrel, 2016. Foto: Artur Martins. 


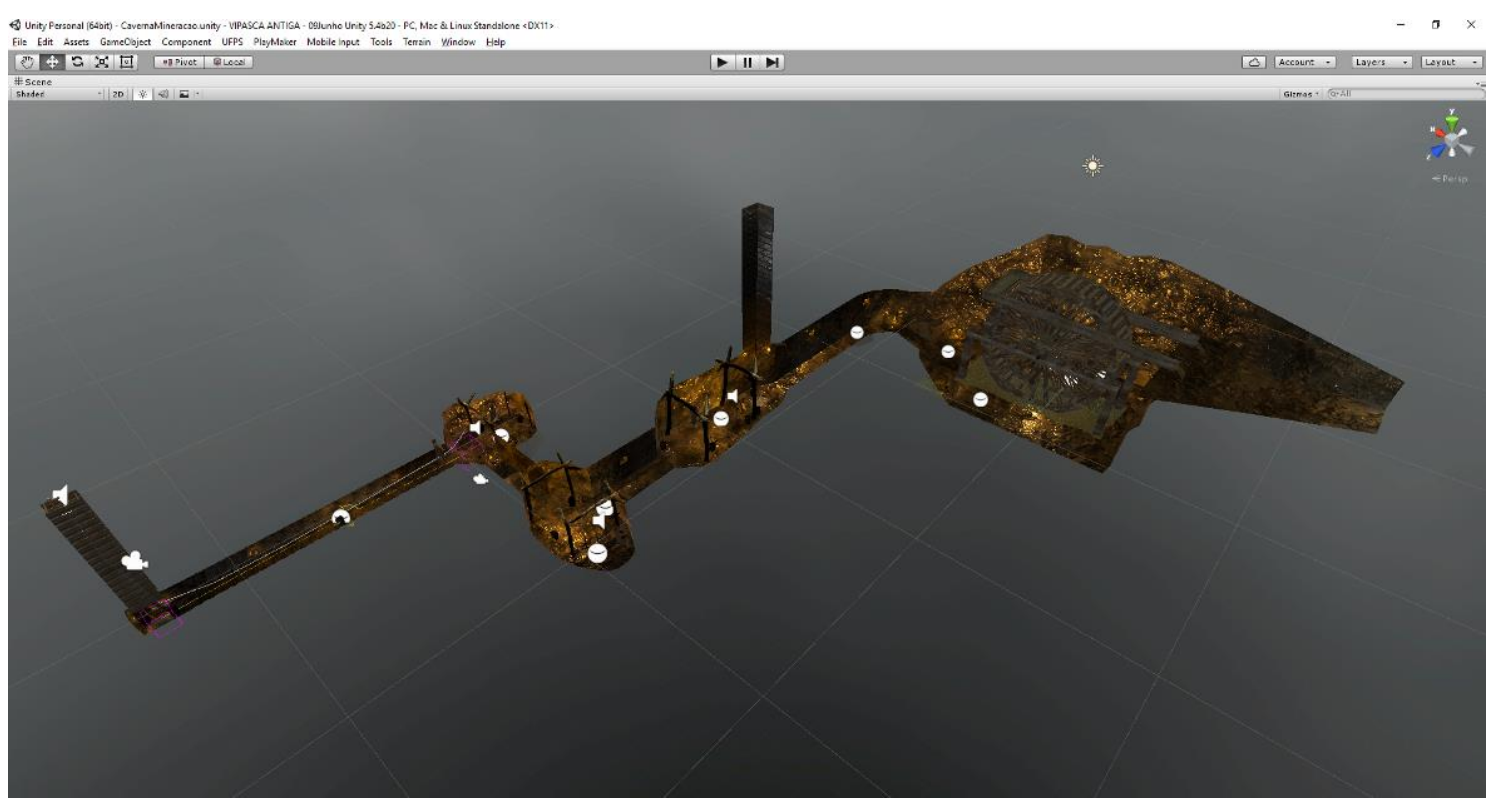

Fig. 86 - Conjunto final das galerias no Unity.

\subsubsection{Pessoas}

Todas as pessoas presentes no aplicativo Vipasca Antiga foram adquiridas na loja online Turbosquid ${ }^{45}$ (Fig. 87): a modelagem inorgânica de modelos tridimensionais é extremamente complexa e requer o treinamento de habilidades específicas, ficando ainda mais difícil de ser realizada quando se trata de modelos para motores gráficos - todos os objetos devem ser low-poly, ou seja, conter um número pequeno de polígonos para não afetar negativamente a performance do jogo/aplicativo. $\mathrm{O}$ processo de desenvolvimento nos casos de modelos low-poly costuma ser o inverso: primeiro modela-se uma versão própria para animações ou renderizações estáticas que, devido à própria exigência de detalhamento nesses tipos de produção, contêm um número muito alto de polígonos (alcançando, muitas vezes, alguns milhões); quando finalizado, esse modelo extremamente detalhado passa por um processo denominado retopologia que, como o nome indica, é a arte de se refazer a topologia de um objeto tridimensional - em outras palavras, um novo objeto é modelado por cima do original, mas contando com o menor número de polígonos possível. A retopologia é essencial para modelos low-poly, pois sem esse trabalho o processamento do aplicativo exigiria demais do computador, ficando, até mesmo, inviável em algumas situações.

\footnotetext{
${ }^{45}$ www.turbosquid.com/3d-models/3d-ancient-roman-people-model/842628
} 

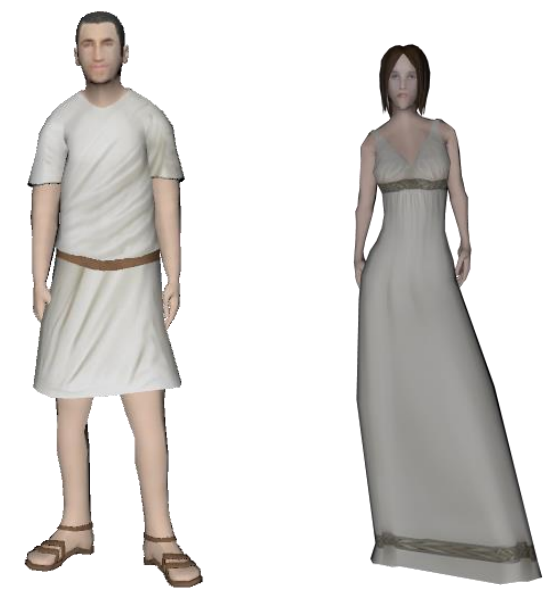

Fig. 87 - Modelos de pessoas utilizados no aplicativo Vipasca Antiga.

Tanto o rigging ${ }^{46}$ (colocação de esqueleto articulado) dos modelos quanto suas animações são do site Mixamo. A plataforma Mixamo, da empresa Adobe, permite "rigar" qualquer modelo automaticamente, apenas posicionando sobre ele as junções principais do corpo (joelhos, cotovelos, pescoço etc.); depois, basta escolher as animações que deseja aplicar ao modelo e editar suas características básicas (velocidade, altura/distância dos braços, temperamento etc.), salvando todo o pacote de animações e modelo "rigado" em formato .FBX para Unity (Fig. 88).

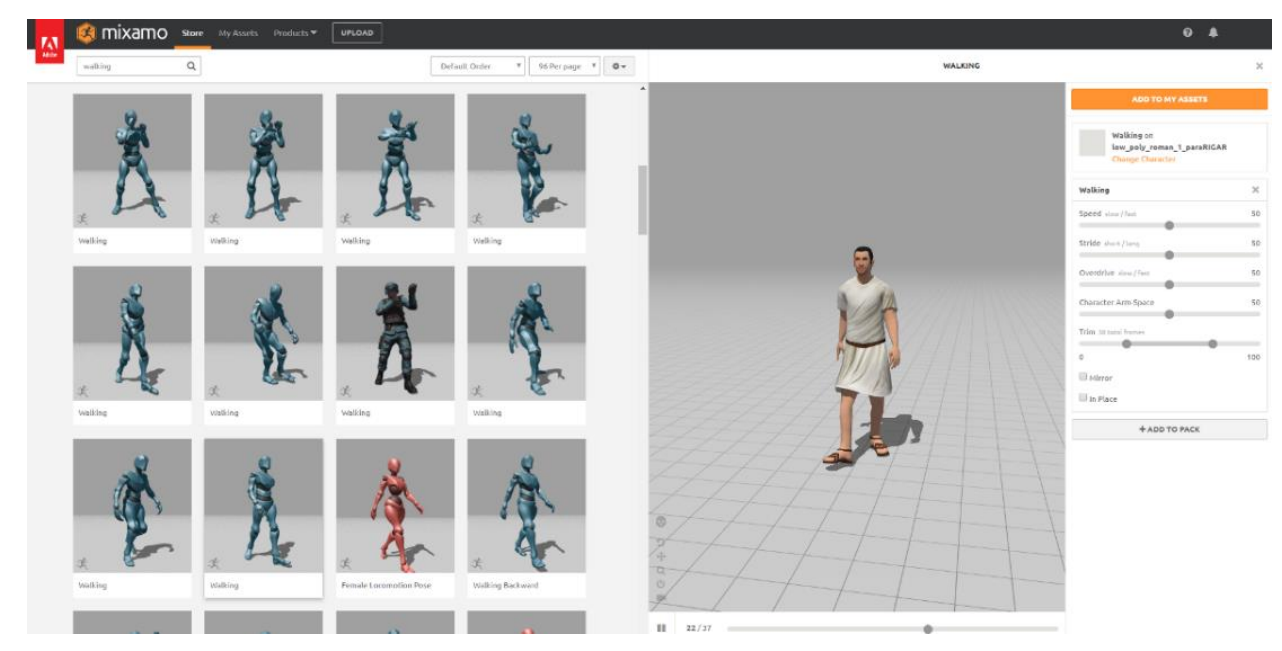

Fig. 88 - Interface da plataforma Adobe Mixamo.

${ }^{46}$ Mais informações: https://en.wikipedia.org/wiki/Skeletal_animation (Acesso em 12/07/2016) 
No total, 34 animações masculinas e 10 animações femininas foram editadas no Mixamo e aplicadas aos NPCs ${ }^{47}$ no aplicativo Vipasca Antiga (Fig. 89).
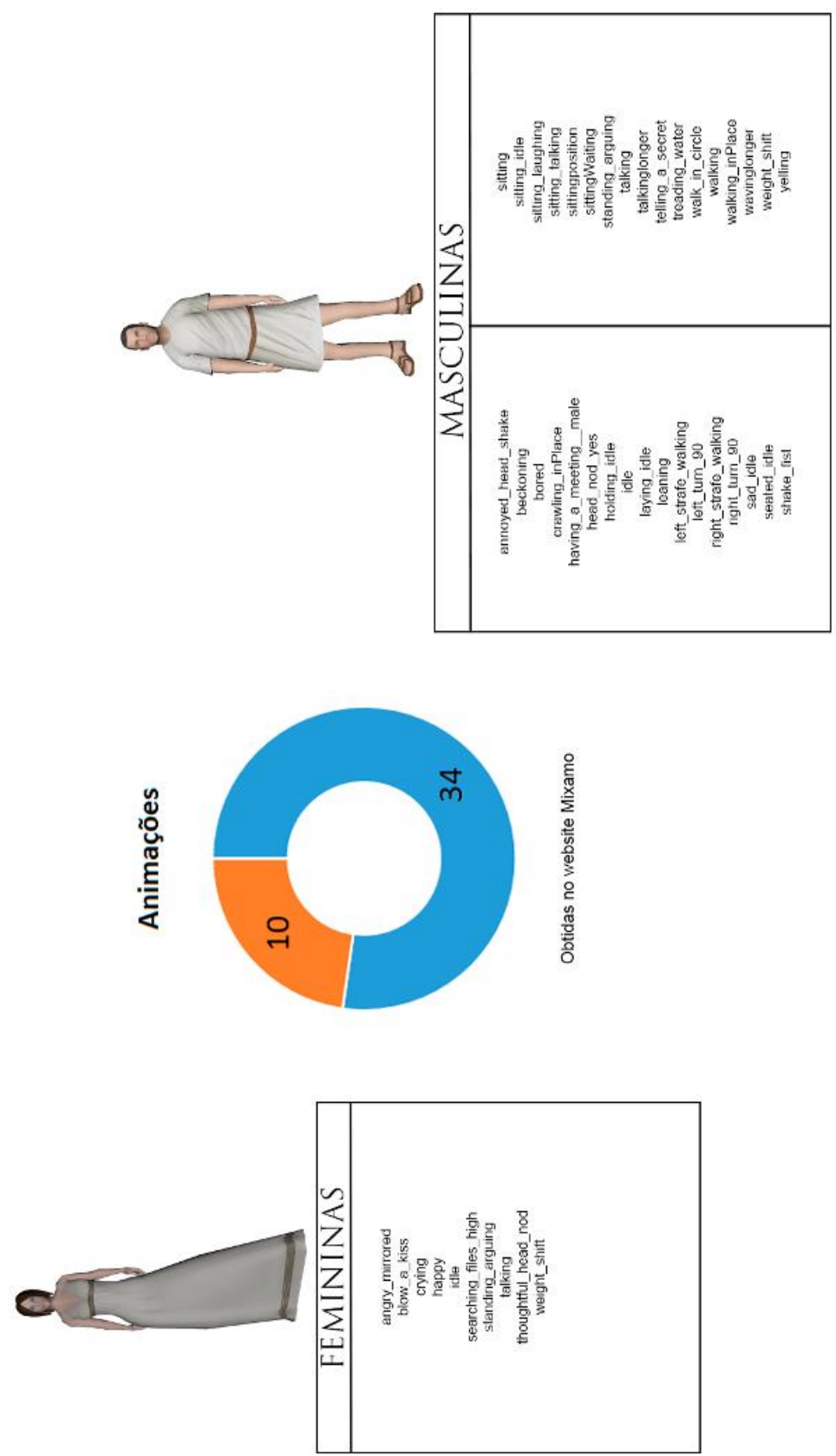

Fig. 89 - Gráfico com o total de animações e tabela com a lista das animações utilizadas.

47 Non-Playable Characters, ou seja, personagens do jogo com os quais apenas interagimos, não os incorporando como jogadores. Dito de outro modo: personagens coadjuvantes. Mais informações: https://en.wikipedia.org/wiki/Non-player_character (Acesso em 12/07/2016) 


\section{INTERATIVIDADE/PROGRAMAÇÃO}

\subsection{Player}

O primeiro componente colocado no terreno do aplicativo foi o jogador (player) em si: somente com ele temos noção exata das escalas dos demais objetos, bem como a visualização de perto das texturas pintadas no terreno (que se apresentam mescladas em camadas).

Embora o Unity forneça um jogador (First Person Character Controller) em sua pasta de assets básicos, a animação da movimentação ainda não está totalmente fluida, muitas vezes parecendo que estamos controlando um "robô" em cena. Para contornar esse problema, foi utilizado o asset UFPS: Ultimate FPS ${ }^{48}$.

O UFPS é um player profissional que possui movimentação semelhante a dos jogos famosos em primeira pessoa (e tem correspondência total com gamepads ${ }^{49}$, tal como o do Xbox 360, configurado dentro do aplicativo). Em seu painel de controle é possível configurar, por exemplo, a aceleração, a velocidade em corrida, a altura do pulo, o agachamento, a sensibilidade do mouse (responsável pela visualização, emulando a cabeça do jogador) e também a altura do jogador dentro do ambiente virtual tridimensional (nesse caso, ficou estabelecida a altura de 1,65m) (Fig. 90).

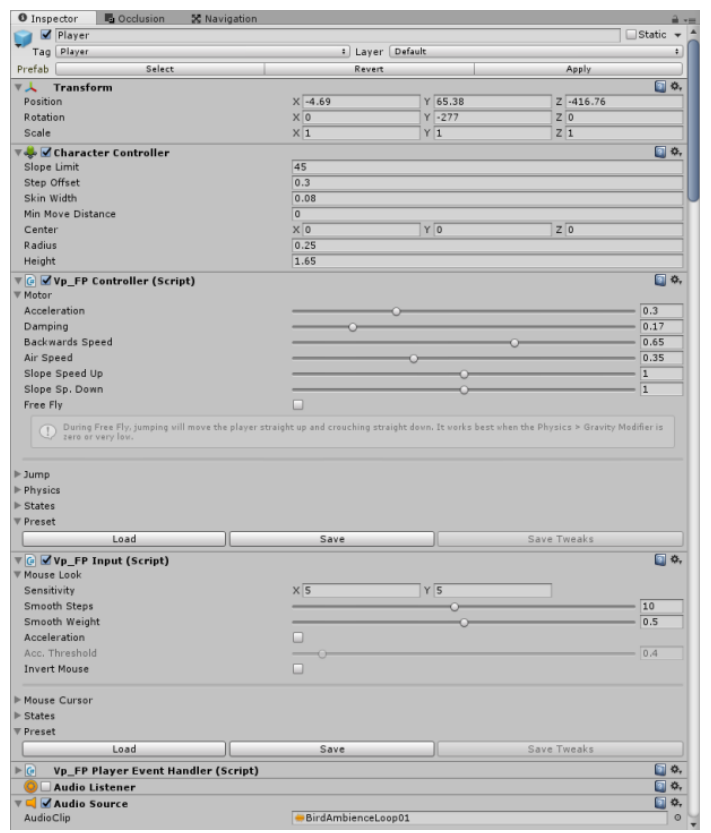

Fig. 90 - Tela do UFPS mostrando as configurações finais do jogador.

\footnotetext{
${ }^{48}$ www.assetstore.unity3d.com/en/\#!/content/2943

${ }^{49}$ Controle de console de videogame.
} 
Outra característica que torna o UFPS tão versátil é a sua capacidade de variar os sons dos passos do jogador e, além disso, permitir que esses sons sejam diferentes para cada tipo de piso sobre o qual estamos. É possível separar na tela de configuração do asset todas as categorias para as quais desejamos ter sons e acrescentar as texturas que desejamos que o UFPS reconheça e emita som. Para o aplicativo Vipasca Antiga foram criadas seis categorias de pisos: concreto, terra, madeira, grama, cascalho e calçada (Fig. 91).

Para os sons dos passos, uma vez que os do Unity em si são apenas de um tipo, foram utilizados os assets Rural Sound Pack ${ }^{50}$ e High Quality Footsteps ${ }^{51}$.

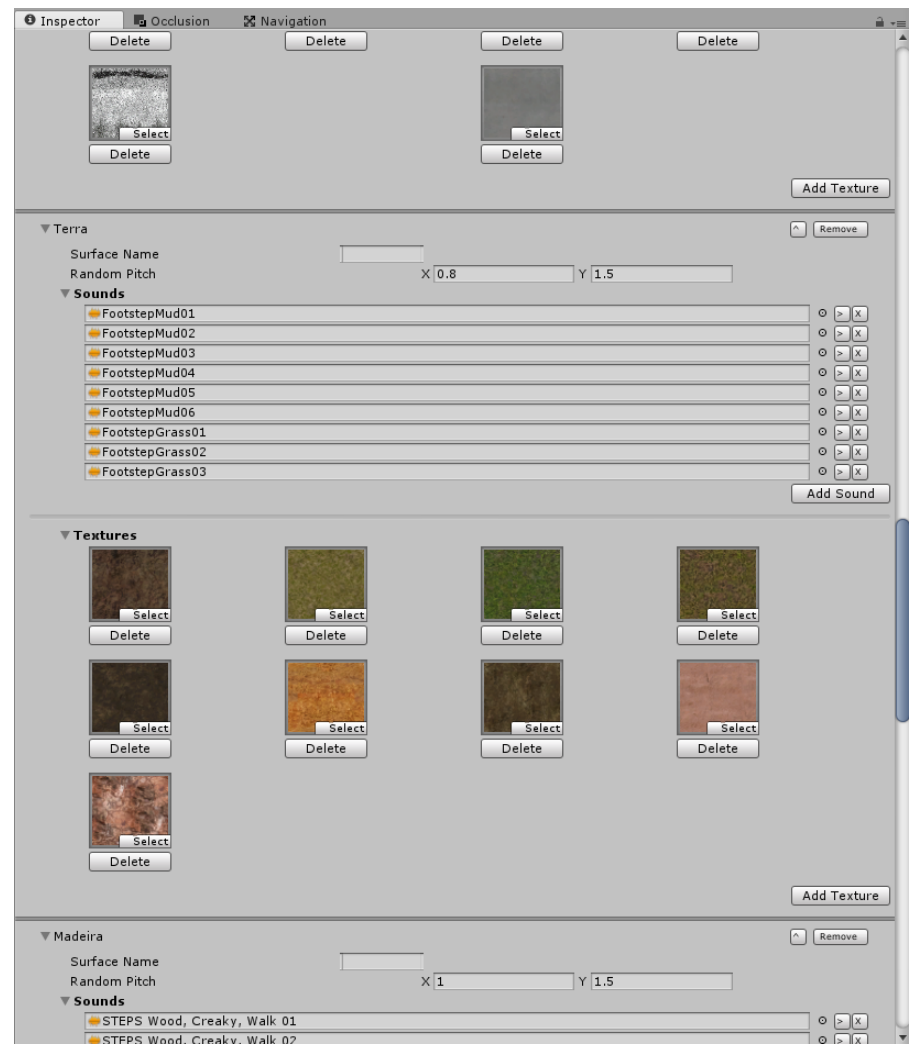

Fig. 91 - Tela de configuração de sons de passos do UFPS.

${ }^{50}$ www.assetstore.unity3d.com/en/\#!/content/25156

${ }^{51}$ www.assetstore.unity3d.com/en/\#!/content/41261 


\subsection{Waypoints}

Uma das principais preocupações antes mesmo de começar a produção do aplicativo de fato, era a de que houvesse pessoas se movimentando pelo povoado, dando dinamicidade e vida à simulação.

Para que os caminhos entre os aglomerados não ficassem vazios e também não existissem apenas pessoas paradas entre as insulae e domus, foi implementado um sistema em que elas caminhassem entre alguns pontos espalhados por toda a paisagem. Alguns testes iniciais de Inteligência Artificial (IA) que simulavam multidões não foram satisfatórios: por exemplo, as pessoas não obedeciam aos caminhos estabelecidos entre os aglomerados, ficando tudo muito confuso quando navegávamos com o jogador entre os NPCs.

A solução encontrada foi a de restringir um pouco a Inteligência Artificial dos NPCs, estabelecendo um sistema de pontos pelos quais eles poderiam caminhar. Para tanto, foi utilizado o asset Simple Waypoint System ${ }^{52}$. O SWS permite ao desenvolvedor a colocação de conjuntos de pontos (waypoints) pelo terreno, formando trilhas (paths). A essas trilhas os NPCs são conectados por meio de scripts $^{53}$ e configurados de modo que ajam de acordo com uma das características fornecidas pelo asset: splines (linhas retas), bezier (linhas curvas) ou navmesh (navegação pelo terreno). Tratando-se de um terreno amplo - e desejando que, dentro das limitações, os NPCs agissem de modo mais natural possível - foi escolhida para o Vipasca Antiga a navegação do tipo navmesh, ou seja, o Unity computa e identifica para o SWS quais lugares do terreno podem ser caminhados e quais lugares representam obstáculos a serem evitados (avoidance) (Fig. 92).

\footnotetext{
52 www.assetstore.unity3d.com/en/\#!/content/2506

53 Linguagem de programação executada dentro de um programa. Mais informações: https://en.wikipedia.org/wiki/Scripting_language (Acesso em 12/07/2016)
} 


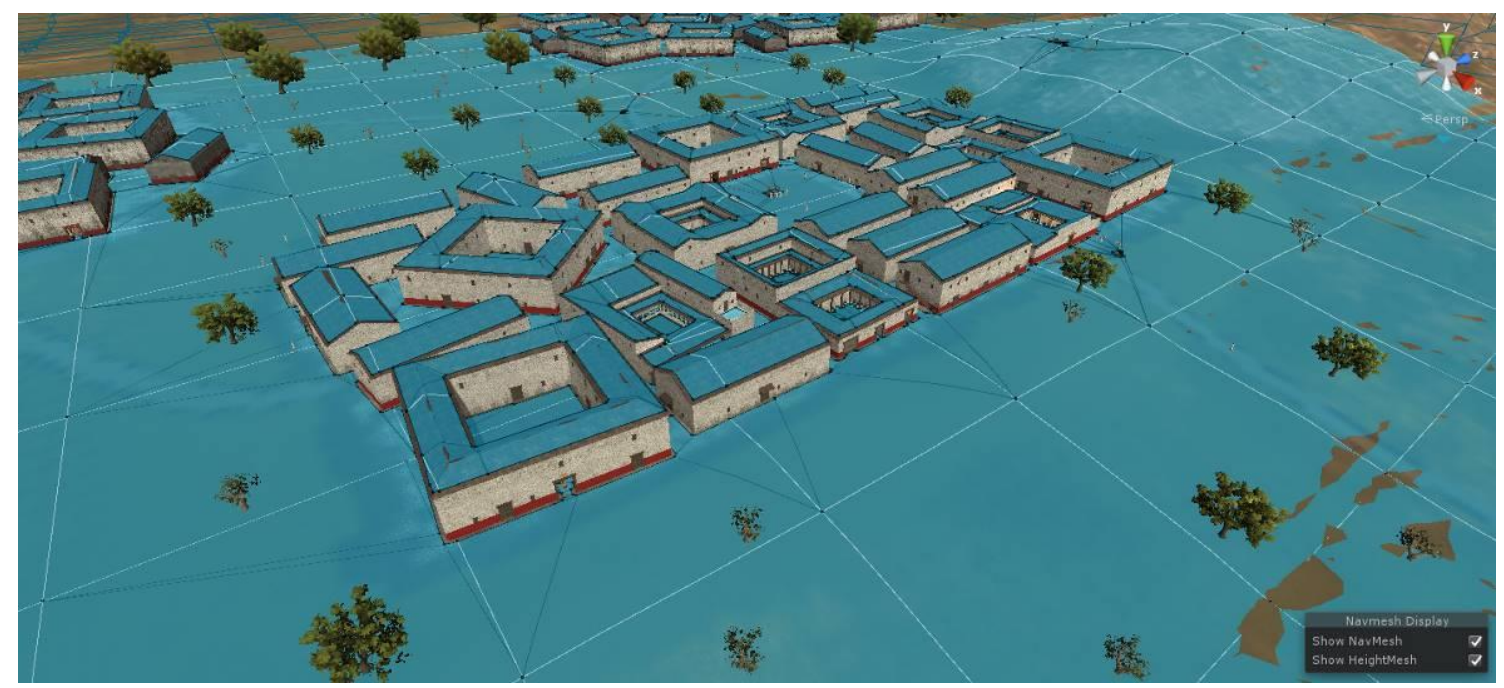

Fig. 92 - Navmesh dentro do Unity: as cores azuis são áreas que podem ser navegadas por NPCs.

O sistema de pontos foi estabelecido de modo que houvesse dois tipos principais de caminhos: 1) caminhos entre os aglomerados - nos quais os NPCs obedeciam aos trajetos de cascalho/terra espalhados pelo terreno, indo de um aglomerado a outro; 2) caminhos dentro do aglomerado - no quais os NPCs caminhariam apenas entre as "ruas" dos aglomerados. Os resultados podem ser vistos nas Figs. 93-94.

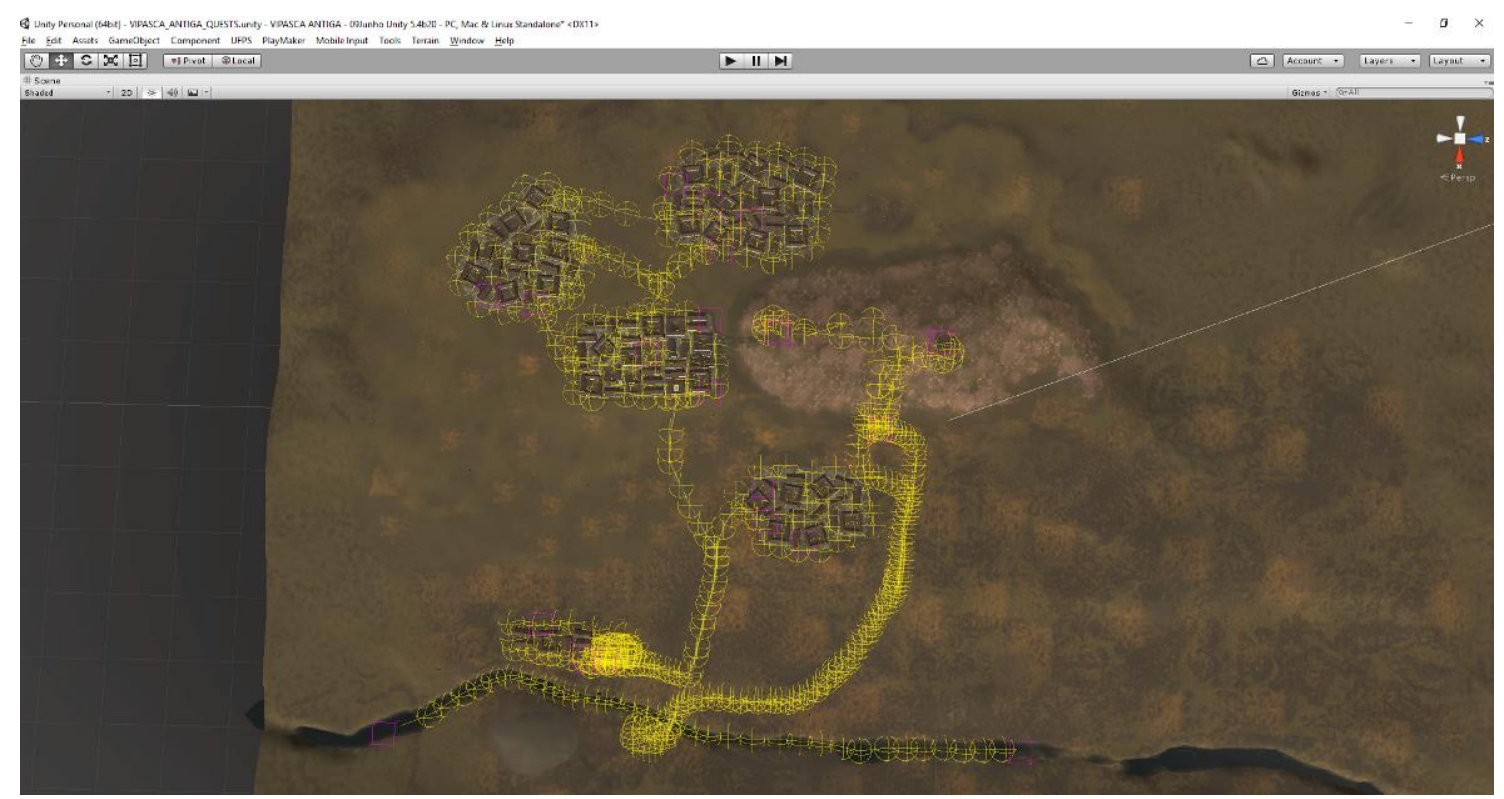

Fig. 93 - Conjunto de todas as trilhas de waypoints espalhadas pela paisagem. 


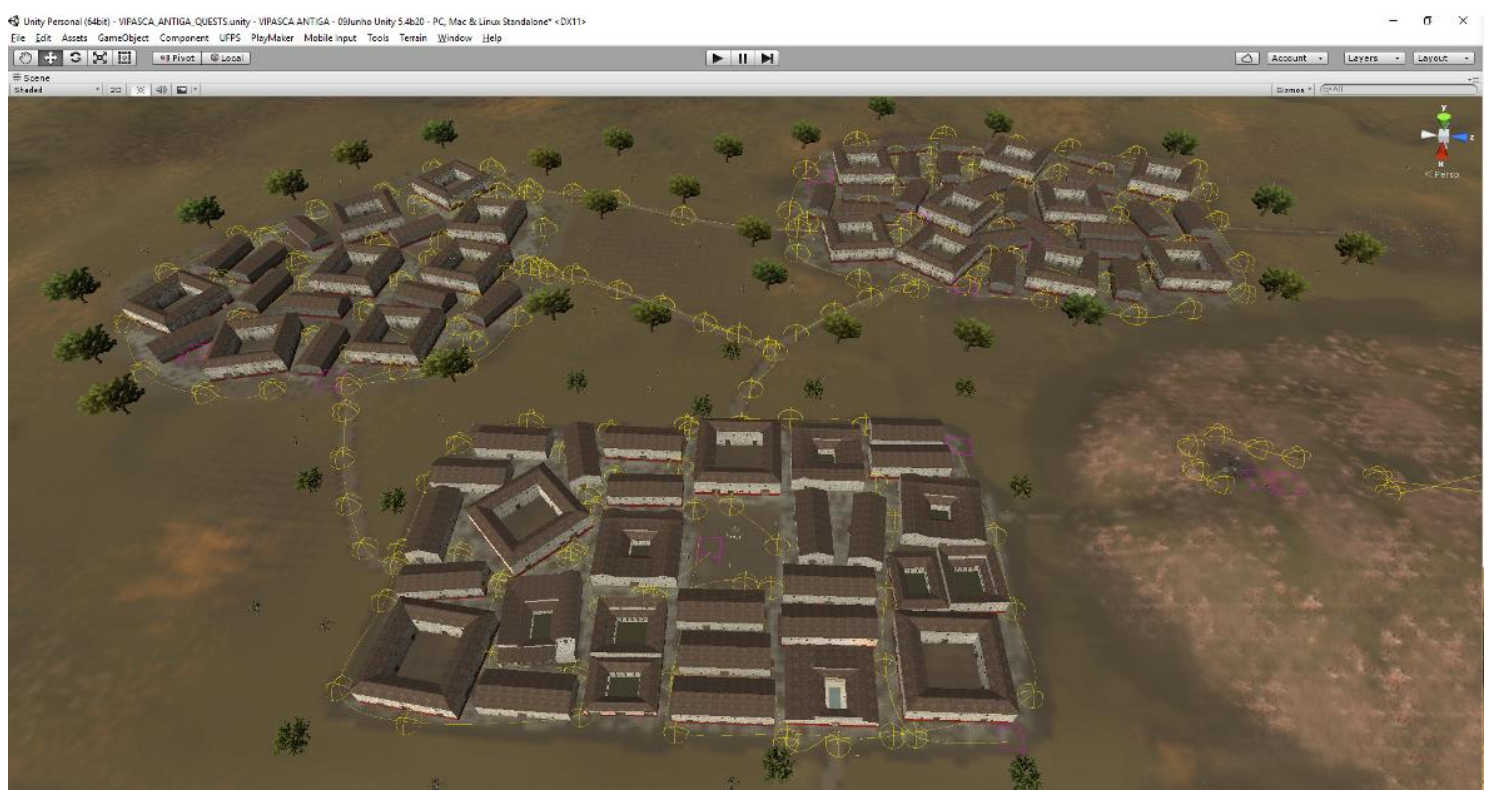

Fig. 94 - Detalhe dos waypoints nos aglomerados e nos caminhos que os conectam.

Após a colocação das trilhas, cada NPC recebeu o script de movimentação do SWS. Esse script permite a edição de algumas características, tais como velocidade, qualidade de desvio de obstáculos (incluindo outros NPCs) e busca por trilhas. Além do tipo de navegação, já mencionado, é possível escolher no editor o tipo de $l o o p^{54}$ desejado: para o aplicativo Vipasca Antiga foram escolhidos o tipo ping pong (no qual o NPC segue os pontos em ordem crescente e retorna pela trilha seguindo pontos decrescentes e viceversa), e o tipo random (no qual o NPC segue os pontos de forma randômica) (Fig. 95).

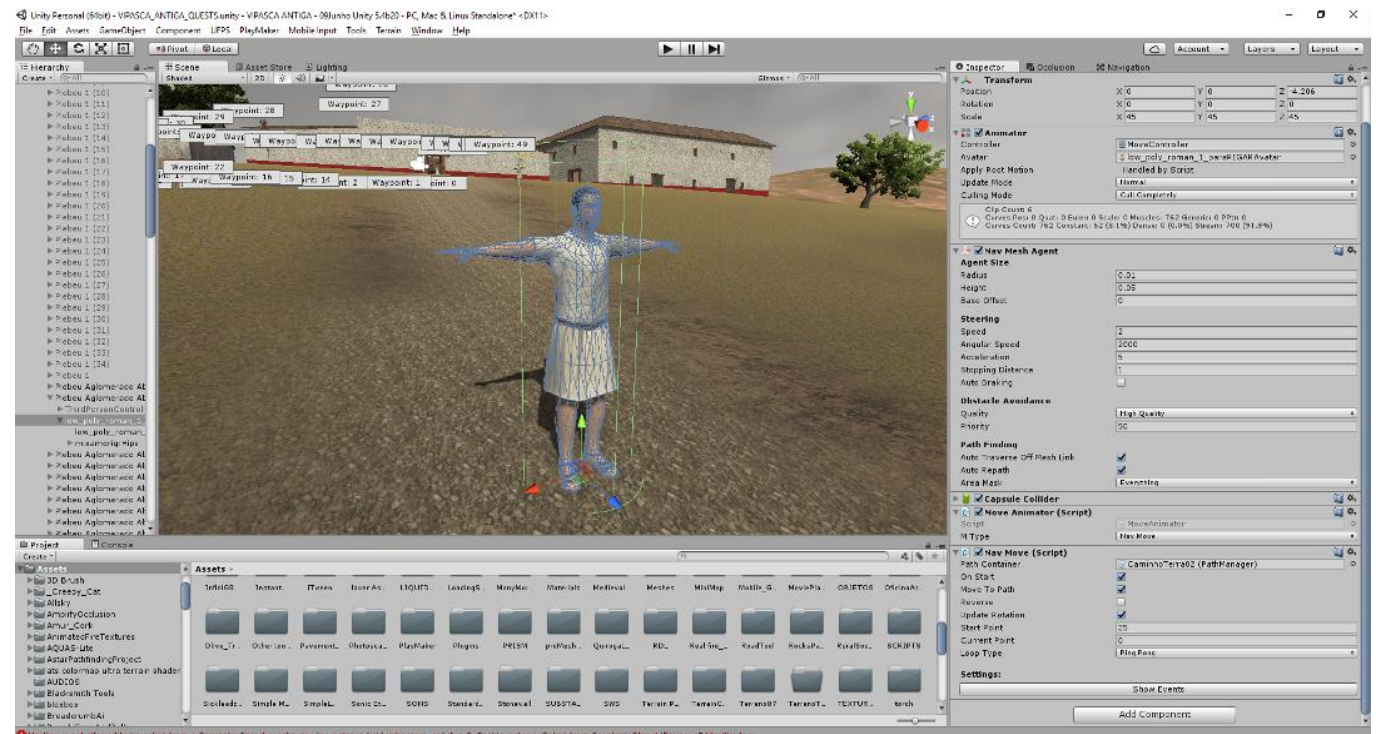

Fig. 95 - Tela de edição do SWS (à direita) aplicado a um NPC.

${ }^{54}$ Laço; a capacidade de recomeçar quando termina. 


\subsection{Quests e Diálogos}

O sistema de quests (missões) talvez seja a principal característica do aplicativo Vipasca Antiga: as duas missões existentes compõem tanto um game como um meio de aprendizado de História/Arqueologia.

Vipasca era um povoado grande e isso é refletido no ambiente virtual tridimensional. Embora na versão final do aplicativo exista a opção de simples navegação pelo território, a experiência de Vipasca Antiga foi pensada a fim de que suas missões sejam trabalhadas. Existiria uma chance muito grande de desinteresse por parte dos usuários caso eles apenas navegassem entre edifícios e pessoas, sem terem um porquê. Mais: provavelmente ficariam perdidos no ambiente, deixando de explorar áreas que, como historiador e arqueólogo, acredito serem importantes dentro da paisagem mineradora de Vipasca.

Desse modo, dentre as ideias levantadas para gamificar ${ }^{55}$ Vipasca Antiga, a que se mostrou mais adequada foi aquela não muito complexa e que, ao mesmo tempo, fizesse com que o usuário navegasse pelos pontos considerados principais: encontrar as Tábuas de Bronze que estivessem perdidas por Vipasca, recebendo pistas da localização a partir de conversas estabelecidas com alguns NPCs espalhados pela região. O início da missão se dá na Casa do Procurador, quando o jogador deve falar com o procurator metallorum em pessoa: dele receberá a incumbência de encontrar sete Tábuas de legislação espalhadas pelo território. Como recompensa pelo esforço ${ }^{56}$, o jogador recebe o certificado de arrendatário das minas e o direito de visitar as galerias subterrâneas de exploração mineral. Somente desse modo o usuário pode ver as galerias: é o objetivo final do aplicativo e, acredita-se, aquele que manterá o interesse do jogador em encontrar todas as Tábuas.

Definidos os objetivos, a próxima etapa foi a de estabelecer o sistema de quests e os diálogos entre o jogador e os NPCs. Para isso, foi utilizado um dos assets mais completos de desenvolvimento de missões para o Unity, o Dialogue Sytem ${ }^{57}$.

As quests foram desenvolvidas dentro do próprio editor do Dialogue System. Uma simples linha de programação em linguagem Lua ${ }^{58}$ (desenvolvida por uma equipe de

\footnotetext{
${ }^{55}$ Gamification, em inglês. O ato de tornar uma atividade em jogo. O conceito será pormenorizado mais adiante nesta tese.

${ }^{56}$ Mais uma característica central da gamificação (gamification) que será detalhada posteriormente.

${ }^{57}$ www.assetstore.unity3d.com/en/\#!/content/11672

58 Mais informações: https://en.wikipedia.org/wiki/Lua_(programming_language) (Acesso em 12/07/2016)
} 
brasileiros) - que depois teve a sua variante de contagem inserida como script em cada Tábua a ser encontrada - foi suficiente para estabelecer o corpo da missão principal, a saber: [lua(Variable["Tábuas"])] de sete encontradas (Figs. 96-97). A segunda missão, a de encontrar o mineiro para ganhar acesso às galerias, sequer precisou de linhas adicionais de programação, demonstrando a facilidade de uso da ferramenta Dialogue System por quem não é programador.

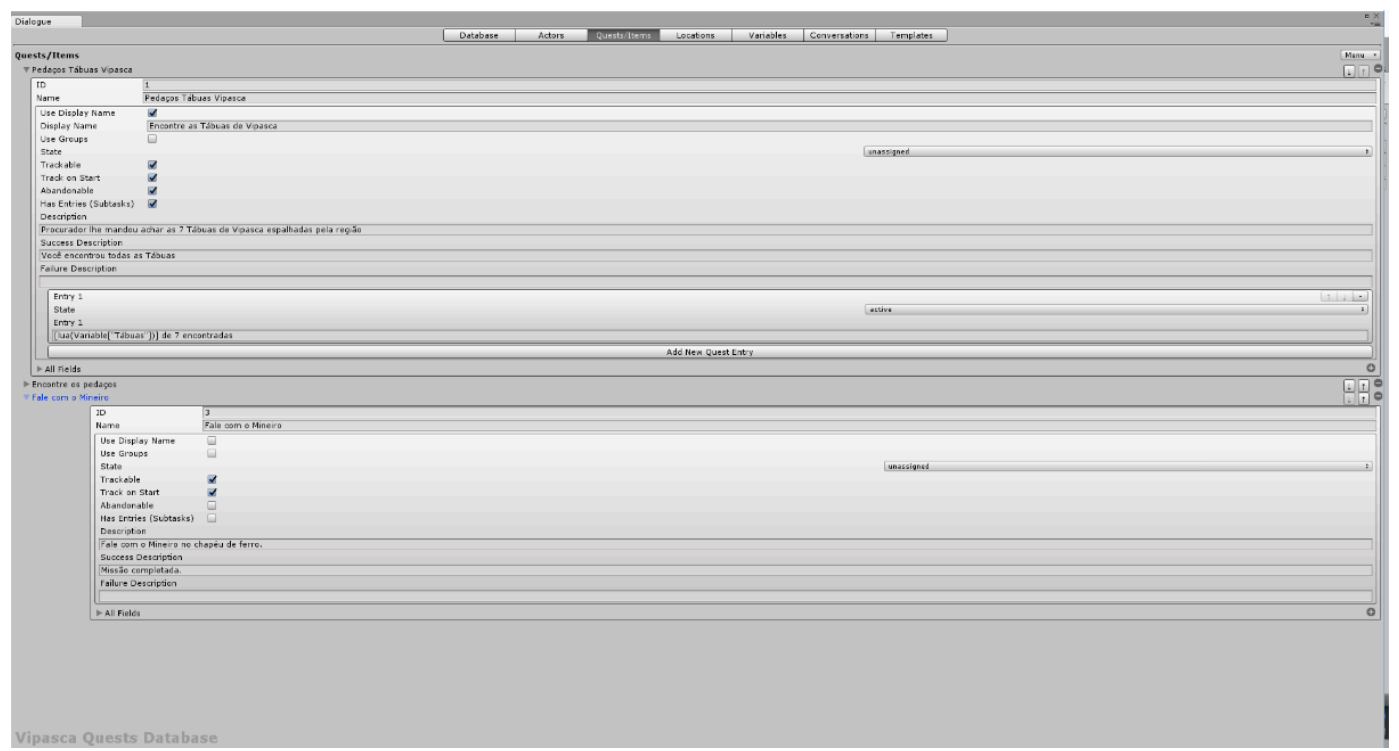

Fig. 96 - Tela de edição das quests no Dialogue System.

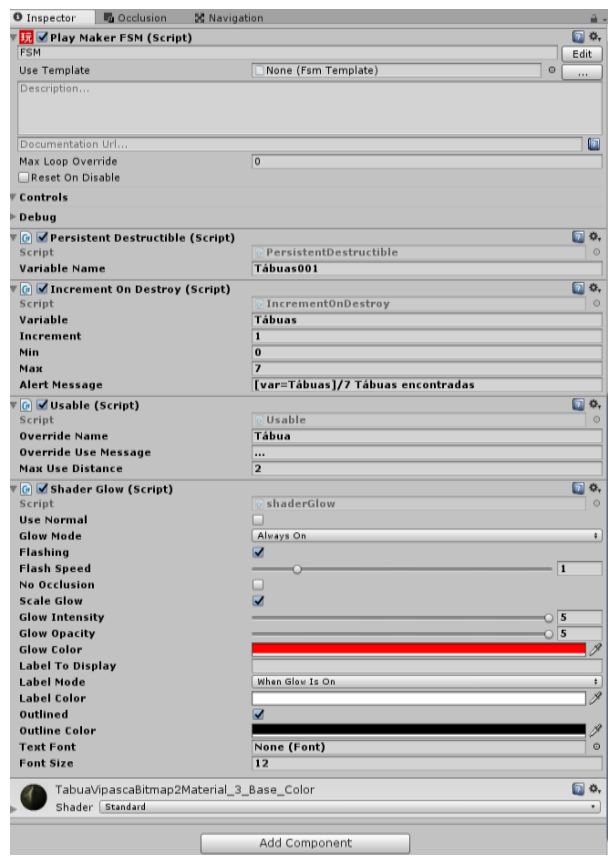

Fig. 97 - Script de contagem das tábuas (Increment On Destroy) aplicado ao objeto 3D e que afeta a quest principal. 
Finalizado o sistema principal de missões, começou a escrita dos diálogos. Dentre os 266 NPCs existentes no aplicativo, 78 foram escolhidos como atores, ou seja, personagens aptos a emitirem caixas de diálogo na tela. E dentre os 78 atores, 22 deles possuem diálogos interativos e 56 possuem diálogos engatilhados (Fig. 98).

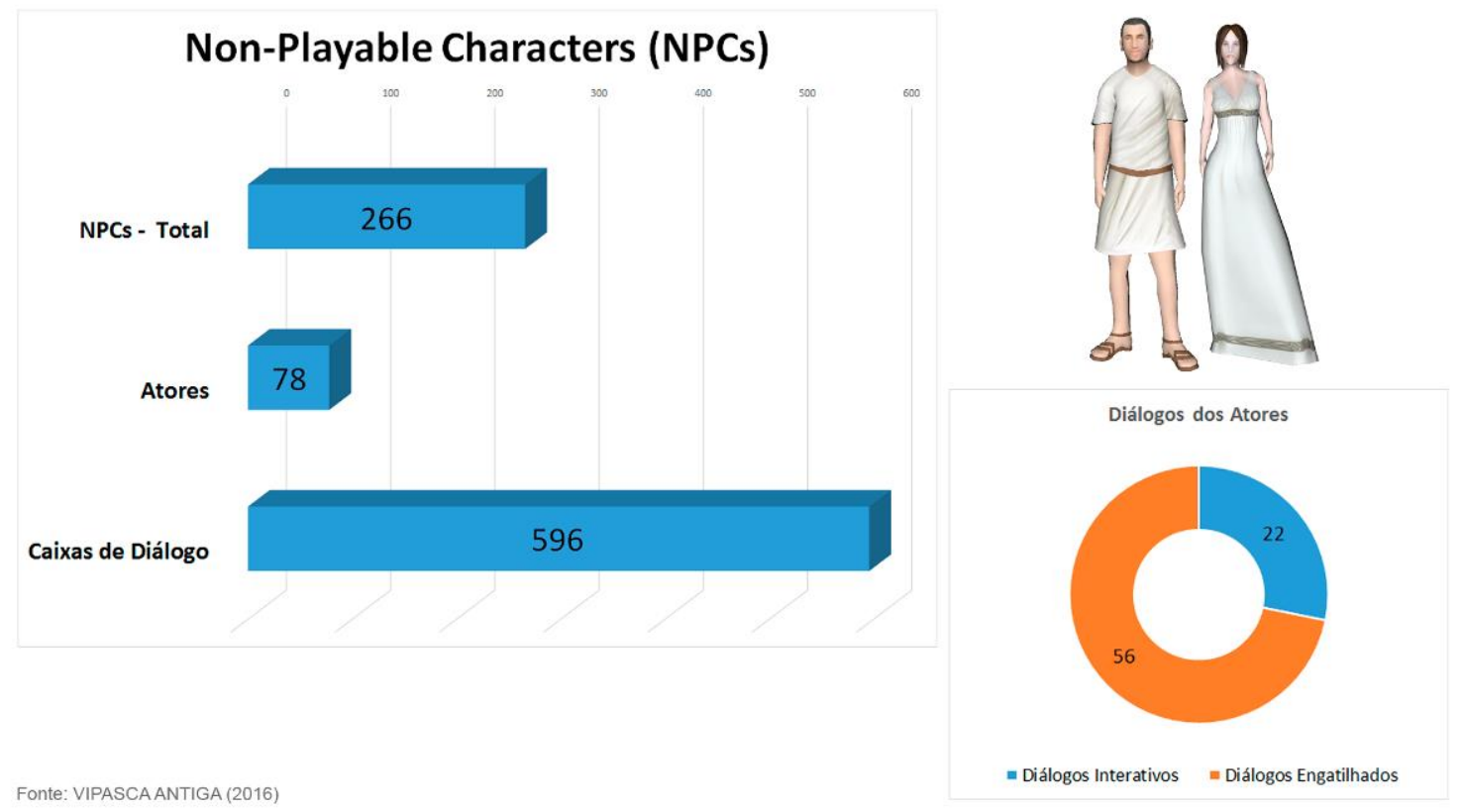

Fig. 98 - Gráfico mostrando o total de NPCs e a divisão de seus diálogos.

O diálogo interativo é aquele em que o NPC dispara um texto e o jogador tem a opção de escolher uma dentre várias respostas para dar continuidade à conversa. O Dialogue System permite ao desenvolvedor a criação de diálogos extensos e número de respostas muito grande, contudo, para o Vipasca Antiga, apenas duas respostas possíveis do jogador foram colocadas em tela a cada diálogo. Essa opção foi feita com base nas seguintes constatações realizadas ao longo dos anos de minha experiência como jogador de games eletrônicos:

1) Quanto mais simples, melhor - a interface de um jogo é algo que "assusta" os usuários que não têm convívio com games, quanto mais opções ele tiver, mais ficará "perdido" e mais demorará para se sentir confortável e terminar as missões;

2) As idades influenciam - obviamente, essa constatação não pode ser seguida muito à risca: existem jogadores experientes com 40, 50, 60 anos ou mais. Porém, a probabilidade de que um usuário com mais de 40 anos não tenha a 
mesma desenvoltura nos games que um adolescente (ou uma criança) de hoje em dia é grande: assim, uma interface simples favorece o interesse dos jogadores não-experientes;

3) Controles simplificados - duas opções de respostas na tela fazem com que o jogador necessite apenas pressionar uma das duas teclas oferecidas (ou um dos dois botões, no caso de utilizar um gamepad): desse modo, o usuário precisa somente deslizar o dedo das teclas de movimentação do personagem (W, A, S, D) para a fileira numérica de cima e pressionar as teclas 1 ou 2 (ou no caso de visualização de fotogrametrias e sinalizadores, a tecla 3 ou E) (Fig. 99).

Como mencionado, foram escritos 22 diálogos interativos (Fig. 100). Deles, sete acionam o aparecimento das Tábuas espalhadas pela paisagem: os demais diálogos tiveram por objetivo ensinar um pouco mais da história de Vipasca e do cotidiano romano em geral (por exemplo, é necessário aprender sobre o processo de produção das cerâmicas e lucernas, ou entender mais sobre os ingredientes que compunham os tipos de pães na Antiguidade). Importante frisar que os diálogos que acionam as Tábuas estão em NPCs relativamente próximos aos objetos a serem encontrados: caberá ao jogador buscar os objetos baseado em sua própria curiosidade de exploração, uma vez que as indicações (pontos vermelhos) que aparecem no minimapa da tela apenas indicam as proximidades dos NPCs que disparam os acionamentos das Tábuas.

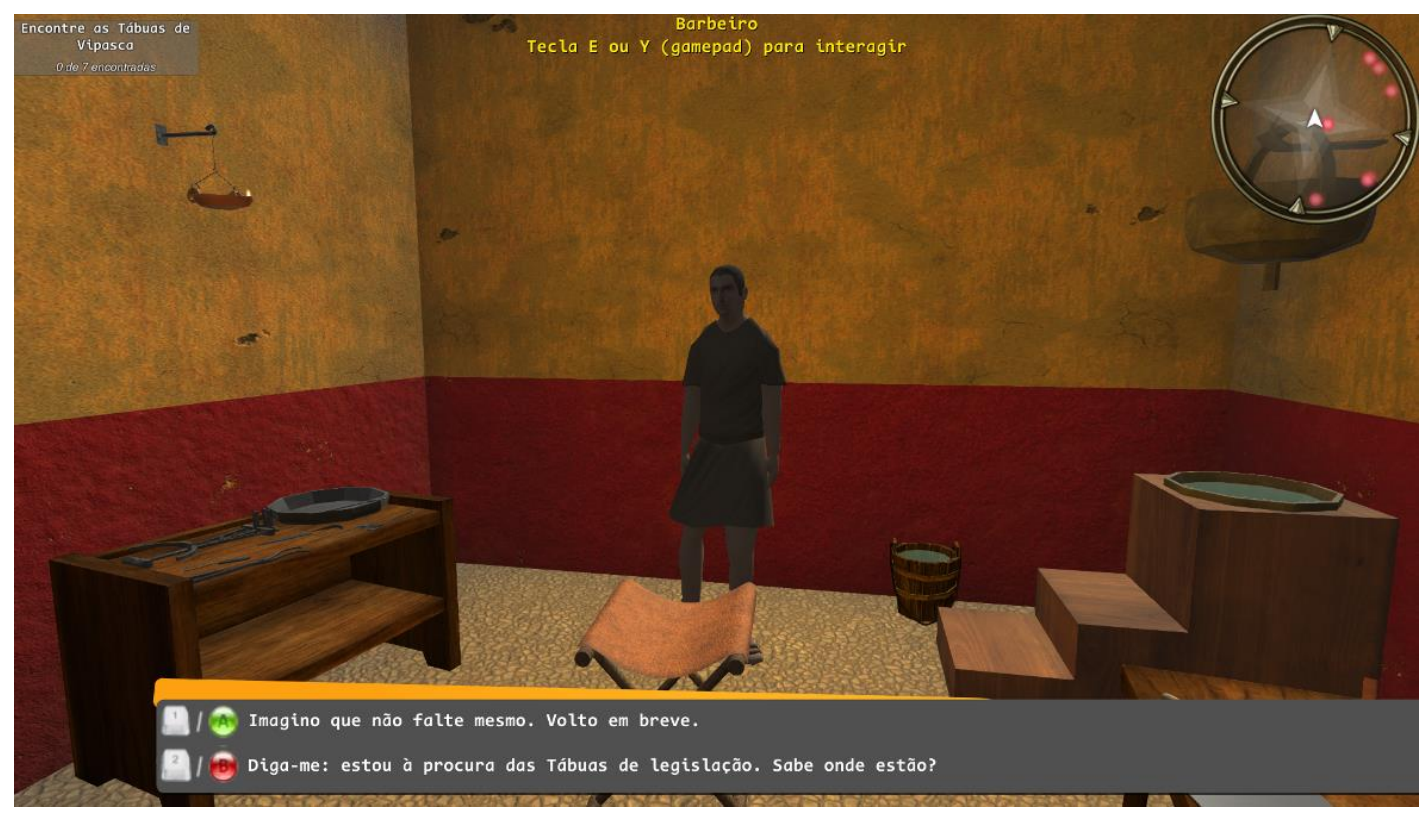

Fig. 99 - Sistema simplificado de respostas aos diálogos no aplicativo. 


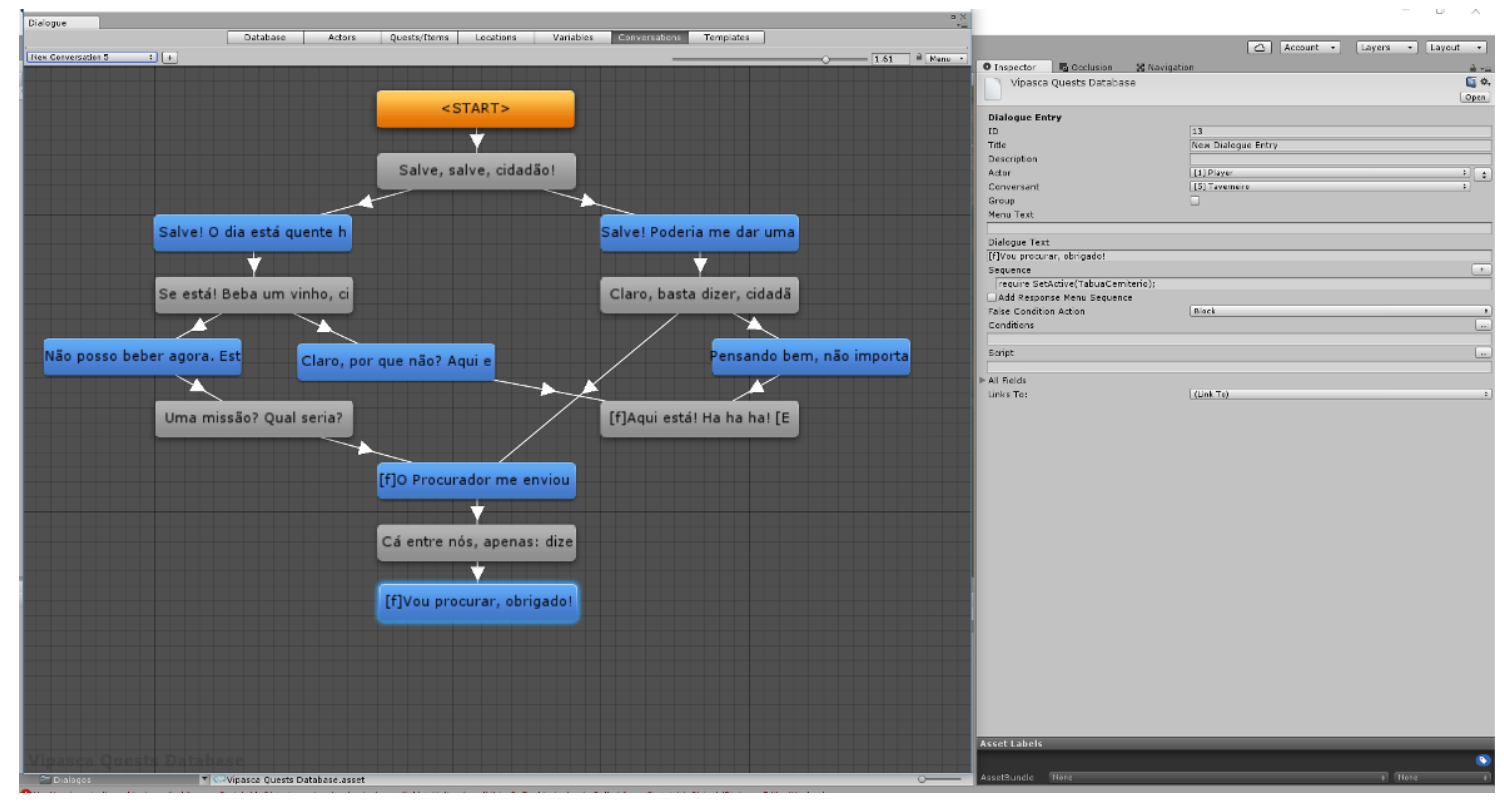

Fig. 100 - Exemplo de edição de diálogo interativo: as caixas cinzas são textos do NPC enquanto as azuis são as respostas do jogador.

O diálogo engatilhado, por sua vez, é bastante utilizado em jogos para "dar vida" aos ambientes. São linhas de texto que aparecem sobre a cabeça do NPC que está falando no momento (Fig. 101). Esse tipo de diálogo acrescenta muito conteúdo ao jogo, uma vez que serve para representar o cotidiano da localidade em questão.

No caso do Vipasca Antiga, foram duas as utilizações de diálogos engatilhados:

1) Ensino de História - as linhas de texto foram escritas a partir da pesquisa histórica/arqueológica feita durante todo o Doutorado, ou das transcrições diretas das Tábuas de Vipasca realizadas por José d'Encarnação (MARTINS 2012): como no caso das linhas do pregoeiro no fórum, que menciona diversas leis que estão nas Tábuas;

2) Cotidiano simulado - linhas de texto que mencionam o dia a dia da população de Vipasca. Nesse caso, os textos são criações literárias baseadas em estudos que foram feitos durante o meu percurso acadêmico, ou até mesmo diálogos que tratam de temas como amor, alcoolismo ou preconceito. 


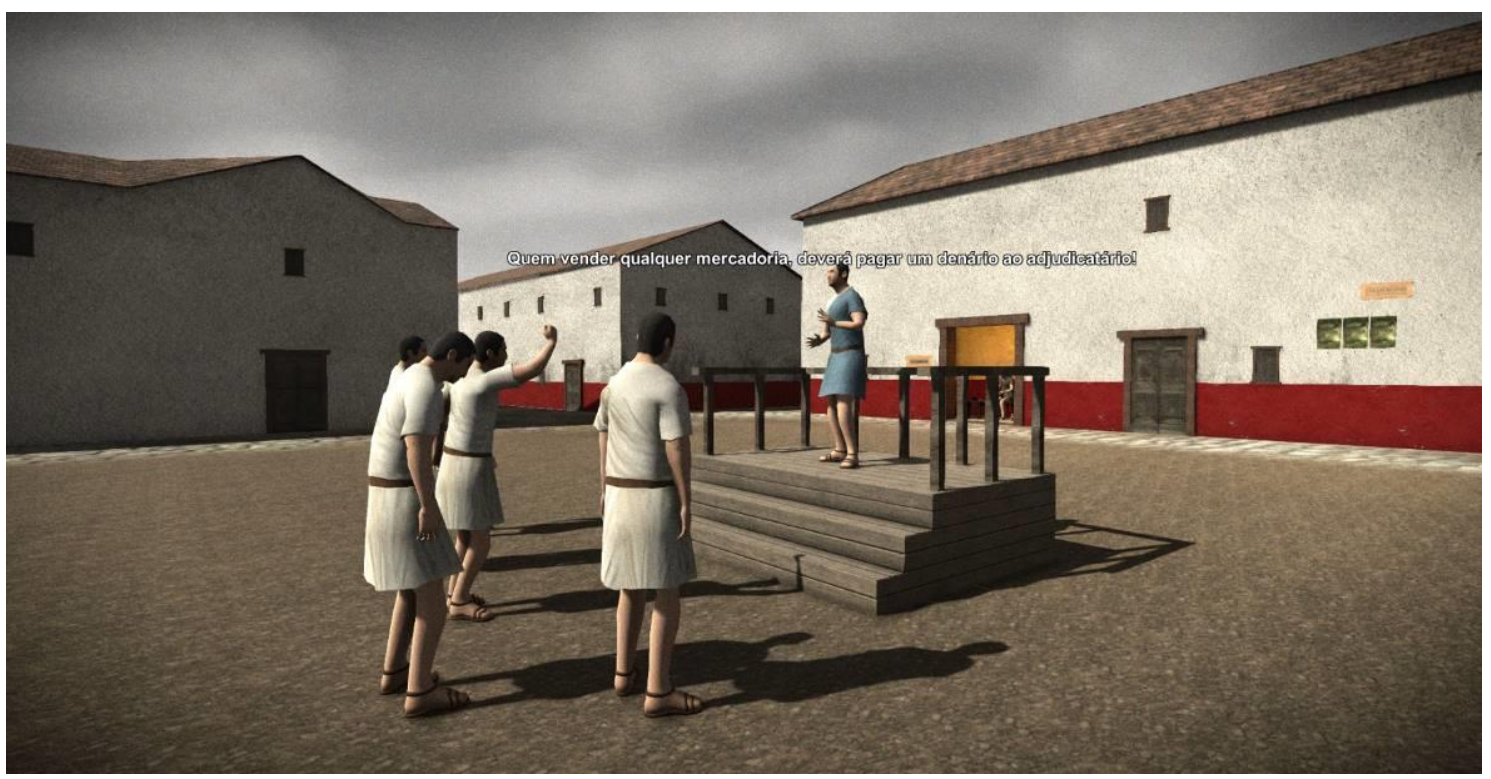

Fig. 101 - Diálogo engatilhado sobre a cabeça do pregoeiro no fórum.

Os diálogos engatilhados criados no Dialogue System foram postos em cena de acordo com as seguintes etapas: 1) adição dos scripts de barking ${ }^{59}$ aos NPCs; 2) edição das características fornecidas pelos scripts: intervalo de tempo em segundos para o aparecimento dos textos, bem como a ordem dos diálogos (se serão sequenciais ou randômicos); 3) criação do gatilho (trigger) sobre o terreno - esse elemento é um simples objeto vazio cúbico (gameobject empty) que possui colisores (colliders) funcionando como detectores da entrada/saída do jogador; quando o jogador entra no gatilho, o texto do NPC é disparado na tela - quando sai, o texto é resetado (ou seja, volta ao estágio inicial) (Fig. 102).

Somando-se os diálogos interativos e os engatilhados, foram escritas 596 caixas de texto para o aplicativo Vipasca Antiga.

\footnotetext{
${ }^{59}$ Barking (latindo, em português) é o nome técnico dado pelo Dialogue System aquilo que denominei "engatilhado". Optei por essa tradução devido ao estranhamento que a tradução direta do termo traria e também porque o surgimento dos textos na tela se dão apenas quando o jogador adentra um trigger (gatilho, em português) posicionado sobre o terreno.
} 


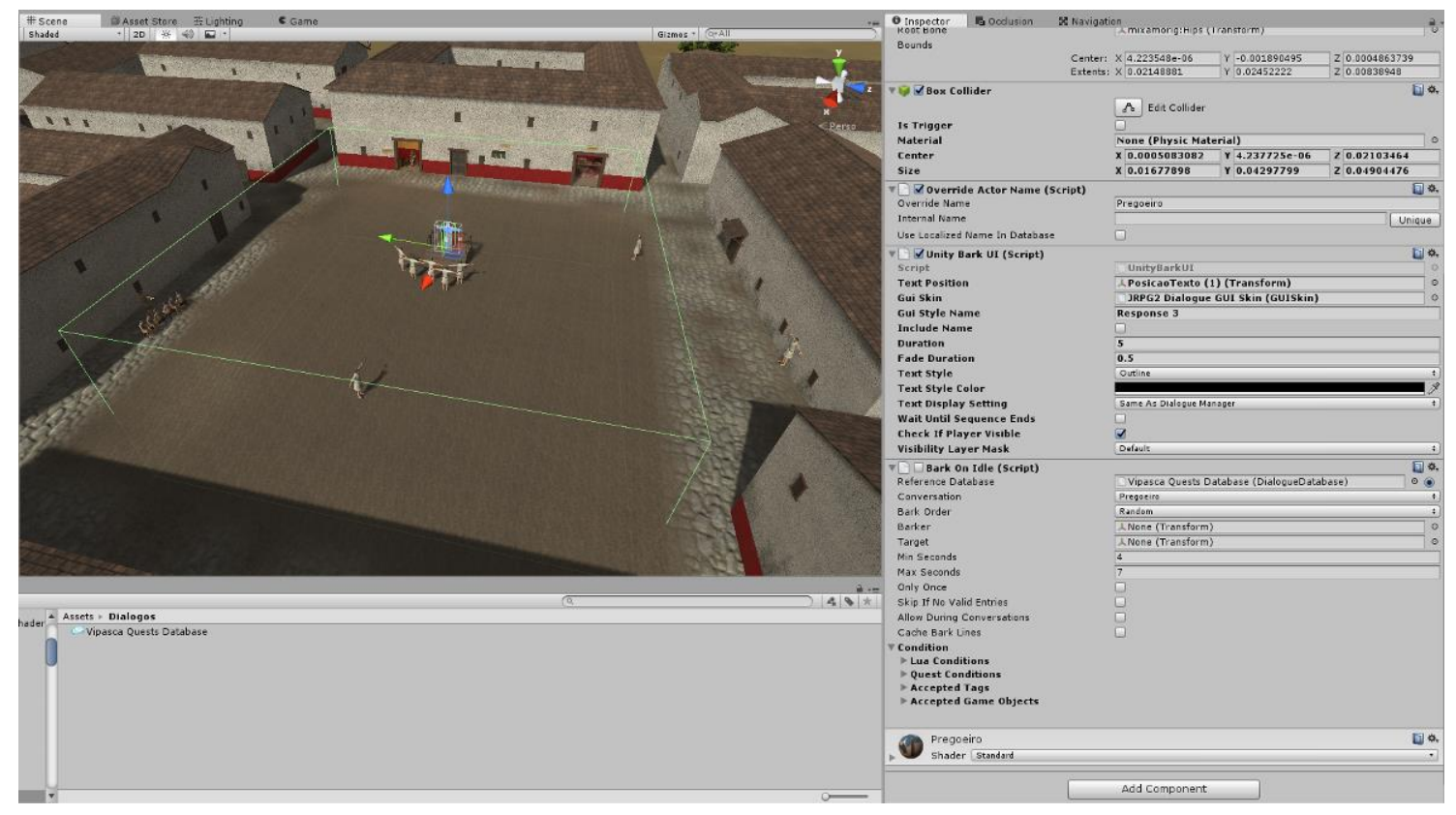

Fig. 102 - À esquerda, o gatilho do NPC (arestas verdes); à direita, o painel de edição do diálogo engatilhado.

\subsection{GUI (Graphical User Interface)}

Um aspecto importantíssimo em qualquer jogo eletrônico ou aplicativo é a interface gráfica de usuário (graphical user interface - GUI $)^{60}$. A GUI é a utilização de ícones gráficos para estabelecer a interação entre o usuário e o computador: por exemplo, o sistema operacional Windows contém uma GUI que permite você a clicar em botões que abrem programas, salvam arquivos, copiam e colam; o ponteiro do mouse na tela também faz parte da GUI do Windows (e quando ele trava, agora você sabe que é também um travamento da GUI do sistema, pois não consegue mais se comunicar com o computador...).

Os diálogos do aplicativo Vipasca Antiga (bem como os menus e qualquer outra informação que esteja na tela e não seja em 3D) estão atrelados à GUI do Unity. Embora não seja uma GUI extremamente funcional (motivo de grandes reclamações da comunidade de desenvolvedores Unity), ela serviu adequadamente aos propósitos do aplicativo, sem a necessidade de adquirir uma nova. O modo mais simples de se entender uma GUI é imaginá-la como um editor de imagens (por exemplo, Photoshop): monta-se

\footnotetext{
60 Mais informações: https://en.wikipedia.org/wiki/History_of_the_graphical_user_interface (Acesso em 12/07/2016)
} 
camadas de imagens e textos umas sobre as outras, posicionando-as nos locais desejados, mas sempre estando ligadas à "tela de pintura" (canvas) do arquivo.

A GUI do Unity funciona do mesmo modo: adicionamos na hierarquia da cena o componente Canvas e, dentro dele, podemos colocar botões diversos (que são programados depois), textos e imagens (estáticas ou movie textures, ou seja, filmes animados). Todo o Canvas sempre ficará atrelado à câmera do jogador e, quando acionado, aparecerá na tela cobrindo a visualização do que está atrás (no caso, os objetos tridimensionais).

No aplicativo Vipasca Antiga, foram criados nove tipos de canvas para interação do usuário:

1) Diálogos - todos os diálogos que surgem na tela estão presentes no canvas oriundo do Dialogue System (Fig. 103). Foram adicionadas imagens referentes às teclas (e botões de gamepad) ao lado dos textos, e também no canto superior esquerdo da tela aparece uma pequena caixa de texto com a contagem das Tábuas encontradas;

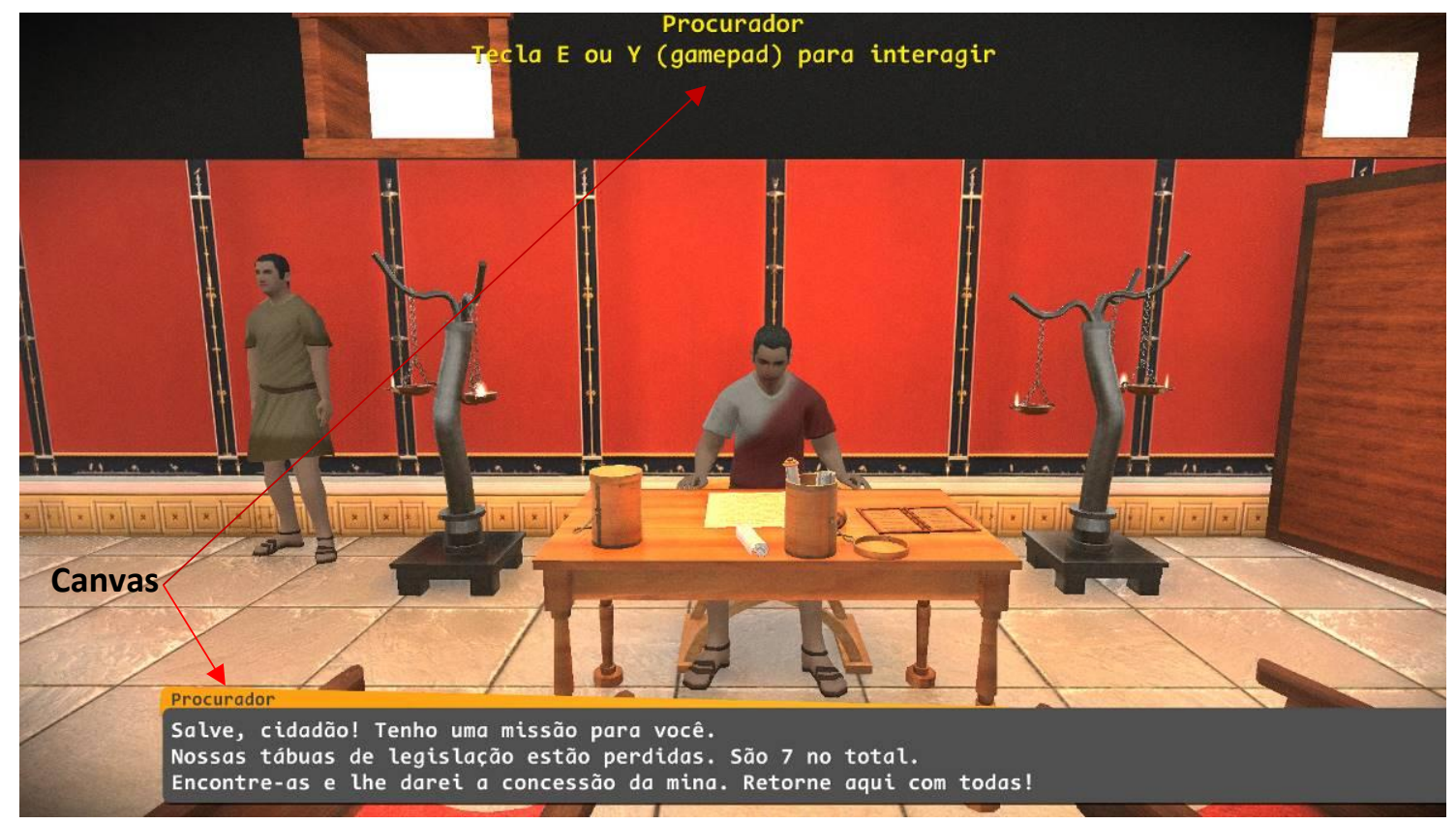

Fig. 103 - Canvas de diálogo.

2) Transcrições das Tábuas - imagens com as transcrições surgem na tela quando o jogador encontra alguma das Tábuas de Vipasca (Fig. 104). Essas 
imagens foram montadas no Adobe Photoshop e depois exportadas como arquivos de extensão .PNG (que lidam com transparências) para dentro do Unity para serem usadas nos canvas das Tábuas;

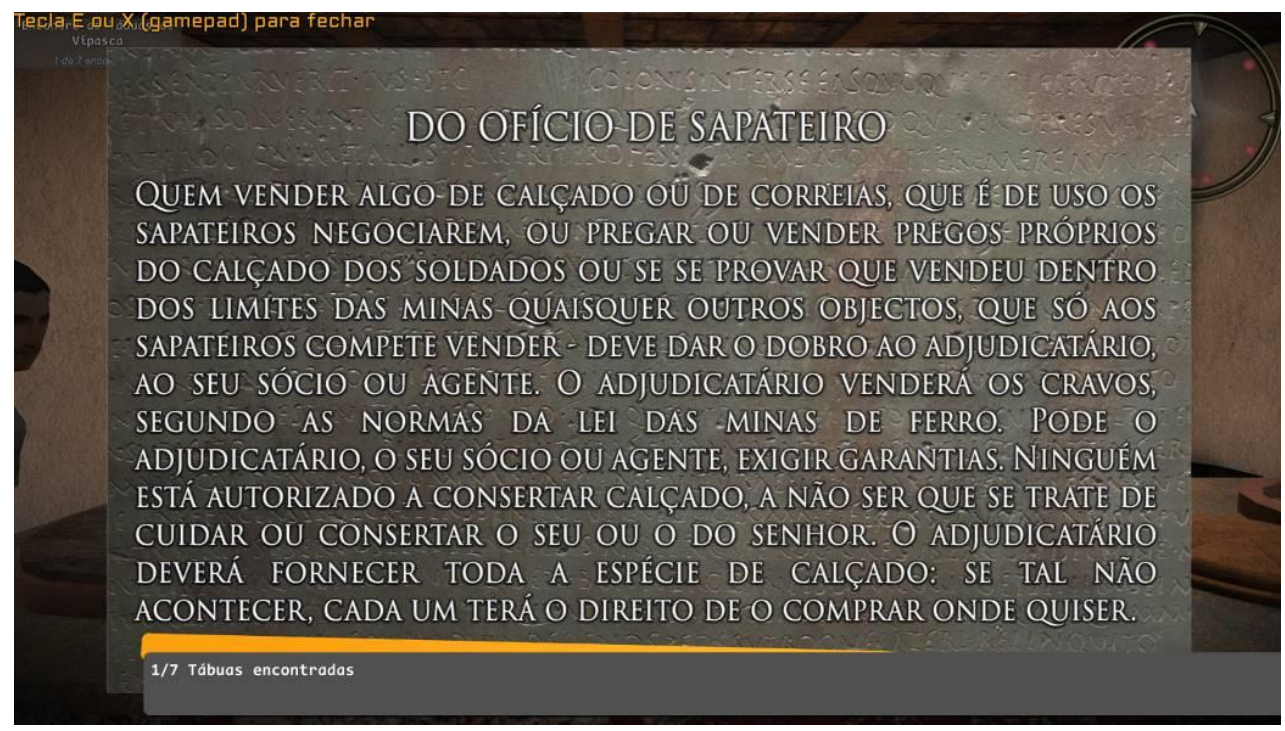

Fig. 104 - Canvas com imagem da transcrição da Tábua previamente feita no Adobe Photoshop.

3) Placas de sinalização - os textos (simples traduções das localidades existentes nos marcadores) foram criados utilizando-se a opção de escrita presente na GUI do Unity. A nitidez dos caracteres da GUI é superior ao de imagens feitas em editores, tornando-se visível em qualquer resolução de tela que o jogador escolha (Fig. 105);

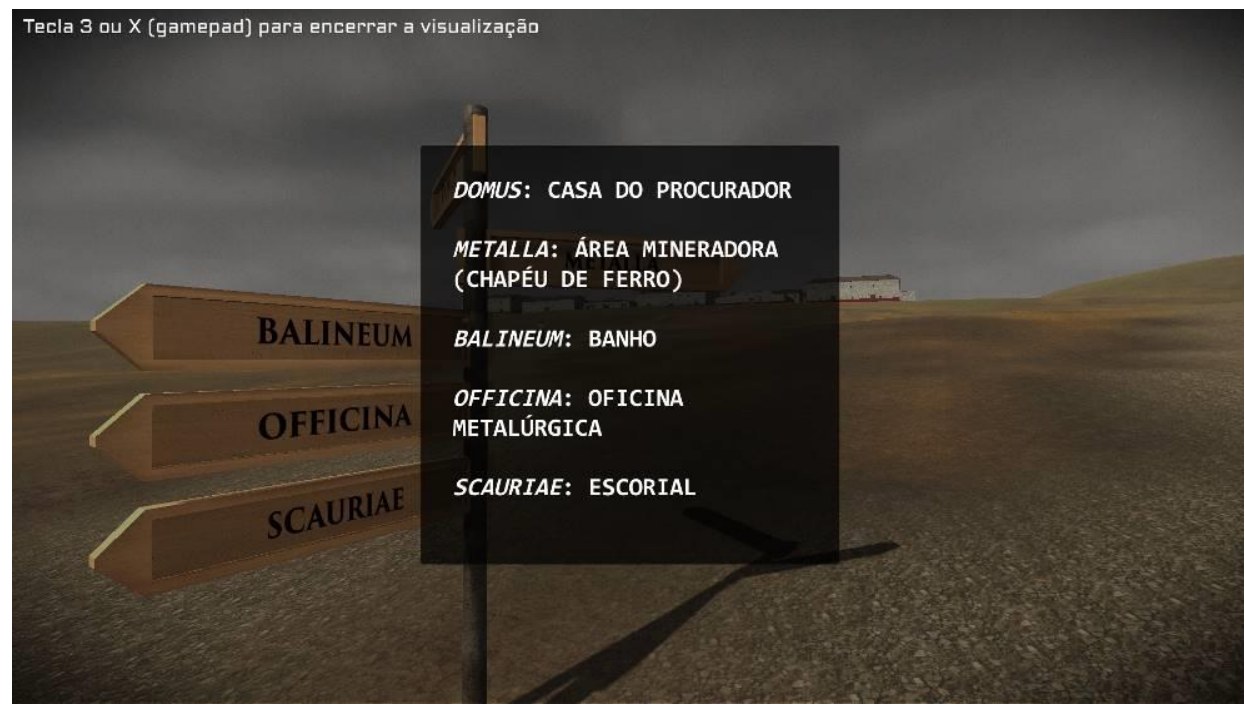

Fig. 105 - Canvas de sinalização. 
4) Área da paisagem - utilizando-se imagens feitas no Photoshop, os arquivos foram colocados dentro de canvas que surgem quando o jogador entra em alguma área maior da região (por exemplo, chapéu de ferro ou necrópole) (Fig. 106);

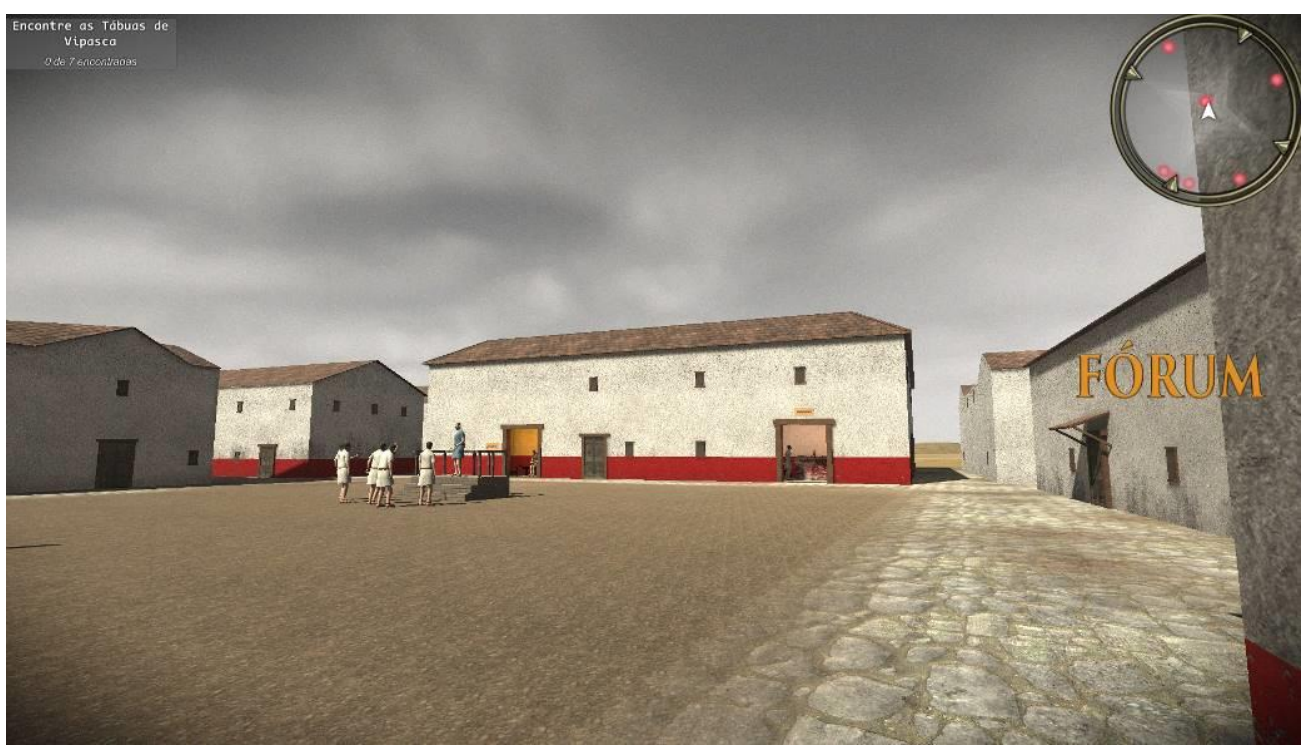

Fig. 106 - Canvas mostrando a imagem referente à área ("Fórum").

5) Relatos arqueológicos - atrelados aos estandartes romanos espalhados pela paisagem, todos os textos foram escritos diretamente nos canvas para fácil visualização em tela de jogo. Esses relatos contam um pouco mais sobre as escavações realizadas na região e os vestígios encontrados (Fig. 107);

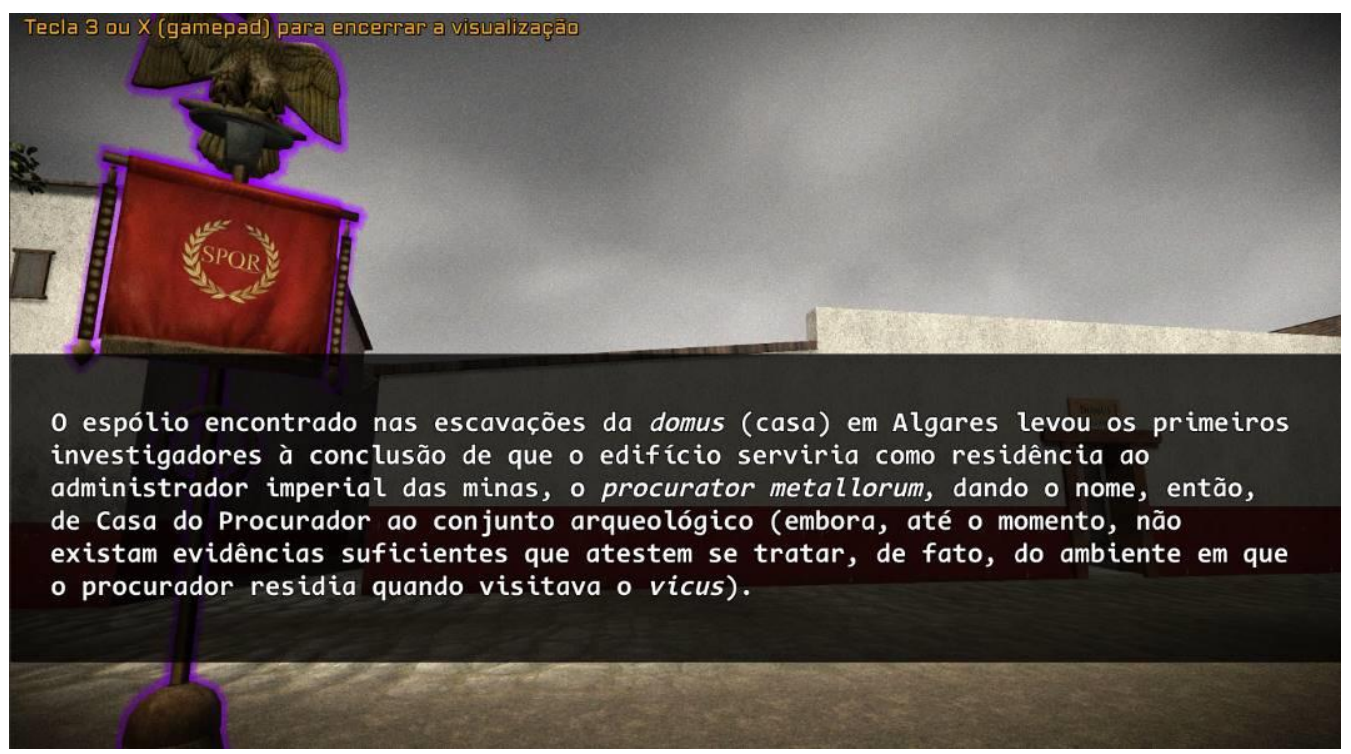

Fig. 107 - Canvas com relato arqueológico. 
6) Interação - textos ou imagens com teclas/botões surgem na tela para indicar interatividade do jogador com o ambiente (Fig. 108). Geralmente são canvas que servem para engatilhar os demais canvas já mencionados;

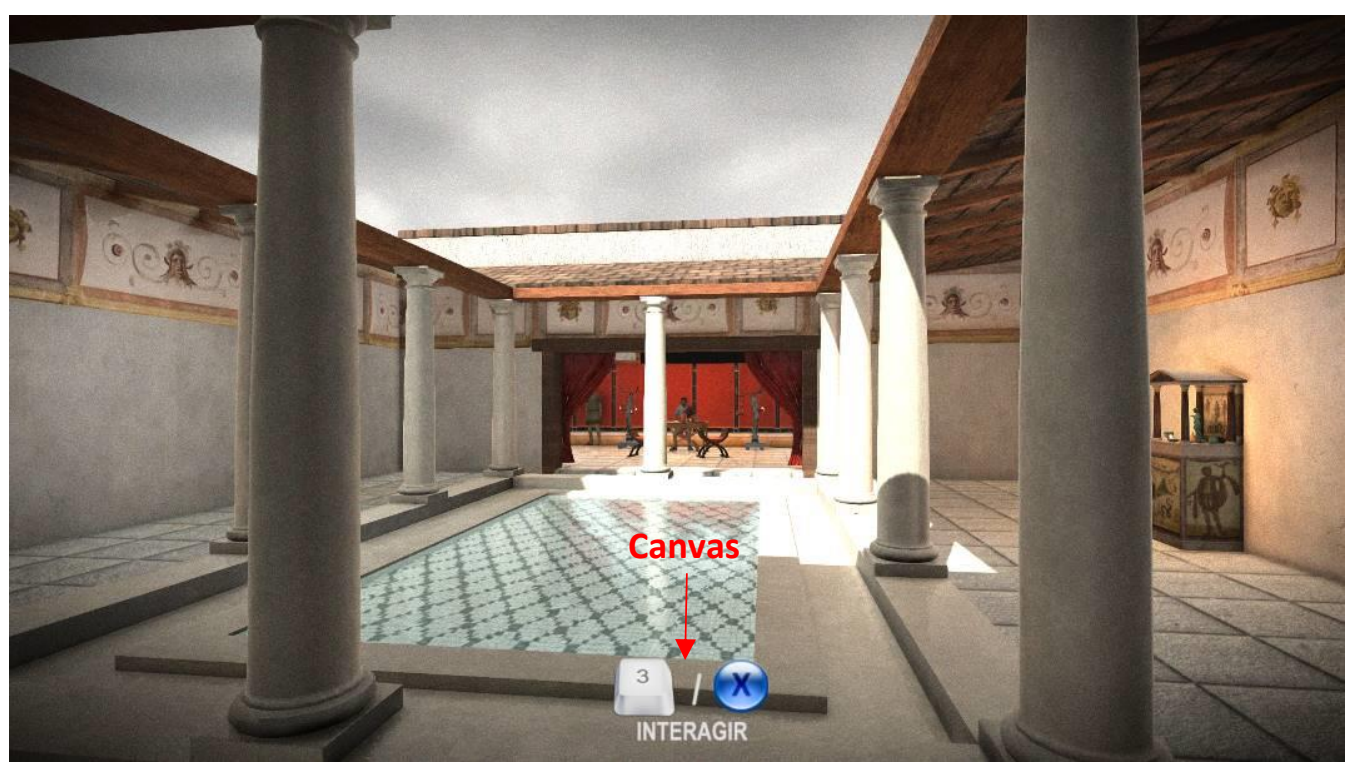

Fig. 108 - Canvas de interação.

7) Minimapa - mostrando os pontos vermelhos de interesse na região, o minimapa é um canvas constituído de diversas imagens (os círculos de delimitação e o sinalizador do jogador) que interage, por script, com os objetos (vazios) que contêm os pontos vermelhos (Fig. 109);

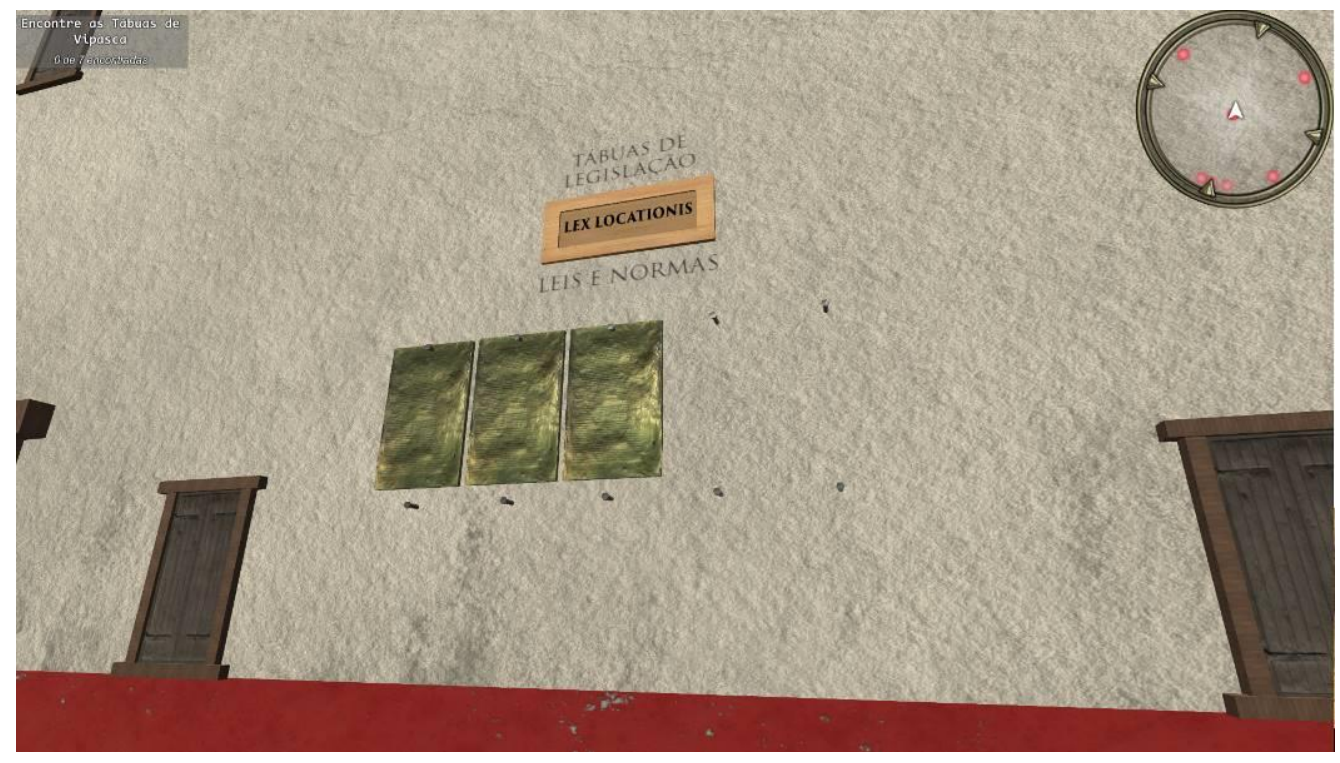

Fig. 109 - Canvas de minimapa (canto superior direito). 
8) Мепи - as telas dos menus são imagens únicas criadas no Photoshop e inseridas em seus canvas (Fig. 110);

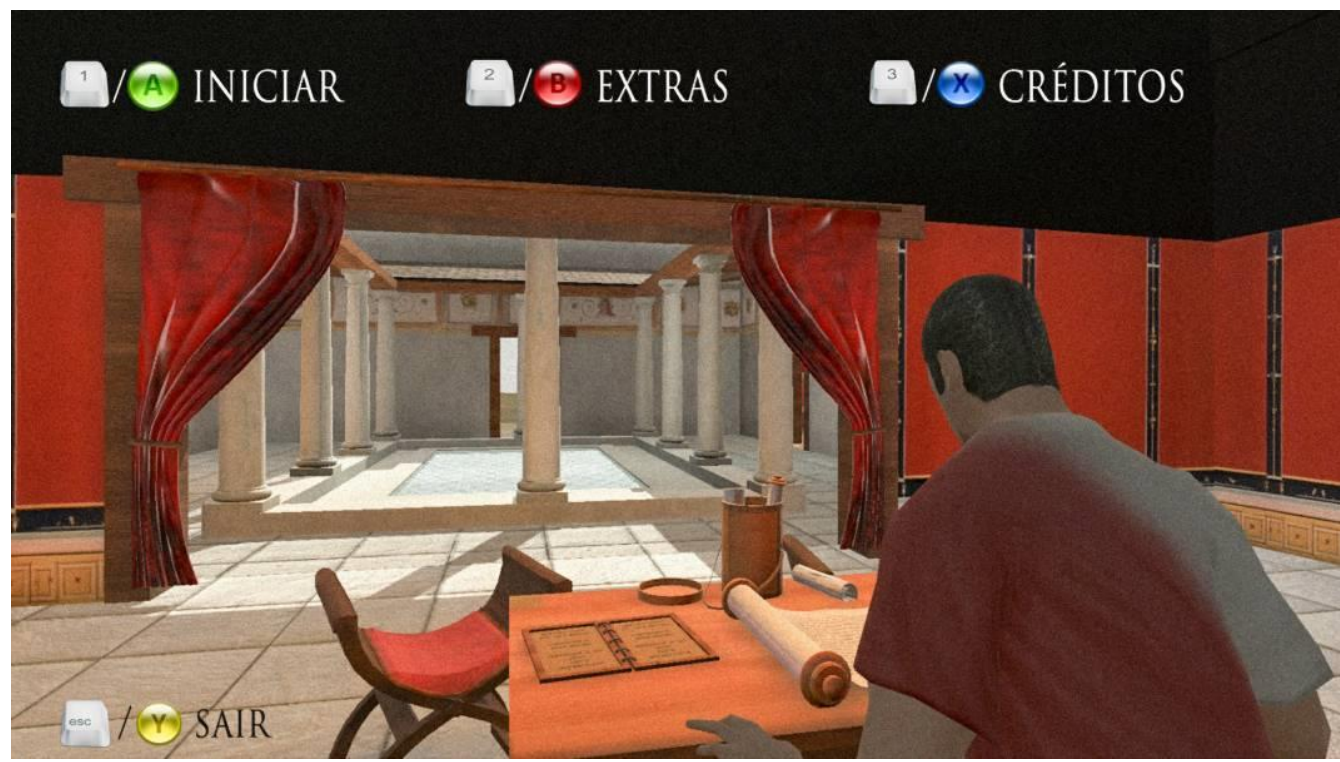

Fig. 110 - Canvas de menu.

9) Navegação na Galeria de Imagens e de modelos fotogramétricos - o canvas conta com simples botões que servem para o usuário navegar entre fotografias e modelos tridimensionais (nesse caso, também rotacioná-los) (Fig. 111).

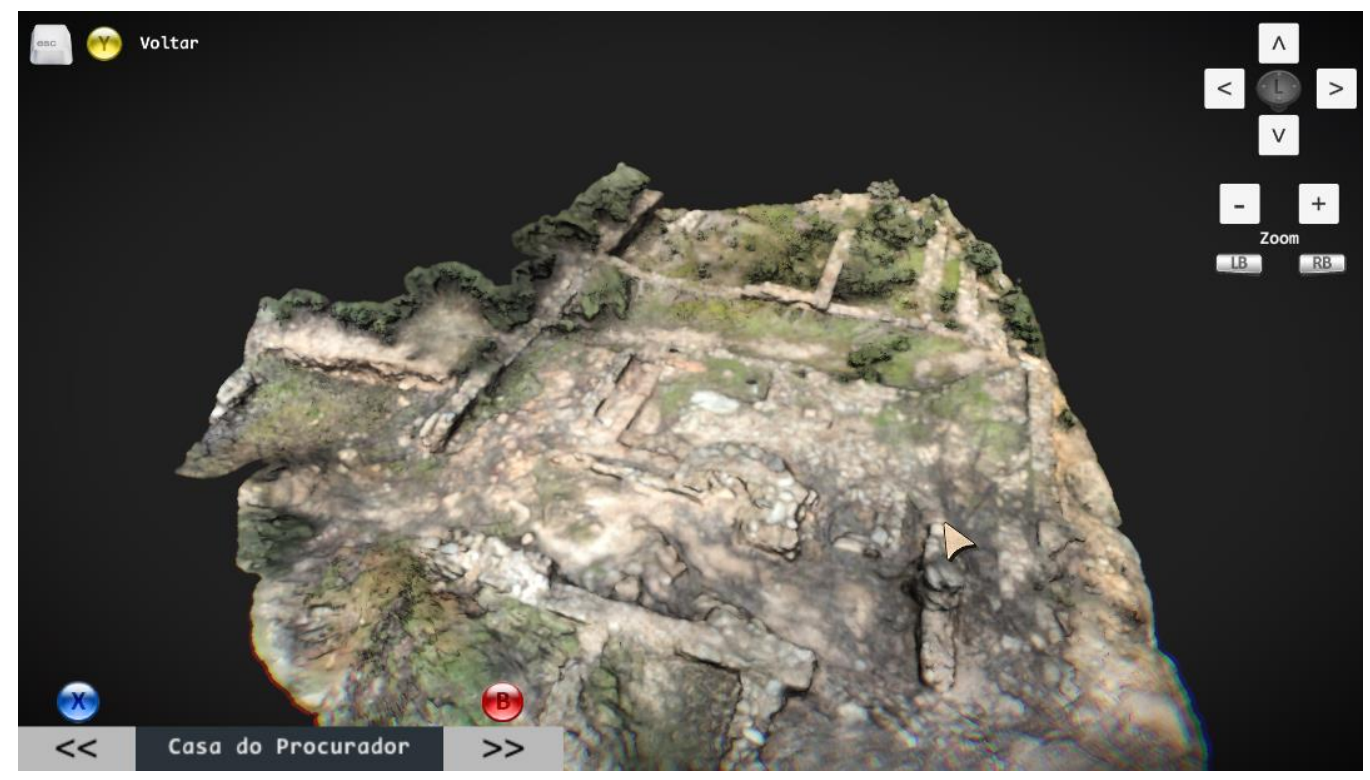

Fig. 111 - Canvas de navegação na galeria de objetos tridimensionais. 


\subsection{Fotogrametrias}

A fotogrametria ${ }^{61}$ vem sendo muito utilizada no âmbito arqueológico por permitir tanto a obtenção de dados mensurados como a visualização tridimensional de artefatos que muitas vezes estão em reservas técnicas de museus. Também há o caso de museus que usam a fotogrametria para disponibilizar ao público uma parte de seu acervo de modo online.

A fotogrametria é a melhor técnica para obtenção de modelos tridimensionais que, de outro modo, seriam muito complexos de modelar. Por se tratar de malhas criadas a partir de fotografias, os modelos possuem texturas fotorrealistas ${ }^{62}$, eliminando a necessidade de mapeamento UV. Por outro lado, o nível de detalhamento dos modelos fotogramétricos pode ser muito alto, alcançando, por vezes, milhões de polígonos: é preciso, então, que esses modelos sejam retrabalhados antes de serem inseridos no motor gráfico Unity: um processo denominado decimate (dizimar), que remodela o objeto de acordo com o número final de polígonos pretendidos pelo usuário.

Todos os modelos fotogramétricos do aplicativo Vipasca Antiga foram obtidos a partir de fotografias realizadas em campo (Casa do Procurador, esgoto e oficina metalúrgica) e na reserva técnica do Museu de Aljustrel (lucerna, taças e almofariz), e utilizando-se o programa Agisoft Photoscan, um dos principais softwares de fotogrametria do mercado. As etapas de produção seguiram o workflow ditado pelo próprio programa, a saber (Fig. 112):

1) Alinhamento das fotos - o processamento de todas as fotos inseridas no programa a fim de se obter pontos de referência em comum que auxilie na identificação dentro do espaço tridimensional (X, Y, Z);

2) Construção de nuvem de pontos - versão tridimensional do objeto a partir dos pontos obtidos no alinhamento: nessa etapa é possível editar a nuvem, subtraindo as partes desnecessárias (por exemplo, o céu e edifícios distantes, no caso de vestígios em campo);

3) Construção da malha - versão final do objeto após a edição das nuvens de ponto. Geralmente o modelo contém milhares (ou milhões) de faces poligonais;

\footnotetext{
${ }^{61}$ Mais informações: https://en.wikipedia.org/wiki/Photogrammetry (Acesso em 12/07/2016)

62 Mais informações: https://en.wikipedia.org/wiki/Photorealism (Acesso em 12/07/2016)
} 
4) Construção da textura - o programa faz o mapeamento UV e insere a textura no modelo final. A qualidade da textura depende da resolução das fotografias utilizadas;

5) Redução da malha - esse processo é essencial quando queremos exportar o modelo para motores gráficos ou inseri-los em arquivos PDF. Dizimando (decimating) as faces, obtemos um número aceitável de polígonos mesmo ocorrendo uma simplificação da malha final. É necessário reconstruir a textura após dizimar a malha.

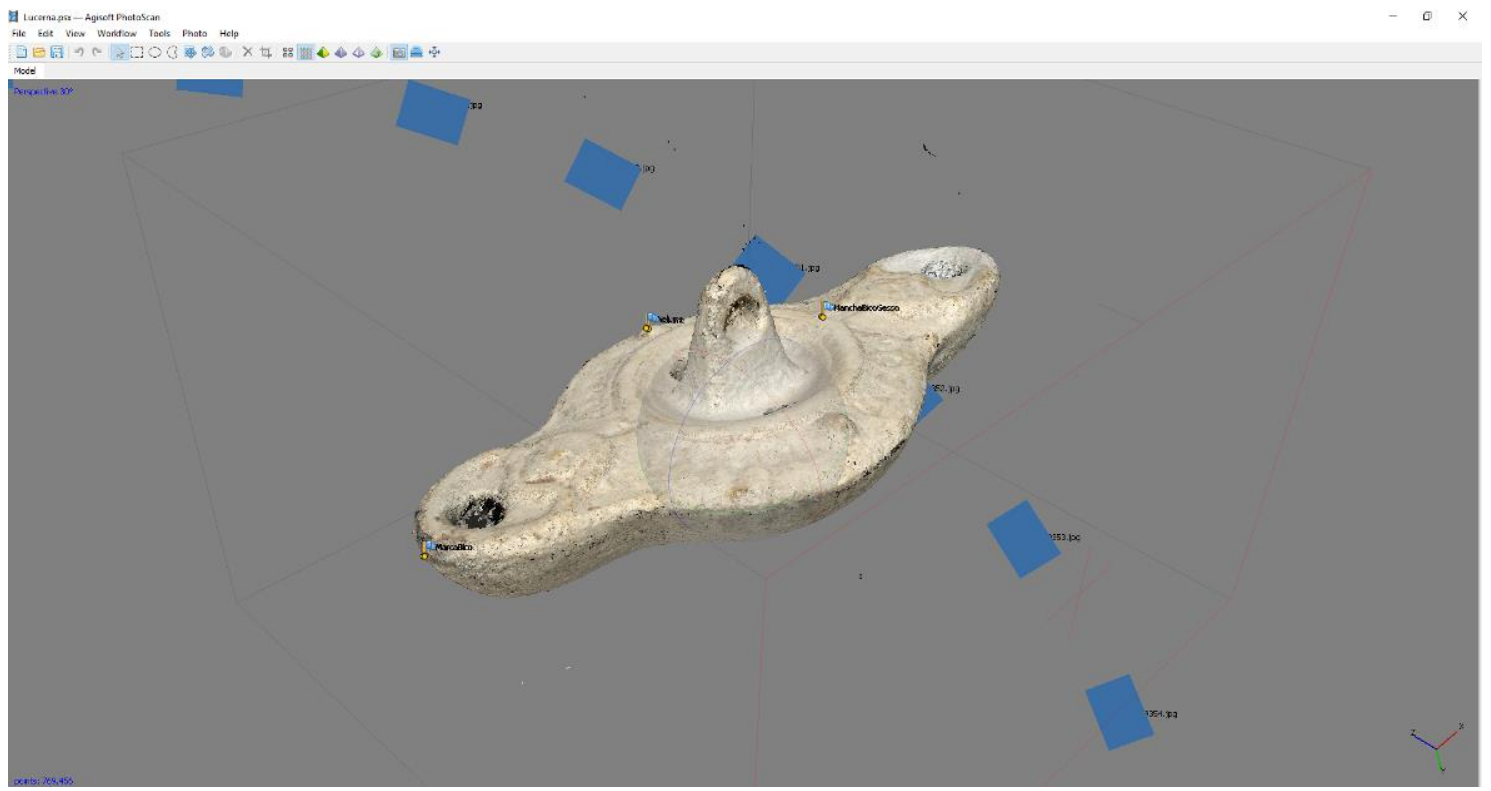

Fig. 112 - Nuvem densa de pontos obtida a partir do alinhamento de fotos da lucerna encontrada durante escavações na Casa do Procurador.

Importante destacar que a fotogrametria depende muito (como toda fotografia) da luz disponível no momento do trabalho: dias muito ensolarados causarão "estouros de luz” indesejados em vestígios externos; apenas um ponto de iluminação causará sombras nos artefatos fotografados em laboratório. A iluminação ideal acaba por ser uma série de tentativas e erros e consome parte substancial do trabalho de fotogrametria. No caso dos artefatos do aplicativo Vipasca Antiga, pôde-se contar com apenas 2 pontos de luz, o que causou pequenas sombras nos objetos (mas que não prejudicou o produto final). Outro aprendizado importante adquirido quando das fotografias dos artefatos foi o do uso de uma mesa giratória: ela se mostrou essencial para o sucesso da fotogrametria - foi utilizada uma base giratória plástica com diâmetro de $30 \mathrm{~cm}$ e marcada a cada $15^{\circ}$, 
totalizando 24 fotos para cada ângulo de câmera. Na maioria dos casos, três ângulos foram suficientes para resultado satisfatório.

Após a produção dos modelos, eles foram exportados como arquivos .FBX e importados no Unity. Utilizou-se o asset Camera Orbit ${ }^{63}$ para que o usuário pudesse girar os objetos e também aproximá-los ou afastá-los. Toda a interação se dá por meio de botões posicionados dentro do canvas (ou, no caso do uso de gamepads, movimentandose as alavancas analógicas e apertando-se os botões correspondentes) (Fig. 113).

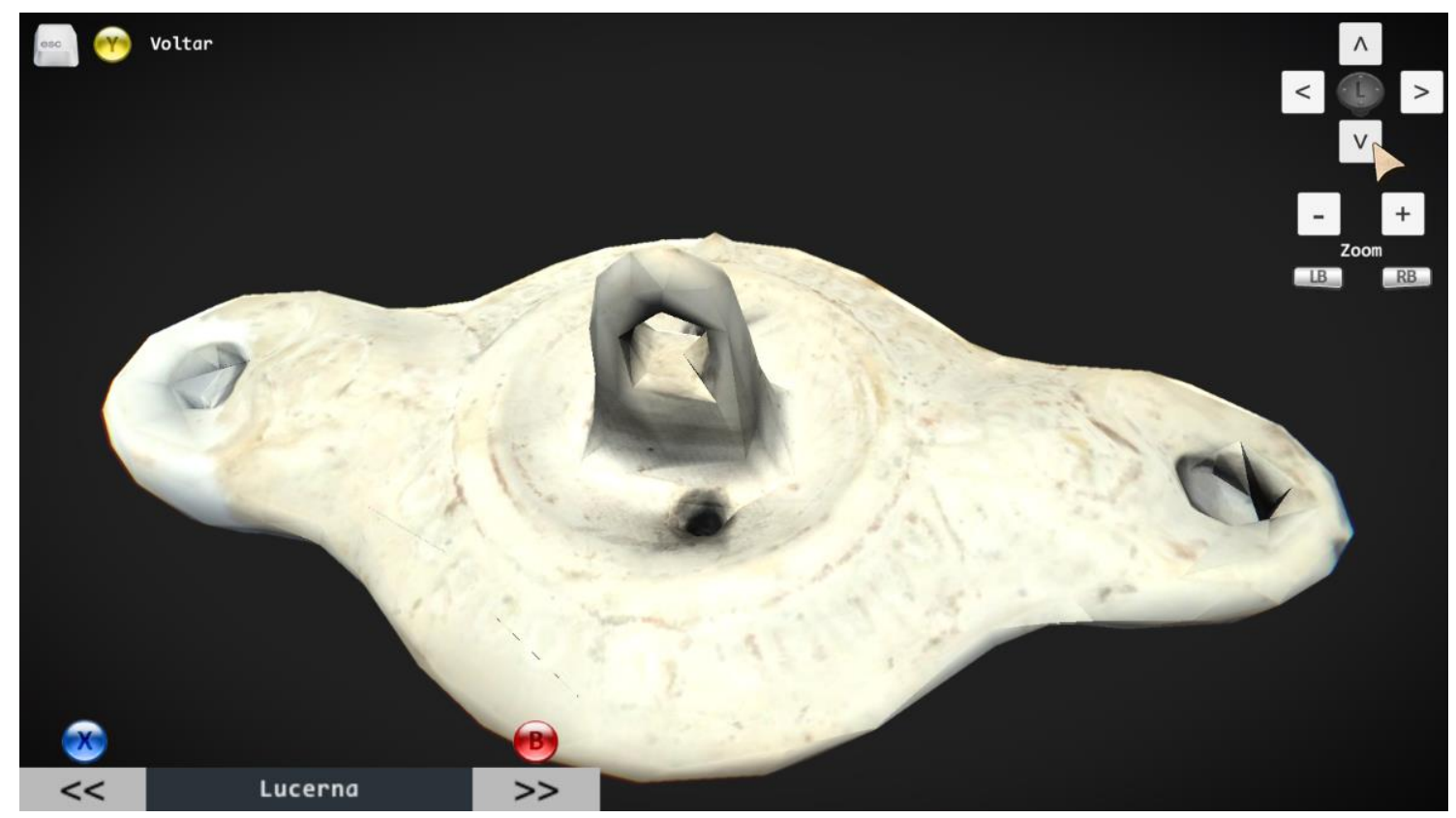

Fig. 113 - Sistema de movimentação da câmera a partir dos botões no canvas.

\subsection{Galeria de Imagens}

Uma galeria de imagens que mostre ao usuário os vestígios arqueológicos tem a função de estabelecer a correlação entre aquilo que é visto no ambiente virtual tridimensional e a aquilo que está em campo atualmente.

Os trabalhos ciberarqueológicos devem ser transparentes, oferecendo ao público a possibilidade de verem os materiais que deram origem às construções dos modelos virtuais: esse é um meio de validar o próprio desenvolvimento do aplicativo - jamais se deve buscar "aquilo como realmente foi", mas, sim, "aquilo que poderia ter sido", e uma

\footnotetext{
${ }^{63}$ www.assetstore.unity3d.com/en/\#!/content/44146
} 
excelente maneira de se fazer isso é também deixar que as pessoas façam correlações mentais por si mesmas.

Desse modo, utilizou-se o asset $3 D$ Presentations $\mathrm{Kit}^{64}$ para estabelecer a Galeria de Imagens do Vipasca Antiga. O asset tem fácil configuração - basta anexar as fotos aos objetos 3D vazios - e já possui canvas de navegação próprio, permitindo ao jogador avançar ou retroceder as fotografias. No total, 32 fotos foram utilizadas na galeria, mostrando os principais vestígios a céu aberto que pertenceram à paisagem mineradora Antiga da região (Fig. 114).

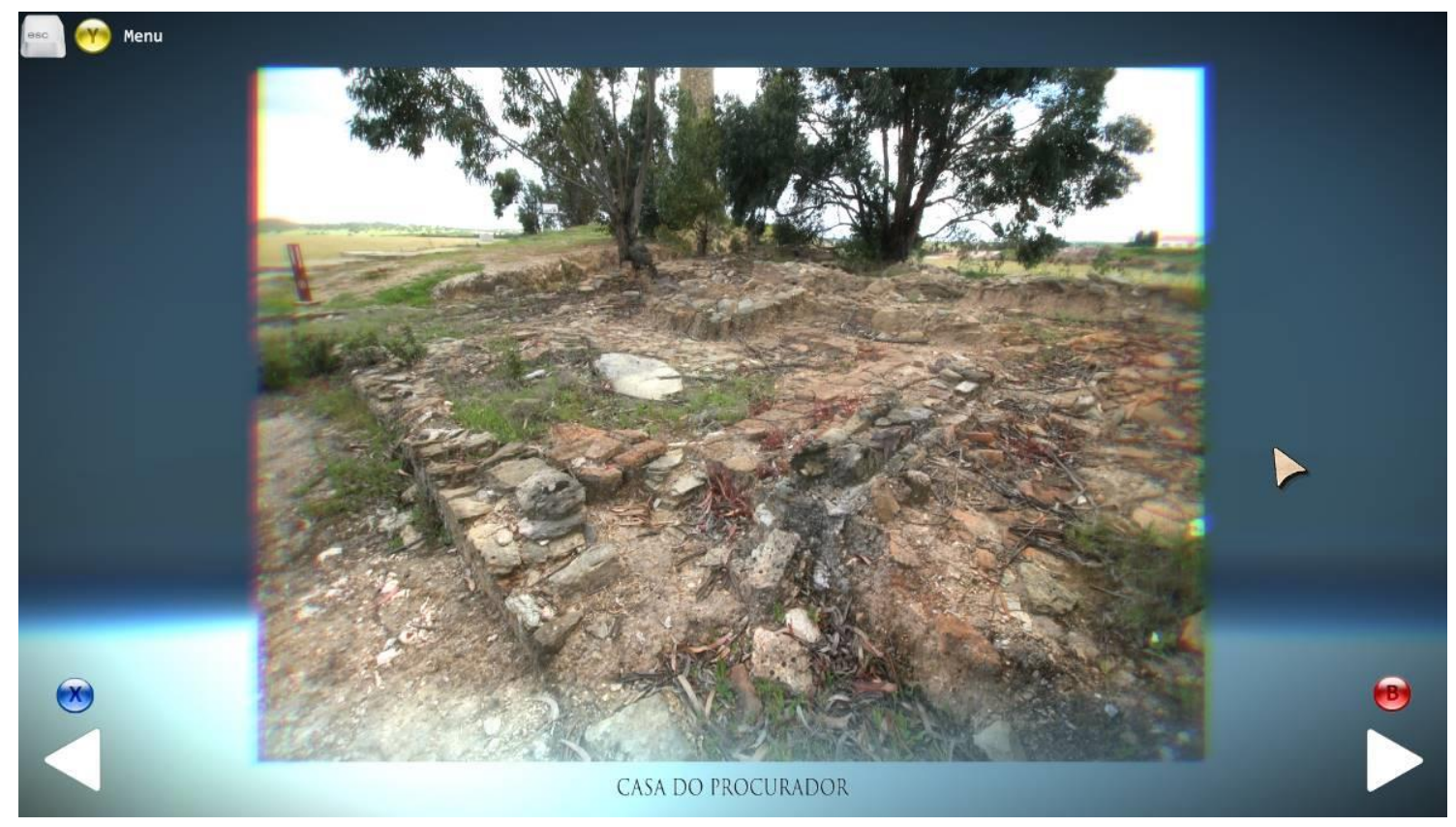

Fig. 114 - Tela da Galeria de Imagens mostrando um exemplo de fotografia e o canvas de navegação.

\section{7 Áudio}

$\mathrm{O}$ áudio é peça fundamental na imersão do jogador em um ambiente virtual tridimensional. Tornar o som ambiente o mais próximo possível daquilo que o jogador entende como "realidade" é uma tarefa que consome um tempo substancial no desenvolvimento de qualquer aplicativo de Realidade Virtual.

Para o aplicativo Vipasca Antiga, foi utilizado como base a trilha de áudio denominada "BirdAmbienceLoop0", presente no já mencionado asset Rural Sound Pack.

\footnotetext{
${ }^{64}$ www.assetstore.unity3d.com/en/\#!/content/48444
} 
Essa trilha foi anexada diretamente no player do UFPS como um som 2D, ou seja, sem se misturar ao resto dos demais sons. Esse áudio é ouvido durante toda a experiência dentro da cena principal do aplicativo, exceto nas galerias de extração mineral, e possui sons baixos de natureza, de campo aberto.

Os demais áudios dentro da cena principal e nas galerias foram todos configurados para se comportarem como sons $3 \mathrm{D}$, ou seja, tendo o seu volume variando de acordo com a posição do jogador - quanto mais próximo da fonte de áudio, mais alto o som 3D, e vice-versa.

No caso dos sons de queima de minérios nos fornos e na oficina, foi utilizado o asset Volumetric Audio ${ }^{65}$ para auxiliar na disposição do som 3D: as lenhas dos fornos e da oficina para as quais se pretendia que emitissem sons receberam o script do asset e a trilha de áudio correspondente à queima (Fig. 115). Como todo som 3D no Unity, o áudio é acionado por raycast (um raio constante emitido pelo objeto-fonte que tem a função de "encontrar" o seu alvo; nesse caso, o jogador): quanto menor a distância entre o player e o raycast emitido pela fonte, mais alto será o volume do áudio ${ }^{66}$.

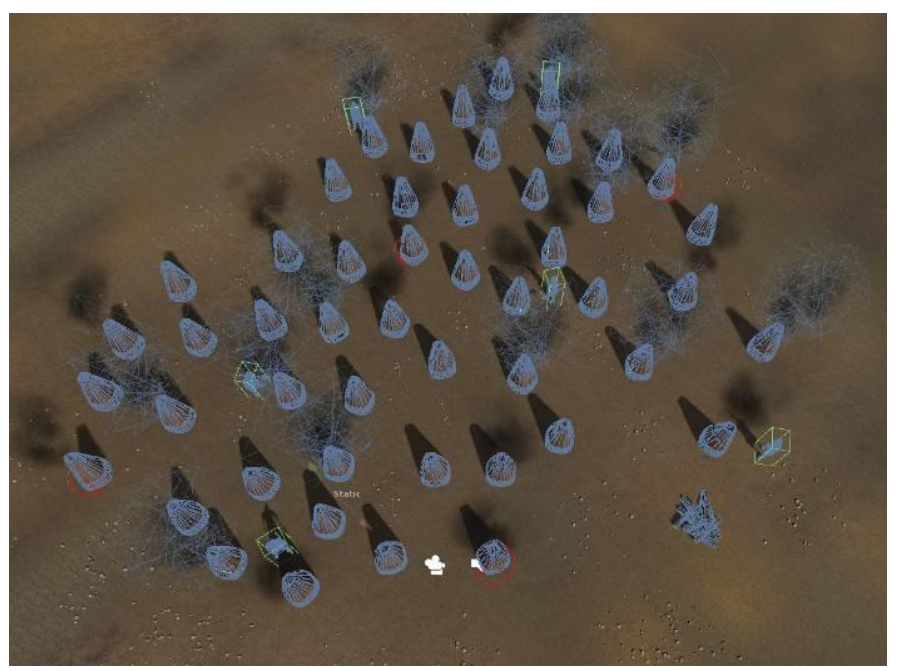

Fig. 115 - Fornos de redução com sistema 3D de áudio: os círculos vermelhos nas bases de alguns dos fornos são os emissores de raycast.

Os sons da água do Ribeira de Feitais foram obtidos por um método semelhante: criou-se uma série de waypoints (os mesmos do asset Simple Waypoint System já mencionado) ao longo da ribeira e atrelou-se uma fonte de áudio 3D à trilha criada. Um

\footnotetext{
${ }^{65}$ www.assetstore.unity3d.com/en/\#!/content/17125

${ }^{66}$ É necessário dizer que os raycasts exigem bastante processamento: assim, apenas quatro raycasts foram mantidos nos fornos, pois o número inicial deles (um para cada forno) tornou o aplicativo extremamente lento quando chegávamos próximos à área, prejudicando a performance.
} 
$s c r i p t^{67}$ colocado nessa fonte de áudio fez com que ela também agisse emitindo raycasts, acompanhando o jogador de ponto em ponto conforme ele avança ao longo das margens da ribeira.

Por fim, os sons de passos que variam conforme a textura do solo/chão sobre o qual andamos são todos 2D e já foram mencionados quando discorri sobre o Player.

\section{PERFORMANCE}

\subsection{Lightmaps}

Realizar o lightmapping ${ }^{68}$ é fundamental para a performance de um jogo. O lightmap (mapa de luz) é a computação das luzes incidente sobre os objetos e a geração de texturas que substituem a necessidade de haver iluminação em tempo real. Em outras palavras, o lightmap é uma "pintura" de texturas com sombras que substitui a necessidade de uma fonte de luz. A substituição traz o enorme benefício de diminuir a quantidade de memória RAM necessária para computar as texturas em tela e as sombras projetadas.

O lightmap acrescenta realismo à cena: o baking (ato em si de processar as texturas em mapas de luz) computa não só as sombras como, também, a iluminação global (global illumination ${ }^{69}$ ) do ambiente, gerando iluminação indireta - a computação dos raios de luz emitidos pela fonte luminosa e refletidos por todas as superfícies dos objetos (Figs. 116-117).

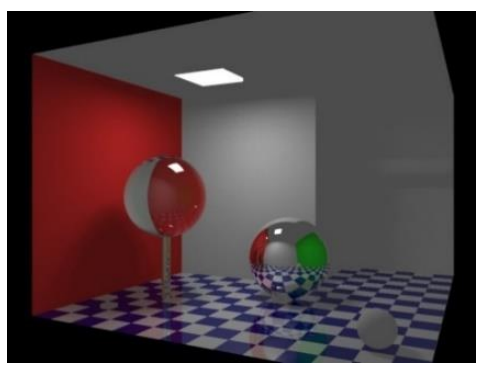

Fig. 116 - Renderização sem iluminação global: note como as áreas distantes da luz do teto estão indefinidas e como as sombras não possuem nuances. In: https://en.wikipedia.org/wiki/Global_illumination (Acesso em 12/07/2016).

\footnotetext{
${ }^{67}$ A ideia da construção do sistema utilizando-se o SWS, bem como o script, foi encontrada no seguinte website (o qual retém os créditos pela solução): https://doctorllama.wordpress.com/2014/07/29/howto-create-a-3d-sound-of-a-large-area-e-g-river-in-unity-3d/

68 Mais informações: https://en.wikipedia.org/wiki/Lightmap (Acesso em 12/07/2016)

${ }^{69}$ Mais informações: https://en.wikipedia.org/wiki/Global_illumination (Acesso em 12/07/2016)
} 


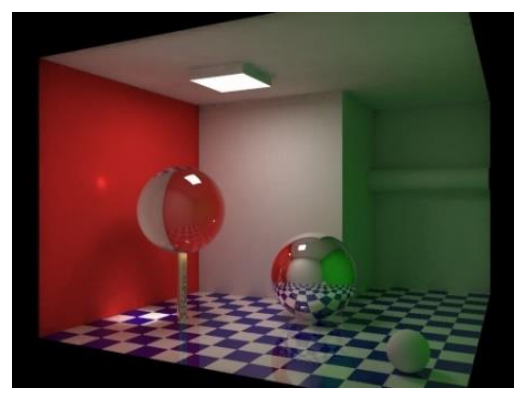

Fig. 117 - Renderização com iluminação global: os raios de luz são refletidos por todas as superfícies, aumentando o realismo. In: https://en.wikipedia.org/wiki/Global_illumination (Acesso em 12/07/2016).

A desvantagem do lightmap, contudo, é somente ser aplicado a objetos estáticos: os grandes beneficiários desse tipo de iluminação acabam sendo os edifícios e componentes presentes em ambientes fechados (por exemplo, mobiliários) que não necessitem de mudança de luz (como a que existe no passar das horas de um dia, por exemplo).

A versão do Unity utilizada incialmente (5.3.4) apresentou problemas durante o lightmapping $^{70}$ da cena principal do aplicativo Vipasca Antiga. Algumas vezes o lightmapping demorava 12 horas para ser finalizado e, na maioria das vezes, apresentava algum erro durante o processamento, nunca finalizando as tarefas. O lightmapping, quando obtido com sucesso, apenas acontecia se as configurações de qualidade de iluminação estivessem as mais baixas possíveis, tornando a cena toda desagradável de ser vista, com texturas em baixíssima resolução.

Após a realização de pesquisas nos fóruns oficiais da Unity, ficou constatado que, de fato, a versão 5.3 do motor gráfico contém bugs que atrapalham o lightmapping. A solução encontrada foi a migração para a versão beta $5.4 \mathrm{~b} 20$, que demonstrou ser eficiente na geração dos lightmaps: obtiveram-se resoluções adequadas mesmo com a configuração do lightmapping estando em valores medianos, levando cerca de quatro horas para o baking total (Fig. 118). O lightmapping final da cena principal (ou seja, a das missões) do aplicativo Vipasca Antiga gerou oito lightmaps com resolução 2048 x 2048px e ficou com tamanho de 85,3 MB (Fig. 119).

\footnotetext{
${ }^{70}$ Para mais informações sobre o lightmapping do Unity: http://docs.unity3d.com/460/Documentation/Manual/LightmappingInDepth.html (Acesso em 12/07/2016)
} 


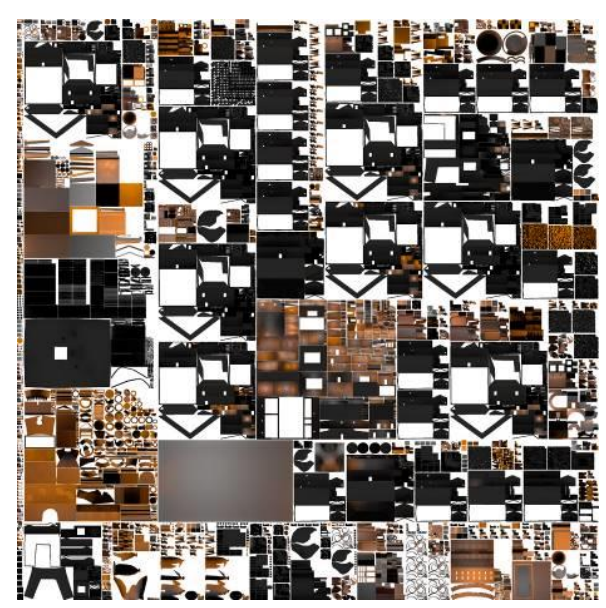

Fig. 118 - Um dos lightmaps finais do aplicativo Vipasca Antiga.

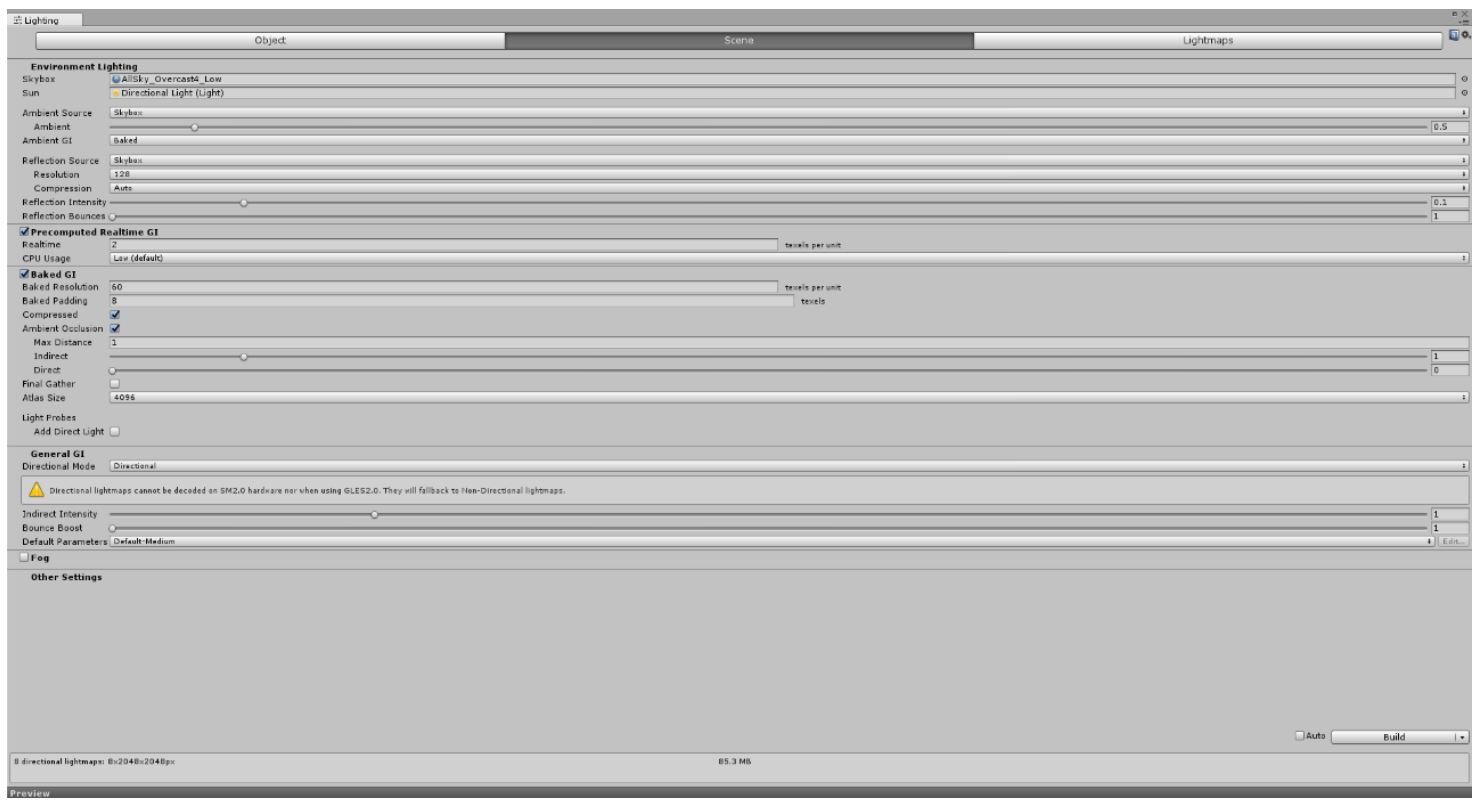

Fig. 119 - Painel de configuração do lightmapping no Unity.

No caso dos NPCs em tela, que são dinâmicos, eles não puderam se beneficiar do lightmapping. Assim, eles receberam iluminação da fonte de luz direcional presente na cena (emulando a luz solar), em tempo real. Esse é o único modo de objetos que se movimentam terem sombra. Inicialmente, havia quase o dobro de NPCs que existem na versão final do aplicativo (266), porém, isso começou a comprometer a performance, fazendo com que o número de FPS (frames per second, ou quadros por segundo) caísse consideravelmente. A solução foi eliminar praticamente metade dos NPCs que estavam em cada aglomerado de Vipasca: manteve-se inalterado, contudo, o número de NPCs que caminham pelas estradas entre as partes do povoado. 
(É necessário mencionar que na qualidade Low do aplicativo toda a iluminação em tempo real foi subtraída em prol da melhor performance possível em computadores que não possuem placas de vídeo dedicadas.)

\subsection{Occlusion Culling}

A oclusão (obscurecimento momentâneo) é primordial para os jogos eletrônicos. Occlusion Culling é a característica de desabilitar a renderização de objetos que não estejam sendo vistos diretamente pela câmera, ou que estejam sendo obstruídos/obscurecidos por outros colocados à frente ${ }^{71}$.

Na verdade, a occlusion culling emula o que acontece com os nossos olhos: se você avista um museu na rua da cidade, obviamente estará diante de tudo: carros, outros edifícios, pessoas, gatos, cachorros, porquinhos da índia, postes de iluminação etc.; porém, ao entrar no museu tudo aquilo que você avistou na rua deixa de ser visto: agora apenas o ambiente interno do museu chega aos seus olhos; e mais: as paredes internas divisórias do museu impedem que você enxergue o que está atrás delas (exceto o Superman, claro, mas isso é outro assunto) (Fig. 120).

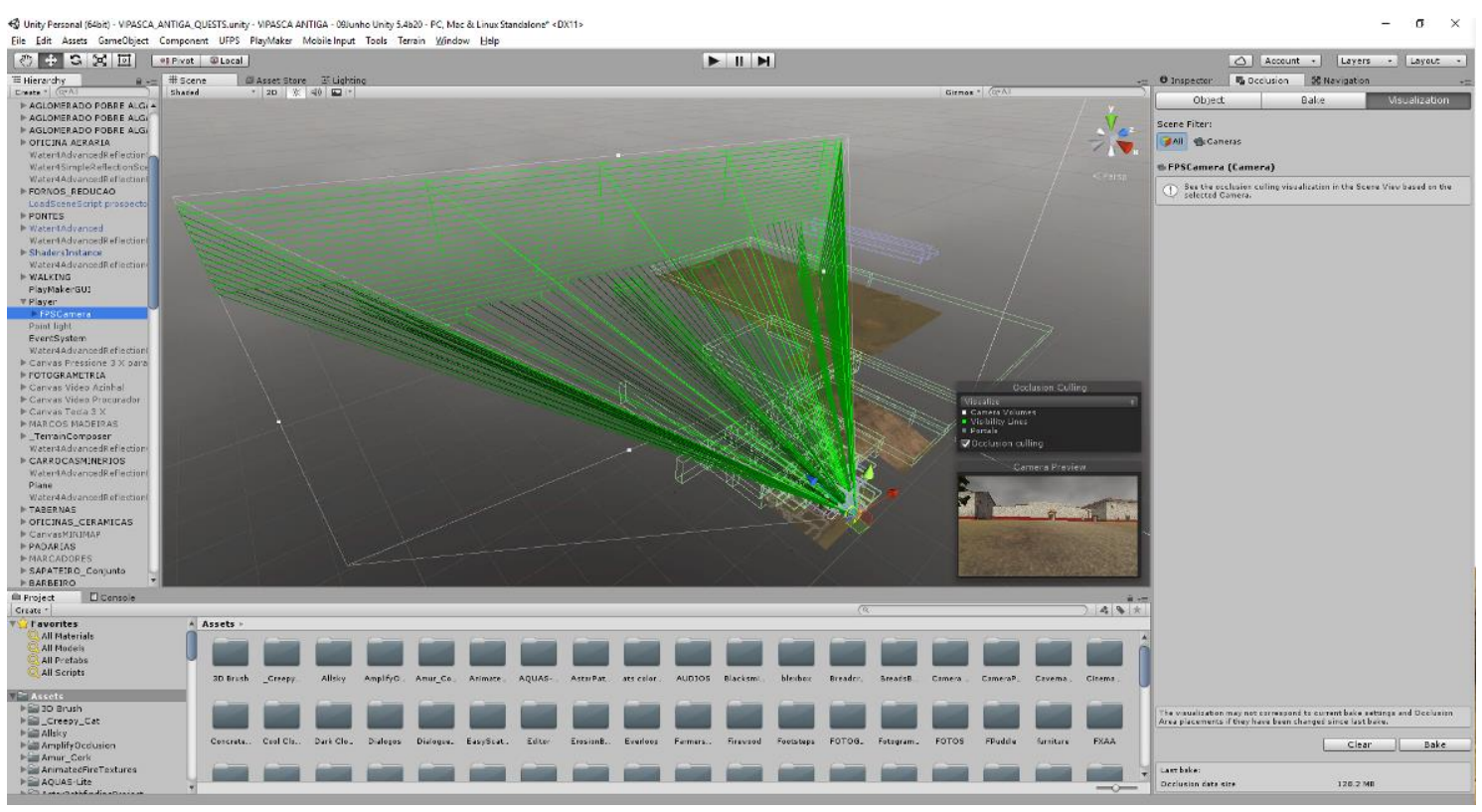

Fig. 120 - Tela de visualização da oclusão: as linhas verdes representam o alcance de visão da câmera; note que apenas um pequeno pedaço do terreno é renderizado.

\footnotetext{
${ }^{71}$ Mais informações: https://docs.unity3d.com/Manual/OcclusionCulling.html (Acesso em 12/07/2016)
} 
Esse princípio de obscurecimento traz ganhos de performance gigantescos para os jogos. Se a oclusão não for computada, absolutamente todos os objetos em cena - com seus triângulos e vértices - serão renderizados (ou seja, vistos) pela câmera do jogador durante todo o tempo. Em uma paisagem complexa como a do aplicativo, isso significaria 12,5 milhões de triângulos (ou 11,8 milhões de vértices), causando um estresse do processador do computador, fazendo com que os quadros por segundo caiam drasticamente (quando ficam abaixo de 12 FPS já se nota "travamentos" na tela). Com a oclusão computada, temos um número que varia entre 1,5 e 4 milhões de vértices quando estamos em ambiente externo (observando a paisagem), sendo que essa contagem diminui bastante quando entramos em algum local fechado (na Casa do Procurador, por exemplo, o número varia entre 200 mil e 1 milhão de polígonos de acordo com o cômodo em que estamos).

No caso do aplicativo Vipasca Antiga, a occlusion culling foi configurada de modo que a menor célula a ser obscurecida tivesse $1 \mathrm{~m}^{3}$, e que o menor buraco entre as células tivesse $0,5 \mathrm{~m}$ de espaçamento (para que objetos não "desapareçam" da tela quando observamos algo através de algum tipo de "buraco", por exemplo, janelas ou suportes laterais da ponte de madeira sobre a ribeira. $\mathrm{O}$ tempo total de processamento da oclusão foi de aproximadamente 14 horas e ficou com o tamanho de 128,2 MB (Fig. 121).

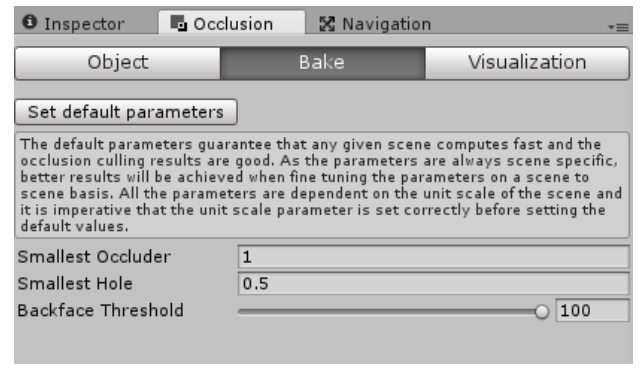

Fig. 121 - Painel de configuração de occlusion culling.

Para otimizar a oclusão, optou-se por empregar a técnica de billboards nas domus e insulae do terreno. Billboard é uma representação gráfica 2D de um objeto 3D: ou seja, é uma espécie de "fotografia" que utilizamos para substituir os objetos 3D que estão distantes da câmera - não tendo seus volumes distinguíveis; quando chegamos a uma determinada distância do billboard, a imagem 2D é substituída pelo objeto 3D original. Foi utilizado o asset Real Imposters LOD System ${ }^{72}$ para gerenciar a criação dos billboards

\footnotetext{
72 www.assetstore.unity3d.com/en/\#!/content/40188
} 
e estabelecer a distância entre eles e o jogador que dispararia a substituição. Podemos ver na Fig. 122 que apenas os edifícios próximos ao jogador (que está diante da Casa do Procurador) estão tridimensionais: os edifícios dos demais aglomerados são imagens 2D.
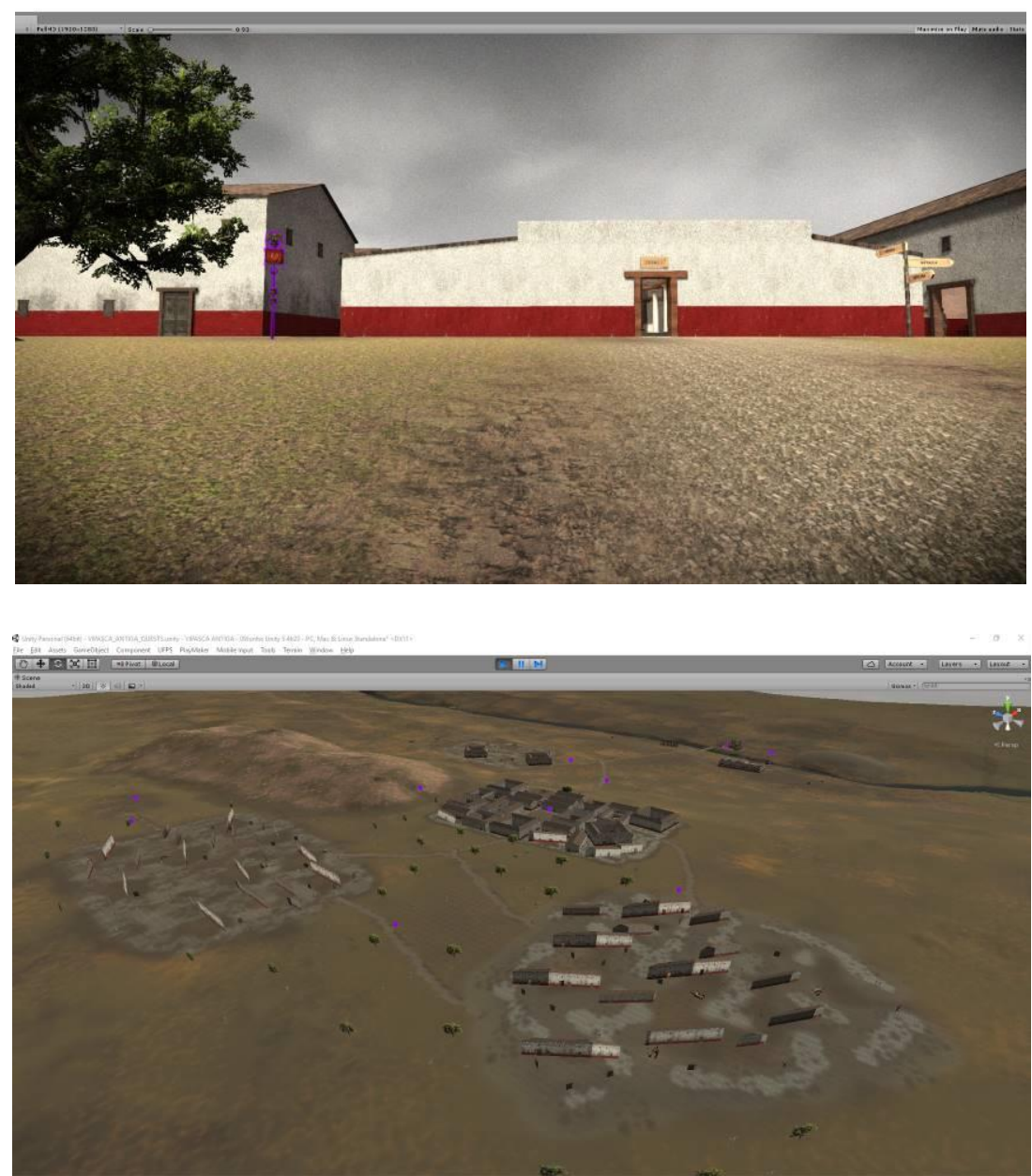

Fig. 122 - Acima, a câmera visualizando a Casa do Procurador; abaixo, os billboards 2D dos edifícios nos aglomerados (distantes da câmera).

Embora a oclusão seja aplicada essencialmente a objetos estáticos, os NPCs do aplicativo tiveram suas animações ocultadas quando não os vemos na tela: esse recurso serve para melhorar a performance final do aplicativo, uma vez que animações são grandes consumidoras de processamento computacional (Fig. 123). 


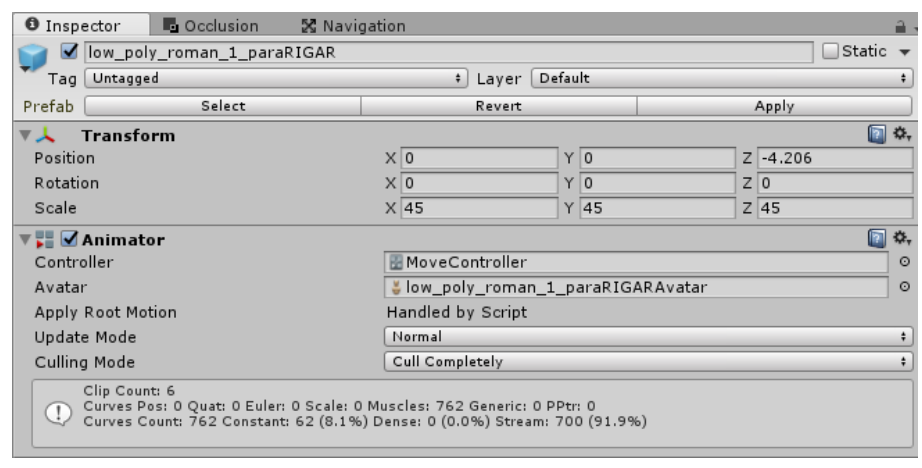

Fig. 123 - Painel de edição do NPC animado com o recurso Culling Mode configurado para Cull Completely.

\subsection{Vegetação}

A vegetação foi o último componente a ser colocado em tela, somente após os testes de performance indicarem que não haveria queda de quadros por segundo significativa na tela. Acrescentar flora a ambientes amplos como o terreno do aplicativo Vipasca Antiga deve ser algo muito bem planejado, pois o número de polígonos na tela pode aumentar bastante, principalmente se optarmos por colocarmos gramas como objetos 3D ao invés de texturas.

Existem duas árvores principais na paisagem de Aljustrel que foram marcantes também em época romana: a oliveira (Olea europaea L.) e a azinheira (Quercus ilex) todo o entabuamento dos poços e galerias de extração mineral foi feito com esta espécie de árvore. Ambos os modelos 3D foram obtidos na loja da Unity ${ }^{73}$, já otimizados para jogos eletrônicos (ou seja, contendo poucos polígonos e possuindo $\mathrm{LOD}^{74}$ ).

Devido a limitações de processamento, não seria possível espalhar verdadeiras "florestas" pela paisagem digital. Assim, apenas algumas árvores foram colocadas em cena, totalizando 288 (172 oliveiras e 116 azinheiras). Nas árvores também foi aplicado o asset Real Imposters LOD System para que, à distância, os objetos se tornassem imagens

\footnotetext{
73 Oliveira: www.assetstore.unity3d.com/en/\#!/content/61874

A azinheira não possui modelo 3D próprio, então foi utilizado um semelhante: www.assetstore.unity3d.com/en/\#!/content/28809

${ }^{74}$ Level of detail (nível de detalhe, em português), é a característica de um objeto possuir duas ou mais modelagens que se alternam conforme a distância que estão do jogador: quanto mais próximo, maior o nível de detalhamento da malha do objeto; quanto mais distante, menor o número de polígonos. Mais informações: https://en.wikipedia.org/wiki/Level_of_detail (Acesso em 12/07/2016)
} 
2D. A fim de não aumentar o processamento de sombras no aplicativo, todas elas foram ignoradas nas árvores (Fig. 124).

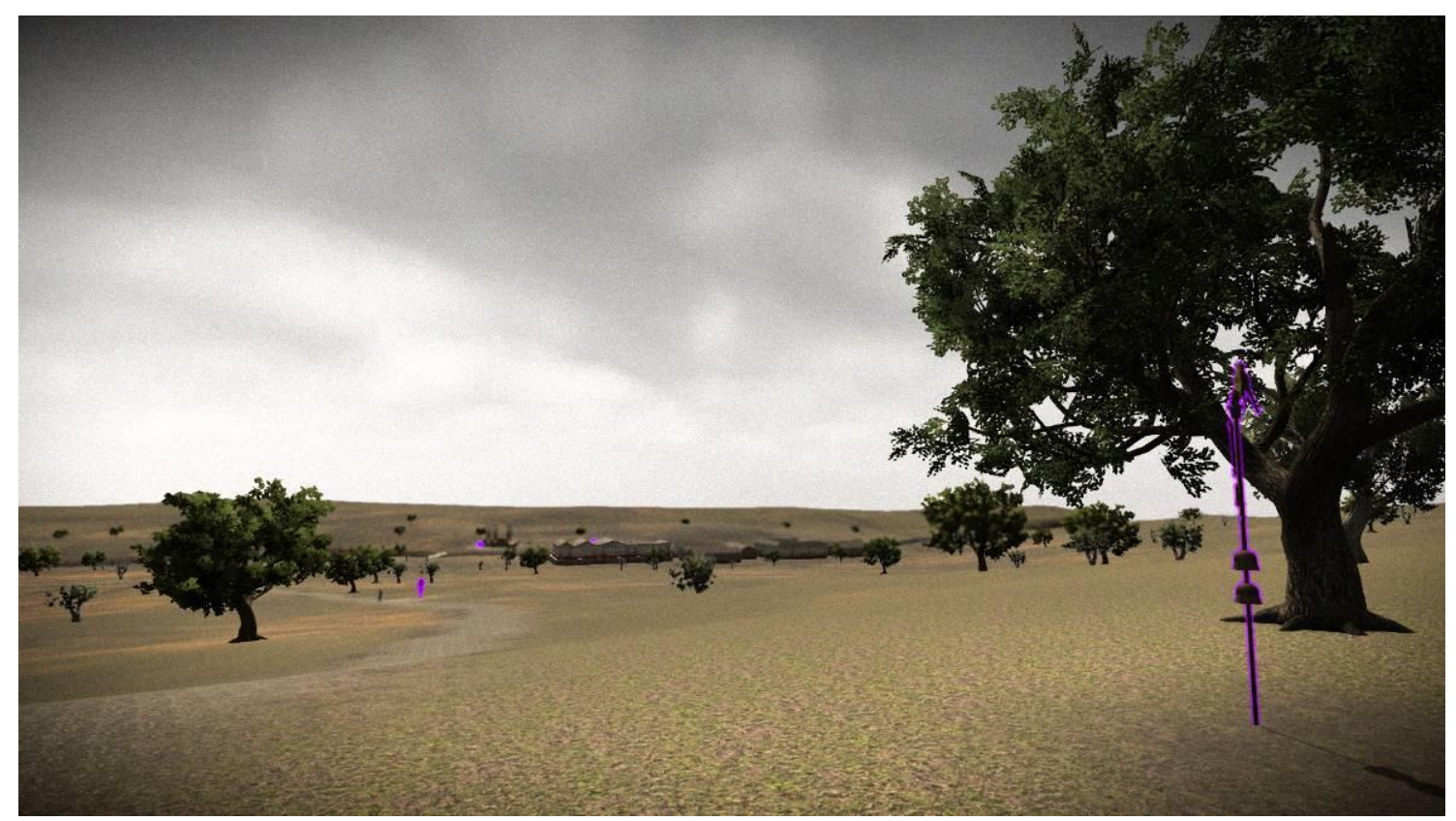

Fig. 124 - Árvores espalhadas pela paisagem (sombras desativadas).

Também foi criada uma versão do aplicativo voltada para computadores mais potentes (equipados, por exemplo, com placas de vídeo da série Nvidia GeForce 700 ou superior ${ }^{75}$ ) na qual existem gramas no terreno. Contudo, para não tornar o resultado final inviável, optou-se por pintar as texturas das gramas no terreno ao invés de usar malhas 3D: essas pinturas agem como billboards. A escolha da vegetação rasteira também foi feita pelo arqueólogo Artur Martins e depois pintada por todo o terreno de Vipasca, intercalando-se as imagens obtidas no asset HQ Photographic Textures Grass Pack Vols. 1 e $2^{76}$ (Fig. 125). As gramas não aparecem todas de uma vez na tela do aplicativo, pois traria prejuízo ao número de quadros por segundo: elas vão sendo carregadas de acordo com a posição em que o jogador está. No caso do Vipasca Antiga, utilizou-se a distância máxima de carregamento de vegetação de 250 (unidades/metros) e a densidade da pintura das gramas de 0,2 (Figs. 126-127). O resultado foi o de uma cena com gramas

\footnotetext{
75 O ideal seria a utilização de placas da série 900 (a 960, 970 ou 980).

${ }^{76}$ www.assetstore.unity3d.com/en/\#!/content/32656
} 
pintadas que traz realismo maior sem forçar demais o processamento do computador (Fig. 128).
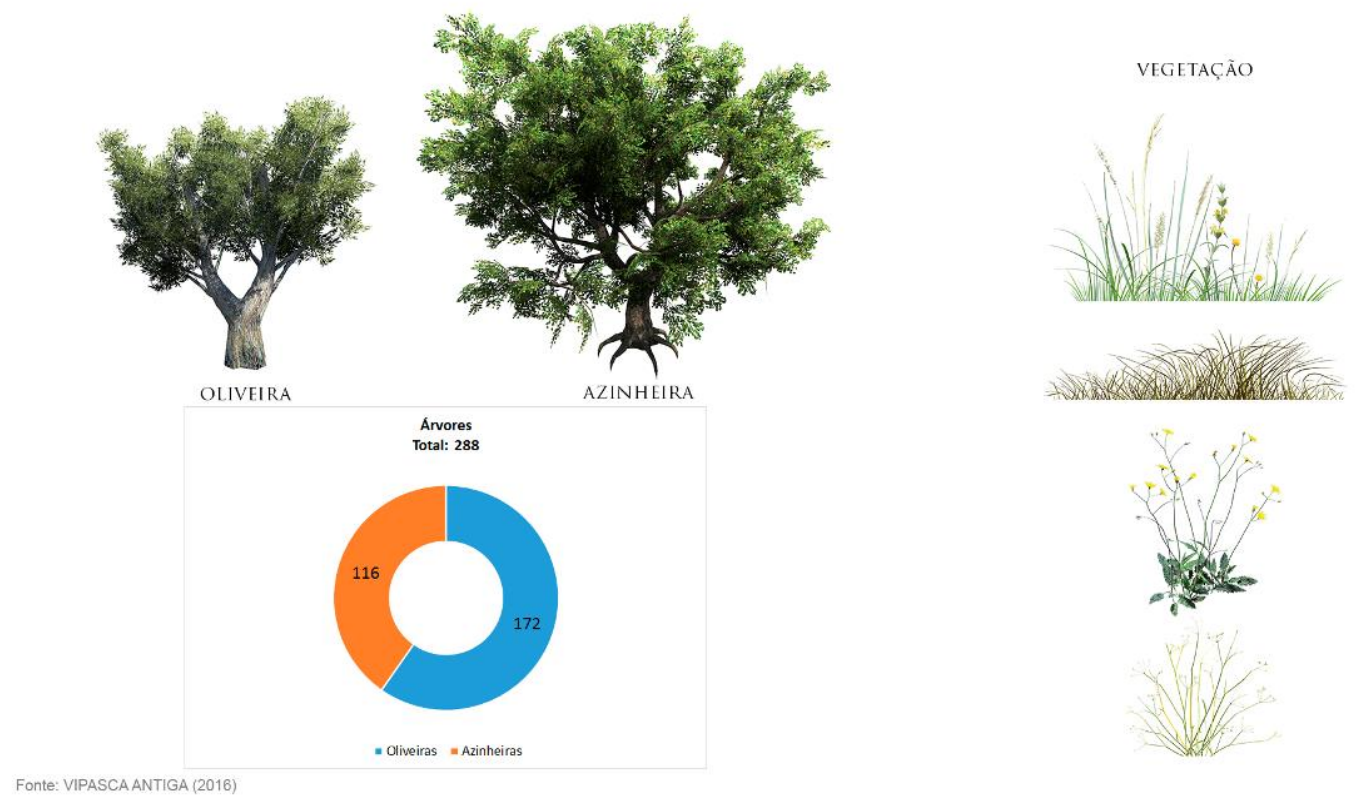

Fig. 125 - Gráfico com a contagem de árvores e as texturas usadas como vegetação.

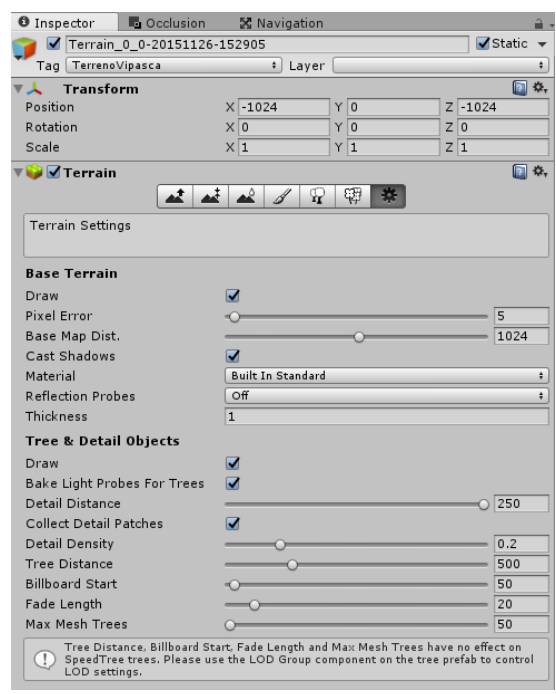

Fig. 126 - Painel de edição mostrando a distância dos detalhes (gramas) e sua densidade. 


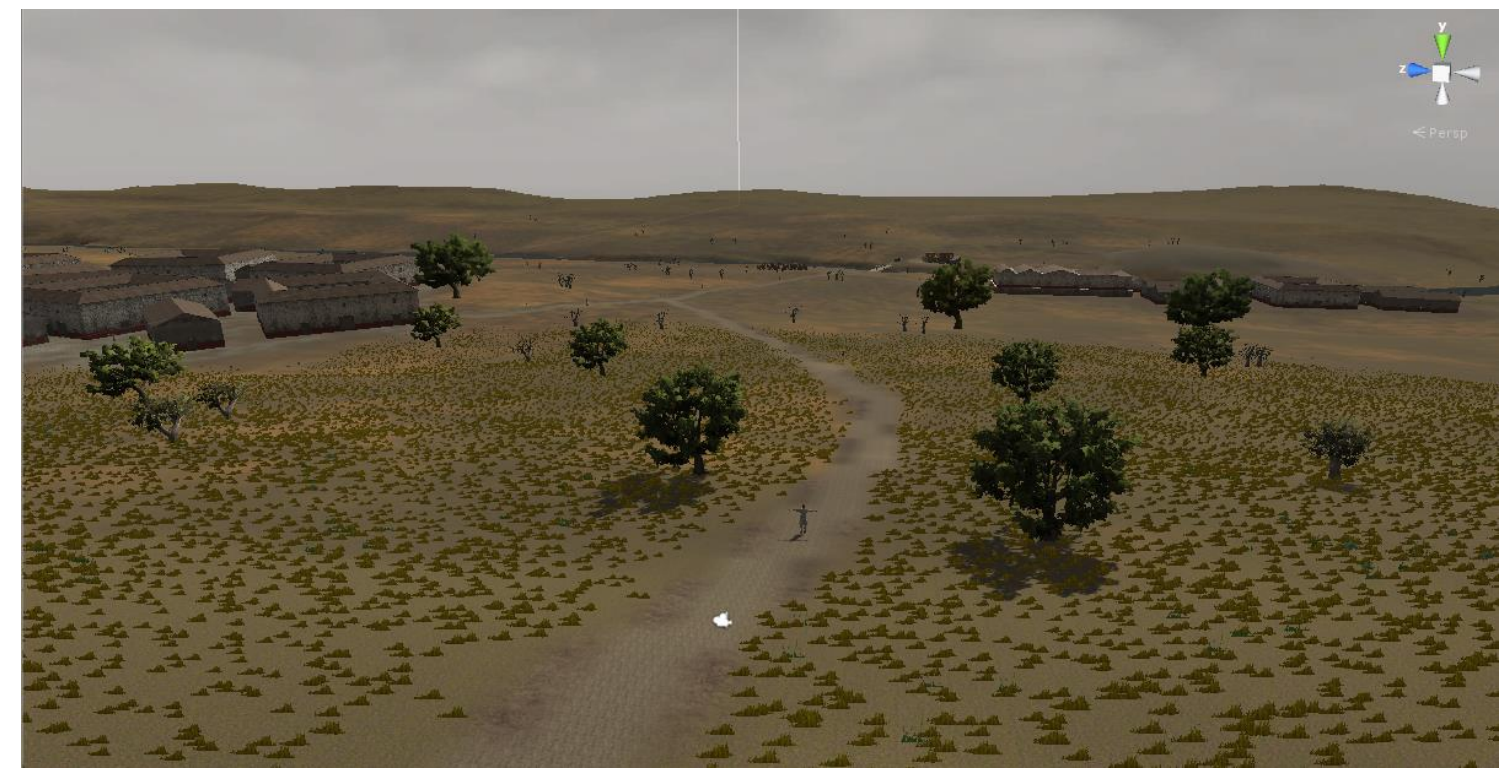

Fig. 127 - Cena dentro do Unity: note como as gramas terminam após uma determinada distância no horizonte.

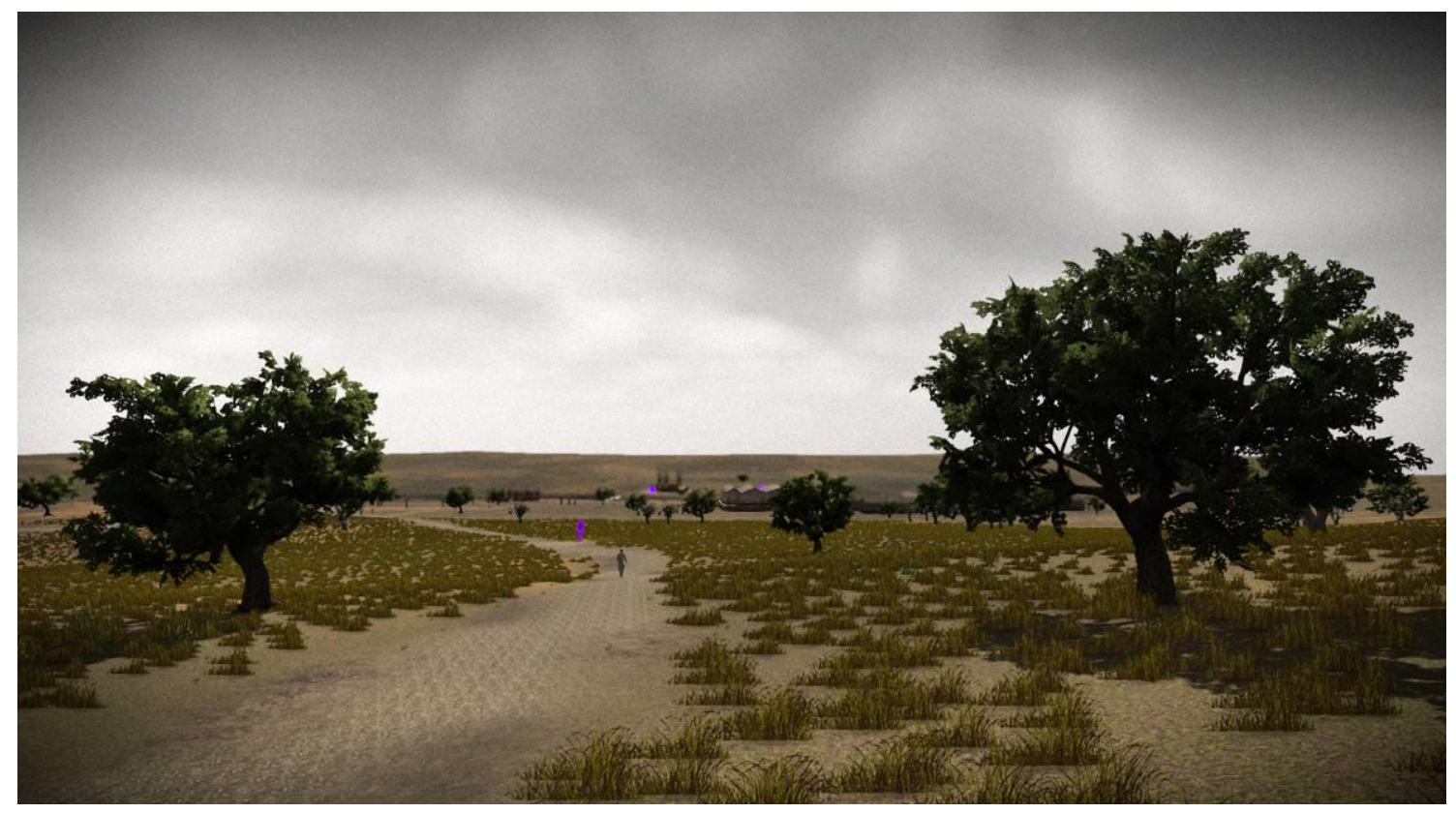

Fig. 128 - Resultado final dentro do aplicativo. 


\subsection{Qualidade}

Com toda a cena estabelecida, foi realizada a configuração da qualidade final do projeto. Nessa etapa é possível acertar valores como o da distância das sombras, da qualidade das texturas, do anti-aliasing ${ }^{77}$ (antisserrilhamento), e do V-Sync ${ }^{78}$ (sincronização vertical).

Quanto maiores os valores, mais processamento exigirá do computador. Como podemos ver na Fig. 129, a configuração Low tem sua qualidade de textura definida para a metade (Half Res), tem todas as sombras desabilitadas e, fator importante, tem o $V$-Sync também desabilitado: essa opção permite que o aplicativo rode com o maior número de quadros possíveis que o processador (e a placa de vídeo, se houver) consiga renderizar por segundo. Certamente haverá screen tearing na tela, mas é algo a ser desconsiderado para que o aplicativo possa rodar aceitavelmente em computadores com configurações de hardware mais modestas.

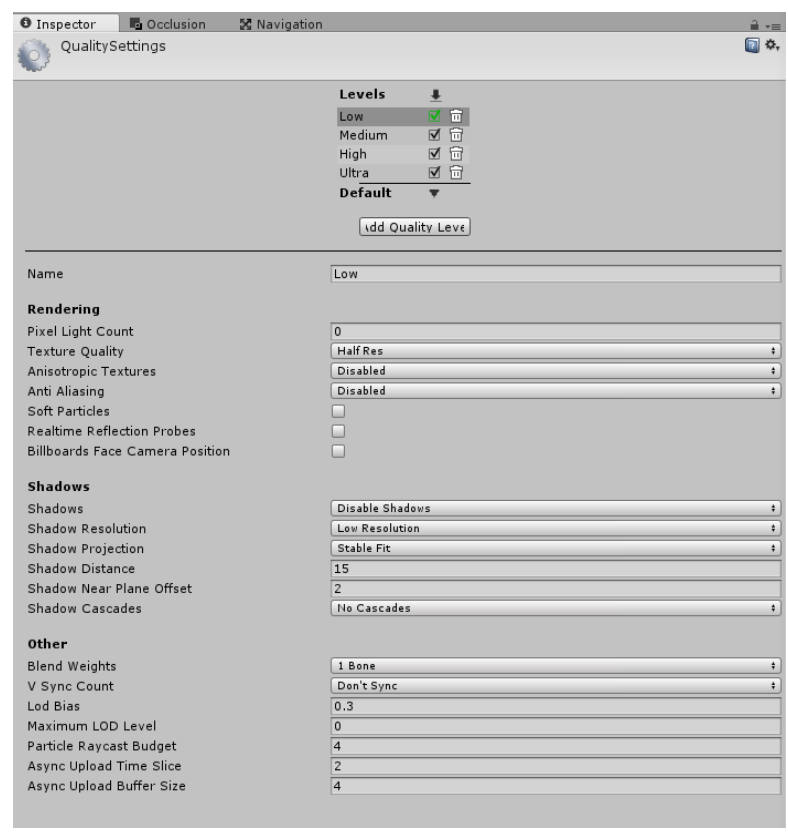

Fig. 129 - Painel de configuração de qualidade: nível Low (baixo).

\footnotetext{
77 O efeito de anti-aliasing permite diminuir o serrilhado que aparece nas arestas dos objetos 3D em cena, melhorando a definição. Mais informações: https://en.wikipedia.org/wiki/Spatial_anti-aliasing (Acesso em 12/07/2016)

78 O Vertical Synchronization faz com que os quadros por segundo (FPS) do jogo fiquem sincronizados com a taxa de atualização de imagens do monitor. No Brasil, a taxa de atualização geralmente é de 59 Hertz: um jogo que apresente 60 FPS terá uma fluidez muito maior e sem ocorrer screen tearing (quando um quadro é enviado antes que o outro tenha sido devidamente renderizado na tela, causando pequenas linhas de "sobreposição". Mais informações: http://www.tecmundo.com.br/video-game-e-jogos/1828-oque-e-v-sync-vertical-synchronization (Acesso em 12/07/2016)
} 
A Fig. 130, por sua vez, mostra a configuração Ultra. Nela, observamos que a qualidade de texturas está definida para o máximo (Full Res), o anti-aliasing está com uma amostragem de quatro vezes, as sombras estão com resolução alta e distância mínima de 150 (unidades/metros), dois níveis de LOD estão habilitados, e o V-Sync está definido para Every V Blank, ou seja, o número de FPS deve corresponder à taxa de atualização do monitor utilizado com o computador.

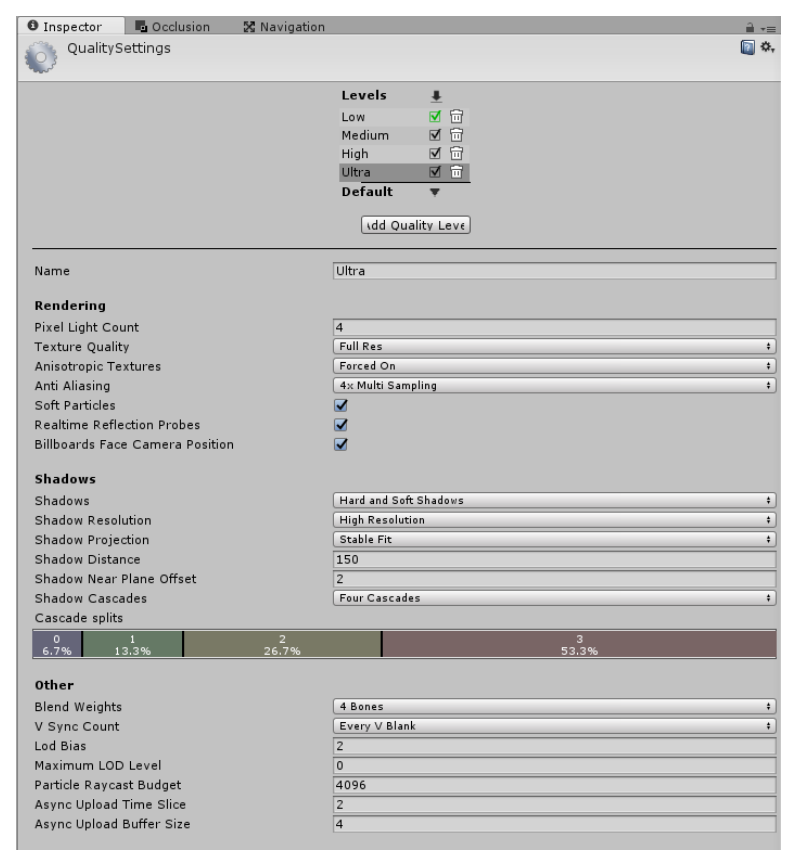

Fig. 130 - Painel de configuração de qualidade: nível Ultra.

\subsection{Efeitos}

Os efeitos de câmera foram habilitados apenas para a qualidade Ultra, visando computadores que atendam aos requisitos recomendados para rodar o aplicativo.

Os efeitos são meramente estéticos, mas dão à cena ares cinematográficos e seguiram estritamente o meu gosto visual. Para os efeitos foram utilizados dois assets principais, o PRISM - Realistic Post-Processing ${ }^{79}$ e o Amplify Occlusion ${ }^{80}$.

O PRISM - Realistic Post-Processing é um conjunto de efeitos de pósprocessamento (ou seja, ligados diretamente à câmera do jogador, como uma camada) que não afeta negativamente a performance do aplicativo. Para o Vipasca Antiga foram

\footnotetext{
${ }^{79}$ www.assetstore.unity3d.com/en/\#!/content/50819

${ }^{80}$ www.assetstore.unity3d.com/en/\#!/content/56739
} 
configurados os seguintes efeitos: Depth of Field (profundidade de campo) - para esmaecer os objetos que estão distantes; Vignette (vinheta) - máscara ovalada que escurece os cantos da tela; Filmic Noise (ruído de filme) - geração de ruídos que emulam lentes cinematográficas; Exposure Adaptation (adaptação de exposição) - regulagem automática do "obturador" da câmera do jogador, permitindo que a entrada de luz na cena seja dinâmica; Color Correction LUT ${ }^{81}$ (corretor de cor LUT) - para dar um tom esverdeado à cena; Godrays (raios divinos) - luzes que atravessam o céu, dando um tom etéreo à cena; e Gamma Correction $^{82}$ (correção de gamma) - controlador de luminescência da cena (Figs. 131).

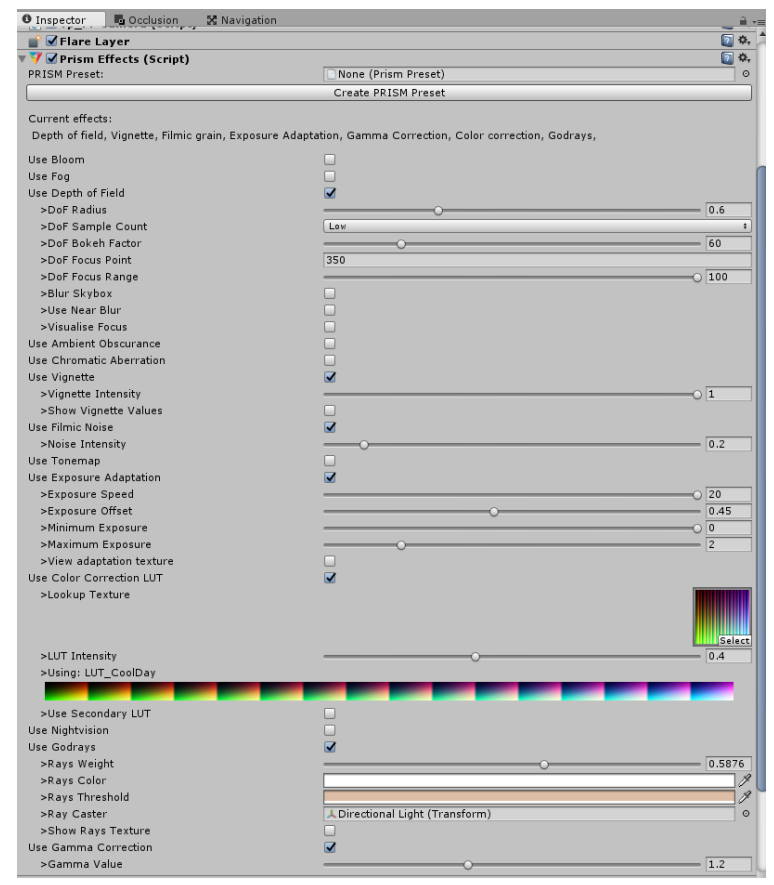

Fig. 131 - Painel de configuração do PRISM.

O Amplify Occlusion foi utilizado para melhorar a oclusão de ambiente gerada por lightmapping. É importante não confundir oclusão do ambiente com a occlusion culling: enquanto esta deixa de renderizar objetos que não são vistos diretamente pela câmera, aquela calcula quanto de cada ponto da cena está exposto à luz ambiente, reforçando as sombras existentes entre as paredes de um cômodo ou a junção entre um edifício e o

\footnotetext{
${ }^{81}$ Look Up Table: técnica que modifica a imagem original a partir da aplicação de uma camada de valores de cores baseados em fórmula matemática. Muito utilizado na indústria cinematográfica para modificar as cores das cenas gravadas, permitindo "manipular" o sentimento pretendido para a cena. Mais informações: http://nofilmschool.com/2011/05/what-is-a-look-up-table-lut-anyway (Acesso 12/07/2016)

82 Mais informações: https://en.wikipedia.org/wiki/Gamma_correction (Acesso em 12/07/2016)
} 
terreno, por exemplo. Assim, o Amplify Occlusion foi configurado para realçar os pontos de contatos entre as superfícies dos objetos, trazendo maior realismo à cena (Fig. 132).
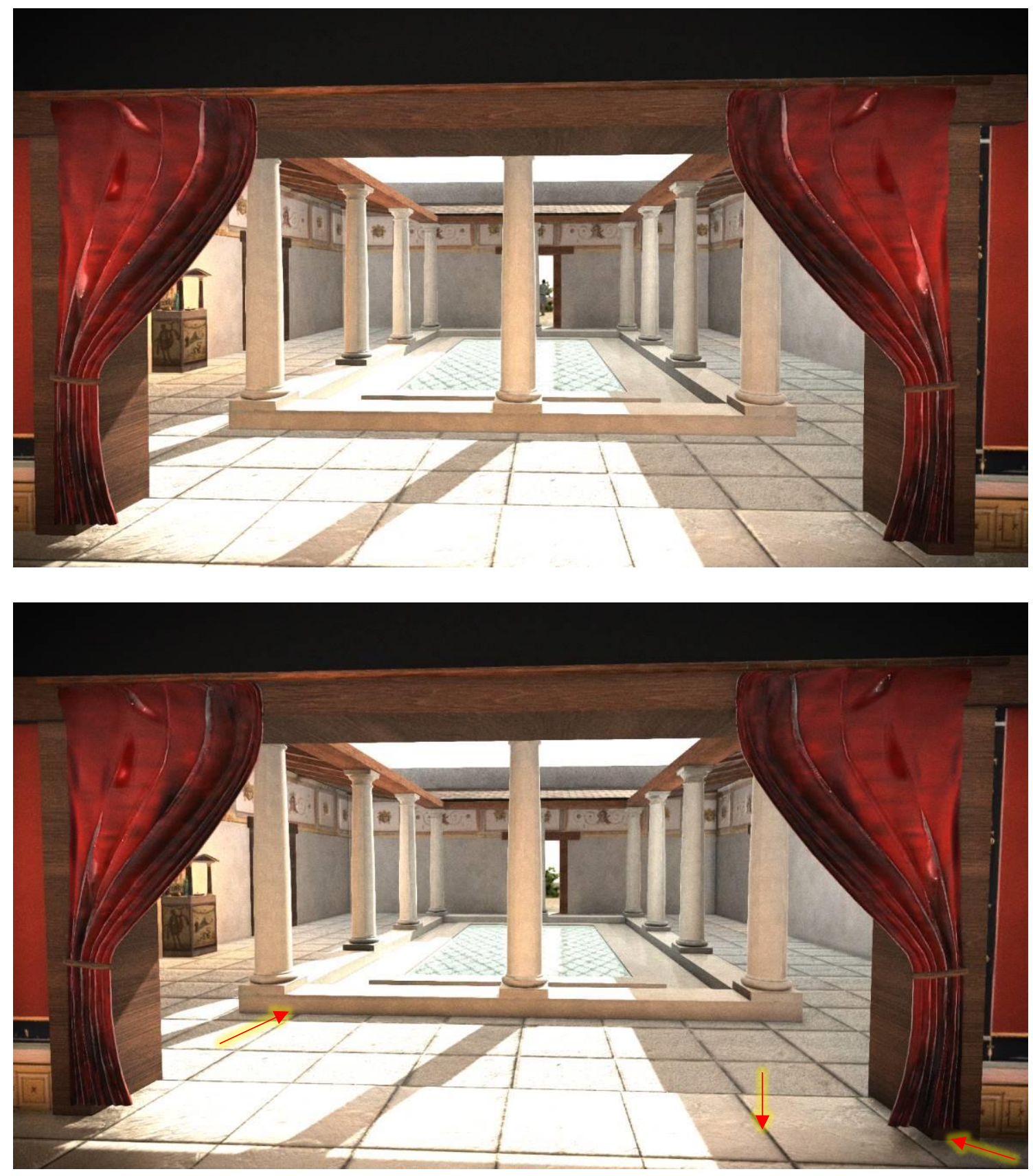

Fig. 132 - Acima, sem o efeito de oclusão de ambiente; abaixo, com o efeito acionado. As setas vermelhas indicam algumas das áreas de oclusão. Apesar de sutil, o efeito traz mais realismo à cena.

\subsection{Performance em números}

Embora durante todo o desenvolvimento tenha sido testado, somente após a finalização do aplicativo é que se pôde obter dados conclusivos sobre sua performance. 
Como todo jogo, o objetivo central é o de alcançar o maior número de FPS possível, garantindo fluidez à experiência. Um número inferior a 12 FPS causará travamentos e quebra de imersão. Números iguais a 30 FPS serão suficientes para uma boa experiência. Números iguais ou superiores a 60 FPS serão ideais, alcançando fluidez máxima. E, no caso de aplicativos voltados para a Realidade Virtual com alto grau de imersão - ou seja, com o uso de HMDs como o Oculus Rift, são requeridos, no mínimo, 90 FPS para o usuário não sentir motion sickness ${ }^{83}$.

Devido à complexidade presente em suas cenas, com muitos objetos, animações e sons 3D, o aplicativo Vipasca Antiga foi pensado, desde o início, para ser utilizado em computadores que possuam GPU (placa de vídeo) dedicada. Isso não é impedimento para que usuários testem o aplicativo em seus computadores com placas de vídeo integradas, mas, certamente, o resultado não será satisfatório para uma experiência plena. Porém, sabendo-se que ainda existem muitos usuários com sistemas operacionais Windows 32bit, a versão sem grama foi produzida para esse tipo de arquitetura, para que o maior número de computadores possíveis possa rodar Vipasca Antiga: a opção pela arquitetura 32-bit limitará o uso da memória RAM para, no máximo, $4 \mathrm{~GB}$, mas representa uma quantidade suficiente para rodar o aplicativo sem problemas de desempenho (desde que observados os requisitos mínimos, claro). A versão com gramas, por sua vez, foi pensada para rodar em computadores mais recentes, com placas de vídeo potentes: o sistema operacional necessário, nesse caso, é o de arquitetura 64-bit, permitindo que o aplicativo consuma mais de 4 GB de memória RAM, auxiliando o processador do computador.

Foram realizados testes em três computadores diferentes, com as seguintes configurações:

1) Computador 1 (desktop): processador Intel Core i7-4790 (3.60 Hz), $32 \mathrm{~GB}$ de memória RAM, placa de vídeo GeForce GTX 980 (DirectX 11), Windows 10 (64-bit);

2) Computador 2 (notebook) $)^{84}$ : processador Intel Core i7-5500U (2.40 Hz), $8 \mathrm{~GB}$ de memória RAM, placa de vídeo GeForce 830M (DirectX 11), Windows 10 (64-bit);

\footnotetext{
${ }^{83}$ Enjoo de movimento: muito comum em viagens a barco, por exemplo. Mais informações: https://en.wikipedia.org/wiki/Motion_sickness (Acesso em 12/07/2016)

${ }^{84} \mathrm{O}$ notebook esteve conectado à fonte de energia durante todos os testes, garantindo suprimento necessário ao hardware.
} 
3) Computador 3 (desktop): processador Intel Core i5-2300 $(2.80 \mathrm{~Hz}), 8 \mathrm{~GB}$ de memória RAM, placa de vídeo GeForce 9600 GT (DirectX 10), Windows 10 (64-bit).

As medições foram feitas utilizando-se o programa MSI Afterburner ${ }^{85}$ para conferir o número de FPS em tela sem prejudicar o desempenho do aplicativo. A interface gráfica do programa pode ser vista na Fig. 133.

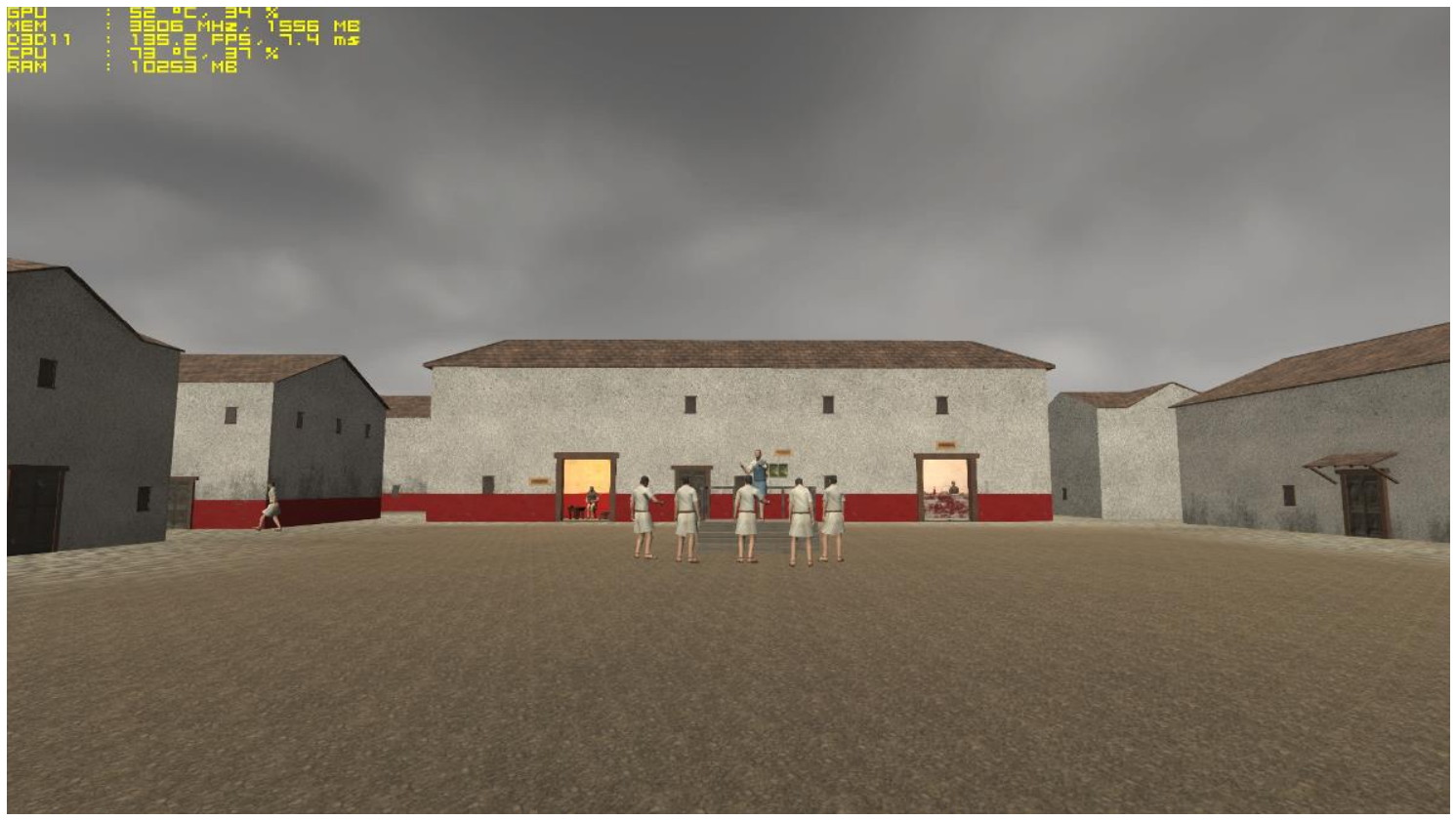

Fig. 133 - A interface gráfica do MSI Afterburner é mostrada no canto superior esquerdo, em amarelo. O número de FPS é mostrado no campo D3D11.

É importante frisar que foram observadas as variações de FPS em dois pontos do Vipasca Antiga:

1) Topo do chapéu de ferro, com vista para a ponte da ribeira;

2) Centro do fórum, com vista para a rostra e o pregoeiro.

Foram anotados o número mínimo de FPS alcançados no topo do chapéu de ferro, e o número máximo de FPS observados no fórum. Esses números foram anotados, durante os testes com os três computadores, nas seguintes configurações de resolução e qualidade para a versão sem gramas:

1) Resolução 1280 x 720 / Qualidade Low;

\footnotetext{
${ }^{85}$ www.gaming.msi.com/features/afterburner
} 
2) Resolução 1280 x 720 / Qualidade Ultra;

3) Resolução 1366 x 768 / Qualidade Low $^{86}$;

4) Resolução 1366 x 768 / Qualidade Ultra ${ }^{87}$;

5) Resolução 1920 x 1080 / Qualidade Low;

6) Resolução 1920 x 1080 / Qualidade Ultra;

No caso da versão com gramas, apenas a qualidade Ultra foi utilizada, pois é a que melhor trabalha com os efeitos de iluminação sobre a grama. Desse modo, as resoluções foram as seguintes:

1) Resolução 1280 x 720 / Qualidade Ultra;

2) Resolução 1366 x 768 / Qualidade Ultra ${ }^{88}$;

3) Resolução 1920 x 1080 / Qualidade Ultra;

As figuras abaixo mostram os resultados obtidos.

${ }^{86}$ Teste realizado apenas no notebook, configurando a maior resolução de tela disponível.

87 Idem.

88 Idem. 


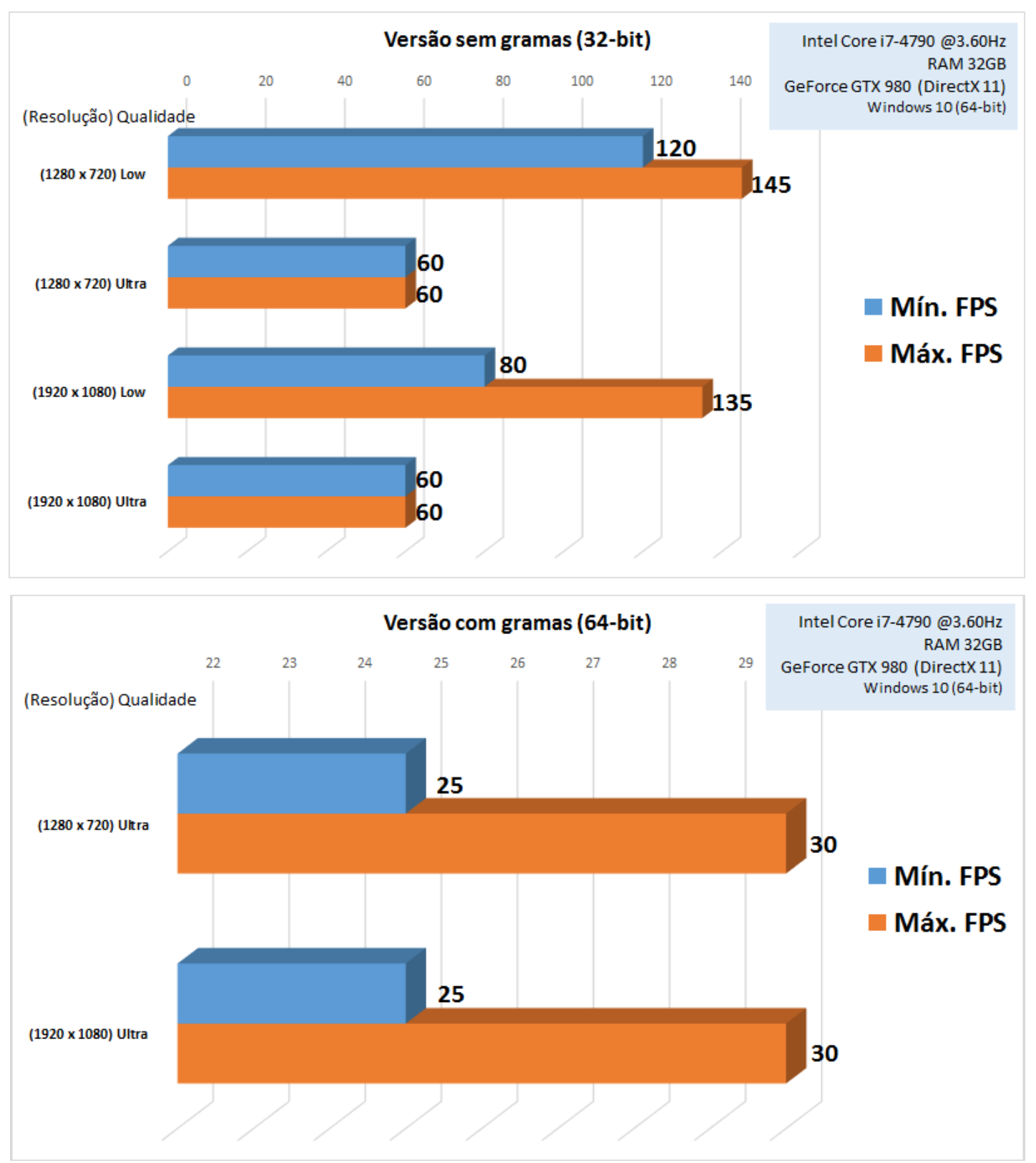

Fig. 134 - Resultados de FPS obtidos no computador 1. 


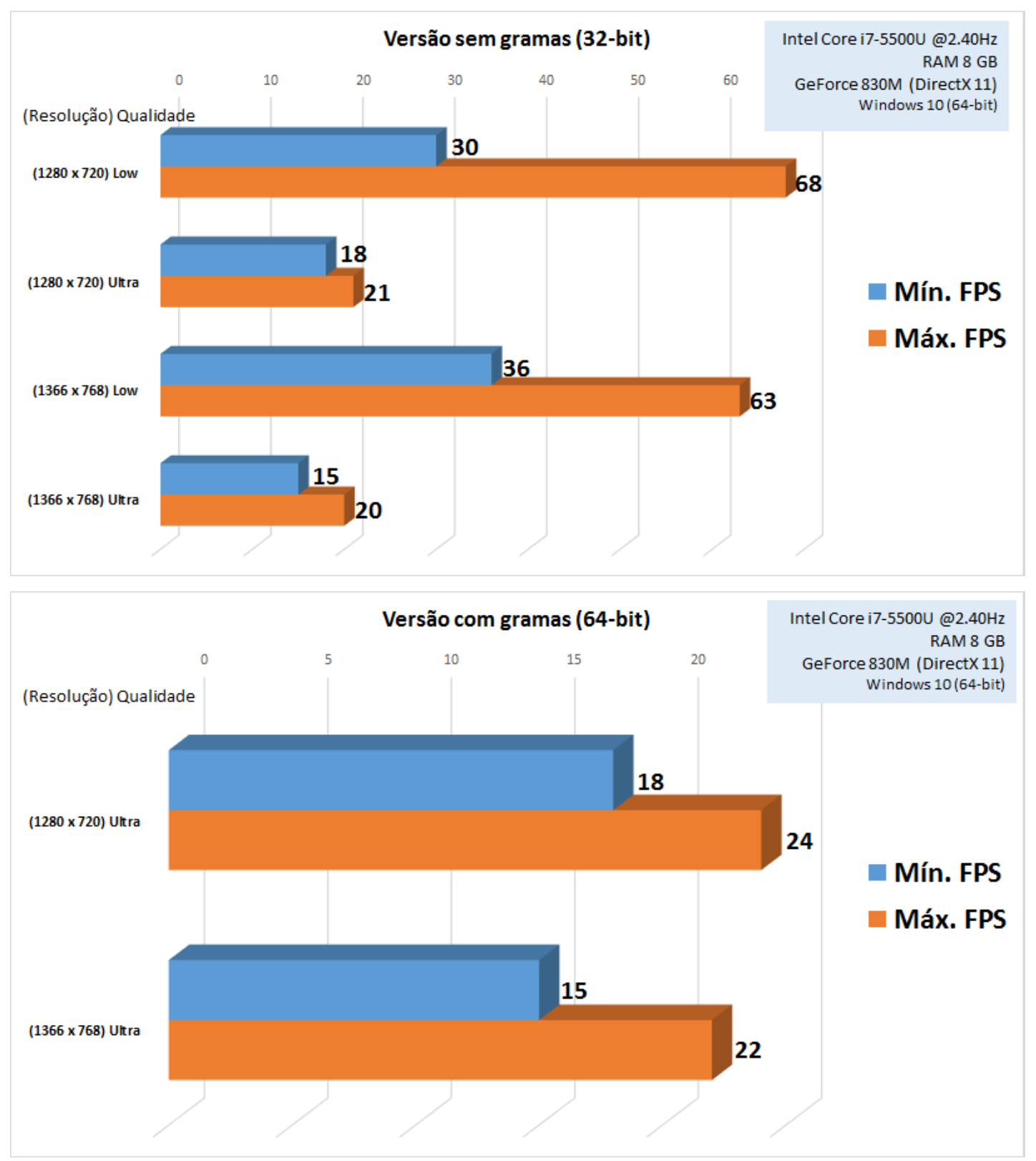

Fig. 135 - Resultados de FPS obtidos no computador 2. 


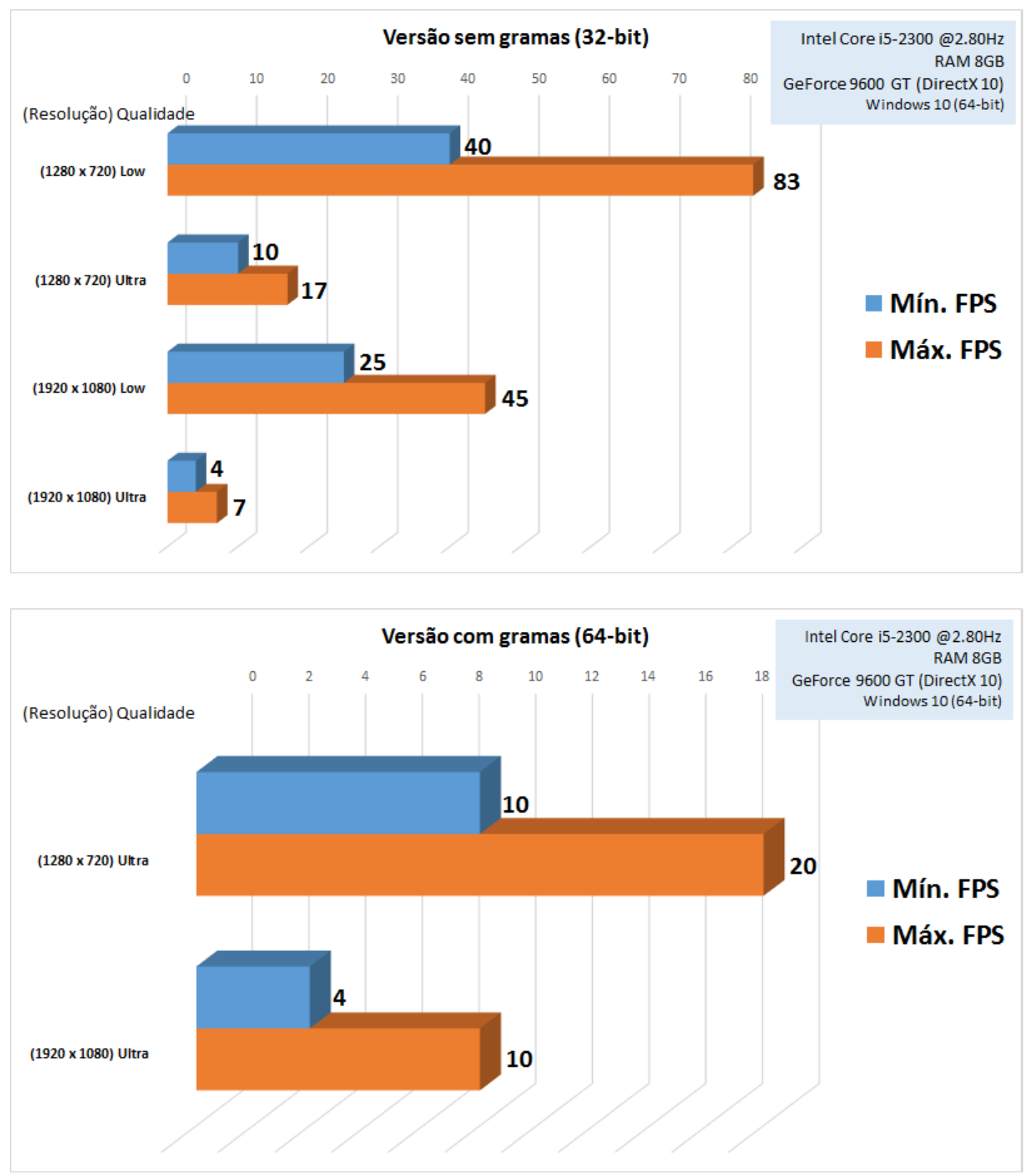

Fig. 136 - Resultados de FPS obtidos no computador 3.

Como podemos notar (Fig. 134), o computador 1 foi quem obteve os melhores resultados de desempenho, mantendo-se, sempre, igual ou acima de 60 FPS na versão sem gramas $^{89}$. A versão com gramas também alcançou o número máximo de FPS pretendidos, uma vez que ficou limitada a 30 FPS para garantir fluidez mesmo com a

\footnotetext{
${ }^{89}$ Importante frisar que a qualidade Ultra do aplicativo sem gramas tem sua taxa de sincronização travada em 60 quadros por segundo, sendo impossível o computador alcançar números superiores, mesmo possuindo poder de processamento. Essa opção de trava visa evitar o desgaste desnecessário da placa de vídeo.
} 
grande quantidade de polígonos e efeitos de ventos que as gramas trazem consigo. Assim, pode-se afirmar algo que já é subentendido: quanto melhor a configuração de hardware do computador, melhor será a performance do aplicativo.

O computador 2 (Fig. 135), por sua vez, mostrou-se apto a rodar o aplicativo em sua versão sem gramas na qualidade mais baixa (Low), mesmo em sua resolução máxima (1366 x 768), ficando acima dos 60 FPS. No caso da versão com gramas, os resultados medidos na resolução máxima (e qualidade Ultra) praticamente são os mesmos obtidos com a mesma configuração na versão sem gramas: variando entre 15 e 22 FPS. Desse modo, é possível utilizar o Vipasca Antiga tendo uma boa experiência mesmo apresentando cerca de 1/3 do número ideal de FPS.

Já o computador 3 (Fig. 136), configurado com hardware mais modesto - e uma placa de vídeo bastante antiga e com $\mathrm{API}^{90}$ DirectX ${ }^{91} 10$, foi o que mostrou os piores resultados. Apenas na resolução mais baixa $(1280$ x 720$)$ e na qualidade Low o computador conseguiu manter uma taxa de FPS constante acima de 40 (chegando a 83 nessa configuração) na versão sem gramas. É possível também utilizar a resolução máxima, com a qualidade baixa, mas a taxa mínima de FPS ficará abaixo dos 30. No caso da qualidade Ultra, os resultados foram péssimos na resolução mais baixa (10 17 FPS), e impraticáveis na resolução máxima, variando entre 4 e 7 FPS. A versão com gramas, por sua vez, deixou claro que apenas poderá ser rodada na resolução mais baixa (10 20 FPS), mas com falta de fluidez. Os resultados da resolução máxima foram semelhantes à versão sem gramas.

Podemos concluir, então, que os resultados em todos os computadores mostram Vipasca Antiga como um aplicativo passível de ser experienciado em diversas configurações. Todos os computadores alcançaram o número mínimo de FPS (ou seja, 30) na resolução mais baixa $(1280$ x 720$)$ e qualidade Low para que o usuário consiga aproveitar o aplicativo, em sua versão sem gramas, de modo fluido. Caso deseje aumentar, nessa versão, a resolução para o máximo, bem como a qualidade, o jogador deverá possuir placa de vídeo superior a GeForce 9600 GT (algo simples, uma vez que essa série de placas foi descontinuada há alguns anos) - embora não tenham sido

\footnotetext{
${ }^{90}$ Application Programming Interface (Interface de Programação de Aplicativos, em português): uma série de protocolos e ferramentas utilizada no desenvolvimento de softwares e aplicativos. Mais informações: https://en.wikipedia.org/wiki/Application_programming_interface (Acesso em 12/07/2016)

${ }^{91}$ Uma coleção de APIs. Mais informações: https://en.wikipedia.org/wiki/DirectX (Acesso em 12/07/2016)
} 
realizados testes, é possível acreditar que placas de vídeo recentes integradas aos processadores (como a Intel HD Graphics 5500, por exemplo) consigam alcançar resultados melhores do que os obtidos no computador 3 .

A versão com gramas, contudo, somente rodará plenamente em hardware mais avançado, com placas de vídeo da série GeForce 900 da Nvidia ou equivalente, mantendo os 30 FPS pretendidos no desenvolvimento. Deve-se levar sempre em consideração, porém, que a tecnologia computacional avança significativamente todos os anos: esperase que, logo, as placas de vídeo mais avançadas se tornem modelos básicos no mercado, barateando o custo e permitindo um acesso maior aos usuários.

As Figs. 137-138 mostram comparativos dos resultados obtidos nos três computadores rodando o aplicativo Vipasca Antiga.

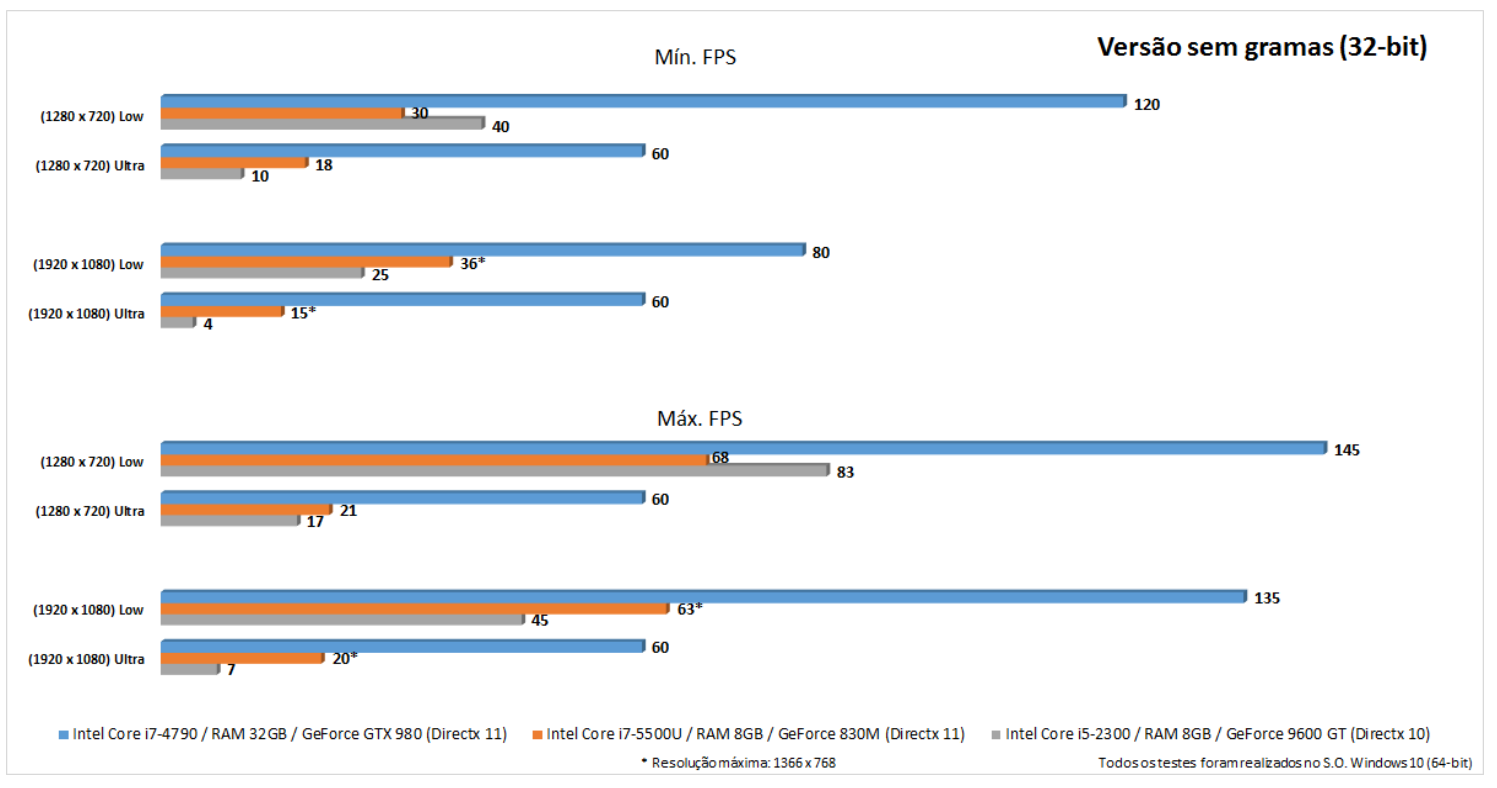

Fig. 137 - Comparativo dos resultados obtidos nos 3 computadores: versão sem gramas. 


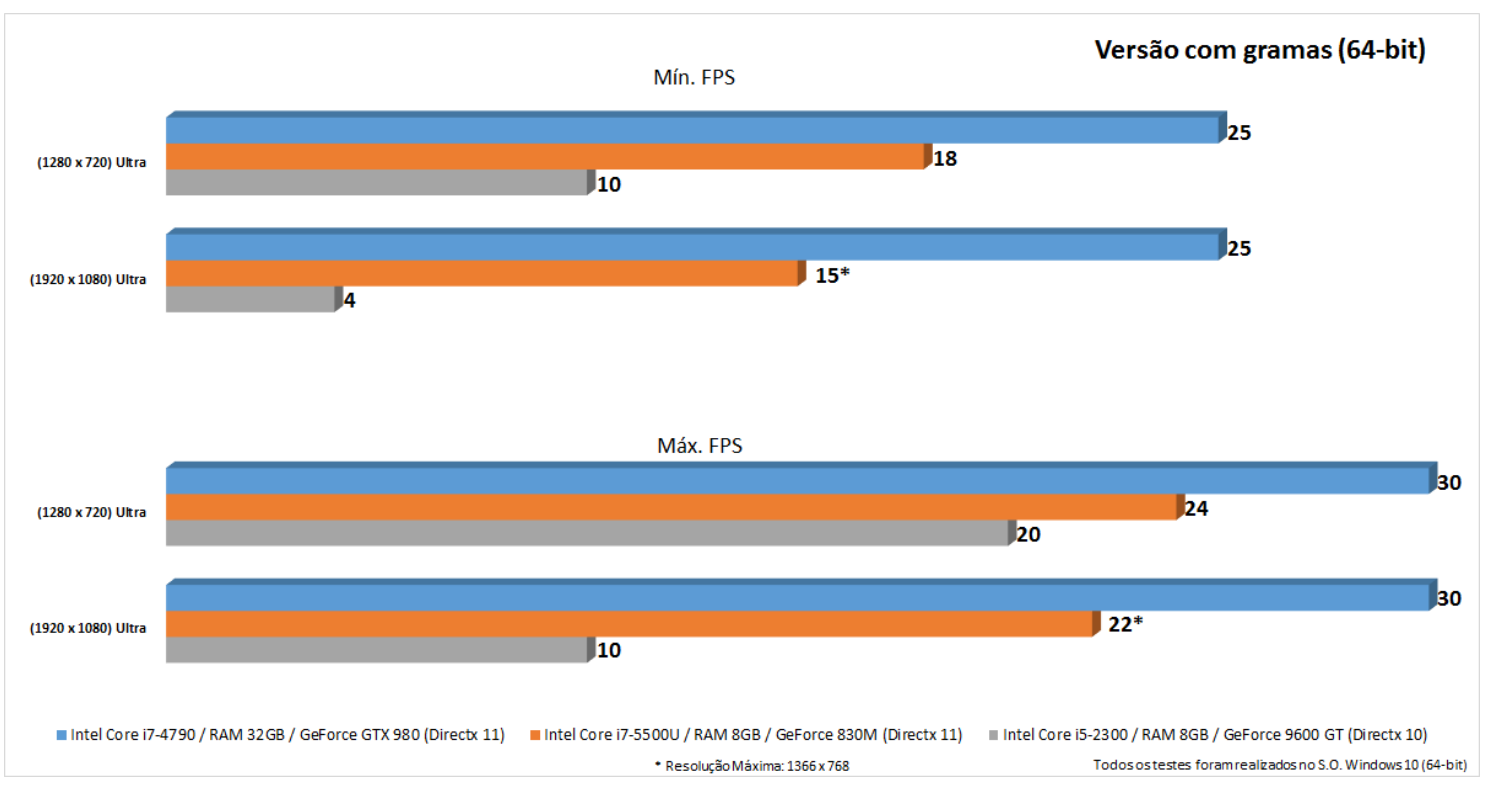

Fig. 138 - Comparativo dos resultados obtidos nos 3 computadores: versão com gramas.

Finalmente, ficaram estabelecidos os seguintes requisitos de Sistema para o aplicativo Vipasca Antiga:

1) Mínimos:

SO: Windows 7 ou mais recente (32bit)

Processador: Intel Core i5 2.00 GHz ou AMD equivalente

Memória: 4 GB de RAM

Placa de vídeo: NVIDIA GeForce 9600 ou maior com 1GB Memória RAM

DirectX: Versão 10

Armazenamento: 2,5 GB de espaço disponível

2) Recomendados:

SO: Windows 10 (64bit)

Processador: Intel Core i7 2.40 GHz ou AMD equivalente

Memória: 8 GB de RAM

Placa de vídeo: NVIDIA GeForce 960 ou maior com 2GB Memória RAM

DirectX: Versão 11

Armazenamento: 2,5 GB de espaço disponível 


\section{RESUMO - VIPASCA ANTIGA: RELATANDO O DESENVOLVIMENTO}

Se o capítulo anterior apaziguou a raiva dos arqueólogos com o meu trabalho até então, este serviu para trazer um pouco de satisfação aos amantes de computação gráfica. Espero que todos se sintam bem ao ler minha pesquisa: não hierarquizo áreas de conhecimento.

Iniciei com as problemáticas referentes à modelagem e texturização daquilo que é visto em cena no aplicativo Vipasca Antiga. Apresentei as dificuldades da modelagem do terreno dentro do motor gráfico Unity e depois parti para todos os demais objetos relevantes do aplicativo: Casa do Procurador, oficina metalúrgica, insulae, balneum, fornos de redução, roda hidráulica, poço de extração, pisão, tavernas, padarias, oficinas de ceramistas, açougue e pessoas. Exemplifiquei com imagens do programa Autodesk Maya (utilizado na modelagem e texturização) e capturas de tela do Unity.

A seguir, apresentei questões referentes à interatividade/programação do aplicativo. Mostrei o sistema de movimentação dos transeuntes e carroças bem como a programação dos diálogos existentes e as missões que o usuário tem de completar. Também discorri sobre a interface gráfica que auxilia o jogador no ambiente virtual tridimensional e as capturas de câmera que geraram modelos tridimensionais a partir da técnica da fotogrametria.

Por fim, escrevi sobre os testes de performance do aplicativo, preocupando-me em apresentar gráficos comparativos em três computadores com configurações de hardware diferentes.

Foi um capítulo longo e pormenorizado, mas acredito que todas as informações que estão nele ajudem a quebrar um pouco do preconceito que as pessoas geralmente têm sobre jogos eletrônicos. Se fui bem-sucedido em meu intento, o leitor terá compreendido que existe um trabalho hercúleo por trás da produção de interações ciberarqueológicas. 


\section{CAPÍTULO VII}

\section{"O COMPLEXO DE FRANKENSTEIN" OU "COSTURANDO AS IDEIAS PARA MOSTRAR A VOCÊ QUE ESTE TRABALHO TEVE RELEVÂNCIA”}

"Comece pelo começo", disse o Rei com muita gravidade, "e siga até o fim: daí pare."

- Lewis Carroll, Alice no País das Maravilhas

Parecia que eu ouvia o seu grito sussurrado, "O horror! O horror!"

- Joseph Conrad, O Coração das Trevas

Você chegou até aqui: a parte final, o corolário de quatro anos de pesquisa. Acredito que esteja aqui após percorrer um dos dois caminhos: 1) ou leu o trabalho completo e respirou fundo antes de encarar algumas (longas) conclusões; ou 2) simplesmente leu a Introdução, os Resumos dos capítulos e agora vai tentar entender tudo por uma espécie de engenharia reversa textual. Os dois modos, a meu ver, são justos e não julgo o seu comprometimento (caminho 1) ou a sua preguiça (caminho 2): só de estar aqui já uma vitória para o autor.

Acredito que seja hora, então, de retomar algumas coisas que foram ditas ao longo deste texto, e também introduzir algumas questões novas (afinal, uma pesquisa nunca acaba quando termina). Infelizmente, não há jeito fácil de se fazer um capítulo de conclusão (ões), mas vou tentar, ao máximo, tornar essa nossa última experiência juntos algo agradável (a essa altura já somos quase íntimos, não?).

HUMANIDADES DIGITAIS: HISTÓRIAS INTERATIVAS, ARQUEOLOGIA INTERATIVA

Permita-me retomar algo que eu disse no começo deste trabalho: muitos arqueólogos são tecnofóbicos, fogem dos computadores como se essas máquinas digitais tivessem um quê de sobrenatural. Sendo assim, estão acostumados a divulgar os resultados de suas pesquisas por meio quase exclusivamente textual (quando muito, há mapas e fotos que, obviamente, também estão presos a uma página de papel ou PDF). Contudo, conheço muitos que são apegados a seus smartphones e vivem postando no 
Facebook textos gigantescos sobre política ou fotos do último churrasco entre amigos. Não há absolutamente nada de errado nisso, afinal, somos humanos também! Mas devo ressaltar aqui a incoerência que surge por vezes, uma vez que muitos dos meus colegas que agem assim também são aqueles que criticam o "vício" que a tecnologia traz - e o fazem por meio do Facebook...

Entretanto, eu seria desonesto se dissesse que a tecnologia só assusta os arqueólogos. Isso é um mal que atinge as Humanidades de um modo geral. Durante o meu período de graduação em História tive colegas que não gostavam muito de tecnologia pelo fato de não a entenderem, ou mesmo por questões ideológicas (tecnologia lembra Engenharia; Engenharia lembra Escola Politécnica; Escola Politécnica lembra conservadores de direita que nunca entram em greve; Tecnologia = Engenharia = Escola Politécnica $=$ Demônio). Os celulares com internet ainda não existiam na época e, tenho certeza, muitos dos que estudaram comigo acabaram por se converter ao uso "viciante" de dispositivos eletrônicos depois. Mas, mesmo assim, é extremamente comum que as Humanidades estejam intimamente ligadas aos textos: são pilhas e pilhas de livros, dissertações e teses que estão nas bibliotecas, esperando ansiosamente que algum professor os citem na bibliografia para que saiam do "limbo acadêmico" que as estantes representam. Ideias excelentes, trabalhos inovadores... Ficam restritos ao mundo textual impresso, distantes da população que não frequenta as universidades. Mesmo havendo um esforço muito grande por parte das bibliotecas em digitalizar seus acervos e disponibilizá-los online, ainda assim esbarramos em um problema muito sério que aflige o século XXI: as pessoas já não costumam mais ler como antes. E não estou falando apenas em quantidade...

Acredito que estamos vivendo um momento que pode nos trazer à lembrança o Renascimento quando lidamos com a comunicação. Os meios de estabelecer diálogos durante esse período eram bastante mesclados, fazendo com que textos, ilustrações, pinturas, esculturas tivessem uma intercomunicação: nesse caso, basta lembrarmo-nos das propagandas do rei Felipe II em Portugal durante o século XVI, que traziam símbolos e textos em uma mesma mídia a fim de legitimar o governo de um monarca que pouco seria visto pela população portuguesa (BOUZA-ÁLVAREZ 1998). Hoje em dia as mídias estão muito bem conectadas, fazendo com que áudios e vídeos acompanhem a informação textual e, mais do que ilustrar o que é dito, colaboram na transmissão de informação. Exemplos dessa nova tendência são os vídeos do YouTube sobre ciências editados com 
o software Adobe After Effects do canal TED-Ed ${ }^{92}$. Essa mistura de diversos meios de comunicação tem sido, cada vez mais, introduzida no campo das Humanidades: é a chamada Humanidades Digitais (Digital Humanities).

Sendo recente (surgida há quase duas décadas graças ao barateamento do custo dos computadores e outros dispositivos eletrônicos digitais), as Humanidades Digitais ainda passam por debates sobre a sua conceituação, sobre aquilo que realmente é. Tomarei por base algumas ideias de Erik Champion em seu livro Critical Gaming: interactive History and Virtual Heritage (2015) que, ao meu ver, consegue não apenas convencer o leitor de que as Humanidades Digitais são uma área cognitiva relevante, como também transmite suas ideias de modo claro e didático (como todo acadêmico deveria fazer, em minha opinião).

Uma das preocupações centrais de Champion é combater a noção ainda muito presente de que Humanidades Digitais (doravante HD) são principalmente "serviços computacionais aplicados à digitalização e processamento de texto e literatura" (CHAMPION 2015: 5). Pensada assim, as HD seriam representadas apenas por ferramentas digitais de análise textual (por exemplo, algum programa que fizesse uma relação de quantas vezes uma determinada rua é mencionada no calhamaço Ulisses de James Joyce e quais personagens transitaram por ela), ou, então, seriam os PDFs originados a partir do escaneamento de livros físicos. Erik Champion, no entanto, utiliza o primeiro capítulo de seu livro para questionar esse uso "tradicional" das HD e para afirmar que visualizações não baseadas em textos também podem ser levadas em consideração (e, muitas vezes, trazendo mais benefícios no campo do conhecimento). Mais: Champion lança uma questão interessante ao leitor (2015: 7) - por que grande parte das aplicações no campo das HD são baseadas em computadores desktop? Por que não podem ser também inseridas na Realidade Virtual ou demais ambientes não baseados em desktop? A resposta a essa pergunta, creio eu, deve-se mais às limitações de recursos financeiros por parte das universidades do que má vontade ou falta de capacidade dos pesquisadores: somente neste ano de 2016 é que a Realidade Virtual teve o seu boom, com o lançamento de diversos dispositivos (principalmente HMDs) a preços voltados ao consumidor final. Certamente até 2020 o uso da Realidade Virtual será algo comum para todos, tal como são os smartphones hoje em dia.

\footnotetext{
92 Vídeo interessantíssimo sobre o gato de Schrödinger: https://youtu.be/z1GCnycbMeAac
} 
Champion segue seu capítulo com mais um apontamento com o qual eu concordo: ele diz que a predileção por material baseado em textos é limitadora quando queremos alcançar um público amplo (2015: 10). Segundo um relatório da UNESCO de 2014, citado pelo autor, embora $84 \%$ dos adultos ao redor do mundo saibam ler, ainda enfrentam dificuldades em interpretar textos. Somada essa questão aos $16 \%$ de adultos analfabetos, fica claro que nem sempre utilizar apenas textos em aplicações digitais pode ser a melhor solução para o que almejamos. Assim, se bem desenvolvida, uma aplicação de HD pode ser centrada em visualização não-textual e, ao mesmo tempo, contar uma história, gerando significados. Talvez o maior exemplo desse caso sejam os jogos (games).

Para Champion (2015: 32), "um jogo é um desafio que oferece a possibilidade, temporária ou permanente, de resolução tática sem resultados prejudiciais ao mundo real do participante". Um jogo também deve ter algumas regras que o participante/usuário deve conhecer para dar andamento à experiência a fim de completar seu objetivo principal. Porém, é importante ter em mente que o modo como um designer elabora um jogo é diferente do modo como um jogador o experiencia. Jogos vão além de modelos: são simulações. Essa distinção foi feita por Beat Schwendimann (2010):

- Um modelo é um produto (físico ou digital) que representa um sistema de interesse. Um modelo é semelhante, e mais simples, do que o sistema que representa, aproximando-se, o máximo possível, da maior parte das características salientes do sistema real. Um bom modelo é uma troca judiciosa entre o realismo e a simplicidade. Uma característica essencial de um modelo é a manipulação. Um modelo pode ser um modelo físico (por exemplo, um modelo de escala de uma casa de arquitetura física, um modelo de aeronave, um manequim de moda ou um modelo de organismo em pesquisa biológica); ou um modelo conceitual (por exemplo, um modelo computacional, um modelo estatístico ou matemático, um modelo de negócio).

- Modelagem é o ato de construir um modelo.

- Uma simulação é o processo de utilização de um modelo para estudar o comportamento e o desempenho de um sistema real ou teórico. Em uma simulação, os modelos podem ser usados para estudar as características existentes ou sugeridas de um sistema. O objetivo de uma simulação é estudar as características de um sistema real ou fictício manipulando variáveis que não podem ser controladas em um sistema 
real. As simulações permitem avaliar um modelo para otimizar o desempenho do sistema ou fazer previsões sobre um sistema real. As simulações são úteis para estudar as propriedades de um modelo de um sistema da vida real que de outra forma seria muito complexo, muito grande/pequeno, muito rápido/lento, não acessível, muito perigoso ou inaceitável para engajar. Enquanto um modelo pretende ser fiel ao sistema que representa, uma simulação pode usar um modelo para explorar estados que não seriam possíveis no sistema original.

- Simular é o ato de usar um modelo para uma simulação.

As conceituações acima não entram no campo filosófico que já mencionei anteriormente neste trabalho (DELEUZE \& GUATTARI 2000; BOSTROM 2003; LÉVY 2007), mas dão uma noção prática do uso de simulações em jogos - e no campo das HD em geral. O desenvolvimento do aplicativo Vipasca Antiga teve em seu cerne, desde o início, a preocupação em simular a antiga região mineradora romana que dá nome ao produto: longe de afirmar que o aplicativo é Vipasca tal como ela, de fato, foi, eu digo que o aplicativo foi, sim, a utilização de modelos para testar uma hipótese de como Vipasca poderia ter sido. A intenção nunca foi a de exaurir o tema, dizendo "Olhem, aqui está uma reconstrução definitiva de Vipasca com a qual todos os pesquisadores concordam. Assunto encerrado". Simplesmente é impossível, em uma pesquisa acadêmica (ou talvez em todas... tenho minhas dúvidas), sermos donos da verdade absoluta, os reis e rainhas do conhecimento: humildemente, a minha simulação de Vipasca pretende fazer com que mais questionamentos surjam, que haja mais interesse por parte dos pesquisadores de estudarem o local, que exista (e isso é fundamental) financiamento de escavações na área, pois a maior parte de Vipasca, provavelmente, ainda está debaixo do solo. Sendo muito honesto com você, eu desejo que minha simulação esteja "ultrapassada" daqui uns anos: quero que ela tenha servido de base e inspiração para outras simulações baseadas em dados mais recentes advindos de escavações futuras. Não tenho a vaidade, como muitos pesquisadores têm, de ser o "único" a ter feito uma simulação desse tipo sobre Vipasca. Ficarei imensamente satisfeito se, futuramente, souber que em minha simulação houve acertos e, também, erros que necessitam ser corrigidos.

Além disso, a simulação Vipasca Antiga, como pode notar ao utilizá-la, tem regras e objetivos, ou seja, é também um jogo (que pretende prender a atenção do usuário). E, 
tratando-se de um jogo histórico, é pertinente responder às indagações feitas por Erik Champion em seu livro (2010: 85). Farei isso brevemente, seguindo a ordem das questões:

1) Dados os seus recursos, o que exatamente você deseja que seus jogadores experienciem e retenham em termos de entendimento histórico?

Resposta: É desejado que os usuários experimentem uma área de conhecimento que não é muito abordada em estudos históricos ou até mesmo arqueológicos: a mineração. Espera-se que o usuário retenha conhecimentos básicos de todo o processo de extração e tratamento de minérios realizado pelos romanos na Antiguidade.

2) Por que e como irão os ambientes interativos (jogos, realidade virtual, realidade mista) colaborar nesta experiência e ajudar os participantes a refletirem sobre a experiência em si e o conteúdo aprendido?

Resposta: O uso da Realidade Virtual traz consigo elementos de aprendizado que os textos, por si mesmos, não são capazes de fornecer enquanto no texto o leitor imagina, na RV ele vivencia. O ambiente interativo de Vipasca Antiga foi desenvolvido de modo que o participante possa fazer perguntas aos NPCs e obter respostas que irão ajudar tanto na conclusão do objetivo principal do jogo (ou seja, encontrar todas as tábuas espalhadas pela região), como no aumento do conhecimento sobre questões básicas do cotidiano romano antigo. Assim, espera-se que a experiência, quando completada, tenha colaborado para aprofundar temas que o participante já conhecia, ou despertar o interesse pelo estudo de questionamentos que não eram sabidos antes.

3) Como você (e o jogador e a audiência) saberá quando o público compreende os objetivos e os resultados de seus esforços? Esse conhecimento requer um treinador humano, narrador ou avaliador? Ou podem as recompensas, os comentários e a notificação de objetivo ser transmitidos por um computador? Resposta: Todo o sistema de objetivos e recompensas de Vipasca Antiga é fornecido por meio de HUD, aparecendo na tela as informações, atualizadas em tempo real, sobre aquilo que falta ser completado e, posteriormente, sobre aquilo que ainda deve ser realizado. Não é necessário treinamento humano prévio, pois todas as opções de uso são apresentadas na tela para o participante 
(bem como todas as recompensas). Recomenda-se, contudo, que Vipasca Antiga seja um tema a ser trabalhado em sala de aula por professores que, idealmente, forneçam aos alunos uma base histórica sobre Roma Antiga antes da experiência com o aplicativo.

Acredito que responder a esses questionamentos seja de imensa ajuda ao desenvolvedor da simulação/jogo. Sempre é necessário ter bem claro em mente os objetivos do aplicativo em produção. As respostas dos usuários ao aplicativo, contudo, não é algo que possa ser previsto antes do lançamento do produto final. Muitas vezes, como já dito, desenvolvedor e usuário pensam totalmente diferente.

Como é sugerido por Champion (2010: 90), as simulações históricas deveriam alcançar os seguintes objetivos:

- Providenciar (a certo ponto da experiência) uma estrutura na qual o jogador (talvez "participante" seja uma palavra melhor) obtenha uma visão geral do que foi documentado, simulado e construído.

- Transmitir um sentido de contexto histórico e o modo no qual ele modelou as ações dos habitantes.

- Propiciações para ajudar os participantes a entender e explicar a informação de uma forma que melhor se adapte a eles, e não ao designer, e permitir diferentes caminhos, ações e seleção de metas.

- Encorajar os participantes a buscarem mais informações para eles mesmos além da simulação histórica.

No caso do aplicativo Vipasca Antiga, creio que todos os objetivos elencados por Erik Champion tenham sido alcançados. Como relatei no capítulo anterior, todos os modelos foram baseados em trabalhos arqueológicos realizados em Aljustrel: a consulta à bibliografia, ao acervo no museu local e conversas com o arqueólogo responsável pelos estudos da região serviram para trazer ao mundo 3D aquilo que, até então, estava impresso em páginas. Esses modelos, aliados à pesquisa sobre história e arqueologia da Roma Antiga que realizo desde a Iniciação Científica, tornaram possível estabelecer uma simulação de um passado em potencial da antiga Vipasca. E, sendo uma simulação histórica calcada em vestígios arqueológicos, ela, então, insere-se no campo da Ciberarqueologia. 
E, sendo a Ciberarqueologia um diálogo entre a Realidade Virtual e a Arqueologia para o estudo das Humanidades, podemos dizer que ela também faz parte das Humanidades Digitais.

\section{ENTRE VIAGENS NO TEMPO E QUANTA}

Esse é aquele momento do final de temporada de Doctor Who quando o Doutor se regenera: é triste, uma lágrima escorre, tudo fica sem sentido por alguns instantes... É hora de dizer adeus a quem nos levou por muitos mundos e realidades.

A analogia que estabeleci neste trabalho serviu para auxiliar no entendimento sobre aquilo que é real e como uma simulação pode ser construída. Se você entrasse na TARDIS e viajasse até Vipasca, poderia observar por si mesmo a dinamicidade da região, com seu desmonte do chapéu de ferro, suas carroças carregando minérios, seus fornos ardendo o tempo todo, a sua terrível poluição etc. Contudo, caso lhe falte um convite feito pelo Doutor, acredito que você, mesmo assim, ainda pode experimentar a Vipasca romana: basta iniciar o aplicativo de realidade virtual que desenvolvi nesta pesquisa. A diferença entre ambos? Tudo dependerá exclusivamente de você: sair da TARDIS e caminhar por Vipasca é, realmente, tão diferente de segurar um joystick e, do mesmo modo, andar pela paisagem? O senso de presença é subjetivo. Estar/Sentir-se em algum lugar varia de pessoa para pessoa, sendo que, muitas vezes, questões biológicas ditam nossa percepção do ambiente (basta lembrar das ideias de Maturana e Varela que explicitei neste trabalho ou, mais comumente, perguntar a alguém se a cor que você enxerga é a mesma que ela está vendo).

Vou além. Correndo aqui um grande risco ao meu futuro como acadêmico, afirmo que, afora a percepção, as duas realidades observadas (aquela fornecida pela viagem da TARDIS e a fornecida por minha simulação) são válidas, que existe mais do que uma realidade em jogo. E que essa realidade é quântica.

Não sou físico, mas tentarei a seguir, brevemente, explicar o porquê de minha afirmação. Vamos lá! 
Talvez ainda não seja fácil para a maioria das pessoas acreditar que tudo o que conseguem observar, tudo aquilo a que estão expostas não seja apenas $o$ seu universo, mas, sim, um universo dentre muitos.

Desde o início do século XX, começou-se a cogitar a existência de um conjunto muito provavelmente infinito - universal. Essa ideia foi fomentada graças aos trabalhos desenvolvidos pelo cientista alemão Max Planck (1858 - 1947) que, em 1900, publicou seu artigo sobre a energia irradiada pelo espectro da radiação térmica e apresentou à comunidade acadêmica sua elegante fórmula $\mathbf{E}=\mathbf{h} . \mathbf{f}$, na qual a frequência da radiação $\mathbf{f}$ (em hertz) multiplicada pela constante $\mathbf{h}$ (representando um pacote de energia denominado quantum) resulta na energia $\mathbf{E}$ de um fóton (partícula elementar da luz). Desse modo, Planck foi responsável por lançar as primeiras sementes - que depois seriam irrigadas por Einstein, Bohr, Heisenberg e Schrödinger - daquilo que foi denominado Mecânica Quântica: ramo de estudos que fez frente à mecânica clássica que vinha inabalável na Física desde os tempos de Newton.

A mecânica quântica trouxe ao mundo a incerteza. Se antes, de acordo com o que postulavam Newton e Maxwell, os movimentos dos objetos grandes (como os celestiais e as maçãs) poderiam ser calculados tanto no passado como no futuro, agora, com a teoria quântica, ficava claro que as predições não valiam para o campo microscópico de células, átomos e partículas subatômicas: a aleatoriedade reinava. Os estudos no campo quântico mostram que não é possível, por exemplo, predizer com exatidão o movimento de elétrons que circundam um núcleo atômico. Os físicos e matemáticos trabalham, então, com previsões probabilísticas da mecânica quântica - já não temos mais a certeza de que uma determinada partícula terá uma posição $\mathrm{X}$ em um tempo $\mathrm{Y}$, mas é muito provável (e isso é confirmado empiricamente) que ela habitará uma determinada região $\mathrm{X}$ durante um tempo Y. Dentre os experimentos que auxiliam o entendimento da mecânica quântica, o denominado "experimento da dupla fenda" é um dos mais famosos (Fig. 139). 
(a)

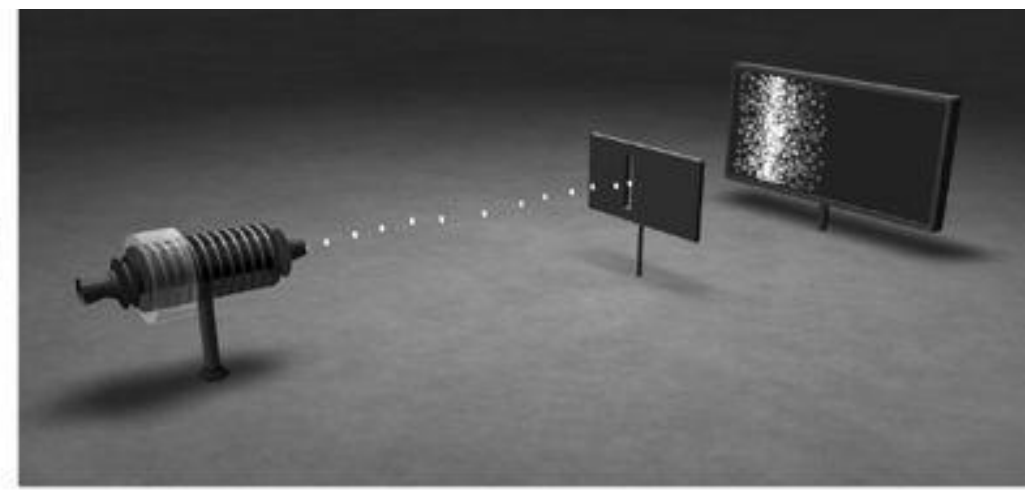

(b)

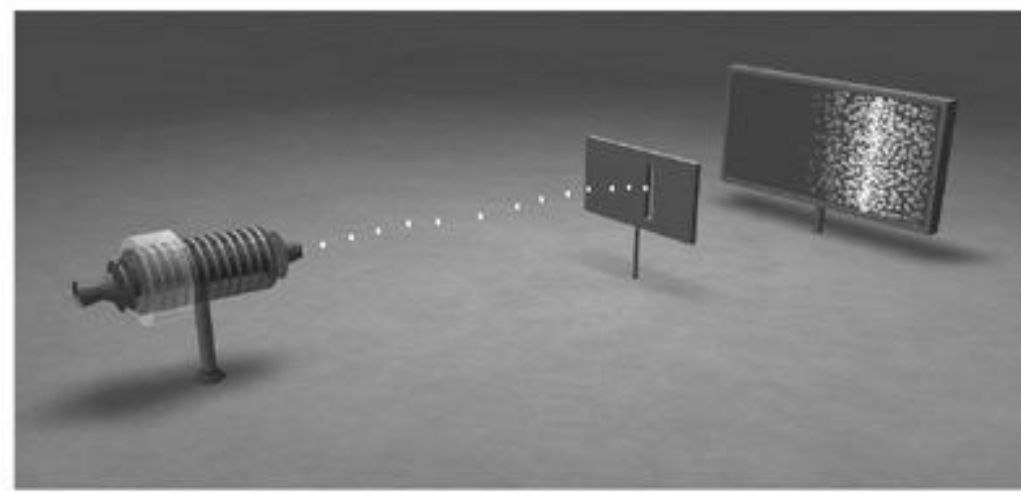

(c)

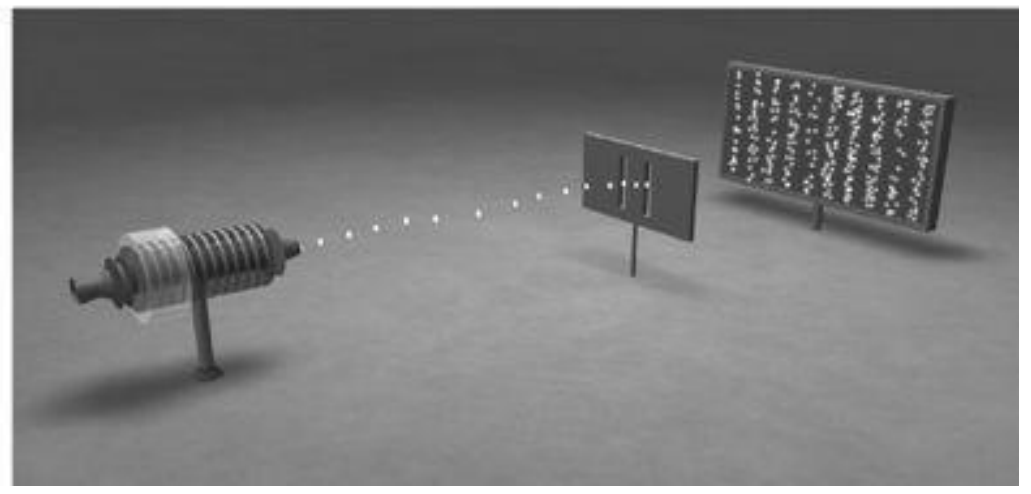

Fig. 139 - Experimento da dupla fenda (GREENE 2012: 242)

O experimento, simples, consiste em um canhão de elétrons que dispara um feixe contra uma barreira que tem duas fendas estreitas e, atrás dela, uma tela para nos mostrar a posição dos elétrons emitidos. Quando apenas uma das fendas - por exemplo, a da esquerda - está aberta, os elétrons passam pela abertura e atingem a tela no lado esquerdo, formando uma risca. Isso também acontece quando apenas a fenda da direita está aberta (e forma uma risca no lado direito da tela). Contudo, quando ambas as fendas estão abertas, algo peculiar ocorre: a tela atrás delas nos mostra a formação de várias riscas, levando-nos a crer que a presença de uma fenda modifica os possíveis locais de detecção dos elétrons que passam pela outra fenda e vice-versa (GREENE 2012: 241). O 
"experimento da dupla fenda" nos mostra que cada elétron "sabe", de algum modo, que existem duas fendas. Mas por que isso acontece?

Ao observar o padrão das riscas na tela, fica claro que elas retratam ondas. $\mathrm{O}$ elétron, então, atua como se arremessássemos uma pedra na água: ao atingir a superfície, emite uma onda que possui cristas (pontos mais altos) e vales (pontos mais baixos); se jogarmos duas pedras ao mesmo tempo, notaremos também que nas regiões onde o vale de uma onda cruza com a crista da outra, ambas as ondas se anulam e o nível da água fica estável. É exatamente com esse padrão de interferência que o elétron se comporta. Apesar dessa similaridade, o físico alemão Max Born, em 1926, chamou a atenção para que não pensássemos os elétrons como as pedras que são arremessadas na água. Born afirmou que as partículas são como ondas que oscilam de um lugar para outro: nos locais em que os valores da onda são altos - como nas cristas - nós provavelmente encontraremos a partícula; nas regiões em que os valores da onda são baixos (vales), provavelmente não serão encontradas partículas; e nos locais em que as ondas se anulam (quando sobrepostas) não encontraremos partícula alguma. Tal como acontece na superfície da água, à medida que a onda se expande, seus valores são afetados. Assim, podemos interpretar esses valores flutuantes como probabilidades flutuantes, levando ao que é denominado "onda de probabilidade" na mecânica quântica. E são essas ondas de probabilidade que explicam o comportamento quando as duas fendas do experimento estão abertas: a onda emitida pelo canhão de elétrons bate na barreira e se fragmenta em duas; esses fragmentos, também agindo como ondas, atravessam as fendas e seguem em direção à tela; as probabilidades de uma partícula aparecer nos pontos altos e baixos da onda tornam-se claras no resultado final: as riscas formadas na tela são as regiões de cristas e vales, enquanto os espaçamentos entre elas são as regiões de contato entre o vale de uma onda com a crista de outra (GREENE 2012: 244).

A probabilidade da teoria quântica, dessa maneira, explica como o elétron "sabe" para onde ir quando passa pela barreira com as fendas: comportando-se como onda, a partícula consegue existir em mais de um lugar ao mesmo tempo.

Porém, a teoria quântica torna-se ainda mais complexa quando sabemos que não existe um modo de vermos essas ondas de probabilidades. A abordagem desenvolvida por Bohr diz que sempre que tentarmos medir a posição de um elétron em uma onda de probabilidade, nosso próprio ato de observação impedirá o sucesso pois o elétron reagirá à medição concretizando-se em um local específico (fazendo com que a onda de 
probabilidade entre instantaneamente em colapso em todos os locais, menos um). Uma vez concluída a observação do elétron, a onda voltará a se espalhar, reiniciando as probabilidades, fazendo com que o elétron seja medido em outro local. É por essa razão que enxergamos os pontos que formam as riscas no "experimento da dupla fenda": a tela força o elétron a abandonar suas múltiplas opções disponíveis e o obriga a definir-se em um local específico.

Em resumo, a mecânica quântica propala que a realidade é baseada em ondas de probabilidade e, ao mesmo tempo, essas ondas não podem ser vistas. Um verdadeiro nó górdio? Segundo o físico Brian Greene, não. Em suas palavras (2012: 249):

Felizmente, apesar de todas as suas características misteriosas e ocultas, a mecânica quântica é testável. De acordo com os seguidores da interpretação de Copenhague [Bohr e seu grupo], quanto maior for uma onda de probabilidade em um local determinado, maior será a possibilidade de que, quando a onda entrar em colapso, o elétron esteja situado nesse único ponto que persiste. Essa afirmação produz previsões. Façamos um determinado experimento um bom número de vezes, estabeleçamos a frequência com que encontramos a partícula em diferentes locais e verifiquemos se as frequências observadas concordam com as probabilidades ditadas pela onda de probabilidade. Se a onda for 2874 vezes mais alta em um local do que em outro, encontraremos a partícula 2874 mais vezes no primeiro local do que no segundo? Previsões como essa têm sido realizadas com enorme sucesso.

A abordagem de Bohr, contudo, mostrou-se carente não só de uma boa base matemática para sustentar seus argumentos como sequer mostrou-se clara: Bohr não define o que é "medição" e "observação" (seria realizada por seres humanos? Por máquinas?). Para contornar esse incômodo, o físico austríaco Erwin Schrödinger formulou em 1925 sua equação que descreve como o estado quântico de um sistema físico muda com o tempo. Ou seja, segundo Schrödinger as ondas de probabilidade não entram em colapso jamais.

Para descrever matematicamente como uma onda de probabilidade varia no tempo, Schrödinger estabeleceu que sua equação tivesse propriedade linear: com isso, resolveu a "impossibilidade" de se medir pontos em uma onda. A equação de Schrödinger nos mostra que as ondas podem ser divididas em duas ou mais frações a fim de terem pontos específicos medidos e que, uma vez postas novamente em conjunto, fornecem ao analista a evolução da onda no tempo, permitindo que se façam predições sobre as regiões 
mais prováveis de serem povoadas com elétrons. O trabalho de Schrödinger, por sua vez, não apenas se tornou um dos pilares da teoria quântica como mostrou ao mundo que pode ser aplicado para descrever todas as partículas existentes (em outras palavras, sua equação serve tanto para o elétron a ser medido como ao ser humano e/ou a máquina que o mede).

As suas ideias foram aprofundadas algum tempo depois pelo físico estadunidense Hugh Everett III. Everett estabeleceu o que foi denominado "Muitos Mundos" na mecânica quântica. Segundo ele, mesmo se dividirmos uma onda de probabilidade para observarmos o elétron - como sugere Schrödinger - as medições obtidas em cada um dos fragmentos serão reais: nada distinguirá uma da outra, porém, o aparelho medidor - e a leitura feita pelo seu cérebro - fará essa distinção, pois não é possível ler duas (ou mais) medições ao mesmo tempo. Assim sendo, de acordo com Everett, existem duas (ou mais) realidades concomitantes, dois (ou mais) universos que existem ao mesmo tempo sem que nenhum deles seja mais real do que o outro: a abordagem de "Muitos Mundos", então, estabelece a existência de um multiverso, com cada universo tendo a sua realidade própria, mas que, ao serem medidos, tornam os demais universos invisíveis para o observador.

Em outras palavras: tudo aquilo que vivemos pode ser duas coisas ao mesmo tempo. Se cada subdivisão tiver a sua própria subdivisão, chegaremos a um número enorme de possibilidades, todas reais (uma vez que a mecânica quântica é real). Deixeme ilustrar com um exemplo pessoal: no exato momento em que escrevo meu trabalho, um outro Alex, em seu universo paralelo muito parecido com o meu, não só terminou a tese como foi concursado e é professor em uma universidade de prestígio; do mesmo modo, um outro Alex abandonou a faculdade e ficou rico produzindo jogos eletrônicos (esse Alex eu invejo, de verdade)...

O que quero dizer aqui com toda essa conversa sobre quanta é: diversas realidades podem existir ao mesmo tempo, e nenhuma estará errada. Você viajando na TARDIS para o passado ou navegando pelo Vipasca Antiga terá a mesma experiência: ambas as realidades, de fato, existem e são válidas.

Para finalizar esse tema quântico, mais um apontamento. Você se lembra quando, lá no começo da pesquisa, eu mencionei Nick Bostrom e a ideia de que poderíamos viver em uma simulação computacional? Pois bem, estou redigindo esse último capítulo em 
novembro de 2016 e, acredite, esse tema voltou a ser discutido seriamente entre a comunidade acadêmica durante todo o ano ${ }^{93}$.

Obviamente, uma simulação computacional que dê conta de toda a complexidade de nosso universo teria de ser realizada por computadores quânticos (que já são objetos de pesquisa há algum tempo). Mas o que eu realmente quero chamar a atenção aqui é: de algum modo, essa simulação do universo seria muito semelhante à simulação que desenvolvi para o aplicativo Vipasca Antiga. E isso graças aos conceitos de mecânica quântica que apresentei.

Como viu no capítulo anterior, existe um método de trabalho em ambientes tridimensionais virtuais denominado Occlusion Culling (Fig. 120). A oclusão permite que apenas aquilo que é observado diretamente pelo usuário seja renderizado na tela, ocultando todo o restante. Resumindo, a oclusão não difere do conceito de partículas e ondas da Mecânica Quântica, pois tudo o que vemos no monitor, todo o mundo simulado, somente passa a existir quando o observamos diretamente. Se o universo realmente for uma simulação computacional como alguns pesquisadores estão inclinados a crer, então a teoria quântica estaria presente tanto na parte física dos computadores (a fim de suprir a necessidade de processamento), como nos motores gráficos responsáveis por desenvolver e rodar as simulações.

Termino essa divagação sobre a Mecânica Quântica reiterando: viajar com o Doutor na TARDIS ou caminhar pelo aplicativo Vipasca Antiga são duas realidades válidas; realidades quânticas, pois só existem a partir das propriedades atômicas que permitem haver um universo que só se mostra concretizado quando observado pelo viajante/usuário. Uma simulação ciberarqueológica não é menos real - ou menos passível de credibilidade - do que aquilo que trazemos à luz ao escavarmos.

\section{ARQUEÓLOGOS PÓS-HUMANOS}

Em um universo quântico paralelo os arqueólogos são seres plenamente satisfeitos com seus dispositivos eletrônicos e os usam com frequência quando vão a campo. Nesse universo, fazer simulações de realidade virtual não causam mais estranhamento e já não

\footnotetext{
${ }^{93}$ Recomendo assistir ao Isaac Asimov Memorial Debate em que pesquisadores renomados apresentam suas ideias em um debate mediado por Neil deGrasse Tyson em abril de 2016 sobre o argumento de 0 universo ser uma simulação: https://youtu.be/wgSZA3NPpBs
} 
são apenas uma novidade: são parte do cotidiano arqueológico, são tão corriqueiras quanto fotografar uma quadra de escavação. Esse universo ciberarqueológico pleno não é o meu infelizmente: mas estamos no caminho certo.

Nós aprendemos com as máquinas. As máquinas aprendem conosco. A cada dia a Aprendizagem Automática (ou Machine Learning, em inglês; ALPAYDIN 2016) sabe mais sobre nós sem que a tenhamos de programar. O Big Data nos traz uma quantidade massiva de informação que precisa ser filtrada e analisada. Empresas de todos os portes vêm anunciando dispositivos de Realidade Virtual (e, consequentemente, os barateando), aumentando nossas opções de trabalho e consumo pessoal. Enfim, o nosso presente está repleto de máquinas e programas de Inteligência Artificial que nos auxiliam no dia a dia. E isso tende a se intensificar doravante: tenho certeza de que, ao ler esse trabalho que tem em mãos, com certeza mais algumas novidades eletrônicas estarão no mercado.

Meu trabalho só foi possível de ser realizado graças às máquinas: desde a internet que utilizei para fazer minhas primeiras pesquisas sobre o tema, passando pelos aviões modernos que me levaram até Portugal, estando presente na minha câmera digital e computador de renderização e programação, até a impressora que será responsável por deixar um exemplar físico na biblioteca do Museu de Arqueologia e Etnologia da USP em absolutamente cada etapa do meu trabalho eu fui auxiliado pela tecnologia das máquinas. Eu acredito que exista uma simbiose entre nós, humanos, e máquinas, e que isso não é um futuro apocalíptico. Quando digo "simbiose", não me refiro apenas ao que é físico, como implantes em nossos corpos: estou, principalmente, me referindo à programação, ao modo de pensar. Vipasca Antiga tem transeuntes que caminham graças à Inteligência Artificial - e eu precisei aprender a trabalhar com a ferramenta correta para chegar a um resultado final satisfatório (e nós humanos temos feito isso antes mesmo de sermos homo sapiens sapiens). Para aprender essa ferramenta, utilizei o meu próprio computador (com internet, claro): ou seja, foi uma via de mão dupla.

Do mesmo modo, tenho plena consciência da rapidez com que a tecnologia avança nos dias de hoje. Sei que o próprio motor gráfico que utilizei para desenvolver minha simulação (Unity) receberá várias atualizações até o momento em que este trabalho for finalizado. Assim, terei de, frequentemente, me "reciclar" a fim de que minhas habilidades estejam sempre atualizadas: ou seja, o aprendizado simbiótico nunca termina. 
Foi assim que produzi minha pesquisa: em um diálogo estreito com as máquinas e seus "cérebros" (programas), desenvolvi minhas aptidões cognitivas e físicas (afinal, todo programa requer um uso próprio do mouse, por exemplo). E acredito que será assim o futuro dos arqueólogos: eles serão pós-humanos (ou transhumanos, como preferir).

A minha Ciberarqueologia, como já disse, é pós-humana. Ela lida com simulações, é simbiótica, e não está fechada em si mesma (será sempre atualizada graças à própria atualização tecnológica). Vipasca Antiga é fruto do meu esforço em produzir uma ciberarqueologia pós-humana.

E se você chegou até aqui, pode ter certeza de uma coisa: uma parte de seu consciente irá guardar algumas das informações que leu (e que experimentou no aplicativo).

Informações produzidas pelo conjunto homem-máquina. 


\section{BIBLIOGRAFIA}

ADAMS, Gavin. A mirada estereoscópica e sua expressão no Brasil. São Paulo, 2004. Tese de Doutorado - ECA, Universidade de São Paulo.

ALPAYDIN, Ethem. Machine Learning. The new AI. Cambridge, MA: MIT Press, 2016.

ANSCHUETZ, Kurt F. et al. "An archaeology of landscapes: perspectives and directions". In: Journal of Archaeological Research, v. 9, n⿳2 2, 2001.

ATTRIDGE, Alex N. et al.. "Virtual reality in enfineering education". In: Global Engineering Education Conference (EDUCON), pp. 751-757, 2011.

AZUMA, Ronald T. "A Survey of Augmented Reality". In: Presence: Teleoperators and Virtual Environments 6, 4 (August 1997), pp. 355 - 385, 1997.

BARCELÓ, J. A. \& VICENTE, O. "Qué hacer con un modelo arqueológico virtual. Aplicaciones de la inteligencia artificial en visualización científica". In: Virtual Archaeology Review (VAR), v. 2, no 4, Sevilla, pp. 53-57, 2011.

BATESON, Gregory. Mind and nature: a necessary unity. New Jersey: Hampton Press, 2002.

BATESON, Gregory. Steps to an ecology of mind. Chicago: University of Chicago Press, 1999.

BAUDRILLARD, Jean. Simulacros e Simulação. Lisboa: Relógio D’Água Editores, 1991.

BEYER, Mark \& LANEY, Douglas. The importance of 'Big Data': a definition. Gartner, 21 June, 2012.

BLASCO, Josep. "Procesos de documentación arqueológica y generación de modelos virtuales". In: Virtual Archaeology Review (VAR), v. 2, n³, Sevilla, pp. 65-69, 2011.

BOSTROM, Nick. “Are you living in a computer simulation?”. In: Philosophical Quarterly, vol. 53, n' 211, pp. 243-255, 2003.

BOUZA-ÁLVAREZ, Fernando. Imagen y propaganda: capítulos de historia cultural del reinado de Felipe II. Madrid: Tres Cantos, Akal, 1998.

BRAGA, Mariluci. "Realidade virtual e educação". In: Revista de Biologia e Ciências da Terra, v. 1, n⿳0 1, 2001.

BRYSON, Steve. "Virtual reality in scientific visualization". In: Communications of the ACM, v. 39, pp. 62-71, 1996.

BURKLE, Martha \& KINSHUK. "Learning in virtual worlds: the chalenges and opportunities”. In: International Conference on CyberWorlds, pp. 320-327, 2009.

CARDOSO, João B. F. "O cenário no cinema 3D: a tridimensionalidade como elemento de significação". In: Confederación Iberoamericana de Asociaciones Científicas y Académicas de la Comunicaión, 2011.

CHAMPION, Erik. Critical gaming: interactive history and virtual heritage. Surrey: Ashgate, 2015. 
CHAPMAN, Henry. Landscape archaeology and GIS. Gloucestershire: Tempus, 2006.

CLARK, Jeffrey T. "The fallacy of reconstruction". In: FORTE, Maurizio (ed.). CyberArchaeology. Oxford: Archaeopress, BAR, v. 2177, pp. 63-73, 2010.

CLARK, Richard. "Media will never influence learning". In: Educational Technology Research and Development, v. 42, n⿳0 2, pp. 21-29, 1994.

CLARK, Richard. "Reconsidering research on learning from media". In: Review of Educational Research, v. 53, no 4, pp. 445-459, 1983.

CLARKE, David (org.). Spatial archaeology. London: Academic Press, 1977.

CRAIG, Allan B. Understanding augmented reality. Concepts and applications. San Francisco: Morgan Kaufmann Publishers, 2013.

CRONE, Robert A. "The history of stereoscopy”. In: Documenta Ophthalmologica, 81, pp. 1-16, 1992.

DAWKINS, Richard. O gene egoísta. Tradução: Rejane Rubino. São Paulo: Companhia das Letras, 2007.

DE PAOLIS Lucio T. et al.. "A simulation of life in a medieval town for edutainment and touristic promotion". In: International Conference on Innovations in Information Technology, pp. 361-366, 2011.

DELEUZE, Gilles \& GUATTARI, Félix. Mil platôs. Capitalismo e esquizofrenia. Vol. 1. São paulo: Editora 34, 2000.

DOMÍNGUEZN, Vicente et al. "Asignación del color en modelos tridimensionales". In: Virtual Archaeology Review (VAR), v. 2, n 3, Sevilla, pp. 33-37, 2011.

ESTALAYO MORENO, M. A. "Pintura y escultura digital 3D con Zbrush aplicada a la arqueología”. In: Virtual Archaeology Review (VAR), v. 2, no 3, Sevilla, pp. 161-164, 2011.

EVANS, T. \& DALY, P. (eds.), Digital Archaeology. Bridging method and theory. London, New York: Routledge, 2006.

FAN, Rong \& LIU, Ying. "Research on augmented reality interactive games". In: Third Pacific-Asia Conference on Circuits, Communications and System (PACCS), 2011.

FAN, Shaojing et al.. "The application of virtual reality in environmental education: model design and course construction". In: International Conference on Biomedical Engineering and Computer Science (ICBECS), 2010.

FARJAS, Mercedes. "La realidad virtual y el análisis científico: de la nube de puntos al documento analítico". In: Virtual Archaeology Review (VAR), v. 2, no 4, Sevilla, pp. 139-144, 2011.

FEITO HIGUERUELA, F. R. \& SEGURA SÁNCHEZ, R. J. "Herramientas SIG 3D". In: Virtual Archaeology Review (VAR), v. 1, n 1, Sevilla, pp. 87-91, 2010.

FELLNER, Dieter W. "Practical 3D reconstruction of cultural heritage artefacts from photographs - potentials and issues". In: Virtual Archaeology Review (VAR), v. 2, no 4, Sevilla, pp. 95-103, 2011. 
FORTE, Maurizio. "About virtual archaeology: disorders, cognitive interactions and virtuality”. In: FORTE, M., BARCELO, J. \& SANDERS, D. (eds.), Virtual reality in archaeology. Oxford: Archaeopress, BAR, v. 843, 2000.

FORTE, Maurizio (ed.). Cyber-Archaeology. Oxford: Archaeopress, BAR, v. 2177, 2010.

FORTE, Maurizio et al. "Cyber-Archaeology and virtual collaborative environments". In: FORTE, Maurizio (ed.). Cyber-Archaeology. Oxford: Archaeopress, BAR, v. 2177, pp. 110-117, 2010b.

FORTE, Maurizio. “Cyber-Archaeology: a post-virtual perspective”. MIT Press, 2012.

FORTE, Maurizio. "Cyber-Archaeology: an eco-approach to the virtual reconstruction of the past". In: Proceedings of the 14th International Conference on Virtual Systems and Multimedia. Budapest, pp. 261-268, 2008.

FORTE, Maurizio. "Cyber-Archaeology: notes on the simulation of the past". In: Virtual Archaeology Review (VAR), v. 2, n 4, Sevilla, pp. 7-18, 2011.

FORTE, Maurizio. "Cyber-Archaeology. How 3D modeling is unpeeling the Neolithic at Çatalhöyük”. In: Current World Archaeology, Issue 61, pp. 36-40, 2013.

FORTE, Maurizio et al. "Desktop virtual reality systems between site and landscape". In: Proceedings of the $11 \mathrm{~h}$ International Conference on Virtual Systems and Multimedia: Virtual Reality at Work. Budapest, 2005.

FORTE, Maurizio et al. "Interactive landscapes reconstruction: a Web 2D and 3D opensource solution". In: MUDGE, M. et al. (eds.), The $6^{\text {th }}$ International Symposium on Virtual Reality, Archaeology and Cultural Heritage VAST, 2005.

FORTE, Maurizio. "Introduction to Cyber-Archaeology". In: FORTE, Maurizio (ed.), Cyber-Archaeology. Oxford: Archaeopress, BAR, v. 2177, pp. 9-13, 2010c.

FORTE, Maurizio. "Mindscape: ecological thinking, cyber-anthropology and virtual archaeological landscapes". In: FORTE, M. \& WILLIAMS, P. R. (eds.), The reconstruction of archaeological landscapes through digital technologies. Oxford: Archaeopress, BAR, v. 1379, pp. 95-108, 2010d.

FORTE, Maurizio et al. "Open heritage: an open source approach to 3D real-time and webbased landscape reconstruction". In: Proceedings of the 11h International Conference on Virtual Systems and Multimedia: Virtual Reality at Work. Budapest, pp. 313-320, 2005.

FORTE, Maurizio et al. "The narrative approach of virtual heritage real-time applications". In: FORTE, M. \& WILLIAMS, P. R. (eds.), The reconstruction of archaeological landscapes through digital technologies. Oxford: Archaeopress, BAR, v. 1379, 2010e.

FORTE, Maurizio. Virtual Archaeology: re-creating ancient worlds. New York: Harry N. Abrams, 1996.

FORTE, Maurizio et al. "VR WebGIS: an open source approach to 3D real-time landscape management". In: Proceedings of the 11h International Conference on Virtual Systems and Multimedia: Virtual Reality at Work. Budapest, 2005. 
FORTE, Maurizio \& PIETRONI, Eva. "3D collaborative environments in archaeology: experiencing the reconstruction of the past". In: International Journal of Architectural Computing, v. 7, $\mathbf{n}^{\mathbf{0}}$ 1. Liverpool: University of Liverpool, pp. 57-76, 2009.

FRISBY, John P. \& STONE, James V. Seeing. The computational approach to biological vision. Cambridge, Massachusetts, London: The MIT Press, 2010.

FRISCHER, Bernard. "Art and science in the age of digital reproduction: from mimetic representation to interactive virtual reality". In: Virtual Archaeology Review (VAR), v. 2, no 4, Sevilla, pp. 19-32, 2011.

GIBBONS, Garry. "Visualisation in archaeology: connecting. Research and practice". In: Virtual Archaeology Review (VAR), v. 1, n² 2, Sevilla, pp. 13-17, 2010.

GIBSON, William. Neuromancer. São Paulo: Aleph, 4ª ed., 2008.

GLEICK, James. A informação. Uma história, uma teoria, uma enxurrada. Tradução: Augusto Pacheco Calil. São Paulo: Companhia das Letras, 2013.

GREENE, Brian. A realidade oculta. Universos paralelos e as leis profundas do cosmo. Tradução: José Viegas Jr. São Paulo: Companhia das Letras, 2012.

HAYLES, N. Katherine. How we became posthuman. Virtual bodies in cybernetics, literature, and informatics. Chicago: The University of Chicago Press, 1999.

HARAWAY, Donna. “A Manifesto for Cyborgs: science, technology, and socialist feminism in the 1980s". In: Socialist Review 80, pp. 65-108, 1985.

HIRT, Alfred Michael. Imperial Mines and Quarries in the Roman World. Organizational aspects: 27BC - AD 235. New York: Oxford University Press, 2010.

HO KIM, Joon. "Cibernética, ciborgues e ciberespaço: notas sobre as origens da cibernética e sua reinvenção cultural”. In: Horizontes Antropológicos, ano 10, n⿳21. Porto Alegre, pp. 199-219, 2004.

HROZEK, Frantisek et al.. "Virtual reality. Creation, usage and education". In: 14 ${ }^{\text {th }}$ International Conference on Interactive Collaborative Learning (ICL), pp. 480-483, 2011.

INGOLD, Tim. "The temporality of the landscape". In: World Archaeology. London: Taylor \& Francis Ltd., v. 25, nº 2, 1993.

JONES, Samuel T. et al. "Low-cost high-performance scientific visualization". In: Computing in Science \& Engineering, v. 3, pp. 12-17, 2001.

JÚNIOR, Gesmar de Paula Santos et al. "Realidade Aumentada Móvel". In: Tendências e Técnicas em Realidade Virtual e Aumentada, v. 3, pp. 60-74, 2013.

KILTENI, Konstantina et al. "The sense of embodiment in Virtual Reality”. In: Presence, Vol. 21, n' 4, pp. 373-387, 2012.

KOESTLER, Arthur. O fantasma da máquina. Tradução: Christiano Monteiro Oiticica, Hesiodo de Queiroz Facó. Rio de Janeiro: Zahar, 1969. 
KOZMA, Robert. "Learning with media". In: Review of Educational Research, v. 61, no 2 , pp. 179-212, 1991.

KURZWEIL, Ray. A era das máquinas espirituais. Tradução: Fábio Fernandes. São Paulo: Aleph, 2007.

KURZWEIL, Ray. How to create a mind. The secret of human thought revealed. New York: Penguin Books, 2013.

KURZWEIL, Ray. The singularity is near: when humans transcend biology. New York: Penguin Books, 2006.

LANGTON, Christopher G. (ed.). Artificial life. The proceedings of an interdisciplinary workshop on the synthesis and simulation of living systems (Los Alamos, New Mexico, September 1987), v. 6. Boston: Addison-Wesley Publishing Company, 1988.

LANGTON, Christopher G., TAYLOR, Charles, FARMER, J. Doyne \& RASMUSSEN, Steen (eds.). Artificial life II. The proceedings of the workshop on artificial life (Santa Fe, New Mexico, February 1990), v. 10. Boston: Addison-Wesley Publishing Company, 1991.

LANGTON, Christopher G. (ed.). Artificial life III. The proceedings of the workshop on artificial life (Santa Fe, New Mexico, June 1992), v. 17. Boston: Addison-Wesley Publishing Company, 1993.

LETTVIN, Jerome et al. "What the Frog's Eye Tells the Frog's Brain". In: Proceedings of the Institute for Radio Engineers, v. 47, pp. 1940-1951, 1959.

LÉVY, Pierre. As tecnologias da inteligência: o futuro do pensamento na era da informática. Tradução: Carlos Irineu Costa. São Paulo: Editora 34, 2008.

LÉVY, Pierre. Cibercultura. Tradução: Carlos Irineu Costa. São Paulo: Editora 34, $3^{\text {a }}$ ed., 2010.

LÉVY, Pierre. O que é o virtual? Tradução: Paulo Neves. São Paulo: Editora 34, 2007.

LIPTON, Lenny. Foundations of the stereoscopic cinema. A study in depth. New York: Van Nostrand Reinhold Company, 1982.

LOCK, Gary. "Computers, learning and teaching in archaeology". In: EVANS, T. \& DALY, P. (eds.), Digital Archaeology. Bridging method and theory. London, New York: Routledge, pp. 226-235, 2006.

MACHADO, Liliane et al. "Serious games para saúde e treinamento imersivo". In: Fátima L. S. Nunes; Liliane S. Machado; Márcio S. Pinho; Cláudio Kirner. (Org.). Abordagens Práticas de Realidade Virtual e Aumentada. Porto Alegre: SBC, p. 31-60, 2009.

MARTINS, Artur (cord.). As Tábuas de Bronze de Aljustrel. Aljustrel: Câmara Municipal de Aljustrel, 2012.

MARTIRE, Alex da S. Arqueologia da paisagem mineira romana: a Hispânia e a Lusitânia. São Paulo, 2012. Dissertação de Mestrado - MAE, Universidade de São Paulo. 
MARTIRE, Alex da S. et. al. "DOMUS: a utilização de recursos 3D para o ensino da Arqueologia romana". In: Perspectivas da arqueologia provincial romana no Brasil. São Paulo: Annablume, pp. 85-103, 2015.

MATURANA, Humberto R. \& VARELA, Francisco J. A árvore do conhecimento. As bases biológicas da compreensão humana. São Paulo: Editora Palas Athena, 2011.

MATURANA, Humberto R. \& VARELA, Francisco J. Autopoiesis and Cognition: the realization of the living. Dordrecht: D. Reidel Publishing Company, 1980.

MAZURYK, Tomasz \& GERVAUTZ, Michael. "Virtual reality. History, applications, technology and future". Institute of Computer Graphics and Algorithms, Vienna University of Technology, 1996.

MCCORMICK, Bruce H. et al.. Visualization in Scientific Computing, v. 21, no 6. ACM SIGGRAPH, 1987.

MCGONIGAL, Jane. Reality is broken. Why games make us better and how they can change the world. New York: Penguin Books, 2011.

MELL, Peter \& GRANCE, Timothy. The NIST definition of cloud computing. Gaithersburg: National Institute of Standards and Technology, 2011.

MENDIBURU, Bernard. 3D movie making. Stereoscopic digital cinema from script to screen. Burlington: Elsevier, Focal Press, 2009.

MINSKY, Marvin. The society of mind. New York: Simon \& Schuster Paperbacks, 1988.

MOORE, Michael G. "Teoria da distância transacional". Tradução: Wilson Azevêdo. In: KEEGAN, D. (ed.). Theoretical Principles of Distance Education. New York: Routledge, pp. 22-38, 1993.

MORE, Max \& VITA-MORE, Natasha (eds.). The transhumanist reader: classical and contemporary essays on the science, technology, and philosophy of the human future. West Sussex: John Wiley \& Sons, 2013.

MORAVEC, Hans. Homens e robots. O futuro da inteligência humana e robótica. Tradução: José Luís Malaquias F. Lima. Lisboa: Gradiva, 1992.

MURRAY, Janet H. Hamlet no holodeck: o futuro da narrativa no ciberespaço. Tradução: Elissa Khoury Daher, Marcelo Fernandez Cuzziol. São Paulo: Itaú Cultural/UNESP, 2003.

NETTO, Antonio V. et al.. "Realidade virtual. Definições, dispositivos e aplicações". In: REIC - Revista Eletrônica de Iniciação Científica, ano 2, n⿳0 1, 2002.

NICOLELIS, Miguel. Muito além do nosso eu. A nova neurociência que une cérebro e máquinas e como ela pode mudar nossas vidas. São Paulo: Companhia das Letras, 2011.

NORVIG, Peter \& RUSSEL, Stuart. Inteligência Artificial [Ebook Kindle]. Rio de Janeiro: Editora Campus-Elsevier, 2014.

PANTELIDES, V. "Reasons to use Virtual Reality in Education". In: VR in the Schools, v. $\mathbf{1}, \mathbf{n}^{\mathbf{0}} \mathbf{1}, 1995$. 
PAPADOUPOLOS, C. \& SAKELLARAKIS, Y. "Virtual windows to the past: reconstructing the 'ceramics workshop' at Zominthos, Crete". In: Proceedings of the 38th Conference on computer applications and quantitative methods in archaeology. Granada, 2010.

PAPADOUPOLOS, K. \& KEFALAKI, E. “At the computer's edge. The value of virtual constructions to the interpretation of cultural heritage". In: Archaeomatica, $\mathbf{n}^{\mathbf{0}} 4$, pp. 46$51,2010$.

PELLINI, José Roberto. "Uma conversa sobre arqueologia, paisagem e percepção com Robin, o Bom Camarada". In: Revista do Museu de Arqueologia e Etnologia. São Paulo, 19, 2009.

PÉREZ MACÍAS, J. A. et al. In ábditas terras. Investigações arqueológicas em Aljustrel. Huelva: Ediciones Consulcom, 2013.

PÉREZ MACÍAS, J. A. et al.. "Os scavrarii de Vipasca". In: Actas del V Simposio Internacional sobre Minería y Metalurgia Históricas en el Suroeste Europeo (León 2008). Eds. Josep M. Mata-Perelló, Lisard Torró Labat y Maria Natividad Fuentes Prieto. SEDPGYM, 2011.

PÉREZ MACÍAS, J. A. et al.. "Primeiros resultados do 'Projecto Vipasca"”. In: Vipasca, arqueologia e história, $\mathbf{n}^{\mathbf{0}} \mathbf{2 ,} \mathbf{2}^{\mathrm{a}}$ série, 2007.

PÉREZ MACÍAS, J. A. et al.. "Primeiras evidências de mineração de cobre em Aljustrel". In: Vipasca, arqueologia e história, $n^{0}$ 2, $4^{\mathbf{a}}$ série, no prelo. Aljustrel: Câmara Municipal de Aljustrel, no prelo.

PIETRONI, E. \& PESCARIN, S. "VR cooperative environments for the interpretation and reconstruction of the archaeological landscape". In: Virtual Archaeology Review (VAR), v. 1, nº 2, Sevilla, pp. 25-29, 2010.

PIMENTEL, Ken \& TEIXEIRA, Kevin. Virtual reality: through the new looking glass. New York: McGraw-Hill, $2^{a}$ ed., 1995.

PLETINCKX, Daniel. "Virtual archaeology as an integrated preservation method". In: Virtual Archaeology Review (VAR), v. 2, n⿳ 4, Sevilla, pp. 33-37, 2011.

RABIN, Steve (ed.). Introdução ao desenvolvimento de games, v.1. Tradução: Opportunity Translations. São Paulo: Cengage Learning, 2011.

REILLY, Paul. “Towards a virtual archaeology”. In: LOCKYEAR, K. e RAHTZ, S. (eds.), Computer Applications in Archaeology 1990. Oxford: British Archaeological Reports (Int. Series 565), pp. 133-139, 1990.

RHYNE, Theresa-Marie. "Computer games and scientific visualization". In: Communications of the ACM, v. 45, pp. 41-44, 2002.

RODRIGUES, Marcos A. et al.. "A case study of 3D Technologies in higher education: scanning the metalwork collection of Museums Sheffield and its implications to teaching and learning". In: International Conference on Information Technology Based Higher Education and Training (ITHET), 2011.

RODRÍGUEZ HIDALGO, J. M. "De la reconstrucción tradicional a la virtual. Una visión desde la arqueología". In: Virtual Archaeology Review (VAR), v. 1, no 1, Sevilla, pp. 163-167, 2010. 
ROSENBLUM, L. et al. (eds.). Scientific visualization. Advances and challenges. London/SanDiego: Academic Press, 1994.

SANDERS, Donald H. "Enabling archaeological hypothesis testing in real time using the reveal documentation and display system". In: Virtual Archaeology Review (VAR), v. 2, $\mathbf{n}^{\mathbf{0}}$ 4, Sevilla, pp. 89-94, 2011.

SANGREGORIO, E. et al. "The Archaematica Project: towards a new application of the computer graphics in archaeology". In: Sixth eurographics Italian chapter conference, Salerno - Italy, July 2nd - 4th, 2008. Aire-la-Ville: Eurographics Association, pp. 1-5, 2008.

SCHIFFER, Michael B. Formation processes of the archaeological record. Albuquerque: University of New Mexico Press, 1987.

SCHWENDIMANN, Beat. What is the difference between a simulation and a model? [Updated]. In: http://proto-knowledge.blogspot.com.br/2010/12/what-is-differencebetween-simulation.html

SHANKS, Michael \& TILLEY, Christopher. Re-constructing archaeology: theory and practice. London: Routledge, $2^{\mathrm{a}}$ ed., 1992.

SHERMAN, William R. \& CRAIG, Alan B. Understanding virtual reality. Interface, application, and design. San Francisco: Morgan Kaufmann Publishers, 2003.

SIDERIS, A. \& ROUSSOU, M. "Making a new world out of an old one: in search of a common language for archaeological immersive VR representation". In: Proceedings of 8th International Conference on Virtual Systems \& Multimedia/VSMM, pp. 31- 42, 2002.

SIDERIS, A. et al. "The virtual reconstruction of the hellenistic asclepieion of Messene". In: IMEROS, n 4, 2004.

SLATER, Mel et al. "Simulating virtual environments within virtual environments as the basis for a psychophysics of presence". In: ACM Transactions on Graphics, Vol. 29, $\mathbf{n}^{\circ}$ 4, Article 92, 2010.

SKABÓ, Csaba et al.. "Processing 3D scanner data for virtual reality". In: $\mathbf{1 0}^{\text {th }}$ International Conference on Intelligent Systems Design and Applications, pp. 1281-1286, 2010.

SOBOTA, B. et al.. "Virtual reality and its technologies in education: our experiences" In: $10^{\text {th }}$ IEEE International Conference on Emerging eLearning Technologies and Applications, pp. 351-355, 2012.

STONE, Robert J. "Haptic feedback: a brief history from telepresence to virtual reality". In: Haptic Human-Computer Interaction, v. 2058, 2001.

SUTHERLAND, Ivan. "A head-mounted three dimensional display". In: AFIPS '68 (Fall, part I) Proceedings of the December 9-11, 1968, Fall Joint Computer Conference, part I. New York: ACM, pp. 757-764, 1968.

SUTHERLAND, Ivan. "Sketchpad. A man-machine graphical communication system". In: DAC '64 Proceedings of the SHARE design automation workshop. New York: ACM, pp. 329-346, 1964. 
SUTHERLAND, Ivan. “The ultimate display”. In: Proceedings of IFIP Congress, pp. 506$508,1965$.

TAYLOR, Walter W. "A study of archaeology”. In: American Anthropologist 50 (3), part 2, pp. 1-256, 1948.

TORI, Romero. Educação sem distância. As tecnologias interativas na redução de distâncias em ensino e aprendizagem. São Paulo: Editora Senac, 2010.

TILLEY, Christopher. A phenomenology of landscape: places, paths and monuments. Oxford: Ber Publishers, 1994.

VARELA, Francisco J., THOMPSON, Evan \& ROSCH, Eleanor. The embodied mind: cognitive science and human experience. Cambridge: MIT Press, 1991.

VARELA, Francisco J. \& BOURGINE, Paul (eds.). Toward a practice of autonomous systems. Cambridge: MIT Press/Bradford Books, 1992.

VERGA, F. \& FABBRI, F. "3D reconstruction of the poggio sommavilla territory (Sabina tiberina, Rieti- Italy) a new approach to the knowledge of the archeological evidences". In: Virtual Archaeology Review (VAR), v. 2, no 3, Sevilla, pp. 23-26, 2011.

VILA BONAMUSA, L. \& VILADRICHTOR, L. "Digitalización 3D en arqueologia". In: Virtual Archaeology Review (VAR), v. 2, n⿳0 3, Sevilla, pp. 75-81, 2011.

WHEATLEY, D. \& GILLINGS, M. Spatial Technology and Archaeology: the Archaeological Applications of GIS. London: CRC Press, 2002.

WIENER, Norbert. Cibernética e sociedade: o uso humano de seres humanos. Tradução: José Paulo Paes. São Paulo: Cultrix, 1968.

WICKENS, Christopher D. "Virtual reality and education". In: IEEE International Conference on Systems, Man and Cybernetics, pp. 842-847, 1992.

XUE, Han \& ZHANG, Jing. "Applying virtual reality to web-based education”. In: First International Multi-Symposiums on Computer and Computational Sciences (IMSCCS), 2006.

ZONE, Ray. 3-D filmmakers. Conversations with creators of stereoscopic motion pictures. Lanham, Toronto, Oxford, 2005.

ZONE, Ray. Stereoscopic cinema and the origins of 3-D film, 1838-1952. Kentucky: The University Press of Kentucky, 2007.

ZUBROW, E. "Digital Archaeology: a historical context". In: EVANS, T. \& DALY, P. (eds.), Digital Archaeology. Bridging method and theory. London, New York: Routledge, pp. 10-31, 2006.

ZUFFO, Marcelo et al.. "Realidade virtual na educação e a Nave Mário Schenberg". In: Revista Fonte, $\mathbf{n}^{\mathbf{0}}$ 8. Minas Gerais: 2008. 